\title{
Het tekort : studies over de arbeidsmarkt voor mijnwerkers in het Luikse kolenbekken vanaf het einde van de negentiende eeuw tot 1974
}

Citation for published version (APA):

Roels, L. (2014). Het tekort : studies over de arbeidsmarkt voor mijnwerkers in het Luikse kolenbekken vanaf het einde van de negentiende eeuw tot 1974. [Doctoral Thesis, Maastricht University]. Uitgeverij Verloren. https://doi.org/10.26481/dis.20140403Ir

Document status and date:

Published: 01/01/2014

DOI:

10.26481/dis.20140403Ir

Document Version:

Publisher's PDF, also known as Version of record

Please check the document version of this publication:

- A submitted manuscript is the version of the article upon submission and before peer-review. There can be important differences between the submitted version and the official published version of record.

People interested in the research are advised to contact the author for the final version of the publication, or visit the DOI to the publisher's website.

- The final author version and the galley proof are versions of the publication after peer review.

- The final published version features the final layout of the paper including the volume, issue and page numbers.

Link to publication

\footnotetext{
General rights rights.

- You may freely distribute the URL identifying the publication in the public portal. please follow below link for the End User Agreement:

www.umlib.nl/taverne-license

Take down policy

If you believe that this document breaches copyright please contact us at:

repository@maastrichtuniversity.nl

providing details and we will investigate your claim.
}

Copyright and moral rights for the publications made accessible in the public portal are retained by the authors and/or other copyright owners and it is a condition of accessing publications that users recognise and abide by the legal requirements associated with these

- Users may download and print one copy of any publication from the public portal for the purpose of private study or research.

- You may not further distribute the material or use it for any profit-making activity or commercial gain

If the publication is distributed under the terms of Article $25 \mathrm{fa}$ of the Dutch Copyright Act, indicated by the "Taverne" license above, 
Het tekort 


\author{
Onder redactie van \\ Prof. Dr. A.-J. Bijsterveld (voorzitter) \\ Dr. W.J.M.J. Rutten (redactiesecretaris) \\ Prof. Dr. E. Aerts \\ Prof. Dr. A.M.J.A. Berkvens (vicevoorzitter) \\ Dr. M. van der Eycken \\ Dr. J.J. de Jong \\ Dr. R. Nouwen \\ Raad van Advies \\ Drs. Th.J.F.M. Bovens (Maastricht) \\ H. Reijnders (Hasselt) \\ Prof. Dr. C. Bruneel (Louvain-la-Neuve) \\ Prof. Dr. A. Heinen (Aken) \\ Prof. Dr. P.M.M. Klep (Nijmegen) \\ Prof. Dr. A. Labrie (Maastricht) \\ Prof. Dr. J.M.W.G. Lucassen (Amsterdam) \\ Prof. Dr. J.C.G.M. Jansen (Maastricht) \\ Prof. Dr. H. Soly (Brussel) \\ Prof. Dr. R. van Uytven (Antwerpen)
}

De in deze serie verschenen delen staan vermeld op pag. 28 o.

Stichting Maaslandse Monografieën

De Stichting Maaslandse Monografieën werd in 1964 in het leven geroepen door het Sociaal Historisch Centrum voor Limburg en Limburgs Geschied- en Oudheidkundig Genootschap en staat onder bestuur van:

Drs. F.L.J.F. Jadoul (voorzitter)

Mevr. Mr. C. de Koster (secretaris)

Drs. H.J.L.M. Boersma MBA (penningmeester)

Mevr. B.J.F.M. Berden-Van Lier MMO

Prof. Dr. P.M.J.E. Tummers (vicevoorzitter) 


\section{Het tekort}

Studies over de arbeidsmarkt voor mijnwerkers in het Luikse kolenbekken vanaf het einde van de negentiende eeuw tot 1974

door

LEEN ROELS

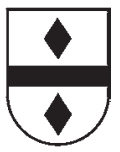

Hilversum

Verloren 2014 
Dit onderzoek kwam tot stand met steun van de Nederlandse Organisatie voor Wetenschappelijk Onderzoek en

de Faculteit der Cultuur- en Maatschappijwetenschappen van de Universiteit Maastricht

De uitgave van dit proefschrift werd mede mogelijk gemaakt door de

Stichting Dr. P.G.J.M. Janssens

Stichting Sociaal Historisch Centrum voor Limburg

Stichting Unger van Brero Fonds

Op het omslag: Barakkenkamp bij zetel Xhawirs te Xhendelesse van de NV Wérister, ca. ı96o. Coll. Blegny-Mine.

ISBN 978-90-8704-428-2

Tevens verschenen als proefschrift aan de Universiteit Maastricht.

(C) 2014 Leen Roels \& Uitgeverij Verloren, Torenlaan 25, I2II JA Hilversum

Typografie Rombus, Hilversum

Omslagontwerp Het Lab, Arnhem

Druk Wilco, Amersfoort

Bindwerk Van Waarden, Zaandam

No part of this book may be reproduced in any form without written permission from the author and publisher. 


\section{Inhoud}

Woord vooraf

Inleiding

Theoretisch kader $\quad$ I8

Historiografie $\quad 20$

Onderzoeksaanpak: bronnen en methodologie $\quad 23$

$\begin{array}{ll}\text { Opzet en indeling van dit boek } & 26\end{array}$

I Steenkoolwinning en arbeidsmarkt in het Luikse mijnbekken: een overzicht 28

$\begin{array}{ll}\text { Bedrijfsstructuur en ontwikkeling } & 29\end{array}$

$\begin{array}{lr}\text { De bedrijfsstructuur } & 29\end{array}$

De ontwikkeling van de steenkoolproductie $\quad 38$

De evolutie van het aantal arbeidskrachten $\quad 42$

Demografische en geografische aspecten van de arbeidsmarkt voor mijnwerkers $\quad 43$

Discrepanties op de lokale arbeidsmarkt 43

Het Belgische rekruteringsgebied en de binnenlandse pendel 47

$\begin{array}{ll}\text { Grensarbeiders } & 60\end{array}$

Immigranten 6 I

Het Luikse en Nederlands-Limburgse kolenbekken vergeleken 65

2 'In Belgium, women do all the work'. De arbeid van vrouwen in de Luikse mijnen, negentiende - begin twintigste eeuw $\quad 7 \mathrm{I}$

Vrouwen in een mannenwereld $\quad 77$

Mannenwerk, vrouwenwerk? $\quad 83$

In en uit de mijn $\quad 86$

De lengte van het dienstverband $\quad 87$

De periode tussen de dienstverbanden $\quad 88$

De mobiliteit tussen de mijnen en alternatieve werkgelegenheid 90

$\begin{array}{ll}\text { Plaats in de levenscyclus } & 9 \mathrm{I}\end{array}$

Loon naar werk? $\quad 93$

$\begin{array}{ll}\text { Besluit } & 96\end{array}$

3 Buitenlandse arbeiders in de Luikse steenkolenmijnen, I900-1974 99

Aanloop: het verdwijnen van een beroepstraditie $\quad$ I03

$\begin{array}{ll}\text { De kolenslag: I945-I958 } & \text { I07 }\end{array}$

Afloop: Het verdwijnen van een traditionele industrie $\quad$ II2

Besluit II5 
4 Où sont les mineurs belges? Het tekort aan mijnwerkers tijdens en na de Tweede Wereldoorlog

Arbeidsintensieve steenkoolnijverheid

Het demografisch deficit als structurele oorzaak voor het arbeidstekort

De Tweede Wereldoorlog als katalysator van het arbeidstekort $\quad$ I26

$\begin{array}{ll}\text { Dwangarbeid } & \text { I28 }\end{array}$

De Kolenslag en de 'desertie van de zonen' $\quad$ I30

De dalende arbeidsproductiviteit en de slechte financiële situatie in de Belgische mijnen

De steenkolenslag

Arbeidsomstandigheden en arbeidsvoorwaarden: het mijnwerkersstatuut $\quad$ I36

$\begin{array}{ll}\text { Propaganda voor mijnarbeid } & \text { I37 }\end{array}$

$\begin{array}{ll}\text { Huisvesting } & \text { I37 }\end{array}$

$\begin{array}{ll}\text { Opleiding } & \text { I38 }\end{array}$

Duitse krijgsgevangenen $\quad$ I40

De komst van de vreemdelingen: ongewenst maar onvermijdelijk I42

$\begin{array}{ll}\text { Besluit } & \text { I43 }\end{array}$

5 'Pour garder un mineur, il faut en recruter plusieurs'. Arbeidsdynamiek en arbeids$\begin{array}{ll}\text { verloop } & \text { I45 }\end{array}$

$\begin{array}{ll}\text { Literatuur over het arbeidsverloop } & \text { I47 }\end{array}$

Bronnen en methoden $\quad$ I50

De ontwikkeling van het relatieve arbeidsverloop na de Tweede Wereldoorlog $\quad$ I53

De in- en uitstroom nader bekeken: het saldo $\quad$ I58

De in- en uitstroom nader bekeken: de instroom I6I

De in- en uitstroom nader bekeken: de uitstroom $\quad$ I65

Het 'overlevingspercentage' als maatstaf voor het verloop, I924-I976 I69

$\begin{array}{ll}\text { Overlevingspercentages naar afkomst } & \text { I72 }\end{array}$

$\begin{array}{ll}\text { De gepresteerde diensttijd } & 176\end{array}$

$\begin{array}{ll}\text { Het absenteïsme } & 179\end{array}$

$\begin{array}{ll}\text { Besluit } & \text { I84 }\end{array}$

Samenvatting en conclusie $\quad$ I87

$\begin{array}{ll}\text { Structuurelementen } & \text { I88 }\end{array}$

De vraagzijde: de zoektocht naar mijnwerkers $\quad$ I9o

De aanbodzijde: de vlucht uit de mijnen $\quad$ I93

Arbeidsmarktgedrag en de wet van de remmende voorsprong $\quad$ I95

$\begin{array}{ll}\text { Bijlagen } & \text { I97 }\end{array}$

I Lonen en arbeidsduur $\quad$ I98

2 Overzicht van de mijnsluitingen in het Luikse bekken, I903-I980 208

3 Overzicht van de soorten ontgonnen steenkool in het Luikse bekken in I93I 2II

4 De Luikse regio in $1947 \quad 2$ 2I2 
5 De belangrijkste mijnwerkersgemeenten in de provincie Luik (naar het aantal inwonende mijnwerkers op totale bevolking), I9ı

6 De werkboekjes als bron voor vrouwenarbeid in de Luikse mijnen

7 Gegevens over de in- en uitstroom van Belgische en buitenlandse mijnwerkers per jaar, I947-I972

8 De administratie van het Fonds National de Retraite des Ouvriers Mineurs (FNROM)/ Nationaal Pensioenfonds voor Mijnwerkers (NPM) als bron

9 Verantwoording van het kaartmateriaal

Io De nettoproductie van steenkolen bij de Luikse mijnen, I900-I979

II De personeelsbezetting bij de Luikse mijnen, I900-I979

I2 Het aantal buitenlandse arbeiders in het ondergrondse personeelsbestand van de Luikse mijnen naar nationaliteit, I95I-I976

I3 Het aantal Belgen en buitenlanders in het bovengrondse personeelsbestand van de Luikse mijnen, I95I-I976

\section{Gebruikte afkortingen}

Archieven

Gebruikte literatuur

\section{Grafieken}

I.I Het aantal actieve steenkolenmijnen (NV's) en hun zetels in het Luikse bekken, I904-I979

I.2 De arbeidskracht (schaal links) en de productie (x I.ooo ton) in het Luikse bekken, I850-1978

I. 3 Het totale aantal arbeiders, het aantal Belgische en buitenlandse arbeidskrachten in de Luikse mijnen, I904-I973

I.4 Het aantal geboortes per duizend inwoners in de Luikse regio, de provincie Luik en België, I866-I964

I.5 Het aandeel I4-20-jarigen en I4-30-jarigen in de totale ondergrondse bezetting van de Luikse mijnen, I929-I976

I.6 Het aandeel van de sectoren in de totale werkgelegenheid in de provincie Luik, teljaren I9I0, I937, I947, I96I en I970

I.7 Het aantal Nederlanders en Duitsers werkzaam in de Luikse mijnen, ondergronds, I95I-I969

I.8 De regionale herkomst van de Italiaanse gastarbeiders in de Luikse mijnen, aantallen uit de selecte steekproef FNROM (N=245), I946-I964

I.9 De nettoproductie bij de Nederlandse en Luikse steenkolenmijnen, I900-I974 (in duizend ton) 
I.IO Het aantal arbeiders (ondergronds en bovengronds) in de Nederlandse en Luikse mijnen, I904-I974

2.I De evolutie van het totaal aantal arbeidsters in de Belgische steenkoolnijverheid, I89I-I902

2.2 Het aantal vrouwen ondergronds in de Belgische mijnen (per leeftijdscategorie), I89I-I902

2.3 Het aantal vrouwen bovengronds in de Belgische mijnen (per leeftijdscategorie), I89I-I902

2.4 De lengte van het dienstverband

2.5 De periode tussen de dienstverbanden

2.6 De afwezigheid per maand

3.I De nettoproductie in het Luikse bekken (x I.000 ton), I900-I974

IOO

3.2 Het totale aantal arbeiders, het aantal Belgische en buitenlandse arbeidskrachten in de Luikse mijnen, I904-I973

3.3 De verdeling van de buitenlandse mijnwerkers naar nationaliteit in de Luikse mijnen, november 1923

3.4 De verdeling van de buitenlandse mijnwerkers naar nationaliteit in de Luikse mijnen, december 1954

3.5 De verdeling van de buitenlandse mijnwerkers naar nationaliteit in de Luikse mijnen, december 1958

3.6 De percentages buitenlanders in personeelsbezetting ondergronds en bovengronds bij de Luikse mijnen, I95I-I973

3.7 De verdeling van de buitenlandse mijnwerkers naar nationaliteit in de Luikse mijnen, december 1965

3.8 Het percentage buitenlanders in de Luikse mijnen, I930-I973

4.I Het totale aantal arbeiders, het aantal Belgische en buitenlandse arbeidskrachten in de Luikse mijnen, I930-I960 (per 31 december)

4.2 De ontwikkeling van de arbeidsproductiviteit in de Luikse mijnen (in kg per arbeider per dienst van 8u-netto), I920-I950

4.3 De steenkolenproductie in het Luikse bekken (x I.000 ton), I930-I950

4.4 De geboorte- en vestigingssaldi in de Luikse regio (jaarlijkse gemiddelden), I857/65-I962/64

4.5 De bevolking naar leeftijd in de Luikse regio (in promille), I947

4.6 De bevolking naar leeftijd in België (in promille), I947

4.7 Het aantal Duitse krijgsgevangenen tewerkgesteld in de Luikse mijnen, I945-I947

4.8 Het verschil in rendement tussen de vrije arbeiders en de Duitse krijgsgevangenen in het Luikse bekken, 1946

5.I Het relatieve arbeidsverloop in de Luikse mijnen, I947-I972

5.2 Het aandeel Belgen en buitenlanders in het arbeidsverloop in de Luikse mijnen, I947-1972

5.3 Het relatief arbeidsverloop in de Luikse mijnen, ondergronders, I95I-I968

5.4 Het saldo van in- en uitstroom van de Luikse mijnen, I947-I972 
5.5 Het saldo van in- en uitstroom naar nationaliteit in de Luikse mijnen (ondergronders), I95I-I972

5.6 Het aandeel van I4-30-jarigen in de totale ondergrondse bezetting, I956-1976 I6o

5.7 De gemiddelde leeftijd van de ondergronders in het Luikse bekken, I956-I976 I6o

5.8 De jaarlijks inkomende Belgen en buitenlanders in de Luikse mijnen als percentage van hun totale bezetting, I947-I972

5.9 De afkomst van de ingetreden ondergrondse arbeiders in de Luikse mijnen, I955-I975

5.Io Het arbeidsverloop van en naar het Luikse bekken, I950-1969

5.II De winst van of verlies aan mijnwerkers uit andere Belgische bekkens, I950-1969

5.I2 De jaarlijks vertrokken Belgen en buitenlanders als percentage van hun totale bezetting, Luikse mijnen, I947-I972

5.I3 De jaarlijks vertrokken ondergrondse arbeiders naar nationaliteit als percentage van hun totale bezetting, I950-I972

5.I4 De redenen voor het vertrek van ondergrondse arbeiders uit de Luikse mijnen, I955-I975

5.I5 Het overlevingspercentage in de steekproef FNROM als geheel (naar uittredejaar)

5.I6 Het overlevingspercentage naar intredecohortes (steekproef FNROM naar uittredejaar)

5.I7 De overlevingspercentages naar afkomst, intredecohort I924-I930

5.I8 De overlevingspercentages naar afkomst, intredecohort I93I-I944

5.I9 De overlevingspercentages naar afkomst, intredecohort I945-I955

5.20 Het gemiddeld aantal gewerkte dagen per maand in de Luikse mijnen, I930-I940

5.2I Het gemiddeld aantal gewerkte dagen per maand in de Luikse mijnen, I946-I966

5.22 Het gemiddeld aantal gewerkte dagen in de Luikse en Kempische mijnen, per jaar (I930-I966)

5.23 Het gemiddeld aantal gewerkte dagen per jaar (geboortecohort I9Io en I920)

\section{Tabellen}

I.I De gemiddelde productie en de ondergrondse personeelsbezetting in de Luikse mijnen, vergeleken met de Kempische en Nederlandse mijnen, I928-I968

I.2 De geboortecijfers in de Belgische provincies, I846-I9I2 (indexcijfers, I846=ioo)

I.3 Het geboortecijfer per gemeente, Belgen en buitenlanders, I963-I964

2.I Het aantal werknemers in de steenkoolnijverheid naar geslacht (voor alle leeftijden), I846, I880 en I896

2.2 Het aantal vrouwelijke arbeidskrachten naar leeftijd in het Luikse bekken, I895-I900

2.3 De ordening van de mijnwerksters naar het aantal dienstverbanden

2.4 Het verband tussen het aantal dienstverbanden en het aantal verschillende 
werkgevers

2.5 De gemiddelde daglonen in Luik voor I846 (in BEF) 94

2.6 Het gemiddeld netto-dagloon ondergronds in de Belgische steenkoolnijverheid, I895-I900 (in BEF)

3.I Het aantal Belgen, buitenlanders en Duitse krijgsgevangenen in de Luikse mijnen, I945-1946 108

3.2 De geografische spreiding van displaced persons (DP's), I947 IIO

4.I De arbeidsproductiviteit in de steenkolenmijnen in enkele Europese landen $\quad$ I20

4.2 Het aantal geboortes per I.000 gehuwde vrouwen in de leeftijdsklasse I 5 tot 50 jaar in België, in de provincie Luik en in enkele Luikse gemeenten met een belangrijke industriële bevolking, I880-196I

4.3 Het aantal en aandeel buitenlanders onder de Luikse mijnwerkers, 1938-1947 (per 3I december)

4.4 Het aantal tewerkgestelde Russische krijgsgevangen in de Luikse mijnen per maand in 1943 en 1944 (tot en met juli)

5.I Het vertrek uit de Luikse mijnen. Cumulatieve percentages van het totaal aantal mijnwerkers in de intredecohort

5.2 Het percentage Belgische mijnwerkers woonachtig buiten de Luikse regio en buiten de provincie Luik bij het eerste dienstverband

5.3 De geografische herkomst van de arbeiders in de Luikse mijnen naar geboorteplaats, I924-1966

5.4 Het vertrek uit de Luikse mijnen naar afkomst. Cumulatieve percentages van het totaal aantal mijnwerkers naar afkomst in de intredecohort

5.5 De gepresteerde diensttijd per intredecohort, alle dienstverbanden ondergrondse mijnwerkers

5.6 De gepresteerde diensttijd naar afkomst (Luikenaren, pendelaars en buitenlanders), alle dienstverbanden

\section{Tabellen bijlagen}

B.I De aard van de beloning en de arbeidsduur van houwers in het Luikse bekken in 1896

B.2 De houwerslonen in het Luikse bekken in 1896

B.3 De loonkosten in de steenkoolnijverheid in de landen van de EGKS, in BEF 203

B.4 Het aantal personeelsleden onder akkoordlonen per mijn in 1956

B.5 De berekeningswijze van de akkoordlonen van ondergronders in 1956

B.6 De gemiddelde nettolonen per dag of per dienst in het Luikse bekken in BEF, I904-1966

B.7 De inkomende en uitgaande Belgen per jaar, I947-1972 217

B.8 De inkomende en uitgaande buitenlanders per jaar, I947-I972 2I8

B.9 De gebruikte codes voor de bekkens en NV's $\quad 225$

B.ro De gebruikte codes voor de mijnzetels $\quad 225$ 


\section{Kaarten}

I Het aandeel van de mannelijke mijnwerkers in het bevolkingsaantal per gemeente in de provincies Luik en Limburg (woonplaats), Igro

2 Het aandeel van de mannelijke arbeiders in de extractieve nijverheid op de totale bevolking per gemeente in de Luikse regio, I947

3 Het aandeel van de mannelijke arbeiders in de extractieve nijverheid op de totale bevolking per gemeente in de provincie Luik, I96I

4 De woonplaats van de mijnwerkers werkzaam bij de S.A. des Charbonnages d'Espérance et Bonne Fortune, Igog

5 De woonplaats van de Belgische mijnwerkers werkzaam bij de S.A. des Charbonnages d'Espérance et Bonne Fortune, 30 juni 1953

6 De woonplaats van de mijnwerkers werkzaam bij de S.A. des Charbonnages d'Ougrée-Marihaye, I9o9

7 De woonplaats van de Belgische mijnwerkers werkzaam bij de S.A. des Charbonnages d'Ougrée-Marihaye, 30 juni 1953

8 De woonplaats van alle Belgische mijnwerkers werkzaam in de Luikse steenkoolnijverheid, 30 juni 1953

9 Het aantal mijnwerkers in de Luikse regio naar woonplaats, Belgen en vreemdelingen/buitenlanders, I947

\section{Verklaring der tekens in tabellen en bijlagen}

- $\quad$ de gegevens ontbreken

- nul

$\mathrm{o}(\mathrm{o}, \mathrm{0}) \quad$ het getal is minder dan de helft van de gekozen eenheid

Niets (blank) een cijfer kan op logische gronden niet voorkomen 


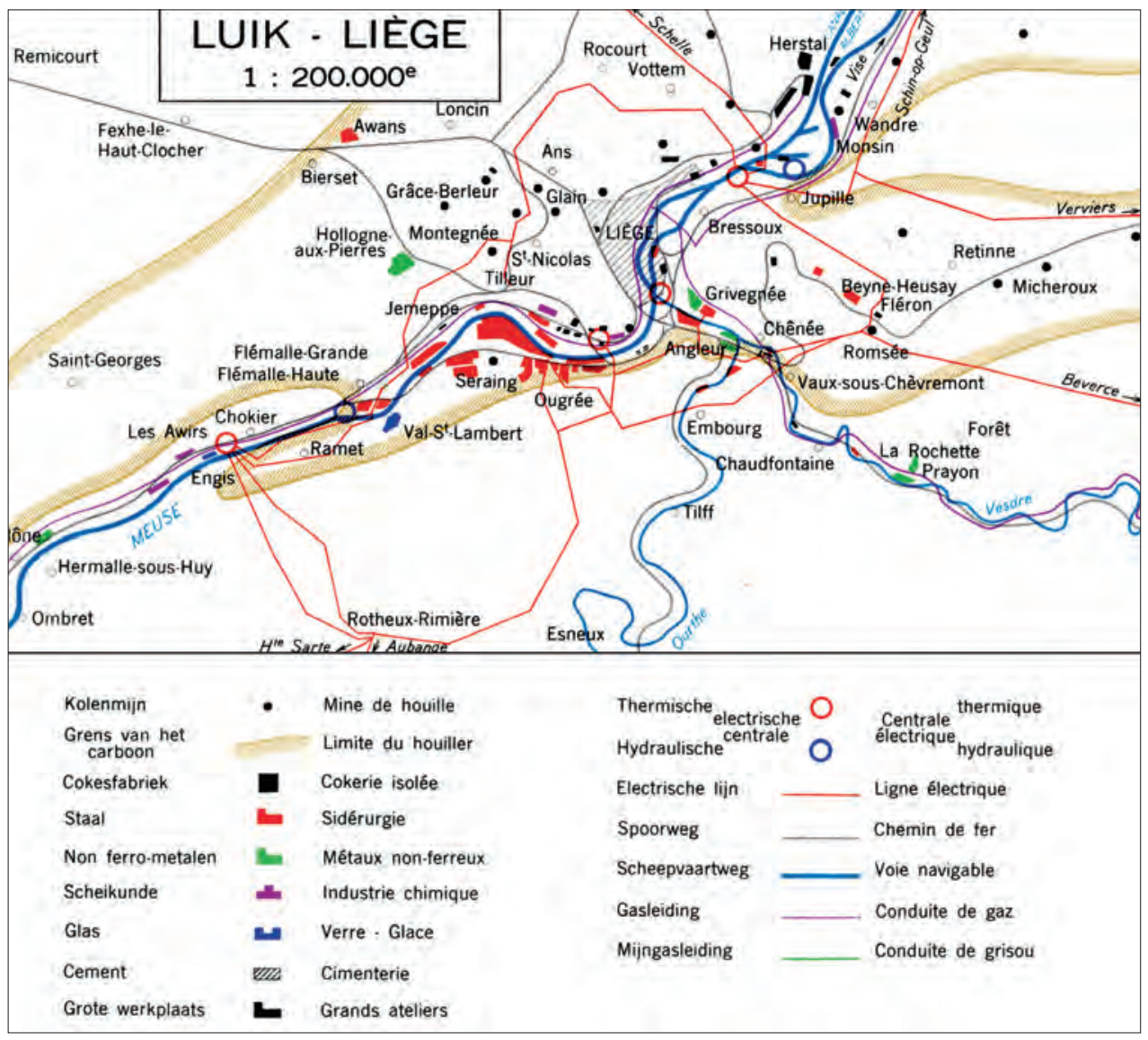

Het Luikse bekken: industrie en infrastructuur, ca. 1950. Atlas van België, uitgegeven door het Nationaal Comité voor Geografie (Brussel I950-I972) blad 40 (inzet: Luik). 


\section{Woord vooraf}

Over het algemeen is onderzoek doen en promoveren, doctoreren zoals de Vlamingen het noemen, een eenzaam gebeuren. Toch is het dankzij heel veel mensen dat ik deze opgave heb kunnen voltooien. In die zin was er enige gelijkenis tussen het traject van promoveren en mijn geliefde onderwerp, het mijnwerkersberoep. Een zware, uitdagende job, met soms weinig licht aan het einde van de tunnel, werd draaglijk door samenwerking, inspiratie en kameraadschap.

In de eerste plaats ben ik uiteraard mijn promotor Ad Knotter en copromotor Willibrord Rutten dankbaar voor hun begeleiding, constructieve kritiek, geduld en begrip. Dat dit boek nu voor u ligt is mede hun verdienste. In dat licht zeg ik ook dank aan de Stichting Maaslandse Monografieën, die bereid was mijn onderzoek in haar reeks op te nemen, en aan Uitgeverij Verloren. Ella Muyres-Schilder was mijn steun en toeverlaat bij het drukklaar maken van het boek. De schitterende foto's zijn afkomstig van de documentatiecentra van vzw Blegny-Mine en het Musée de la Vie Wallonne te Luik. De mooie GIS-kaarten werden verzorgd door Erwin Steegen, afdelingshoofd Archieven en collecties bij het Regionaal Historisch Centrum voor Limburg.

Ook een woord van dank aan Eric Vanhaute, hoogleraar economische en sociale geschiedenis aan de UGent. Door zijn aanmoediging te solliciteren ben ik in Maastricht terechtgekomen. Voor die onderzoeksplaats dank ik de Nederlandse Organisatie voor Wetenschappelijk Onderzoek (NWO), hoogleraar Ad Knotter en de Universiteit Maastricht.

Historisch onderzoek doen is niet mogelijk zonder de bereidwilligheid en hulpvaardigheid die ik heb ontmoet bij verschillende archiefinstellingen. In het bijzonder dank ik Bruno Guidolin van het CLADIC, Ludo Bettens van het IHOES, Eric Verbraeken van het RIZIV en de medewerkers van het Rijksarchief Hasselt en het Rijksarchief Luik. Verder kreeg ik welkome ondersteuning van professor Eric Geerkens (Universiteit Luik), onder meer bij het raadplegen van de archieven van het Mijnwerkerspensioenfonds, en van Thei Dibbets die, als vrijwilliger, de carrières van honderden mijnwerkers heeft ingevoerd in de computer.

Voor een jarenlange, prettige en inspirerende samenwerking dank ik Serge Langeweg. Samen gingen we de uitdaging aan de bijzonderheden van de arbeidsmarkt voor mijnwerkers te ontdekken. Dat gaandeweg de verschillen tussen de Luikse en Nederlandse markt groot bleken, zorgde voor al maar interessantere discussies. Toen Bart Delbroek, medekoempel, maar dan uit de Kempen, zich ook in de discussie mengde ontstond er een ware euregionale vergelijking. Doorheen de jaren werd mijn onderzoek ook gevoed door opmerkingen en aanvullingen van Leen van Molle, Frank Caestecker, Ben Gales, Peter Scholliers, Ernst Homburg, Hans Kasper en vele mede-aio's. Voor de inspirerende en bemoedigende gesprekken gedurende de eindspurt ben ik Fabian zeer dankbaar. 
Dat ik mij bijzonder snel thuis voelde in Maastricht had alles te maken met de collega's van het Sociaal Historisch Centrum voor Limburg (SHCL), waar ik mijn werkplek had. Naast de nodige professionele ondersteuning boden ze mij gedurende bijna zes jaar een hechte vriendschappelijke basis. Ik had het geluk na mijn tijd bij het SHCL nog meer fijne collega's te treffen: bij het E,til, bij Continium en bij Erfgoedcel Mijn-Erfgoed. Zij toonden altijd veel interesse en ik kon steeds rekenen op hun begrip.

Verder een dikke merci aan al die vrienden en familieleden die soms, wellicht tot vervelens toe, moesten aanhoren hoe het gesteld was met het onderzoek en de mijnwerkers. Niettemin werd er steeds geïnformeerd en geluisterd. Tot slot, maar niet in het minst, ben ik dankbaar dat ik gaandeweg het traject ook nog een wederhelft heb gevonden in Maastricht. Niet velen is het gegeven zoveel interesse, ondersteuning en vertrouwen te krijgen.

Maastricht, januari 2014 


\section{Inleiding}

De Belgische mijnen kan ieder met eigen ogen gaan bekijken. Zij liggen geen uur sporens van de Nederlandse grens af. Uit de Nederlandse mijnstreek is het zelfs maar een paar uur fietsen. Naar het Zuiden, waar de Luikse mijnen liggen ... Hier in Luik zitten we midden in de oude Belgische mijnstreek. Het is het Frans-talige land en de mijnen bieden een Franse aanblik. Het is eigenlijk veel erger. Terwijl er in het Noord-Franse mijngebied na de vorige wereldoorlog, tengevolge van de verwoestingen, heel wat bovengrondse installaties geheel zijn vernieuwd, staan hier nog de meest-ouderwetse gevaarten. Kleine mijntjes, waarop, zoals in Engeland, de productie verschrikkelijk laag moet zijn. Deze mijnen zijn het zorgenkind van de Belgische regering. De kostprijs van de kolen is hoog. Toch gaat men er maar zeer schoorvoetend toe over nu en dan een mijn te verlaten ... ${ }^{\text {. }}$

Dit citaat komt uit de Nederlandse Volkskrant van I947. De auteur, René Renckens was toen journalist van de Limburger Koerier, en zou later voorlichter worden van de Nederlandse Staatsmijnen en adjunct-directeur van de voorlichtingsdienst van de EGKS (Europese Gemeenschap voor Kolen en Staal). Het citaat maakt duidelijk dat de Luikse mijnen in vergelijking met de Nederlandse erg ouderwets waren. Het transformatieproces naar een geïndustrialiseerde maatschappij had hier veel eerder plaatsgevonden dan in de beide Limburgen.

Door de sterke ontwikkeling van de mijnbouw in de negentiende eeuw bestond er aan het begin van de twintigste eeuw in Luik reeds een gevestigde en geconsolideerde arbeidsmarkt voor mijnwerkers. De mijnwerker was geen nieuw en vreemd fenomeen, in tegenstelling tot beide Limburgen, waar het mijnwerkersberoep aanvankelijk nieuw en onbekend was. ${ }^{2}$ Daar ving de grootschalige productie van steenkool pas aan in de eerste decennia van de twintigste eeuw. Bovendien was de mijnwerker slechts één van de vele industriearbeiders in het sterk geïndustrialiseerde Luikse bekken. Er bestond in Luik geen mono-industrie, waarbij één enkele nijverheid vrijwel volledig voorziet in de industriële werkgelegenheid. Voor de vragers op de arbeidsmarkt, de mijnbedrijven, was er grote concurrentie in het aantrekken van werkkrachten.

In de loop van de twintigste eeuw werd het voor de Luikse mijnen steeds moeilijker voldoende mijnwerkers in Luik zelf te vinden. Sterker nog, na de Tweede Wereldoorlog stonden alle Belgische mijnregio's voor de uitdaging om voldoende arbeidskrachten voor het mijnwerk aan te trekken. In deze wederopbouwperiode bestond er een grote vraag naar kolen en daarvoor waren veel mijnwerkers nodig. Renckens wijst erop dat er zich in die periode weinig Belgen geroepen voelden om in de Luikse mijnen te gaan werken en dat er ook wat dat betreft grote verschillen waren met Nederland:

I Renckens, Kompels, 68-69.

2 Voor de arbeiders die naar de Waalse bekkens pendelden, was het uiteraard een minder vreemd gegeven. 


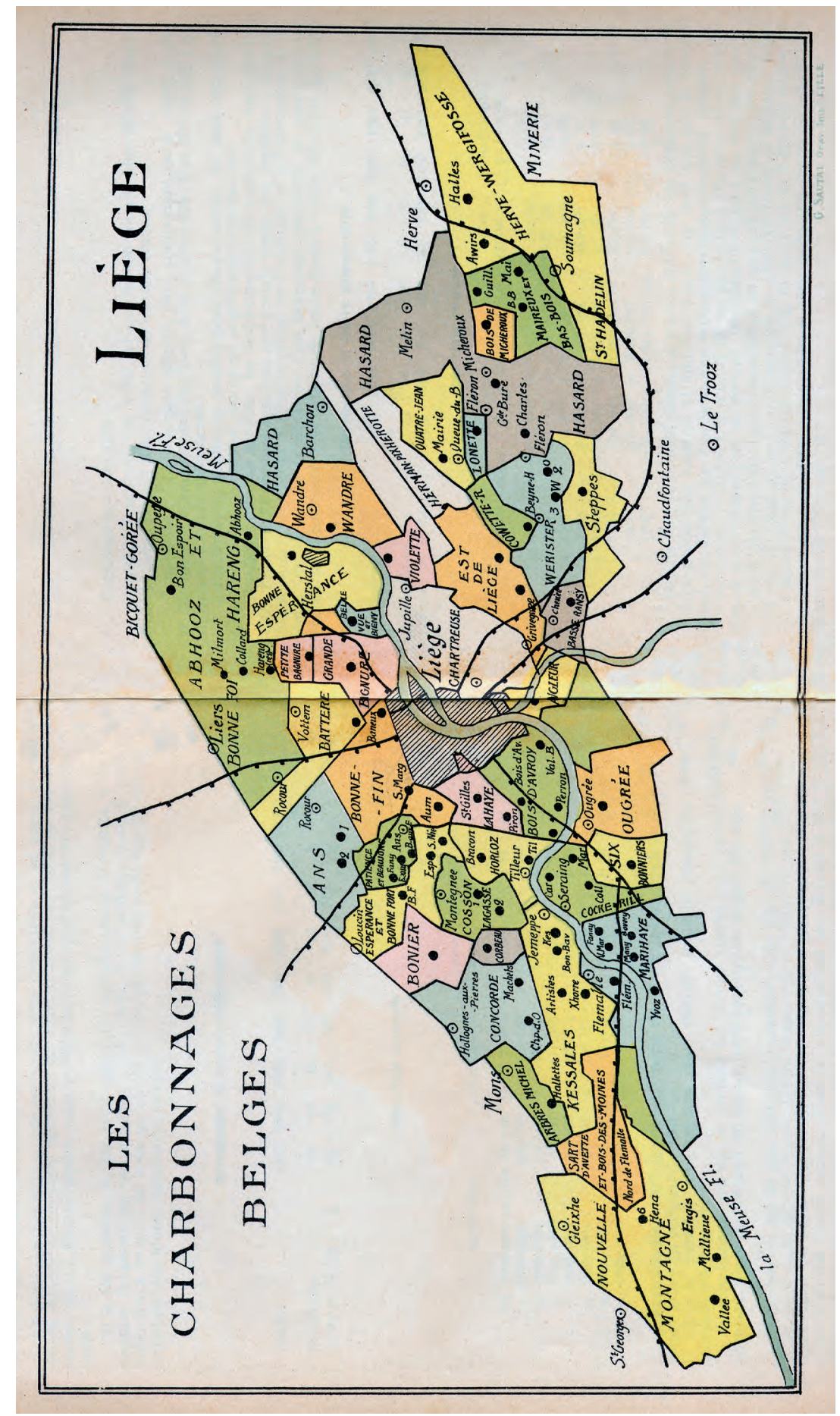

Situering van de kolenconcessies in het Luikse bekken, ca. I907. Les charbonnages: études financières sur les principales valeurs de charbonnages français et étrangers (z.p. 1907). Kaartblad: Belgique, Liège. 
Het schijnt onmogelijk te zijn jonge, Belgische arbeiders naar de mijnen te krijgen, omdat daar de omstandigheden nogal wat anders liggen dan in Nederland en de waardering voor het mijnwerkersvak, speciaal als vak, veel te wensen overlaat. Er wordt niet zo veel aandacht geschonken aan de vakbekwaamheid. Het liefst zet men buitenlanders aan de kool.3

Met dit citaat introduceert hij het centrale thema van deze studie: het tekort aan mijnwerkers in de Luikse kolenindustrie. Renckens onthult ook welk alternatief de Luikse mijnen vonden: buitenlandse mijnwerkers. Er zou zelfs een voorkeur zijn voor deze arbeidsmigranten. In alle mijnbekkens was het moeilijk om voldoende arbeiders te vinden en aan de mijn te binden, en overal maakte men gebruik van buitenlandse arbeidskrachten, maar Luik en bij uitbreiding de andere Waalse bekkens vormden hierin toch een tamelijk extreem geval. Het relatieve gebrek aan ontwikkeling van het Luikse bekken had een negatief effect op het arbeidsaanbod. Het arbeidstekort werd vlak na de Tweede Wereldoorlog zo acuut dat er een extreem groot beroep op arbeidsmigranten moest worden gedaan, in het bijzonder uit Italië. Ook in andere perioden en in andere steenkolenbekkens werd er een beroep gedaan op buitenlandse arbeidskrachten. Met deze studie zal ik echter aantonen dat het Luikse bekken uitzonderlijk was wat betreft het grote aandeel migranten in de mijnen.

Om het centrale thema te onderzoeken en bovenstaande stelling te onderbouwen werd een aantal centrale onderzoeksvragen gesteld: Hoe groot was dit arbeidstekort en hoe evolueerde het? Wat waren de oorzaken? Het vraagstuk van het arbeidstekort wordt benaderd vanuit zowel vraag- als de aanbodzijde. Wat betreft de vraagzijde zijn de volgende vragen van belang: Hoe trachtten de mijnwerkgevers het arbeidstekort op te lossen? Met welke problemen en uitdagingen werden zij daarbij geconfronteerd? Wat was de rol van de overheid? Was er sprake van deelmarkten voor bijzondere groepen mijnwerkers? In hoeverre slaagden werkgevers erin voldoende mijnwerkers aan zich te binden? Aan de aanbodzijde stelden we de volgende vragen: Welke groepen arbeiders kozen voor een beroep als mijnwerker? Wat was hun geografische en sociale afkomst en hoe verliepen hun carrières? Hoe was het demografische gedrag van de arbeiders in het Luikse bekken en welke gevolgen had dat voor het arbeidsaanbod in kwalitatieve zin? Hoe was het arbeidsverloop en in hoeverre verschilden groepen mijnwerkers in hun arbeidsmarktgedrag?

Het boek gaat in op de strategieën die door de mijnwerkgevers werden aangewend om voldoende arbeidskrachten te vinden. De oorzaken en pogingen tot oplossing van het arbeidstekort worden besproken in vijf deelstudies, waarin verschillende groepen op de arbeidsmarkt aan bod komen: behalve mijnwerkers uit de Luikse regio betreft dit ook vrouwen, migranten, pendelaars, grensarbeiders, en gedurende en na de Tweede Wereldoorlog krijgsgevangenen en displaced persons. Er wordt onderzocht wanneer, waarom en hoe deze groepen al dan niet met succes deelnamen aan de arbeidsmarkt voor mijnwerkers. De resultaten van de deelonderzoeken geven inzicht in het arbeidsmarktgedrag van deze groepen aan de aanbodzijde. 


\section{THEORETISCH KADER}

Voor de beantwoording van deze vragen naar groepsvorming op de arbeidsmarkt voor Luikse mijnwerkers vormt het sociologisch arbeidsmarktonderzoek van Van Hoof uit I987 een geschikt theoretisch uitgangspunt. Hij stelt dat de arbeidsmarkt niet homogeen is, maar gedifferentieerd, en dat er verschillende sociale groepen aan deelnemen. Het referentiekader van veel arbeidsmarktonderzoek wordt gevormd door een aan de neo-klassieke economie ontleende voorstelling van de arbeidsmarkt: een abstract model van vraag, aanbod en loonvorming. Van Hoof definieert de arbeidsmarkt echter als een sociale arena, waarin actoren bepaalde verhoudingen aangaan als individuen of sociale groepen. Hij omschrijft de arbeidsmarkt als: 'het totaal van processen dat plaatsvindt tussen de vragers en aanbieders van arbeidsvermogen en de daarmee samenhangende regels en institutionele voorzieningen, waardoor zowel de allocatie als de prijsvorming van arbeid tot stand komt' . ${ }^{4}$

Wat deze benadering bruikbaar maakt is de aandacht voor de bredere maatschappelijke betekenis van de arbeidsmarkt: 'De verhoudingen op de arbeidsmarkt zijn van grote invloed op de geleding in de samenleving naar groeperingen met van elkaar verschillende bestaansmogelijkheden en levensstijl, die ongelijkwaardige posities in het maatschappelijk verkeer innemen'. De nadruk wordt gelegd op de verdelingsfunctie van de arbeidsmarkt: Hoe wordt het beschikbare werk verdeeld over het aanbod? Dit sluit aan bij de theorie van de dubbele arbeidsmarkt die de arbeidsmarkt beschouwt als een systeem met verschillende segmenten. ${ }^{5}$ Vereenvoudigd is er het bovenste segment: banen met werkzekerheid, hoge lonen en promotiekansen, en het onderste segment waarin zich de jobs met lagere lonen, weinig of geen werkzekerheid en promotiekansen bevinden. Verwant met de theorie van de dubbele arbeidsmarkt is het concept van arbeidsmarktsegregatie die onder meer tot uiting komt in de verschillende positie van mannen en vrouwen op de arbeidsmarkt. Horizontale segregatie houdt in dat mannen en vrouwen zich in duidelijk onderscheiden deelgebieden van de arbeidsmarkt concentreren. Naast horizontale is er ook verticale segregatie. Deze houdt in dat mannen en vrouwen zich op verschillende functieniveaus bevinden binnen eenzelfde sector. Vrouwen zullen eerder terug te vinden zijn in de lagere functies waar de lonen ook navenant zijn. ${ }^{6}$

Verder onderscheidt Van Hoof twee soorten arbeidsmarkten: de werkgelegenheidsmarkt waarop allocatie (ruil van arbeidsprestaties, ontmoeting van vraag en aanbod) plaatsvindt en waar individuele aanbieders en vragers elkaar ontmoeten; en de loonmarkt, waarop de lonen worden bepaald, en waar partijen en organisaties van werkgevers en werknemers (en de overheid als derde partij) elkaar ontmoeten (de collectieve arbeidsverhoudingen). In de voorliggende studie gaat het uitsluitend over de eerste, de werkgelegenheidsmarkt. ${ }^{7}$ Vragers en aanbieders hebben op deze werkgelegenheidsmarkt tegengestelde belangen: aanbieders willen een zo groot mogelijke werkzekerheid en een zo hoog mogelijke beloning; vragers hebben belang bij een soepele in- en uitschakeling van arbeid en zo laag mogelijke arbeidskosten. Van Hoof gaat ervan uit dat de arbeidsmarkt wordt gekenmerkt door een ongelijke

4 Van Hoof, De arbeidsmarkt als arena, Iо, I6, I77-I8I.

5 Ibidem, 40-44.

6 De Groot, Fabricage van verschillen, 17-32.

7 Van Hoof, De arbeidsmarkt als arena, I5-I6. 
machtsverdeling tussen vraag en aanbod. Het voordeel bevindt zich over het algemeen aan de vraagzijde. ${ }^{8}$ Hij geeft echter aan dat er ook deelmarkten te vinden zijn waar bepaalde categorieën arbeiders erin slagen een relatief sterke arbeidsmarktpositie op te bouwen. ${ }^{9}$ Het onderzoek zal uitwijzen dat dit ook voor de Luikse arbeidsmarkt voor mijnwerkers gold.

Naast Van Hoofs benadering worden ook enkele concepten uit het historisch arbeidsmarktonderzoek aan het theoretisch kader toegevoegd. Dit soort onderzoek biedt de mogelijkheid verschillende aspecten van sociale dynamiek in een interdisciplinair kader te combineren. In klassieke verklaringsmodellen wordt arbeidsmarktgedrag steeds teruggebracht tot economische factoren. ${ }^{\text {Io }}$ Het aspect prijsvorming zou zowel het gedrag van werknemers als dat van werkgevers kunnen verklaren. In een overzicht van de literatuur over historisch arbeidsmarktonderzoek geeft Leo Noordegraaf aan dat er meer aspecten dan prijsvorming voor de historische studie van de arbeidsmarkt relevant zijn: transformatie (dat wil zeggen de overgang van zelfstandige arbeid naar loonarbeid), mobiliteit en mobilisering, segmentering, werkgelegenheid en werkloosheid, en regulering. Deze aspecten vormen de invalshoeken met behulp waarvan het gedrag van verschillende groepen op de arbeidsmarkt, zoals allochtonen en autochtonen, mannen en vrouwen, vaste en losse arbeiders, wordt onderzocht. ${ }^{\text {II }}$ De aspecten en de verschillende groepen komen in de vijf hoofdstukken aan bod.

Hoofdstuk I behandelt de evolutie van de werkgelegenheid en de invloed van concurrerende nijverheden op de Luikse arbeidsmarkt. Hoe ontwikkelde zich de werkgelegenheid in de Luikse steenkoolnijverheid en hoe werd deze ingevuld? Anders dan in Nederlands- en Belgisch-Limburg was er in Luik geen sprake van een monocultuur. Alternatieve werkgelegenheid kon bijvoorbeeld gevonden worden in de ijzer- en staalnijverheid. Tevens wordt in hoofdstuk I het rekruteringsgebied van de Luikse mijnen geschetst, en worden pendelarbeid en grensarbeiders besproken. Dit sluit aan bij het aspect mobiliteit dat Noordegraaf omschrijft als 'de verplaatsing in geografische zin naar arbeidsmarkten waarop de migrant dezelfde positie in de arbeidsverhoudingen inneemt als in zijn oorspronkelijke verblijfplaats'. ${ }^{\text {I2 }}$ Onderzoek op microniveau geeft meer duidelijkheid over de afkomst van de arbeidskrachten. Zijn deze afkomstig uit andere industrietakken, rurale regio's, van over de provincie- en/of de landsgrenzen? In hoofdstuk 3 komen de arbeiders aan bod die van verder weg kwamen: de verschillende contingenten buitenlandse arbeiders, hun aandeel en de evolutie daarin worden geschetst. In hoofdstuk 5 is er aandacht voor het arbeidsverloop van de Luikse mijnwerkers.

De Luikse mijnen konden gezien hun lange voorgeschiedenis rekenen op een aanzienlijke groep geschoolde mijnwerkers. Buitenlandse arbeiders waren meestal ongeschoold en werden valk aangenomen om het zware en vuile werk te doen; ook hun kansen op promotie waren gering. Op die manier ontstond segmentering van de arbeidsmarkt naar aard en zekerheid van het dienstverband. Deze segmentering sluit aan bij de eerder genoemde theorieën rond de dubbele arbeidsmarkt en segregatie. Belangrijk is te onderzoeken in welke mate en wanneer deze segmenten voorkwamen, en welke de eventuele verschillen met de

8 Ibidem, $182-184$.

9 Ibidem, 204.

Io Matthijs, De mateloze negentiende eeuw, 6 .

II Noordegraaf, 'Arbeid en arbeidsmarkt', 369.

12 Ibidem, 36r. 
andere mijnbouwregio's waren. In hoofdstuk 2 wordt dieper ingegaan op het aandeel vrouwen op de Luikse arbeidsmarkt voor mijnarbeiders en welke positie zij innamen. Het aspect regulering is onder meer van belang in verband met de rol van de overheid. In hoofdstuk 4 waarin de situatie tijdens en na de Tweede Wereldoorlog wordt besproken, komt uitgebreid aan bod hoe de overheid in die periode grip tracht te krijgen op de arbeidsmarkt voor mijnwerkers in het kader van de wederopbouw. Waar mogelijk werd ook een vergelijkend perspectief nagestreefd met de nabijgelegen mijnregio's in Belgisch- en Nederlands-Limburg.

In het historisch arbeidsmarktonderzoek werd in navolging van het sociologisch onderzoek ook het begrip 'strategie' geïntroduceerd. ${ }^{13}$ Dit begrip impliceert dat aan menselijk gedrag bepaalde motieven en doelbewuste keuzen ten grondslag liggen. Een uitgangspunt dat in historisch onderzoek moeilijk te operationaliseren is omdat er vaak niet meer kan gevraagd worden naar motieven en intenties. Wat wel onderzocht kan worden zijn de uitkomsten van de keuzen. ${ }^{14}$ In voorliggende studie wordt het arbeidsmarktgedrag bestudeerd als indirect bewijsmateriaal voor strategisch gedrag van zowel mijnwerkgevers als mijnwerkers. Voor de werknemers worden transities van professionele aard op het microniveau bestudeerd. Denk hierbij aan verandering van werkgever, overgang naar een andere taak binnen het bedrijf, emigratie naar een andere mijnregio en pendelarbeid. Dergelijke transities veronderstellen een welbepaalde keuze, en het is de bedoeling te achterhalen wat de bepalende factoren voor het maken van die keuzes zijn geweest. Het individu wordt hierbij gezien als een rationele actor, die actief en flexibel omgaat met transformaties en daar zelf ook aan bijdraagt. Ook vanuit de vraagzijde, de werkgevers, is er sprake van arbeidsmarktstrategieën: hoe slagen zij erin een voldoende groot en geschoold arbeidersbestand op te bouwen? Deze strategieën kunnen zich beperken tot de korte termijn, maar kunnen ook eerder een langetermijneffect beogen. Door het strategisch handelen te bestuderen kan de brug tussen micro- en macrogeschiedenis worden geslagen. ${ }^{\text {i5 }}$

\section{HisTORIOGRAFIE}

Historische studies waarin het begrip arbeidsmarkt centraal staat maken sinds het begin van de jaren I980 hun opmars. In internationale studies over mijnbouwgeschiedenis ging het aanvankelijk vaak over de arbeidsverhoudingen. Vooral over de organisaties van mijnwerkers en werkgevers en de ideologieën achter deze organisaties is veel geschreven. ${ }^{16}$ Sinds het midden van de jaren 1980 werden ook concepten als gender, etniciteit en processen van klassenvorming geïntroduceerd. ${ }^{17}$ Ook werd steeds vaker de regio als niveau van onderzoek genomen, vooral onder aansporing van Klaus Tenfelde. ${ }^{18}$ Deze studie sluit aan bij die tendens naar een regionale aanpak. ${ }^{\text {ig }}$

\footnotetext{
I3 Baud en Engelen, 'Nawoord: arbeid, inkomen en gezinsstrategie', I49-158, I5I.

14 Knotter, 'Inleiding', 9.

15 Knotter, 'Inleiding'; Kok, 'Collectieve strategie en individuele levensloop'.

I6 Enkele voorbeelden: Edwards en Bird, Management control and union power; Jaffe, The struggle for market power; Campbell et al., Miners, unions and politics.

17 Berger, 'Introduction', I-II.

I8 Tenfelde, 'Towards a social history of mining'; Feldman en Tenfelde, Workers, owners and politics in coal mining.

I9 Voor een historiografisch overzicht over mijnwerkersgeschiedenis in de negentiende en twintigste eeuw zie: Tenfelde, 'The Miners' Community and the Community of Mining Historians', I2OI-I215; Phimister, 'Global Labour History', 573-589.
} 
Onder invloed van de sociale wetenschappen werd er pas in de jaren I980 in België en Nederland aandacht geschonken aan de historische studie van arbeidsmarkten als invalshoek voor het samenbrengen van economische en sociale verschijnselen. Voordien werd arbeid net zoals in de internationale studies voornamelijk bestudeerd vanuit het perspectief van de arbeidersbewegingen. ${ }^{20}$ Ook een aantal grote figuren uit de ondernemerswereld, zoals in Luik Cockerill, vormden meermaals een interessant onderzoeksonderwerp. ${ }^{21}$ Nog maar weinig is er getracht beide partijen en hun dynamiek in één werkstuk te verenigen, zoals in het artikel van Kurgan-Van Hentenryck en Puissant over 'Industrial relations in the Belgian coal industry', waarin zowel de werknemers, de werkgevers als de overheid en hun onderling overleg worden besproken. ${ }^{22}$ In onderzoek naar de technologische ontwikkeling en rationalisering in de mijnbouw komen ook vaak arbeidsmarktaspecten aan bod. ${ }^{23}$

In vergelijking met de Luikse regio verschenen er relatief veel wetenschappelijke studies over de Kempen en Nederlands-Limburg. ${ }^{24}$ Recent (in 20II) publiceerde Serge Langeweg een studie over mijnbouw en arbeidsmarkt in Nederlands-Limburg en presenteerde Bart Delbroek de resultaten van zijn onderzoek in een nog niet gepubliceerd proefschrift over de arbeidsmarkt voor mijnwerkers in Belgisch-Limburg. ${ }^{25}$ Serge Langeweg onderzocht de opbouw, uitbouw en consolidatie van de Nederlandse arbeidsmarkt voor mijnwerkers, waarbij aspecten als herkomst, werving, mobiliteit en binding aan bod komen. Bart Delbroek richtte zijn onderzoek op de dagelijkse werking van de arbeidsmarkt in de Kempische mijnen. In 1999 verscheen er een themanummer van Brood \& Rozen, een synthese van een colloquium over de sociale geschiedenis van de Belgisch-Limburgse mijnen. De redactie geeft daarin aan dat vooral de specifieke invalshoek vernieuwend was: af van de traditionele 'organisatiegeschiedenis' naar een benadering waarbij de actoren centraal staan. ${ }^{26}$ Een invalshoek die ook voorliggende studie inspireerde.

Een voorbeeld voor mijn onderzoek in Luik was tevens het onderzoek van Bart Pluymers en Mieke Van Haegendoren over de mijnwerkers in de Belgische Kempen. ${ }^{27}$ Deze studie maakte eveneens gebruik van steekproeven om bepaalde vragen over de werking van de arbeidsmarkt te beantwoorden; het onderzoek loopt evenwel maar tot aan de vooravond van de Tweede Wereldoorlog.

De reden voor de grotere aandacht voor de mijnindustrie in de beide Limburgen is waarschijnlijk dat in beide regio's de mijnindustrie de voornaamste werkgever was en andere industrieën van minder belang waren. In Luik ging de aandacht in de twintigste eeuw veel meer uit naar andere belangrijke industrieën in het Luikse bekken, bijvoorbeeld de ijzeren staalindustrie. Over de andere Waalse kolenbekkens, de zogenaamde Zuiderbekkens, verschenen er al eerder een aantal wetenschappelijke studies. Jacquemyns schreef in het

\footnotetext{
20 Van den Eeckhout en Scholliers, 'Social history in Belgium'. Wat betreft Luik en Wallonië zie bijvoorbeeld: Vandendriessche, La centrale des Francs-Mineurs; Dethier, Centrale Syndicale des Travailleurs des Mines; Puissant, L'évolution du mouvement; Rouge Métal. 2I Zie bijvoorbeeld: Caulier-Mathy, 'Industrie et politique au Pays de Liège'; idem, 'Les dirigeants de l'industrie houillère belge'; Halleux en Bouchard, Cockerill; Gasson, Histoire des sciences et des techniques; Kurgan-Van Hentenryck et al., Dictionnaire des patrons en Belgique.

22 Kurgan-Van Hentenryck en Puissant, 'Industrial relations in the Belgian coal industry'.

23 Gales, Delven en slepen; Geerkens, La rationalisation dans l'industrie belge.

24 Zie bijvoorbeeld: De Rijck en Van Meulder, De ereburgers; Minten et al., Een eeuw steenkool in Limburg; Kreukels, Mijnarbeid: volgzaamheid en strijdbaarheid; Raedts, De opkomst, de ontwikkeling en de neergang van de steenkolenmijnbouw in Limburg.

25 Langeweg, Mijnbouw en arbeidsmarkt; Delbroek, 'In de put'.

26 Brood \& Rozen (1999) nr. 3.

27 Pluymers, De Limburgse mijnwerkers; idem, Personeelsbeleid.
} 
interbellum een belangrijke en uitgebreide studie over de Borinage. ${ }^{28}$ Het bekken rondom Charleroi kreeg veel belangstelling in de context van de grootste mijnramp uit de Belgische mijngeschiedenis: Marcinelle. ${ }^{29}$

Het is vooral de ontwikkeling van het Luikse industriebekken in de negentiende eeuw die werd bestudeerd, onder meer door Suzy Pasleau en René Leboutte ${ }^{30}$. Beide auteurs behandelen echter de arbeidsmarkt in zijn geheel, en niet enkel die voor mijnwerkers. Nicole Caulier-Mathy focuste zich wel grotendeels op de steenkolenindustrie en behandelt in haar onderzoek vooral de technologische vooruitgang, juridische aspecten en eigendomsstructuren. ${ }^{3 \mathrm{I}}$ Er werd minder aandacht besteed aan de Luikse steenkoolindustrie in de twintigste eeuw. Het belangrijkste overzichtswerk, en meteen ook standaardwerk voor de hele Luikse mijnarbeid, is dat van Claude Gaier, Huit siècles de houillerie liégeoise uit I988. In dit werk wordt de eeuwenlange geschiedenis van de Luikse mijnindustrie in al haar aspecten behandeld. Deze publicatie bevat ook een uitgebreide bibliografie. Helaas werd de tekst niet geannoteerd, waardoor het niet steeds mogelijk was te achterhalen uit welke bronnen of literatuur bepaalde bevindingen kwamen. Bovendien vormt de twintigste eeuw slechts een klein deel van de bestudeerde periode. Daarnaast bestaan er wel een aantal meer populariserende werken, onder meer een uitgave van André De Bruyn over Anciennes Houillères de la Région liégeoise, eveneens uit I988. Daarin is een overzicht van de belangrijkste mijnzetels en hun geschiedenis te vinden. ${ }^{32}$ Ook de uitgave 'Vivre et Survivre' van het Musée de la Vie wallonne en 'Des mines et des hommes au Pays de Liège' uitgegeven door o.m. de Provincie Luik schetsen op beeldende wijze de mijnen en mijnwerkers in de Luikse regio. ${ }^{33}$

Voor de twintigste-eeuwse geschiedenis van het Luikse, en bij uitbreiding de Waalse bekkens, zijn ook een aantal meer algemene studies ${ }^{34}$ van belang en studies over verschillende migrantengroepen in België, zoals die van Anne Morelli, Frank Caestecker en Idesbald Goddeeris. ${ }^{35}$ In 2007 verscheen er een themanummer van het Belgisch Tijdschrift voor Nieuwste Geschiedenis over recent onderzoek naar de geschiedenis van migranten in België, gevuld met bijdragen over de Poolse, Russische, Hongaarse, Turkse, Italiaanse, Spaanse en Griekse immigratie. ${ }^{36}$ De arbeidsmigratie naar de steenkolenmijnen speelt in deze bijdragen uiteraard ook een belangrijke rol. ${ }^{37}$ Recent verscheen bovendien nog een uitgebreide monografie met bijdragen over Vlaamse migranten in Wallonië. ${ }^{38}$ De invalshoek was echter anders dan in mijn onderzoek, waarbij getracht wordt alle mijnwerkers op de arbeidsmarkt in beeld te brengen. Zo is er een aparte deelstudie over het vrouwelijk arbeidsbestand in de

\footnotetext{
28 Jacquemyns, La vie sociale dans le borinage houiller; zie over de Borinage ook Puissant, L'évolution du mouvement ouvrier. 29 De Roeck et al., Tutti Cadaveri.

3o Pasleau, Industries et populations; Leboutte, Reconversions de la main-d'œuvre.

3I Caulier-Mathy, 'De wording van de steenkoolindustrie', 177-223; idem, 'Le patronat et le progres technique', 4I-6I; idem, 'La persistance de l'Ancien Regime', 53-89; idem, 'L'industrie houillère du bassin liégeois', I5I-174.

32 De Bruyn, Anciennes Houillères de la Région liégeoise.

33 Havelange et al., Vivre et survivre; Remits, Des mines et des hommes au Pays de Liège.

34 Bijvoorbeeld: Demoulin en Kupper, Histoire de la Wallonie; Joris en Archambeau, Wallonie; Hasquin, La Wallonie.

35 Bijvoorbeeld: Caestecker, 'Centraaleuropese mijnwerkers in België'; idem, 'Vervanging of verdringing', 309-325; Morelli, Geschiedenis van het eigen volk, en Goddeeris, De Poolse migratie in België.

36 Belgisch Tijdschrift voor Nieuwste Geschiedenis XXXVII (2007) 3-4. Bijna twintig jaar eerder wijdde het BTNG reeds een themanummer aan de steenkoolnijverheid in West-Europa, naar aanleiding van een internationaal colloquium op initiatief van de groep 'Mine et Mineurs': Techniques, pouvoirs, main d'oeuvre et reconversion dans les mines de charbon d'Europe occidentale XIX (I988) I-2.

37 In 1988 verscheen er onder leiding van Michel Dumoulin ook een uitgebreide bibliografie over dit onderwerp: La question charbonnière et l'immigration en Belgique. Bibliographie rétrospective 1945-1970 (SYBIDI Document IV, I988).

38 Goddeeris en Hermans, Vlaamse migranten in Wallonië, 1850-2000.
} 
Luikse mijnen, een niet eerder uitgebreid bestudeerde groep (hoofdstuk 2).

Door het gebrek aan voorstudies over het Luikse kolenbekken in de twintigste eeuw kon voor deze studie slechts in beperkte mate worden voortgebouwd op bestaande publicaties. Het bleek niet vanzelfsprekend om zicht te krijgen op de meer dan 40 mijnbedrijven in het Luikse bekken, hun diverse mijnzetels en de grote verschillen in omvang en productieperiode. In tegenstelling tot de beide Limburgen was er geen duidelijke opstart- en sluitingsfase van de mijnen, maar kenmerkte de Luikse steenkolennijverheid zich door een langdurig en complex proces van fusies, tijdelijke productie-onderbrekingen en sluitingen. In de voorbereiding op voorliggend onderzoek is daarom een database opgebouwd met gegevens over alle mijnzetels in het Luikse mijngebied. ${ }^{39}$ Deze database werd onder meer benut voor het reconstrueren van de carrières van mijnwerkers (zie hoofdstuk 2 en 5). De gegevens zullen toegankelijk worden gemaakt voor verder onderzoek via het Centre Liégeois d'Archives et de Documentation de l'Industrie Charbonnière (CLADIC) te Blegny.

\section{ONDERZOEKSAANPAK: BRONNEN EN METHODOLOGIE}

Doel van deze studie was het verrichten van longitudinaal historisch onderzoek naar de ontwikkeling van de Luikse arbeidsmarkt voor mijnarbeid in de twintigste eeuw. Het was een bewuste keuze om vooral via kwantitatief onderzoek de probleemstelling te benaderen. In het eerder genoemde basiswerk van Claude Gaier komt de twintigste eeuw zoals gezegd maar summier aan bod en wordt vooral geput uit kwalitatief bronnenmateriaal. Voorliggend onderzoek hoopt hierop een aanvulling te vormen én een aanzet te geven tot verder, eventueel meer kwalitatief onderzoek. In de verschillende deelstudies wordt getracht inzicht te krijgen in de strategieën en het gedrag van zowel aanbieders als vragers op de arbeidsmarkt door op individueel niveau verzamelde microgegevens (via selecte steekproeven) over de mijnwerkers en hun carrières te combineren met macrogegevens (op basis van geaggregeerde gegevens) over de ontwikkeling van de werkgelegenheid in de steenkoolnijverheid en in de Luikse regio in het algemeen. Informatie werd verzameld over het arbeidsmarktgedrag van verschillende (groepen) mijnwerkers en gecombineerd met geaggregeerde gegevens omtrent productie, arbeidskracht, werkomstandigheden, lonen, en productiviteit. De onderzoeksvragen worden beantwoord door een combinatie van dit empirisch micro- en macro-onderzoek en waar mogelijk aangevuld met kwalitatieve gegevens zodat bepaald strategisch gedrag aannemelijk wordt gemaakt.

Voor dit onderzoek werd gebruikgemaakt van verschillende soorten bronnenmateriaal. Voor het micro-onderzoek werden (selecte) steekproeven genomen uit een collectie werkboekjes van mijnwerkers en uit de loopbaanadministratie van mijnwerkers (op zogeheten 'rekenkaarten') in het archief van het Nationaal Pensioenfonds voor Mijnwerkers (NPM) - Fonds National de Retraite des Ouvriers Mineurs (FNROM). Deze bronnen maken het mogelijk de carrière van individuele mijnwerkers te volgen. Uit beide bronnen werden selecte steekproeven genomen en databases aangelegd: een database met Io7 mijnwerksters op

39 Gebaseerd op de jaarlijkse overzichten van de actieve mijnen en hun productie en arbeidskracht in de Annales des Mines. Deze informatie werd nog aangevuld met de gegevens uit een bestand van Bruno Guidolin (CLADIC). 
basis van de werkboekjes, en een database met de carrières van bijna 800 mijnwerkers op basis van de 'rekenkaarten'. De collectie werkboekjes of livrets d'ouvriers werd geraadpleegd bij het Centre Liégeois d'Archives et de Documentation de l'Industrie Charbonnière (CLADIC). In deze werkboekjes werd de loopbaan van een werknemer genoteerd en dat maakt ze uitermate geschikt voor micro-onderzoek op individuele basis (zie voor een uitgebreide toelichting bijlage 6). Het archief van het FNROM kon worden geraadpleegd bij het Institut d'histoire ouvrière, économique et sociale (IHOES). Dit pensioenfonds, opgericht in I920, ontving de sociale zekerheidsbijdragen van zowel werkgevers als werknemers in de mijnindustrie. Het fonds hield een uitgebreide administratie bij over alle mijnwerkers in dienst van een Belgische mijn en is daarom bijzonder interessant voor het reconstrueren van loopbanen. In bijlage 8 wordt uitgebreid stilgestaan bij de historische achtergrond en de archieven van dit pensioenfonds. ${ }^{40}$

Voor het macro-onderzoek werd geaggregeerd cijfermateriaal uit statistische reeksen gehaald. De belangrijkste gepubliceerde bron van belang voor het verzamelen van cijfermateriaal over de Belgische mijnen is het tijdschrift Les Annales des Mines / Annalen der Mijnen. Deze periodieke uitgave werd voor het eerst gepubliceerd in 1896 onder redactie van de Administration des Mines / Het Mijnwezen. Het Mijnwezen ressorteerde onder het Ministère de l'Industrie et du travail, vanaf 1934 het Ministerie van Economische Zaken. In naam van de overheid controleerde deze instelling de toepassing van wetten en reglementen die betrekking hadden op de mijnindustrie. Om deze taak uit te voeren beschikte ze over een corps van ingenieurs die regelmatig de mijninstallaties van het land bezochten en inspecteerden. ${ }^{45}$ De Annales bevatten naast allerlei technische rapporten en studies, ook verschillende statistische gegevens, die jaarlijks werden gepubliceerd. Met behulp van deze gegevens konden statistische reeksen worden opgesteld over de productie en de productiviteit, het personeel, de loonvorming, en het rendement. De bijhorende archieven van het Mijnwezen bevinden zich in het Algemeen Rijksarchief te Brussel. Voor dit onderzoek werden hieruit ook enkele statistieken geraadpleegd, de gegevens die werden teruggevonden kwamen echter grotendeels overeen met de gegevens uit de Annales. Ongetwijfeld bevatten de archieven van het Mijnwezen nog veel interessante kwalitatieve info die nooit terechtgekomen is in de gepubliceerde Annales. In verband met dit onderzoek is er echter voor gekozen de tot nu toe minder geraadpleegde en onderzochte archieven van het FNROM en FEDECHAR (zie verderop) te benutten.

Ook de volks- en industrietellingen van I846, I880, I896, I910, I920, I930, I947 en I96I werden geraadpleegd bij de Direction générale Statistique et Information économique (voorheen het Institut National de Statistique) te Luik. Beide reeksen moeten wel met de nodige voorzichtigheid worden benaderd. Door bijvoorbeeld de (te) lage opgaven door de telplichtigen geven de resultaten uit de industrietelling van 1846 minima aan. ${ }^{42}$ Ook in de Annales de Mines

40 Voor beide bronnen, werkboekjes en rekenkaarten, kon er omwille van praktische redenen geen a-selecte steekproef worden genomen. In het geval van de werkboekjes werd er voor gekozen een selectie te maken op basis van redactiedatum en geslacht om zeker voldoende respondenten voor de onderzoekspopulatie van vrouwelijke mijnwerkers te verzamelen. Door de resultaten vervolgens te vergelijken met eerder onderzoek werd de representativiteit getoetst. In het geval van de rekenkaarten was het omwille van de bewaarwijze van de bron (in archiefkasten geordend op geboortedatum) niet mogelijk a-select de respondenten te verzamelen. Hier werd de pragmatische keuze gemaakt om te selecteren op geboortedatum, een criterium dat mijns inziens weinig vertekening oplevert.

4I Van Doorslaer, 'Inleiding', 22.

42 De Belder en Vanhaute, 'Sociale en economische geschiedenis', I24. 
wordt aangegeven dat het aantal werknemers in realiteit hoger lag dan de opgaven in de statistieken. ${ }^{43}$ Door echter de statistische reeksen voornamelijk te gebruiken om tendensen aan te geven hoeft dit geen ernstig bezwaar te zijn.

De volks- en industrietellingen gaven tevens de mogelijkheid om plaatsgebonden informatie te verwerken. Op basis van deze gegevens werden met behulp van GIs (Geographical Information System) kaarten vervaardigd van de regionale spreiding van de mijnwerkersbevolking en het personeelsbestand in de Luikse mijnen. De kaarten werden gemaakt door dr. Erwin Steegen van het Regionaal Historisch Centrum Limburg. ${ }^{44}$ De gemeentelijke administratie gaf over de Luikse regio ook aparte studies uit in verband met de volkstellingen van I947 en I96I, waarin meer gedetailleerde informatie en statistieken zijn terug te vinden (zie hoofdstuk I).

In het Rijksarchief in Hasselt (RAH) werd het archief van de Fédération des Associations Charbonnières de Belgique (FEDECHAR), sinds Igog de patroonsorganisatie van de Belgische mijnen, geraadpleegd. Pas tijdens dit onderzoek werd het archief ontsloten via een inventaris. ${ }^{45}$ FEDECHAR was een onafhankelijke werkgeversorganisatie die alle Associations Charbonnières van de vijf Belgische bekkens en alle Belgische mijnvennootschappen verenigde. ${ }^{46}$ Haar taak was de studie van alle mijnvraagstukken en het formuleren van gemeenschappelijke doelen en maatregelen om deze te bereiken. Vooral voor geaggregeerd cijfermateriaal over de rekrutering van buitenlanders voor de mijnen en het arbeidsverloop was dit archief interessant. ${ }^{47}$ Ook werd in dit archief een interessant onderzoek teruggevonden over akkoordlonen. ${ }^{4}$ Verder werd er ook kwantitatieve informatie gehaald uit contemporaine rapporten. ${ }^{49}$

Andere geraadpleegde archieven zijn dat van de regionale werkgeversorganisatie, l'Association Charbonnière de la Province de Liège, dat zich bij het IHOEs bevindt, en de bedrijfsarchieven van een aantal mijnen. Deze bevinden zich bij de Archives de l'Etat à Liège (AEL), het IHOES en het CLADIC..$^{\circ}$ Deze archieven bevatten zeer gefragmenteerde informatie die weinig bruikbaar bleek voor een systematische analyse van de arbeidsmarkt voor Luikse mijnwerkers. In bijlage ro to 13 worden de geaggregeerde gegevens weergegeven waarmee een aantal van de grafieken in deze studie zijn vervaardigd. Er is een overzicht van de productiecijfers, het personeelsbestand en het aantal arbeidsmigranten naar herkomst.

\footnotetext{
43 Bovendien werd er een onderscheid gemaakt tussen het aantal ingeschreven arbeiders en de gemiddelde personeelsbezetting: 'le nombre des occupés est la moyenne arithmétique des nombres moyens calculés mensuellement; le nombre moyen mensuel est égal au total des journées prestées pendant les jours d'extraction divisé par le nombre de jours d'extraction'. In de meeste statistieken wordt het aantal ingeschreven arbeiders op 3I december weergegeven en ook voor dit onderzoek werd voor zover mogelijk dit telmoment aangehouden. Annales des Mines (I896) 508.

44 Zie bijlage 9 voor een verantwoording van het kaartmateriaal.

45 Van der Eyken et al., Inventaris van het archief van de Fédération des charbonnages de Belgique.

46 Ibidem, I4-I5.

47 RAH, archief FEDECHAR, inv.nrs. 567-597, 606-614, I579-1582.

48 RAH, archief FEDECHAR, inv.nr. 1679.

49 Bijvoorbeeld: Office National du Placement et du Chômage, Main-d'œuvre et production dans les mines (te raadplegen bij het CLADIC).

50 In de AEL worden onder meer de archieven van de S.A. Patience et Beaujonc, Bois d'Auroy, Bonne Espérance, Batterie et Violette, Colard, Gosson-Kessales, Grande Bacnure, La Minerie en Six Bonniers bewaard; in het IHoes de archieven van de S.A. Andenne, Ans et Rocourt, Batterie, Violette et Bonne fin. Het CLADIC beheert het archief van onder meer de S.A. Argenteau-Trembleur. Voor de mijnarchieven bewaard bij de AEL werd door Georges Hansotte een inventaris gemaakt. Zie bijvoorbeeld: Hansotte, Inventaire des archives du charbonnages des Six-Bonniers.
} 
De uit deze bronnen verzamelde kwantitatieve gegevens werden gecombineerd met kwalitatief bronnenmateriaal en een omvangrijk arsenaal aan secundaire literatuur over de regionale ontwikkeling in het Luikse bekken, de evolutie in de Luikse mijnindustrie en de Belgische steenkoolnijverheid. De Leuvense professor Demeure de Lespaul schreef decennialang bijdragen over 'le problème charbonnier belge', vaak in het Bulletin de l'Institut de Recherches Economiques. ${ }^{\text {I }}$ Over de Luikse regio verscheen er een aantal studies van econoom Louis Davin..$^{2}$ Bijzonder waardevol was ook een aantal contemporaine uitgaven, zoals de studies van geografen José A. Sporck en Omer Tulippe, het rapport Sauvy en een verzameling studies over de Luikse regio. ${ }^{53}$

\section{OPZET EN INDELING VAN DIT BOEK}

Deze studie maakt deel uit van een breder onderzoeksproject getiteld Mining labour markets in the Euregio Meuse-Rhine in the 2oth century. Dit behelst een lange-termijnanalyse van de arbeidsmarkt voor mijnwerkers in de voormalige mijnbouwregio's van de huidige Euregio Maas-Rijn in vergelijkend perspectief. In dit project participeerden de Vrije Universiteit Brussel, de RWTH Aachen en de Universiteit Maastricht. In 20II werden studies over de beide Limburgen afgerond. ${ }^{54}$ De comparatieve benadering werd een eerste keer toegepast in 2008 met het verschijnen van een themanummer in het Tijdschrift voor Sociale en Economische Geschiedenis over 'Arbeidsmigranten en grensarbeiders'. Daarin werd de inzet van arbeidsmigranten en grensarbeiders in de voormalige mijngebieden van België, Nederland en Aken met elkaar vergeleken. Eind 2008 verscheen in het jaarboek van het Sociaal Historisch Centrum voor Limburg een artikel waarin het aandeel buitenlandse arbeiders in de steenkolenmijnen van Luik en Nederlands-Limburg met elkaar werd vergeleken. ${ }^{55}$ Een herwerkte en Engelstalige versie verscheen in het Mitteilungsblatt des Instituts für soziale Bewegungen. ${ }^{6}$

In het voorliggende boek worden verschillende deelstudies gepresenteerd over de Luikse mijnarbeidsmarkt, die elk een eigen perspectief op het tekort aan arbeiders belichten. Bij elke deelstudie wordt het theoretisch kader, historiografie en methodologie verder uitgediept. De hoofdstukken zijn als afzonderlijke studies ontstaan; twee werden reeds eerder als artikel gepubliceerd. ${ }^{57}$ Daardoor komen er soms overlappingen en herhalingen voor. In totaal omvat het boek vijf hoofdstukken. Het eerste hoofdstuk (I) biedt een algemeen overzicht over de steenkoolwinning en de geografische en demografische aspecten van de arbeidsmarkt voor mijnwerkers in het Luikse bekken. Dan wordt in hoofdstuk 2 dieper ingegaan op de vrouwenarbeid in de Luikse mijnen. Tot in de twintigste eeuw hadden vrouwen in Luik een belangrijk aandeel in het personeelsbestand: Aan de vooravond van de Eerste

5I Bijvoorbeeld: Demeure de Lespaul, 'L'Industrie Charbonnière Belge et la Crise', I65-I88; idem, 'La solution du problème charbonnier belge', 303-320; idem, La situation inquiétante de l'industrie houillère belge; idem, L'industrie charbonnière belge et le plan Schuman.

52 O.m.: Davin en Priebe, Économie régionale sans frontière; Davin en Le Pas, Industries d'avenir; Davin et al., Problèmes de croissance.

53 Tulippe, Atlas de Belgique; Sporck, L'activité industrielle; Pressat en Sauvy, Le rapport Sauvy; Lambert en Mineur, L'économie de la région liégeoise.

54 Langeweg, Mijnbouw en arbeidsmarkt; Delbroek, 'In de put'.

55 Langeweg en Roels, 'Buitenlandse arbeiders in de steenkolenmijnen van Luik en Nederlands-Limburg'.

56 Langeweg, Roels en Knotter, 'Regional labour markets and international migration'.

57 Roels, “'In Belgium, women do all the work”', en 'Buitenlandse arbeiders in de Luikse steenkolenmijnen'. 
Wereldoorlog werkten er nog bijna 2500 vrouwen in de Luikse mijnindustrie, meer dan 6 procent van de totale personeelsbezetting..$^{8}$ Om beter zicht te krijgen op deze groep werd de onderzoeksperiode vervroegd naar het einde van de negentiende eeuw.

Een andere groep op de Luikse arbeidsmarkt voor mijnwerkers, de buitenlanders, wordt besproken in hoofdstuk 3. Uit het onderzoek naar de migrantenarbeid in de Luikse mijnen bleek de periode tijdens en na de Tweede Wereldoorlog een omslagpunt. Het arbeidstekort tijdens die periode en de daaropvolgende maatregelen van zowel de mijnwerkgevers als de overheid vormen het onderwerp van hoofdstuk 4. In het laatste hoofdstuk komen het arbeidsverloop en de carrières van de Luikse mijnwerkers aan bod. In het besluit worden de resultaten uit de verschillende deelonderzoeken en hoofdstukken samengevat en wordt getracht een aantal algemene conclusies te trekken.

Het eindpunt van het onderzoek werd ingegeven door praktische overwegingen. In 1974 wordt de algemene migratiestop afgekondigd. Bovendien wordt er vanaf 1974 in de Annales de Mines geen onderscheid meer gemaakt tussen de Zuiderbekkens. Waar mogelijk werden de cijfers aangevuld met eerder genoemde andere statistische reeksen. Sommige mijnen in het Luikse waren reeds aan het eind van de jaren 1950 gesloten (Grand Makets, Val Benoît), andere zetels zetten de bedrijvigheden voort tot het einde van de jaren 1970 (ArgenteauTrembleur). ${ }^{59}$ In 1980 volgde dan de sluiting van de laatste mijn in het Luikse bekken: de NV Argenteau-Trembleur (vandaag beter bekend als de mijn van Blegny).

58 'Economische statistiek van de extractieve nijverheden en van de metaalnijverheid, I9I3', Annales des Mines, rgrg.

59 Voor een overzicht van de mijnsluitingen in het Luikse bekken zie bijlage 2. 


\section{Hoofdstuk I Steenkoolwinning en arbeidsmarkt in het Luikse mijnbekken: een overzicht}

In dit hoofdstuk wordt een overzicht gegeven van de ontwikkeling van de steenkoolwinning en de arbeidsmarkt in het Luikse steenkolenbekken in de twintigste eeuw. In het begin van die eeuw (1903) bereikte de kolenproductie in Luik een hoogtepunt, na een gestage groei in de voorafgaande periode. $\mathrm{Na} 1903$ trad eerst stagnatie op en in de jaren I920 begon een geleidelijke productiedaling, die met ups and downs voortduurde tot aan de sluitingsperiode in de jaren I96o en I970. Doordat de Luikse mijnen reeds vroeg waren ontgonnen, werd de ontginning steeds moeilijker en arbeidsintensiever. Men moest steeds dieper graven en de makkelijk toegankelijke steenkolenlagen raakten uitgeput. Uitputting is het uiteindelijke lot van elke mijn. De geologische omstandigheden waren evenmin gunstig. Het erg 'verkreukelde' karakter van de Luikse steenkolenlagen, veroorzaakt door allerlei opstuwingen, verschuivingen, breuken en verzakkingen, deed de exploitatiekosten oplopen.

Door de uitputting en de geologische omstandigheden moest er steeds meer arbeid worden ingezet om een gelijke hoeveelheid kolen naar boven te halen. De arbeidsproductiviteit in de Luikse mijnen was relatief laag. Door de kleinschalige structuur van de industrie waren er weinig mogelijkheden om de arbeidsproductiviteit door technische innovatie en arbeidsbesparende investeringen te verhogen. Zolang er een markt voor de in Luik geproduceerde huisbrandkolen bestond bleven de Luikse mijnen winstgevend, maar de mijnondernemers konden hun productie alleen op peil houden door de inzet van meer arbeid. Die bleek echter steeds moeilijker te vinden. Door de vroege toepassing van geboortebeperking in Luik (en Wallonië in het algemeen) was de bevolkingsontwikkeling niet gunstig voor de creatie van een ruim arbeidsaanbod, en op de lokale arbeidsmarkt ondervonden de mijnen grote concurrentie van de arbeidsvraag in andere economische sectoren, zoals de staalindustrie. ${ }^{\mathrm{I}}$ De Luikse arbeidersbevolking kon bovendien steeds meer terecht in de handel- en dienstensector, die gedurende de twintigste eeuw verder uitbreidde. ${ }^{2}$

Om aan deze sectoriële krapte op de arbeidsmarkt het hoofd te bieden moesten de Luikse mijnondernemers een beroep doen op arbeidskrachten van buiten de Luikse regio. $\mathrm{Al}$ in de negentiende eeuw was er een omvangrijke migratie uit de aangrenzende Vlaamse provincies Limburg en Brabant ontstaan. ${ }^{3}$ Door de verbetering van de transportmiddelen nam die steeds meer de vorm aan van dagelijkse of wekelijkse pendel. Ondanks de concurrentie

I Pressat en Sauvy, Le rapport Sauvy, 8-9, 39-40; Sporck, L'activité industrielle, II4; Leboutte, 'Motivations des acteurs de la transition démographique', 299-300.

2 Sporck, L'activité industrielle, 57, 77, 94-95, 126.

3 Quairiaux, 'Migrants flamands en Wallonie avant I9I4', 349. 
van de Kempische mijnen op deze arbeidsmarkt sinds de jaren I920, bleven de Luikse mijnen een aanzienlijk contingent Vlaamse pendelaars aantrekken, vooral uit het zuiden van de provincie Limburg en de aangrenzende Brabantse gemeenten. Daarmee werden de arbeidstekorten echter niet opgelost. Al vóór de oorlog werden er immigranten aangetrokken. Vooral Polen, die reeds ervaring hadden opgedaan in Silezië of het Ruhrgebied werden gerekruteerd. Na de Tweede Wereldoorlog werd de arbeidsschaarste acuut. De steenkoolwinning kon in Luik alleen worden voortgezet door de massale inzet van arbeidsmigranten, in eerste instantie voornamelijk Italianen. Een bilateraal verdrag werd snel besloten aangezien Italië met een surplus aan ongeschoolde arbeiders en een tekort aan steenkool voor de wederopbouw zat. De overeenkomst verzekerde Italië van voldoende toevoer van steenkolen in ruil voor grote contingenten arbeidskrachten.

In dit hoofdstuk komen eerst de structuur en ontwikkeling van de steenkolenwinning aan de orde, en vervolgens de geografische en demografische aspecten van de mijnarbeidsmarkt. De binnenlandse pendel uit het Belgische rekruteringsgebied wordt in kaart gebracht op verschillende meetmomenten. Vervolgens wordt een overzicht gegeven van de grensoverschrijdende pendel en - vooruitlopend op hoofdstuk 3 - van aspecten van de buitenlandse arbeidsmigratie. In een laatste paragraaf wordt de arbeidsmarktontwikkeling in het Luikse bekken vergeleken met die in Nederlands-Limburg.

\section{BEDRIJFSSTRUCTUUR EN ONTWIKKELING}

\section{De bedrijfsstructuur}

Het Luikse mijnbekken was gevestigd op het meest oostelijke deel van een steenkoolgordel langs de Haine, Samber en Maas met een lengte van ongeveer zo kilometer en een maximale breedte (tussen Herstal en Beyne) van I3 kilometer. Deze steenkoolgordel, in totaal ongeveer $175 \mathrm{~km}$ lang, doorkruist Zuid-België en maakt deel uit van de Anglo-Germaanse steenkoolformatie die loopt van de Britse eilanden via Noord-Frankrijk en België naar Nederlands-Limburg en Duitsland. Het Luikse bekken omvatte een gebied van zo'n 32.000 hectare. ${ }^{4}$ Zijn maximale ontginbare diepte was I. 250 meter. Nog dieper werd alleen minderwaardige kool aangetroffen. De Luikse steenkoolmijnen waren minder diep dan bijvoorbeeld die in de Borinage: slechts drie mijnschachten bereikten een diepte van I.Ioo meter. De winbare kolenbundel bevatte een 50-tal steenkoollagen, waarvan de gemiddelde dikte in Luik het geringste was in België, namelijk minder dan $70 \mathrm{~cm}$, terwijl de minimum ontginbare pijlerhoogte $40 \mathrm{~cm}$ moest zijn.

De Luikse steenkoolafzettingen behoorden tot de moeilijkst ontginbare ter wereld. Oorspronkelijk werden steenkolenlagen vrijwel horizontaal gevormd, nagenoeg evenwijdig aan elkaar. Door later opgetreden krachten in de aarde werden deze lagen tot golvende lagen geplooid en soms door storingen uit hun verband gerukt. ${ }^{5}$ Er was geen dagbouw, alleen schachtmijnen, die vaak door watervoerende deklagen dienden te worden aangelegd.

4 Pasleau, Industries et populations, 62.

5 Van Rummelen, 'Carbonische steenkolen', 546-547; zie ook: Bunge, In het schijnsel van de mijnlamp, I5-I6. 
Water was het voornaamste probleem in het merendeel van de Luikse mijnen. Over het algemeen waren de Luikse mijnen minder gashoudend dan bijvoorbeeld de mijnen in de Borinage. Om I.00o ton steenkool te ontginnen moest men in 1957 in Luik een galerij van 33 meter ontsluiten, voor de andere Waalse bekkens een galerij van 22 meter en minder dan $\mathbf{2} 2$ meter in de Kempen. Men moest 6,5 $\mathrm{m}^{3}$ water oppompen per ton steenkool, in Henegouwen was dit 3,2 m³ en in de Kempen slechts o,6 $\mathrm{m}^{3}$. De ventilatie liep op tot $4.794 \mathrm{~m}^{3}$ lucht per ton ontgonnen steenkool, terwijl er slechts $3.346 \mathrm{~m}^{3}$ lucht nodig was in de Kempen. Er moest daardoor meer arbeid worden ingezet: in Luik had men 106 mijnwerkers nodig om netto Ioo ton steenkool boven te halen, in het bekken van Charleroi waren dat er 9I en in de Kempen slechts $67 .^{6}$

Het Luikse bekken werd opgedeeld in vijf subregio's met hun eigen kenmerken, gewoonten, producten en mijnwerkers. Men onderscheidde het (weinig belangrijke) bekken van Huy, dat van de Bovenmaas en Seraing, van het Plateau van Ans en Montegnée, dat van Luik en de Benedenmaas, en van het plateau van Herve. In het begin beperkte de steenkoolwinning zich tot de geërodeerde flanken van de Maasvallei, voornamelijk langs de linkeroever van de Maas en via verspreide schachtjes tot de heuvels van het plateau van Herve, waar de steenkool vrij dicht onder de oppervlakte voorkwam. Pas sinds het begin van de negentiende eeuw, met de toename van met stoom aangedreven bemalingspompen en extractiemachines en de ontwikkeling van de moderne ijzer- en staalnijverheid, ontstonden er mijnen op de vlakte van de Bovenmaas, bijvoorbeeld te Seraing. Later konden door de ontwikkeling van de spoorwegen mijnen ontsloten worden op de Luikse randplateaus van Haspengouw en Herve. Vooral de mijnen van de Benedenmaas kenden aan de vooravond van de Eerste Wereldoorlog een uitbreiding. ${ }^{7}$

Er werden reeds kolen gedolven in het Luikse bekken vanaf het einde van de twaalfde en het begin van de dertiende eeuw, vooral onder leiding van religieuzen (onder meer van de kathedraal Saint-Lambert). ${ }^{8}$ Vanaf de veertiende eeuw heerste er in het prinsbisdom Luik een bijzonder juridisch systeem, dat gebaseerd was op het principe dat de eigenaar van een stuk grond ook eigenaar was van de ondergrond. Dit principe werkte stimulerend voor het individueel ondernemerschap en zo werd de kolendelving een vaak uitgeoefende activiteit. De bijhorende klassieke uitbatingvorm, de zogenaamde sociétés des comparchonniers, een lokaal aandeelhouderssysteem, hield stand tot het begin van de negentiende eeuw. Deze comparchonniers verdeelden de kosten en vervolgens de opbrengsten en de verliezen. De aandelen waren overerfbaar, dus er ontstond op den duur vaak een veelheid aan aandeelhouders. ${ }^{9}$ Onder deze houders of vennoten vond men, althans in het begin, zowel eenvoudige mijnwerkers als handelaars en edellieden en grootgrondbezitters. Het eigendomsrecht op de steenkolenlagen en het systeem van comparchonniers betekenden een grote impuls voor de Luikse steenkoolnijverheid. Ze zorgden echter ook voor een aantal belemmeringen: beperkte middelen, zeer kleine en op routine draaiende ondernemingen, roofbouw, juridi-

6 Gaier, Huit siècles de houillerie liégeoise, 35; Pasleau, Industries et populations, 22.

7 Leboutte, Reconversions de la main d' oeuvre et transition démographique, 80, 92.

8 Gaier, Huit siècles de houillerie liégeoise, I24.

9 Leboutte, Reconversions de la main d' oeuure et transition démographique, 99. 


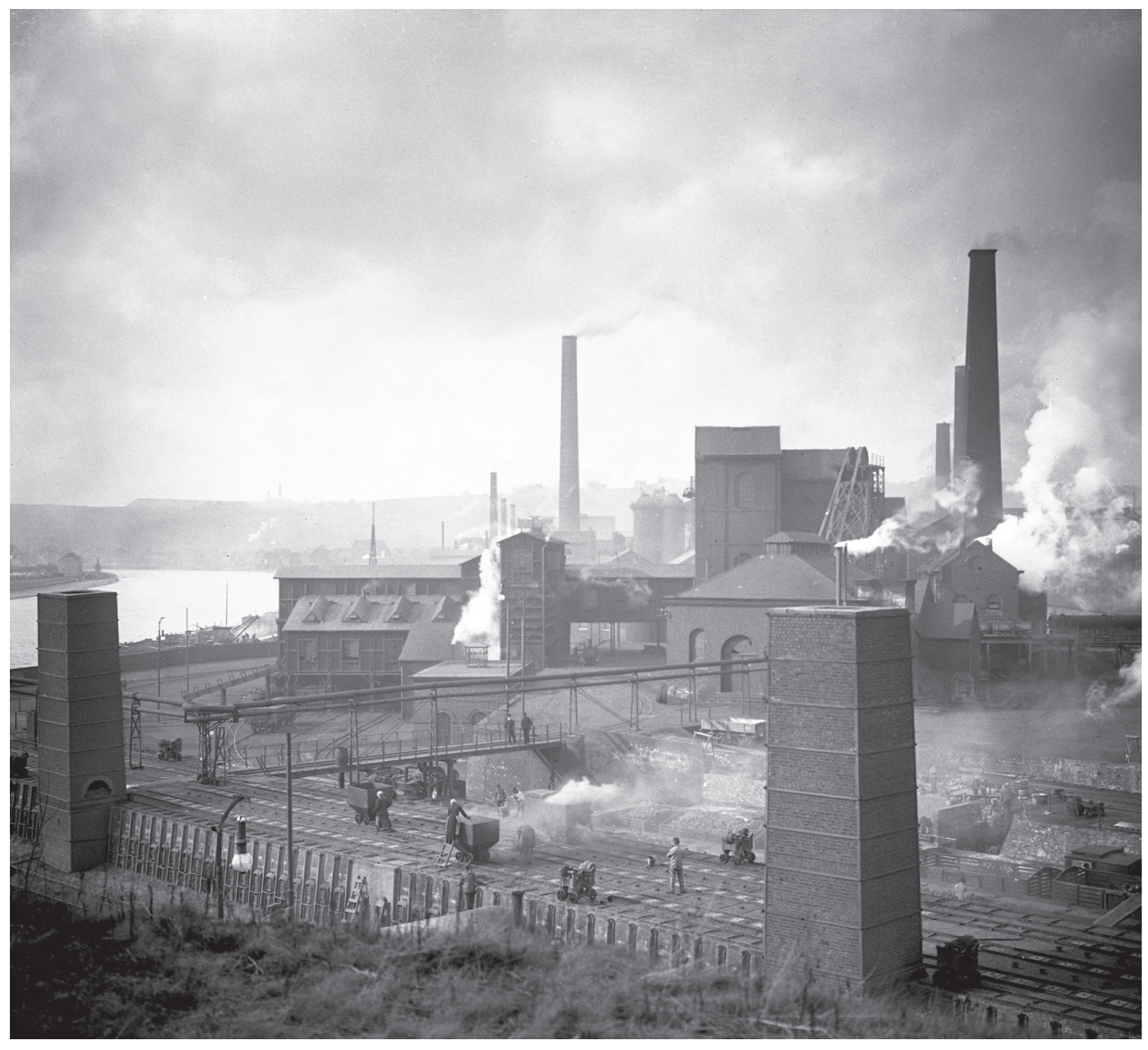

Zetel Grande Bacnure (Grand Bac) van de NV Bois d'Auroy te Sclessin, begin twintigste eeuw. Foto Gustave Marissiaux. Copyright Province de Liège - Musée de la Vie wallonne.

sche strijd tussen rechthebbers en concurrerende exploitaties, en gebrek aan professionele vorming van heel wat ondernemers.

Het napoleontische regime organiseerde de steenkoolontginning op een rationelere basis door aan de staat het recht voor te behouden om mijnconcessies te verlenen. In de Codes des Mines (Mijnwet) van I8Io werd het recht tot ontginning toegekend aan ondernemers die hun technisch en financieel kunnen hadden bewezen. Bovendien kon een concessie niet zomaar worden gedeeld en/of doorverkocht. Dit nieuwe regime noopte de comparchonniers zich te reorganiseren en te moderniseren. Om de ontginningskosten te drukken werd nu een rationele ontginning nagestreefd, dat wil zeggen er werd met de ontginning van de diepste steenkolenlaag begonnen. Hiervoor was het gebruik van stoommachines voor het uitpompen van grondwater en de ventilatie en de verbetering van het ondergronds transport vereist. De diepte van de zetels evolueerde mee en tegen I899 bedroeg de gemiddelde diepte 389 meter. ${ }^{\text {10 }}$ Bovendien vestigde men de uitbatingen zo dicht mogelijk bij de water-

Io Ibidem, 98, Io6. In het bekken van het Centre bedroeg de gemiddelde diepte 422 meter, in het bekken van Charleroi 570 meter 
en spoorwegen, teneinde de transportkosten te drukken. De kleine aandeelhouders werden verdrongen door industriëlen, grondeigenaars en grote renteniers.

De technische vooruitgang vergde veel geld en organisatie, en er ontstond een nieuwe scheiding tussen kapitaal (van de investeerders) en het mijnwerk zelf. De kleine, artisanale mijntjes begonnen langzaamaan tot het verleden te behoren. In navolging van John Cockerill investeerden verschillende staalbedrijven (bijvoorbeeld van S.A. d'Ougrée-Marihaye) in de Luikse steenkoolnijverheid om de toevoer aan brandstof voor hun eigen activiteiten te verzekeren. ${ }^{\text {II }} \mathrm{Zij}$ creëerden de eerste geïntegreerde, goed uitgeruste bedrijven, bemachtigden de beste steenkolenlagen en hadden bijgevolg een hoge productie. Tegen I842 was er sprake van ro6 mijnzetels, waarvan er dertien niet meer actief waren. De overblijvende 93 mijnzetels kunnen onderverdeeld worden naar graad van modernisering. 43 procent van de mijnzetels was van het artisanale type, dat wil zeggen er was geen pomp- of ophaalinstallatie aanwezig. Deze artisanale zetels bevonden zich vooral bij Seraing en Flémalle en op het plateau van Herve. 28 procent van de mijnzetels had alleen een ophaalmachine; deze bevonden zich op het plateau van Herve en in het zuidwesten van het Luikse bekken. De meest moderne mijnzetels waren uitgerust met zowel pomp- als ophaalmachines en lagen verspreid in het hele bekken. ${ }^{\mathrm{I} 2}$ Samen maakten ze 29 procent van de mijnzetels uit. ${ }^{13}$ Het Corps des Mines werd tegelijkertijd met de uitvaardiging van de mijnwet opgericht en speelde een regulerende rol. Hoewel de staat via het concessiesysteem controle uitoefende op de steenkoolnijverheid, was er in het Luikse bekken nooit sprake van een overheidsparticipatie of nationalisatie. Bij de oprichting van de EGKS na de Tweede Wereldoorlog in I95I was België het enige lid zonder staatsmijn(en). ${ }^{\mathrm{I}}{ }^{2}$

Het aantal uitbatingszetels nam gestaag toe tot het Luikse bekken er in het midden van de negentiende eeuw een honderdtal telde. Kleine uitbatingen die onvoldoende garanties boden qua rentabiliteit en veiligheid kregen geen wettelijke concessie en verdwenen. De Luikse mijnondernemingen bleven echter familiebedrijven, ook als zij de vorm van naamloze vennootschappen aannamen, hetgeen vanaf 1870 steeds meer het geval was. Sindsdien streefde men ernaar het aantal ondernemingen te concentreren om over grotere concessies en meer technische middelen te kunnen beschikken. De bedoeling was een zo groot mogelijk ontginbaar deel van de steenkolenlaag te verwerven, zodat de onderneming voldoende rendabel werd. ${ }^{15}$ Als gevolg hiervan begon het aantal mijnzetels en mijnondernemingen af te nemen. Deze beweging bleef voortduren tot het einde van de Luikse mijnindustrie. ${ }^{16}$ Dit was echter niet steeds een duidelijk lineair proces. Sommige mijnzetels werden enige tijd gesloten, bijvoorbeeld omwille van een ramp of waterdoorbraak, maar gingen weer open voor ontginning wanneer dit opnieuw rendabel werd. De steenkoolmijnen konden als vennootschappen meerdere mijnzetels uitbaten. Het aantal mijnzetels was aanvankelijk aan-

en in het bekken van Mons (Borinage), 666 meter. Annales des Mines de Belgique (I899) 662-667.

II Pasleau, Industries et populations, 86 .

12 Zij bevonden zich in de gemeentes Ans, Battice, Cheratte, Flémalle, Herstal, Herve, Jemeppe, Montegnée, Ougrée, Rocourt, Saint-Nicolas, Sclessin, Seraing, Tilleur, Vottem en Wandre.

13 Pasleau, Industries et populations, 63-65, I44.

I4 Minister van Buitenlandse Zaken Spaak (onder regering Van Acker III) deed hieromtrent de veelzeggende uitspraak: 'On ne nationalise pas des cadavres'. In: Gaier, Huit siècles de houillerie liégeoise, I24.

I5 Leboutte, Reconversions de la main d' oeuvre et transition démographique, roo.

I6 Zie bijlage 2 voor een overzicht van de mijnsluitingen in het Luikse bekken. Hierin werden ook de sluitingen opgenomen van zetels die achteraf weer in productie gingen. 


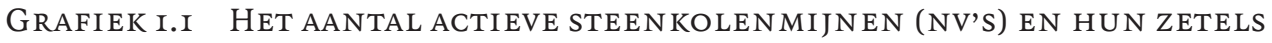
IN HET LUIKSE BEKKEN, I9O4-I979

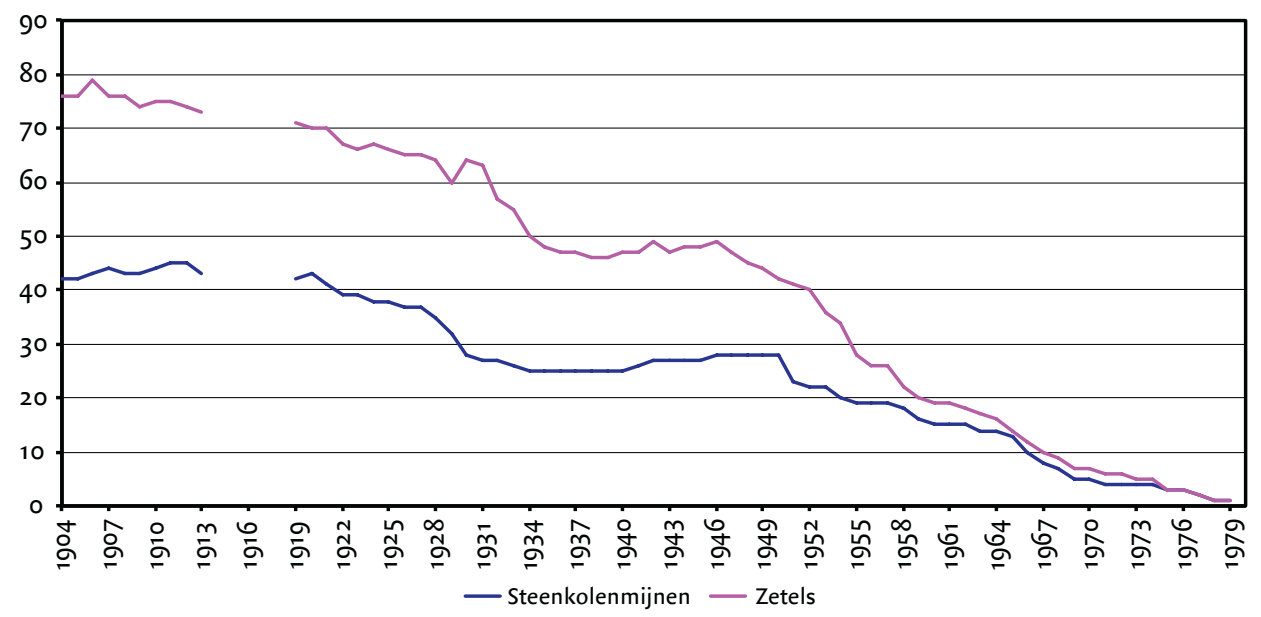

Bron: Annales des Mines de Belgique, I905-I970; Belgisch Kolenbureau, Basisstatistieken 1967, 5; 1980, 5.

zienlijk groter dan het aantal maatschappijen (grafiek I.I). Tegen het einde van de jaren I960 zien we dat de twee lijnen in grafiek I.I elkaar bijna raken. De bedrijfsconcentratie ging dus gepaard met een concentratie van de productie en de verwerking. Aan het eind baatten de meeste NV's nog slechts één mijnzetel uit. De uitgestrektheid van de concessies varieerde nogal en nam uiteraard toe naarmate er meer geconcentreerd werd. De grootste was die van de S.A. des Charbonnages de Wérister. In de achttiende eeuw begonnen met een kleine schacht in het land van Herve, eindigde zij met een concessie van 4.897 ha (verdeeld over twee gescheiden gebieden). De grootste concessie in één geheel was die van de S.A. des Charbonnages du Hasard van 3.609 ha.

Het is bij de analyse van een steenkolenbekken belangrijk rekening te houden met de soorten steenkool die er worden ontgonnen. Verschillende soorten steenkool hebben een verschillende waarde en afzetmarkt. Men onderscheidt vlamkool, gasvlamkool, gaskool, vetkool, magere kool en antraciet. Antraciet is het einde van de inkolingsreeks en bevat meer dan 90 procent koolstof en minder dan ro procent vocht en heeft dus de hoogste verbrandingswaarde. Om die reden was antraciet uitermate geschikt voor verwarmingsdoeleinden en daarom werd ze huisbrandkool genoemd. Bijna het volledige gamma steenkoolsoorten kwam voor in het Luikse bekken, met uitzondering van de meest vette (Flénu) kolen. ${ }^{17}$ Terwijl in het begin vooral vetkool en halfvette kool werd ontgonnen uit de jongste, bovenste lagen, werd nadien uit de diepere pijlers meer en meer magere (ongeveer 70 procent van de ontgonnen steenkool) en halfvette steenkool naar boven gehaald. ${ }^{18}$ Deze laatste soort werd aanvankelijk onder meer geleverd aan spijkermakers en smeden. In de jaren I950 werd halfvette kool nog ontgonnen door de S.A. des Charbonnages de Kessales, S.A. des

I7 Pasleau, Industries et populations, 574; Gezamenlijke Steenkolenmijnen in Limburg, Leerstof voor de Houwersopleiding, Deel I; Grond, 'Onze kolen', 5I-53.

I8 Zie bijlage 3 voor een overzicht van de soorten ontgonnen steenkool in het Luikse bekken begin jaren I930. 


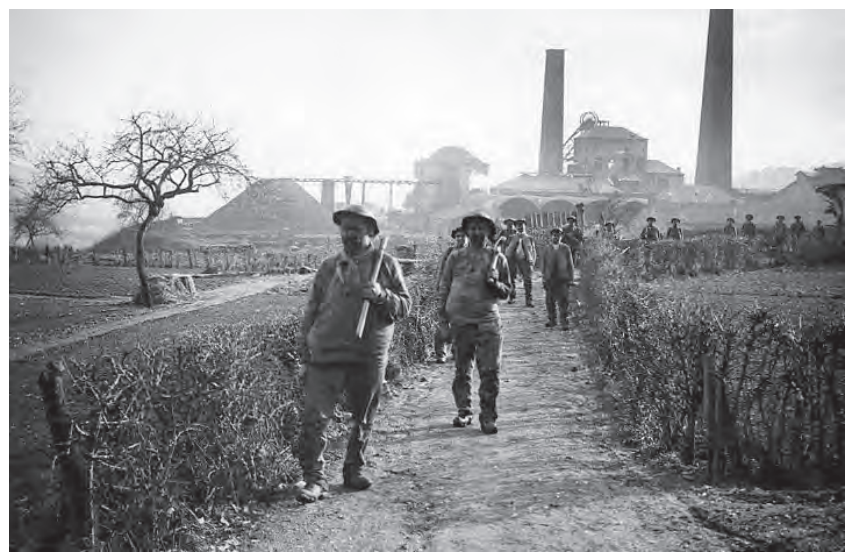

$\mathrm{Na}$ de shift, steenkolenmijn Horloz, begin twintigste eeuw. Foto Gustave Marissiaux. Copyright Province de Liège - Musée de la Vie wallonne.

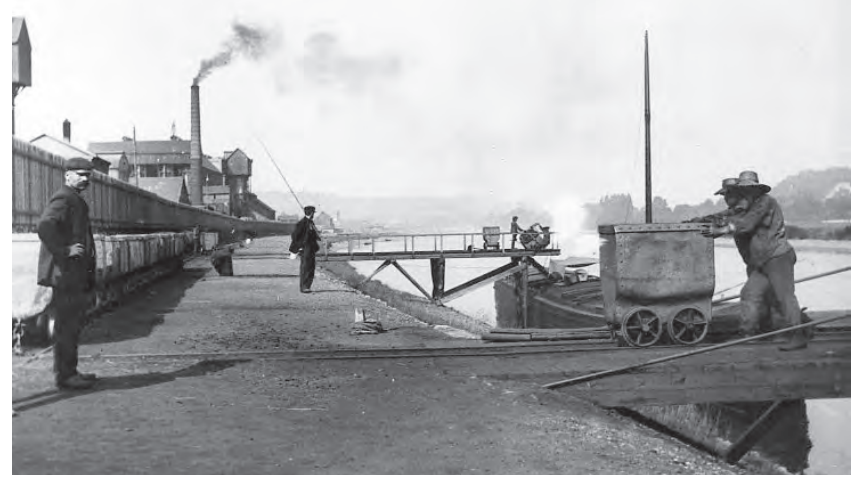

Laadhaven van de NV Nouvelle Montagne, begin twintigste eeuw. Foto Gustave Marissiaux. Copyright Province de Liège - Musée de la Vie wallonne.

Charbonnages de Cockerill en de steenkolenmijnen op het plateau van Herve: onder meer S.A. des Charbonnages de Wérister, S.A. des Charbonnages de Quatre-Jean et Minerie. Deze kolen werden gebruikt als industriekolen (en eventueel gemengd met uit andere bekkens afkomstige kolen van betere kwaliteit). De trois-quarts kolen (tussen I 6 en 2I procent vluchtige bestanddelen) werden toen nog alleen bovengehaald door de S.A. des Charbonnages de Marihaye en de S.A. des Charbonnages de Bois d'Auroy. ${ }^{\text {19 }}$

De magere steenkool werd oorspronkelijk gebruikt voor huishoudelijke doeleinden, in distilleerderijen en in kalk- en steenovens. Tijdens de crisis van I873-I875 kregen de Luikse steenkolenmijnen veel concurrentie van de mijnen uit het Rijnland (Pruisen), Engeland en Frankrijk. Tussen I870 en I9ıo kende het Luikse bekken (maar ook de steenkolenmijnen in Henegouwen) een lagere groei dan de Duitse bekkens en het bekken Nord-Pas-deCalais in Frankrijk. België kon de concurrentie het hoofd bieden met de ontwikkeling van een uitgebreid water- en spoorwegennet. De besparing in transportkosten hield de Belgische steenkolenprijzen onder controle. ${ }^{20}$ In het laatste kwart van de negentiende eeuw steeg bovendien de vraag naar huisbrandkolen door de demografische expansie, loonstijgingen, vooruitgang in de levensstandaard, de introductie van goedkope kachels vanaf 1885 , en de ontwikkeling van centrale verwarming. Deze stijgende vraag naar huisbrandkolen vormde

19 Atlas van België, blad 38 (koolmijnen II) opgemaakt door A. en A. Delmer.

20 Pasleau, Industries et populations, 65. 
een sterke stimulans voor de Luikse steenkolenindustrie. Zo werd de mijn van Cheratte, verlaten sinds 1877 door teveel wateroverlast, heropend in I9Io omdat de investeringen weer rendabel werden. ${ }^{21}$ De steenkolenmijnen richtten bovengrondse verwerkingsbedrijven op teneinde een goede kwaliteit steenkool te kunnen aanbieden. In I9oo waren er tien triageen wasinstallaties die samen ongeveer 200.000 ton steenkool (I4 procent van de Belgische productie) aanleverden. Tegen I920 waren er meer dan twintig verwerkingsbedrijven die samen meer dan 700.000 ton verwerkte steenkool produceerden, ofwel 25 procent van de totale Belgische productie in huisbrandkolen. Ze stelden bijna vijfhonderd arbeiders te werk. In I93 I waren er elf steenkolenmijnen die ook briketten produceerden en tien die eierkolen vervaardigden.

In I963 was het aandeel van Luik gegroeid tot 43 procent (992.00o ton) van de totale Belgische productie aan huisbrandkolen. Tegelijkertijd daalde het aantal mijnen met cokesfabrieken doordat de vetkoollagen in het Luikse bekken uitgeput raakten.22 Het Luikse bekken kon dus zijn bestaan verlengen als bevoorrader van huisbrandkolen. Tegen het midden van de twintigste eeuw produceerden vrijwel alle mijnen gelegen in het noorden van het bekken (Ans, Herstal en Cheratte) huisbrandkolen. ${ }^{23}$ Hierin verschilde het Luikse bekken in belangrijke mate van het Kempische mijnbekken, dat uitsluitend vetkool produceerde. De vraag naar vet- of industriekolen vanuit de staalnijverheid was veel minder stabiel dan de vraag naar magerkolen voor huisbrand. ${ }^{24}$ Bovendien kon de hoge prijs per ton voor huisbrandkolen, die sowieso hoger lag door de uitgebreide verwerking, wegens deze stabielere vraag langer worden gehandhaafd. Toch daalde deze na het begin van de jaren ig6o onherroepelijk door de concurrentie van andere, goedkopere en efficiëntere brandstoffen. ${ }^{25}$

TABEL I.I DE GEMIDDELDE PRODUCTIE EN DE ONDERGRONDSE PERSONEELS-

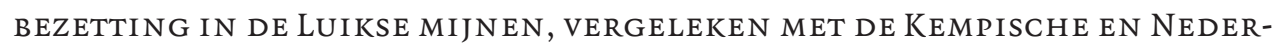
LANDSE MIJNEN, I928-I968

\begin{tabular}{|c|c|c|c|c|c|c|c|c|c|}
\hline & \multicolumn{3}{|c|}{ Kempen } & \multicolumn{3}{|c|}{ Ned. Limburg } & \multicolumn{3}{|c|}{ Luik } \\
\hline jaar & zetels & $\begin{array}{l}\text { gem. prod. } \\
\text { x I.00o ton }\end{array}$ & $\begin{array}{l}\text { gem. } \\
\text { bezetting }\end{array}$ & zetels & $\begin{array}{l}\text { gem. prod. } \\
\text { x I.00o ton }\end{array}$ & $\begin{array}{l}\text { gem. } \\
\text { bezetting }\end{array}$ & zetels & $\begin{array}{l}\text { gem. prod. } \\
\text { x I.000 ton }\end{array}$ & $\begin{array}{l}\text { gem. } \\
\text { bezetting }\end{array}$ \\
\hline I928 & 5 & 578 & $3 \cdot 508$ & I2 & 895 & 2.060 & 64 & 90 & 576 \\
\hline 1938 & 6 & I.089 & 3.560 & $\mathrm{I2}$ & I.I24 & I. 829 & 46 & II9 & 624 \\
\hline 1948 & 7 & I.I34 & 6.294 & $\mathrm{I} 2$ & 919 & 2.029 & 45 & 90 & 740 \\
\hline 1958 & 7 & I. 425 & 5.859 & $\mathrm{I} 2$ & 990 & 2.646 & 22 & I84 & I.I72 \\
\hline 1968 & 5 & I.697 & 4.943 & I0 & 666 & $2.67 \mathrm{I}$ & 9 & I67 & 832 \\
\hline
\end{tabular}

Bron: Eigen berekeningen op basis van: Delbroek, 'In de put', 470-47I, 474-475, 476-477; Verslag van den (Hoofd-) Ingenieur, resp. Inspecteur-Generaal der Mijnen; Annales des Mines de Belgique, I929-I969.

De Luikse mijnen waren opvallend kleiner dan de nieuwe, moderne Limburgse mijnen. Zoals uit tabel I.I blijkt, waren de Nederlandse en Kempische mijnbouw veel grootschaliger

2I Leboutte, Reconversions de la main d' oeuvre et transition démographique, I05, Io8.

22 Gaier, Huit siècles de houillerie liégeoise, IIo-II3.

23 Atlas van België, blad 38 (koolmijnen II) opgemaakt door A. en A. Delmer.

24 Minten et al., Een eeuw steenkool in Limburg, 85. Coppé, Problèmes d'économie charbonnière, 8r.

25 C.E.C.A. $1952-1962,464-465$. 


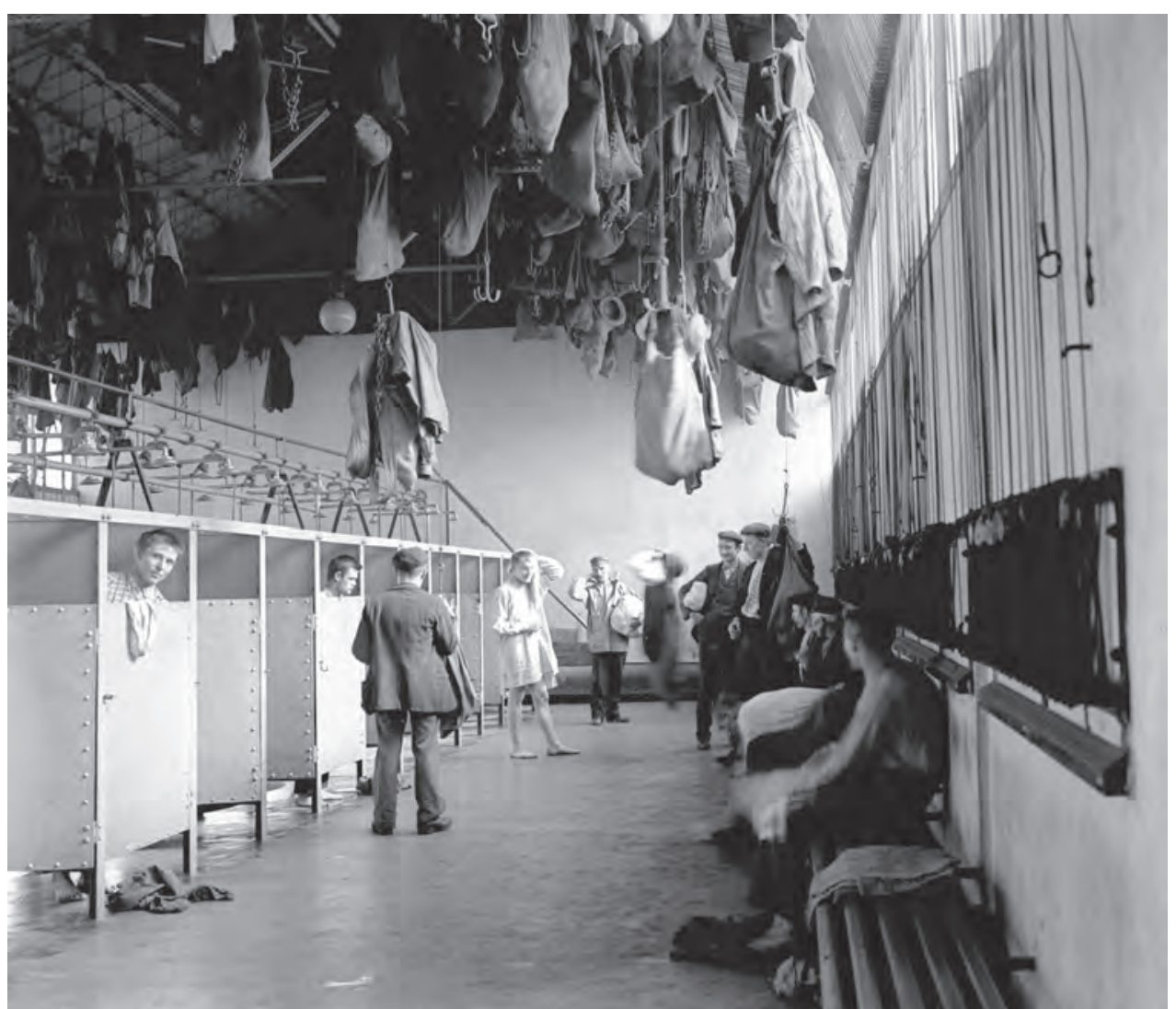

Badzaal van de NV Espérance et Bonne Fortune, begin twintigste eeuw. Foto Gustave Marissiaux. Copyright Province de Liège - Musée de la Vie wallonne.

opgezet dan de Luikse. Een voorbeeld kan dat illustreren: in 1938 had de kleinste mijnonderneming in Nederland, Willem-Sophia in Kerkrade, I.404 arbeiders in dienst. Daarentegen was de kleinste Luikse mijn, Arbre Saint-Michel, met 99 arbeiders bijna vijftien maal zo klein. Het grootste mijnbedrijf in Nederland, Staatsmijnen, had een totale bezetting van I9.03I mijnwerkers, ${ }^{26}$ verdeeld over vier ontginningszetels. Dat was ruim het vijfvoudige van de grootste Luikse mijn, Hasard, een bedrijf dat zeven ontginningszetels exploiteerde met een totaal van 3.480 mijnwerkers. ${ }^{27}$ De gemiddelde productie van de Nederlandse mijnzetels bedroeg in 1938 het vijftienvoudige van de Luikse.

Anders dan in de Kempen bleef de rol van de banken in het Luikse bekken beperkt. ${ }^{28}$ De Société Générale had wel enige invloed op de S.A. des Charbonnages de Bois d' Avroy en Cockerill, en de Banque de Belgique had aandelen bij de S.A. des Charbonnages d'Ougrée en Espérance et Bonne For-

26 Dit cijfer betreft alleen het personeel in dienst van de mijnbouwsector van het bedrijf.

27 Westen, 'Statistisch overzicht', 312-319; Annales des Mines de Belgique, 1939.

28 De Rijck en Van Meulder, De ereburgers, I7, 434; Gaier, Huit siècles de houillerie liégeoise, I3I; Caulier-Mathy, 'Les dirigeants de l'industrie houillère belge', 36 . 
Noël Bovy, opzichter bij de NV Ans et Rocourt, ca. 1920. Foto Famille Bovy. Coll. Blegny-Mine.

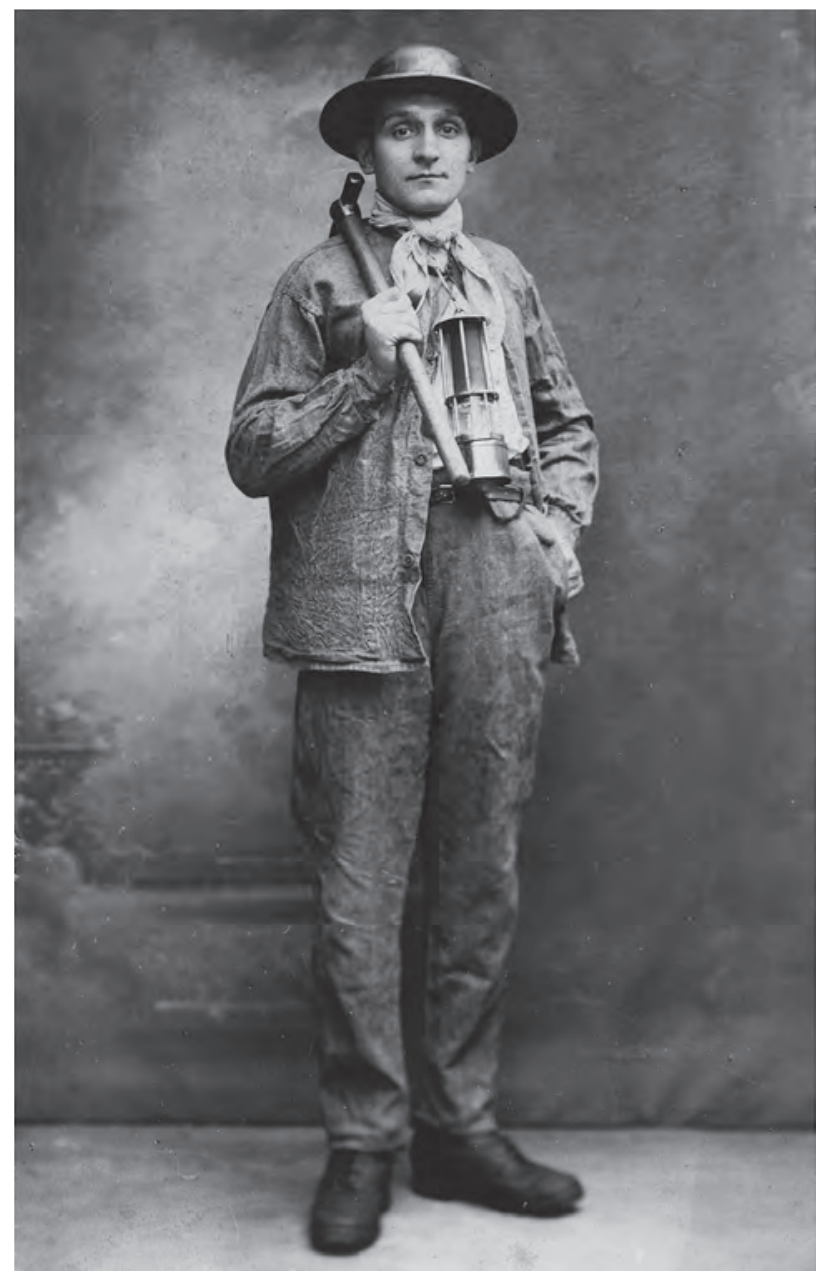

tune, maar de onafhankelijke mijnen waren in het Luikse bekken in de meerderheid. ${ }^{29}$ Enige invloed van de banken werd wel uitgeoefend door bemiddeling van de staalnijverheid, die altijd op zoek was naar de goedkoopste cokeskolen. ${ }^{30}$ Zoals vermeld werden die steeds minder bovengehaald in het Luikse bekken. Zo bleef de particularistische geest van de Luikse mijnondernemers behouden.

De ondernemers in het Luikse bekken werden gekenmerkt door onderlinge concurrentie, rivaliteit en isolement ook ten opzichte van de andere bekkens. Door de kolenproducenten werd vooral individualistisch gehandeld, er heerste een competitieve stemming en er was weinig neiging tot onderlinge verstandhouding. Bij pogingen om het kolenpatronaat landelijk te organiseren viel het uitgesproken particularisme en de hegemonie van de familiebedrijven in het Luikse bekken sterk op. ${ }^{31}$ Dit particularisme werd nog versterkt door het

29 Bijna tweederde van de Luikse mijnen is volledig onafhankelijk in I957, In: Hannecart, Roch, Le dernier carré, 368.

30 Gaier drukt het in zijn boek als volgt uit: 'guerre des gras (vet- of cokeskolen voor metaal en staalnijverheid) et des maigres (huisbrandkolen)'. In: Gaier, Huit siècles de houillerie liégeoise, I26.

3I In I929 werd Cobechar (Comptoir Belge des Charbon), het steenkolensyndicaat opgericht. Lidmaatschap was echter op vrijwillige 
feit dat de leiding van de steenkolenmijnen over het algemeen in handen was van een aan de Luikse Mijnschool afgestudeerd hoger kader. ${ }^{32}$ Zo ontstond een gesloten netwerk van Luikse kolenproducenten. Veel van deze afgestudeerden speelden een belangrijke rol in andere, zelfs buitenlandse bekkens, maar omgekeerd was er weinig buitenlandse interesse voor de Luikse mijnen. ${ }^{33}$ Ook waren de Luikse mijnbazen over het algemeen gekant tegen een al te sterke staatsinmenging en controle, tenzij uitzonderlijke situaties het onvermijdelijk maakten, zoals de kolencrisis van 1958 .

\section{De ontwikkeling van de steenkoolproductie}

Het Luikse bekken was tussen 1836 en 1900 verantwoordelijk voor 20-25 procent van de Belgische steenkoolproductie. ${ }^{4}$ De forse opbloei in de steenkoolproductie vanaf de tweede helft van de negentiende eeuw stagneerde al vóór het uitbreken van de Eerste Wereldoorlog. Aan de vooravond van die oorlog was de Luikse kolenmijnbouw zijn hoogtepunt reeds gepasseerd (zie grafiek I.2). Het Luikse bekken bereikte in I903 zijn maximumproductie met meer dan 6 miljoen ton steenkolen, wat toentertijd meer dan een vierde van de totale Belgische steenkolenproductie uitmaakte.

In vergelijking met de rest van de economie waren de Belgische steenkolenmijnen relatief gespaard gebleven van de verwoestingen tijdens de Eerste Wereldoorlog. Er kon al snel weer worden geproduceerd. Toch traden de structuurproblemen in de Waalse bekkens steeds meer op de voorgrond. De mijnen waren reeds voor een groot deel uitgeput en de versnipperde eigendomsstructuren bemoeilijkten zware investeringen. Hoge rendementen konden er niet meer worden gehaald en veel Waalse mijnen verdwenen hierdoor in de marginaliteit. Er was bovendien concurrentie van de nieuw geopende moderne mijnen in het Belgisch-Limburgse bekken. De vraag naar steenkool liep in het interbellum terug door een groter verbruik van petroleum in de scheepvaart, een opmars van hydraulische energie en de elektrificatie van de spoorwegen.

Ook werd de beschikbare steenkool steeds efficiënter gebruikt. ${ }^{35}$ Dankzij de grote kolenschaarste in de buurlanden en de langdurige mijnstakingen in de Verenigde Staten (vanaf 1920), Engeland (I92I en 1926) en de bezetting van het Duitse Ruhrgebied (tot eind I925) kon het Waalse bekken aanvankelijk toch een zekere winstmarge behouden. ${ }^{6}$ In de omringende landen werd er ondertussen echter gewerkt aan een rendementsstijging, waardoor België geconfronteerd werd met grote concurrentie en dumpingpraktijken. ${ }^{37}$ Een handelsakkoord uit 1925 gaf Duitsland de volledige vrijheid inzake de export van steenkool naar België, terwijl de Duitse binnenlandse markt ondertussen afgeschermd werd voor Belgi-

\footnotetext{
basis en in de praktijk controleerde het syndicaat slechts 7 procent van de totale Belgische output omdat vooral de Luikse mijnen dwarslagen. Pas in 1935 met de oprichting van het Nationaal Steenkolenambt werden alle steenkoolproducenten bij wet verplicht toe te treden. In: Minten et al., Een eeuw steenkool in Limburg, 88.

32 Ibidem, 25; Hannecart, Roch, Le dernier carré, 53, 57.

33 Er waren Franse aandeelhouders in de S.A. des Charbonnages d'Ans et Rocourt, de Franse Wendel familie had aandelen in de S.A. des Charbonnages de Six Bonniers en tot het einde van de Eerste Wereldoorlog was de S.A. des Charbonnages de Wandre in Duitse handen (Suermondt frères). In: Gaier, Huit siècles de houillerie liégeoise, 202-208.

34 Minten et al., Een eeuw steenkool in Limburg, 22.

35 C.E.C.A. $1952-1962,262$.

36 Minten et al., Een eeuw steenkool in Limburg, 83.

37 'Le Mouvement Syndical. II', I675-1676.
} 


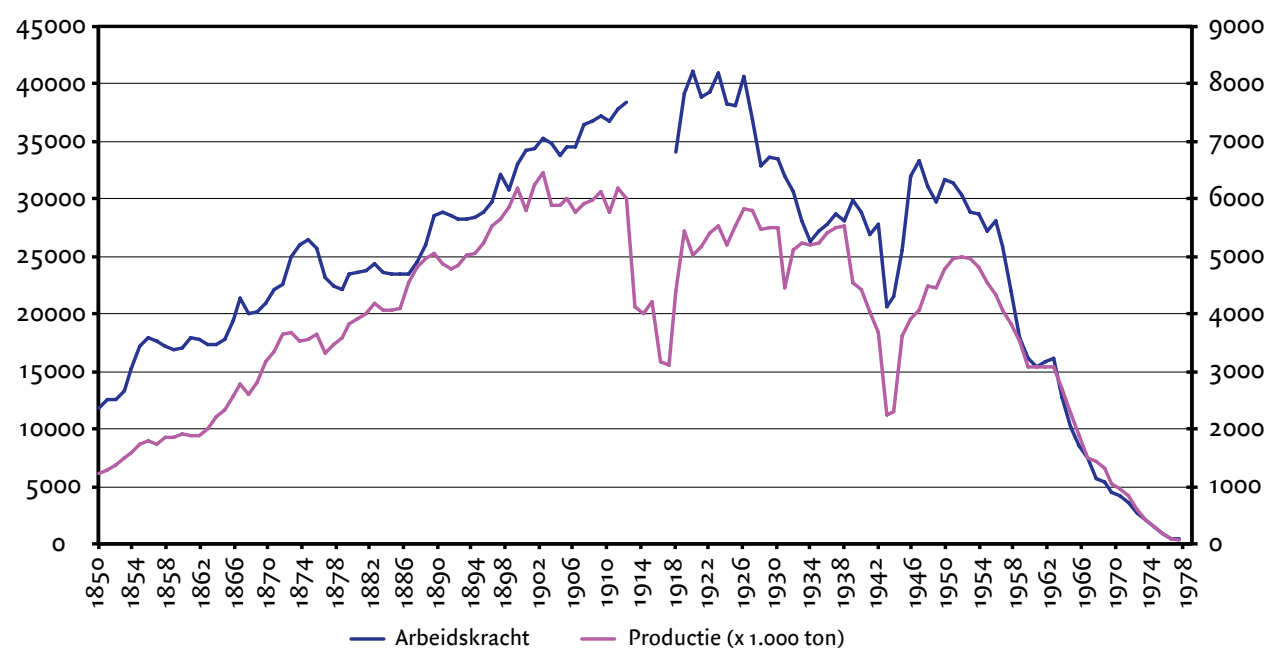

Bron: I850-I903: Pasleau, Industries et populations, 594-595; I900-I974: Annales des Mines de Belgique, I9oI-I980; I9I9-I922: Geerkens, La rationalisation dans l'industrie belge, I24I en I244 (Tableau 2 en 8); I940-I945: RAH, archief FEDECHAR, inv.nrs. 606-609: 'Jaarlijkse statistische overzichten' (Zie bijlage ro en II).

sche kolenimport. $3^{8}$ Tegen 1927 werd tussen Duitsland en Engeland een ware steenkolenoorlog gevoerd met erg lage steenkolenprijzen als resultaat.

De wereldwijde recessie na 1929 trof ook de Belgische steenkoolnijverheid. De vraag naar steenkool viel enorm terug en de overheid moest de mijnen ondersteunen. In tegenstelling tot de naoorlogse periode gebeurde dit nog op indirecte wijze: via importheffingen en contingenteringen. De druk was ook groot; zowel de mijnen als mijnwerkers zelf hadden er baat bij dat de overheid regulerend optrad. Vanaf 1933 volgden er productiebeperkingen om de crisis te bedwingen: werkloosheidsdagen werden ingevoerd. Tegen 1935 was de markt hersteld, mede door devaluatie van de Belgische frank met 28 procent en de algemene opleving van de conjunctuur, maar in 1936 daalde de productie weer als gevolg van de algemene mijnwerkersstaking in dat jaar. ${ }^{39}$ De buitenlandse afzetmarkt werd steeds belangrijker. Het grote aandeel van de export maakte de Belgische steenkoolindustrie uitermate gevoelig voor protectionistische maatregelen in de afzetlanden..$^{\circ}$

De dalende tendens in de productie zette zich door tot het uitbreken van de Tweede Wereldoorlog. Tijdens de bezetting werd het dieptepunt bereikt door een tekort aan arbeidskracht en productiemoeilijkheden. De situatie na de Tweede Wereldoorlog was van een andere orde dan de situatie na de Eerste Wereldoorlog. Ditmaal steeg de vraag naar brandstof enorm en steenkool was nog steeds de meest voor de hand liggende energiebron in WestEuropa. In tegenstelling tot de Franse en Duitse kolenmijnen waren de Belgische mijnen vrijwel onbeschadigd gebleven. Dit betekende dat de Belgische mijnen niet alleen voldoen- 
de steenkolen voor de Belgische wederopbouw moesten leveren, maar ook voor de wederopbouw in de andere Europese landen. Om dit te bereiken riep Achille van Acker in 1945 de kolenslag uit. Met de hulp van een mijnwerkersstatuut en bijhorende loonsverhogingen werd getracht voldoende arbeiders te verzamelen om een sterke productieverhoging te bereiken..$^{4}$ Belgische arbeiders waren echter steeds minder bereid het gevaarlijke, ongezonde en zware mijnwerk te doen en de mijnen moesten overgaan tot een massale rekrutering van buitenlandse arbeiders. De migratiepolitiek was gericht op het aanbieden van tijdelijke arbeidscontracten, waarmee periodes van grote vraag naar steenkool en arbeidstekorten konden opgevangen worden. Wanneer de conjunctuur dan omsloeg kon dit arbeidssurplus weer makkelijk worden afgedankt. Leboutte toonde aan dat er in de jaren I950 een duidelijk verband was tussen de kolenvoorraden (als indicatie voor de vraag) en de rekrutering van buitenlandse arbeiders. ${ }^{42}$

Pas na 1947 zien we wederom een stijgende lijn in de productie van het Luikse bekken (grafiek I.2), maar het vooroorlogs niveau werd nooit meer bereikt. Tot I947 was er nog een tekort aan steenkolen voor de Belgische industrie, maar na 1948 kwam daar verandering in. Niet alleen volstond de productie voor de dekking van de nationale behoeften, er ontstonden zelfs onverkochte voorraden. De reducering van de afzetmogelijkheden kende verschillende oorzaken. Een deel van de industrie deed minder beroep op steenkolen, want stookolie en elektriciteit kwamen meer en meer in aanmerking voor de benodigde drijfkracht. Bovendien werd de verkoop in het buitenland bemoeilijkt door de stijging van de steenkoolproductie in verschillende landen. Dat was bijvoorbeeld het geval in Frankrijk. Ook lag de kostprijs te hoog, omdat de lonen na de oorlog sterk gestegen waren in het kader van de kolenslag. De Belgische overheid stelde goedkope kredieten ter waarde van zo'n 750 miljoen BEF beschikbaar aan de steenkoolindustrie om bij te dragen aan een modernisering en zo tot een vermindering van de kostprijs. Eveneens werden er subsidies uitbetaald die per jaar opliepen tot 500 miljoen BEF.43 Bovendien werd er tijdens de Tweede Wereldoorlog een compensatiestelsel opgebouwd, waardoor renderende mijnen financiële hulp verschaften aan verlieslatende mijnen. De productie werd kost wat kost opgedreven, waardoor de steun niet gekanaliseerd werd naar de meest levenskrachtige bedrijven, maar versnipperd werd over verschillende onrendabele mijnen. ${ }^{44}$ Vanaf I95I zien we daardoor een opleving in de Luikse steenkoolproductie om het naoorlogse hoogtepunt te bereiken in 1953 .

De Koreaanse oorlog van I950 tot I953 en later de Suezcrisis (I956) deden de vraag naar steenkool nog even stijgen, maar reeds na 1954 werd de definitieve productiedaling voor de Luikse mijnen ingezet. 45 Vanaf het einde van 1957 en vooral na 1958 verslechterde de toestand voor de Belgische steenkoolindustrie snel. Met de kolencrisis werd de teloorgang van de Luikse mijnen voortgezet. Wereldwijd was er een overproductie aan brandstoffen en daalde de vraag naar West-Europese steenkool. Deze kolencrisis had verschillende oorzaken: vooruitgang en verbeteringen in de staalindustrie zorgden ervoor dat er minder brandstof nodig was voor eenzelfde eindresultaat. Bovendien werd er steeds meer steenkool in-

4I Zie bijlage I voor een overzicht van de lonen en arbeidsduur in het Luikse bekken. Als er in volgende hoofdstukken wordt verwezen naar lonen en/of arbeidsduur vindt de lezer in deze bijlage meer achtergrondinformatie.

42 Leboutte, 'Coal mining, foreign workers and mine safety', 220-222.

43 Vandeputte, Economische geschiedenis van België, 25.

44 Minten et al., Een eeuw steenkool in Limburg, 152.

45 C.E.C.A. $1952-1962,262$. 
gevoerd vanuit de Verenigde Staten en Groot-Brittannië en vanaf de jaren I96o ook vanuit de UssR, Australië, Zuid-Afrika en Polen. Ondanks de hogere transportkosten was deze geïmporteerde steenkool vaak goedkoper, omdat ze werd geproduceerd in dagbouwmijnen. In West-Europa daarentegen diende men steeds dieper te graven om steenkool van de gewenste kwaliteit te vinden, waardoor de productiekosten stegen. Opnieuw bleek dat de kostprijzen in de Belgische mijnen in vergelijking met de andere kolenproducerende landen veel te hoog lagen. Bovendien won aardolie als efficiënte en goedkope brandstof steeds meer terrein..$^{46}$ In 1929 genoten de steenkolen (en bruinkool) in de zes landen van de EGKS nog met 94,5 procent een bijna absolute voorrang onder de energiebronnen, in I 952 was dit aandeel gedaald tot 74,6 procent. De mijnondernemers moesten noodgedwongen hun verkoopprijzen verlagen en er ontstonden enorme onverkochte voorraden. ${ }^{47} \mathrm{Om}$ de zaken nog te verslechteren liep op ro februari 1958 de overgangsperiode van vijf jaar ingesteld door de EGKS af..$^{8}$ Dit betekende het einde van de hulp betaald door Duitse en Nederlandse mijnen voor een modernisering van de Belgische steenkolenmijnen. In totaal betaalden de Duitse mijnen 52, I miljoen dollar en de Nederlandse mijnen 4,4 miljoen dollar aan deze vereffening. De Belgische regering subsidieerde met een zelfde totaalbedrag van 56,6 miljoen dollar. ${ }^{49}$

De ontginning van steenkool was niet meer rendabel wegens de ontginningsmoeilijkheden, de hoge lonen en het gemis aan gekwalificeerd personeel..$^{50}$ Niettemin leek het onmogelijk in korte tijd over te gaan tot mijnsluitingen. Ondanks het gebrek aan personeel stelden de Belgische steenkolenmijnen behoorlijk wat arbeiders te werk. In november I 960 was nog 8,6 procent van de industriearbeiders in België mijnwerker (het hoogste aandeel in de EGKS). ${ }^{51}$ In Luik hielden de mijnen in dat jaar nog bijna 18.000 arbeiders aan het werk. De afbouw van de steenkoolindustrie moest dus geleidelijk geschieden. Na I957 voltrok zich steeds hetzelfde scenario bij een dalende vraag naar steenkool: eerst werd de onverkoopbare steenkool opgeslagen en ontstond een grote voorraad, daarna werd werktijdverkorting ingevoerd om de productie te doen dalen. Alleen als het echt niet anders kon werd er overgegaan tot de sluiting van een mijn. Alleen al in 1959 werden de Belgische mijnen ondersteund door de overheid met 800 miljoen BEF subsidies..$^{52}$

In ruil voor een productiedaling van 5,5 miljoen ton kende de Hoge Autoriteit van de EGKS eveneens nieuwe subsidies toe voor de periode I959-I962 (voor een totaal bedrag van 7,5 miljoen dollar). ${ }^{53}$ Voor de jaren I960-I963 werd de Belgische steenkolenmarkt opnieuw geïsoleerd door importquota in te stellen (onder artikel 37 van het Verdrag van Parijs). ${ }^{54} \mathrm{Om}$ het hoofd te kunnen bieden aan de kolencrisis werd in I96I de Directoire de l'Industrie Charbonnière opgericht. Deze instelling had als taak het regelen van de Belgische steenkolenproductie, verkoop, import en export en diende beslissingen te nemen inzake sluitingen van onrendabele mijnen en rationalisaties. 55

\footnotetext{
46 Poelmans, 'Concentration of ECSC Coal Companies', 5-6.

47 Vandeputte, Economische geschiedenis van België, 45.

48 Vinck, 'De toekomst van de steenkool', 62, 66.

49 'Chronologisch Overzicht', 228.

50 Vandeputte, Economische geschiedenis van België, 70.

5I C.E.C.A. $1952-1962,307$.

52 Poelmans, 'Concentration of ECSC Coal Companies', 7, I2.

53 Spierenburg en Poidevin, The history of the High Authority, 4I6-4I7.

54 Ibidem, 492-503.

55 Poelmans, 'Concentration of ECSC Coal Companies', I8.
} 


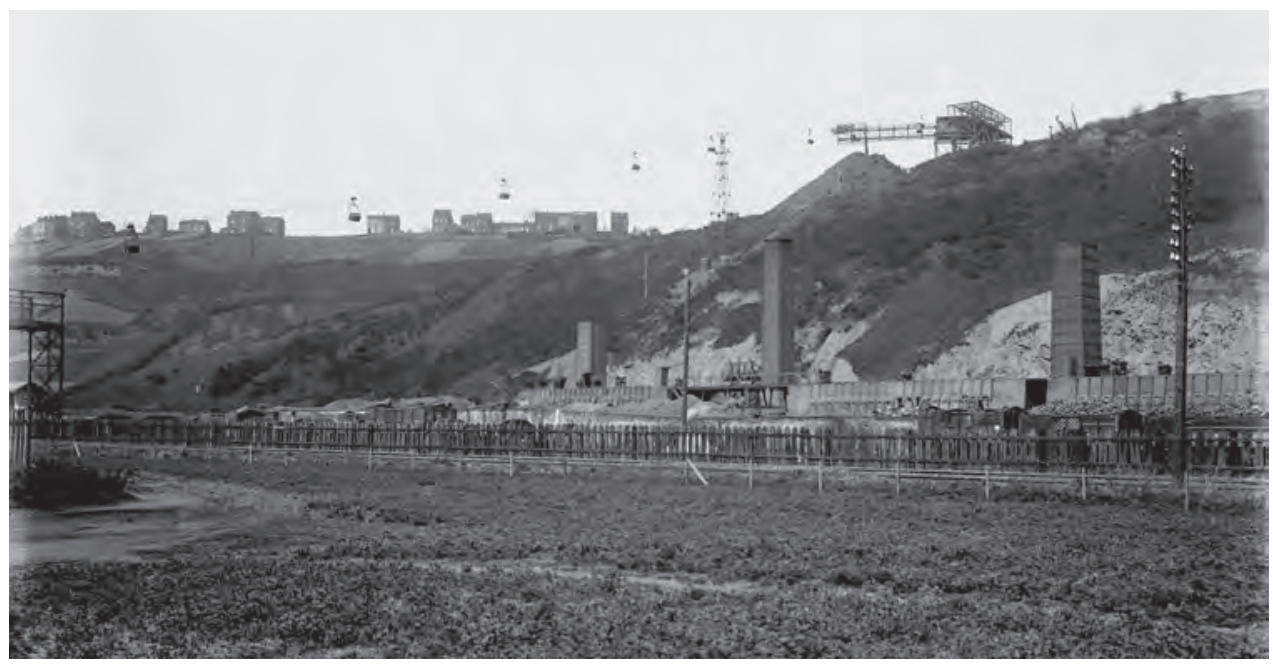

Cokesovens en terril (steenberg) te Tilleur. Copyright Province de Liège - Musée de la Vie wallonne.

Een kleine, tijdelijke opleving van de steenkolenmarkt vond nog plaats ten gevolge van de strenge winter van $1962-1963$, maar daarna werd de daling onherroepelijk. De conjunctuur was negatief, de staalnijverheid ging achteruit en nam minder steenkool af, en de voorkeur ging steeds meer uit naar petroleumproducten. Niettegenstaande een inkrimping van de productie ontstonden er wederom enorme voorraden. Het bleek meer en meer dat de Belgische steenkoolproductie niet meer kon worden afgezet tegen normale voorwaarden. Het probleem bleek van structurele aard en had een Europese dimensie, want ook landen zoals Frankrijk en Duitsland hadden af te rekenen met ernstige aanpassingsproblemen door de Amerikaanse concurrentie en de grondige wijzigingen in het energieverbruik. In I966 werd voor de eerste maal minder steenkool dan petroleum aangewend. Gedurende datzelfde jaar begon de levering van aardgas uit Nederland en werd ook de eerste industriële atoomcentrale voltooid. ${ }^{5}$ De populariteit van steenkool als energiebron was sterk tanende. In de loop van de jaren ig6o werden dan ook verschillende Luikse mijnen gesloten: onder meer de S.A. des Charbonnages de Wérister, Bonnier, Gosson-Kessales, Bonne-Espérance, Abhooz, Espérance et Bonne Fortune. Van de I5 mijnbedrijven in I96o bleven er tegen I970 nog 5 over. ${ }^{57} \mathrm{De}$ laatste mijn, die in Argenteau en Trembleur, werd in I980 gesloten.

\section{De evolutie van het aantal arbeidskrachten}

De stagnatie van de productie na I903 leidde aanvankelijk niet tot een vermindering van de arbeidsinzet. Pas in de jaren 1920 werd het maximum aan arbeidskrachten in de Luikse mijnen bereikt (zie grafiek I.3). 
GRAFIEK I.3 Het TOTALE AANTAL ARbEIDERS, HET AANTAL BELGisCHE EN BUITENLAN DSE ARBEIDSKRACHTEN IN DE LUIKSE MIJNEN, I9O4-I973

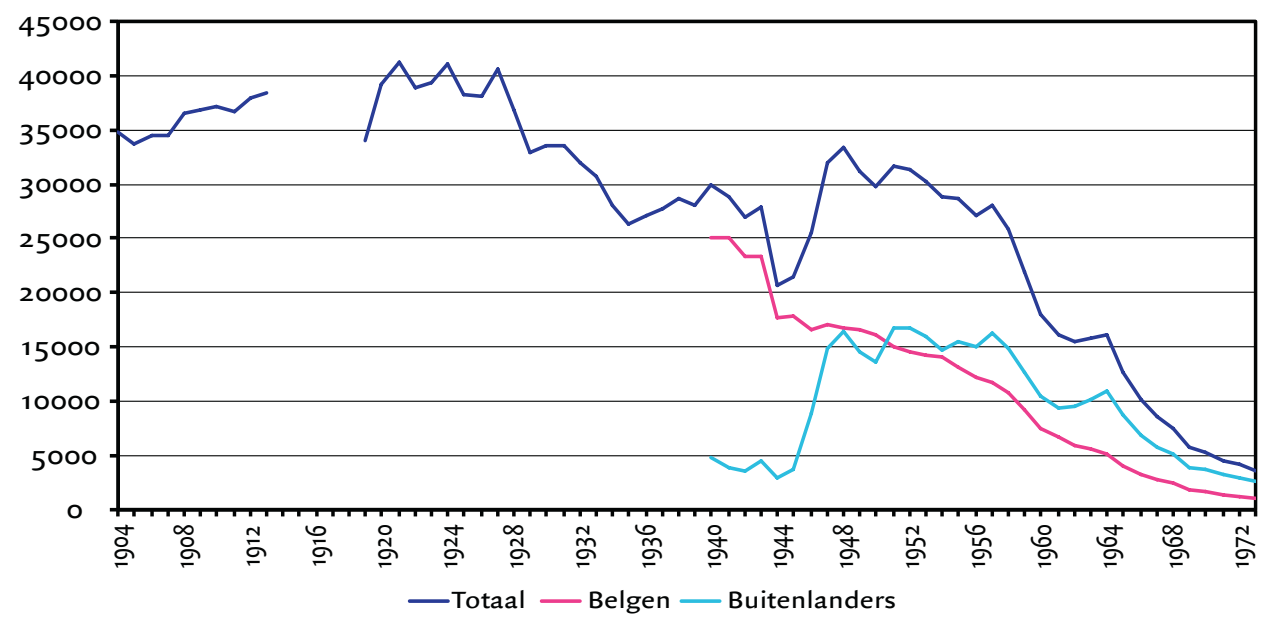

Bron: I900-Ig03: Pasleau, Industries et populations, 594-595; 'Technische kenmerken van de Belgische Steenkolenontginning', Annales des Mines de Belgique, 1958-1974.

Zij stelden in I92I, I924 en I927 meer dan 40.000 mijnwerkers te werk. Daarna nam het arbeidsbestand bijna constant af tot aan de Tweede Wereldoorlog. Bij het uitbreken hiervan keerde een deel van de buitenlandse werknemers terug naar hun thuisland en ook de Belgische mannen werden gemobiliseerd. Dit resulteerde in een verdere daling van het arbeidsbestand van de Luikse mijnen. Pas na de oorlog slaagde men erin het tij te keren en zien we opnieuw een stijgende tendens. Deze was echter uitsluitend te danken aan de enorme toevloed van buitenlandse arbeidskracht: Duitse krijgsgevangenen, displaced persons en Italiaanse arbeiders. De arbeidsinbreng van de Belgen nam af en we kunnen stellen dat de binnenlandse arbeidsmarkt voor mijnwerkers was uitgeput. Het naoorlogs maximum in arbeidskracht werd bereikt in I 948 met ruim 33.000 mijnwerkers.

\section{DEMOGRAFISCHE EN GEOGRAFISCHE ASPECTEN VAN DE ARBEIDSMARKT VOOR MIJNWERKERS}

\section{Discrepanties op de lokale arbeidsmarkt}

Voor de steenkoolsector waren voldoende arbeidskrachten onontbeerlijk. In de Borinage waren de lokale arbeidsreserves toereikend om de groei van de mijnindustrie mogelijk te maken, maar in de overige Waalse steenkolenbekkens was dat niet het geval..$^{8}$ Daar verkoos de plaatselijke bevolking de metaal- en glasindustrie boven de mijnen. Daardoor waren die bekkens afhankelijk van een continue immigratie van arbeidskrachten, eerst vanuit het om- 
liggende platteland, vanaf de jaren I870 ook vanuit Vlaanderen. ${ }^{59}$ De mijnen rekruteerden regionaal. In vergelijking met de industriële regio's in Henegouwen had het Luikse industriële bekken een voordelige geografische ligging. Omringd door agrarische gebieden met een hoge demografische densiteit, zoals de arrondissementen Borgworm en Tongeren, fungeerde het Luikse bekken als een aantrekkingspool voor een groot deel van de bevolking in het oosten van het land. ${ }^{60}$ Veel Vlamingen uit Limburg werkten in de Luikse mijnen. In I 876 was I3,3 procent van de arbeiders in de Luikse mijnindustrie van Vlaamse herkomst. Circa 7,5 procent van de arbeidskracht was afkomstig uit buurlanden Duitsland, Nederland en Luxemburg. In dat jaar werkten er meer dan 25.000 arbeiders in de Luikse mijnen. ${ }^{6 r}$

In het laatste kwart van de negentiende eeuw nam de vraag naar mijnwerkers sterk toe. De ontwikkeling van centrale verwarming en de introductie van goedkope kachels zorgden voor een stijging in de vraag naar huisbrandkolen. Terwijl de vraag naar mijnwerkers toenam, daalde het aanbod. In dezelfde periode begon de overheid de arbeidsmarkt voor mijnwerkers te reguleren en vanaf 1892 werden vrouwen en kinderen uit de ondergrond geweerd. Ook de arbeidsduur voor ondergronds werk werd ingeperkt. ${ }^{62}$ Bovendien ontstond er langzaamaan onder de Luikse bevolking een zekere afkeer van het mijnwerk. Jongeren die normaal gezien net zoals hun vaders in de mijn zouden werken, maakten gebruik van de vele beroepsmogelijkheden in het sterk geïndustrialiseerde Luikse bekken om aan het zware, gevaarlijke en ongezonde werk in de steenkolenmijnen te ontkomen. ${ }^{63}$

Ook de vruchtbaarheid speelde een rol bij de vermindering van het aanbod. Aanvankelijk lag de vruchtbaarheid bij de mijnwerkersfamilies bijzonder hoog omdat kinderen al op jonge leeftijd gingen werken in de mijn en zo bijdroegen aan het gezinsinkomen. In het laatste kwart van de negentiende eeuw veranderde het demografisch gedrag van de mijnwerkers. De levensstandaard was aanvankelijk sterk verhoogd, maar door de economische neergang in die periode kwam deze weer in het gedrang. Vooral de ongeschoolden, vrouwen en kinderen, werden getroffen door werkloosheid. Door het aantal kinderen te beperken, trachtten de mijnwerkersgezinnen hun recent gewonnen welvaart te beschermen. ${ }^{64}$ Volgens Leboutte waren de mijnwerkers pioniers bij het toepassen van geboortecontrole. ${ }^{65}$ In grafiek I.4 is de daling van het geboortecijfer in de provincie Luik en de Luikse regio goed te zien. De Luikse regio vormt het industriële hart van de provincie Luik, zonder de agrarische delen van de provincie. ${ }^{66}$

In de jaren I86o lag het geboortecijfer in de Luikse regio hoger dan in de provincie Luik en in heel België. In het begin van de twintigste eeuw was het echter gedaald tot onder het niveau van beide gebieden. Het geboortecijfer van de provincie Luik was toen het laagste van België: gemiddeld 17,3 geboortes per duizend inwoners in I912. Het hoogste geboortecijfer van gemiddeld $3 \mathrm{I}, 8$ geboortes was toen voor buurprovincie Limburg. ${ }^{67}$

59 Caestecker, 'Vlaamse arbeidsmigranten in Wallonië', 46; Leboutte, 'Mobilité spatiale de la main-d'œuvre', ${ }_{5} 6$.

6o Nols, 'Zone de recrutement', 355; Alexandre S. en J., 'Les migrations définitives et alternantes', 3II-3I7.

6I Leboutte, Le livret d'ouvrier dans la province de Liège, 45 .

62 Tot tien uur in I89I, tot negen uur in I909. Zie bijlage I.

63 Caestecker, 'Vlaamse arbeidsmigranten in Wallonië', 48. Zie hoofdstuk 4 over de naoorlogse situatie waarin deze 'vlucht uit de mijnen' uitgebreid aan bod komt.

64 Caestecker, 'Arbeidsmarktstrategieën in de Belgische mijnindustrie', 45.

65 Leboutte, Reconversions de la main-d'oeuvre et transition démograpique, $16_{3}, 483$.

66 Zie bijlage 4 voor meer uitleg over deze Luikse regio en een lijst met de tot de Luikse regio behorende gemeenten.

67 Lemaire, La Wallonie qui meurt, 9 . 
GRAFIEK I.4 Het AANTAL Geboortes PER DUIZEND INWONERS IN DE LUIKSE REGIO, DE PROVINCIE LUIK EN BELGIË, I866-I964

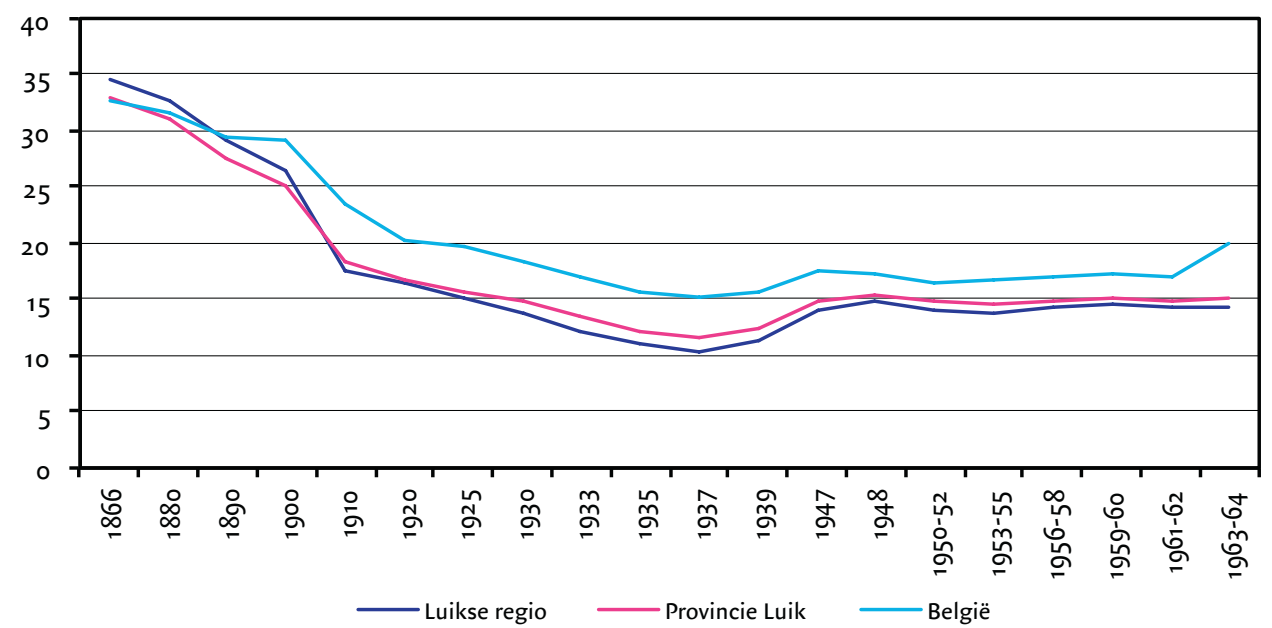

Bron: La Région Liégeoise. Démographie. Logement. Industrie et Commerce, I95I; La Région Liégeoise. Démographie. Logement. Industrie-Commerce-Services, 1966 (1947-1964: eigen berekeningen).

De geïndustrialiseerde provincies krijgen vanaf eind negentiende eeuw allen te maken met een dalend geboortecijfer. In tabel I.2 is te zien hoe het geboortecijfer in de provincie Luik na 1895 in vergelijking met de andere provincies het sterkste daalt.

TABel i.2 De Geboortecijfers in De Belgische provinCies, I846-I9I2 (INDEXCIJFERS, I846=IOO)

\begin{tabular}{|l|c|c|c|c|c|c|c|c|c|}
\hline & $\begin{array}{c}\text { Ant- } \\
\text { werpen }\end{array}$ & Brabant & $\begin{array}{c}\text { Oost- } \\
\text { Vlaanderen }\end{array}$ & $\begin{array}{c}\text { West- } \\
\text { Vlaanderen }\end{array}$ & $\begin{array}{c}\text { Hene- } \\
\text { gouwen }\end{array}$ & Luik & Limburg & $\begin{array}{c}\text { Luxem- } \\
\text { burg }\end{array}$ & Namen \\
\hline I846 & I00 & I00 & I00 & I00 & I00 & I00 & I00 & I00 & I00 \\
\hline I856 & I02 & I00 & I03 & I04 & I02 & 98 & I00 & 94 & 98 \\
\hline I866 & II2 & I07 & II2 & II2 & I06 & I05 & I07 & 94 & IOI \\
\hline I876 & I22 & I07 & III & II4 & I00 & I04 & II3 & 93 & 94 \\
\hline I885 & I2I & 97 & I08 & III & 87 & 93 & I09 & 84 & 82 \\
\hline I895 & II2 & 89 & II5 & II4 & 82 & 82 & II2 & 8 I & 79 \\
\hline I9I0 & 92 & 69 & 99 & 95 & 64 & 62 & II7 & 76 & 66 \\
\hline I9II & 90 & 65 & 95 & 92 & 62 & 57 & II4 & 73 & 64 \\
\hline I9I2 & 90 & 64 & 94 & 88 & 62 & 56 & II4 & 74 & 65 \\
\hline
\end{tabular}

Bron: eigen berekeningen op basis van: Lemaire, La Wallonie qui meurt, 9 . 


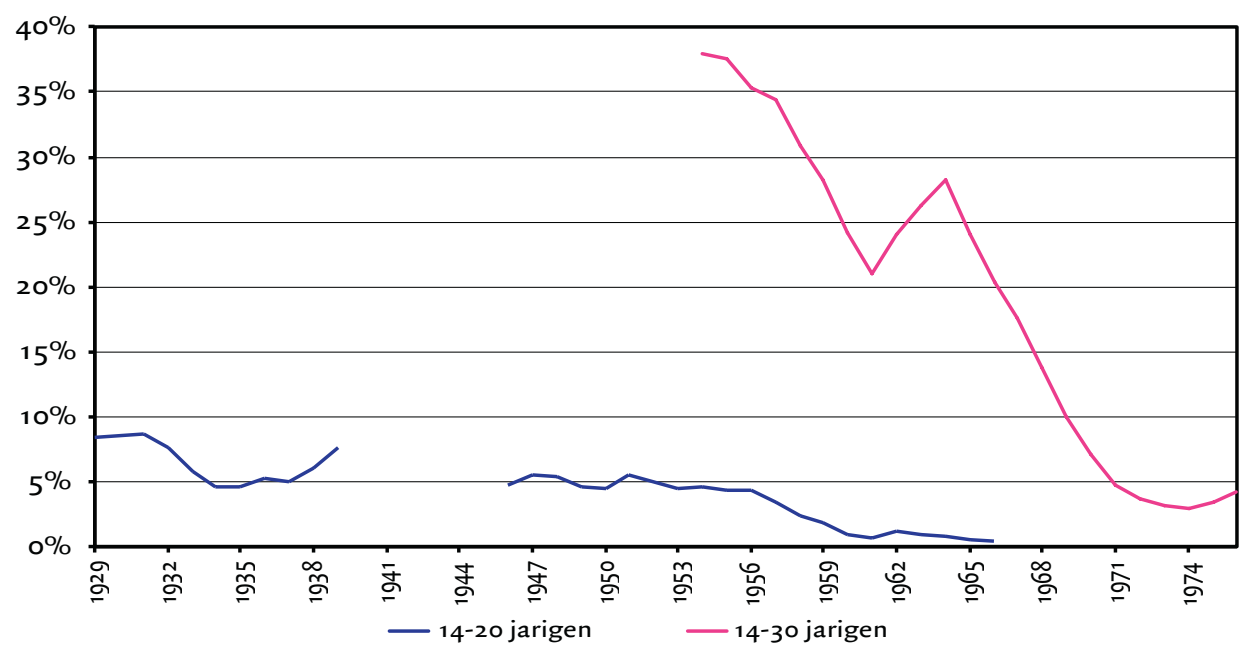

Bron: 'Economische statistiek van de extractieve nijverheden en van de metaalnijverheid', Annales des Mines de Belgique, I930-1967 (I4-20-jarigen); 'Technische kenmerken van de Belgische Steenkolenontginning', Annales des Mines, I955; RAH, archief FEDECHAR, inv.nr. 568 e.v. (eigen berekeningen) (14-30-jarigen).

De verklaring voor het feit dat het lokale arbeidersaanbod niet kon voldoen aan de enorme vraag naar arbeidskrachten bestond dus uit ten minste twee componenten: enerzijds het demografisch deficit door de lage geboortecijfers, waardoor er minder jongeren beschikbaar waren voor het werk in de Luikse steenkolenmijnen, anderzijds de zogenaamde 'vlucht uit het mijnbedrijf', de afkeer van de Luikse beroepsbevolking voor het mijnwerk, waardoor dit lagere aantal jongeren ook nog eens de alternatieven op de arbeidsmarkt boven het werk in de mijnen verkoos. Het gevolg was dat het aandeel van jongeren in de ondergrondse personeelsbezetting sterk daalde. Dat was vooral in de jaren 1930 en vervolgens na de Tweede Wereldoorlog het geval (grafiek I.5). Deze daling was voor de mijnbedrijven problematisch. Een groot aantal jonge arbeidskrachten kon op termijn een zekere garantie bieden voor een stabiel arbeidsbestand. ${ }^{68}$ Uit grafiek I. 5 blijkt dat het aandeel van jongeren structureel afnam met twee conjuncturele 'dippen' ten tijde van de crisis van de jaren I930 en de kolencrisis op het einde van de jaren 1950. Na deze laatste crisis zien we een laatste opleving in het aandeel jongeren, het gevolg van nieuwe wervingsacties voor Turken en Marokkanen. ${ }^{69}$

Het aantal personen dat bereid was in de mijn te werken was mede afhankelijk van de alternatieve werkgelegenheid in andere sectoren. ${ }^{70}$ In tegenstelling tot de mijnwerkers in Belgisch- en Nederlands-Limburg waar eerder sprake was van een monocultuur, hadden de Luikse arbeiders de keuze uit verschillende opties. ${ }^{7 \mathrm{I}}$ Vooral de metaalnijverheid vormde een

68 Delbroek, 'In de put', I62.

69 Grimmeau, 'De immigratiegolven', II5-II7.

70 Pluymers, De Limburgse mijnwerkers, 29.

7I Dit gold vooral voor de Belgische arbeidskrachten; de buitenlandse arbeiders werden, vooral na de Tweede Wereldoorlog, onder specifieke voorwaarden tewerkgesteld. Eén daarvan was dat ze alleen mochten werken in de mijnbouwsector. 


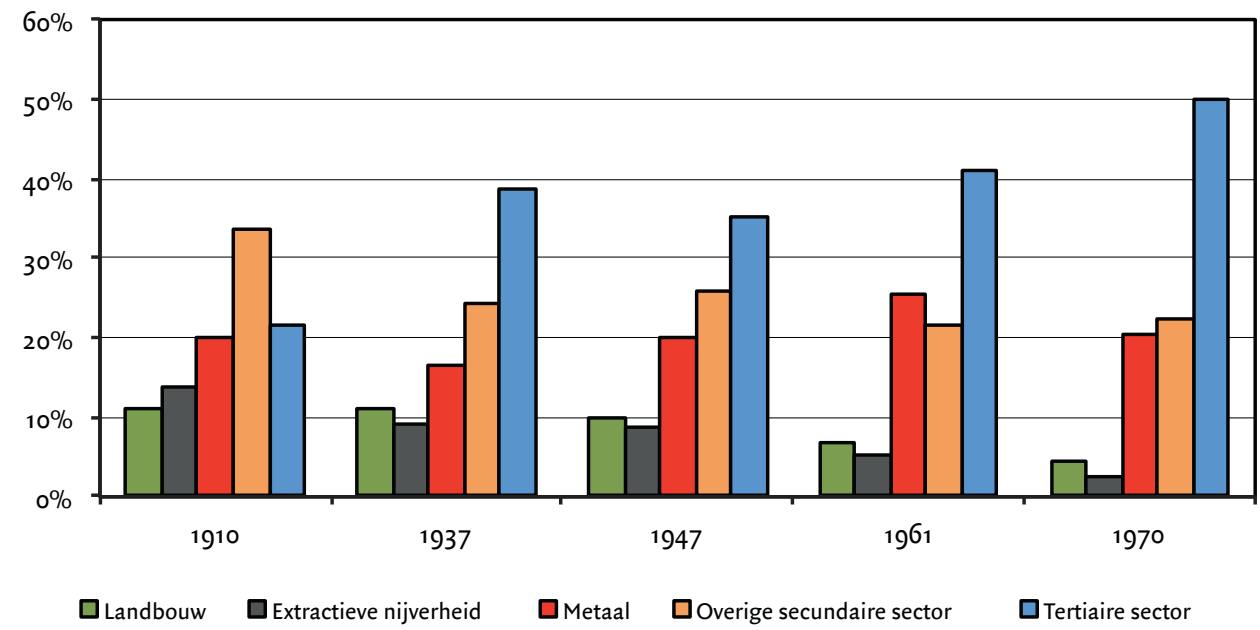

Bron: Berekend op basis van De Brabander, De regionaal-sectoriële verdeling van de economische activiteit in België; Volks- en industrietellingen r910, 1937, 1947, 196r en 1970; La Région Liégeoise. Démographie. Logement. Industrie et Commerce, I95I; La Région Liégeoise. Démographie. Logement. Industrie-Commerce-Services, ig66.

N.B.: Overige secundaire sector is de secundaire sector zonder de extractieve en metaalnijverheid.

belangrijke concurrerende bedrijfstak. In grafiek I.6 is de evolutie van het aandeel van de sectoren in de totale werkgelegenheid te zien. Het aandeel van de metaalnijverheid steeg, na een kleine daling in $\mathbf{1 9 3 7}$, tot in de jaren I960. De werkgelegenheid in de extractieve nijverheid daalde daarentegen alleen maar, net zoals die in de primaire landbouwsector. Wat verder opvalt is de forse toename van de handel en diensten (tertiaire sector). Tegen I970 nam deze sector de helft van de werkgelegenheid voor zijn rekening en werd daarmee de belangrijkste werkgever.

\section{Het Belgische rekruteringsgebied en de binnenlandse pendel}

De grote discrepanties tussen vraag en aanbod op de lokale arbeidsmarkt voor mijnwerkers lokten migratie en pendel uit om het evenwicht tussen vraag en aanbod te herstellen. De aantrekkingskracht van een regio wordt bepaald door de vraag naar arbeidskracht en loonverschillen, maar ook door de kwaliteit en de snelheid van de beschikbare transportmiddelen. Omdat de Luikse steenkoolnijverheid onvoldoende lokale arbeidskrachten kon aantrekken, was het belangrijk arbeiders van verder weg te halen. ${ }^{72}$ Dit kregen de Luikse mijnen voor elkaar door hoge lonen te bieden, vooral in vergelijking met de lonen in de agrarische sector, en transport van en naar de mijnen te vergemakkelijken.

Reeds na aanvang van de industriële revolutie in de negentiende eeuw werden de arbeiders voor de Luikse mijnen niet uitsluitend ter plekke gerekruteerd. Nabijgelegen dorpen 
zorgden voor de nodige aanvullingen op de arbeidskracht. ${ }^{73}$ Naarmate de vraag naar mijnwerkers steeg, breidde het rekruteringsgebied van de mijnen steeds verder uit. De steenkoolindustrie had veel werkkrachten nodig en oefende een grote aantrekkingskracht uit op arbeiders van het platteland. Ook onervaren arbeiders waren gewild: veel Vlamingen werkten in de nachtploeg om het zware, maar minder ingewikkelde onderhoudswerk te doen. De redenen om te pendelen waren legio: loonverschillen, mogelijkheden om de sociale ladder te beklimmen, betere werkomstandigheden of periodes van werkloosheid. ${ }^{74}$ Dankzij de creatie van goedkope treinabonnementen in 1869 werd het voordelig dagelijks te pendelen naar de industriebekkens. Definitieve vestiging en migratie was niet meer noodzakelijk en er ontstond een grotere groep pendelaars. ${ }^{75}$ In vergelijking met zijn buurlanden kende België in het begin van de twintigste eeuw een uitzonderlijk mobiele arbeidsbevolking. ${ }^{76}$ Veel arbeiders gaven er de voorkeur aan op het platteland te blijven wonen en van daaruit te pendelen naar de industriële bekkens. Er bestond een grote weerstand om het thuisfront en de rurale omgeving definitief te verlaten: 'C'est l'impossibilité de convaincre les migrants d'abandonner leur campagne pour venir s'installer dans les régions industrielles'. ${ }^{77} \mathrm{De}$ katholieke Belgische regering vond het bovendien belangrijk om de invloed van de stad tot een minimum te beperken. Door de subsidiëring van treinabonnementen voor arbeiders hoopte ze deze invloed en de daarmee gepaard gaande secularisering af te remmen: '... d'arracher les populations laborieuses aux habitudes de désordre et de démoralisation qu'elles prennent en venant s'installer dans les grandes villes' ${ }^{78}$

In 1896 werd het wekelijkse abonnement ingevoerd, waardoor arbeiders van nog verder weg konden reizen. Afhankelijk van de afstand werd er gekozen om dagelijks of wekelijks te pendelen. ${ }^{79}$ Voor de pendelaars van verder weg werden er door de mijnen zogenaamde phalanstères ingericht waar ze doordeweeks konden verblijven. ${ }^{80}$ Volgens Mahaim maakte ca. I3 procent van de mijnwerkers in het Luikse bekken in 1909 gebruik van de treinabonnementen, maar in sommige mijnen kon dit aandeel oplopen tot bijna 25 procent. Het overgrote deel van deze geabonneerden waren onervaren werkkrachten, die vaak de nachtdiensten deden. Er bevonden zich weinig houwers in deze groep. Die waren meer sedentair. Van de treinpendelaars koos 32 procent ervoor gedurende de week een onderkomen te zoeken in de buurt van de mijn, de rest, 68 procent, pendelde dagelijks. Mahaim vermeldt ook grote verschillen tussen de mijnen onderling. Hij wijst erop dat er in de kleinere steenkolenmijnen minder treinpendelaars werkten en dat ook de ligging voor verschillen zorgde. De mijnen in het noorden van de provincie hadden meer treinpendelaars onder hun arbeiders, en de mijnen in het land van Herve, bijvoorbeeld S.A. des Charbonnages d'Argenteau-Trembleur, minder. ${ }^{81}$

Uiteraard speelde de vooruitgang in transportmiddelen een belangrijke rol in de pendelarbeid. De veelheid aan transportmiddelen in de Luikse regio en daarbuiten liet een grote

73 Pasleau, Industries et populations, 577.

74 Leboutte, 'Mobilité spatiale de la main-d'oeuvre', I55.

75 Pas in 1896 werd het systeem van werkabonnementen echt een succes met de creatie van nieuwe soorten abonnementen. Zie: Quairiaux, 'Migrants flamands en Wallonie avant I9I4', 347.

76 Pasleau, 'Les migrations de main-d'œuvre en Belgique', I73.

77 Nols, 'Zone de recrutement', 365.

78 Kuborn, Topographie médicale du Royaume de Belgique, 26-27.

79 Mahaim, 'Les ouvriers mineurs', 70, 74.

8o Nols, 'Zone de recrutement', 322, 346.

8I Mahaim, 'Les ouvriers mineurs', 8I-87. 
mobiliteit van de arbeidskracht toe, en bood ook een grotere vrijheid in arbeidskeuze en minder risico op werkloosheid. ${ }^{82}$ In de eerste helft van de twintigste eeuw oefende vooral de uitbreiding en modernisering van het spoorwegennet invloed uit op de pendelmogelijkheden, de afgelegde afstanden en de duur van het traject. ${ }^{83}$ Later maakte de opkomst van de autobus nieuwe trajecten mogelijk. Zo ontstonden er busdiensten die onder meer pendelaars uit het land van Herve naar de Luikse mijnen brachten. ${ }^{84}$ Vanaf het eind van de jaren I950 maakten steeds meer pendelaars gebruik van een eigen bromfiets of auto om naar hun werkplek te reizen. Door de betere verbindingen en de modernisering verminderde de duur van het afgelegde traject sterk. ${ }^{85}$ In 1956 was er volgens een contemporaine studie geen enkele pendelaar meer die meer dan 3 uur onderweg was. ${ }^{86}$

Het woongebied van de mijnwerkers werkzaam in de Luikse mijnen breidde zich gedurende de twintigste eeuw verder uit. Steeds meer mijnwerkers waren woonachtig buiten de echte mijnbouwgebieden. De pendel binnen de Luikse regio nam verder toe, maar ook het aantal pendelaars dat van buiten de Luikse regio kwam steeg sterk. Dit was te wijten aan een daling van de actieve bevolking in de regio en de aantrekkingskracht van andere sectoren. Steeds meer mensen keerden de mijnen de rug toe. ${ }^{87}$ Het aandeel mijnwerkersgemeentes, dat wil zeggen gemeentes waarvan meer dan 15 procent van de inwoners de kost verdiende in de extractieve sector, nam tussen I9Io en I947 en tussen I947 en I96I sterk af (zie de kaarten I, 2 en 3). ${ }^{88}$ In I9Io kende de provincie Luik nog I4 van die zogenaamde mijnwerkersgemeentes (Ayeneux, Beyne-Heusay, Flémalle-Grande, Glain, Grâce-Berleur, Melen, Micheroux, Montegnée, Queue-du-Bois, Retinne, Romsée, Saint-Nicolas, Soumagne en Tilleur) (zie bijlage 5). In I947 waren er nog vier mijnwerkersgemeentes in de Luikse regio: Cheratte, Beyne-Heusay, Micheroux en Retinne. ${ }^{89}$ Tegen I96r kunnen we nog slechts één gemeente onderscheiden met meer dan 15 procent mijnwerkers (Micheroux). De gemeente Cheratte was in 1947 een echte mijnwerkersgemeente geworden: 15 tot 20 procent van haar inwoners was toen mijnwerker, terwijl dit in I9Io minder dan 5 procent was. Dit was het gevolg van de vestiging van een nieuwe mijnzetel van de S.A. des Charbonnages de Hasard in Cheratte in Igro.

Volgens Sporck oefenden de mijnen in 1947 weinig aantrekkingskracht uit op de andere delen van de Luikse regio. Het gebrek aan arbeidskracht werd vooral opgevuld door buitenlandse mijnwerkers, die zich voornamelijk in de buurt van de mijn vestigden. In die groep kwamen er dus maar weinig pendelaars voor. Verder bespeurde hij een algemene daling van de arbeiders die woonden waar ze werkten, dus een stijging van het aantal pendelaars. ${ }^{\circ \circ}$

82 Sporck, L'activité industrielle, 34 .

83 De Leener, 'Les abonnements ouvriers', 585-586.

84 Gaier, Huit siècles de houillerie liégeoise, $\mathrm{I}_{3}$.

85 Van der Eycken, 'Verkeerswegen als bindteken?’, 87-88; La Région Liégeoise. Démographie. Logement. Industrie et Commerce, I95I; La Région Liégeoise. Démographie. Logement. Industrie-Commerce-Services, I966.

86 Nols, 'Zone de recrutement', 347.

87 Sporck, L'activité industrielle, 123-126.

88 In Igro werd als categorie 'mijnindustrie' aangegeven, voor 1947 en I96I is er de categorie 'extractieve nijverheid', hiertoe behoren ook de steengroeves. In bijlage 5 een overzicht van de belangrijkste mijngemeentes in I9Io. De kaarten werden aangemaakt met behulp van het programma GIS (Geographical Information System). Ik dank Erwin Steegen voor zijn hulp bij het opmaken van de kaarten (zie bijlage 9 voor een verantwoording van het kaartmateriaal).

89 Aangezien we voor teljaar 1947 alleen gegevens hebben voor de Luikse regio, is het mogelijk dat bepaalde mijnwerkersgemeentes uit zicht blijven. Van de mijnwerkersgemeentes uit teljaar I 9 Io ontbreken echter enkel de gegevens voor Melen.

90 Sporck, L'activité industrielle, 77. 
De meeste pendelaars waren afkomstig uit Haspengouw in de provincie Limburg, dat aan het begin van de twintigste eeuw nog overwegend agrarisch was. Zuid-Limburg was van oudsher economisch en verkeersgeografisch georiënteerd op de Luikse industrie..$^{9 \mathrm{I}}$ Veel Zuid-Limburgers waren werkzaam in de Luikse mijnen. ${ }^{92}$ Hoewel er in I9Io nog geen mijnen in Belgisch-Limburg in productie waren blijkt uit kaart I dat daar wel al heel wat mijnwerkers woonden: enkele kleinere gemeenten dicht bij de provinciegrenzen, zoals Millen, Gingelom, Gelinden, Koninksem, Hoepertingen, Ordingen en Herten, hadden 2 tot 5 procent mannelijke mijnwerkers onder hun inwoners. Een aantal grotere gemeenten, noordelijker gelegen in de provincie, zoals Zonhoven, Genk en Paal hadden hetzelfde percentage mijnwerkers. Ook Beringen, waar vanaf 1922 de eigen kolenproductie van start ging, had in I910 reeds mijnwerkers onder zijn inwoners. ${ }^{93}$

Vanaf 1920 kregen de Luikse mijnen concurrentie van de Kempische mijnen op de Limburgse arbeidsmarkt. Enerzijds trachtten deze nieuwe mijnen ervaren Waalse mijnwerkers aan te trekken, anderzijds deden ze een beroep op de Vlaamse mijnwerkers die voordien in de Waalse mijnen hadden gewerkt en die nu dichter bij huis konden werken. In de mijn van Winterslag bestond het ondergrondse personeelsbestand aanvankelijk uit 8,8 procent Waalse mijnwerkers en I2,5 procent Vlamingen afkomstig uit Waalse mijnen. Toen de mijn van Beringen met de productie van start ging, bestond zelfs één derde van de ondergronders uit voormalige pendelaars naar de Luikse mijnen. ${ }^{94}$

Het effect van deze ontwikkelingen blijkt uit de evolutie van het rekruteringsgebied van twee mijnen waarvoor gegevens beschikbaar zijn in I909 en I953. Mahaim verzamelde in augustus-september 1909 gegevens over de woonplaats van mijnwerkers werkzaam bij S.A. des Charbonnages d'Espérance et Bonne Fortune (met drie zetels te Ans, Luik en Montegnée) en S.A. des Charbonnages d'Ougrée-Marihaye (met vier zetels te Seraing en één te Flémalle-Grande) (kaarten 4 en 6). Deze konden worden vergeleken met de woonplaats van Belgische mijnwerkers werkzaam bij diezelfde mijnen in het jaar 1953 (kaarten 5 en 7). Uit kaart 4 blijkt dat het rekruteringsgebied van Espérance et Bonne Fortune zich in 1909 uitstrekte tot ver in Belgisch-Limburg. Mijnwerkers waren niet alleen afkomstig uit het zuiden van de provincie (Tongeren en Sint-Truiden en omliggende gemeenten), maar ook uit Midden-Limburgse plaatsen als Genk, Hasselt en Tessenderlo. Bovendien trok de mijn pendelaars aan uit het oosten van Brabant, tot in Tienen. Uit kaart 5 blijkt dat de mijn Espérance in 1953 niet langer mijnwerkers aantrok uit de gemeentes gelegen voorbij Hasselt, ongetwijfeld een gevolg van de concurrentie met de Limburgse mijnen. Het zuiden van de provincie Limburg en ook de aangrenzende gemeenten in Brabant blijven echter als vanouds leveranciers van mijnwerkers, die blijkbaar de Luikse mijnen prefereerden boven de Kempische.

Ook de mijn Ougrée-Marihaye trok in 1909 arbeiders uit Belgisch-Limburg aan, maar in veel geringere mate dan Espérance et Bonne Fortune (kaart 6). Het lijkt er dus op dat beide mijnen elkaar weinig beconcureerden op de arbeidsmarkt. Opvallend is dat het wegvallen van het wervingsgebied in Midden-Limburg niet had geleid tot een wijziging in het geografi-

9I Pluymers, De Limburgse mijnwerkers, 39 .

92 Drie kwart van de Vlaamse arbeiders in de Luikse mijnen in de periode 1850 tot 1930 was afkomstig uit Limburg. In: Leboutte, Le livret d'ouvrier dans la province de Liège, 47.

93 Pluymers, Personeelsbeleid in de Belgisch-Limburgse steenkoolmijnen.

94 Idem, De Limburgse mijnwerkers, 25. 
sche rekruteringspatroon van beide mijnen (zie kaart 7). Espérance et Bonne Fortune bleef vooral in het noordwesten, Ougrée-Marihaye vooral ten zuiden van Luik werven. Dat had te maken met de ligging van beide mijnen. De zetels van Ougrée-Marihaye waren vanuit het noorden moeilijker bereikbaar.

Mahaim voorspelde al de opkomende concurrentie van de Limburgse mijnen: 'Par qui remplacera-t-on ces Campinois qui nous viennent aujourd'hui par trains entiers?'95 Bovendien keerde een aantal pendelaars de mijnbouw de rug toe toen de lonen in de landbouw gunstiger werden. Toch bleven er nog steeds Limburgers en andere Vlamingen in de Luikse mijnen werken. Dit blijkt uit kaart 8 waarop de woonplaatsen van alle Belgische mijnwerkers werkzaam in de Luikse steenkoolnijverheid en woonachtig in België op 30 juni r953 worden weergegeven. In dat jaar strekte het rekruteringsgebied zich uit over bijna het gehele oostelijke deel van het land en ook de provincie Belgisch-Limburg leverde nog een belangrijk aandeel mijnwerkers, ondanks het feit dat er in de Limburgse mijnen voldoende werkgelegenheid was. Er bestond dan ook een felle concurrentie op de arbeidsmarkt tussen de Limburgse en Luikse mijnen. Zo deinsden de Luikse mijnen er niet voor terug busdiensten in te leggen die door het gebruikelijke rekruteringsgebied van de Belgisch-Limburgse mijnen liepen. ${ }^{96}$ In 1953 leverde Belgisch-Limburg I.8I2 mijnwerkers aan de Luikse mijnen, I. 350 uit het arrondissement Tongeren en 462 uit het arrondissement Hasselt. Ook het arrondissement Leuven (Vlaams-Brabant) was belangrijk als rekruteringsgebied: 445 mijnwerkers pendelden hier vandaan. Verder leverde ook het arrondissement Turnhout in de provincie Antwerpen een deel mijnwerkers: 260. Bijna 20 procent van de Belgische mijnwerkers werkzaam in de Luikse mijnen was in 1953 afkomstig van buiten de provincie Luik (op een totaal van 13 .59I personen). ${ }^{97}$

Op het einde van 1947 waren er in de Luikse regio 3.740 mijnwerkers uit een andere Belgische regio werkzaam, waarvan I.490 afkomstig uit de Waalse regio en 2.250 uit de Vlaamse. Op het totale aantal arbeidskrachten in de Luikse mijnen was dit II,7 procent. In 1954 was het aantal pendelaars verder gestegen naar 4.773 , terwijl het totaal aantal Belgen tewerkgesteld in de Luikse steenkoolnijverheid was gedaald. Er bevonden zich dus in verhouding steeds meer pendelaars onder de Belgische arbeidskrachten. Dit werd onder meer veroorzaakt door de recessie van 1953-I954, die het rekruteren van arbeiders van verder weg bevorderde. De regio's die voorzien werden van speciale autobusdiensten leverden de meeste pendelaars. In het midden van 1956 waren er 53 busdiensten die de Luikse regio met andere regio's verbonden: dertien diensten in de Noordelijke Kempen, dertien in OostLimburg, acht rond Sint-Truiden, vijf rond Hasselt, vijf rond Aarschot, vier rond Diest, vier in de grensregio van Herve en één rond Andenne. Het gebrek aan homogeniteit in het rekruteringsgebied en het feit dat er steeds meer pendelaars van verder weg kwamen, bewijst hoe moeilijk het was voor de Luikse mijnen om arbeidskrachten te vinden op de lokale arbeidsmarkt, dit in tegenstelling tot de Luikse metaalindustrie, waarvan het aandeel werknemers gerekruteerd in de eigen regio verder steeg. Die vond de benodigde arbeidskrachten steeds meer in de Luikse regio zelf. $9^{8}$

95 Mahaim, 'Les ouvriers mineurs', 83, 88.

96 Delbroek, 'In de put', 35I-353.

97 Eigen berekeningen op basis van: Office National du Placement en du Chômage, Main-d'œuvre et production dans les mines. 98 Nols, 'Zone de recrutement', 337-357. 
KAART I HET AANDEEL VAN DE MANNELIJKE MIJNWERKERS IN HET BEVOLKINGSAANTAL PER GEMEENTE IN DE PROVINCIES LUIK EN LIMBURG (WOONPLAATS), I9IO

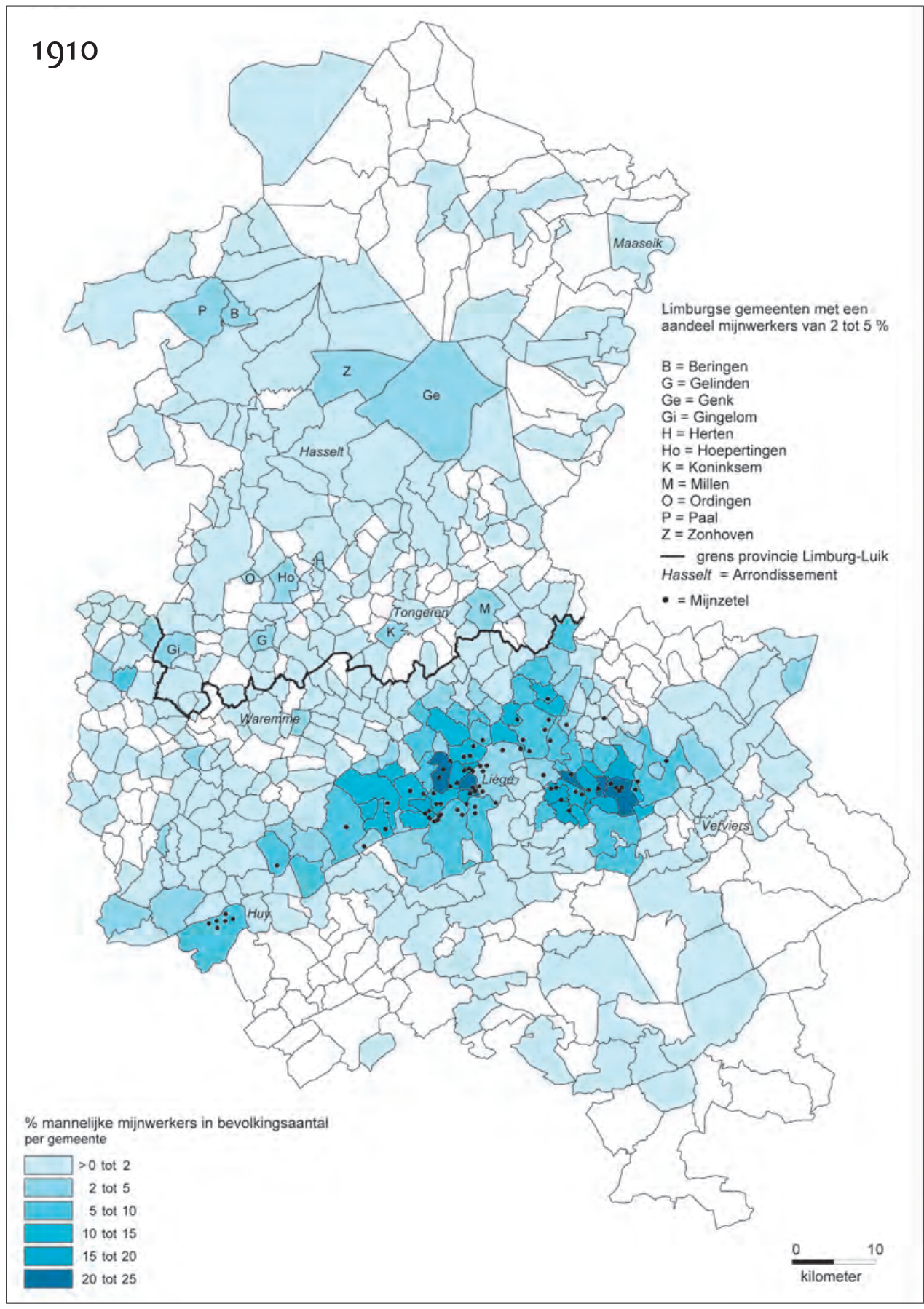

Bron: Recensement de l'industrie et du commerce (3i décembre igio). 
KAART 2 Het AANDEEl VAN DE MANNELIJKE ARbEIDERS IN DE EXTRACTIEVE NiJVERHEID OP DE TOTALE BEVOLKING PER GEMEENTE IN DE LUIKSE REgio, I947

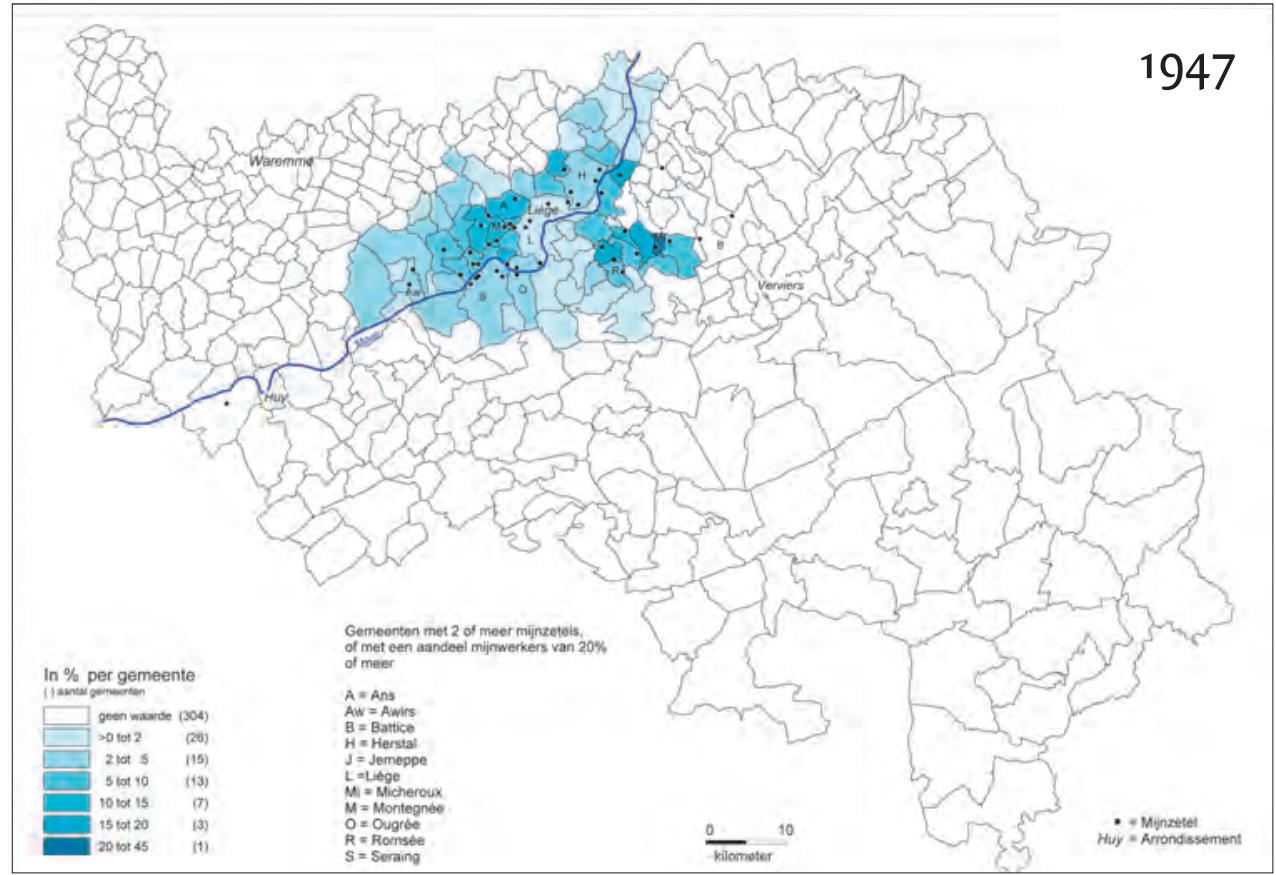

Bron: La Région Liégeoise. Démographie. Logement. Industrie et Commerce, I95I. De blanco gemeenten zijn de gemeenten die buiten de Luikse regio vallen en waarvoor geen gegevens voorhanden waren. 

I96I

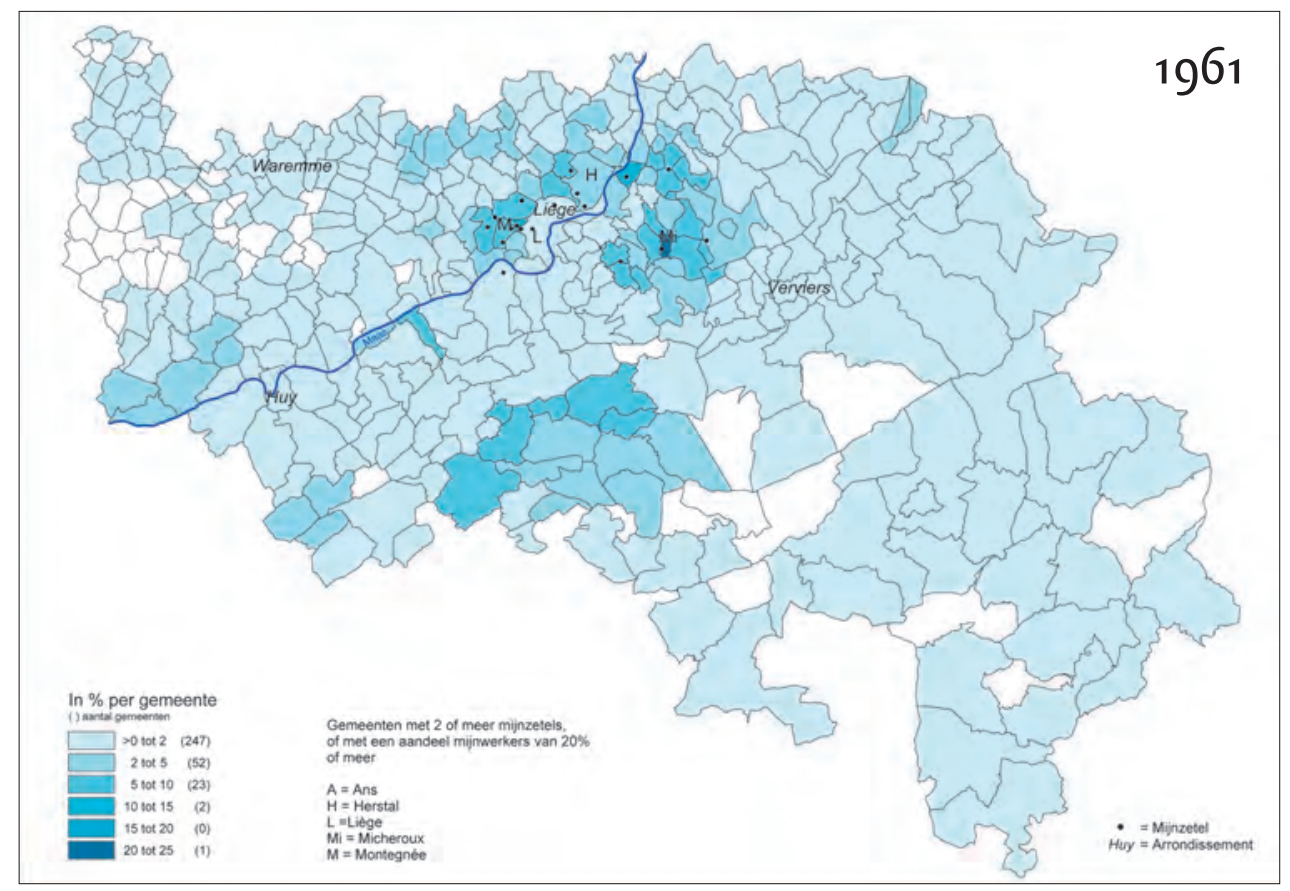

Bron: Recensement général de la population/ Algemene volkstelling, 3 I december I96r. De donkerder gekleurde gemeenten in het zuidwesten (o.m. Ouffet, Anthisnes, Poulseur, Sprimont en Rouvreux) en het westen (o.m. Moha en Ehein) van de provincie Luik hebben te maken met de daar aanwezige steengroeves. (In: Service public de Wallonie, Direction générale opérationelle de l'agriculture, des ressources naturelles et de l'environnement, Les carrières en Wallonie. Un monde à (re)découvrir, 2010). Bij de volkstellingen van I947 en I96I werd namelijk extractieve nijverheid als categorie gebruikt en niet mijnindustrie zoals bij de industrietelling van IgIo. 
KAART 4 DE WOON PLAATS VAN DE MIJNWERKERS WERKZAAM BIJ DE S.A. DES Charbonnages d'Espérance et Bonne Fortune, igog

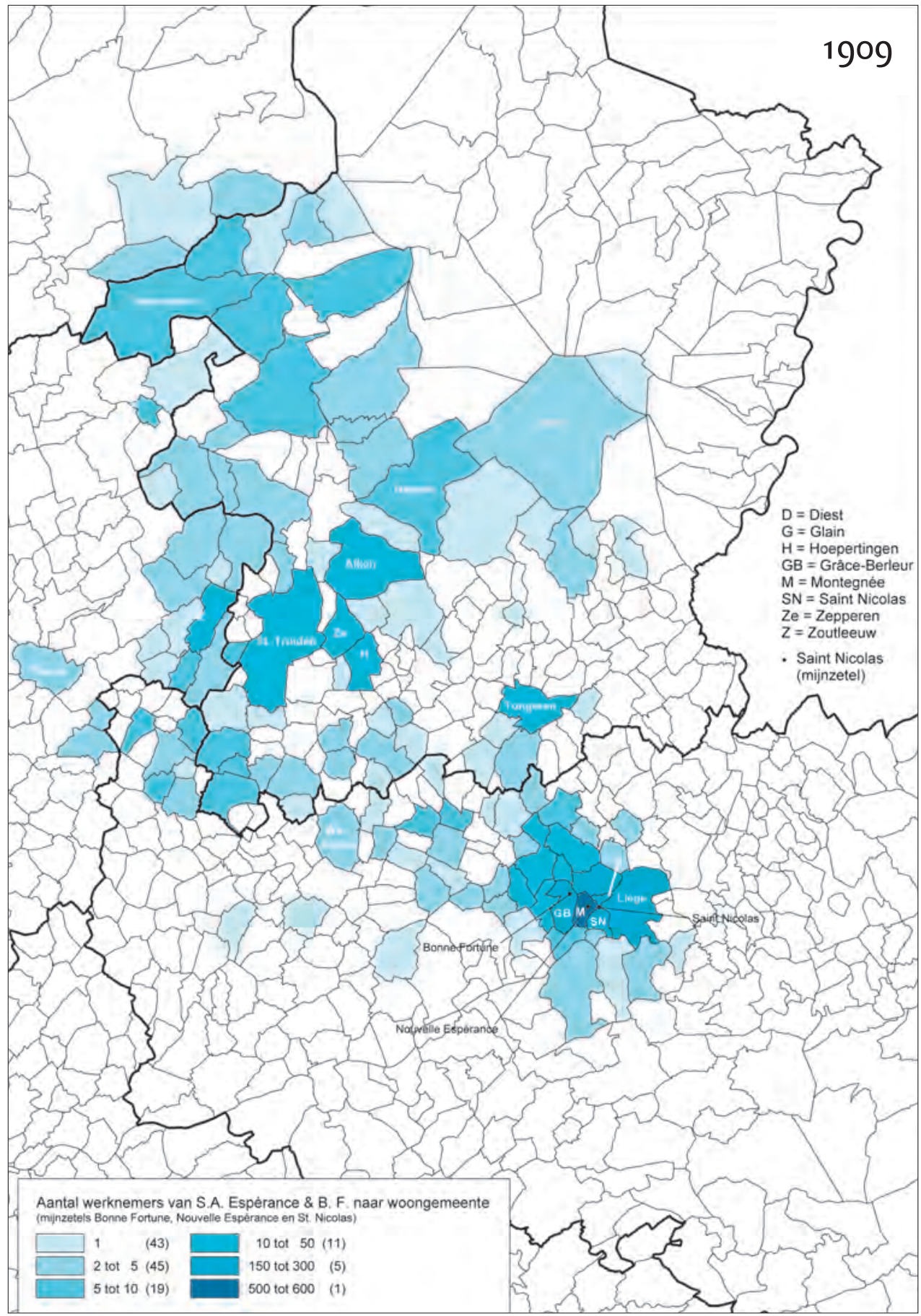

Bron: Mahaim, 'Les ouvriers mineurs', 93-95. 
KAART 5 DE WOON PLAATS VAN DE BELGISCHE MIJNWERKERS WERKZAAM BIJ DE S.A. Des Charbonnages D'Espérance ET Bonne Fortune, 30 JUni I 953

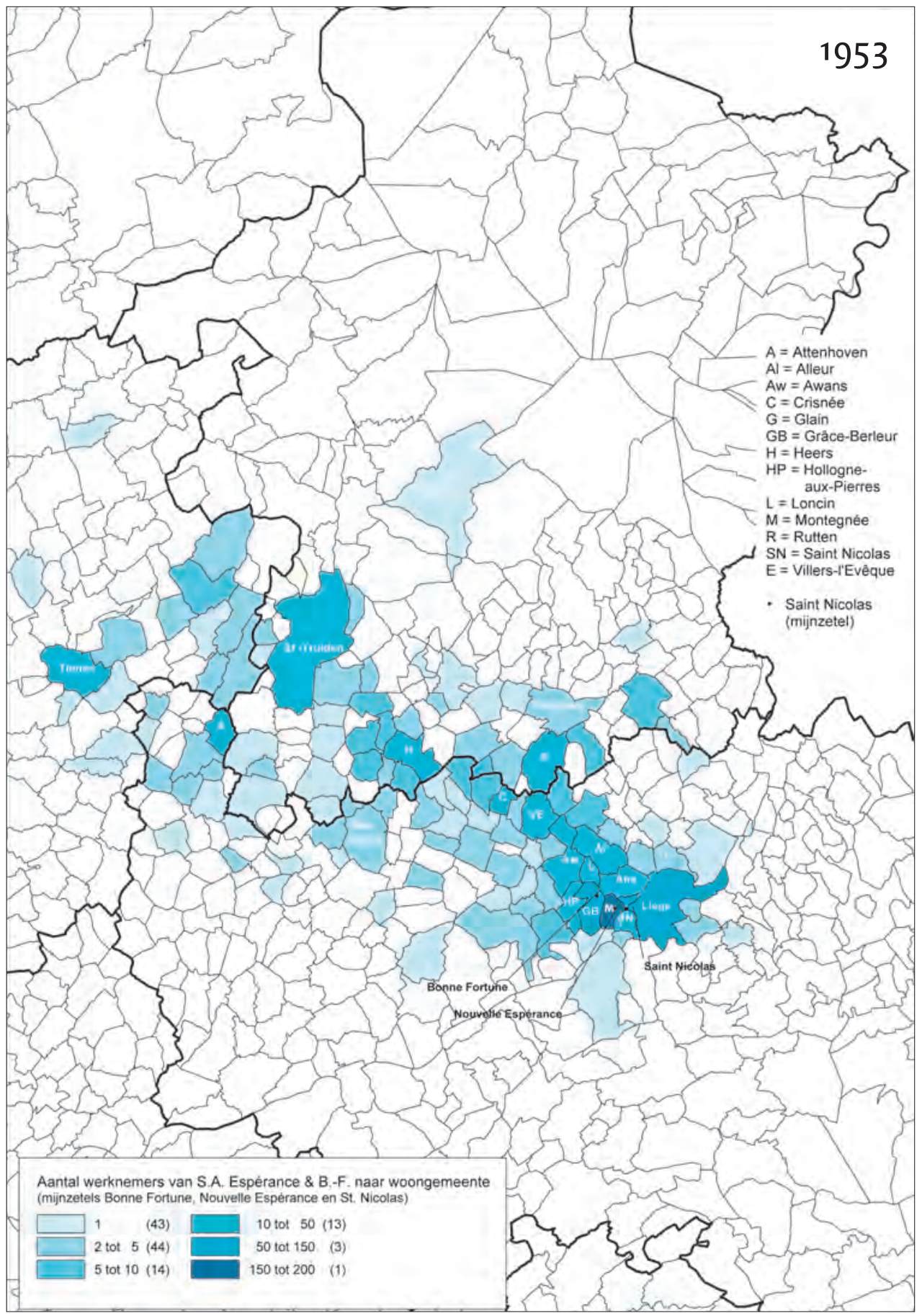

Bron: Office National du Placement et du Chômage, Main-d'œuvre et production dans les mines. 
KAART 6 DE WOONPLAATS VAN DE MIJNWERKERS WERKZAAM BIJ DE S.A. DES Charbonnages D'OUgRÉE-MarihaYe, IgO9

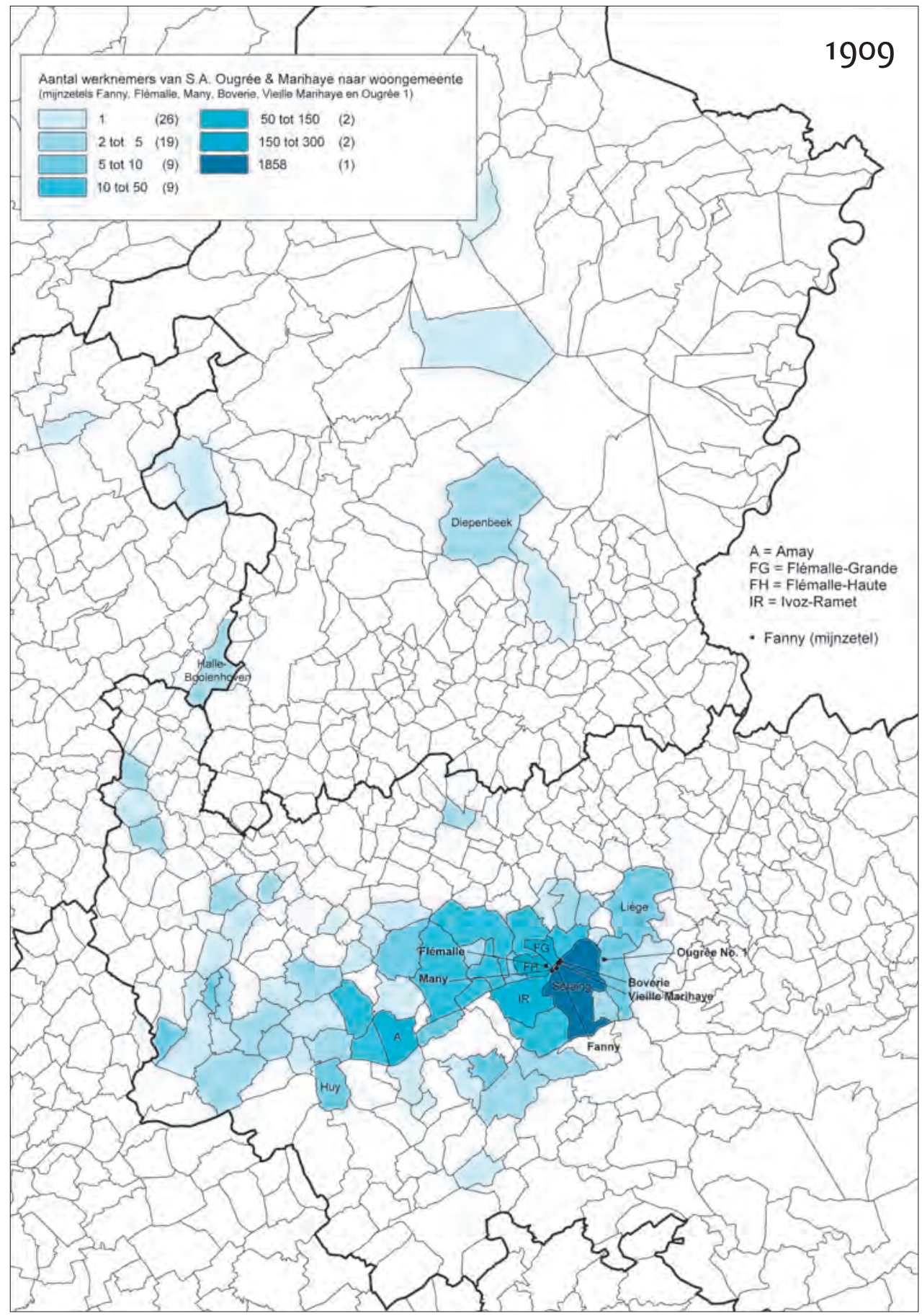

Bron: Mahaim, 'Les ouvriers mineurs', I02-I03. 
KAART 7 DE WOON PLAATS VAN DE BELGISCHE MIJNWERKERS WERKZAAM BIJ DE S.A. Des Charbonnages D'OUgréE-MarihaYe, 30 JUNI I 953

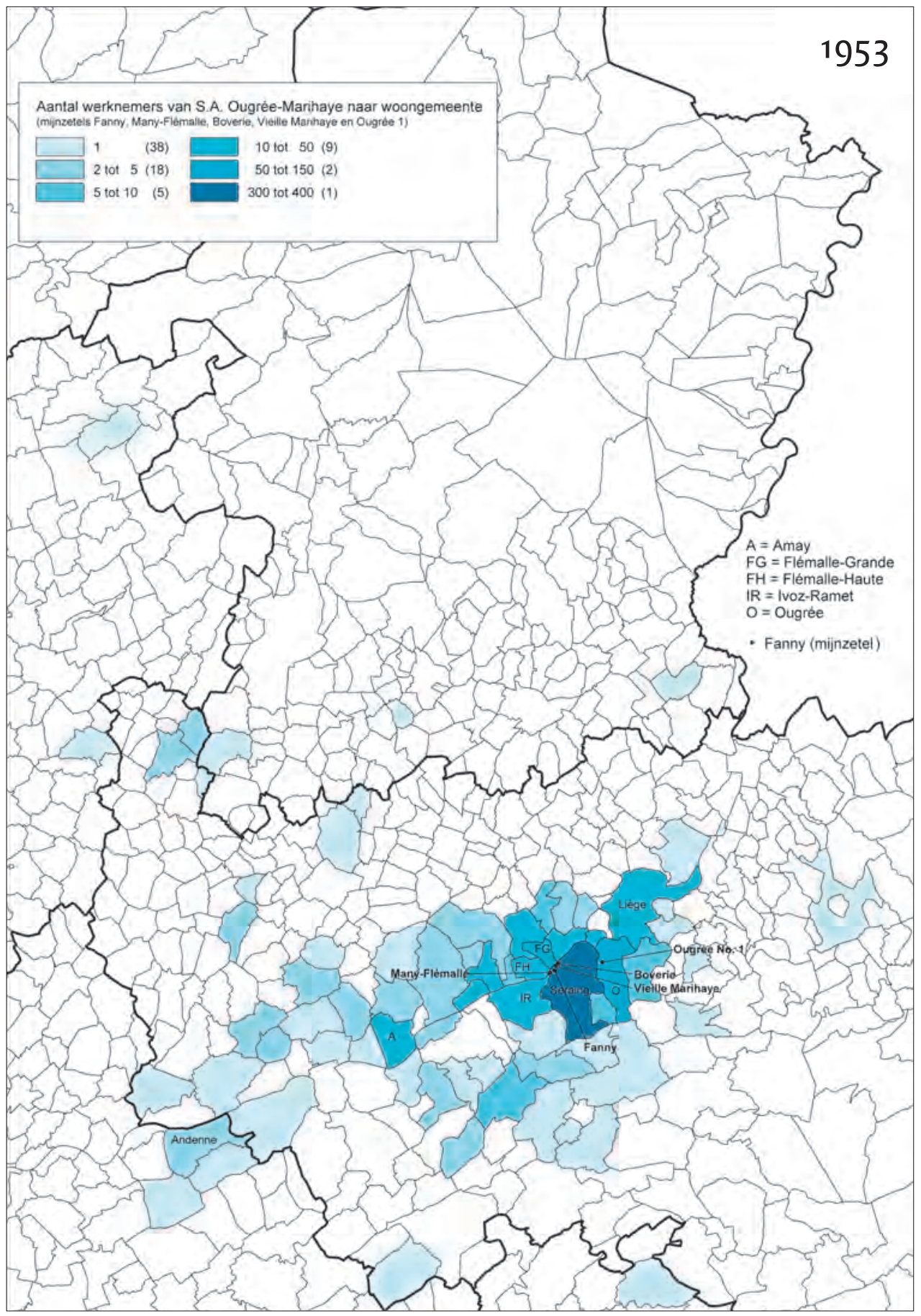

Bron: Office National du Placement et du Chômage, Main-d'œuvre et production dans les mines. 
KAART 8 DE WOONPLAATSEN VAN ALLE BELGISCHE MIJNWERKERS WERKZAAM IN DE LUIKSE STEENKOOLNIJVERHEID, 30 JUNI I953

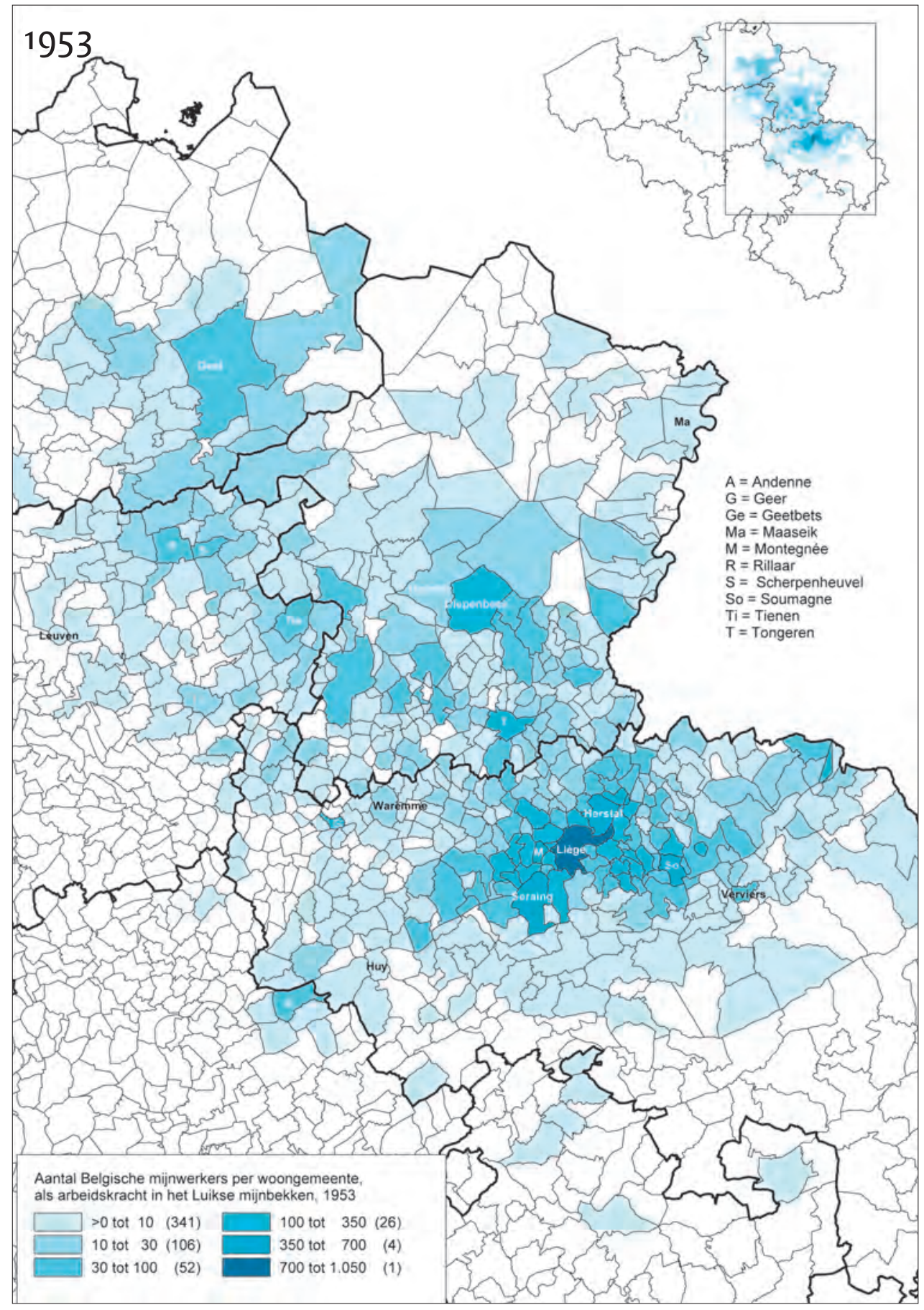

Bron: Office National du Placement et du Chômage, Main-d'œuvre et production dans les mines 


\section{Grensarbeiders}

Niet alleen voor Vlamingen was Wallonië het beloofde land. Ook uit de buurlanden kwamen pendelaars om in de industriebekkens te werken. ${ }^{99}$ Vóór de Eerste Wereldoorlog oefenden de Belgische mijnen nog weinig aantrekkingskracht uit op de Nederlandse arbeiders. Uit de volkstelling van igio kunnen we afleiden dat er toen slechts 49 mannen en I8 vrouwen van Nederlandse afkomst werkzaam waren in de Belgische steenkoolnijverheid. ${ }^{\text {100 }}$ Tijdens het interbellum steeg het aantal Nederlanders in de Luikse mijnen, vooral door de reeds genoemde vooruitgang in de vervoermiddelen. Het was niet meer noodzakelijk zich te vestigen in de buurt van de werkplek. ${ }^{\text {ior }}$ In de tweede helft van de jaren 1930 was de selectie van de Nederlandse mijndirecties zo streng dat ze vele bij de arbeidsbeurzen ingeschreven werklozen weigerden aan te nemen. Duitse én Belgische mijnen waren wel bereid deze Nederlandse werklozen op te nemen. De Arbeidsbeurs van Sittard speelde hierbij een coördinerende rol en via deze weg kwamen tussen I936 en I939 bijna 3.000 Nederlanders naar België om er te werken. 1937 was hierbij een topjaar; bijna I.700 werklozen werden toen aangetrokken. ${ }^{\text {I02 }}$ In dat jaar werd in de Belgische mijnen ook de arbeidsduurverkorting van de 48-naar 45-uren week ingevoerd; extra arbeidskrachten waren dus erg nodig. ${ }^{103}$

Toch nam de pendel van Nederland naar België pas na de Tweede Wereldoorlog een grote vlucht. Na de bevrijding kampten de Luikse mijnen met een enorm tekort aan arbeidskracht en ze trachtten dit op allerlei manieren in te vullen. De dicht bij de Nederlandse grens gelegen Luikse mijnen probeerden in Nederland personeel te werven, vaak met de hulp van illegale ronselaars, en organiseerden kosteloos pendelvervoer per autobus. ${ }^{104}$ De mijn Patience et Beaujonc maakte bijvoorbeeld gebruik van een busdienst die mijnwerkers uit Kerkrade ophaalde. ${ }^{105}$ De belangrijkste reden om naar België te pendelen waren de hogere lonen. De basislonen waren in België zo'n 25 à 30 procent hoger dan in Nederland. Ook waren de Belgische lonen alleen gebonden aan minimumschalen en niet aan maximumschalen, zoals in Nederland: bij een grotere vraag naar een bepaald soort arbeidskrachten kon dus een hoger loon worden gegeven. Dit was zeker het geval voor de Luikse mijnarbeid. In Wallonië werden er hogere lonen betaald dan in de Kempen, wat de aantrekkelijkheid van het Luikse bekken ten opzichte van de Belgisch-Limburgse mijnen verklaart. ${ }^{106}$ De hogere kinderbijslag was ook een troef in het voordeel van de Belgische mijnen. Bovendien werd er door de Belgische mijnen veel verlof toegekend (zes dagen dubbel betaald verlof, twaalf bijkomende betaalde dagen en tien betaalde feestdagen in de jaren 1950) en hadden deze grensarbeiders recht op gratis treinkaartjes. ${ }^{\text {I07 }}$ In I949 steeg de koers van de Belgische frank ten opzichte van de Nederlandse gulden waardoor

99 Rutten, 'Buitenbeentjes', 3-53.

Ioo Population - Recensement général du 31 décembre 1910.

Ior 'Onder grensarbeiders verstaan wij arbeiders of employés die werk hebben gevonden in een van de buurlanden, terwijl ze domicilie behouden in hun eigen land, waarheen zij dagelijks of wekelijks terugkeren'. Zie: Rutten, 'Buitenbeentjes', 5 .

I02 Langeweg, Van adreskantoor tot arbeidsvoorziening, 55.

I03 Baudhuin, Histoire économique de la Belgique, 13.

I04 Rutten, 'Alsof de taalgrens niet bestond', I2I.

I05 L'Association Charbonnière de la Province de Liège: Dossiers Divers, Carton II, Directoire de l'Industrie Charbonnière. Direction 'Problèmes du Travail' - Avantages extra-légaux et extra-conventionnels aux ouvriers mineurs.

Io6 Sillekens, De Limburgse arbeidsmarkt, I54-155; RHCL, Centraal Archief DSM, Personeel, nr. I79.

I07 RHCL, Centraal Archief DSM, Personeel, nr. I79. 
GRAFIEK I.7 Het AANTAL NederLAN DERS EN DUitsers WERKZAAM IN DE LUIKSE MIJNEN, ONDERGRONDS, I95I-I969

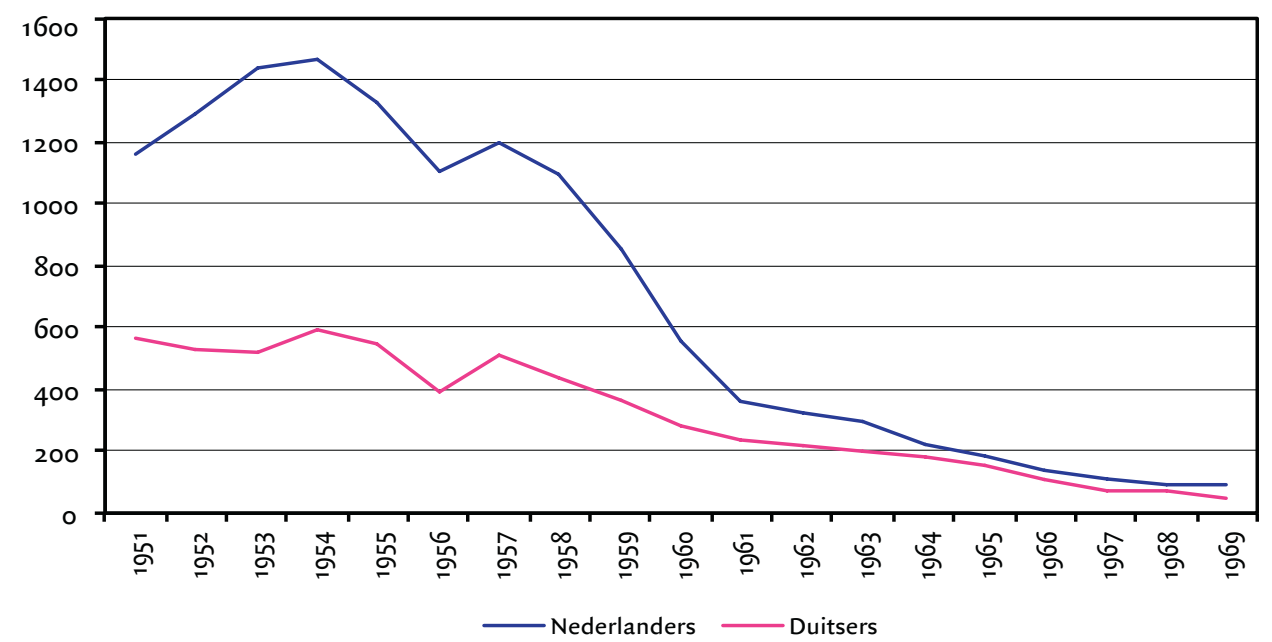

Bron: 'Technische Kenmerken van de Belgische Steenkolenontginning', Annales des Mines de Belgique, I954-I970; RAH, archief FEDECHAR, inv.nr. 6I4: 'Statistieken over tewerkgesteld personeel'.

werken in België nog voordeliger werd. ${ }^{\mathrm{r}}{ }^{8}$ Een sterke stijging van de Nederlandse grenspendel naar de Luikse mijnen was het gevolg.

Het hoogtepunt van de Nederlandse grenspendel naar Luik viel in de jaren I953-I954 (grafiek I.7). Na de kolencrisis in 1958 daalde het aantal Nederlanders in de Luikse mijnen sterk; men verkoos in de Nederlandse mijnen te werken of naar het Akense bekken te trekken, waar de mijnen ook goed betaalden. Door de stakingsgolven in de winter van ig6oI96I en de bijhorende onrust nam de pendelbeweging vanuit Nederland naar Luik verder af om tegen het einde van de jaren ig6o onbelangrijk te worden. ${ }^{\text {Io9 }}$

Het aantal mijnwerkers in de Luikse mijnen met de Duitse nationaliteit was minder uitgesproken, maar had eveneens te maken met de aantrekkelijke Luikse lonen: een ondergronder kon in het begin van de jaren I960 in Luik ca. 20 procent meer verdienen dan in het Akense bekken. De Luikse mijnwerkgevers zagen ook potentieel in dit rekruteringsgebied, getuige de busdienst die door S.A. Gosson in I954 werd ingesteld om mijnwerkers van Herzogenrath naar Tilleur te vervoeren. De busdienst werd al snel verboden door de Duitse autoriteiten omdat ze vreesden voor een sterk verloop naar de Belgische mijnen. ${ }^{\text {Iro }}$ Ook de grenspendel van Duitsland naar Luik nam tegen het einde van de jaren I96o sterk af.

\section{Immigranten}

Ondanks de binnenlandse en de grenspendel bleven de Luikse mijnen met een arbeidstekort kampen. Om het structurele tekort op de arbeidsmarkt voor mijnwerkers op te vullen

I08 Rutten, 'Alsof de taalgrens niet bestond', I22.

109 Sillekens, De Limburgse arbeidsmarkt, 152-153.

II Klank, 'Secondary labour force or permanent staff?', I48. 


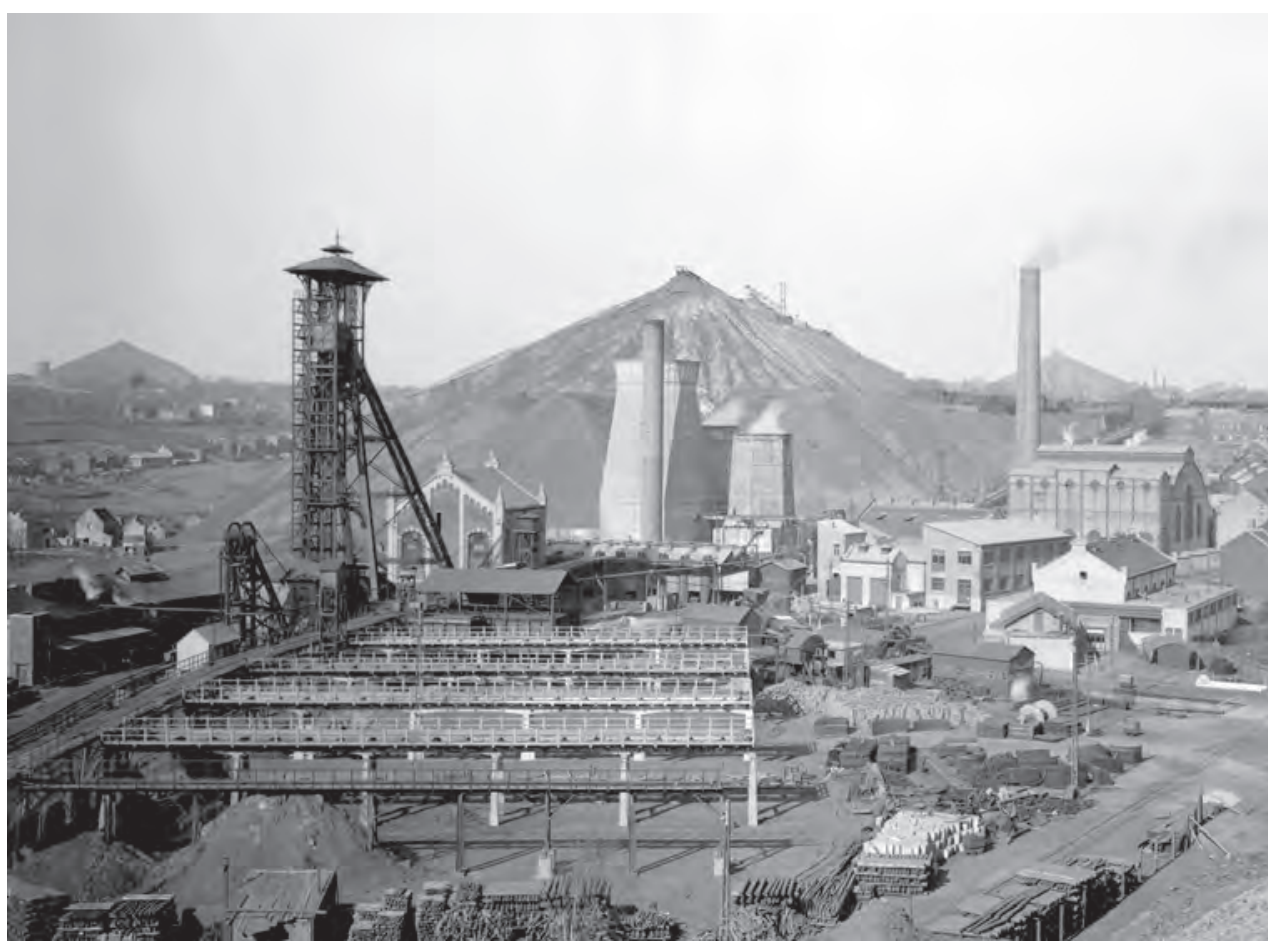

Zetel 2 (Gosson 2) van de NV Gosson-Kessales. Copyright Province de Liège-Musée de la Vie wallonne.

ging het Belgische mijnpatronaat, met goedkeuring van de overheid, na de Eerste Wereld-

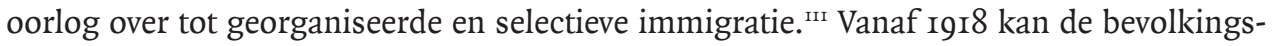
groei in de Luikse regio volledig verklaard worden door migratie, want de natuurlijke aangroei was tot het midden van de jaren 1960 negatief. De bijdrage van het migratiesaldo aan de bevolkingsgroei en dus aan de groei van het arbeidsaanbod was in de Luikse regio essentieel. ${ }^{12}$ In het interbellum en na de Tweede Wereldoorlog tot 1958 toen de kolencrisis uitbrak, was er over het algemeen sprake van een groot vestigingsoverschot. Zo werd de steenkoolindustrie de nijverheid die de meeste arbeidskrachten van buiten de Luikse regio ontving, en dan vooral vanuit het buitenland. ${ }^{\mathrm{Ir} 3}$

Een belangrijke groep buitenlandse arbeidskrachten waren de Poolse mijnwerkers, vooral in de periode vóór 1930. Een groot deel van deze Polen was afkomstig uit het Ruhrgebied waar de situatie voor hen na de Eerste Wereldoorlog ongunstig was geworden. Ze moesten kiezen voor de Duitse of Poolse nationaliteit en de meesten die de Poolse nationaliteit verkozen, keerden niet terug vanwege de slechte economische vooruitzichten in het moederland. ${ }^{\mathrm{II}}$

De grootste groep buitenlanders die in de Luikse steenkoolnijverheid kwam werken werd gevormd door de Italianen. Zij werden na de Tweede Wereldoorlog massaal aange-

III Pluymers, De Limburgse mijnwerkers, 3 I.

112 La Région Liégeoise. Démographie. Logement. Industrie et Commerce, I95 I; La Région Liégeoise. Démographie. Logement. Industrie-CommerceServices, ig66.

113 Sporck, L'activité industrielle, 36.

II4 Versteegh, De onvermijdelijke afkomst?, 48-51. 
GRAFIEK I.8 DE REGIONALE HERKOMST VAN DE ITALIAANSE GASTARBEIDERS IN DE LUIKSE MIJNEN, AANTALLEN UIT DE SELECTE STEEKPROEF FNROM $(\mathrm{N}=245)$, I946-I964

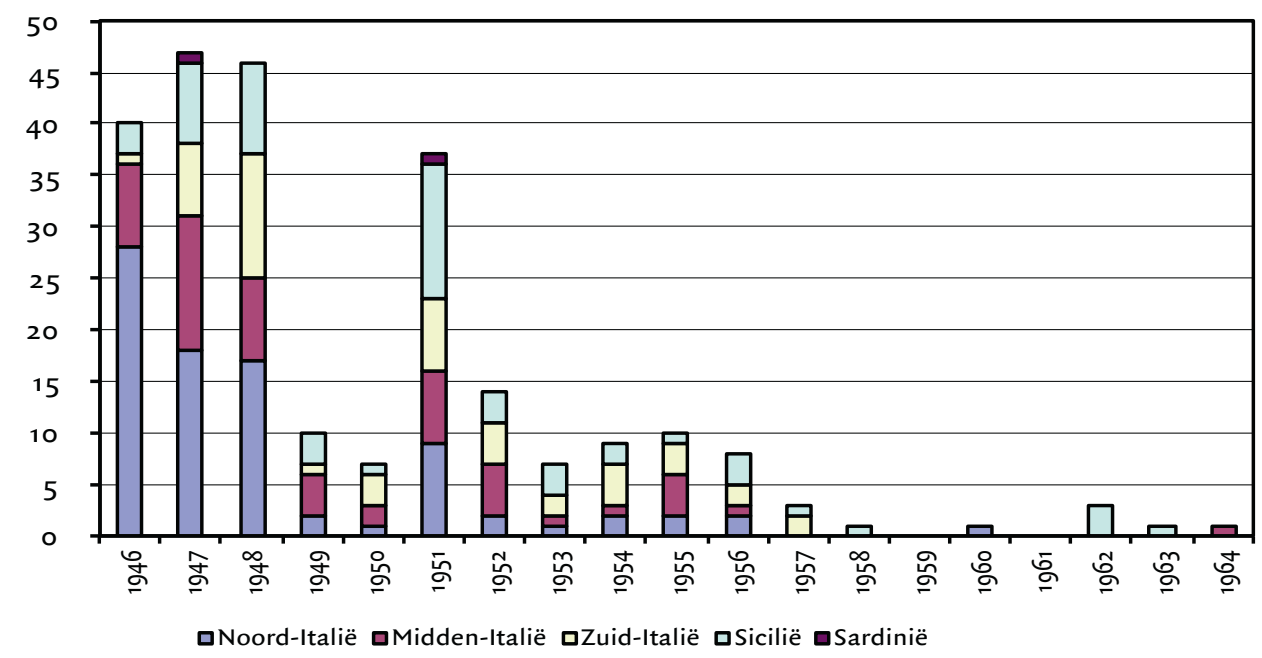

Bron: Steekproef FNROM (zie grafiek r.8).

worven en werden zeer belangrijk voor de Luikse mijnen. In I952 was tweederde van de buitenlandse arbeidskrachten van Italiaanse afkomst. Door het bilateraal verdrag van juni 1946 werd de officiële rekrutering van Italianen voor de Belgische mijnen geregeld. De aanwerving moest feitelijk door Italiaanse plaatsingsbureaus gebeuren, maar in de praktijk organiseerden Belgische mijnen vaak zelf aanwervingcampagnes ter plaatse. Hun voorkeur ging uit naar kandidaten die politiek 'ongevaarlijk' waren en die afkomstig waren uit het noorden. Zuid-Italianen hadden bij de Belgische industrie een negatieve reputatie. ${ }^{115}$

Uit een analyse van de geboorteplaatsen van de Italiaanse mijnwerkers uit de steekproef in de pensioenfiches (zie grafiek I.8) blijkt dat in het eerste jaar na het verdrag 70 procent van de Italianen inderdaad afkomstig was uit het noorden (de populairste regio was Veneto). In de jaren daarna wonnen de Midden- en Zuid-Italiaanse gebieden (met als belangrijkste regio's Abruzzen en Apulië) en Sicilië aan belang en in de jaren I950 waren het vooral die streken die de Italiaanse arbeiders leverden. ${ }^{\mathrm{II} 6}$ De kandidaat mijnwerkers mochten niet ouder zijn dan 35 jaar, ${ }^{117}$ maar dit was, althans voor het Luikse bekken, eerder wens dan werkelijkheid, zo blijkt uit de steekproef. In de jaren die volgden op het verdrag werden er ook heel wat oudere Italianen aangeworven (5I Italianen in de leeftijdscategorie 36-44 jaar). ${ }^{\mathrm{II} 8}$

De werk- en woonvoorwaarden van deze arbeiders voldeden niet aan de verwachtingen en waren niet conform de afspraken. Vooral de huisvesting was een enorm probleem. De mijnen slaagden er niet in te voorzien in degelijke woningen voor dit enorme contingent

1 5 Dumoulin, 'Pour une histoire de l'immigration italienne en Belgique', 4I.

II6 Noord-Italië: Emilia-Romagna, Friuli, Ligurië, Lombardije, Piemonte, Trentino en Veneto; Midden-Italië: Abruzzen, Lazio, Marche, Toscane en Umbrië; Zuid-Italië: Apulië, Basilicata, Calabrië, Campanië en Molise.

117 Dumoulin, 'Pour une histoire de l'immigration italienne en Belgique', 37.

II8 Zie ook: Dumoulin, 'Pour une histoire de l'immigration italienne en Belgique', 38. 

BELGEN EN VREEMDELINGEN/BUITENLANDERS, I947

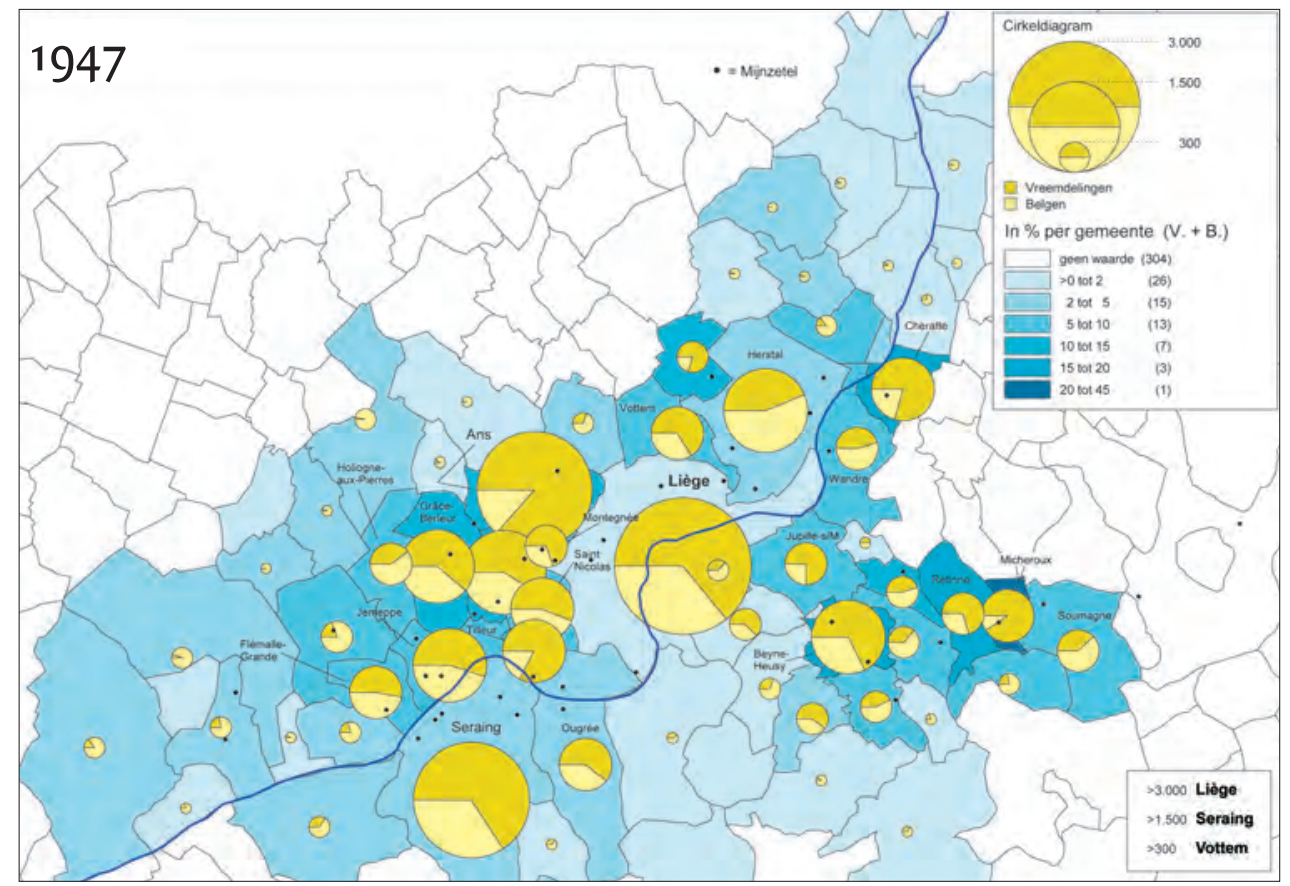

Bron: La Région Liégeoise. Démographie. Logement. Industrie et Commerce, I95I.

aan arbeiders en waren genoodzaakt een groot deel van hen onder te brengen in de barakken, waar eerder de Russische en/of Duitse krijgsgevangenen werden gehuisvest. ${ }^{\text {I9 }}$ De werkloosheid in Italië was echter zo hoog dat de Belgische mijnen veel Italiaanse arbeiders bleven aantrekken. Ze konden hier goed verdienen en konden profiteren van dezelfde sociale zekerheid als de Belgische arbeiders. Desondanks kon een deel onder hen hier niet aarden. De Italiaanse mijnwerkers werden volgens Gaier in de beginperiode gekenmerkt door de vele ongevallen door onervarenheid, een moeilijke en dure opleiding, veel absenteïsme en veel ziektedagen. ${ }^{120}$ De Italiaanse overheid ging na de rampen bij Many (I953), Quaregnon en Marcinelle (1956) harde eisen stellen aan de Belgische mijnen en stopte de officiële migratie. ${ }^{121}$ Toch waagden nog vele Italianen hun kans in België, van 1956 tot 1970 zag men een onophoudelijke migrantenstroom, vooral mensen afkomstig uit het zuiden en van de eilanden. ${ }^{122}$

Uit de telling van I947 blijkt dat van de 14.843 buitenlandse mijnwerkers in de Luikse mijnen er I4.I42 in de Luikse regio woonden, dat is ruim 95 procent. In datzelfde jaar werkten er 17.067 Belgen in de Luikse mijnen; daarvan woonden er 9.620, of nog geen 57 pro-

II9 Gaier, Huit siècles de houillerie liégeoise, I65.

I20 Ibidem, I64.

I2I Dat er onenigheid bestond over het naleven van de afspraken en het toepassen van het nieuwe arbeidscontract (I954) speelde uiteraard ook een rol; Dumoulin, 'Pour une histoire de l'immigration italienne en Belgique', 27, 47-52.

122 Morelli, 'De immigratie van Italianen', 202-206; zie ook hoofdstuk 3. 
cent in de Luikse regio. De meerderheid van de arbeidsmigranten vestigde zich dus dicht bij de werkplaats (zie kaart 9). ${ }^{123}$

Voor zover het ging om gezinsmigratie waren de buitenlandse arbeiders ook welkom, omdat zij een positieve invloed hadden op de geboortecijfers. ${ }^{124}$ Uit een onderzoek naar het geboortecijfer in verschillende vestigingsgemeenten in de provincie Luik bleek dat het geboortecijfer in gezinnen van migranten in het algemeen hoger lag dan in die van Belgen. Voor de provincie Luik als geheel was dit I4,73 per duizend voor de Belgen, I9,5I per duizend voor de vreemdelingen. In de mijnwerkersgemeenten was dit verschil nog aanzienlijk groter (zie tabel I.3).

TABEL I. 3 HET GEBOORTECIJFER PER GEMEENTE, BELGEN EN BUITEN LAN DERS, I963-I964

\begin{tabular}{|l|c|c|c|c|}
\hline & Totale bevolking & Buitenlanders & Belgen & Aantal buitenlanders \\
\hline Liège & $\mathrm{I} 3,97$ & $\mathrm{I} 6,92$ & $\mathrm{I} 3,42$ & 23.935 \\
\hline Angleur & $\mathrm{I} 5,60$ & 22,33 & $\mathrm{I} 4,99$ & $\mathrm{I} .075$ \\
\hline Ans & $\mathrm{I} 5,5 \mathrm{I}$ & 23,88 & $\mathrm{I} 3,22$ & $3.60 \mathrm{I}$ \\
\hline Bressoux & $\mathrm{I} 3,87$ & $22, \mathrm{I} 4$ & $\mathrm{I} 3,04$ & $\mathrm{I} .3 \mathrm{IO}$ \\
\hline Chênée & $\mathrm{I} 3,45$ & $\mathrm{I} 9,74$ & $\mathrm{I} 3, \mathrm{I} 3$ & 608 \\
\hline Grivegnée & $\mathrm{I} 3,77$ & $\mathrm{I} 9,49$ & $\mathrm{I} 3,48$ & $\mathrm{I} .283$ \\
\hline Herstal & $\mathrm{I} 3,42$ & $2 \mathrm{I}, 36$ & $\mathrm{II}, 73$ & 5.196 \\
\hline Jemeppe & $\mathrm{I} 2,98$ & $\mathrm{I} 6,56$ & $\mathrm{I} 2, \mathrm{I} 3$ & 2.355 \\
\hline Jupille & $\mathrm{I} 4,03$ & $\mathrm{I} 6,70$ & $\mathrm{I} 3,72$ & $\mathrm{I} . \mathrm{I3} 8$ \\
\hline Montegnée & $\mathrm{I} 5,59$ & $2 \mathrm{I}, 27$ & $\mathrm{I} 2,86$ & 3.808 \\
\hline Ougrée & $\mathrm{I} 3,4 \mathrm{I}$ & $\mathrm{I} 8, \mathrm{I} 3$ & $\mathrm{I} 2, \mathrm{I} 9$ & 4.358 \\
\hline Seraing & $\mathrm{I} 2,35$ & $\mathrm{I} 8,83$ & $\mathrm{I}, 78$ & 7.966 \\
\hline Arr de Liège & $\mathrm{I} 4,52$ & $\mathrm{I} 9, \mathrm{I} 6$ & $\mathrm{I}, 68$ & 94.744 \\
\hline Province de Liège & $\mathrm{I} 5,26$ & $\mathrm{I} 9,5 \mathrm{I}$ & $\mathrm{I} 4,73$ & $\mathrm{III} .468$ \\
\hline Royaume & $\mathrm{I} 6,98$ & 20,77 & $\mathrm{I} 6,75$ & $55 \mathrm{I} .432$ \\
\hline
\end{tabular}

Bron: La Région Liégeoise. Démographie. Logement. Industrie-Commerce-Services, 1966.

\section{HET LUIKSE EN NEDERLANDS-LIMBURGSE KOLENBEKKEN VERGELEKEN ${ }^{125}$}

In een rapport van de EGKS uit I96o werd een onderscheid gemaakt tussen oude, volwassen en jonge steenkolenbekkens in Europa. De Waalse bekkens, alsmede Nord-Pas-de-Calais en Centre-Midi in Frankrijk, werden tot de oude bekkens gerekend, Saarland en het Ruhrgebied tot de volwassen bekkens, en Nederlands-Limburg, de Kempen, Aken en Lotharingen tot de jonge bekkens. ${ }^{226}$ De ouderdom van het Luikse mijngebied was bepalend voor de

123 Sporck, L'activité industrielle, 82.

124 Pressat en Sauvy, Le rapport Sauvy; zie ook: La Région Liégeoise. Démographie. Logement. Industrie-Commerce-Services, I966, 23; Tulippe, Atlas de Belgique, I8-27.

125 Deze paragraaf is o.m. gebaseerd op: Langeweg en Roels, 'Buitenlandse arbeiders in de steenkolenmijnen van Luik en Nederlands-Limburg'; zie ook Langeweg, Mijnbouw en arbeidsmarkt.

126 C.E.C.A. 1952-1962, 2 Io (aldaar: Lister, Europe's Coal and Steel Community. 
structuur en de omvang van de mijnbedrijven, voor de inrichting en de organisatie van het werk ondergronds, voor de productiviteit en voor de ontwikkeling van de arbeidsmarkt in de twintigste eeuw. Dat blijkt duidelijk als wij de ontwikkeling in Luik vergelijken met die in het nabijgelegen jonge Nederlandse bekken.

De steenkolenwinning rond Luik was in de negentiende eeuw tot bloei gekomen als gevolg van de vroege industriële ontwikkeling van België. De twee à drie mijnen in de Nederlandse provincie Limburg hadden daar geen deel aan gehad. ${ }^{127}$ Pas met de opening in I899 van de Oranje-Nassaumijn in Heerlen begon de Nederlandse mijnbouw aan een periode van snelle expansie. De steenkolenwinning in Luik was op dat moment al lang een gevestigde industrie. In het laatste jaar van de negentiende eeuw produceerden de Luikse mijnen 5.849 .000 ton steenkool. In totaal werkten er 30.700 mijnwerkers. ${ }^{128}$ De netto-productie van de Nederlandse steenkolenmijnen, vijftig kilometer noordelijker, stak daar met 2I2.972 ton erg schril bij af. Het aantal mijnwerkers, dat 8I 3 bedroeg, ook. ${ }^{\mathrm{I} 29}$ In de loop van de twintigste eeuw zouden de verhoudingen geheel omkeren, zoals de grafieken I.9 en I.Io laten zien. In 1924 bereikten de Nederlandse mijnen voor het eerst een hogere productie dan de Luikse. Aan het eind van de jaren I920 passeerde ook de personeelsbezetting van de gezamenlijke Nederlandse mijnbedrijven die van de Luikse (grafiek I.Io).

Vanaf omstreeks I89o leidden ontwikkelingen aan zowel de vraag- als aanbodzijde van de arbeidsmarkt tot structurele wijzigingen van de personeelssamenstelling bij de Luikse mijnen. De vraag naar mijnwerkers steeg snel, toen de markt voor huisbrandkolen tengevolge van veranderende stookgewoonten veel groter werd. In Luik, waar veel steenkool voor huishoudelijk gebruik werd ontgonnen, steeg de werkgelegenheid voor mijnwerkers in de volgende decennia spectaculair. De jaren tussen I880 (22.305 mijnwerkers) en I9I3 (38.432 mijnwerkers) lieten bijna een verdubbeling zien van het aantal werknemers in de Luikse steenkolenmijnen. ${ }^{130}$

De personeelsvoorziening kwam echter in gevaar door ontwikkelingen aan de aanbodzijde. Aan het eind van de negentiende eeuw begon de traditionele mijnwerkersbevolking een ambitie te ontwikkelen om haar kinderen uit de mijnen te houden en vaker te kiezen voor alternatieve werkgelegenheid, daarbij geholpen door de uitbouw van het stelsel van beroepsonderwijs. ${ }^{13 \mathrm{I}}$ Deze mentaliteitsverandering uitte zich in de keuze om minder kinderen te nemen, zodat deze meer mogelijkheden kregen. ${ }^{132}$ De traditie om van vader op zoon in de put af te dalen begon geleidelijk aan te verdwijnen. Het tekort aan Waalse arbeidskrachten werd verder versterkt door het in 1892 in werking tredende verbod op mijnarbeid voor vrouwen en kinderen. ${ }^{\mathrm{I} 3}$

Deze fundamentele wijzigingen aan de vraag-en aanbodzijde leidden vanaf het begin van de twintigste eeuw tot een noodzakelijke uitbreiding van de regionale rekrutering. Vooral na de agrarische crisis van de jaren 1880 kwamen veel Vlamingen op de werkgelegenheid in de Luikse mijnen af. De migratiestroom van Vlamingen naar Luik begon na het uitbreken

I27 Gales, Delven en slepen, 53-54.

128 Annales des Mines de Belgique (I900) 605, 608.

129 Verslag van den ingenieur der mijnen, betreffende de exploitatie der mijnen en steengroeven in Limburg over het jaar 1899, I.

I30 L'industrie en Belgique.

I3I Caestecker, 'Centraaleuropese mijnwerkers in België', I65.

132 Idem, 'Vervanging of verdringing', 3 13.

I33 Pasinomie: collection complète, 596-599. Zie ook: Roels, “In Belgium, women do all the work”'. 
Grafiek i.9 De netToproductie bij de Nederlan DSE EN Luikse SteEnKoLENMIJNEN, IGOO-I974 (IN DUIZEND TON)

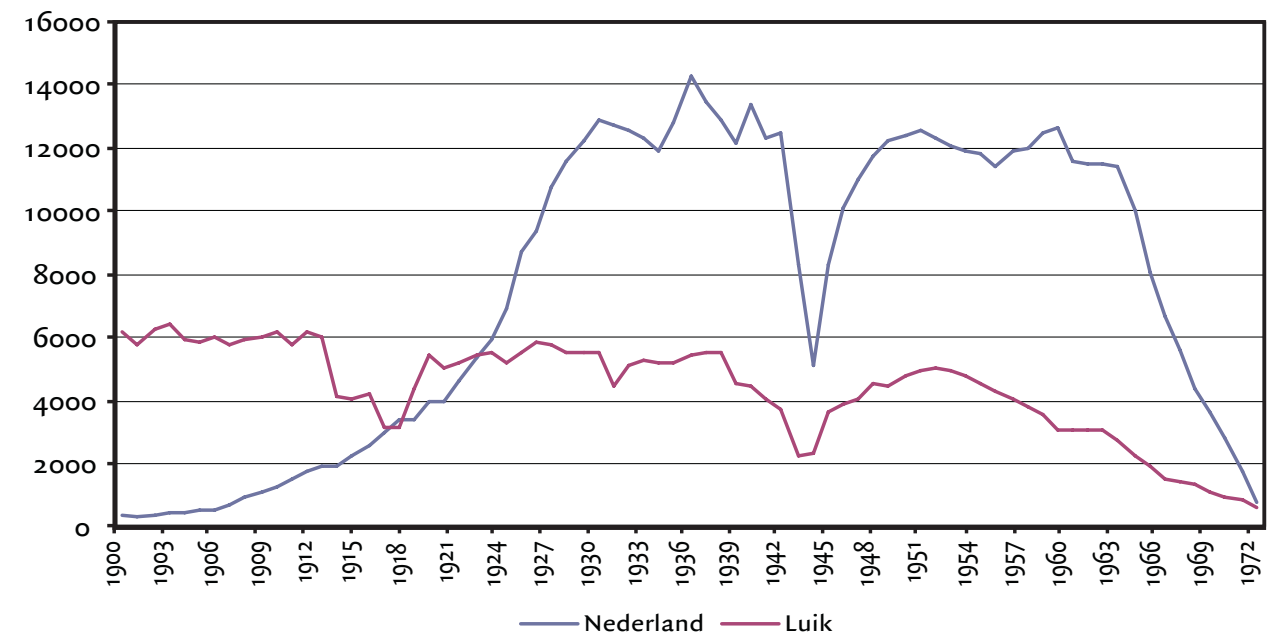

Bronnen: Verslag van den (Hoofd-) Ingenieur, resp. Inspecteur-Generaal der Mijnen; Annales des Mines de Belgique; Geerkens, La rationalisation dans l' industrie belge, I24I (Tableau 2); I940-I945: RAH, archief FEDECHAR, inv.nrs. 606-609: 'Jaarlijkse statistische overzichten'.

GRAFIEK I.IO HET AANTAL ARBEIDERS (ONDERGRONDS EN BOVENGRONDS) IN DE NEDERLANDSE EN LUIKSE MIJNEN, I904-I974

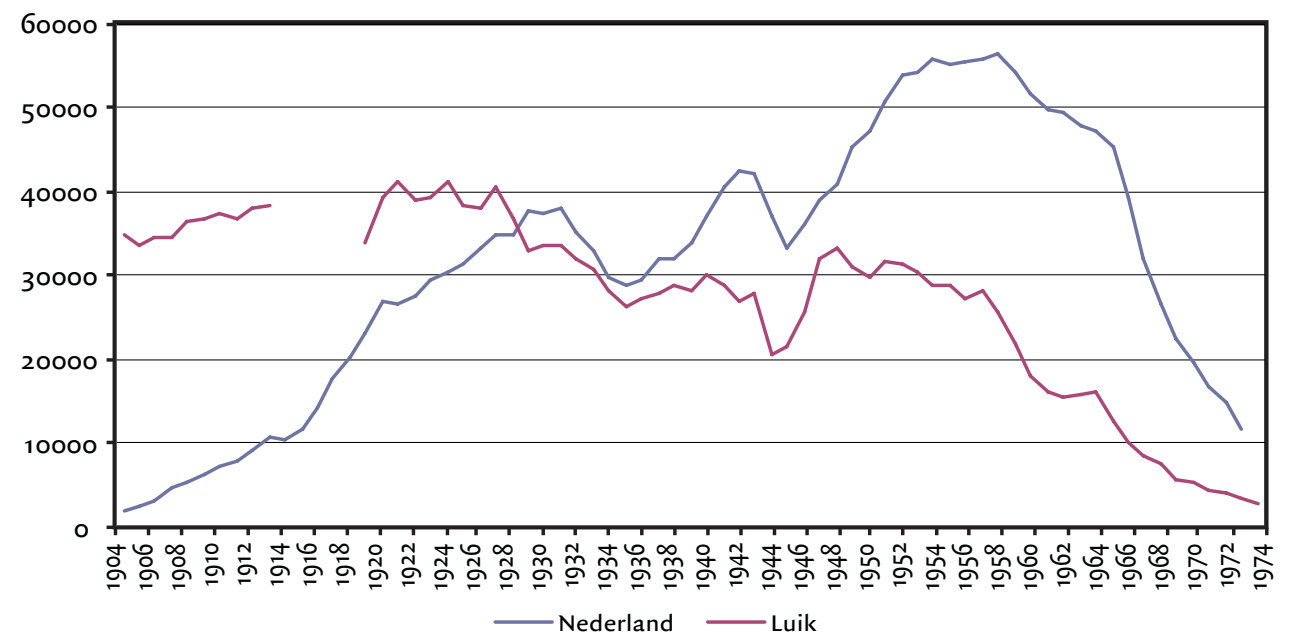

Bronnen: Verslag van den (Hoofd-) Ingenieur, resp. Inspecteur-Generaal der Mijnen; Annales des Mines de Belgique; Geerkens, La rationalisation dans l' industrie belge, I244 (Tableau 8); I940-I945: RAH, archief FEDECHAR, inv.nrs. 6o6-609: 'Jaarlijkse statistische overzichten'. 
van de Eerste Wereldoorlog in I9I4 te verminderen. Na de oorlog dienden zich alternatieven voor de Vlaamse arbeiders aan. Wie koos voor het beroep van mijnwerker, kon voortaan dichter bij huis terecht, in het nieuw ontgonnen Belgisch-Limburgse steenkolenbekken. ${ }^{134}$ Toch bleven er voorlopig nog heel wat Vlamingen in Wallonië werken. De komst van deze Vlaamse arbeidskrachten was niet voldoende om het tekort aan lokale mijnwerkers te dekken. Zoals in de meeste andere mijnbekkens moesten ook de directies van de Luikse mijnen een beroep doen op mijnwerkers van buitenlandse afkomst. Toch was dit een geleidelijk proces. In november 1923 was het aantal mijnwerkers met een niet-Belgische nationaliteit in de Luikse mijnen nog beperkt. De 2.512 buitenlanders maakten slechts 5,7 procent van de totale arbeidskracht uit. ${ }^{\mathrm{I} 5}$ Dit geeft aan dat de Luikse mijnen toen nog in ruim voldoende mate terecht konden op de nationale arbeidsmarkt. In I930, het laatste normale jaar vóór de depressie van de jaren I930, was het aandeel buitenlanders in de Luikse mijnen weliswaar gestegen ten opzichte van zeven jaar eerder, maar het bedroeg met bijna i6 procent slechts de helft van het percentage buitenlanders in de Nederlandse mijnbouw. ${ }^{136}$

In de eerste drie decennia van de eeuw was de aanwerving van buitenlandse mijnwerkers in Nederland aanzienlijk groter dan in Luik. Dat is terug te voeren op de mate waarin er een regionale mijnwerkerstraditie was ontstaan. In het oudere Luikse mijnbouwbekken bestond er eind negentiende eeuw een vaste kern van lokale en regionale families, waarin het beroep van mijnwerker werd overgedragen van generatie op generatie. Hoewel die traditie in de periode tot circa 1935 langzaam maar zeker begon te verdwijnen, konden de Luikse mijnen in die periode in redelijke mate putten uit de nationale en regionale arbeidsmarkt. Waalse mijnwerkers konden worden vervangen door arbeidskrachten uit andere delen van België.

De Nederlandse mijnen stonden op een heel ander punt in hun levenscyclus. De regionale en nationale arbeidsmarkt, niet of nauwelijks bekend met het beroep van mijnwerker, was in de opbouwfase tot het begin van de jaren 1930 niet in staat te voldoen aan de grote vraag vanuit de mijnbedrijven. Vooral voor de ondergrondse vakkrachten was men aangewezen op het buitenland. Het Duitse achterland, dat in die periode één arbeidsmarkt met de Limburgse mijnstreek vormde, leverde het gros van die geschoolde mijnwerkers. Bij de Nederlandse mijnen steeg het aantal buitenlanders van 429 (I7 procent van de totale arbeidersbezetting) in 1905 tot II.969 (32 procent) in I930. Deze sterke absolute en relatieve toename duidt op tekorten op de regionale en nationale arbeidsmarkt voor mijnwerkers.

Het gebied in Limburg waar na Igoo de mijnen verschenen, had van oudsher een ruraal karakter zonder industriële traditie van betekenis. ${ }^{137}$ Van meet af aan zagen de mijndirecties zich daarom gedwongen om voor een kwantitatief en kwalitatief adequate personeelsvoorziening een beroep te doen op arbeidsmigranten van buiten Limburg. Buitenlandse arbeidskrachten werden vooral aangenomen als geschoolde krachten voor het ondergrondse werk. Dat was niet alleen van belang voor de productie, maar had ook een opleidingsdoel. ${ }^{{ }^{13}}$ Nederlandse mijnwerkers leerden in de ondergrondse praktijk het houwersvak van

I34 Caestecker, 'Vakbonden en etnische minderheid', 6o.

135 Ingeschreven arbeiders november I923, in: Annales des Mines de Belgique, I928, 246-247.

I36 RAH, archief FEDECHAR, inv.nr. 612: 'Statistieken'.

137 Langeweg, 'Trekarbeiders en pendelaars', 295-308.

138 Versteegh, De onvermijdelijke afkomst?, 225-227. 
hun ervaren buitenlandse collega's. In de loop van de tijd bouwden de Limburgse mijnen op die manier een vaste kern van geschoolde Nederlandse mijnwerkers op. Daarmee verdween langzamerhand de afhankelijkheid van de Nederlandse mijndirecties van de ondergrondse vakman uit het buitenland. De toenemende aanwezigheid van geschoolde Nederlandse mijnwerkers had een wijziging in het rekruteringsbeleid van de mijnen tot gevolg. In de tweede helft van de jaren 1920 richtte dat beleid zich meer dan voorheen ook op ongeschoolde buitenlandse arbeiders. ${ }^{139}$ In deze jaren bestond er een grote vraag naar mijnwerkers. De arbeidstekorten moesten worden opgevuld met de rekrutering van nieuwe groepen buitenlanders. In 1930 was het percentage buitenlanders gestegen naar $3 \mathrm{I}, 9$ procent. ${ }^{\mathrm{I} 40}$

In de loop van I93I werd de mondiale economische crisis merkbaar in de mijnbouwsector. Vooral de buitenlandse mijnwerkers werden getroffen door de golf van ontslagen waartoe de Nederlandse mijnbedrijven overgingen. Buitenlanders die aan het eind van de jaren I 920 waren gerekruteerd, werden het eerst ontslagen. Aan het eind van 1930 hadden de gezamenlijke mijnen Ir.969 arbeiders met een niet-Nederlandse nationaliteit in dienst. Vijf jaar later was dat aantal gedaald tot 4.564, een afname van 62 procent. In diezelfde periode nam ook het aantal Nederlandse mijnwerkers af, maar slechts met 5,3 procent. De daling van de in Limburg geboren mijnwerkers was met 2,7 procent nog geringer. ${ }^{14}$ Voor het eerst kregen de mijndirecties in de jaren 1930 te maken met een ruime arbeidsmarkt en konden ze opteren voor de meest preferente groep: jonge autochtone arbeiders die geworteld waren in de regio. Het werd een beleid, dat ook na de crisis kon worden voortgezet: er kon een regionale beroepstraditie ontstaan.

Ook de Luikse mijnen ontkwamen niet aan de crisis van de jaren 1930. Opvallend is echter dat de afnemende werkgelegenheid niet in de eerste plaats op de buitenlandse arbeiders werd afgewenteld. In Luik ging in de crisisjaren de uittocht van traditionele Waalse mijnwerkers gewoon door. Waar de Nederlandse mijnen erin slaagden een begin te maken met een beroepstraditie in eigen streek, verdween die in Luik. In Luik nam het aantal Belgische mijnwerkers tussen I930 en 1935 met 22,7 procent af, het aantal buitenlanders slechts met I6,2 procent. ${ }^{\mathrm{I} 2}$ De traditionele Luikse mijnwerkersgezinnen bleven volharden in hun eenmaal ingezette streven indien mogelijk de mijnen te verlaten. De Vlamingen uit het zuiden van Limburg en het Brabantse Hageland opteerden er in de jaren I930 steeds vaker voor hun loopbaan als mijnwerker voort te zetten in de nieuwe Belgisch-Limburgse mijnen. ${ }^{143}$ Terwijl er in de Nederlandse mijnen in de jaren 1930 een vaste kern van autochtone arbeidskrachten kon worden gevormd, was in Luik het omgekeerde het geval. Waalse en Vlaamse mijnwerkers keerden de Luikse steenkolenwinning voorgoed de rug toe. Een regionale traditie van mijnarbeid ging teloor: voortaan zouden de Luikse mijnen sterk afhankelijk worden van mijnwerkers uit het buitenland.

Het economisch herstel in de tweede helft van de 1930 leidde in Nederland niet tot het werven van nieuwe groepen buitenlanders. De groeiende behoefte aan mijnwerkers werd vrijwel geheel bevredigd door jonge autochtone arbeiders die direct na de lagere school naar

I39 Brassé en Van Schelven, Assimilatie van vooroorlogse immigranten, I46; Versteegh, De onvermijdelijke afkomst?, 225.

I40 Jaarverslag AMF over 1930, I4.

I4I Idem over 1930 en 1935.

142 RAH, archief FEDECHAR, inv.nr. 6I2: 'Statistieken'.

I43 Caestecker, 'Vervanging of verdringing', 315-3 I6. 
de eigen opleidingen van de mijnen waren gegaan. ${ }^{\mathrm{I} 44}$ De Luikse mijnen daarentegen waren in de tweede helft van de jaren 1930 genoodzaakt de toenemende werkgelegenheid grotendeels op te vangen door de rekrutering van mijnwerkers van buitenlandse origine. Tussen eind 1935 en eind 1939 steeg het aantal arbeidsplaatsen in de Luikse mijnen met 698. Het aantal buitenlanders in de steenkolenwinning steeg in diezelfde periode echter met ruim I.800: ${ }^{145}$ het proces van vervanging van Belgische arbeidskrachten door buitenlanders in de Luikse mijnbouw ging ook na de crisistijd dus gewoon door.

Na de Tweede Wereldoorlog gingen de in de jaren I930 duidelijk aan het licht getreden ontwikkelingen in snel tempo voort. De Nederlandse mijnen wisten vooral door de uitbouw van een systeem van interne beroepsopleidingen jonge Limburgers te interesseren voor een carrière in de mijn. Die jonge aanwas was beschikbaar dankzij een gunstige demografische ontwikkeling. Zonder buitenlandse inbreng kon men ook in het naoorlogse Nederland niet, maar buitenlanders kregen in de mijnen vooral een bufferfunctie, waarmee conjuncturele schommelingen konden worden opgevangen. De kern van de bezetting was van Nederlandse origine. De Luikse mijnen daarentegen werden geheel afhankelijk van arbeidsmigranten.

In de jaren direct na de Tweede Wereldoorlog steeg het aantal buitenlandse arbeiders in de Luikse mijnen explosief: tussen eind I944 en eind 1952 verzesvoudigde het contingent mijnwerkers met een niet-Belgische nationaliteit. In dezelfde jaren nam het aantal Belgen in de Luikse steenkolenwinning met ruim drieduizend man af. Het was duidelijk dat in het algemeen Belgen de verouderde Luikse mijnen uit wilden. De afkeer van de lokale arbeidskrachten voor het beroep van mijnwerker was zeer groot, zeker voor het ondergrondse werk. ${ }^{\mathrm{I} 4}$ Omdat de Belgen massaal deserteerden, werd de 'kolenslag', die premier Achille van Acker in 1945 had uitgeroepen, in de Luikse mijnen gestreden door een vreemdelingenlegioen. In 1954 bestonden de buitenlandse troepen voor bijna tweederde uit Italianen. Ook de demografische ontwikkeling leidde er toe dat er nauwelijks voldoende jonge Luikenaren beschikbaar waren om te voldoen aan de vervangingsvraag van de mijnen. In die situatie werd de aanwezigheid van buitenlandse mijnwerkers in het ondergrondse bedrijf een structureel verschijnsel.

I44 Kreukels, Mijnarbeid, 4I9-420.

I45 RAH, archief FEDECHAR, inv.nr. 6I2: 'Statistieken'.

I46 Demeure de Lespaul, L'Avenir de notre production de houille, I8. 


\section{Hoofdstuk 2}

\section{'In Belgium, women do all the work'` De arbeid van vrouwen in de Luikse mijnen, negentiende - begin twintigste eeuw}

Dat vrouwen tot aan het begin van de twintigste eeuw in België als mijnwerkster ondergronds werkten, en bovengronds nog veel langer, is een weinig onderzocht gegeven. Dit is verwonderlijk, gezien het feit dat de mijnwerkster voor vele kunstenaars een populair motief vormde. Een groep kunstenaars met socialistische sympathieën vond hierin een dankbaar onderwerp en bovendien werd deze kunst actief ondersteund door de groeiende Belgische Werkliedenpartij - Parti Ouvrier Belge (opgericht in I885). Vanaf de jaren I880 werd de hiercheuse ${ }^{\mathrm{I}}$ één van de meest geschilderde, gebeeldhouwde en later gefotografeerde arbeidsters in België. Toch is over deze groep vrouwen heel weinig bekend. ${ }^{2}$ Uitgaande van theorieën over seksesegregatie op de werkvloer, literatuur over de ontwikkelingen in andere landen, voornamelijk Groot-Brittannië en Noord-Frankrijk, en een beperkt empirisch onderzoek zal in dit hoofdstuk getracht worden de situatie in België, en meer bepaald in de Luikse mijnen, nader toe te lichten. Nagegaan zal worden of de algemene inzichten uit de internationale en nationale literatuur door empirisch onderzoek kunnen worden bevestigd.

Was het inderdaad zo dat Belgische vrouwen meer en langer werkten dan vrouwen elders, zoals het citaat in de titel van dit hoofdstuk ons doet geloven? In de tweede helft van de negentiende eeuw vertoonden de Belgische vrouwen, samen met de Britse, in de industriële sector inderdaad de hoogste activiteit. ${ }^{3}$ Wanneer we enkel de extractieve nijverheid in rekening brengen zien we dat de Belgische vrouwen gedurende de tweede helft van de negentiende eeuw in deze sector veel meer vertegenwoordigd waren, tussen de 4 en bijna I4 procent, dan de Britse vrouwen, met een maximum van 3, II procent. ${ }^{4}$

In Emile Zola's roman Germinal vinden we een neerslag van het leven van de mijnwerkers in de Noord-Franse regio in de periode I866-I869. In die periode waren er 14.000 vrouwen aan het werk in de Franse extractieve bedrijven, een aandeel van 8,8I procent (op een totaal

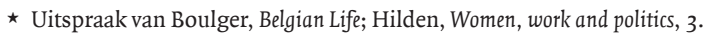

I Omdat de 'hierchage', het slepen van de steenkool, de voornaamste bezigheid van de vrouwelijke mijnwerkers was, werd dit al snel de algemene benaming voor vrouwen die ondergronds werkten.

2 Hilden, Women, work and politics, 4I4-4I5. In 1996 verscheen een licentiaatsverhandeling over vrouwen- en kinderarbeid in de steenkolenmijnen van Seraing (Salée, Le travail des femmes et des enfants dans les charbonnages) en in 2002 verscheen er een artikel van de hand van Suzy Pasleau eveneens omtrent de vrouwenarbeid in Seraing (Pasleau, 'La femme, un acteur à part entière de l'industrialisation'). Twee oudere licentiaatsverhandelingen die niet werden opgenomen in universiteitscatalogi: Maron, Le travail des femmes et des enfants dans les mines du Hainaut en Bairin, Le travail des femmes dans mines de la province de Liège, behandelen ook de vrouwenarbeid in de mijnbouw. De eerste kon jammer genoeg niet worden ingezien.

3 Pott-Buter, Facts and Fairy Tales about Female Labor, 277.

4 Berekend op basis van Mitchell, International historical statistics, I46, I60.

5 Zola, De Mijn.
} 
van 159.000 werknemers). ${ }^{6}$ Eén van de hoofdfiguren in de roman van Zola is de mijnwerkster Cathérine Maheu, die als taak had de mijnwagens tot de voet van de schacht te transporteren. Onder haar werkten een resem andere vrouwen en meisjes als ondergrondse sleepsters. Zij behoorden tot een groep mannen en vrouwen die samen op akkoordloon werkten. Volgens Zola wilden de mijnondernemers de ondergrondse vrouwenarbeid afschaffen en deze vrouwen door mannen laten vervangen, maar dit stuitte op tegenstand van de mijnwerkers, die het bijkomend inkomen van vrouwen en dochters nodig hadden. Deze arbeid in groeps- en familieverband was in de mijnindustrie niet uitzonderlijk. Getrouwde vrouwen die kinderen te verzorgen hadden stopten over het algemeen met het mijnwerk. Door het in huis nemen van kostgangers konden zij eventueel voor een extra inkomen zorgen. ${ }^{7}$ In 1892 werd een verbod ingesteld op de ondergrondse arbeid van vrouwen, waarna hun tewerkstelling in het Franse mijnbedrijf snel daalde. ${ }^{8}$ In 1896 bedroeg hun aandeel nog slechts 2,6 procent. ${ }^{9}$ Toen de vrouwen in Frankrijk enkel nog bovengronds aan de slag mochten, werden ze geconcentreerd in twee functies: de triage - het sorteren van de steenkool, en de lampisterie - het onderhoud van de mijnlampen. ${ }^{\mathrm{IO}}$

Ook in Groot-Brittannië maakte de tewerkstelling van vrouwen in de steenkolenmijnen tot het begin van de negentiende eeuw deel uit van de gezinseconomie. ${ }^{\text {II }}$ Mannelijke familieleden gebruikten hun hulp waar het maar mogelijk was. ${ }^{12}$ Net als in Noord-Frankrijk was hun belangrijkste taak het slepen van de steenkool: het trekken van sleeën of kuipen gevuld met steenkool of puin, van het kolenfront naar de bodem van de schacht. Modernisering ging gepaard met een toename in arbeidsmogelijkheden voor jonge mannen in de Britse steenkoolindustrie, terwijl de technologische ontwikkeling de mogelijkheden voor vrouwen juist deed dalen: hun taken werden meer en meer door paarden en machines overgenomen. Mijnen met dunne steenkolenlagen en/of weinig kapitaal pasten zich echter maar moeizaam aan de technologische vooruitgang aan. Tegen 1840 bleef de ondergrondse arbeid van vrouwen slechts in belangrijke mate voortbestaan in bepaalde regio's in Engeland, namelijk Yorkshire, West-Lancashire, East-Scotland en South-Wales. Het aantal vrouwen in de mijnen, zowel ondergronds als bovengronds, kan omstreeks die tijd worden geschat op 5.000 à $6.000 .{ }^{13}$ In de statistieken van $\mathrm{I} 84 \mathrm{I}$ voor de gehele extractieve nijverheid vinden we een aantal van 7.000 vrouwen terug. Op een totaal van 225.000 arbeiders (mannen én vrouwen) vormt dit slechts 3,II procent. ${ }^{14}$ Min of meer toevallig werd door de Children's Employment Commission omstreeks 1840 'ontdekt' dat er vrouwen ondergronds werkten en dit zorgde voor de nodige ophef. ${ }^{15}$ Het mogelijk destructieve effect van mijnwerk op het huishouden

6 Mitchell, International historical statistics, I49.

7 Vanja, 'Frauenarbeit im Bergbau', I9-20.

8 Le Tirant, Femmes à la mine, I73. Het verbod op ondergrondse arbeid voor vrouwen en kinderen was reeds in I874 ingesteld, maar werd vooralsnog niet toegepast. In 1892 werd het opnieuw ingesteld.

9 Mitchell, International historical statistics, I49.

Io Le Tirant, Femmes à la mine.

II '... a system of work organization consisting of a "team" of workers who were often members of the same household', MarkLawson en Witz, 'From "family labour" to "family wage"'?, 152.

12 Humphries, 'The Most Free From Objection ...', 946-947.

I3 John, By the sweat of their brow, I9.

I4 Mitchell, International historical statistics, I6o.

I5 Vanja, 'Frauenarbeit im Bergbau', I8. 
werd meer en meer een publieke vrees. Bovendien vonden steeds meer mijnwerkers zelf het ondergrondse werk immoreel en ongepast voor vrouwen. Hoewel deze houding tegenover vrouwenarbeid in de mijnen niet algemeen was, kregen de tegenstanders de overhand en werd de ondergrondse arbeid van vrouwen reeds in 1842 afgeschaft. ${ }^{16}$

Ondanks het verbod bleef er in Groot-Brittannië toch een honderdtal vrouwen tot het einde van de negentiende eeuw ondergronds werken, aangezien de naleving van het verbod moeilijk te controleren was in afgelegen gebieden en de boetes bij een overtreding niet erg hoog waren. ${ }^{17}$ In de jaren 1880 werd er ook werk gemaakt van de afschaffing van de bovengrondse vrouwenarbeid. In 1874 bedroeg het aandeel vrouwen in het bovengronds mijnbedrijf nog 6,25 procent (6.899 op IIO.2I8), maar in Igoo was dit aandeel reeds gedaald tot 3,13 procent. ${ }^{18}$ Het boek van Angela John over de vrouwenarbeid in de Britse steenkoolmijnen, waaraan dit onder meer is ontleend, geeft een aantal aanknopingspunten voor een vergelijking met de Belgische situatie. Zij baseerde haar bevindingen vooral op rapporten van Arthur Munby, een Victoriaans dichter en advocaat, die dagboeken bijhield met observaties omtrent vrouwenarbeid. Hij verzamelde ook foto's van werkende vrouwen. Wat Zola voor de mijnwerksters in Noord-Frankrijk deed, deed Munby voor de mijnwerksters in GrootBrittannië.

In Pruisen werd de inzet van vrouwen in de mijnbouw, en daarmee de rol van vrouwenarbeid in het gezinsinkomen, al in de achttiende eeuw sterk ingeperkt door de grote invloed van de staat op de organisatie van de kolenwinning. De Pruisische mijnbouw was tot op zekere hoogte op militaire leest geschoeid. Net zoals het leger werd ook de mijnbouw beschouwd als een mannenwereld. Vrouwenarbeid in de mijnen werd van steeds mindere betekenis, zeker in vergelijking tot de situatie in Groot-Brittannië, Frankrijk, en in het latere België. Deze tendens zette zich in de negentiende eeuw voort. In I 827 werd in de Pruisische gebiedsdelen aan de linker Rijnoever een verbod ingesteld op de ondergrondse vrouwenarbeid in de steenkolenmijnen. Ook bovengronds mochten ze maar een beperkt aantal werkzaamheden meer verrichten. Voor Düsseldorf werden dezelfde regels in 1858 ingevoerd. Een algemeen verbod op ondergrondse vrouwenarbeid voor het gehele Duitse Keizerrijk werd in 1878 afgekondigd. ${ }^{\text {I9 }}$

De vrouwenarbeid in de Belgische mijnen is uitgebreid beschreven door Patricia Hilden, een Amerikaanse historica. In haar boek Women, Work and Politics. Belgium 1830-1914 geeft ze een zeer omvangrijk overzicht van de vrouwenarbeid, en dus ook van de (ondergrondse) mijnarbeid van vrouwen. Haar hoofdstuk daarover is vooral gebaseerd op contemporaine rapporten. Zij schetst de situatie voor heel België en gaat hierbij soms zeer veralgemenend te werk. De enorme hoeveelheid bronnenmateriaal die in haar onderzoek werd benut, wordt door haar vooral gebruikt als achtergrondinformatie bij een analyse van het discours en de iconografie van de hiercheuses. Volgens Hilden was ook in België de ontginning van steenkool lange tijd een familieaangelegenheid en werd er over het algemeen geen onderscheid

I6 John, By the sweat of their brow, ig.

17 Vanja, 'Frauenarbeit im Bergbau', I8.

I8 John, By the sweat of their brow, 7I, I48.

I9 Vanja, 'Frauenarbeit im Bergbau', 2I-23. 


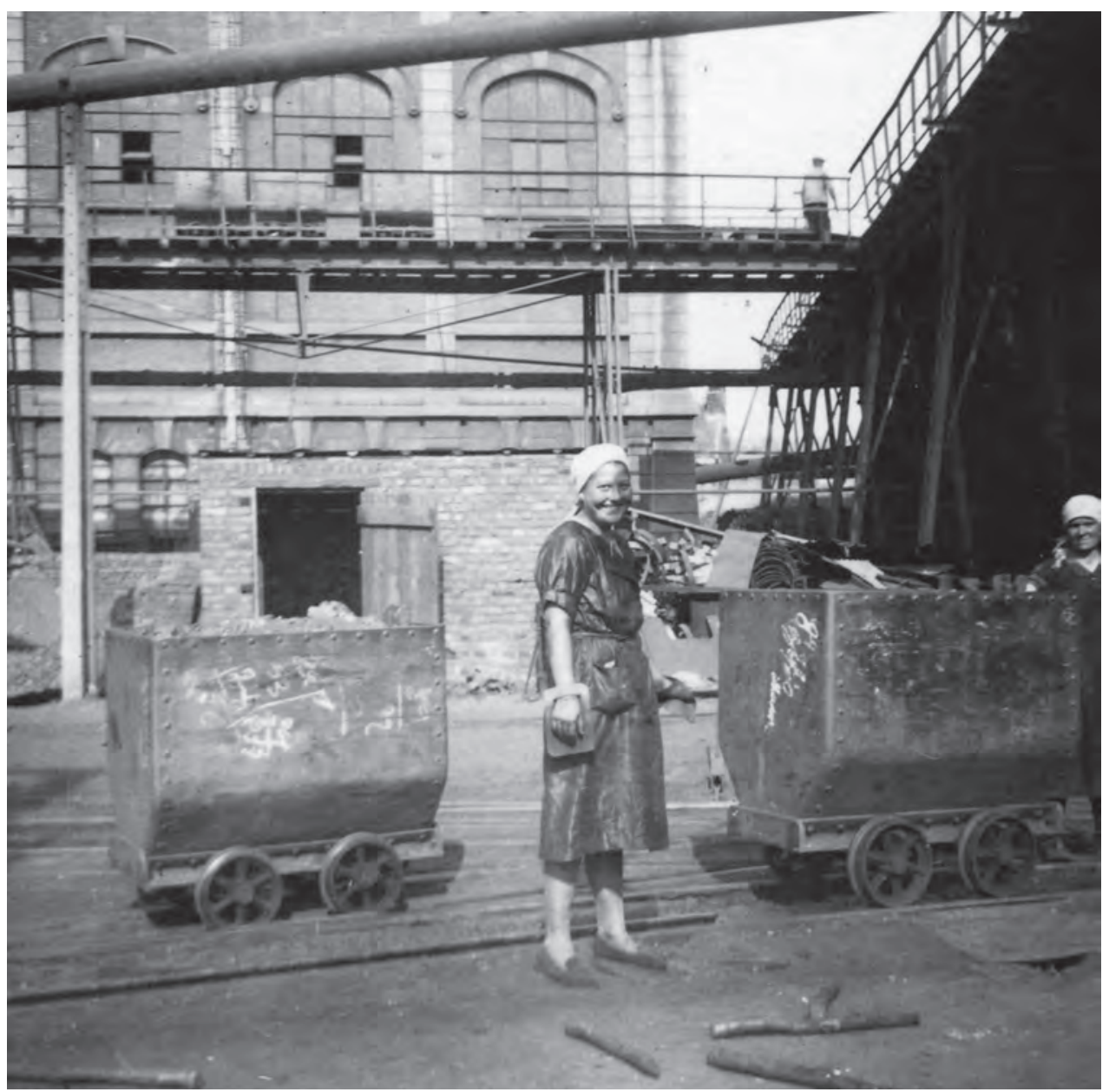

'Hiercheuse' bij de steenkolenmijn Gosson, september 1940. Coll. Blegny-Mine.

gemaakt in arbeidsverdeling naar geslacht. In de achttiende eeuw onderging de steenkoolnijverheid belangrijke veranderingen. Kleinere familiale mijnbedrijven werden opgekocht door grotere consortia en deze zochten grote groepen arbeiders, die nu meestal niet langer in familieverband konden werken. In 1829 waren er in het Luikse reeds negen steenkolenmijnen met meer dan roo werknemers, de grootste, $\mathrm{NV}$ Cockerill, had er zelfs meer dan $400 .{ }^{20}$ Het meeste werk in de steenkoolmijnen bleef volgens Hilden echter ungendered. Tot het laatste kwart van de negentiende eeuw bleef het aantal vrouwen dat ondergronds werkte stijgen. ${ }^{21}$ In 1890 bedroeg het aandeel vrouwen in de steenkoolnijverheid nog 6,47 procent. ${ }^{22}$ De jonge Belgische en liberale regering stond weigerachtig tegenover wetgeving die het vrije marktsysteem in het gedrang zou brengen. Humanitaire overwegingen moesten het 
onderspit delven voor de materiële belangen van de industrie. ${ }^{23} \mathrm{Na}$ de massale stakingen in I886 werd er eindelijk werk gemaakt van een beschermende arbeidswetgeving. De katholieke regering reageerde op de onlusten met een grootschalig onderzoek naar de werkomstandigheden in de industrie. Het resultaat was een wetgeving, die van kracht werd in I892: de wet van 13 december 1889 betreffende de arbeid van vrouwen, jongeren en kinderen in de nijverheidsgestichten. Deze wet was beperkt en alleen kinderen en vrouwen jonger dan 2I jaar die ondergronds werkten voelden de gevolgen. Vrouwen en meisjes die in I892 reeds ondergronds werken mochten dat blijven doen. ${ }^{24}$ Meer dan één vrouw ontdook het verbod bovendien door zich voor te doen als man, maar niettemin verdwenen vrouwen geleidelijk uit het ondergrondse werk. ${ }^{25}$ Pas vanaf I9II werd de ondergrondse mijnarbeid voor alle vrouwen verboden. ${ }^{26}$

Uit bovenstaand overzicht kunnen we concluderen dat de ondergrondse vrouwenarbeid in België blijkbaar langer standhield dan in de rest van West-Europa. Volgens Hilden steeg het aantal mijnwerksters zelfs verder tot het einde van de negentiende eeuw. Bovendien wijst ze op het vrijwel ontbreken van een arbeidssegregatie op basis van geslacht. Dit zou België wel erg uniek maken. Hierbij moeten we wel opmerken dat ze deze uitspraken uit haar inleiding verderop in haar boek enigszins nuanceert. Aan de hand van een eigen empirisch onderzoek zal nagegaan worden of de stellingen van Hilden wel steek houden. Uit literatuur over andere landen bleek immers dat vrouwen in de steenkolenmijnen juist specifieke taken kregen toebedeeld, zowel ondergronds als bovengronds en dat het aantal vrouwen ondergronds sterk regionaal werd bepaald.

De centrale vragen in dit hoofdstuk zijn: kan de Belgische situatie worden vergeleken met die in het buitenland? Hield de ondergrondse mijnarbeid van vrouwen in de Belgische en Luikse mijnen wel zo lang stand als het laattijdige verbod ons doet vermoeden, en zo ja, waarom was dit zo? Uit de buitenlandse historiografie kunnen we afleiden welke taken de mijnwerksters precies vervulden en hoe de arbeidsverdeling er elders uit zag. Was eenzelfde arbeidsorganisatie als in Engeland en Noord-Frankrijk ook in België aanwezig of was er, zoals Hilden aangeeft, weinig verschil tussen de mannelijke en vrouwelijke taken in het Belgische mijnbedrijf?

Wanneer we spreken over vrouwen in de mijnsector raken we aan het concept seksesegregatie. Onder seksesegregatie wordt de ongelijke verdeling van mannen en vrouwen over beroepen en functies verstaan, alsook het daaruit voortvloeiende verschil in beloning. Horizontale segregatie wijst op het feit dat mannen en vrouwen niet gelijk over de verschillende bedrijfstakken en beroepen zijn verdeeld; verticale segregatie betekent dat de posities binnen een bedrijf ongelijk zijn verdeeld: vrouwen bevinden zich vooral in de laagst gewaardeerde en betaalde functies, mannen nemen eerder de hogere functies in. ${ }^{27}$ Op basis van een analyse van de Belgische industrietelling van I896 en de industrie- en handelstelling van I9Io concludeert Nele Bracke dat er aan het einde van de negentiende en het begin van de twintigste eeuw op alle niveaus sprake was van arbeidssegregatie op basis van geslacht.

23 Keymolen, 'Vrouwenarbeid in België omstreeks I860', 27.

24 Nandrin, 'À la recherché d'un acte fondateur mythique'.

25 Hilden, Women, work and politics, $3 \mathrm{I}-36$.

26 Foulon-Busine, Autour des fosses, 33.

27 De Groot, Fabricage van verschillen, 17-32. 
Zij stelt dat de begrippen 'mannelijke' en 'vrouwelijke' sectoren grotendeels ideologisch werden bepaald en dat deze segregatie het gevolg was van een bewuste politiek van de geschoolde arbeiders en de overheid. In sectoren waar men over 'mannelijke' eigenschappen moest beschikken, zoals de mijnbouw, waren de vrouwen ondervertegenwoordigd. ${ }^{28}$ Bracke stelt zowel een horizontale als een verticale arbeidssegregatie naar geslacht vast: de meeste vrouwen waren werkzaam op uitvoerend en dus lager niveau. Het gevolg hiervan was een geringer maatschappelijk aanzien voor de vrouwen en een lager loon. De arbeid van vrouwen werd anders gewaardeerd dan de mannenarbeid en het vrouwenloon werd gezien als een aanvulling op het gezinsinkomen. Dat vrouwen niet in de hoger gewaardeerde functies terechtkwamen wordt verklaard door het feit dat vele vrouwen de loonarbeid verlieten als ze huwden of kinderen kregen. Bracke stelt dat dit slechts een drogreden is, ze konden immers precies omwille van hun vrouwzijn niet opklimmen. ${ }^{29}$

Volgens Gertjan de Groot is de typering van werk als mannen- of vrouwenwerk niet gebonden aan specifieke mannelijke of vrouwelijke eigenschappen of kwalificaties zoals fysieke kracht of scholingsgraad, maar aan de sociale constructie van sekse in de praktijk van het arbeidsproces. ${ }^{30}$ De veranderingen in het productieproces en de introductie van nieuwe technieken tijdens de industriële revolutie maakten andere verdelingen tussen vrouwen- en mannenwerk mogelijk. Volgens sommige auteurs reproduceerde de seksesegregatie in de nieuwe fabrieken de daaraan voorafgaande vormen van gezinsarbeid. Die zorgden ervoor dat vrouwen vooral aanvullende werkzaamheden verrichtten en in een ondergeschikte positie terechtkwamen. De reproductie van de gezinsarbeidsverhoudingen in de fabrieken wordt zowel aan de werkgevers als aan de mannelijke arbeiders toegeschreven. De werkgevers namen mannen in dienst voor de hoofdfuncties en lieten het aan hen over om hulpkrachten aan te nemen. Voortbouwend op de pre-industriële gezinsproductie namen mannen dan hun eigen kinderen of familieleden aan.

De Groot somt in zijn boek ook de meetbare verschillen tussen vrouwen- en mannenarbeid op. Vrouwenwerk werd laag betaald, maar ook het omgekeerde was waar: als een functie laag werd betaald was het meestal vrouwenwerk. Bovendien zouden mannen minder arbeidsverloop hebben en daarom beter geschikt zijn om geschoolde functies te vervullen. Arbeidsverloop is echter ook erg afhankelijk van de leeftijd. Jonge arbeiders en arbeidsters veranderden vaker van baan dan ouderen. Het arbeidsverloop van mannen en vrouwen is bovendien moeilijk te vergelijken omdat ze zelden hetzelfde werk deden. Het hoge arbeidsverloop dat aan vrouwen werd toegeschreven, verkleinde de kans op een loopbaan binnen een bedrijf. Volgens De Groot is het een misvatting dat het veronderstelde hoge arbeidsverloop van vrouwen vooral werd veroorzaakt door vertrek als gevolg van een huwelijk. Arbeidsverloop was eerder afhankelijk van de mate waarin de lokale arbeidsmarkt vrouwen de mogelijkheid bood elders te gaan werken. In dit verband zijn er twee indicatoren die zicht geven op de mate waarin arbeidsters en arbeiders gebonden zijn aan een bedrijf: de lengte van het dienstverband en het aantal keren dat de arbeidster of arbeider bij een bedrijf in en uit dienst treed.

Bovenstaande bedenkingen zorgen voor de volgende onderzoeksvragen: is de arbeidsverdeling en het voorkomen van vrouwen in de Luikse mijnen te wijten aan de voortzetting

28 Bracke, 'De vrouwenarbeid in de industrie in België omstreeks I90o', 200-201.

29 Ibidem.

30 De Groot, Fabricage van verschillen, 17-32. 
van de pre-industriële arbeid in familieverband? Wie waren deze vrouwen, welke functies vervulden ze? Werden ze belast met de minderwaardige taken? Verdienden ze hetzelfde loon als hun mannelijke collega's?

Bronnen voor het onderzoek waren actuele artikelen en onderzoeken over het onderwerp, contemporaine rapporten en verslagen van tijdgenoten, wetgeving, periodieke statistische reeksen en een beperkte (en selecte) steekproef in de voor de Luikse mijnindustrie bewaarde werkboekjes of livrets d'ouvriers. Om zicht te krijgen op het aandeel en belang van vrouwen in de Belgische steenkoolnijverheid zijn we aangewezen op een aantal statistische reeksen. De industrietellingen van 1846 , I880 en 1896 werden geraadpleegd en ook de Statistique des Mines, Minières, Carrières, Usines métallurgiques et Appareils à vapeur du Royaume de Belgique, pour l'année ... Deze statistiek is terug te vinden in de Annales des Mines de Belgique, een publicatie van het Ministère de l'Industrie et du Travail - Administration des Mines vanaf I896. Deze reeksen moeten met de nodige voorzichtigheid worden benaderd. Door de (te) lage opgaven door de telplichtigen geven de resultaten uit de industrietelling van 1846 minima aan. ${ }^{3}$ Ook in de Annales des Mines wordt aangegeven dat het aantal werknemers in realiteit hoger lag dan de gemiddelden in de statistieken. ${ }^{32}$

Om verder te gaan dan louter een samenvatting van contemporaine rapporten en statistische reeksen, ben ik op zoek gegaan naar een bron die meer zicht zou kunnen geven op de loopbanen van deze mijnwerksters. De werkboekjes, waarin voor een werknemer (althans voor bepaalde industrietakken) de carrière werd genoteerd, boden hiervoor een kans (zie bijlage 6). René Leboutte, één van de weinige historici die deze bron reeds benutte, geeft een opsomming van mogelijke onderzoeksvragen die met behulp van de werkboekjes kunnen worden beantwoord: wat is de herkomst van de arbeider/ster? Hoe vaak wisselt hij/zij van werkgever, wanneer start en eindigt de professionele carrière? Wat is de gemiddelde duur van een dienstverband? Wat is het belang van periodes van werkloosheid? Verderop wordt het onderzoek van Leboutte gebruikt om vergelijkingen te maken met de onderzoekspopulatie die in dit hoofdstuk centraal staat: vrouwelijke mijnwerkers. ${ }^{33}$ Ondanks hun rijke informatie werd deze bron nog maar zelden gebruikt in de sociaal-economische geschiedschrijving. Bij mijn weten werden de werkboekjes nog nooit benut om de loopbanen van vrouwen te bestuderen. Voor een korte geschiedenis van deze bron kan ik verwijzen naar een artikel van Bart Delbroek. ${ }^{34}$ In bijlage 6 wordt een uiteenzetting gegeven van de wijze van steekproeftrekking en de beperkingen van de werkboekjes als bron.

\section{VROUWEN IN EEN MANNENWERELD}

Kwantitatieve gegevens over het aandeel van vrouwen in de steenkolenmijnen zijn moeilijk te vinden. Statistische uitgaven, zoals de industrietellingen, maakten vaak geen onderscheid naar ondergrondse of bovengrondse arbeid en een belangrijke bron als de Annales des Mines verscheen pas tegen het einde van de negentiende eeuw. Het feit dat er maar weinig

3I De Belder en Vanhaute, 'Sociale en economische geschiedenis', I24.

32 Annales des Mines de Belgique, I896, 508.

33 Leboutte, Le livret d'ouvrier dans la provincie de Liège, 36.

34 Delbroek, 'Werkboekjes in de $20^{\mathrm{e}}$ eeuw'. 
cijfers zijn, wijst er misschien op dat de (ondergrondse) vrouwenarbeid in het mijnbedrijf niet per se als problematisch werd gezien, maar eerder als normale gang van zaken. Deze conclusie wordt ook getrokken door Dominique Salée die de vrouwen- en kinderarbeid in Seraing onderzocht voor de periode I889-I9I4. ${ }^{35}$

In België steeg het aandeel van de loonarbeid in de loop van de negentiende eeuw sterk en snel, en zeker dat van vrouwen en kinderen in de fabrieken en mijnen. Volgens Patricia Hilden vormden vrouwen en meisjes in de Belgische koolmijnen ongeveer één tiende van de ondergrondse werkkrachten. In het midden van de jaren I860 waren er meer dan 87.000 mijnwerkers aan de slag, waarvan 50.000 mannen en jongens, 5.200 vrouwen en 3.700 meisjes (tot de leeftijd van $\mathrm{I} 6$ jaar) ondergronds. Op het toppunt van de tewerkstelling van vrouwen ondergronds, in de periode tussen 1860 en 1889 , waren er volgens haar wellicht circa Ir.00o vrouwen aan de slag, in verhouding tot ongeveer Ioo.00o mannen. Zij baseert zich hierbij vooral op contemporaine rapporten, maar geeft zelf aan dat die tegenstrijdige cijfers bevatten. ${ }^{6}$ In een enquête van de Medische Commissie van Henegouwen uit r 868 zijn bijvoorbeeld nog volgende aantallen terug te vinden: van de 80.000 Belgische mijnwerkers waren er 13.524 van het vrouwelijke geslacht. 9.122 van hen werkten ondergronds. ${ }^{37}$ Angela John spreekt in haar boek van bijna 7.000 vrouwen in de Belgische steenkoolnijverheid in 1883 en nog een 4.000 -tal vrouwen ten tijde van de grote staking in $1886.3^{8}$ Waar zij deze informatie vandaan haalt is niet duidelijk.

In de industrietellingen van 1846 vinden we geen aanwijzingen omtrent het aantal vrouwen dat ondergronds in de mijnen werkte. Wel zien we dat er in dat jaar voor heel België 7.066 meisjes en vrouwen in de steenkool- en cokesnijverheid werkten. Op een totaal van 46.186 werknemers was dit meer dan 15 procent. ${ }^{39}$ In het Luikse bekken waren I. 535 van de in totaal II.726 arbeiders vrouwen of meisjes, een verhouding van iets meer dan I3 procent. Hiermee lag het aandeel van vrouwen in de steenkoolindustrie in het Luikse bekken iets lager dan in de Belgische steenkoolnijverheid als geheel. In de industrietellingen van I880 werd wederom geen onderscheid gemaakt naar ondergronds of bovengronds werk. Het aandeel van vrouwen in de Belgische steenkoolindustrie bedroeg volgens deze cijfers nog 12,38 procent (II.735 vrouwen op een totaal van 94.757). Dit aandeel was in het Luikse bekken gedaald tot 7,72 procent (I.722 vrouwen op een totaal van 22.305 werknemers). $4^{\circ}$ Wederom valt op dat het aandeel van vrouwen in de Luikse mijnbouw kleiner is dan in heel België. Uit de industrietellingen van 1896 kunnen we afleiden dat op 31 oktober van dat jaar nog 8.98I vrouwen in de Belgische mijnen aan het werk zijn. Op een totaal van II5.793 mijnwerkers vormt dit nog 7,76 procent, een grote daling van het aandeel vrouwen tegenover teljaar I88o. Ondergronds verhielden de vrouwelijke en mannelijke werknemers zich als 989 vrouwen tegenover $85.07 \mathrm{I}$ mannen, een percentage van minder dan I,2. In Luik werkten er op dat moment volgens de industrietellingen nog maar 6o vrouwen onder-

35 Salée, Le travail des femmes et des enfants dans les charbonnages, VII.

36 Hilden, 'The rhetoric and iconography of reform', 417; idem, Women, work and politics, Io8.

37 Vanja, 'Frauenarbeit im Bergbau', 20; Neuville, Naissance et croissance du syndicalisme.

$3^{8} \mathrm{John}$, By the sweat of their brow, I43, I6I.

39 Vrouwen maakten toen 23 procent van de actieve bevolking in de industrie uit. Ze waren het best vertegenwoordigd in de textielnijverheid, waar ze bijna 50 procent van de arbeidskracht uitmaakten. Industrie. Recensement général (15 octobre 1846).

40 L'Industrie en Belgique (1880). 
gronds. ${ }^{41}$ In tegenstelling tot de arbeidsters uit de Borinage hadden de Luikse arbeidsters meer perspectieven dan het afdalen in de mijn om een inkomen te vergaren. Bovendien vervulde Luik een soort voorbeeldfunctie voor de andere Belgische steenkolenbekkens. De uitbaters van verschillende Luikse steenkolenmijnen schaften op eigen initiatief vrouwen- en kinderarbeid af, nog voordat het verbod in werking trad. ${ }^{42}$

TABEL 2.I HET AANTAL WERKNEMERS IN DE STEEN KOOLNIJVERHEID NAAR GESLACHT (VOOR ALLE LEEFTIJDEN), I846, I880 EN I896

\begin{tabular}{|c|c|c|c|c|c|}
\hline & & België & $\%$ & Luik & $\%$ \\
\hline \multirow[t]{3}{*}{ I846 } & mannen & 39.120 & $84,70 \%$ & Io.I9I & $86,91 \%$ \\
\hline & vrouwen & 7.066 & $15,30 \%$ & I. 535 & $13,09 \%$ \\
\hline & totaal & 46.186 & $100,00 \%$ & II. 726 & $100,00 \%$ \\
\hline \multirow[t]{3}{*}{ I880 } & mannen & 83.022 & $87,62 \%$ & 20.583 & $92,28 \%$ \\
\hline & vrouwen & II. 735 & $\mathrm{I} 2,38 \%$ & I. 722 & $7,72 \%$ \\
\hline & totaal & 94.757 & $100,00 \%$ & 22.305 & $100,00 \%$ \\
\hline \multirow[t]{3}{*}{ I896 } & mannen & I06.8I2 & $92,24 \%$ & 28.034 & $93,82 \%$ \\
\hline & vrouwen & $8.98 \mathrm{I}$ & $7,76 \%$ & I. 847 & $6,18 \%$ \\
\hline & totaal & II5.793 & $100,00 \%$ & $29.88 \mathrm{I}$ & $100,00 \%$ \\
\hline
\end{tabular}

Bronnen: Industrie. Recensement général (1846); L'industrie en Belgique (1880); Recensement général des industries (1896).

Uit bovenstaande gegevens uit de industrietellingen kunnen we concluderen dat het aandeel van vrouwen in het mijnbedrijf na 1846 daalde van meer dan 15 naar ruim 12 procent in I880 in België en van ruim I3 naar krap 8 procent in het Luikse bekken. In absolute aantallen is er zowel in heel België als in Luik een toename te zien. In I896 is er zowel in het aandeel als in de absolute aantallen een daling, niet verwonderlijk gezien het verbod op de ondergrondse vrouwenarbeid sinds I892. Tabel 2.I vat de situatie samen.

In I896 verschijnt het eerste deel van de Annales des Mines de Belgique, een driemaandelijkse uitgave met verslagen over de mijnbedrijven in België, uitgegeven door het Ministère de l'Industrie et du Travail - Administration des Mines. Later werden deze uitgaven gebundeld per jaar. In deze Annales vinden we een aantal cijfers dat ons een beeld geeft van de situatie aan het einde van de negentiende eeuw. Uit de evolutie van het aantal vrouwen ondergronds en bovengronds (grafiek 2.I, zie p. 8o) blijkt dat de reeds geschetste ontwikkeling zich versneld doorzet: een groter aantal vrouwen bovengronds en een daling van het aantal vrouwen ondergronds, vooral na I892, om Io jaar later bijna volledig te verdwijnen.

Uit grafiek 2.2 blijkt dat net voor het in werking treden van het verbod, het grootste aantal vrouwen dat ondergronds werkte afkomstig was uit de leeftijdscategorie 16 tot 2I jaar. De sterke daling in deze leeftijdsgroep is duidelijk te verklaren aan de hand van de arbeidswetgeving. Vanaf I892 was het immers verboden voor vrouwen en meisjes onder 2I jaarom ondergronds te werken. De lichte stijging van het aantal bovengronds werkende vrouwen in deze leeftijdscategorie (zie grafiek 2.3) zou erop kunnen wijzen dat zij geen afstand namen

4I Recensement général (31 octobre 1896).

42 Salée, Le travail des femmes et des enfants dans les charbonnages, 6o, Io8. 
GrafieK 2.I DE EVOlutie VAN HET TOtAal AANTAL ARbEIDSTERS IN DE BelgiSCHE STEEN KOOLNIJVERHEID, I89I-I9O2

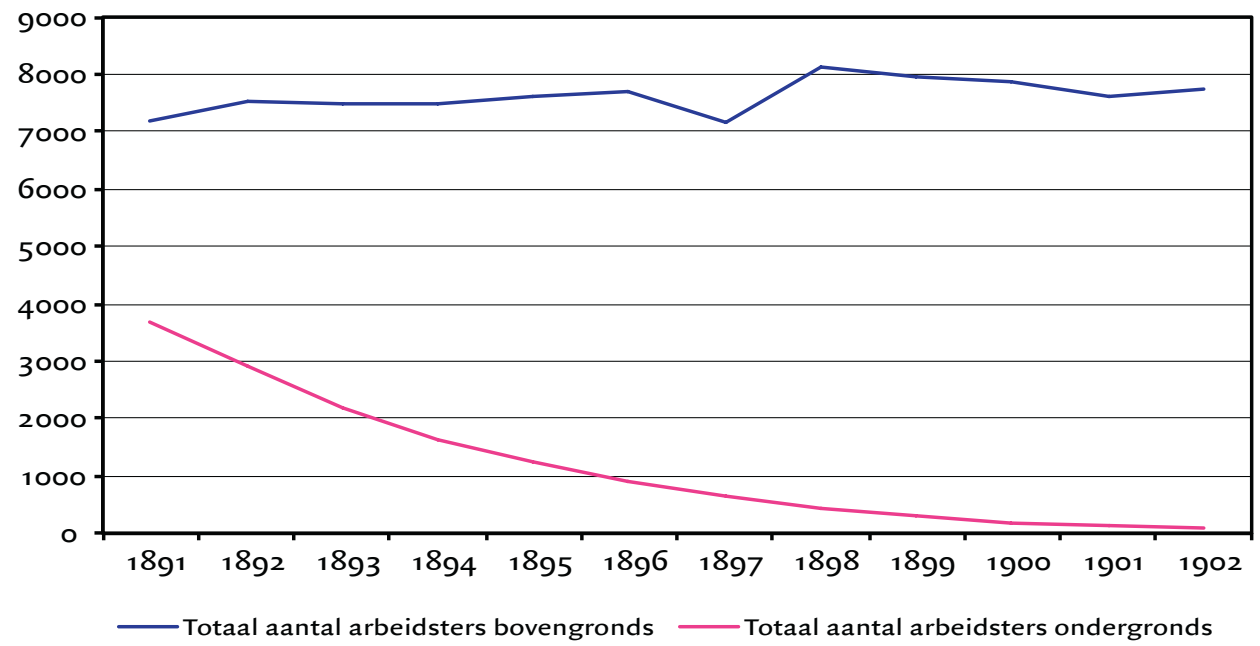

Bron: Annales des Mines de Belgique, I896-rgor, I903.

GRAFIEK 2.2 HET AANTAL VROUWEN ONDERGRONDS IN DE BELGISCHE MIJNEN (PER LEEFTIJDSCATEGORIE), I89I-I9O2

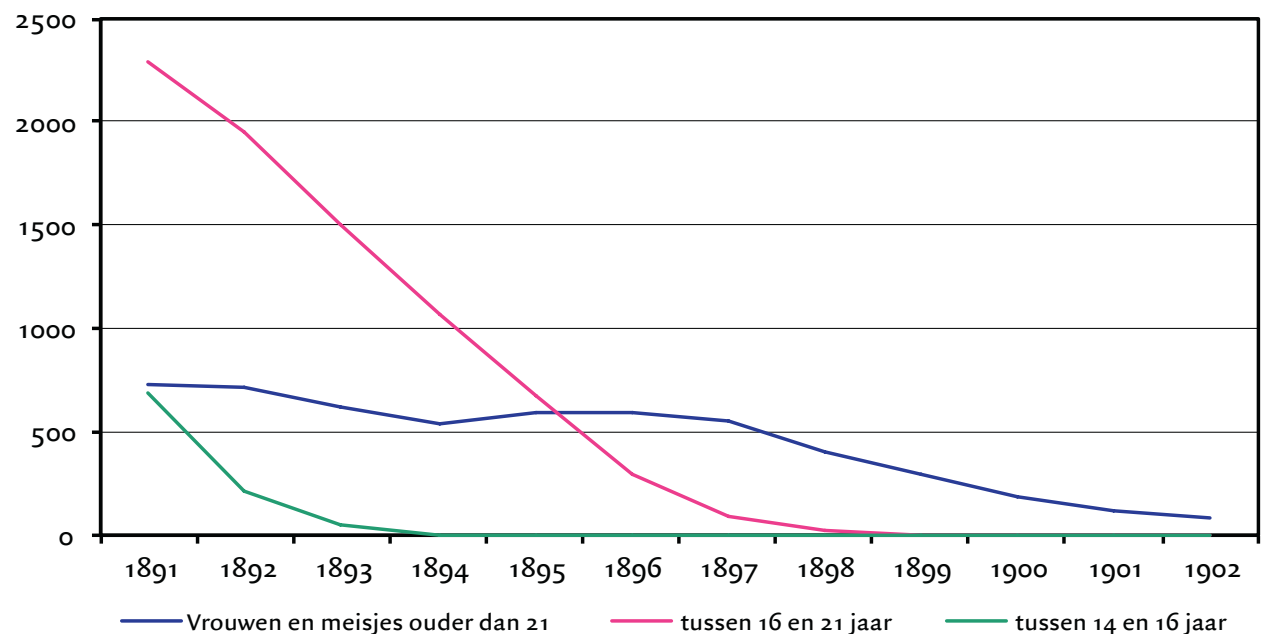

Bron: Annales des Mines de Belgique, I896-1901, 1903

van het mijnbedrijf, maar bovengronds aan de slag bleven. Voor de opvallende daling van het aantal I6-2I-jarigen in I897 vonden we geen directe verklaring. De groep arbeidsters ouder dan 2I jaar bleef opmerkelijk stabiel, zowel ondergronds als bovengronds. Deze groep werd vooralsnog geen beperkingen opgelegd door de wetgever. Wel is het aantal vrouwen in deze leeftijdscategorie over het algemeen kleiner dan in de jongere leeftijdscategorieën. 
GRAFIEK 2.3 HET AANTAL VROUWEN BOVENGRONDS IN DE BELGISCHE MIJNEN (PER LEEFTIJDSCATEGORIE), I89I-I9O2

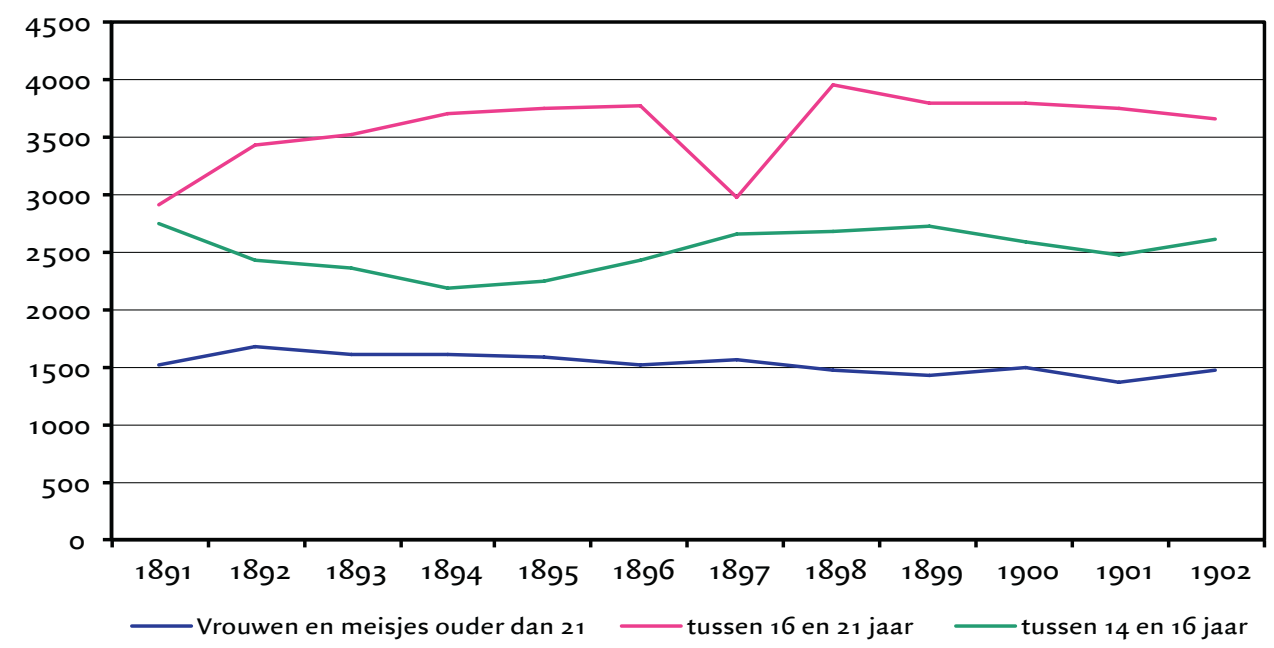

Bron: Annales des Mines de Belgique, I896-Igor, Ig03.

Dit wijst erop dat er na het huwelijk of het eerste kind niet langer werd geopteerd voor arbeid in het mijnbedrijf. Dominique Salée wijst er bovendien op dat vrouwen die niet in hun jeugd met het ondergrondse werk begonnen, dat hoogstwaarschijnlijk op latere leeftijd ook niet meer deden. Tegen het einde van de negentiende eeuw werden er bovendien in Luik steeds meer magerkolen, die voornamelijk voor huishoudelijk gebruik dienden, ontgonnen. Deze steenkool vereiste nog heel wat verdere bewerking voordat ze op de markt kon worden gebracht. Dit makkte een stijging van de bovengrondse werkkrachten mogelijk, waaronder heel wat vrouwen en kinderen. ${ }^{43}$ Voor Luik vonden we eveneens een aantal cijfers. In tabel 2.2 wordt getoond hoe het aantal arbeidsters in Luik verdeeld was naar leeftijd, voor zowel de ondergrond als de bovengrond.

Het valt op dat de vrouwelijke inbreng ondergronds in Luik in deze periode marginaal is. Dat ligt ook voor de hand gezien het verbod op ondergrondse vrouwenarbeid voor de leeftijdscategorie onder $2 \mathrm{I}$ jaar. Toch werkten er nog steeds meisjes en vrouwen in de leeftijdscategorie 16 tot 2I jaar ondergronds. Dit is wellicht te wijten aan het feit dat vrouwen en meisjes aan de slag mochten blijven als zij reeds ondergronds werkten voor het in werking treden van de wet. Er zijn zelfs aanwijzingen dat mijndirecties vooraleer het verbod in werking trad zoveel mogelijk meisjes aannamen, zodat zij verzekerd waren van voldoende vrouwelijke arbeidsreserve. ${ }^{44}$ Hoewel vrouwen ouder dan 2I jaar zonder meer ondergronds mochten blijven, en zelfs mochten beginnen met werken, is hun aandeel niet erg groot.

43 Salée, Le travail des femmes et des enfants dans les charbonnages, $58,64$.

44 Dit was althans het geval in de mijn Bois-du-Luc. Chapelle-Duliere, 'Septembre I893 au charbonnage de Bois-du-Luc', 256-257. 
TABEL 2.2 Het AANTAL VROUWELIJKE ARbEIDSKRACHTEN NAAR LEEFTIJd IN HET LUIKSE BEKKEN, I895-I900

\begin{tabular}{|l|r|r|r|r|r|r|}
\hline Ondergronds & $\mathbf{1 8 9 5}$ & $\mathbf{1 8 9 6}$ & $\mathbf{1 8 9 7}$ & $\mathbf{1 8 9 8}$ & $\mathbf{1 8 9 9}$ & $\mathbf{1 9 0 0}$ \\
\hline Vrouwen en meisjes ouder dan 2I jaar & $4 \mathrm{I}$ & 44 & 34 & 36 & 26 & 27 \\
Vrouwen en meisjes tussen I6 en 2I jaar & $2 \mathrm{I}$ & $\mathrm{I} 2$ & 6 & - & - & - \\
Vrouwen en meisjes tussen I4 en I6 jaar & - & - & - & - & - & - \\
\hline Totaal aantal arbeidsters & 62 & 56 & 40 & 36 & 26 & 27 \\
\hline Totaal aantal mannen en vrouwen & $2 \mathrm{I} .596$ & $2 \mathrm{I} .688$ & $\mathbf{2 2 . 4 1 8}$ & $\mathbf{2 2 . 8 \mathrm { II }}$ & $\mathbf{2 3 . 2 2 8}$ & 25.107 \\
\hline Bovengronds & $\mathbf{1 8 9 5}$ & $\mathbf{1 8 9 6}$ & $\mathbf{1 8 9 7}$ & $\mathbf{1 8 9 8}$ & $\mathbf{1 8 9 9}$ & $\mathbf{1 9 0 0}$ \\
\hline Vrouwen en meisjes ouder dan 2I jaar & 660 & 629 & 640 & $6 \mathrm{I} 7$ & 644 & 652 \\
Vrouwen en meisjes tussen I6 en 2I jaar & $75 \mathrm{I}$ & 750 & 790 & 873 & 763 & 734 \\
Vrouwen en meisjes tussen I4 en I6 jaar & $3 \mathrm{II}$ & 383 & 400 & $36 \mathrm{I}$ & 463 & $4 \mathrm{I} 4$ \\
\hline Totaal aantal arbeidsters & $\mathrm{I} .722$ & $\mathrm{I} .762$ & $\mathrm{I} .830$ & $\mathrm{I} .85 \mathrm{I}$ & $\mathrm{I} .870$ & $\mathrm{I} .800$ \\
\hline Totaal aantal mannen en vrouwen & 6.878 & 7.202 & 7.309 & 7.428 & 7.522 & 7.885 \\
\hline
\end{tabular}

Bron: Annales des Mines de Belgique, I896-rgor.

In Luik werkten er op het moment van de industrietellingen in 1896 nog maar 60 vrouwen ondergronds. Op een totaal van 22.606 mijnwerkers ondergronds in het Luikse bekken is dat verwaarloosbaar (namelijk o,26 procent). Het aandeel vrouwen ondergronds bedroeg op dat moment in Namen nog o,6 procent (I2 op I.995) en in Henegouwen nog bijna I,5 procent (9I7 op 6I.399). Bovengronds zijn de percentages voor Luik, Namen en Henegouwen respectievelijk bijna 25 procent (I.787 op 7.2I5), I4 procent (94 op 65I) en bijna 28 procent (6.III op 2I.867). Het lijkt er dus op dat er een andere evolutie in Henegouwen plaatsvond, met een langere aanwezigheid van vrouwen ondergronds. ${ }^{45}$ Waarin ligt dit verschil? Het lijkt niet gewaagd te veronderstellen dat dit te maken heeft met een verschil in alternatieve werkgelegenheid. In en rond de stad Luik waren voor meisjes en vrouwen aantrekkelijker opties aanwezig dan het harde en gevaarlijke labeur in de steenkolenmijnbouw, al brachten die alternatieven soms minder geld in het laatje..$^{46}$ Ook Angela John meldt dat de vrouwen in het Luikse bekken ophielden met werken in de mijnen toen er alternatieve werkgelegenheid in de regio werd gecreëerd. ${ }^{47}$ De Luikse regio kende inderdaad geen monocultuur, zoals bijvoorbeeld in de Borinage, maar had naast de steenkoolindustrie nog een aantal grote industriële nijverheden die werkgelegenheid en dus alternatieven voor het mijnberoep boden. De provincie Luik was een belangrijk productiecentrum voor ijzer en staal, inclusief machineconstructie, wol (Verviers), wapens en glas (Val-St.-Lambert). ${ }^{48}$

Het voortbestaan van de vrouwenarbeid in de mijnen wijst niettemin op een invloed van zowel de vraag- als aanbodzijde om dit in stand te houden. Zowel de werkgevers, met de liberale regering als ruggesteun, als de werknemers die het vrouwenloon niet konden mis-

45 In de industrietellingen werd alleen rekening gehouden met de provinciegrenzen. Gegevens per steenkolenbekken werden niet verstrekt, in de provincie Henegouwen vinden we volgende mijnbouwregio's: de Borinage, Charleroi en Le Centre. Ook volgens Patricia Hilden werkten er in de Borinage meer vrouwen ondergronds dan elders en was hun aandeel het laagst in het Luikse bekken. Het is echter niet duidelijk waarop zij zich heeft gebaseerd. Hilden, Women, work and politics, , 08.

46 Hilden, 'The rhetoric and iconography of reform', 418.

47 John, By the sweat of their brow, 34 .

48 Hilden, Women, work and politics, 7 . 
sen, speelden een rol bij het in stand houden van een situatie die elders in Europa al eerder werd ingeperkt of afgeschaft. Ook contemporaine rapporten vestigen hierop de aandacht en stellen dat de prijzen van de steenkool zouden stijgen indien dit werk door 'duurdere' mannen zou worden gedaan en dat de inkomsten afkomstig van dit vrouwenwerk vaak onmisbaar waren voor de gezinnen. 49

\section{MANNENWERK, VROUWENWERK?}

In deze paragraaf willen we nagaan of er op de arbeidsmarkt van de Belgische steenkoolindustrie sprake was van verticale arbeidssegregatie naar geslacht. Eerder zagen we dat er elders in Europa drie soorten vrouwenarbeid in de steenkolenmijnen dominant waren: het sleepwerk van de hiercheuses, ${ }^{\circ}$ het sorteerwerk van de trieuses en het onderhoud van de mijnlampen door de lampenistes. Was dit ook het geval in België en in Luik? Zijn er regionale verschillen te bespeuren? Hoe kan deze specifieke arbeidsverdeling worden verklaard?

Volgens Hilden waren arbeidsters in het mijnbedrijf voornamelijk verantwoordelijk voor het vervoeren van de steenkool van het kolenfront naar de oppervlakte. ${ }^{51}$ Mijnwerksters moesten de grote pas gehouwen stukken steenkool in hanteerbare stukken breken en deze laden, aanvankelijk in zakken die ze met een riem aan hun hoofd bevestigden en zo naar boven droegen, en later in mijnwagens die ze naar de oppervlakte duwden en trokken. In de nieuwere mijnen werden de galerijen verbreed zodat pony's en paarden het werk van de hiercheuses konden overnemen, maar in de oudste mijnen was deze modernisering niet mogelijk. ${ }^{52}$

In een verslag van Kuborn, een bekend medicus uit Seraing, uit I 868 vinden we een overzicht van alle taken die vrouwen, meisjes en kinderen vanaf $\mathrm{I} 2$ jaar ondergronds in de Belgische steenkolennijverheid vervulden: ${ }^{53}$

- het transport van de steenkool overdag en het transport van afval (stenen, ...) gedurende de nacht met sleeën in de dwarsgangen/galerijen en verbindingswegen;

- het opvullen van de tijdens de afbouw ontstane leemtes met stenen;

- het scheppen van de steenkool op de transportband;

- het afremmen van de mijnwagens op steile wegen;

- het werk aan de windas;

- de bediening van de pompen;

- het ventileren tijdens de installatiearbeid;

- het herstellen van de rijwegen, het transport van hout, het onderhoud van de lampen en het begeleiden van het transport met paarden.

49 Deneubourg en Wouters, Réflexions sur le travail des femmes, I2.

50 In het Luikse dialect sprak men over 'hièrtcheû': manoeuvre chargé de traîner les différents véhicules servant au transport des produits. Haust, La houillerie liégeoise, II7.

5I Wat meteen de stelling uit haar inleiding omtrent het grotendeels ungendered karakter van het mijnbedrijf nuanceert.

52 Kuborn, Rapport sur l'enquête faite au nom de l'Académie, 20.Volgens een statistiek van de Administration des Mines uit I829 werden er in dat jaar slechts in vier mijnen paarden ingezet voor het transport in de galerijen. Het betrof hier de mijnbedrijven Cockerill, Espérance, Six-Bonniers en Marihaye. Zij behoorden tot de grootste in het Luikse bekken. Caulier-Mathy, Statistiques de la province de Liège, 22-25.

53 Kuborn, Rapport sur l'enquête faite au nom de l'Académie, 38. 


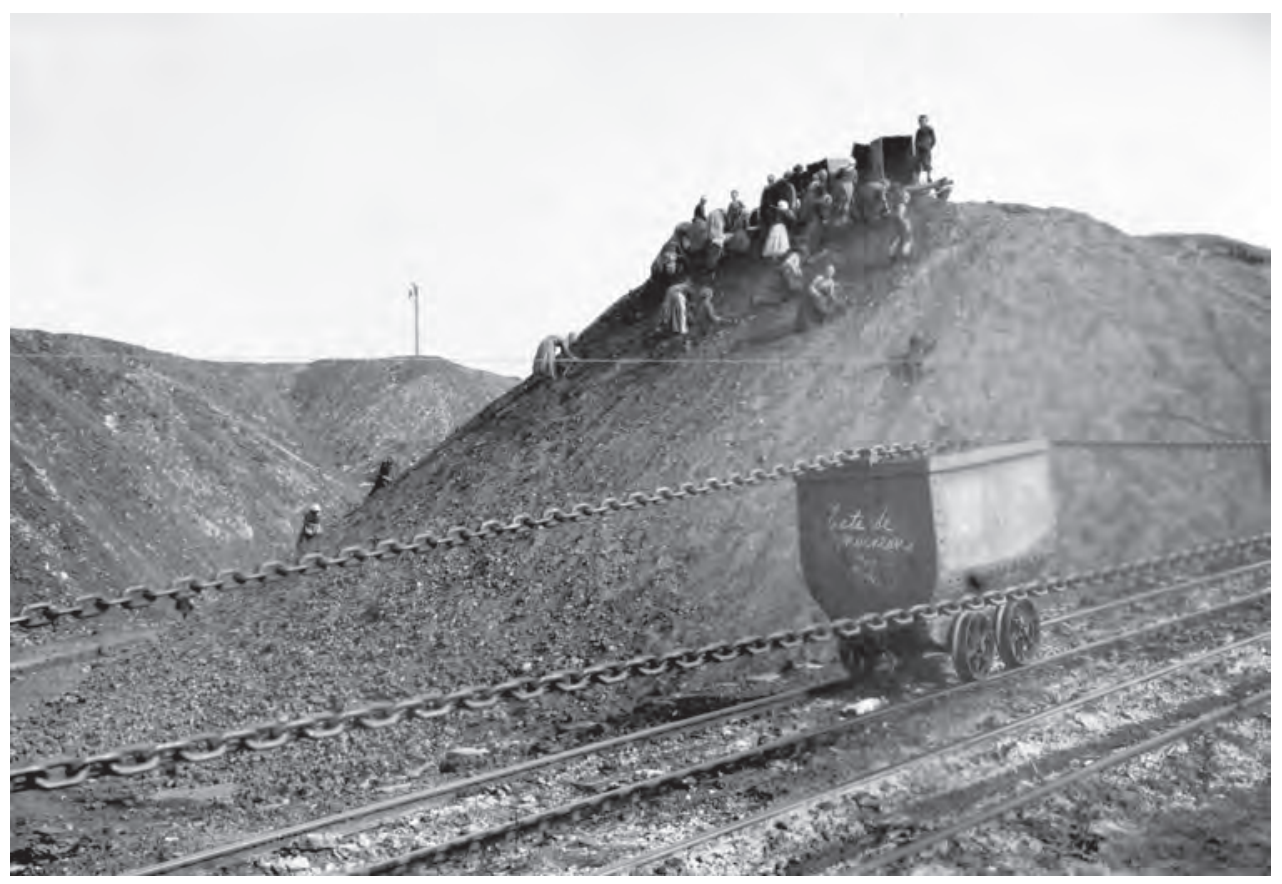

'Ramasseuses d'escarbilles' (sintelraapsters) te Luik, ca. 1900. Foto Gustave Marissiaux. Copyright Province de Liège - Musée de la Vie wallonne.

Hij wijst er eveneens op dat er grote verschillen tussen de bedrijven bestonden. In sommige mijnen werd het duwen van de mijnwagens en het bedienen van de remmen voorbehouden aan mannen. ${ }^{54}$

Het enige beroep dat uitsluitend door mannen werd verricht was dat van houwer, maar er zijn aanwijzingen dat er uitzonderingen op deze regel waren. Arthur Munby bezocht Charleroi in 1865 waar hij met een mijnwerker sprak die hem vertelde over enkele vrouwelijke houwers, waaronder één sterke jonge vrouw die het werk net zo goed verzette als een man. ${ }^{55}$

Bovengronds deden de vrouwen eveneens sleepwerk. Zij waren belast met het laden en uitladen van de zware mijnwagens, maar ook met het wegen en het sorteren van de steenkool en het laden van de treinwagons. Dit laden en uitladen van de mijnwagentjes is ook te zien op de schilderijen van onder meer Renard en andere Luikse kunstenaars..$^{6}$ De mijnwerksters die verantwoordelijk waren voor het sorteren van de steenkool naar grootte en de stenen uitsorteerden stonden bekend als trieuses, 'kolenlezers'.

Buiten de mijn verzamelden voornamelijk oudere en fysiek minder sterke vrouwen, de glaneuses, de nog bruikbare steenkool van de terrils, de steenbergen. In de meeste mijnen waren dit zelfstandige arbeidsters waarvan de rechten op het vergaren van steenkool werden erkend door de mijneigenaren. ${ }^{57}$ Ook in Frankrijk werkten volgens Christina Vanja de licha- 


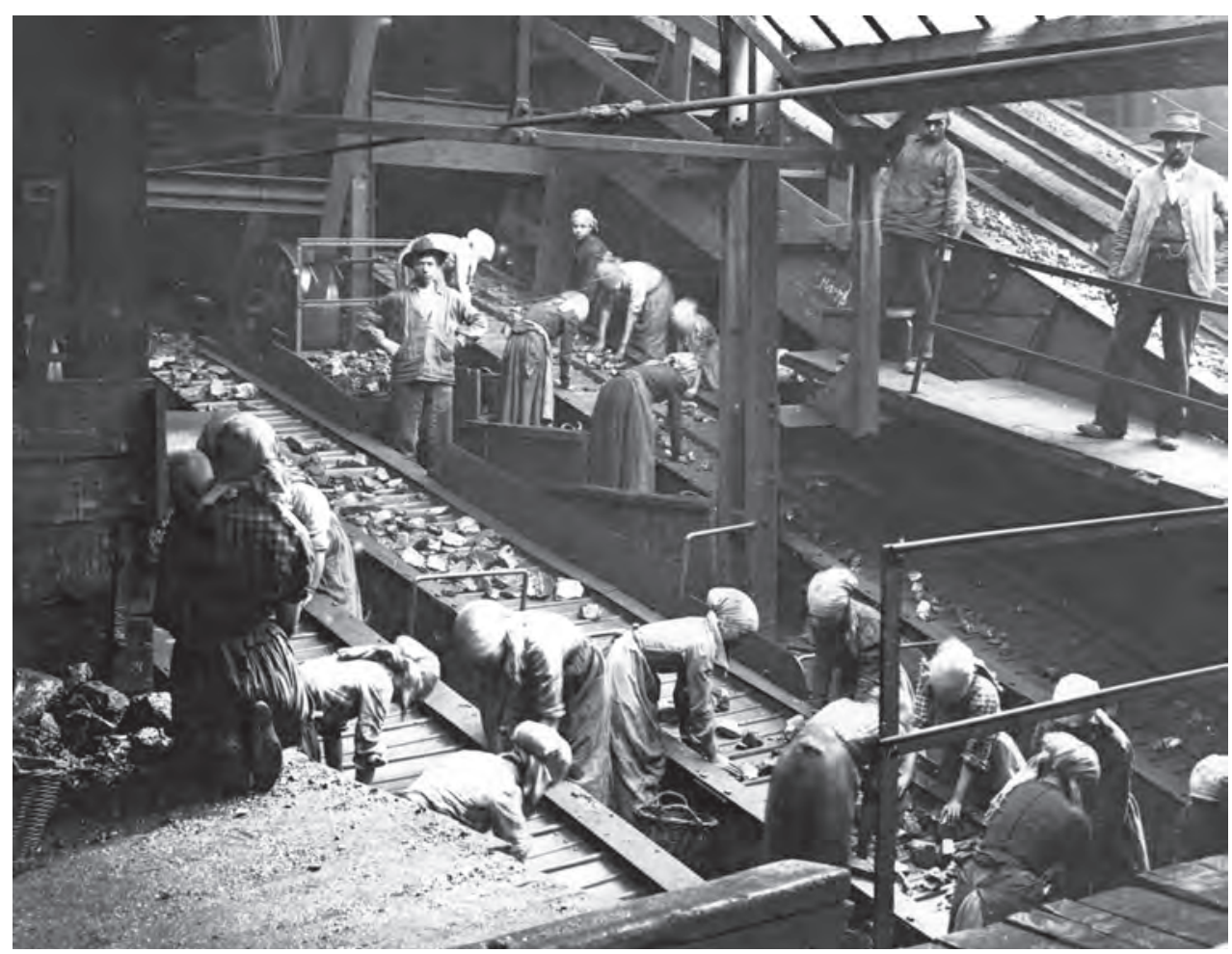

'Épierrage' (het ontdoen van stenen - kolenlezers) bij de NV Gosson-Lagasse, begin twintigste eeuw. Foto Gustave Marissiaux. Copyright Province de Liège - Musée de la Vie wallonne.

melijk zwakkere vrouwen over het algemeen bovengronds als sorteersters op de steenbergen..$^{8}$

In de industrietellingen van 1896 is een gedetailleerd overzicht te vinden van de arbeidsverdeling per bedrijf, naar taak, geslacht en beloning. Voor het Luikse bekken werden er 39 mijnbedrijven opgenomen. Elders in de tellingen blijkt dat er in I896 in het Luikse nog 69 steenkoolbedrijven actief waren en dus is het overzicht niet exhaustief. Niettemin vormt het een erg interessante bron voor het achterhalen van de taakverdeling naar sekse in het mijnbedrijf. ${ }^{59}$ Eerder haalden we al aan dat er op 3 I oktober 1896 nog 60 vrouwen ondergronds werkten; in het overzicht per bedrijf vinden we er 56 van terug. Uit het overzicht kunnen we afleiden dat de ondergrondse arbeidsters drie taken vervulden, althans met drie benamingen werden aangeduid: bouteuse $e^{60}$ (elf vrouwen), hiercheuse (4I vrouwen) en remblayeuse $e^{6 r}$ (vier vrouwen). Dit waren aanvullende functies die ook door (jonge) mannen werden uitge-

lingen terug te vinden.

58 Vanja, 'Frauenarbeit im Bergbau', 20.

59 Recensement général des industries et des métiers, 'Volume IX, Dénombrement A'.

6o Haust, La houillerie liégeoise, 33. Van 'bouter': pousser une berlaine dans la cage en 'bouteû-foû': qui évacue le charbon, ook: 'boutresse'.

6I 'Remblayer': aanaarden, aanvullen, ophogen, opvullen. Deze arbeid werd tijdens de nacht verricht. Kuborn, Rapport sur l'enquête faite au nom de l'Académie, I7. 
voerd. ${ }^{62}$ Een bouteuse was verantwoordelijk voor een specifiek deel van het sleepwerk, namelijk van de pijler naar de steengang, terwijl een hiercheuse het transport naar de schachtmond voor haar rekening nam. Remblayeuses waren ook belast met sleepwerk, maar in omgekeerde richting, namelijk het transport van stenen naar de ontkoolde pijlers toe. Daar aangekomen hadden ze nog een extra taak, namelijk het opvullen van die lege pijler met stenen, ter voorkoming van instorting. ${ }^{6}$ In de tellingen vinden we geen enkele vrouw terug die werkte in de afbouw van de steenkool, en ook bij het graven en onderhouden van galerijen werden ze zelden ingezet, enkel als remblayeuse.

Bovengronds vervulden vrouwen meer diverse functies. De mijnbedrijven hanteerden niet allen dezelfde terminologie en er bestonden meerdere benamingen voor éénzelfde functie. ${ }^{64}$ De functies van de vrouwen bovengronds kunnen gegroepeerd worden in drie grote categorieën:

- transport - slepen, laden en lossen: chargeuses, déchargeuses, culbuteuses, rouleuses, traineuses;

- het sorteren van de steenkool: trieuses, laveurs;

- het onderhoud van de mijnlampen: nettoyeuses de lampes, lampiste.

Zelden vinden we vrouwen terug bij het onderhoud van machines, slechts twee vrouwen werkten als schoonmaakster van de stoomketels.

Wanneer we deze resultaten vergelijken met het buitenland vallen de grote gelijkenissen op. ${ }^{65}$ Net als in het buitenland zijn vrouwen geconcentreerd in bepaalde functies. Salée komt voor Luik ook tot dezelfde conclusie en onderscheidt deze drie categorieën. ${ }^{66}$ Vrouwen vervulden vooral hulptaken. Het is echter niet duidelijk of dit in familieverband plaatsvond voor vader, echtgenoot, zonen en/of broers. Wel kunnen we stellen dat het onderscheid tussen vrouwelijke hulptaken en mannelijke hoofdfuncties wijst op een reproductie van de gezinsarbeidsverhoudingen, zoals De Groot het omschrijft.

\section{IN EN UIT DE MIJN}

De werkboekjes geven interessante informatie over het arbeidsverloop. Van de ro7 vrouwen waarvan de loopbaan, weliswaar niet volledig, kon worden gereconstrueerd, startten er 87 hun carrière in het mijnbedrijf. Negen anderen vingen hun loopbaan aan in de textielsector, vijf in de ijzer- en staalindustrie en drie in overige nijverheden. ${ }^{67}$ Het arbeidsverloop kent verschillende aspecten: de lengte van het dienstverband, de periode tussen twee dienstverbanden, mede in verband met eventuele seizoensfluctuaties, geografische verschillen, zowel wat betreft de afkomst van de arbeidsters als het verloop tussen regio's, en dienstverbanden buiten de mijnsector.

\footnotetext{
62 Opvallend is dat ook het werk als bouteur en bouteuse, door beide geslachten werd vervuld. Er was dus ook een mannelijke variant van de boteresse, althans ondergronds. Salée geeft eveneens aan dat er in het mijnbedrijf geen taken zijn die enkel en alleen door vrouwen werden uitgevoerd. Salée, Le travail des femmes et des enfants dans les charbonnages, 83 .

63 Ibidem, 87.

64 Bovendien lezen we in de industrietellingen de algemene Franse benamingen. In het Waals bestonden er nog andere benamingen voor bepaalde functies. Haust, La houillerie liégeoise; Ruelle, Le Vocabulaire professionnel du Houilleur borain.

65 Le Tirant, Femmes à la mine.

66 Salée, Le travail des femmes et des enfants dans les charbonnages, 59, 8I-88.

67 Van drie vrouwen kon de eerste werkgever niet nader worden bepaald.
} 


\section{De lengte van het dienstverband}

Volgens Patricia Hilden was de werkperiode van de vrouwen in de steenkoolindustrie meestal kort en sporadisch. ${ }^{68}$ Uit grafiek 2.4 kunnen we afleiden dat verreweg de meeste dienstverbanden tussen de vier maanden en de twee jaar duurden. ${ }^{69}$ Erg korte dienstverbanden, variërend van één week tot twee maanden waren niet uitzonderlijk. Dit wijst erop dat mijnwerksters er weinig problemen mee hadden op zoek te gaan naar betere werkomstandigheden. Op het totaal van 107 vrouwen konden we 520 dienstverbanden vaststellen. $.^{70} \mathrm{Ge}-$ middeld zijn dat bijna vijf dienstverbanden per vrouw. René Leboutte leidde uit zijn steekproef van I.I70 werkboekjes af dat een mijnwerker gemiddeld I8 maal tijdens zijn carrière van werkgever veranderde. Uiteraard is vergelijken moeilijk omwille van het verschil in omvang van de steekproef en het verschil in duur van de actieve periode. De periode waarin een vrouw professioneel actief was, was relatief kort: over het algemeen tussen de 5 en 15 jaar. De carrière van een mannelijk mijnwerker was gemiddeld gezien langer: 30-40 jaar. Zelfs als we rekening houden met het feit dat de actieve periode van een man gemiddeld 2 tot 3 keer langer was, en er bijgevolg meer kans was om van werkgever te veranderen, lijkt het arbeidsverloop van de vrouwen uit de selecte steekproef nog niet zo hoog als van hun mannelijke collega's. ${ }^{71}$

\section{GRAFIEK 2.4 DE LENGTE VAN HET DIENSTVERBAND}

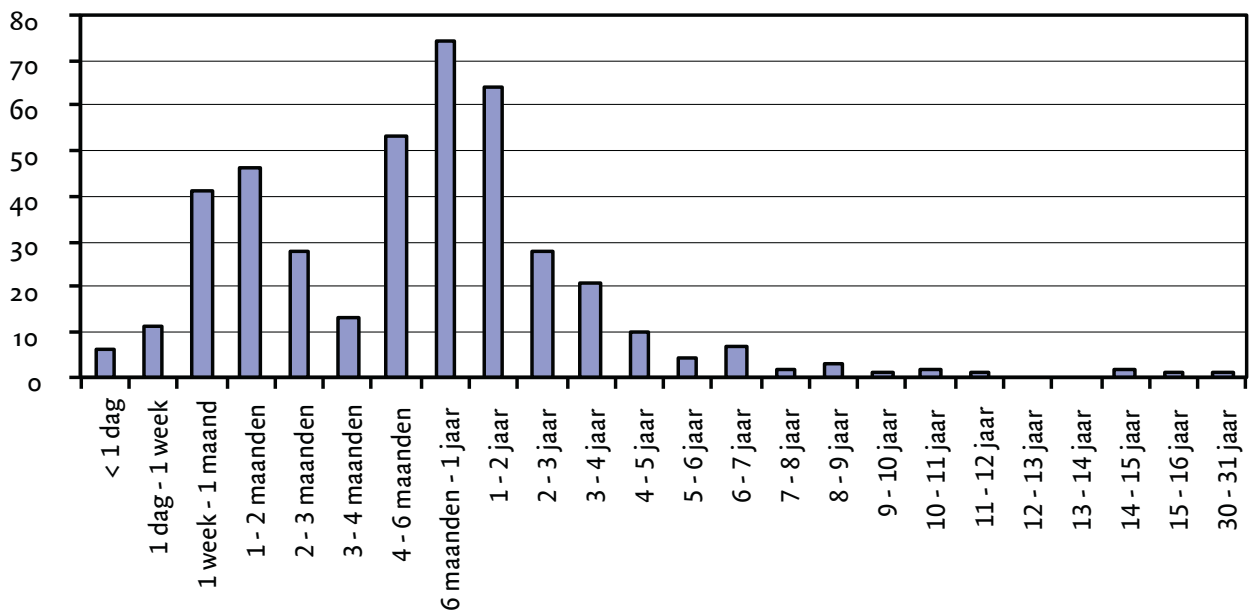

Bron: Steekproef Livrets d'ouvriers CLADIC.

68 Hilden, 'The rhetoric and iconography of reform', $4 \mathrm{I} 7$.

69 Van ror dienstverbanden konden we de duur niet achterhalen door het ontbreken van start- en/of einddatum (op een totaal van 520).

70 Voor deze berekeningen werd er niet per mijnwerkster gekeken, maar werden alle veranderingen in de loopbanen van alle mijnwerksters integraal verwerkt.

7I Leboutte, Le livret d'ouvrier dans la province de Liège, 36-37. 
TABEL 2.3 DE ORDENING VAN DE MIJNWERKSTERS NAAR HET AANTAL DIENSTVERBANDEN

\begin{tabular}{|l|c|r|}
\hline Aantal dienstverbanden & Aantal mijnwerksters & $\%$ \\
\hline$<5$ & $4 \mathrm{I}$ & $48,2 \%$ \\
\hline tussen 5 en 9 & 29 & $34, \mathrm{I} \%$ \\
\hline tussen Io en I4 & 9 & $\mathrm{I0}, 6 \%$ \\
\hline tussen I5 en I9 & 5 & $5,9 \%$ \\
\hline tussen 20 en 24 & $\mathrm{I}$ & $\mathrm{I}, 2 \%$ \\
\hline Totaal & 85 & I00,0\% \\
\hline
\end{tabular}

Bron: Steekproef Livrets d'ouvriers CLADIC.

Ook wanneer we de mijnwerksters ordenen naar het aantal in de werkboekjes genoteerde dienstverbanden in tabel 2.3, valt op dat de grootste groep, 48,2 procent niet erg mobiel was: minder dan 5 dienstverbanden. De turnover, het arbeidsverloop van vrouwen mag dus niet overdreven worden. Eén van de verklaringen hiervoor is het feit een aantal steenkolenmijnen reeds in de tweede helft van de negentiende eeuw niet langer vrouwen tewerkstelden en er ingevolge dus minder mogelijkheden tot arbeidsverloop voor hen waren. ${ }^{72}$

\section{De periode tussen de dienstverbanden}

Uit grafiek 2.5 blijkt dat de meeste vrouwen binnen één dag aan de slag gingen bij een andere werkgever en dat het hun dus niet veel moeite kostte een nieuwe werkplaats te vinden. ${ }^{73}$ Een intervalperiode van vier tot zes maanden kwam ook veel voor. Deze langere periode van afwezigheid zou kunnen wijzen op seizoensarbeid. Zowel mannen als vrouwen stonden er volgens Hilden om bekend afwezig te zijn tijdens de lente wanneer er werk te vinden was in de steenbakkerijen. ${ }^{74}$ In de werkboekjes werd hiervan één geval teruggevonden. Marie Collinet was al een tijdje werkzaam in het mijnbedrijf, met dienstverbanden in verschillende mijnen, toen ze in april I855 het mijnleven voor enkele maanden vaarwel zei om als 'brikkenmaakster' te gaan werken. In september keerde ze terug uit Prusse (het Duitse keizerrijk) om wederom als mijnwerkster aan de slag te gaan. Dit patroon herhaalde zich tot de zomer van I86I, dus zeven jaren op rij. Bovendien kunnen we uit haar werkboekje opmaken dat ze deze seizoensarbeid in de steenbakkerijen samen met haar vader verrichtte. Ook uit andere bron is bekend dat er jaarlijks groepen steenbakkers vanuit het Luikse, en trouwens het hele Maasdal, naar Duitsland trokken, veelal in gezinsverband. 75 Uit grafiek 2.6 blijkt dat de vrouwen vooral afwezig waren tijdens de zomermaanden. ${ }^{76}$ Dit wijst er op dat ze dan wellicht elders werk vonden. Het is ook mogelijk dat ze's zomers op het land werkten.

72 Pasleau, 'La femme, un acteur à part entière de l'industrialisation', 627; Salée, Le travail des femmes et des enfants dans les charbonnages, 60.

73 Van 149 tussenperiodes konden we de duur niet achterhalen door het ontbreken van start- en/of einddatum.

74 Hilden, 'The rhetoric and iconography of reform', 418.

75 Lourens en Lucassen, Arbeitswanderung und berufliche Spezialisierung, I38-139; Leboutte, Reconversions de la main d'œuvre et transition démographique, 470-474; Kusters, De tocht der duizenden.

76 Van de 36 tussenperiodes minder dan of gelijk aan 6 maanden werd gekeken, welke maanden van het jaar het meest aan bod kwamen. 
GRAFIEK 2.5 DE PERIODE TUSSEN DE DIENSTVERBANDEN

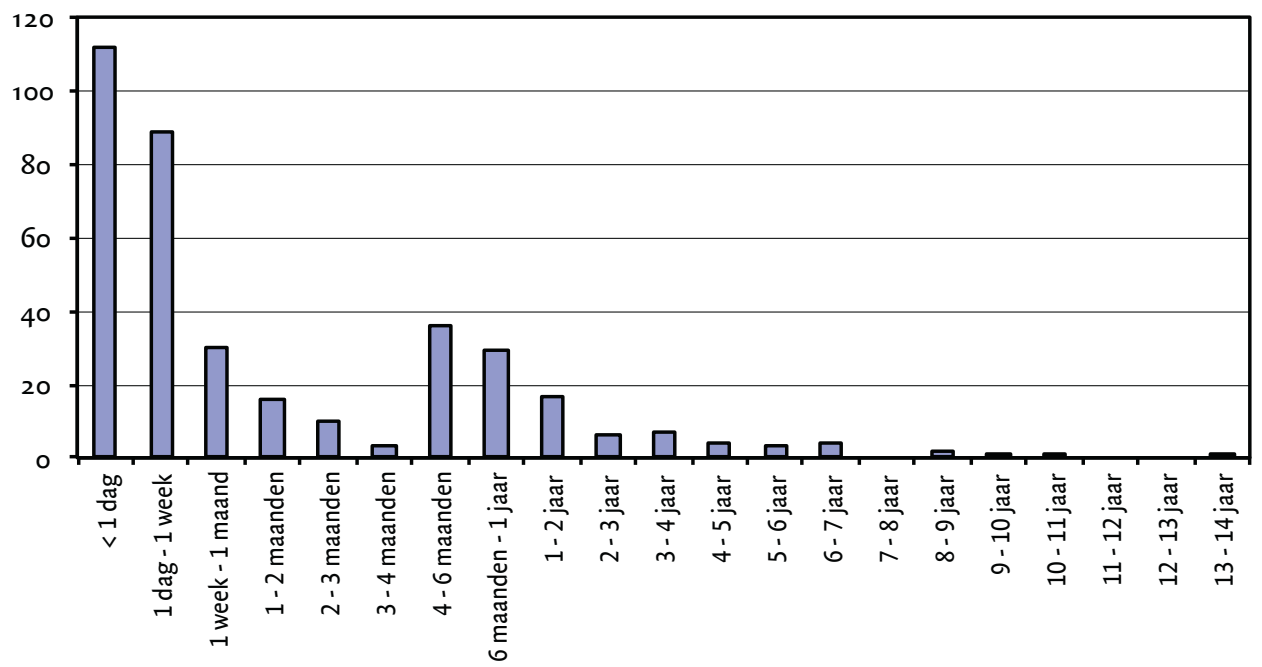

Bron: Steekproef Livrets d'ouvriers CLADIC.

GRAFIEK 2.6 DE AFWEZIGHEID PER MAAND

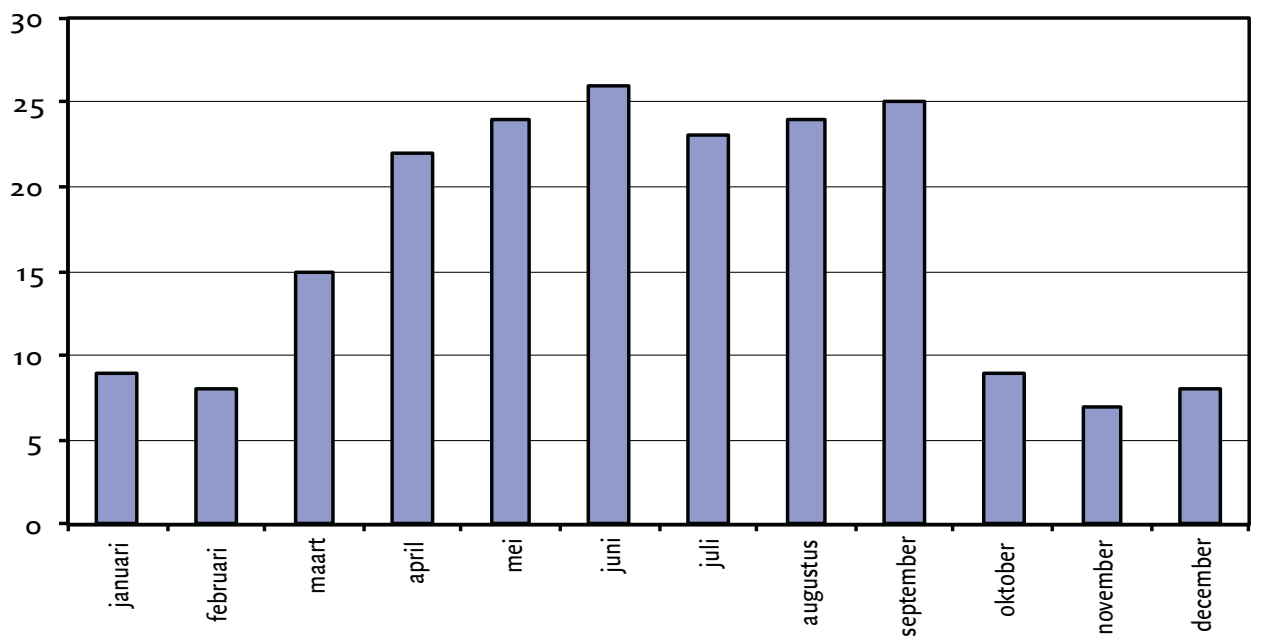

Bron: Steekproef Livrets d'ouvriers CLADIC. 


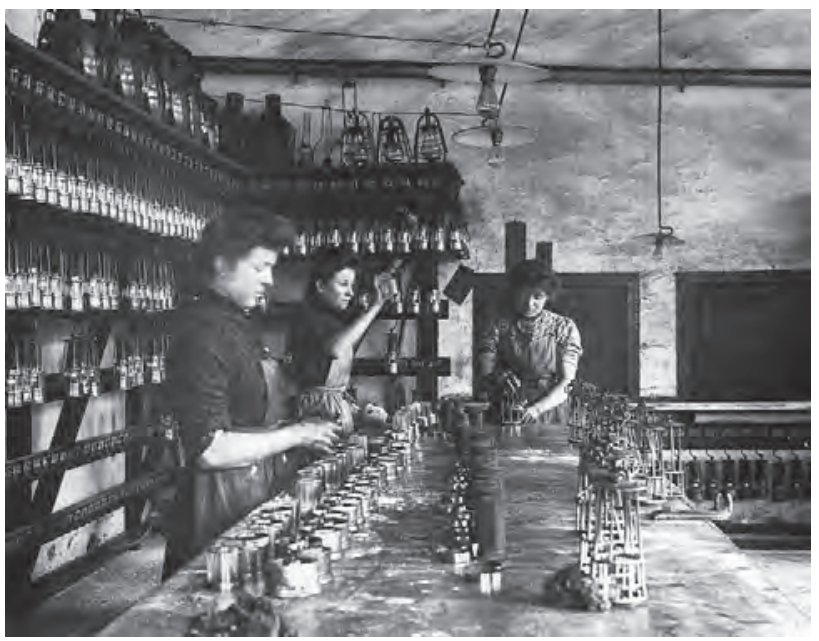

'Lampistes', NV Wérister, begin twintigste eeuw. Foto Gustave Marissiaux. Copyright Province de Liège - Musée de la Vie wallonne.

\section{De mobiliteit tussen de mijnen en alternatieve werkgelegenheid}

De meeste mijnwerksters uit de selecte steekproef, namelijk 95, waren geboren in het Luikse bekken. Van drie mijnwerksters kon geen geboorteplaats worden achterhaald. We kunnen hieruit afleiden dat de arbeidsmarkt voor mijnwerksters vooral lokaal van belang was. Van de niet-Luikse mijnwerksters was er één geboren in Bollenge, Prusse. De andere waren afkomstig uit Limburg (Geetbets, Hasselt en Zonhoven), Luxemburg (Humain, bij Marcheen Famenne, Hermicheux), Antwerpen (Olmen), Vlaams-Brabant (Wezeren) en Henegouwen (Couillet, bij Charleroi). In de werkboekjes werd geen domicilie genoteerd, alleen de geboorteplaats. Van de 4I8 dienstverbanden waarbij zowel een geboorte- als werkplaats bekend is, komen er 132 overeen, dat is 3I, 6 procent. Dit is een indicatie dat de vrouwen doorgaans hun arbeidsplaats niet ver van hun huis vonden. Wanneer we de geografische mobiliteit per arbeidster bekijken, valt op dat de meeste werksters als het ware circuleerden in één bepaalde regio. Ze werkten wel in verschillende mijnen, maar deze bevonden zich over het algemeen dicht bij elkaar. De arbeidsmarkt voor mijnwerksters was dus zeer lokaal bepaald.

In tabel 2.4 wordt het aantal dienstverbanden in verband gebracht met verschillende werkgevers. Hieruit blijkt dat wisseling van arbeidsplaats vaak plaatsvond tussen dezelfde steenkolenmijnen. 55 mijnwerksters keerden na een periode terug naar dezelfde mijnzetel. Veertien mijnwerksters keerden twee maal terug naar dezelfde mijn en elf arbeidsters zelfs drie maal. Wanneer we deze gegevens per NV verwerken krijgen we het volgende resultaat: ${ }^{77}$ 53 mijnwerksters keerden één maal terug bij hetzelfde bedrijf, 27 mijnwerksters startten twee maal opnieuw bij dezelfde NV en veertien zelfs drie maal. In de steenkoolindustrie waren vooral de volgende NV's aantrekkelijk: Horloz (49), Grande Bacnure (48), La Haye (46), Kessales (38) en Gosson-Lagasse (32). Vooral Gérard Cloes, de enige zetel van NV Grande Bacnure, was populair bij de vrouwen uit de selecte steekproef. $7^{8}$ Dit kan te maken hebben met het feit

77 Een NV kon verschillende mijnzetels beheren. Beide aanduidingen werden teruggevonden in de werkboekjes. Het valt op dat de mijnwerksters soms wisselden tussen de zetels van éénzelfde NV.

78 Annales des Mines de Belgique, I897, 442-443. 
dat dit de grotere ondernemingen zijn, maar ook met een bedrijfspolitiek die het aannemen van vrouwen ondersteunde. Kuborn geeft in zijn rapport uit I868 aan dat er toen al verschillende bedrijven waren, waar vrouwen van de ondergrondse arbeid werden uitgesloten. Hij noemt hierbij de NV steenkolenmijnen Cockerill en NV steenkolenmijnen Marihaye. ${ }^{79}$ Sinds I867 waren er geen vrouwen meer welkom bij de NV Cockerill en zoals bij de NV Ougrée werden ook bij de NV Marihaye de vrouwen van het arbeidsproces uitgesloten vanaf $1874 \cdot{ }^{80}$ Dit wordt bevestigd door het onderzoek van Paule Bairin. ${ }^{81}$

TABEL 2.4 HET VERBAND TUSSEN HET AANTAL DIENSTVERBAN DEN EN HET AANTAL VERSCHILLENDE WERKGEVERS

\begin{tabular}{|l|c|c|c|c|}
\hline & \multicolumn{4}{|c|}{ Verschillende werkgevers } \\
\hline Aantal dienstverbanden & I & $<5$ & tussen 5 en 9 & Totaal \\
\hline$<5$ & I4 & 27 & - & $4 \mathrm{I}$ \\
\hline tussen 5 en 9 & - & 24 & 5 & 29 \\
\hline tussen I0 en I4 & - & 5 & 4 & 9 \\
\hline tussen I5 en I9 & - & - & 5 & 5 \\
\hline tussen 20 en 24 & - & - & I & I \\
\hline Totaal & I4 & 56 & I5 & 85 \\
\hline
\end{tabular}

Bron: Steekproef Livrets d'ouvriers CLADIC.

Andere bedrijven in het Luikse waar de vrouwen het meest voor kozen waren: de hoogovens te Sclessin (2I) en spinnerij St. Léonard (I9). Uit de werkboekjes konden volgende alternatieven worden afgeleid:

- IJzer- en staalnijverheid: 30

- Linnennijverheid: 20

- Bottelarij: 3

- Glasnijverheid: I

- Chemische industrie: I

Dit bevestigt de eerdere conclusie dat er voor vrouwen aantrekkelijke alternatieven waren buiten de mijnen, waardoor er in verhouding tot in Henegouwen minder vrouwen in de steenkolenmijnen actief waren. Eén van de mogelijke verklaringen is dat de gemiddelde lonen voor vrouwen in de ijzer- en staalnijverheid hoger waren dan in de steenkoolmijnen. ${ }^{82}$

\section{PlaAts in de LeVEnsCyclus}

In het boek van Hilden wordt aangenomen dat meisjes ondergronds gingen vanaf hun elfde of twaalfde jaar en de mijn over het algemeen tussen hun twintigste en dertigste levensjaar

79 Kuborn, Rapport sur l'enquête faite au nom de l'Académie, 875.

80 Salée, Le travail des femmes en des enfants dans les charbonnages, 91 .

8I Bairin, Le travail des femmes, 44-45. Voor de jaren I85I-1859 berekende zij dat gemiddeld slechts 44,4 procent van de Luikse mijnen gebruik makte van ondergrondse vrouwenarbeid.

82 Dat was althans in 1846 het geval. Dat gold toen echter niet voor de linnennijverheid (zie hiervoor tabel 2.5). 


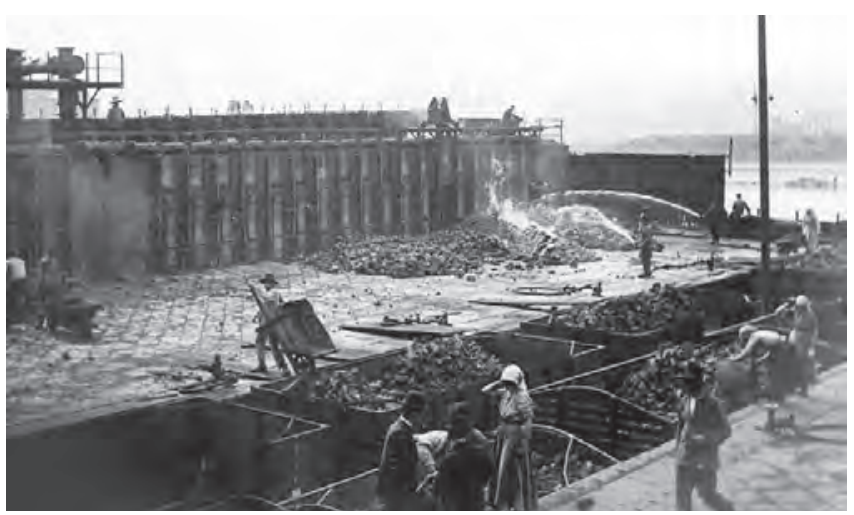

Cokesoven van de NV (Ougrée-)

Marihaye, begin twintigste eeuw. Foto Gustave Marissiaux. Copyright Province de Liège - Musée de la Vie wallonne.

verlieten. Hetzelfde gold volgens haar voor de bovengrondse werksters. ${ }^{83}$ Ook uit het onderzoek van Suzy Pasleau over vrouwenarbeid in Seraing voor de periode I846-188o blijkt dat ongeveer één vijfde van de meisjes tussen io en I4 jaar de stap naar loonarbeid zetten. Het aandeel actieve vrouwen was het hoogst in de leeftijdscategorie 15 tot 25 jaar. $^{{ }^{4}}$ Uit de werkboekjes bleek dat de meeste vrouwen hun beroepsloopbaan startten tussen de leeftijd van I2 en I4 jaar: twintig vrouwen startten toen ze I2 jaar waren, negentien op hun dertiende en achttien op hun veertiende. Zeven meisjes startten nog eerder: twee op hun tiende en vijf in hun elfde levensjaar. Ook uit de industrietellingen blijkt dat er al vroeg met het mijnwerk werd begonnen. In de tellingen van 1846 valt op dat er in Luik 35 meisjes van 9 jaar en jonger aan de slag waren in het mijnwezen, de leeftijdscategorieën 9 tot I 2 jaar en I2 tot I6 jaar omvatten respectievelijk I04 en 290 meisjes. Uit de steekproef van René Leboutte bleek dat de jongens gemiddeld 15 jaar oud waren toen ze hun eerste werkboekje ontvingen. De modus, de leeftijd die hierbij het meeste voorkwam, was I 2 jaar. ${ }^{85}$ In onze selecte steekproef kwam de leeftijd van 13 jaar het meeste voor. Hieruit kunnen we concluderen dat meisjes vrijwel even vroeg als jongens met het werk in de steenkolenmijnen begonnen. Er zijn nog zestien meisjes die met werken startten tussen 15 en 20 jaar en tien tussen 21 en 30 jaar. Enkelen startten op latere leeftijd: 34, 35, 36 en 45 jaar. Van twee vrouwen ( 34 en 36 jaar) weten we echter dat het gevonden werkboekje niet het eerste is, een eerste werkboekje ging verloren of werd bij een vroegere werkgever gehouden. Wellicht startten deze vrouwen reeds eerder met werken. ${ }^{86}$

Wanneer we willen nagaan wanneer deze vrouwen ophielden met werken, stuitten we op het probleem dat in heel veel werkboekjes een laatste uitschrijvingdatum ontbreekt. Slechts van 44 mijnwerksters is dit bekend. Bij deze groep zijn er acht vrouwen die reeds voor hun twintigste levensjaar, althans volgens de informatie uit de werkboekjes, stopten met werken. zeventien anderen stopten voor hun vijfentwintigste en nog eens elf beëindigden hun arbeidsloopbaan voor ze dertig werden. Aangezien de werkboekjes na I883 facultatief werden is het echter mogelijk dat sommige vrouwen daarna nog in een andere sector aan de

83 Hilden, Women, work and politics, rog.

84 Pasleau, 'La femme, un acteur à part entière de l'industrialisation', 620.

85 Leboutte, Le livret d'ouvrier dans la province de Liège, $42-43$.

86 Van I2 vrouwen kon de leeftijd bij aanvang van de beroepscarrière niet achterhaald worden door gebrek aan of onvolledige gegevens. 
slag gingen waar de werkgevers geen werkboekje eisten. ${ }^{87}$ De gemiddelde huwelijksleeftijd in de agglomeratie Luik in 1846 bedroeg 28 jaar voor vrouwen afkomstig uit de stad; tegen I8go daalde deze tot 26,5 jaar. ${ }^{88}$ Uit een vergelijking met de gemiddelde huwelijksleeftijd kunnen we concluderen dat een groot deel van de vrouwen voor of kort na hun huwelijk stopte met werken in de steenkoolindustrie. Uit Suzy Pasleau's studie bleek eveneens het belang van de matrimoniale status voor het al dan niet aanwezig zijn op de arbeidsmarkt. Vóór het huwelijk is vrouwenarbeid ontegensprekelijk een sociale realiteit; in Seraing werken meer dan 8 o procent van de celibataire vrouwen. Van de getrouwde vrouwen is er volgens de bevolkingsregisters maximaal to procent aan het werk. ${ }^{89}$

Vijf vrouwen uit de selecte steekproef beëindigden hun carrière voor hun veertigste levensjaar en slechts drie werkten door tot latere leeftijd: twee stopten toen ze 49 jaar waren en één vrouw werkte door tot ze 52 jaar was. Van 37 andere vrouwen weten we alleen wanneer ze bij de laatst ingeschreven werkgever startten. Aangezien we geen einddatum van dit dienstverband hebben, kunnen we met deze informatie weinig aanvangen. Wel is hieruit te concluderen dat er elf vrouwen minstens tot na hun vijfendertigste levensjaar doorwerken; negen blijven zelfs minstens werken tot na hun veertigste.

Van de vrouwen waarvan we de einddatum van hun laatste dienstverband konden achterhalen, kunnen we berekenen hoe lang ze op de arbeidsmarkt aanwezig waren, weliswaar met kleine of zeer grote tussenpozen. Een tweetal van hen hield de steenkoolindustrie al binnen het jaar voor gezien, vijf anderen hielden het niet langer dan 5 jaar vol en het aantal vrouwen dat een loopbaan kende van meer dan 5 , maar minder dan io jaar bedraagt dertien. Elf vrouwen zijn niet langer dan 15 jaar professioneel actief. Opvallend is echter dat er ook een aantal vrouwen is dat langdurig werkzaam bleef: de langste carrières bedroegen $35 \mathrm{en}$ $4 \mathrm{I}$ jaar. Voor de overige vrouwen was mijnwerk echter een zogenaamd levenscyclusberoep. Ook in een contemporain rapport uit 1870 vinden we hiervoor aanwijzingen. De auteurs stellen dat de meeste meisjes die trouwden niet wachtten tot hun eerste zwangerschap om de mijn te verlaten. Volgens hen stond echtgenote worden over het algemeen gelijk aan niet langer mijnarbeid verrichten. Slechts zeer uitzonderlijk bleven getrouwde vrouwen ondergronds werk verrichten. $9^{\circ}$

\section{LOON NAAR WERK?}

Een groot verloop, aanvullende seizoensarbeid en weinig geschoolde taken, gekoppeld aan een lage alfabetiseringsgraad, ${ }^{95}$ wijzen erop dat vrouwen in het algemeen in het onderste segment van de arbeidsmarkt functioneerden. Op grond hiervan mag worden verondersteld dat de lonen van vrouwen in het algemeen laag waren. In de industrietellingen van I846 werden de werknemers in de steenkoolnijverheid geklasseerd naargelang inkomens-

87 Leboutte, Le livret d'ouvrier dans la province de Liège, 37.

88 Idem, Reconversions de la main d'oeuvre, 296.

89 Pasleau, 'La femme, un acteur à part entière de l'industrialisation', 62I-622.

90 Deneubourg en Wouters, Réflexions sur le travail des femmes, Io; Salée, Le travail des femmes et des enfants dans les charbonnages, Ioo-IoI. 9I 37 van de 107 werkboekjes waren voorzien van een handtekening van de arbeidster. Bij I8 werkboekjes stond er expliciet vermeld dat de houdster ongeletterd was (illettrée). Van de 52 overgebleven werkboekjes weten we niet of dit te wijten is aan eventuele onzorgvuldigheid van de gemeenteambtenaren of daadwerkelijk wijst op ongeletterdheid. 
niveau. Voor heel België zien we dat de meeste vrouwen tussen I à I,50 BEF verdienden. In Luik kreeg het grootste deel vrouwen minder: tussen 50 centimes en I BEF. Wanneer we de lonen van de mannen nader bekijken valt op dat zowel in het Luikse bekken als in heel België de grootste groep mannen een salaris ontving tussen I, 50 en 2 BEF. Gemiddeld verdienden vrouwen in de Belgische steenkoolindustrie dus tweederde tot drievierde van een mannenloon, terwijl ze in Luik gemiddeld de helft of zelfs tweederde minder verdienden. Dit wordt bevestigd door het onderzoek van Salée. De loonverschillen worden verklaard door het feit dat de meeste vrouwen bovengronds werkten, minder gevaarlijk en zwaar werk deden en/of minder productief waren, of als zodanig werden gezien. Het aannemen van vrouwen drukte dan ook de productiekosten, één van de redenen waarom het verbod op vrouwenarbeid enkele keren werd uitgesteld. Een andere verklaring voor het lagere loon voor vrouwen lag in de opvatting dat dit louter een aanvulling op het mannenloon was. ${ }^{92}$

De industrietellingen maken het ook mogelijk een vergelijking te maken met de lonen in andere sectoren (tabel 2.5). We kunnen concluderen dat in I846 het loonverschil tussen mannen en vrouwen alleen hoger lag in de Luikse linnen- en hennepnijverheid. Het gemiddelde dagloon voor zowel mannen als vrouwen lag daar echter opvallend laag. In de metaal-, ijzer- en staalindustrie was er vrijwel geen verschil. Daar lagen de gemiddelde daglonen voor vrouwen bijna even hoog als in de glasnijverheid, waar vrouwen in dat jaar gemiddeld het meest konden verdienen. Ook de gemiddelde daglonen voor mannen waren daar het hoogst. Deze verschillen in loonniveau tussen de verschillende industriële sectoren in het Luikse bekken kunnen misschien deels verklaren waarom alternatieve werkgelegenheid aantrekkelijk was.

TABEL 2.5 DE GEMIDDELDE DAGLONEN IN LUIK VOOR I846 (IN BEF) ${ }^{93}$

\begin{tabular}{|l|c|c|c|}
\hline & \multicolumn{2}{|c|}{$\begin{array}{c}\text { werknemers ouder dan } \\
\text { I6aar }\end{array}$} & $\begin{array}{c}\text { verhouding dagloon vrouwen/ } \\
\text { dagloon mannen }\end{array}$ \\
\hline & mannen & vrouwen & in \% \\
\hline $\begin{array}{l}\text { Steenkoolontginning, } \\
\text { vervaardiging van cokes }\end{array}$ & 2,07 & I,22 & $58,94 \%$ \\
\hline Metaal-, ijzer- en staalindustrie & $\mathrm{I}, 67$ & $\mathrm{I}, 57$ & $94,01 \%$ \\
\hline Glasnijverheid & 2,47 & $\mathrm{I}, 68$ & $68,02 \%$ \\
\hline Linnen- en hennepnijverheid & 0,80 & 0,47 & $58,75 \%$ \\
\hline
\end{tabular}

Bron: L'industrie en Belgique (1846). ${ }^{94}$

Tabel 2.6 geeft ons wat meer duidelijkheid over de loonverschillen tussen mannen en vrouwen ondergronds, maar dit op een moment dat de ondergrondse arbeid van vrouwen al sterk is gedaald. Eerder zagen we dat er in I895 in heel België nog maar I.268 vrouwen ondergronds werkten. ${ }^{95}$

92 Bairin, Le travail des femmes, 70-7I; Salée, Le travail des femmes et des enfants dans les charbonnages, I22-I23.

93 De percentages zijn eigen berekeningen.

94 In de industrietelling van 1880 vonden we een overzicht terug met de gemiddelde daglonen in verschillende industrietakken voor 1846 en I880. Voor I880 werd er geen onderscheid meer gemaakt tussen de lonen van mannen en vrouwen, en dus werden ze in de tabel niet opgenomen.

95 Berekend op basis van gegevens uit: Annales des Mines de Belgique, I896. 


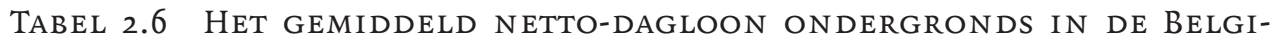
SCHE STEENKOOLNIJVERHEID, I895-I9OO (IN BEF)

\begin{tabular}{|l|c|c|c|c|c|c|}
\hline & $\mathbf{1 8 9 5}$ & $\mathbf{1 8 9 6}$ & $\mathbf{1 8 9 7}$ & $\mathbf{1 8 9 8}$ & $\mathbf{1 8 9 9}$ & $\mathbf{1 9 0 0}$ \\
\hline vrouwen ouder dan 2I & 2,00 & 2,00 & 2,20 & 2,40 & $\cdot$ & 2,95 \\
\hline vrouwen jonger dan 2I & $\mathrm{I}, 85$ & $\mathrm{I}, 90$ & 2,00 & 2,40 & $\cdot$ & - \\
\hline jongens tussen I4 en I6 jaar & $\mathrm{I}, 85$ & $\mathrm{I}, 85$ & 2,00 & 2,20 & $\cdot$ & 2,80 \\
\hline jongens tussen I2 en I4 jaar & $\mathrm{I}, 30$ & $\mathrm{I}, 30$ & $\mathrm{I}, 45$ & $\mathrm{I}, 50$ & $\cdot$ & $\mathrm{I}, 90$ \\
\hline mannen en jongens ouder dan I6 & 3,85 & 3,64 & 3,89 & 4,09 & $\cdot$ & $5,4 \mathrm{I}$ \\
\hline
\end{tabular}

Bron: Annales des Mines de Belgique, I896-rgor.

Gezien de verschillen in leeftijdscategorieën is het vergelijken moeilijk. Wel blijkt hieruit dat een vrouw ouder dan 2I jaar ondergronds iets meer dan de helft van een man (boven de I6 jaar) kon verdienen. Uit de Industrietellingen van I896 blijkt dat de vrouwen die in die periode ondergronds werkten tussen de 2 en 2,99 BEF per dag verdienden: 4I vrouwen uit het overzicht verdienden tussen de 2 en 2,49 BEF, vijftien vrouwen kregen tussen de 2,50 en 2,99 BEF uitbetaald. We konden op basis van deze bron geen link bespeuren tussen de taakomschrijving en het loonpeil. Arbeidsters die hetzelfde werk uitoefenden konden een verschillend salaris ontvangen. Zeer zeker speelde leeftijd ook een rol bij het bepalen van het dagloon. In een aantal gevallen verdienden vrouwen zelfs eenzelfde dagloon als hun mannelijke collega's in dezelfde functies; dit was het geval bij zeven bouteuses. Twee bouteuses kregen zelfs een hoger dagloon dan vijf van hun mannelijke collega's, namelijk tussen de 2 en 2,49 BEF, tegenover minder dan I,50 BEF..$^{96}$ De hiercheuses verdienden echter gemiddeld I BEF minder per dag dan de mannen die dezelfde functie vervulden.

In verhouding tot hun mannelijke collega's kregen bovengrondse werksters over het algemeen een lager dagloon, maar in enkele functies kregen ze hetzelfde betaald, namelijk als lampiste of nettoyeuse de lampes. Dit was echter maar in enkele mijnbedrijven het geval. ${ }^{97}$

Wat opvalt bij het overzicht van de arbeidsverdeling per bedrijf zijn de grote verschillen tussen de bedrijven. Enkele bedrijven lijken weinig of geen verschil te maken tussen mannen- en vrouwenlonen per functie; bij de meerderheid is er echter een duidelijk verschil en bedraagt een vrouwenloon voor dezelfde functie amper de helft tot zelfs minder dan één vierde van een mannenloon. Gezien de beperkte informatie is het echter voorbarig hier conclusies uit te trekken. ${ }^{8}$

96 Het werk van een bouteuse was zwaarder dan dat van een hiercheuse, dit rechtvaardigde een salaris vrijwel gelijk aan of zelfs gelijk aan dat van hun mannelijke collega's.

97 Van de vrouwen ouder dan I6 jaar die bovengronds werkten, verdiende de grootste groep van 769 vrouwen tussen de I en I,49 BEF per dag. Een tweede groep van 5 Io vrouwen kreeg tussen de I,50 en I,99 BEF per dag. Het aantal vrouwen dat minder dan I BEF per dag verdiende bedroeg 35, 44 verdienden meer dan 2 BEF. Meisjes jonger dan 16 jaar verdienden over het algemeen meer dan 0,50 BEF: 20I meisjes kregen een dagloon tussen de 0,50 en o,99 BEF, I74 meisjes verdienden meer dan I BEF per dag. Recensement général des industries et des métiers, 'Volume IX, Dénombrement A'.

98 Temeer daar het uit de industrietellingen niet te achterhalen is om welke steenkoolmijnen het hier precies gaat. De bedrijven werden enkel aangeduid met een nummer en niet bij naam genoemd. 


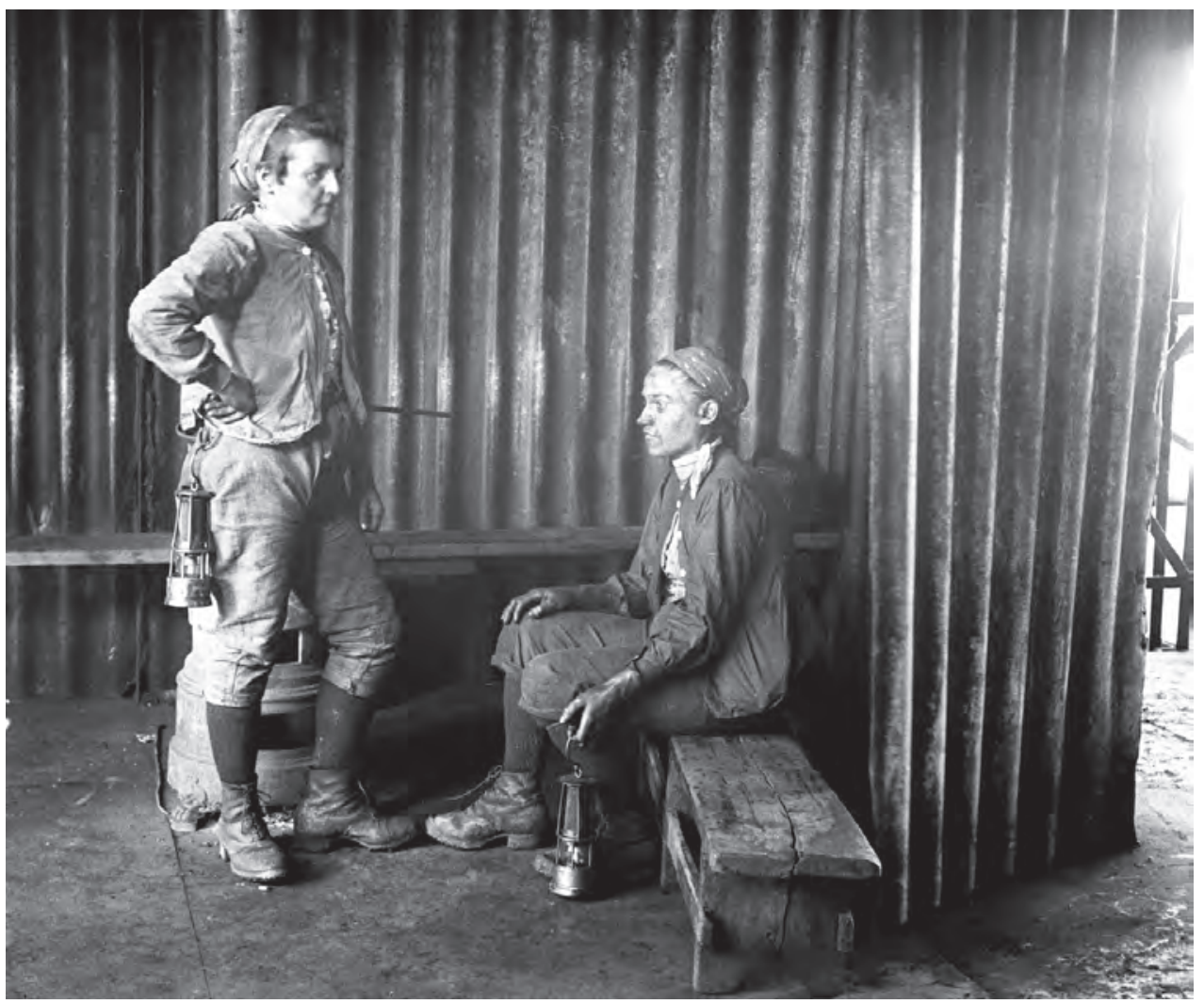

Mijnwerksters (ondergrond) te Luik, begin twintigste eeuw. Foto Gustave Marissiaux. Copyright Province de LiègeMusée de la Vie wallonne.

\section{BESLUIT}

In Belgium, women did all the work? Werkten vrouwen in België inderdaad meer en langer dan hun seksegenoten in de omringende landen, en zo ja, waarom? Dit werd onderzocht aan de hand van de inzet van vrouwen in de steenkolenmijnen. Dat vrouwen in België alle werk deden is uiteraard overdreven, maar het lijkt niet overdreven te stellen dat vrouwen in België in de tweede helft van de negentiende eeuw meer en langer werkten.

Het wettelijke verbod op ondergrondse vrouwenarbeid in landen als Engeland en Duitsland werd aanzienlijk eerder afgekondigd dan in België. Uit de statistieken blijkt dat het belang van vrouwen in de steenkoolindustrie in Groot-Brittannië en Duitsland geringer was dan in België. Hieruit blijkt dat het wetgevend kader een doorslaggevende invloed uitoefende. De beperking van vrouwenarbeid in de Belgische mijnen kreeg pas zijn beslag met de wetgeving van 1889 die ondergrondse arbeid voor vrouwen onder 2I jaar vanaf I892 verbood. Daarmee waren de vrouwen nog niet uit de Belgische mijnen verdwenen. Uit het onderzoek van de werkboekjes bleek dat vrouwen tot in de jaren 1920 werkzaam bleven in de mijnen. Zij werkten in die laatste jaren veelal bovengronds. In Frankrijk, waar het verbod op ondergrondse vrouwenarbeid rond dezelfde tijd inging, lijkt de daling van het aandeel vrou- 
wen zich sneller doorgezet te hebben dan in de Belgische mijnen. ${ }^{99}$ De redenen voor deze lange vrouwelijke aanwezigheid in de Belgische steenkoolnijverheid zijn divers. Op de eerste plaats was het aanzienlijk lagere loon voor vrouwen erg belangrijk in deze industrie waar een groot deel van de productiekosten uit loonkosten bestond. Zowel de werkgevers als de liberale overheid (althans tot in 1884 ) waren om die reden tegen een verbod op vrouwenarbeid. In sommige mijnen waren vrouwen daarnaast onmisbaar omdat de mechanisering van hun arbeid, vooral het zogenaamde 'slepen', niet kon worden doorgevoerd. Vervanging van vrouwenarbeid door machines was te kostbaar of niet mogelijk door geologische omstandigheden: dunne en onzuivere steenkolenlagen. ${ }^{\text {100 }}$

Als wij het aandeel van vrouwen in de Luikse mijnen vergelijken met dat in andere Belgische mijnbouwregio's valt op dat er aanzienlijke verschillen bestonden. Het aandeel van vrouwen bleek in de Luikse steenkoolmijnen gedurende de hele negentiende eeuw kleiner dan in de steenkolenbekkens te Henegouwen. Wij veronderstellen dat dit verschil verklaard kan worden door de ruimere aanwezigheid van alternatieve werkgelegenheid in en rond de stad Luik. Ook in Engeland leek de vrouwenarbeid in de steenkoolindustrie geconcentreerd in een beperkt aantal regio's.

Dit brengt ons bij de tweede vraag: namelijk, wat deden vrouwen precies in de mijnen? Uit het onderzoek bleek dat de functies van de vrouwen in de Luikse mijnen samen te brengen zijn onder de noemer: laaggeschoold en aanvullend. De taakverdeling die tot het einde van de negentiende eeuw in de Luikse mijnen bleef voortbestaan, vertoonde opvallend veel gelijkenissen met de arbeidsverdelingen in andere mijngebieden. Voor de veronderstelling dat deze hun oorsprong vonden in de arbeidsverdeling in familieverband werden echter geen aanwijzingen gevonden. De grote overeenkomsten met de arbeidsverdeling in Frankrijk en Engeland doet ons echter wel vermoeden dat dit het geval was.

We constateerden eveneens een groot arbeidsverloop, korte dienstverbanden en regelmatige loopbaanonderbreking ten behoeve van seizoensarbeid. Volgens De Groot was arbeidsverloop vooral afhankelijk van de mate waarin de lokale arbeidsmarkt vrouwen kansen bood om elders te werken. We zagen dat er in de Luikse regio vele alternatieven waren, maar toch was het arbeidsverloop onder de mijnwerksters niet overdreven groot en zelfs kleiner dan dat van de mijnwerkers. Dit konden we nagaan aan de hand van de lengte van het dienstverband en het aantal keren in- en uitdiensttreding van de arbeidster. Het algemene patroon was dat de hiercheuse gemiddeld op haar twaalfde jaar in het mijnbedrijf begon en dat ze dit zware werk volhield totdat ze in het huwelijk trad en haar eerste kind kreeg. In de negentiende eeuw gebeurde dit gemiddeld tussen 26 en 29 jaar. ${ }^{\text {Ior }}$ Gezien hun plaats in de onderste segmenten van de arbeidsmarkt voor mijnarbeid ligt het voor de hand dat het loon dat de mijnwerksters voor hun labeur kregen navenant was. In het algemeen bedroeg het dagloon van een mijnwerkster nauwelijks de helft van dat van haar mannelijke collega. We konden geen verband ontdekken tussen verloning en een bepaalde functie. Het lijkt ons

99 Dit is wellicht te wijten aan het volledige verbod op vrouwenarbeid ondergronds, terwijl dit in België enkel gold voor vrouwen onder de 2I jaar. Ook wijst Le Tirant erop dat in bepaalde mijnen in Noord-Frankrijk, vrouwen ondanks het verbod, ondergronds aan de slag bleven tot aan het einde van de negentiende eeuw. Dit fenomeen vond zijn oorsprong volgens haar in de Belgische mijnen. Le Tirant, Femmes à la mine, 173 .

Ioo Gaier, Huit siècles de houillerie liégeoise, I59-160.

Ior Leboutte, Reconversions de la main d'œuvre et transition démographique, 37, 296. 
dat de mijnwerksters net omwille van hun vrouwzijn zo laag betaald werden. Alhoewel bepaalde mijneigenaren op eigen initiatief niet langer vrouwen tewerkstelden, bleek dat het lage loon een belangrijke reden vormde om de arbeid van vrouwen ondergronds pas laat te verbieden. Aanwijzingen van protest door mijnwerkers vanwege oneerlijke concurrentie werden voor de Luikse casus niet gevonden. Volgens Hartmann werd de invoering van het verbod op ondergrondse vrouwenarbeid in Engeland door de mijnwerkers om die reden juist ondersteund. ${ }^{\text {I02 }}$

Besluiten we met de stellingen van Hilden. Uit het onderzoek van historische statistieken en de werkboekjes bleek inderdaad dat de Belgische vrouwen langer en meer dan de Britse, Franse en Duitse vrouwen in het mijnbedrijf aanwezig waren. De tweede stelling omtrent het ungendered karakter van de mijnarbeid blijkt echter niet op te gaan. Uit het onderzoek blijkt dat vrouwen juist specifieke taken uitoefenden. 


\section{Hoofdstuk 3 \\ Buitenlandse arbeiders in de Luikse steenkolenmijnen, I900-I974}

Het Luikse steenkoolbekken situeert zich rond de stad Luik, hoofdstad van de gelijknamige Belgische provincie en strekt zich uit in het noorden tot de gemeente Oupeye, in het oosten tot Thimister-Clermont, in het zuiden tot Chaudfontaine en in het westen tot de gemeente Flémalle. De rivier de Maas en sedert de jaren 1930 het Albertkanaal vormen de belangrijkste waterwegen. ${ }^{1}$ In tegenstelling tot de steenkoolnijverheid in Belgisch- en NederlandsLimburg kende de Luikse nijverheid een veel langere voorgeschiedenis. In de omgeving van Luik werd reeds steenkool gedolven tegen het einde van de twaalfde eeuw. ${ }^{2}$ De industrie was primitief. De introductie van pompen aangedreven door stoommachines leidde tot een totale ommekeer in de steenkoolindustrie. De Luikse kolenlagen waren moeilijk te ontginnen. De bodem werd er gekenmerkt door vele gegolfde en verbrokkelde lagen en bevatte veel water, waardoor men in de Luikse mijnen meer dan in de andere Belgische bekkens water diende op te pompen. Bovendien moesten er veel meer steenkolenlagen ontgonnen worden om éénzelfde opbrengst te verkrijgen en diende de luchtverversing intensiever te gebeuren. ${ }^{3}$

Aan de vooravond van de Eerste Wereldoorlog was de Luikse kolenmijnbouw zijn hoogtepunt reeds gepasseerd (zie grafiek 3.I). Het Luikse bekken bereikte in Igo3 zijn maximumproductie met meer dan 6 miljoen ton steenkolen, wat toentertijd meer dan één vierde van de totale Belgische steenkolenproductie uitmaakte. Het naoorlogse hoogtepunt van de Luikse kolenproductie werd bereikt in 1954. De sterke productiedaling na 1912 kan deels worden verklaard door de geologische omstandigheden. Ook het feit dat de Luikse mijnen reeds veel eerder ontgonnen werden kan deze daling verklaren. Uitputting is het uiteindelijke lot van elke mijn. De oudere Luikse mijnen bereikten al vrij vroeg in de twintigste eeuw dit stadium. Samen met de Borinage, het Centrum en het gebied rond Charleroi in de Waalse provincie Henegouwen behoorde het Luikse bekken tot de eerste geïndustrialiseerde gebieden op het Europese vasteland, met als belangrijkste pijlers de steenkoolnijverheid en de ijzer- en staalindustrie. Er ontstond al snel een beroepsbevolking die gewend was aan industriële werkgelegenheid. Tegen het begin van de twintigste eeuw was er sprake van een reeds lang gevestigde mijnwerkerspopulatie. Toch kon ook in dit gebied het lokale arbeidersaanbod niet voldoen aan de enorme vraag naar arbeidskrachten. Er moest in toenemende mate een beroep worden gedaan op arbeidskrachten van buiten de regio. In de loop van de twintigste eeuw, toen de Luikse steenkoolnijverheid al op zijn retour was, werd de aanwezigheid van vreemde arbeidskrachten onmisbaar.

I Direction Générale des Mines à Bruxelles, Carte Générale des concessions houillères de Belgique - Bassin du Sud - Liège - feuille 6 , édition 1946 .

2 Bless et al., Oorsprong en winning van steenkool, 32.

3 Gaier, 'Le bassin minier de Liège', 159-160. 
GRAFiEK 3.I DE NETTOPROdUCTIE IN HET LUIKSE BEKKEN (X I.00o TON), I9ooI974

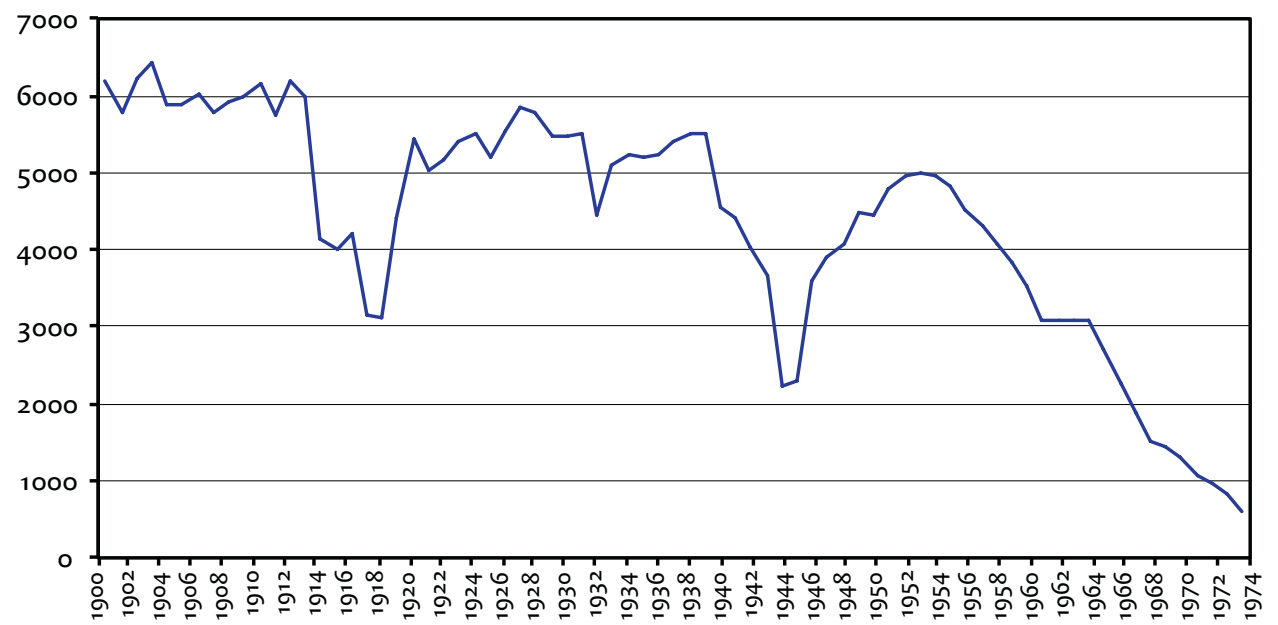

Bron: Annales des Mines de Belgique, I899-1967; Belgisch Kolenbureau, Basisstatistieken 1967, 5; 1980, 5; Geerkens, La rationalisation dans l' industrie belge, I24I (Tableau 2); I940-I945: RAH, archief FEDECHAR, inv.nrs. 606-609 : 'Jaarlijkse statistische overzichten'.

In dit hoofdstuk worden de termen vreemdeling en buitenlander gebruikt voor personen die niet de Belgische nationaliteit hebben. De behandelde periode loopt door tot in I974, toen er in België, net zoals in het merendeel van zijn buurlanden een algemene migratiestop werd afgekondigd. Er is voor gekozen vooral de periode na de Tweede Wereldoorlog uitgebreid te bespreken. We zien dan een enorme sprong in het aantal tewerkgestelde vreemdelingen in de Luikse mijnen (zie grafiek 3.2). Bovendien is de periode vóór de Tweede Wereldoorlog reeds uitvoerig aan bod gekomen in een aantal artikelen en het overzichtwerk van Frank Caestecker. ${ }^{4}$ Een inleidend deel behandelt de periode tot aan de Tweede Wereldoorlog; de oorlog zelf wordt als een intermezzo gezien. De kern van dit hoofdstuk wordt gevormd door de bespreking van de periode I945-I958. Een afsluitend deel behandelt de periode van verdere neergang van de steenkoolindustrie tussen 1958 en I974. De omvang en samenstelling van de groep buitenlandse arbeidskrachten worden nader onderzocht. Zoals we in grafiek 3.2 zien was het aandeel vreemdelingen in het Luikse bekken vooral na de Tweede Wereldoorlog zeer groot. Waarom waren het er zo veel? Welke verschillen waren er door de tijd heen en wat zijn hiervoor de verklaringen?

Een traditionele verklaring voor de aanwezigheid van vreemdelingen op de arbeidsmarkt is hun bufferfunctie. ${ }^{5}$ De migratiepolitiek is gericht op het aanbieden van een tijdelijk arbeidscontract aan migranten, waarmee periodes van arbeidstekorten kunnen worden opgevangen. Wanneer de conjunctuur omslaat kunnen deze arbeiders makkelijk weer worden afgedankt. ${ }^{6}$ Opeenvolgende periodes van intensieve immigratie enerzijds en van evenwich-

4 O.m. Caestecker, 'Centraaleuropese mijnwerkers in België'; idem, 'Vakbonden en etnische minderheid', 5I-63; idem, 'Vervanging of verdringing', 309-326; idem, Alien policy in Belgium. 
GrafieK 3.2 Het totale aANTAl ARbeiders, het Aantal BElgische EN buiTENLANDSE ARBEIDSKRACHTEN IN DE LUIKSE MIJNEN, I904-I9737

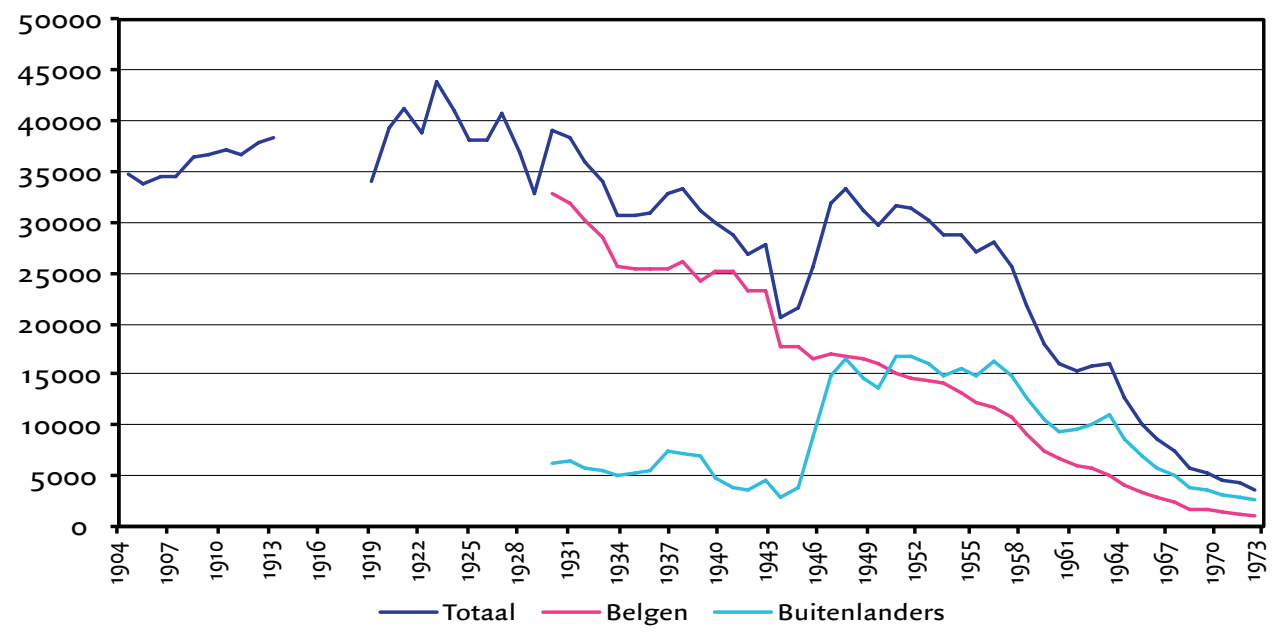

Bron: RAH, archief FEDECHAR, inv.nr. 6I2: 'Statistieken'; 'Technische kenmerken van de Belgische steenkolenontginning', I9581974. (Zie bijlage II).

tige migratie of zelfs negatieve saldi anderzijds vallen samen met de schommelingen van de conjunctuur en zijn vooral afhankelijk van vraag en aanbod op de arbeidsmarkt. In zijn sociologische studie uit 1973 toonde Martens voor de jaren I948-I969 een duidelijk negatief verband aan tussen het aantal mannelijke buitenlanders en het aantal mannelijke werklozen in België.7 De druk om de aanwerving van buitenlandse arbeidskrachten te vergemakkelijken steeg als de arbeidsmarkt gespannen was, terwijl men in periodes van werkloosheid vooral trachtte de Belgische werknemers te beschermen tegen de concurrentie van migranten. ${ }^{8}$

Martens schetst een scenario dat zich na de Tweede Wereldoorlog, maar ook al vroeger in de twintigste eeuw, een aantal keren voordeed:

- om een gebrek aan arbeidskrachten in bepaalde sectoren op te vangen deed het patronaat een beroep op buitenlandse arbeidskrachten;

- als er zich een crisis of economische recessie voordeed waardoor werkloosheid ontstaat, eisten bepaalde drukkingsgroepen - de vakbonden o.a. - een strenge controle op de tewerkstelling van de vreemdelingen;

- daarop nam de overheid bepaalde wettelijke en administratieve maatregelen om de tewerkstelling van vreemdelingen te beperken, te verhinderen of te verbieden. Deze maatregelen werden echter vlug ingetrokken als er zich een herneming van de economie voordeed, om het ritme van de economische groei niet af te remmen of in het gedrang te brengen. ${ }^{9}$ 


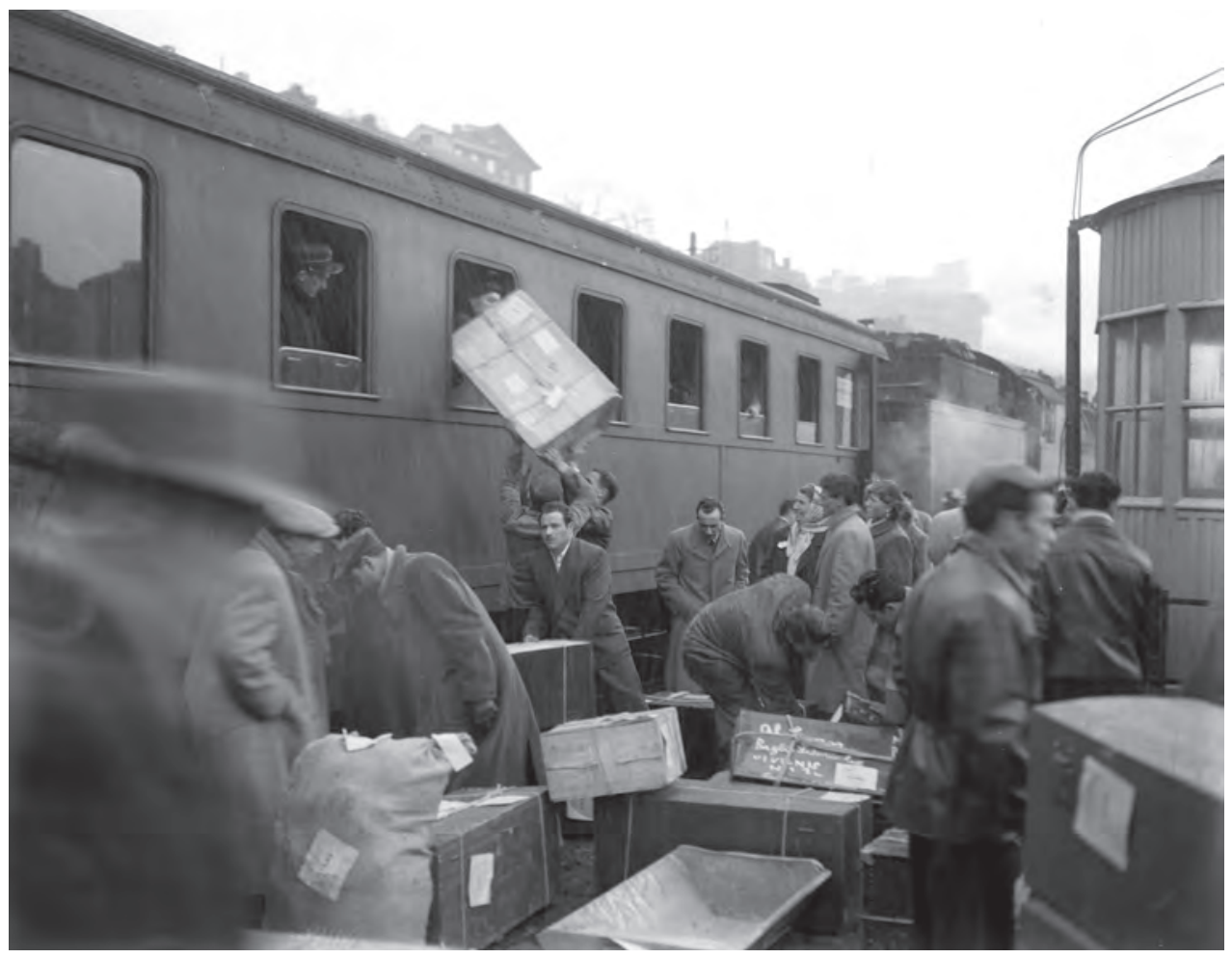

De aankomst van Italiaanse contingenten te Luik, 1956. Copyright Province de Liège - Musée de la Vie wallonne.

René Leboutte omschrijft het als volgt: 'clearly foreign manpower was regarded as a reserve army'. ${ }^{\text {Io }}$ De overheid speelde bij dit alles vooral een faciliterende rol: ze maakte het makkelijker over te gaan tot aanwerving in het buitenland en was bepalend voor de herkomst van de vreemde arbeidskrachten door bilaterale verdragen aan te gaan met bepaalde landen.

De redenering dat het aantrekken van vreemde arbeidskrachten conjunctureel gestuurd wordt, heeft te maken met het bestaan van een dubbele arbeidsmarkt. Deze theorie beschouwt de arbeidsmarkt als een systeem met verschillende compartimenten. Vereenvoudigd zijn er twee segmenten, die stevig van elkaar worden gescheiden door structurele grenzen. In het bovenste segment treft men banen aan met werkzekerheid, hoge lonen en promotiekansen, terwijl in het onderste segment zich de jobs met lagere lonen, geen werkzekerheid en weinig promotiekansen bevinden. Zo éénduidig was de situatie bij de Luikse mijnwerkers niet, maar niettemin kunnen we grote verschillen onderscheiden tussen de Belgische en de buitenlandse werknemers. We zullen zien dat de buitenlandse arbeiders vooral terechtkwamen in de steenkoolnijverheid. Belgen en vreemdelingen werden dus niet gelijk over de verschillende bedrijfstakken en beroepen verdeeld; dit is wat men noemt horizontale arbeidssegregatie. Verticale segregatie betekent dat de posities binnen een bedrijf ongelijk zijn verdeeld: de buitenlanders gingen vooral ondergronds aan de slag, en dan nog vooral als houwer, het meest gewaardeerde, want productiefste mijnwerk, maar ook het 
allerzwaarste. De Luikse steenkoolnijverheid bleef zelfs bij een neergaande conjunctuur moeite houden voldoende arbeidskrachten te vinden; het aanwerven van buitenlanders was een blijvende noodzaak is. Er ontstond een structurele behoefte aan mijnwerkers van buitenlandse nationaliteit. ${ }^{\text {II }}$

\section{AANLOOP: HET VERDWIJNEN VAN EEN BEROEPSTRADITIE}

In de Luikse mijnen had zich in de loop van de negentiende eeuw een vaste kern van fulltime mijnwerkers gevormd. Mijnarbeid werd in veel families een traditie, die van vader op zoon werd overgedragen: 'on ne vient pas à la mine, on y nait'. ${ }^{12}$ Helemaal zelfvoorzienend was de Luikse arbeidsmarkt voor mijnwerkers echter niet. Door het heterogene karakter van het Luikse industriebekken waren er alternatieven voor het beroep van mijnwerker. Vooral de metallurgische industrie oefende aantrekkingskracht uit op lokale en regionale arbeidskrachten. Al in de negentiende eeuw moesten de Luikse mijnen regelmatig een beroep doen op arbeidskrachten die van verder kwamen dan loopafstand. Een groot deel van de Luikse mijnwerkers was afkomstig van het platteland, aangetrokken door een verleidelijk salaris. Naast een eerste migratiegolf van Vlamingen in de periode $1850-1860,{ }^{13}$ die volgde op de agrarische crisis van 1846 , waren er ook buitenlandse migranten. Onder hen was een behoorlijk contingent Nederlanders. Zo rekruteerden de Charbonnages du Sclessin in de jaren I846-I856 een groep mijnwerkers uit Kerkrade. ${ }^{14}$ Veel van deze nieuwkomers vestigden zich in de Luikse voorstad Tilleur. Daar troffen ze andere groepen migranten, afkomstig uit de omgeving van Aken. Hoe groot de groep precies was, is niet bekend. Tilleur kreeg vanwege de migranten uit het Nederlands-Pruisisch grensgebied zelfs de bijnaam 'li p'tite Prusse'. Ook Seraing kende in die tijd een wijk met de naam 'klein-Pruisen'. Het is een aanwijzing dat er in deze snelgroeiende industriestad eveneens een kolonie van migranten uit die streek bestond. Volgens een telling uit 1876 werkten drie- à vierhonderd arbeiders van Nederlandse afkomst in de Luikse mijnen. Duitsers hadden een aandeel van 5,5 procent in de totale personeelsbezetting. Het aantal buitenlandse mijnwerkers bedroeg 9 procent van het totaal. Het aantal Vlamingen liep echter op tot 30 procent. ${ }^{15}$

Vooral na de agrarische crisis van de jaren I88o kwamen veel Vlamingen op de werkgelegenheid in de Luikse mijnen af. Dat werd nog gestimuleerd door de hogere nataliteit van de Vlamingen. ${ }^{16}$ Het invoeren van goedkope spoorwegabonnementen als strategie van de katholieke regering om het tekort aan arbeidskrachten in de industrie met het overschot uit de agrarische sector op te vangen, zorgde ervoor dat veel Vlamingen naar de Waalse industriebekkens trokken. ${ }^{17}$ Sommigen pendelden dagelijks of wekelijks naar het industrië-

\footnotetext{
II Caestecker, Alien Policy in Belgium, 257-259.

12 'Men komt niet naar de mijn, men wordt er geboren'. Delaet, 'Huit siècles d'exploitation charbonnière en Wallonie', 95.

I3 In I876 bleek reeds I3 procent van de personeelsbezetting in de Luikse mijnen van Vlaamse afkomst. Gaier, Huit siècles de houillerie liégoise, 162.

14 Rutten, 'Werken over de grens', 444.

15 Gaier, Huit siècles de houillerie liégoise, I62-163.

I6 Het geboortecijfer lag in het rurale Vlaanderen hoger dan in het geïndustrialiseerde Wallonië. Vandenbroeke, Sociale geschiedenis, 94-108.

17 Caestecker, 'Vervanging of verdringing', 3 го.
} 
le centrum en velen vestigden zich uiteindelijk in Luik. ${ }^{18}$ Uit de industrietellingen van IgIO blijkt dat er 3.506 Vlaamse pendelaars te vinden waren in het Luikse, waarvan er 45 procent tewerkgesteld was in de mijnen. Ze waren vooral afkomstig uit de arrondissementen Hasselt, Leuven en Tongeren. ${ }^{19}$

De migratiestroom van Vlamingen naar Luik begon bij het uitbreken van de Eerste Wereldoorlog in I9I4 te verminderen. Na de oorlog dienden zich meer alternatieven voor de Vlaamse arbeiders aan. Wie koos voor het beroep van mijnwerker, kon voortaan dichter bij huis terecht, in het nieuw ontgonnen Belgisch-Limburgse steenkolenbekken. ${ }^{20}$ Een verklaring hiervoor was tijdswinst: deze Vlamingen hoefden dan immers niet meer zo ver te pendelen. Toch bleven er voorlopig nog heel wat Vlamingen in Wallonië werken, omwille van de onveilige werkomstandigheden, het hoge arbeidsritme en de autoritaire sociale verhoudingen in de nog jonge Limburgse mijnen. De vooruitgang in de metaalindustrie en bouwnijverheid op het einde van de jaren I92o boden echter veel mogelijkheden voor de Vlamingen en zodoende zagen de Waalse mijnen ze uiteindelijk toch vertrekken. ${ }^{21}$

De tijdelijke toevoer van deze voornamelijk rurale, Belgische arbeidskrachten was niet voldoende om het tekort aan lokale mijnwerkers te dekken. Demografische veranderingen onder de traditionele Waalse mijnwerkerspopulatie met als belangrijkste kenmerk een lager kinderaantal, meer alternatieve werkgelegenheid, de gevaarlijke en zware arbeidsvoorwaarden in de mijnen samen met het lage sociale prestige zorgden ervoor dat veel arbeidskrachten niet langer voor het mijnwerk kozen. Bovendien werd de achturenwet in IgIo ingevoerd, waardoor het rendement per mijnwerker achteruitging. ${ }^{22}$ Daarom moesten ook de directies van de Luikse mijnen, zoals in de meeste andere mijnbekkens, een beroep doen op mijnwerkers van buitenlandse afkomst.

Pas vanaf 1923 staan gegevens over het aandeel van buitenlandse arbeidskrachten in de Luikse mijnen ter beschikking. Het aantal mijnwerkers met een niet-Belgische nationaliteit was nog beperkt. De 2.512 buitenlanders in de Luikse mijnen maakten slechts 5,7 procent van de totale arbeidskracht uit. ${ }^{23}$ Dit geeft aan dat de Luikse mijnen toen nog konden putten uit de nationale arbeidsmarkt. Daardoor moesten ze minder dan de Kempische mijnen een beroep doen op buitenlandse arbeidskrachten. In I925 telden die reeds I7 procent vreemdelingen onder hun arbeidskrachten. ${ }^{24}$ Nog in 1930 waren er Luikse mijnen die vrijwel geen buitenlanders tewerkstelden. ${ }^{25}$ Voor het jaar 1923 is ook een overzicht voorhanden van de nationaliteiten van de buitenlandse mijnwerkers in Luik (grafiek 3.3). Daaruit blijkt dat twee nationaliteiten sterk vertegenwoordigd waren: Polen (33 procent) en Italianen ( $3 \mathrm{I}$ procent). De aanwezigheid van deze groepen was het resultaat van gerichte wervingsacties door de patroonsorganisatie van de mijnen FEDECHAR (Fédération des Associations Charbonnières de Belgique), die daarmee begonnen was in het kader van de naoorlogse wederopbouw na de Eerste Wereldoorlog.

I8 Poulain en Foulon, 'L' immigration flamande en Wallonie', aldaar 226.

I9 Quairiaux, 'Migrants flamands en Wallonie avant I9I4', 349.

20 Caestecker, 'Vakbonden en etnische minderheid', 60.

2I Idem, 'Vervanging of verdringing', 312-313.

22 De Groeve, 'De Belgische Steenkoolindustrie', 7I.

23 Ingeschreven arbeiders november I923 in: Annales des Mines de Belgique, I928, $246-247$.

24 Caestecker, 'Vervanging of verdringing', 3 I4.

25 RAH, archief FEDECHAR, inv.nrs. I579-I58I: 'Personeelsstatistieken'. 


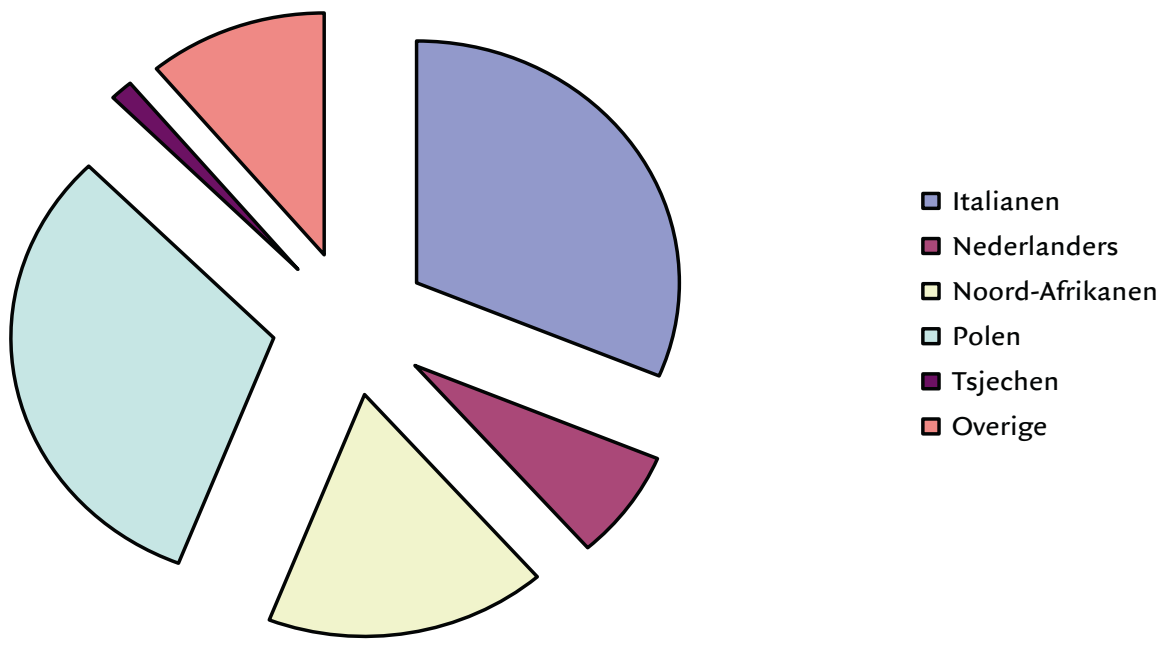

Bron: Annales des Mines de Belgique, 1928, 246-247.

De Italiaanse inbreng van mankracht blijft tot op heden het omvangrijkste migratiefenomeen dat België heeft gekend. Voor de mijnsector werd in 1922 een akkoord gesloten door FEDECHAR, waardoor een officiële rekrutering van kandidaat-mijnwerkers in Italië mogelijk werd. Naast deze collectieve immigratie kwamen tussen I9I9 tot I925 ook veel Italianen op individuele basis naar België, zonder de verplichte tewerkstellingsvergunning te bezitten. Gezien het tekort aan werkkrachten voor de wederopbouw en de mijnontginningen in het tussenoorlogse België werden deze migranten vrij snel op de arbeidsmarkt opgenomen. ${ }^{26}$ In het geval van de Polen ging het vooral om ervaren mijnwerkers uit de mijnbouwregio Silezië of om zogenaamde Ruhrpolen, die een arbeidsverleden als mijnwerker in het Duitse Ruhrgebied hadden. De groep Noord-Afrikanen (I7 procent) bestond voornamelijk uit Marokkaanse arbeiders. Volgens een artikel in de Revue du Travail van I927 werkten er toen 2.037 Noord-Afrikanen in de Belgische mijnen; zij vormden I4 procent van het totaal aantal buitenlandse mijnwerkers. Men veronderstelt dat de Noord-Afrikaanse immigratie in België in die periode voortvloeide uit een migratiestroom die op Frankrijk gericht was. Aangetrokken door een beter loon voor gelijk werk, gingen de Maghrebijnen van de Franse naar de Belgische steenkoolmijnen. ${ }^{27}$

Vanaf 1930 zijn er seriële cijfers van het aantal buitenlanders voorhanden. ${ }^{28}$ Uit de sterke afname van de totale personeelsbezetting tot 1934 is af te leiden dat de economische crisis in die jaren ook in de Luikse mijnen toesloeg (zie grafiek 3.2). Opvallend is echter dat de afnemende werkgelegenheid niet in de eerste plaats op de buitenlandse arbeiders werd afgewenteld, zoals in naburige mijnstreken gebeurde. In Luik nam het aantal Belgische mijnwerkers tussen I930 en I934 met 2I,7 procent af, het aantal buitenlanders slechts met I9,8 


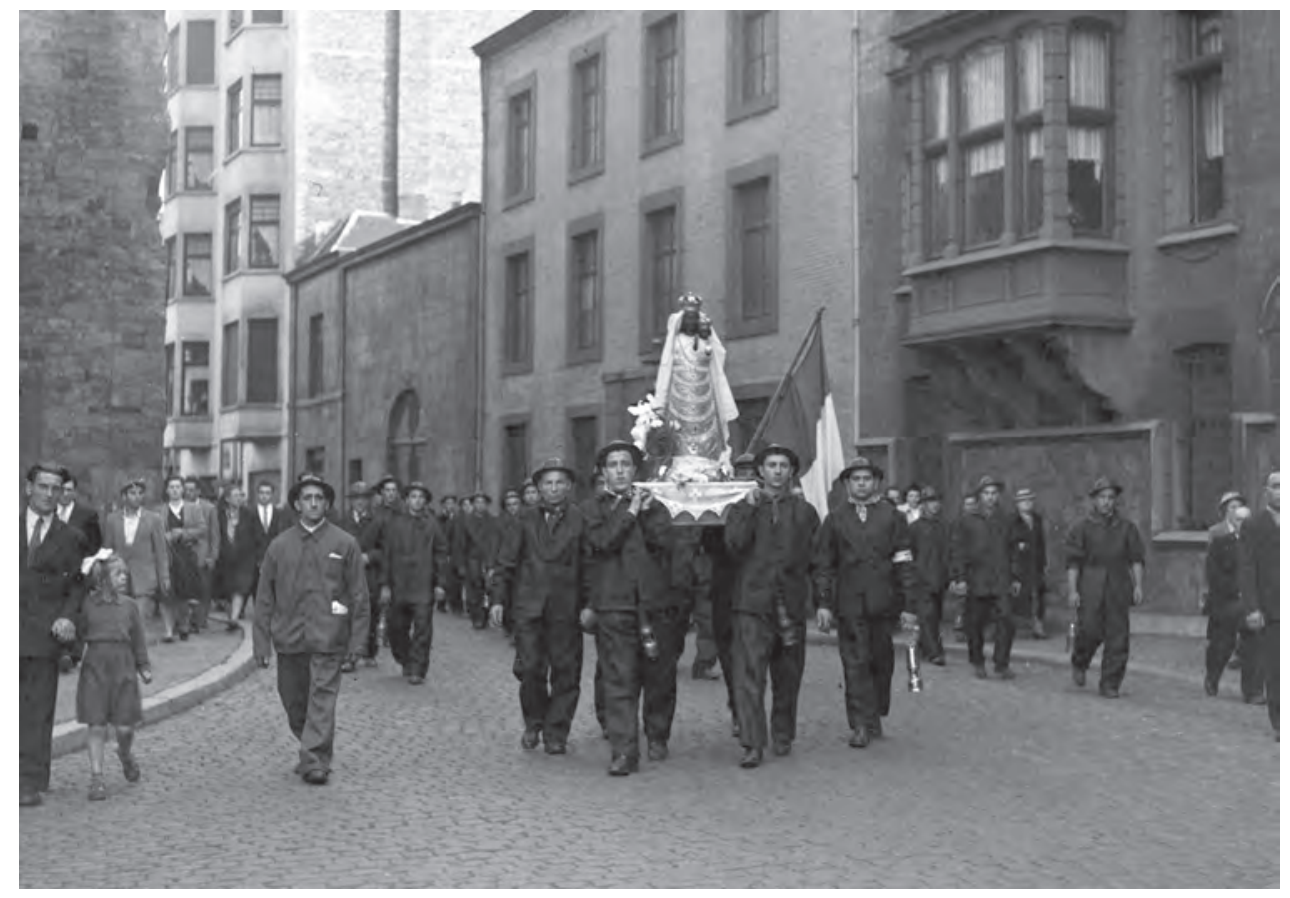

Italiaanse mijnwerkers dragen een Italiaans Mariabeeld door de straten van Luik, 29-06-1951. Copyright Province de Liège - Musée de la Vie wallonne.

procent. ${ }^{29}$ De afname van het aantal Belgische mijnwerkers is deels te verklaren door het vertrek van Vlamingen uit het zuiden van Limburg en het Hageland naar de Belgisch-Limburgse mijnen..$^{\circ}$ Dit is een tegengestelde ontwikkeling aan die in de Kempen en in Nederlands-Limburg. In de Kempen daalde het aantal autochtone mijnwerkers in deze jaren met 9,8 procent tegen een teruggang van het aantal buitenlanders met 22,9 procent; ${ }^{3 \mathrm{I}}$ in Nederlands-Limburg nam het aantal autochtonen af met 5,2 procent, het aantal allochtonen daarentegen met 52 procent. ${ }^{32}$ Ondanks de economische crisis en de geringere werkloosheid in de mijnsector bleven de traditionele Waalse mijnwerkersfamilies zich van de mijnarbeid afwenden. Wallonië werd in het algemeen veel sterker afhankelijk van buitenlandse werkkrachten dan de beide Limburgen. ${ }^{33}$ De traditionele verklaring voor de aanwezigheid van migranten op de arbeidsmarkt, namelijk hun bufferfunctie, lijkt op de Luikse casus niet toepasbaar. Ook tijdens laagconjunctuur werd er, weliswaar in iets mindere mate, een beroep gedaan op buitenlanders om de lokale arbeidsmarkt te versterken.

De stijging van het aantal mijnwerkers in Luik na de omslag van de conjunctuur in de tweede helft van de jaren 1930 is vooral een gevolg van de rekrutering van buitenlanders. Een nieuwe beperking van de arbeidsduur in 1936 veroorzaakte nog meer arbeidstekort. ${ }^{34}$

29 Zie voor de basisgegevens over personeelsbezetting bijlage II.

30 Caestecker, 'Vervanging of verdringing', 3 I5.

3I Pluymers, De Limburgse mijnwerkers, 75.

32 Verslag van de Hoofd-Ingenieur der Mijnen over 1930 resp. 1934.

33 Caestecker, 'Vervanging of verdringing', 316.

34 Goddeeris, De Poolse migratie in België, $2 \mathrm{I}$. 
In 1939 stelden de Luikse mijnen 22,4 procent buitenlanders tewerk, tegen I6 procent negen jaar eerder. In het Kempische bekken daarentegen was er een verdere daling van het aantal buitenlandse mijnwerkers.

Het aandeel buitenlanders kon van mijn tot mijn sterk verschillen. Het gemiddelde percentage buitenlanders bedroeg in I930 I6 procent. Ruim boven dat gemiddelde lagen grote mijnen als Espérance et Bonne Fortune en Hasard maar ook kleinere als Six-Bonniers en Ougrée. Anderzijds waren er ook grote mijnen, zoals Batterie met relatief weinig buitenlanders. Middelgrote bedrijven als Ans et Rocourt en Bonnier hadden zelfs geen enkele buitenlander in dienst. ${ }^{35}$ Een samenhang tussen de grootte van de mijn en de aanwezigheid van buitenlanders lijkt in I93o dus niet aanwezig.

\section{DE KOLENSLAG: 1945-1958}

De heropbouw van het land na de Tweede Wereldoorlog vereiste een enorm aantal arbeidskrachten. In tegenstelling tot de Franse en Duitse steenkolenmijnen waren de Belgische mijnen vrijwel onbeschadigd gebleven. België was op dat moment door zijn snel herstel één van de economische koplopers van Europa. ${ }^{36}$ Dat betekende dat de Belgische mijnen niet alleen voldoende kolen voor de Belgische wederopbouw moesten leveren, maar ook voor die van andere landen. Om dat te bereiken riep de Belgische premier Achille Van Acker in I945 de kolenslag uit. In grafiek 3.I was te zien dat de productie in Luik in de periode I946I950 enorm steeg, mede door een doorgedreven rationalisatie. Om dit te realiseren was het noodzakelijk meer houwers, de productiefste groep mijnwerkers, aan het kolenfront in te zetten. Onder hen bevonden zich vooral buitenlanders. ${ }^{37}$ De kolenslag werd dus dankzij de vreemdelingen gewonnen.

Op het moment dat de Belgische mijnen dringend om mijnwerkers verlegen zaten, verlieten de Belgen massaal de mijnindustrie. Tijdens de oorlog was de vraag naar arbeid opgevangen door Russische krijgsgevangenen en Belgische vrijwilligers (die door mijnarbeid deportatie naar Duitsland wilden vermijden), maar na de bevrijding waren die uit de steenkoolmijnen vertrokken. In het mijnwerkersstatuut van april I945 werden Belgen daarom gelokt met loontoeslagen, extra vrije dagen, aanvullend pensioen en andere voordelen. Ook werden werkloze 'ex-mijnwerkers' verplicht om werk in de mijnen te aanvaarden. ${ }^{38}$ Deze maatregelen brachten echter niet veel op. De verplichte tewerkstelling van ongeveer 50.000 Duitse krijgsgevangenen kon het leed tijdelijk verzachten, maar onder groeiende internationale druk moesten die in I947 ontslagen worden. In grafiek 3.2 zijn de Duitse krijgsgevangenen niet meegerekend. In I946 werden er zo'n 64.00o Duitsers in de Belgische mijnen aan het werk gezet, ruim 28 procent van het totaal aantal mijnwerkers in België. Eind januari 1947 bestond nog één derde van het totale aantal houwers in België uit Duitse krijgsgevangenen. ${ }^{39} \mathrm{Na}$ hun vrijlating in 1947 bleven een 4.000 tal onder hen werken in de Belgi-

35 RAH, archief FEDECHAR, inv.nrs. I579-I58r: 'Personeelsstatistieken'.

36 Hartog, Het Belgische wonder.

37 Demeure de Lespaul, L'industrie charbonnière, 26.

38 Leboutte, 'Coal mining, foreign workers and mine safety', 220.

39 Demeure de Lespaul, L'Avenir de notre production de houille, I5. 


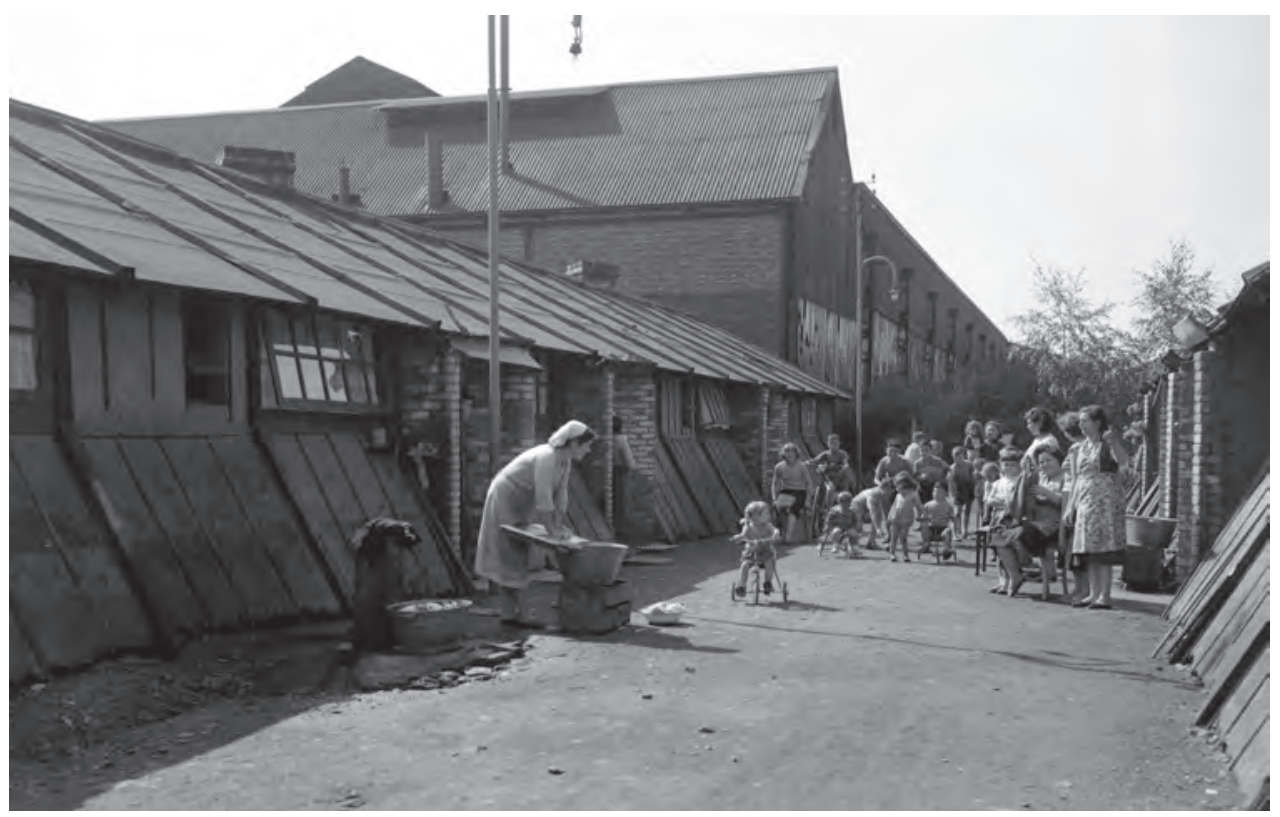

Barakkenkamp te Cheratte, 1957. Copyright Province de Liège - Musée de la Vie wallonne.

sche mijnen als vrije arbeiders..$^{\circ}$ Hoe belangrijk ze voor de Luikse mijnen waren, kunnen we zien in tabel 3.I.

Tabel 3.I Het aAntal Belgen, buitenlanders en Duitse KrijgsgevangeNEN IN DE LUIKSE MIJNEN, I945-I946

\begin{tabular}{|l|c|c|c|c|}
\hline & Belgen & Buitenlanders & Duitse krijgsgevangenen & Totaal \\
\hline $\mathrm{I} 945$ & $\mathrm{I} 7.776$ & 3.753 & 8.469 & 29.998 \\
\hline $\mathrm{I} 946$ & $\mathrm{I} 6.634$ & 8.950 & 7.795 & 33.379 \\
\hline
\end{tabular}

Bron: Goddeeris, De Poolse migratie in België, I57; Annales des Mines de Belgique, I946-I947. (Telmoment is respectievelijk december I945 en december 1946)

De afkeer van de lokale arbeidskrachten voor het beroep van mijnwerker was zeer groot, zeker voor het ondergrondse werk. De Belgische arbeidskrachten bleven de mijn verlaten. Een nieuwe vermindering in 1946 was exclusief te wijten aan het vertrek van ondergrondse arbeidskrachten. ${ }^{4 \mathrm{I}}$ De mijnen waren genoodzaakt andere oplossingen te zoeken. FEDECHAR begon opnieuw een campagne om buitenlandse mijnwerkers te rekruteren. Om het tekort aan Belgische arbeidskrachten op te vangen werd op 20 juni I946 een akkoord met de Italiaanse autoriteiten gesloten om een massale immigratie van Italiaanse werknemers te organiseren, in ruil voor de levering van steenkool voor het herstel van de Italiaanse economie. ${ }^{42}$ Ongeveer I2.300 onder hen (samen met I.200 vrouwen en 2.000 kinderen) bereikten van 


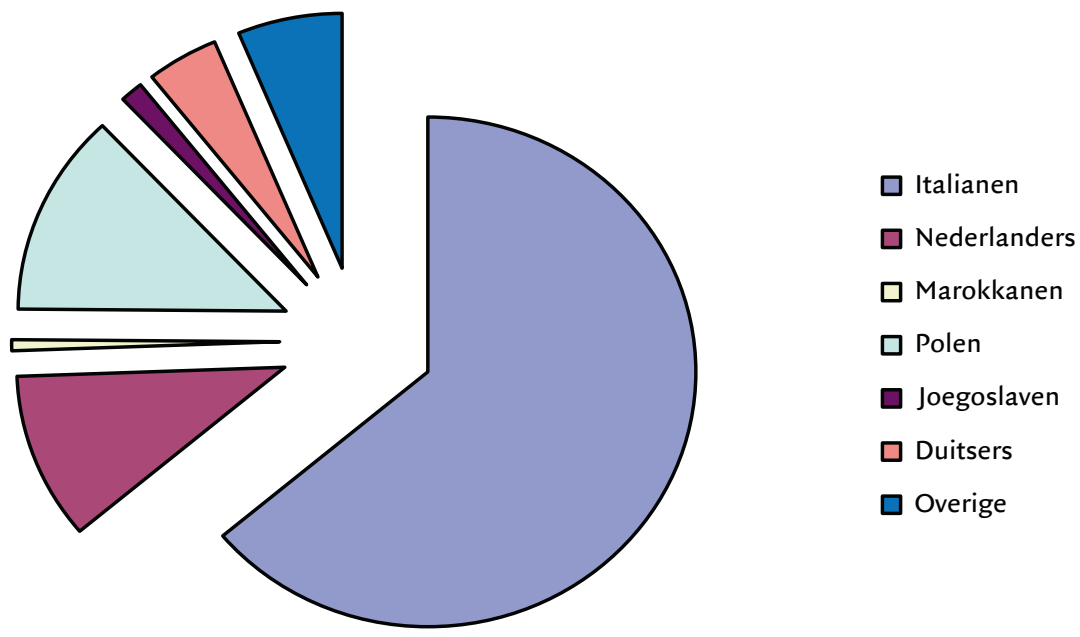

Bron: Annales des Mines de Belgique, 1956, 93-94.

I946 tot 1949 de Luikse mijnen. ${ }^{43}$ De overeenkomst kwam onder druk te staan toen steeds duidelijker werd hoe onveilig en zwaar verouderd sommige mijnen waren. Een ernstig ongeluk in de Charbonnage d'Ougrée-Marihaye (ten zuiden van de stad Luik) in I953 leidde tot het tijdelijk stopzetten van de arbeidsmigratie naar de Belgische mijnen door de Italiaanse overheid. ${ }^{44}$ Dat de Italianen op de Luikse arbeidsmarkt een belangrijke rol speelden is echter ontegensprekelijk: zowel in I954 als in 1958 vormen ze bijna twee derde van de geïmmigreerde arbeidskrachten.

De Italianen waren niet de enigen die de wegkwijnende lokale lichting mijnwerkers kwamen versterken. Bovendien stelden ze vaak teleur vanwege het frequent voortijdig verbreken van het arbeidscontract en hun geringe ervaring. 45 Vanaf de lente van 1947 kwam er een nieuwe Poolse migratiegolf naar België..$^{4}$ Duizenden Oost-Europese displaced persons (personen die hun woonplaats hadden moeten verlaten vanwege de oorlog of de nasleep ervan), werden voor de Belgische mijnbouw gerekruteerd in Duitse kampen. Het was niet de eerste keer dat Brussel displaced persons inschakelde in de steenkoolindustrie. Al in de tweede helft van I945 werden 2.369 Polen in Duitsland geronseld voor de Waalse mijnbekkens. Verdere rekruteringen waren toen uitgebleven door de mogelijkheid om Duitse krijgsgevangenen tewerk te stellen. Pas op het einde van I946, toen het internationaal protest tegen de tewerkstelling van Duitse krijgsgevangenen luider werd en het ernaar uitzag dat de Belgische mijnen hen zouden moeten ontslaan, stelden ook de mijnwerkgevers zich open voor alternatieven. ${ }^{47}$ 


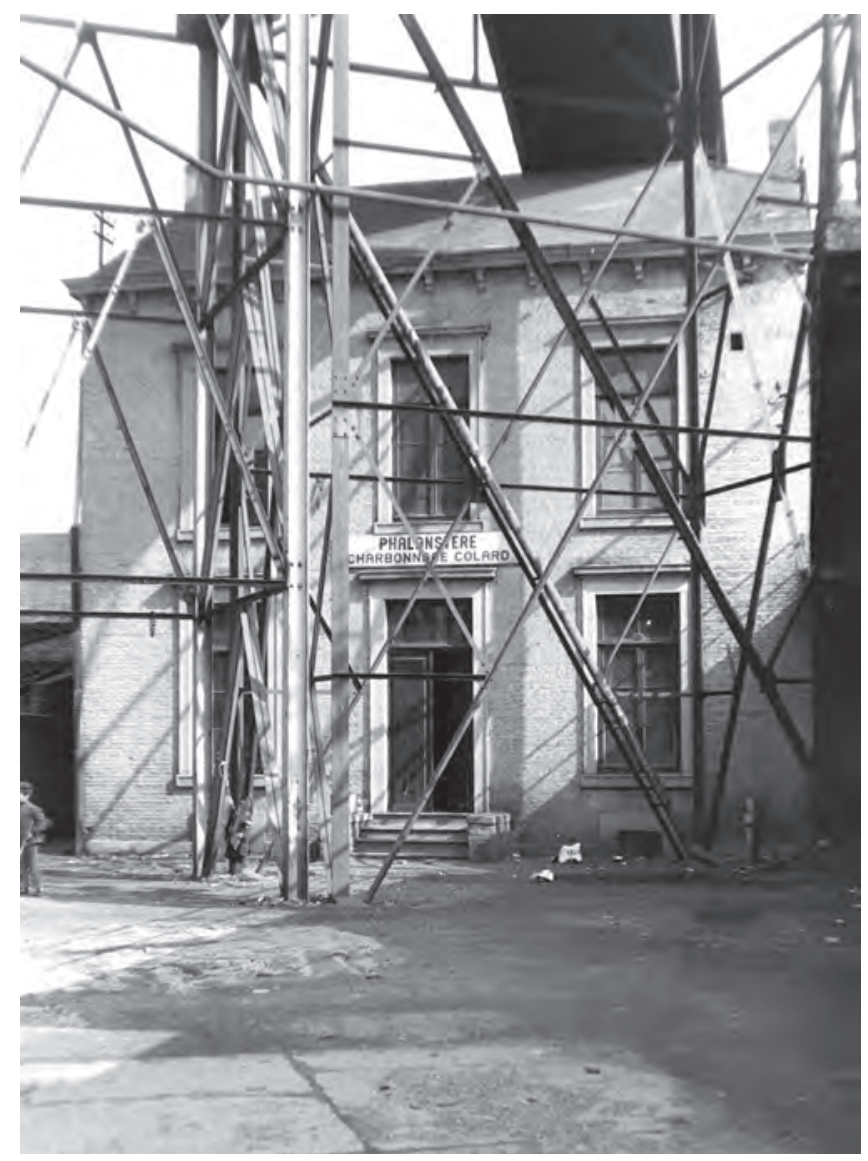

'Phalanstère' bij de zetel Colard te Seraing van de NV Cockerill, 1970. Foto Théodore Bellefroid. Coll. Blegny-Mine.

TABEL 3.2 DE GEOGRAFISCHE SPREIDING VAN DISPLACED PERSONS (DP'S), I947

\begin{tabular}{|l|c|c|c|}
\hline & Aantal DP's & Totaal aantal arbeiders & Percentage DP's \\
\hline Kempen & 6.202 & 39.948 & I5,5\% \\
\hline Centre & 2.199 & 21.596 & 10,2\% \\
\hline Charleroi & 3.570 & 39.703 & $9,0 \%$ \\
\hline Luik & $3.97 \mathbf{I}$ & $3 \mathbf{I . 9 1 0}$ & $\mathbf{I 2 , 4} \%$ \\
\hline Mons & 3.259 & 39.413 & $8,3 \%$ \\
\hline
\end{tabular}

Bron: Goddeeris, De Poolse migratie in België, I57; Annales des Mines de Belgique, I947-1948.

In Luik werden er in I947 3.97I displaced persons in de mijnen tewerkgesteld, dat is 2I procent van het totaal aantal in België. Uit tabel 3.2 blijkt dat de Kempische mijnen het grootste aandeel displaced persons tewerkstelden, de Luikse mijnen bevinden zich op de tweede plaats. In de jaren 1950 is een duidelijke correlatie te zien tussen de kolenvoorraden (als indicatie voor de vraag) en de rekrutering van buitenlandse arbeiders..$^{8}$ In 1949 begon een pe- 


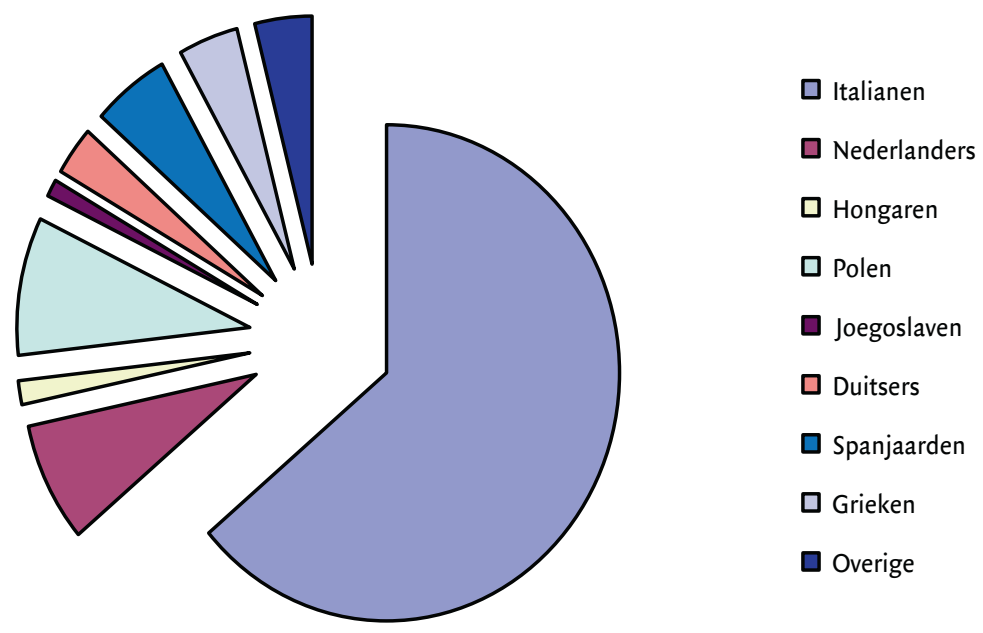

Bron: 'Technische kenmerken van de Belgische steenkolenontginning in I958', 826.

riode van laagconjunctuur met een stijging van de werkloosheid en de steenkolenstocks. Het gevolg was een tijdelijke immigratiestop. Vanaf I januari I 949 werd de immigratie van vreemde werkkrachten verboden. De gebeurtenissen in Korea en de herbewapening deden de vraag naar steenkool echter weer toenemen. Midden I950 waren de mijnautoriteiten opnieuw geïnteresseerd om vreemdelingen te werven. Hiervoor werden nieuwe wervingslanden gecontacteerd. De verruiming van het aanwervingsgebied had te maken met de terughoudendheid bij de Italiaanse regering om nieuwe immigraties naar de Belgische mijnstreken toe te staan na de ramp van Bois-du-Cazier te Marcinelle, waar in 1956262 mijnwerkers het leven lieten, waaronder ${ }_{3} 6$ Italianen. ${ }^{49}$ Tot die catastrofe bleef de aanvoer van Italiaanse arbeiders naar de Belgische mijnen vrijwel ononderbroken doorgaan.

Ten gevolge van de harde eisen die Italië ging stellen, beslisten de Belgische steenkoolmijnen om zich voortaan tot andere landen te richten voor de rekrutering van arbeidskrachten: bilaterale akkoorden werden afgesloten met Spanje in 1956 en Griekenland in I957. Aan het eind van 1957 werkten er 869 Spanjaarden en 928 Griekse mijnwerkers in de Luikse mijnen..$^{\circ}$ In 1956 werd echter alleen de officiële migratie van Italië naar België stopgezet, niet die van verwanten van Italiaanse inwijkelingen, noch van de vele enkelingen die op eigen initiatief naar België bleven komen. Van 1956 tot I970 noteerde men nog een onophoudelijke migrantenstroom vanuit Italië, vooral mensen afkomstig uit het zuiden en van de eilanden. ${ }^{5}$

Grafiek 3.6 toont dat de buitenlandse mijnwerkers vooral ondergronds aan de slag gingen. De lokale arbeiders hadden vooral een afkeer van dit soort werk. Vanaf de jaren ig6o zien we een lichte stijging in het aandeel buitenlanders bovengronds. Dit heeft te maken 
GRAFIEK 3.6 DE PERCENTAGES BUITENLANDERS IN PERSONEELSBEZETTING ONDERGRONDS EN BOVENGRONDS BIJ DE LUIKSE MIJNEN, I95I-I973

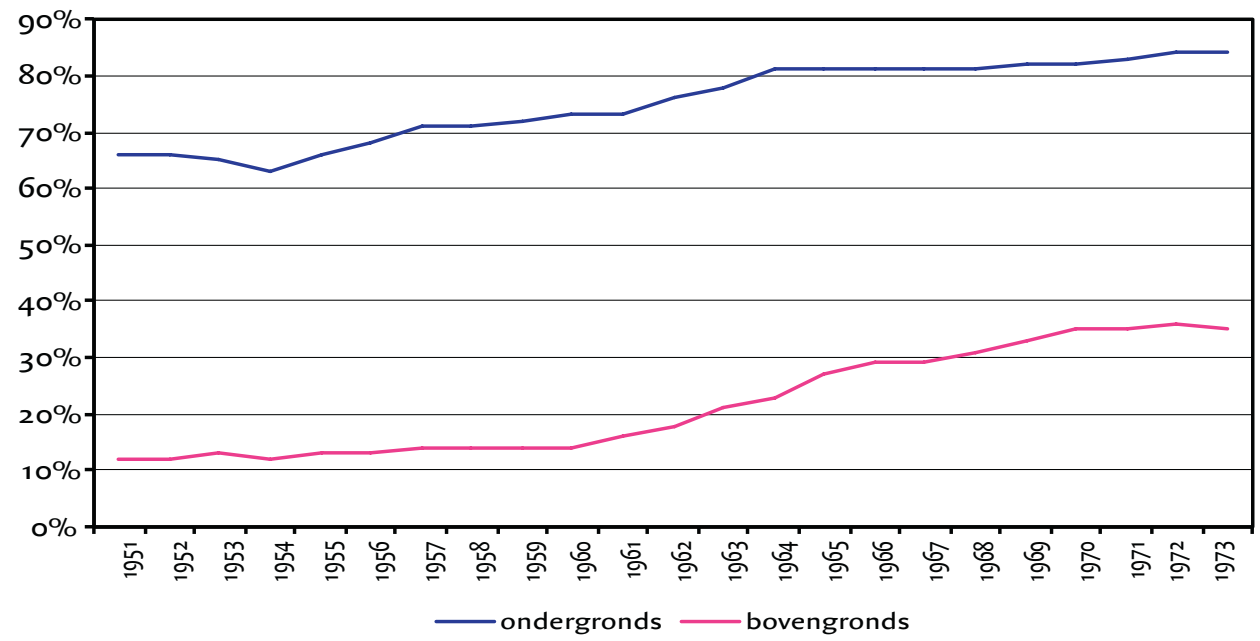

Bron: RAH, archief FEDECHAR, inv.nr. 612: 'Statistieken'; inv.nrs. 1579-158I: 'Personeelsstatistieken'.

met het feit dat het totale aantal mijnwerkers uit meer en meer allochtonen bestond, maar zou er ook op kunnen wijzen dat de eerste generatie buitenlanders dan bovengronds aan de slag mogen. Er is echter een groot verschil tussen de Belgische steenkolenbekkens: voor heel België gold in I969 een aandeel van I3,2 procent vreemdelingen bij de bovengrondse arbeiders. In de Kempen bedroeg dit aandeel slechts 3 procent, maar in Luik werkten er meer dan 32,5 procent buitenlanders in het bovengrondse mijnbedrijf. ${ }^{2}$ Dit heeft ook te maken met het feit dat er in Luik vooral huisbrandkolen werden bovengehaald, die een arbeidsintensievere verwerking bovengronds vereisten.

Wat betreft de verdeling van de buitenlandse arbeidskrachten over de verschillende mijnen zien we in 1955 een totaal andere situatie dan in I930. Bijna alle mijnen hebben nu meer dan de helft buitenlandse werkkrachten in dienst. De mijnen waar nog meer dan de helft Belgen werken behoren tot de kleinere bedrijven met minder dan 700 arbeiders. ${ }^{53}$

\section{AFLOOP: HET VERDWIJNEN VAN EEN TRADITIONELE INDUSTRIE}

De periode I958-I96I werd gekenmerkt door een terugval van het aantal vreemdelingen in België, ook in Luik. Na 1958 werden er geen nieuwe vluchtelingen meer tewerkgesteld in de Belgische mijnbouw. ${ }^{54}$ Het aandeel Italianen onder de vreemde arbeiders bleef echter voorlopig nog stijgen, ondanks het door de Italiaanse overheid gehandhaafde verbod van 


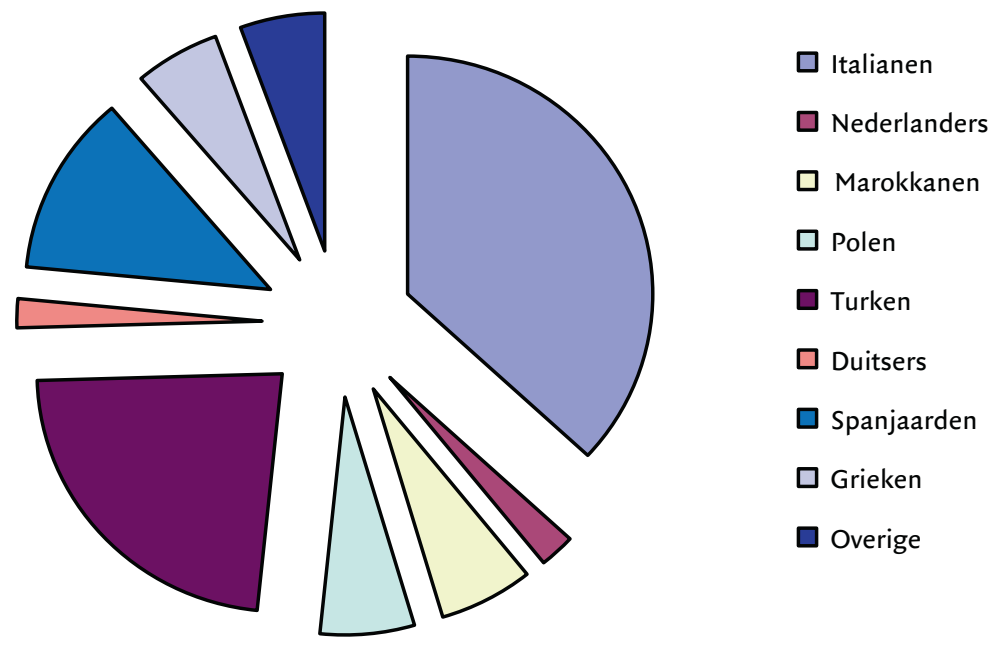

Bron: 'Technische kenmerken van de Belgische steenkolenontginning in 1965', I966, г210.

uitwijking naar de Belgische mijnen. ${ }^{55}$ In de jaren 1962-I966 beleefde België opnieuw een hoogconjunctuur en de arbeidsmarkt was zeer gespannen. In deze jaren werd het rekruteringsveld opnieuw verbreed: ook Marokkanen en Turken werden nu structureel aangeworven. ${ }^{56}$ Het aandeel van Italianen onder de buitenlandse mijnwerkers nam daardoor af. In februari I964 werd een bilateraal verdrag tussen België en Marokko gesloten; op i6 juli ig64 volgde de ondertekening van het akkoord met Turkije. ${ }^{57}$ Vanaf dat jaar werden deze groepen vreemdelingen afzonderlijk in de statistieken van de Annales vermeld. In I969 volgde een akkoord met Tunesië en in I970 met Algerije. Naar aanleiding van deze akkoorden is de Noord-Afrikaanse bevolking in België tussen I96I en I968 vertienvoudigd. In I97I maakten de Turken bijna één vierde van de ondergrondse buitenlandse arbeiders in de Luikse mijnen uit. ${ }^{8}$ Door het aanvaarden van een zekere gezinshereniging hoopte men dat de buitenlandse arbeiders het Belgische grondgebied zouden verkiezen boven dat van de buurlanden, die alleen geïsoleerde migrantenarbeiders opnamen. ${ }^{59}$ Krachtens artikel II van het bilateraal akkoord mochten bijvoorbeeld de Turkse arbeidsmigranten hun familie laten overkomen na een maand gewerkt te hebben. ${ }^{60}$

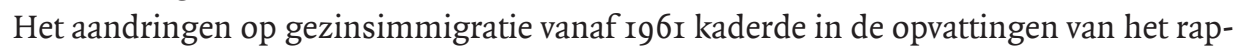
port Sauvy, een Franse demograaf die aantoonde dat er ook om demografische redenen vreemdelingen moesten worden aangetrokken, vooral naar het vergrijsde en kindarme Wal-

55 'Ontwikkeling van het personeelsbestand', 1958, 824.

56 Grimmeau, 'De immigratiegolven', I25.

57 Loriaux, L'immigration marocaine, 3; Wet van I3 december 1976 houdende goedkeuring van de bilaterale akkoorden betreffende de tewerkstelling in België van buitenlandse werknemers; Khoojinian, 'L'accueil et la stabilisation des travailleurs immigrés turcs en Belgique', 95-98.

58 'Ontwikkeling van het personeelsbestand', I972, I6.

59 Attar, 'De geschiedenis van de Maghrebijnse immigratie', 303-304.

6o Bayar, 'Een economisch overzicht', 324. 
GrafieK 3.8 Het percentage buitenlanders in De Luikse MiJnen, i930I973

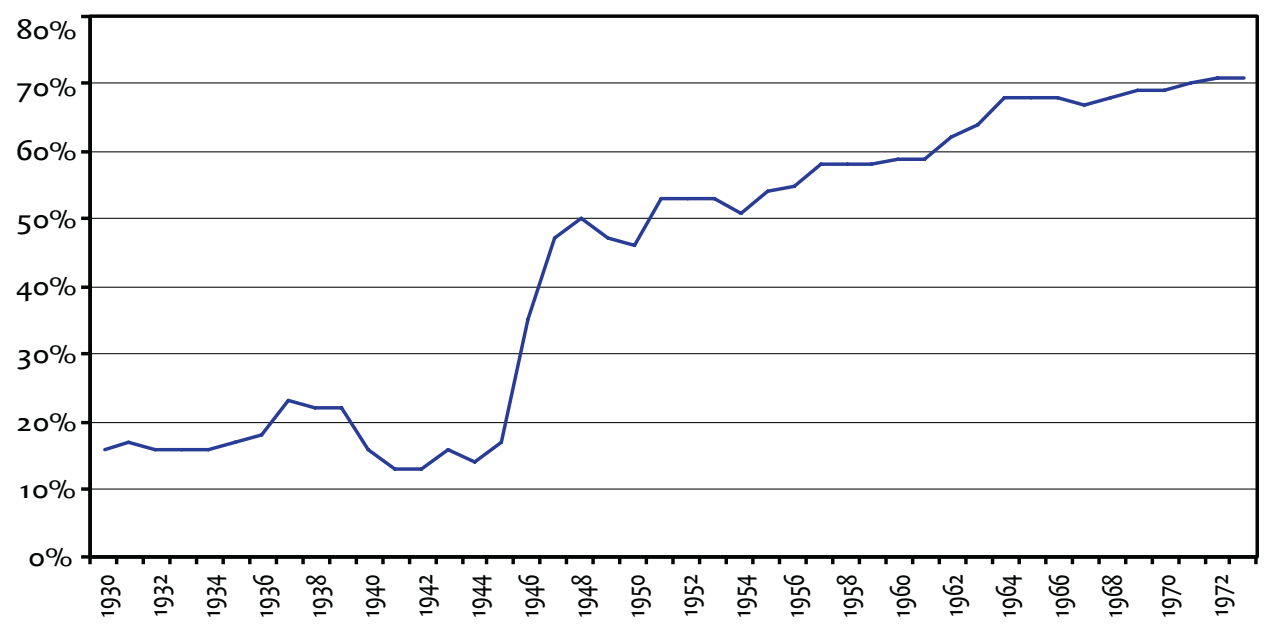

Bron: RAH, archief FEDECHAR, inv.nr. 6I2: 'Statistieken'; inv.nrs. I579-I58I: 'Personeelsstatistieken'; 'Technische kenmerken van de Belgische steenkolenontginning', I958-1974.

lonië. ${ }^{6 r}$ Bovendien werden familieherenigingen gestimuleerd door het mijnpatronaat, dat daarin een middel zag om de mijnwerkers meer aan de mijn te binden en het vroegtijdig verbreken van het arbeidscontract tegen te gaan. ${ }^{62}$ Veel arbeidsmigranten kwamen als toeristen het land binnen en gingen vervolgens op zoek naar werk: de zogenaamde toeristentewerkstelling. Ze werden vaak zonder werkvergunning in dienst genomen. Via medische goedkeuring werd hun aanwezigheid vervolgens geregulariseerd door het Ministerie van Arbeid en Tewerkstelling.

Er ontstond een nieuwe economische crisis toen andere energiebronnen zoals aardolie, aardgas en kernenergie, de steenkool steeds meer gingen vervangen. In februari 1967 ging de overheid, onder druk van de vakbonden, de verblijfswetgeving opnieuw strenger toepassen. ${ }^{6}$ In 1974 besloot België om, net zoals andere West-Europese landen, over te gaan tot een totale immigratiestop. De vreemdelingen die reeds in België verbleven, kregen arbeidskaarten en verblijfsvergunningen. ${ }^{64}$

Gedurende de drie laatste decennia van de steenkolennijverheid was de rol van migranten essentieel. In 1965 was 68 procent vreemdelingen onder de Luikse mijnarbeiders. Als we alleen de ondergrondse werkers in rekening brengen waren dat er zelfs $8 \mathrm{I}$ procent. Tien jaar later waren deze percentages gestegen tot respectievelijk 74 en 85 procent. In sommige Luikse mijnen was er geen enkele Belgische mijnwerker meer ondergronds te vinden. ${ }^{65}$

6r Robert, 'Wallonie I93I-I996', I-3; Pressat en Sauvy, Le rapport Sauvy.

62 Goddeeris, De Poolse migratie in België, r9.

63 Hullebroeck, 'Het algemene migrantenbeleid', I33-I35.

64 Institut Jules Destrée, 'L'immigration comme régulateur de main-d'œuvre'.

65 Gaier, Huit siècles de houillerie liégoise, ${ }_{6} 65$. 
Opleiding van reddingswerkers, reddingscentrale van het Luikse mijnbekken te Glain, ca. 1960. Foto Centrale de sauvetage des charbonnages du bassin de Liège. Coll. Blegny-Mine.

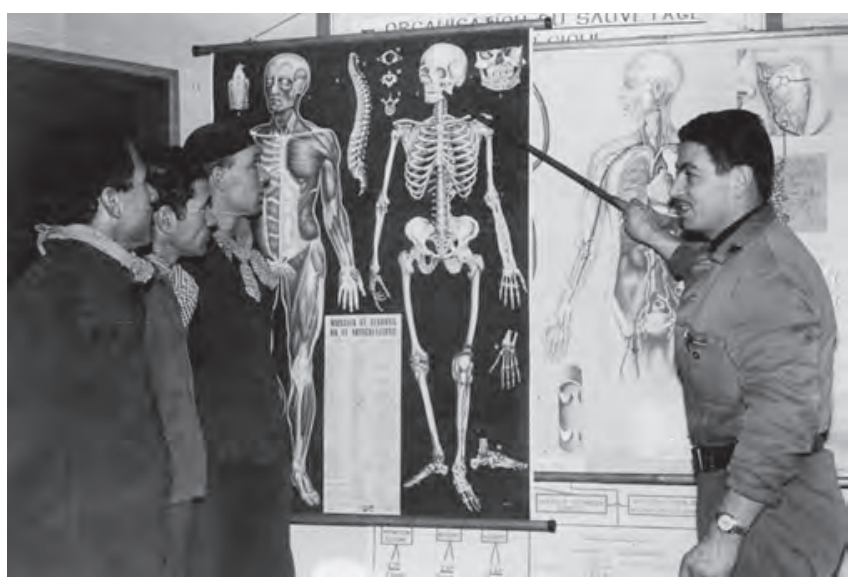

BESLUit

De aanwezigheid van een steeds groter aandeel buitenlanders op de arbeidsmarkt voor de Luikse steenkoolnijverheid wijst er duidelijk op dat het aanbod op de lokale arbeidsmarkt ontoereikend was. Het toont de enorme onwil voor het mijnwerk onder de plaatselijke bevolking. De mijnwerkgevers konden blijkbaar ook geen beroep doen op mijnwerkers uit de Euregio. Het aandeel van Nederlanders en Duitsers in de Luikse mijnen was niet bijzonder groot. De Luikse mijndirecties zochten hun heil verder weg. Eerst in het rurale Vlaanderen en het Ruhrgebied, waar ze ervaren Poolse mijnwerkers vonden, later nog verder, in Oosten Zuid-Europa, en in een laatste fase ook in Noord-Afrika. In tegenstelling tot de beide Limburgse mijngebieden was de arbeidsmarktpolitiek in Luik dus niet gebaseerd op het zo veel mogelijk aantrekken van lokale arbeidskrachten en enkel heil zoeken in buitenlandse rekrutering in periodes van hoogconjunctuur. In het Luikse bekken bestond een structureel tekort aan mijnwerkers. Vanaf I948 was de meerderheid afkomstig uit het buitenland. De reden was dat de lokale bevolking al veel sneller afstand deed van het mijnberoep. De Luikse mijndirecties hadden geen andere keus dan werkvolk elders te zoeken. Toen de Limburgse mijnen zich nog volop in de opbouwfase bevonden waren er in het Luikse al de eerste tekenen van een traditionele mijnwerkersbevolking die zich meer en meer probeerde te onttrekken aan het mijnwerk en alternatieve werkgelegenheid zocht, bijvoorbeeld in de sterk uitgebouwde Luikse staalnijverheid.

Een belangrijke verklaring voor het grote aandeel buitenlanders in de Luikse mijnen is dus het gebrek aan gewillige lokale werkkrachten. Hiervoor is een aantal redenen: de aard van het werk (mijnwerk was zwaar, onveilig en vuil); de vele alternatieven in de metallurgie en bouwnijverheid; de concurrentie van de modernere Limburgse mijnen en de technologische ontwikkeling, waardoor de mijnwerkerstraditie met de bijhorende beroepseer verdween. Misschien was er ook wel sprake van een domino-effect, aangezien het overgrote deel ondergronders op den duur van buitenlandse afkomst was, moet het niet vanzelfsprekend geweest zijn om daar als Belg tussen te functioneren. Terwijl het totaal aantal tewerkgestelden in de Luikse mijnen vanaf eind jaren I920 gedurig afneemt, zien we het aantal 
buitenlandse werkkrachten vanaf I947 bijna constant toenemen. Vanaf dan overschrijdt het aantal allochtonen in de Luikse mijnen het aantal Belgische mijnwerkers.

Om deze werkkrachten aan te trekken gingen de mijndirecties eerst zelf op zoek. Later werd dit meer geregeld door de overheid die verdragen afsloot met de betreffende landen. Om het mijnwerk aantrekkelijk te maken werden er allerlei beloftes gedaan qua huisvesting en salaris. Wanneer de directies deze beloftes niet (konden) waarmaken/waarmaakten, gingen de arbeiders even snel op zoek naar betere werkvoorwaarden.

Ook gezinsmigratie werd als tactiek gebruikt om de mijnwerkers aan het bedrijf te binden. Bovendien werd het om demografische redenen, een (te) laag geboortecijfer in Wallonië, vanaf de jaren I96o ook wenselijk geacht om volledige gezinnen aan te trekken.

Kortom: de Luikse mijnen hadden structureel te kampen met een arbeidstekort dat ze op allerlei manieren probeerden op te lossen. Het aantrekken van vreemdelingen was een constante zorg, in tegenstelling tot de mijnen in Belgisch- en Nederlands-Limburg, die bij periodes van laagconjunctuur de buitenlandse arbeidskrachten afstootten. 


\section{Hoofdstuk 4 \\ Où sont les mineurs belges? \\ Het tekort aan mijnwerkers tijdens en na de Tweede Wereldoorlog}

In de na-oorlogse periode is de kwestie van het gebrek aan arbeidskrachten steeds het voornaamste punt geweest van het Belgische kolenprobleem. Het verlaten van de mijn door de Belgische mijnwerkers, dat men de desertie van de zonen heeft genoemd, heeft een massaal beroep op vreemde werkkrachten ten gevolge gehad. ${ }^{1}$

In dit citaat vatte François Vinck, directeur-generaal Sociale Zaken van de EGKS, in I959 kort en bondig samen met welk probleem de Belgische mijnen na de Tweede Wereldoorlog te kampen hadden. Toen werd de Belgische steenkoolnijverheid en vooral de Waalse mijnen geconfronteerd met een ware vlucht uit de mijnen. ${ }^{2}$ De Luikse casus wordt hier gebruikt om het probleem van de Waalse mijnen te schetsen. Voordien was het al niet makkelijk veel Belgische arbeiders aan te werven voor het zware beroep van mijnwerker. Het steeds groter appel op buitenlanders is een duidelijke getuige van deze ontwikkeling. ${ }^{3}$ De Luikse mijnen laten een opvallend tegengestelde ontwikkeling zien in vergelijking met de naburige Nederlandse mijnen. Terwijl het percentage buitenlanders tot 1935 in de Nederlandse mijnen aanmerkelijk hoger lag dan in de Luikse, draaide deze verhouding na I935 compleet om. Waar de Nederlandse mijnen er kennelijk in toenemende mate in slaagden autochtone arbeiders voor mijnarbeid te interesseren, keerden in Luik steeds meer Belgen de mijnen de rug toe. ${ }^{4}$

De aanwezigheid van grote aantallen arbeidsmigranten in de Luikse mijnen was vooral een naoorlogs fenomeen. Vóór de Tweede Wereldoorlog, in de jaren 1937-1939, was het percentage vreemdelingen al tijdelijk toegenomen tot boven de 20 procent, maar tussen 1945 en 1948 steeg hun aandeel in korte tijd tot bijna 50 procent, om daarna gestaag te groeien tot ca. 70 procent aan het eind van de jaren $1960 .{ }^{5}$ In absolute aantallen steeg het aantal buitenlandse arbeidsmigranten in de Luikse mijnen van minder dan 3.000 in 1944 tot meer dan 16.000 in 1948 (zie grafiek 4.I).

Het aantal mijnwerkers met de Belgische nationaliteit was al gedaald in de eerste helft van de jaren I930. Als gevolg van de economische crisis en de sluiting van mijnzetels vloeiden er bijna negenduizend arbeiders af. Het grootste deel hiervan was Belg. ${ }^{6}$ Door de algemene vermindering van arbeidsplaatsen ontstonden er in die jaren nog geen grote tekorten. De vraag naar mijnwerkers werd net voor de Tweede Wereldoorlog opnieuw groot door de arbeidsduurverkorting van 1937 (van 8 naar 7.30 uren per dag) en de mobilisatie van sep-

I Vinck, 'De toekomst van de steenkool', 65.

2 Het woord 'vlucht' wordt hier gebruikt voor enerzijds vertrekkende mijnwerkers uit de mijnen, anderzijds voor diegenen die beslisten geen mijnwerker te worden. Uit de cijfers blijkt een daling van het aantal tewerkgestelde Belgen, maar dit aantal is uiteraard samengesteld uit beide groepen.

3 Zie hoofdstuk 3.

4 Zie ook: Langeweg en Roels, 'Buitenlandse arbeiders in de steenkolenmijnen van Luik en Nederlands-Limburg'.

5 Zie hoofdstuk 3.

6 Het aantal Belgische arbeiders nam tussen 1930 en 1935 met bijna 7.500 af, dat is 22,7 procent, het aantal buitenlandse arbeiders daalde met circa I.ooo, dat is I6,2 procent. RAH, archief FEDECHAR, inv.nr. 612: 'Statistieken'. Zie ook hoofdstuk 3. 
GRAFiEK 4.I HET TOTALE AANTAL ARBEIDERS, HET AANTAL BELGisCHE EN BUiTENLANDSE ARBEIDSKRACHTEN IN DE LUIKSE MIJNEN, I930-I960 (PER 3I DECEMBER)

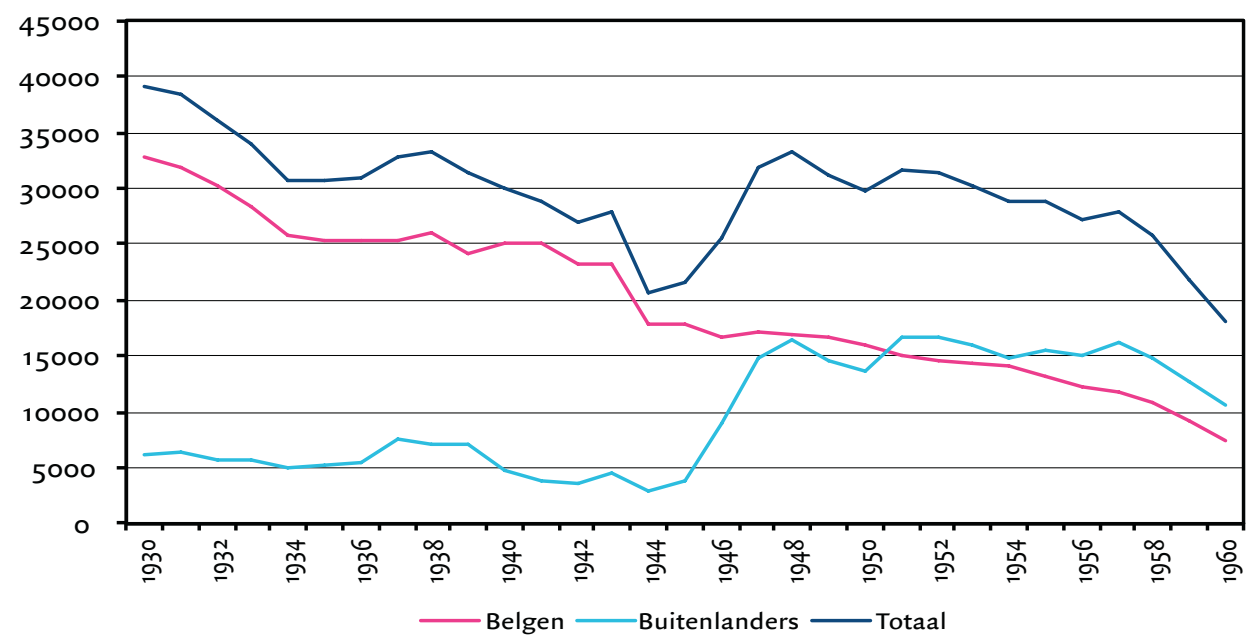

Bron: RAH, archief FEDECHAR, inv.nr. 6I2: 'Statistieken'; Annales des Mines de Belgique, I93I-I95I; 'Technische kenmerken van de Belgische steenkolenontginning', Extrait des Annales des Mines de Belgique, 1958-1974 (Zie ook bijlage II).

N.B.: Buitenlandse arbeiders zonder de Russische en Duitse krijgsgevangenen.

tember 1939. ${ }^{7}$ Tijdens en vlak na de oorlog verliet echter een groot aantal Belgen de Luikse mijnindustrie. In grafiek 4.I is te zien dat die bij het herstel van de economie na de oorlog niet terugkeerden. Het meest opvallend is de sterke daling van het aantal Belgen in de loop van het jaar 1944 .

Uit deze ontwikkelingen kan men afleiden dat er vlak na de Tweede Wereldoorlog een acuut tekort op de Luikse mijnarbeidsmarkt was ontstaan. Op den duur kon dat alleen worden opgelost door een massaal beroep te doen op buitenlandse arbeidskrachten. In dit hoofdstuk onderzoek ik eerst de oorzaken van het tekort. Die hebben zowel betrekking op de vraag- als op de aanbodzijde van de arbeidsmarkt. Geologische factoren, met name de geringe laagdikte en verstoringen, leidden tot een lage arbeidsproductiviteit en weinig mogelijkheden tot mechanisering. Daardoor bleef de Luikse kolenwinning arbeidsintensief en bleef er een grote vraag naar arbeidskrachten bestaan. Aan de aanbodzijde speelden beschikbare alternatieven op de arbeidsmarkt een rol, naast demografische factoren, met name de ontgroening van de Waalse bevolking. Er waren ook mentale oorzaken voor de vlucht uit het mijnbedrijf: men wilde daarin niet meer werken. Vervolgens wordt beschreven hoe het latente probleem van het arbeidstekort door de Tweede Wereldoorlog manifest werd. Na afloop van de oorlog was het probleem zo groot dat het in krachtige termen aan de orde werd gesteld. De term 'desertie' is hiervan één van de meest sprekende voorbeelden. ${ }^{8}$ Dat er op die manier over het gebrek aan bereidwillige autochtonen werd gesproken

7 RAH, archief FEDECHAR, inv.nr. I868: 'Evolutie van de arbeidsvoorwaarden, I949-1954' en I870: 'Rapport sur le problème charbonnier en Belgique, r939'. Zie ook bijlage I.

8 Caestecker, 'Arbeidsmarkt-strategieën in de Belgische mijnindustrie', 44-48 en 50-5I; Jacquemyns, La vie sociale, 4I, heeft het 


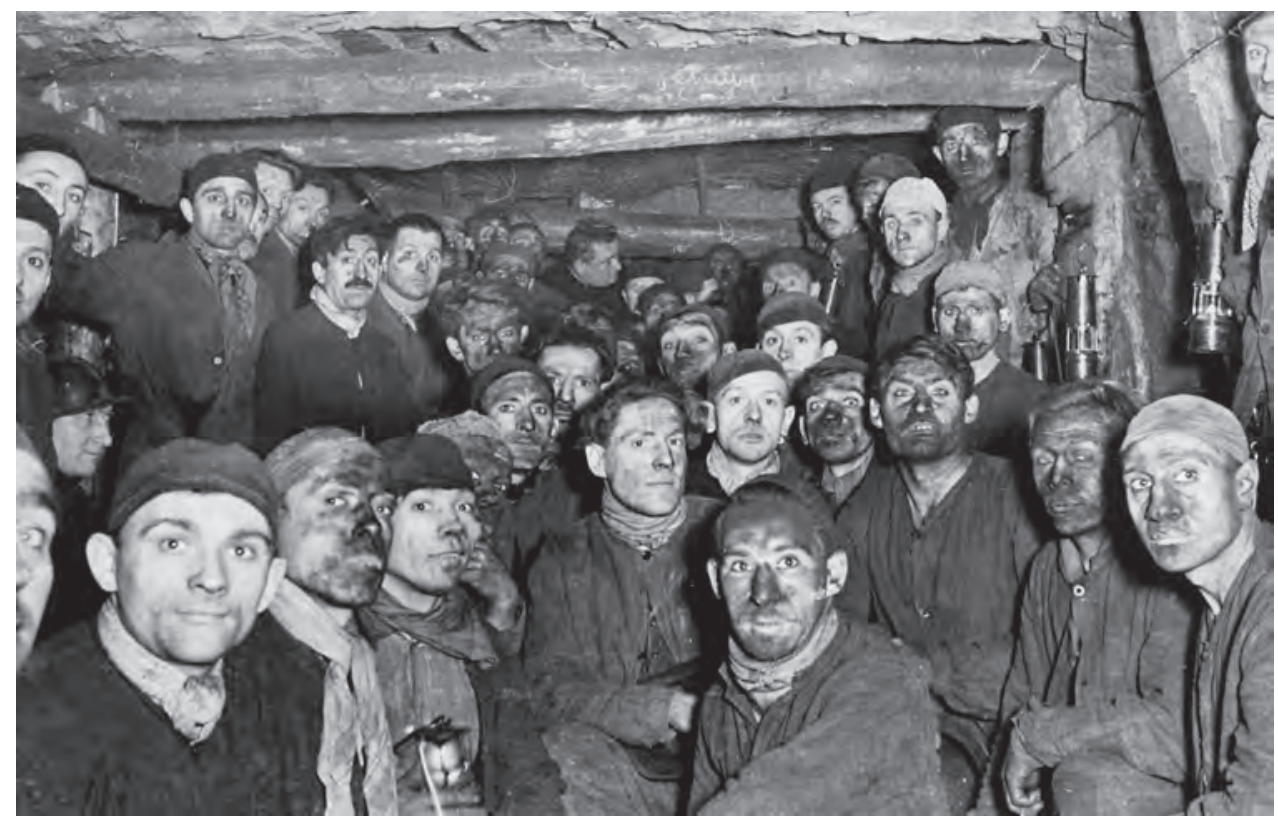

Groep mijnwerkers van de NV Espérance et Bonne Fortune, ondergronds, 1935. Copyright Province de Liège - Musée de la Vie wallonne.

is helemaal in lijn met de heersende oorlogsterminologie. Men sprak over een 'steenkolenslag', en om die strijd te winnen had men een groot aantal mijnwerkers nodig, maar de Belgen 'deserteerden'. De maatregelen van de overheid en de werkgevers om dit arbeidstekort op te lossen, zowel ad hoc als voor de lange termijn, komen aan het slot van dit hoofdstuk aan bod. Hieruit zal blijken dat deze maatregelen zich aanvankelijk vooral op de nationale arbeidsmarkt richtten.

De periode die hier besproken wordt beslaat ongeveer een decennium. We bespreken hoe de situatie ervoor stond aan de vooravond van de Tweede Wereldoorlog, de situatie tijdens de oorlog en de eerste jaren erna. De analyse eindigt in 1947. Om het longitudinaal perspectief niet uit het oog te verliezen, is er soms voor gekozen kwantitatieve gegevens over een langere periode te tonen.

Over het onderwerp verschenen niet erg veel publicaties. Philippe Sunou behandelde uitgebreid de tewerkstelling van de Duitse krijgsgevangenen als tijdelijke oplossing, ${ }^{9}$ en Jan Kohlbacher de thematiek van de Russenkampen bij de Belgisch-Limburgse mijnen..$^{10}$ Bij hen komt de situatie tijdens de Tweede Wereldoorlog en de kolenslag slechts zijdelings aan de orde. Naar de Belgische economie ten tijde van de bezetting werd meer onderzoek gedaan. Ik raadpleegde de publicaties van Gillingham, Milward en Nefors. ${ }^{\text {II }}$ Het werk van

reeds over 'la désertion du travail de la mine'. Het Franse woord 'désertion' lijkt echter minder krachtig dan het Nederlandse 'desertie'.

9 Sunou, Les prisonniers de guerre allemands.

Io Kohlbacher, Het Russisch kamp.

II Gillingham, Geld maken in oorlogstijd; Milward, War, Economy and Society; idem, The reconstruction ofWestern Europe; Nefors, Industriële 'collaboratie' in België. 
Albert Martens over '25 jaar wegwerparbeiders' bleek heel waardevol; op systematische wijze worden in zijn boek de oorzaken van het arbeidstekort en de oplossing daarvan door de inschakeling van de buitenlandse arbeiders uit de doeken gedaan. ${ }^{12}$ Als overzichtswerken werd het boek van Minten e.a. en het boek over de steenkolennijverheid in Luik van Gaier gebruikt. ${ }^{13}$ De meeste informatie werd echter gehaald uit contemporaine rapporten en statistische reeksen. Zo vormen de reeksen uit de Annales des Mines de Belgique, uitgegeven door het Nationaal Instituut voor de Steenkolennijverheid, de basis voor grafieken over productie, aantal arbeiders en rendement. Er werd ook gebruikgemaakt van de personeelsstatistieken van FEDECHAR om het aandeel Russische en Duitse krijgsgevangenen, incivieken en vreemdelingen vast te stellen. Volkstellingen en hierop gebaseerde rapporten geven de nodige achtergrondinformatie over de demografische evolutie. Rapporten van FEDECHAR, de Europese Gemeenschap voor Kolen en Staal, van de Hoofd-Ingenieuren en de Directeuren van het Mijnwezen gaven inzicht in de ideeën en oplossingen van tijdgenoten. ${ }^{\mathrm{I}}$

\section{ARBEIDSINTENSIEVE STEENKOOLNIJVERHEID}

Dat de Belgische steenkoolindustrie zoveel arbeiders zocht, had te maken met het arbeidsintensieve karakter van het mijnwerk. Gemiddeld ging zo'n 6o procent van de totale kosten naar de arbeidsvergoeding. Het verminderen van de totale kosten per ton kon bijgevolg het gemakkelijkst gebeuren via het manipuleren van het arbeidsrendement. De bedrijfsresultaten hingen, veel meer dan in andere sectoren, van de productiviteit van het personeel af. ${ }^{15}$ Vergeleken met de andere Europese steenkoolproducerende landen was de gemiddelde arbeidsproductiviteit in de Belgische steenkoolindustrie echter erg laag (zie tabel 4.I). ${ }^{\mathrm{I}}$

TABEL 4.I DE ARBEIDSPRODUCTIVITEIT IN DE STEENKOLENMIJNEN IN ENKELE EUROPESE LANDEN IN I935

\begin{tabular}{|l|c|}
\hline & Productie per arbeider per dienst (in tonnen) \\
\hline Nederland & $\mathrm{I}, 80$ \\
\hline Aken & $\mathrm{I}, \mathrm{I} 8$ \\
\hline Ruhrbekken & $\mathrm{I}, 69$ \\
\hline België & 0,78 \\
\hline Frankrijk & 0,87 \\
\hline Groot-Brittannië & $\mathrm{I}, \mathrm{I} 8$ \\
\hline
\end{tabular}

Bron: Van Waterschoot van der Gracht, 'De Limburgsche steenkoolmijnindustrie', 69.

De arbeidsproductiviteit verschilde van bekken tot bekken. Zo produceerde een mijnwerker in het Kempische bekken in 1938 per dienst gemiddeld I.035 kg steenkool; in Luik was

I2 Martens, 25 jaar wegwerparbeiders.

I3 Minten et al., Een eeuw steenkool in Limburg; Gaier, Huit siècles de houillerie liégeoise.

I4 O.m. Demeure de Lespaul, Crise. Étude d'une Concentration; Fédéchar, La Belgique devant le Problème Charbonnier; Logelain, 'Note'.

I5 Minten et al., Een eeuw steenkool in Limburg, 85 en 98.

r6 Helfer, 'Meilensteine technischer Innovationen', 4I7. 
dat slechts $627 \mathrm{~kg}$ per dienst. ${ }^{17}$ Dit hing nauw samen met de slechte geologische omstandigheden in het Luikse bekken. Er waren veel dunne $(\mathrm{ca} .30 \mathrm{~cm})$ en verbrokkelde lagen, wat de ontginning bemoeilijkte. De naar boven gehaalde steenkool was over het algemeen bros en sterk verontreinigd, waardoor er een uitgebreide verwerking nodig was. ${ }^{\mathrm{I}}{ }^{8} \mathrm{Het}$ verlies bij het 'wassen' bereikte in België na de Tweede Wereldoorlog ongeveer 40 procent. ${ }^{19}$ In Luik had men het extra probleem dat er enorm veel water uit de mijngangen moest worden gepompt. ${ }^{20}$ Ook de ouderdom van de mijnen speelde een rol: steenkool werd hier al eeuwenlang ontgonnen en men moest steeds dieper graven. De rijkste aders raakten uitgeput en men moest minder voordelige steenkolenlagen ontginnen.

In het Interbellum trachtte men te rationaliseren om de productiviteit op te drijven. Eric Geerkens noemt drie aspecten van de rationalisatie tijdens het interbellum: mechanisatie, organisatie en concentratie. In een eerste fase, in de loop van de jaren I920 was er sprake van een financiële concentratie: het aantal mijnondernemingen in het Luikse bekken verminderde met 35 procent, terwijl het aantal mijnzetels slechts met 8,5 procent afnam. ${ }^{2 \mathrm{E}} \mathrm{Er}$ vonden fusies plaats tussen mijnondernemingen, maar er werd ook een aantal ondernemingen gesloten. In de eerste helft van de jaren I930 werden opnieuw niet-rendabele zetels gesloten of geïntegreerd: in dat decennium nam het aantal mijnzetels in Luik af met 25 procent, zoals trouwens overal in de Waalse bekkens. ${ }^{22}$

\section{GRAFIEK 4.2 DE ONTWIKKELING VAN DE ARBEIDSPRODUCTIVITEIT IN DE}

LUIKSE MIJNEN (IN KG PER ARBEIDER PER DIENST VAN 8 UUR-NETTO), I920-I950

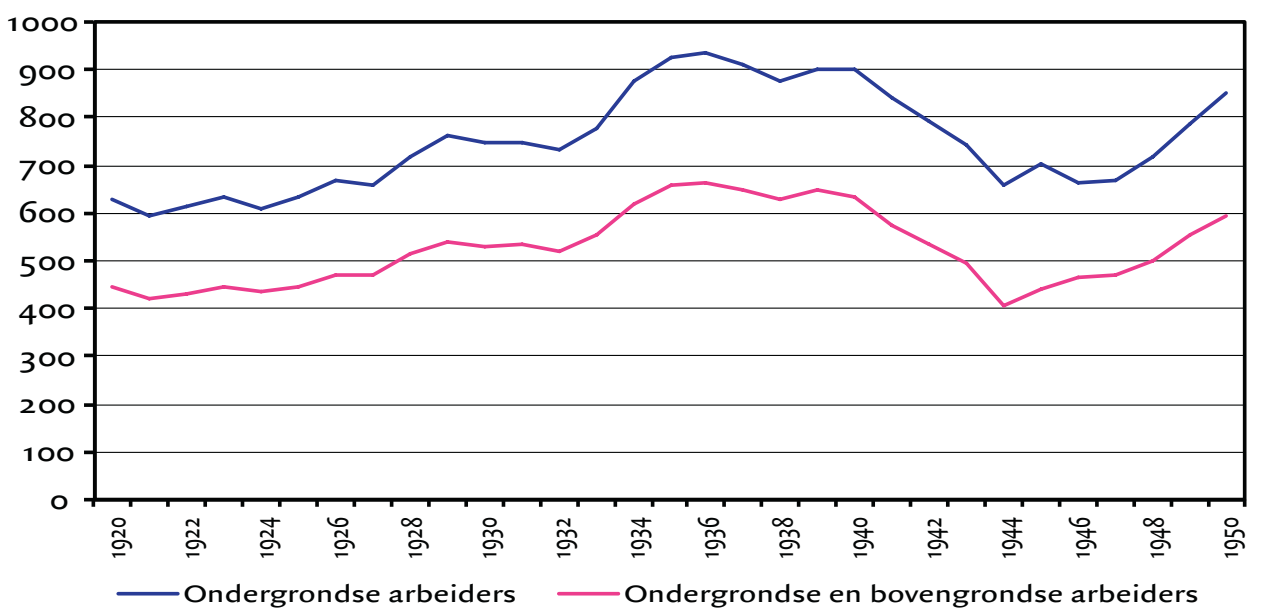

Bron: Annales des Mines de Belgique, I92I-195I.

N.B.: In 1937 werd een dienst verkort tot 7uzo, bij KB van 03/02/1940 werd dit terug opgetrokken naar 8u.

17 Annales des Mines de Belgique, I939, tableau n. II.

18 Helfer, 'Meilensteine technischer Innovationen', 406-407.

I9 Federatie der Belgische Kolenverenigingen, 'Opmerkingen gemaakt omtrent het "Verslag Robinson”'.

20 Gaier, Huit siècles de houillerie liégeoise, 35.

2I Tussen 1920 en 1930 daalt het aantal mijnondernemingen in het Luikse bekken van 43 naar 28, het aantal uitgebate zetels daalt van 70 naar 64 (Annales des Mines de Belgique, I92I-193I).

22 Het aantal mijnzetels in het Luikse bekken daalde tussen I930 en 1935 van 64 naar 48 (Annales des Mines de Belgique, I93I-I936). 
GRAFIEK 4.3 DE STEENKOLENPRODUCTIE IN HET LUIKSE BEKKEN (X I.0OO TON), I930-I950

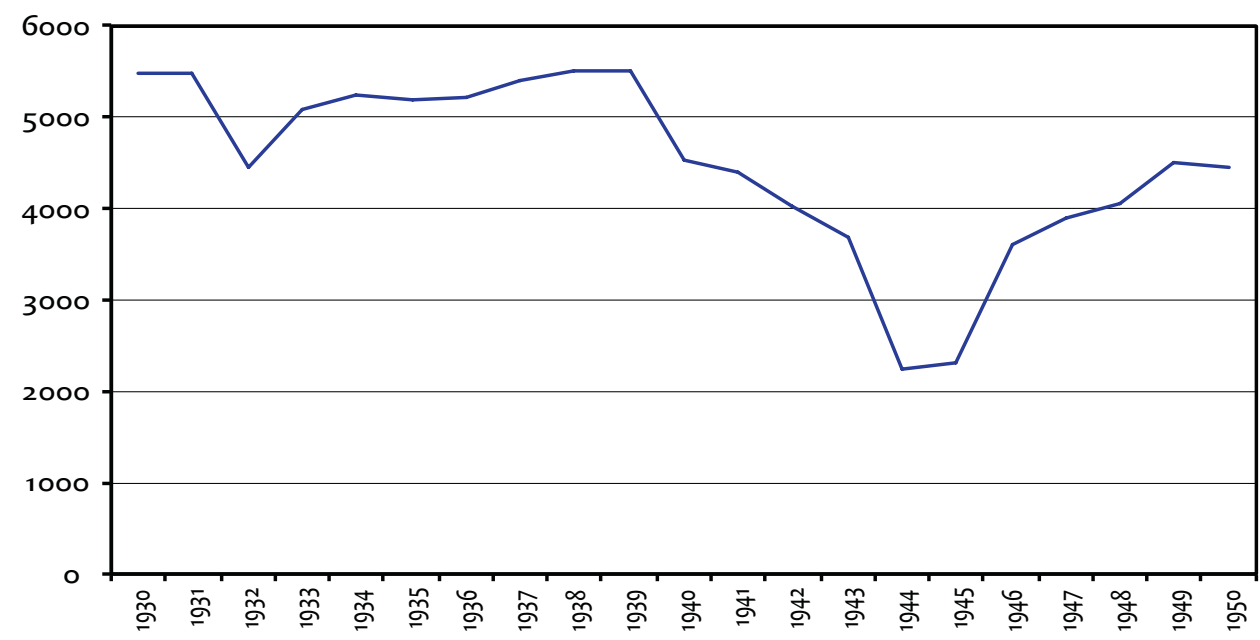

Bron: Annales des Mines de Belgique, I93I-I95I; RAH, archief FEDECHAR, inv.nrs. 606-6og: 'Jaarlijkse statistische overzichten'; Belgisch Kolenbureau, Basisstatistieken over de kolenindustrie, 5 (Zie ook bijlage 10).

De mogelijkheid om te rationaliseren werd mede bepaald door de geologische omstandigheden. ${ }^{23}$ Een volledige mechanisering was in de Waalse bekkens met hun dunne steenkolenlagen onmogelijk. Desondanks probeerde men de mechanisatie van de afbouw en de ontginning via de lange pijler waar mogelijk toe te passen. ${ }^{24}$ Aan de vooravond van de Tweede Wereldoorlog was echter het merendeel van de pijlers in de Waalse bekkens minder dan Ioo meter lang, een groot verschil met de grote mijnen in de Kempen, waar het merendeel de 100 meter juist overschreed. ${ }^{25}$ In de eerste helft van de jaren 1930 resulteerden de rationalisaties in Luik in een stijging van de arbeidsproductiviteit, die tegen het einde van de jaren I930 stabiliseerde (zie grafiek 4.2).

Dankzij de rendementsstijging ging de daling van het aantal arbeiders vooralsnog niet gepaard met een productiedaling. Aan de vooravond van de Tweede Wereldoorlog, in 1938 , produceerden de Luikse mijnen nog meer dan 5,5 miljoen ton steenkolen, ongeveer evenveel als in 1930, maar met bijna vijfduizend arbeiders minder. ${ }^{26}$ Vanaf het begin van de Tweede Wereldoorlog begonnen de arbeidsproductiviteit en de productie echter opnieuw te dalen (grafiek 4.2 en 4.3). Om tijdens en na de oorlog te kunnen blijven voldoen aan de vraag naar steenkool moest men koortsachtig op zoek gaan naar extra arbeidskrachten.

23 Geerkens, 'La rationalisation dans les charbonnages', 344 en 346-347; Demeure de Lespaul, Crise. Étude d'une Concentration. 24 Het gebruik van lange pijlers beperkte het drijven van het aantal galerijen, verminderde de onderhoudskosten en deed het aandeel van de niet-productieve diensten in de totale arbeidskost dalen. Minten et al., Een eeuw steenkool in Limburg, 9I.

25 Geerkens, 'La rationalisation dans les charbonnages', 339-343 en 354; Federatie der Belgische Kolenverenigingen, 'Opmerkingen gemaakt omtrent het "Verslag Robinson"', 484 .

26 Annales des Mines de Belgique, I93 I en I939. 
In het licht van de demografische ontwikkeling in Wallonië na de Tweede Wereldoorlog waren de vooruitzichten voor het aantrekken van Belgische arbeidskrachten op de lange termijn niet gunstig. Bovendien moesten de Luikse mijnen sinds de jaren I920 om arbeiders concurreren met de Kempische kolenmijnen. Zuid-Limburg was traditioneel een rekruteringsgebied voor de Luikse industrie. ${ }^{27}$ Dat er op termijn grote tekorten aan jonge arbeiders zouden ontstaan was al voor de oorlog duidelijk geworden. ${ }^{28}$ Vanaf het begin van de twintigste eeuw begon het geboorteoverschot in de Luikse regio te dalen, om in de crisis van de jaren I930 negatief te worden (zie grafiek 4.4). Er werden minder kinderen geboren dan er mensen stierven. Dit bleef zo duren tot het eind van de jaren I950, toen er opnieuw een miniem geboorteoverschot ontstond.

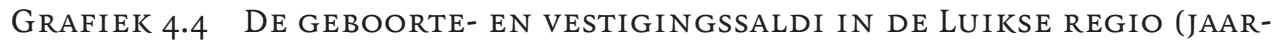
LIJKSE GEMIDDELDEN), I857/65-I962/64

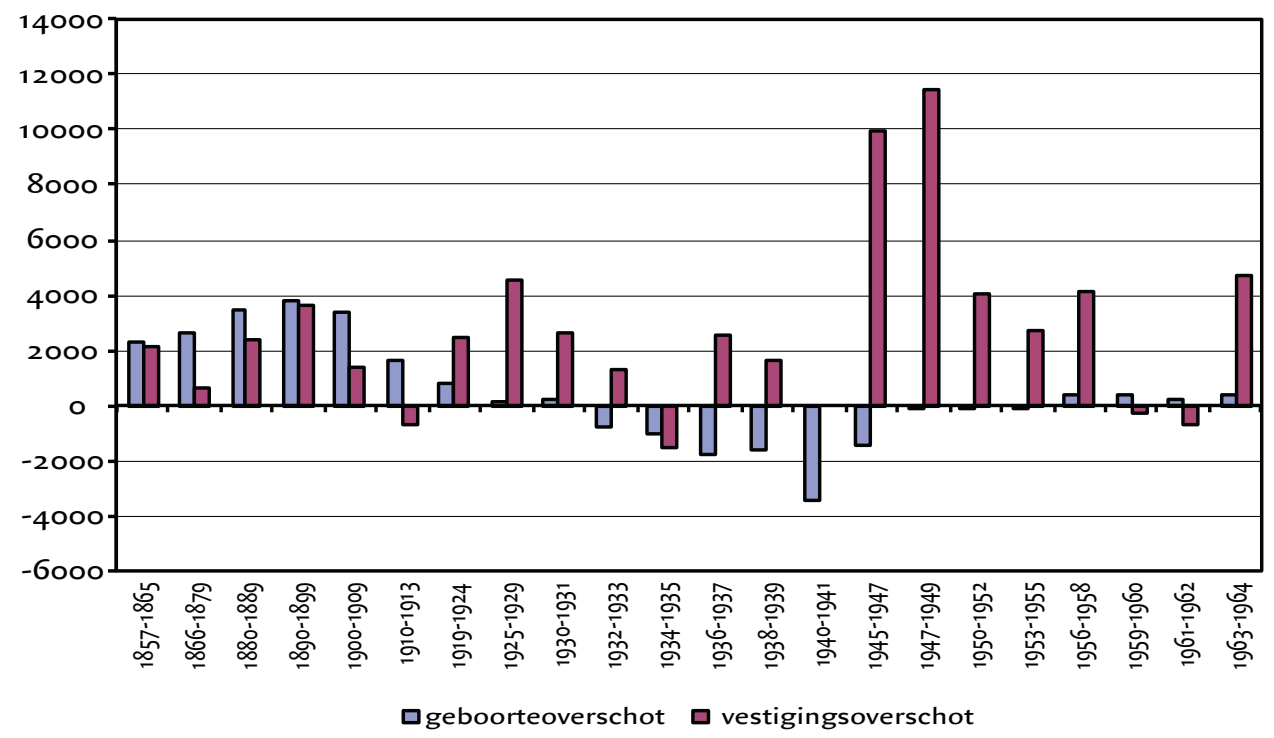

Bron: La Région Liégeoise. Démographie. Logement. Industrie et Commerce, I95I; La Région Liégeoise. Démographie. Logement. Industrie-Commerce-Services, I966.

De lage geboortecijfers werden niet veroorzaakt door een beperking van de nuptialiteit, dus door late en minder huwelijken. In de Luikse regio was het aantal huwelijken per duizend inwoners juist hoger dan in de rest van de provincie Luik en in heel België. Uit tabel 4.2 blijkt dat de huwelijksvruchtbaarheid in de provincie Luik daarentegen een stuk lager was dan in België als geheel. Culturele en sociale oorzaken, met name secularisering, verstedelijking en beter onderwijs, hadden ervoor gezorgd dat er in arbeidersgezinnen al vroeg ge- 


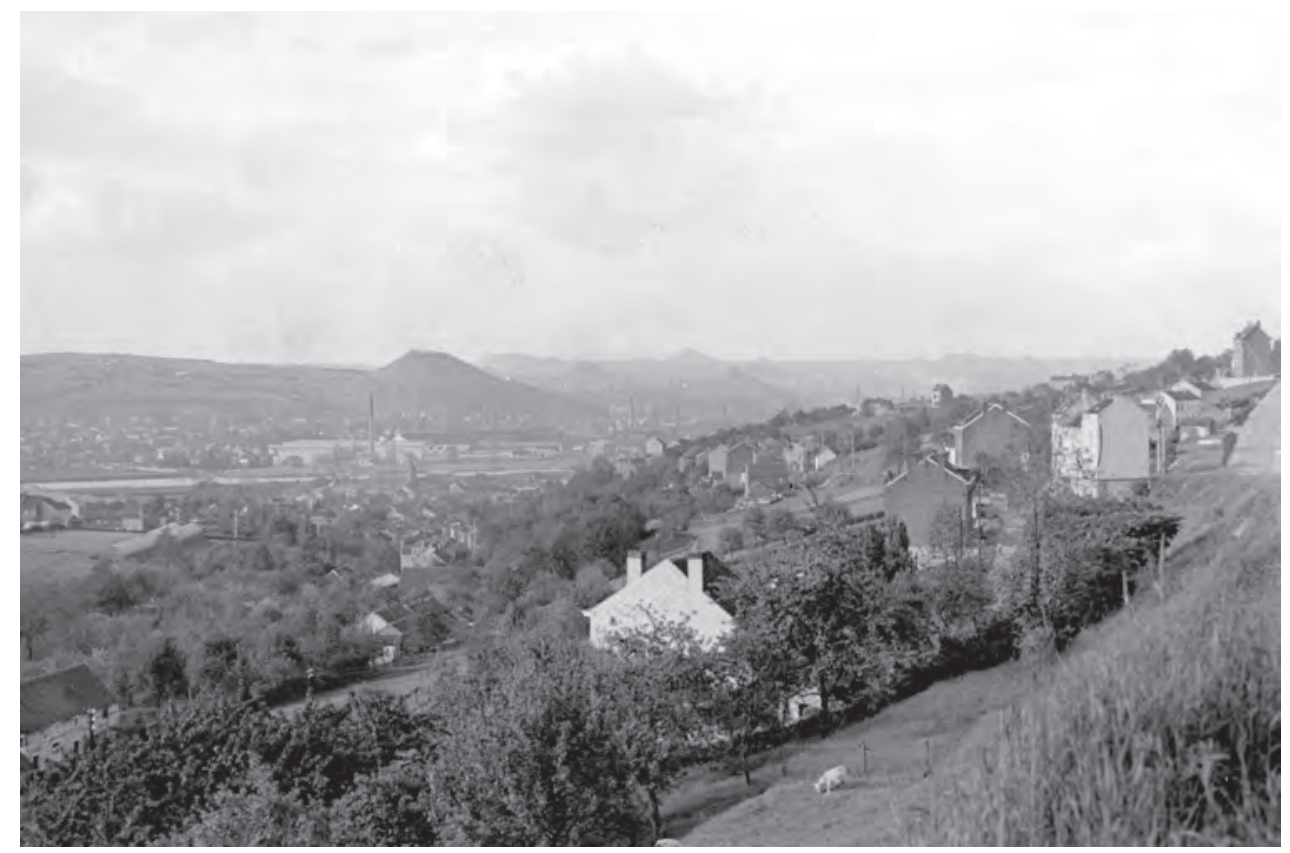

Terrils, Jemeppe-Hollogne, 1938. Copyright Province de Liège - Musée de la Vie wallonne.

boortebeperking werd toegepast. Door het aantal kinderen te beperken, hoopten de ouders hen een betere toekomst te kunnen bieden. ${ }^{29}$

TABEL 4.2 Het AANTAL GeboORTES PER I.000 GEHUWDE VROUWEN IN DE LEEFTIJDSKLASSE I5 TOT 50 JAAR IN BELGIË, IN DE PROVINCIE LUIK EN IN ENKELE LUIKSE GEMEENTEN MET EEN BELANGRIJKE INDUSTRIËLE BEVOLKING, I880-I96I ${ }^{30}$

\begin{tabular}{|c|c|c|c|c|c|c|c|}
\hline & Luik & Herstal & Jemeppe & Ougrée & Seraing & Provincie Luik & België \\
\hline I880 & $2 \mathrm{II}$ & 242 & $\cdot$ & $\cdot$ & $26 \mathrm{I}$ & 246 & 263 \\
\hline I89o & I7I & 208 & $\cdot$ & 242 & $23 \mathrm{I}$ & 212 & 239 \\
\hline I900 & 139 & 175 & IgI & 201 & I89 & 179 & 216 \\
\hline I9Io & 87 & 96 & 113 & 100 & 96 & II9 & I6I \\
\hline I920 & 83 & 84 & $\cdot$ & $\cdot$ & 78 & IOI & 130 \\
\hline 1930 & 68 & $\cdot$ & $\cdot$ & $\cdot$ & $\cdot$ & 83 & Io6 \\
\hline I947 & 94 & 57 & 45 & 205 & 57 & 89 & 104 \\
\hline I96I & 90 & 73 & 73 & 76 & 72 & $9 \mathrm{I}$ & 105 \\
\hline
\end{tabular}

Bron: La Région Liégeoise. Démographie. Logement. Industrie et Commerce, I95I, 50, tabel 4I; La Région Liégeoise. Démographie. Logement. Industrie-Commerce-Services, Ig66.

29 Leboutte, 'Motivations des acteurs de la transition démographique'; idem, Reconversions de la main-d'œuvre et transition démographique, 374-391.

30 Opvallend is het hoge aantal kinderen in Ougrée in 1947. Wellicht heeft dit te maken met het feit dat alle kinderen in een gemeente geboren hiertoe werden gerekend, ook als het domicilie van moeder in een andere gemeente gelegen was. Als noemer werd niettemin het aantal in de gemeente ingeschreven gehuwde vrouwen in de leeftijdsklasse 15 tot 50 jaar genomen. Wellicht is de aanwezigheid van een hospitaal of kraamkliniek in Ougrée hiervoor de verklaring. 
GRAFIEK 4.5 DE BEVOLKING NAAR LEEFTIJD IN DE LUIKSE REGIO (IN PROMILLE), I947

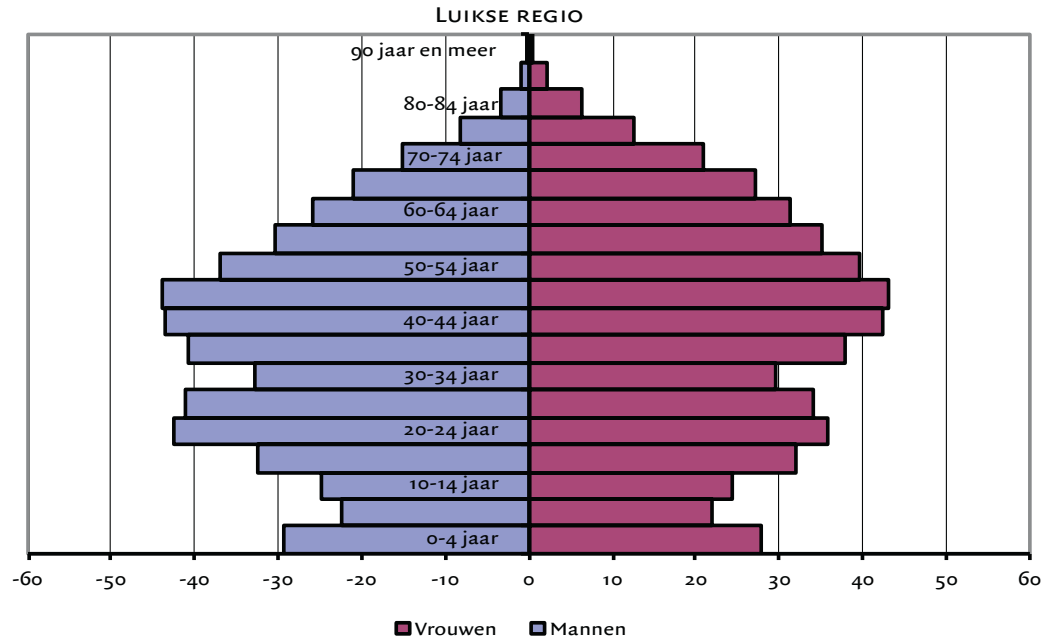

Bron: La Région Liégeoise. Démographie. Logement. Industrie et Commerce, I95I.

GRAFIEK 4.6 DE BEVOLKING NAAR LEEFTIJD IN BELGiË (IN PROMILLE), I947

BELGIË

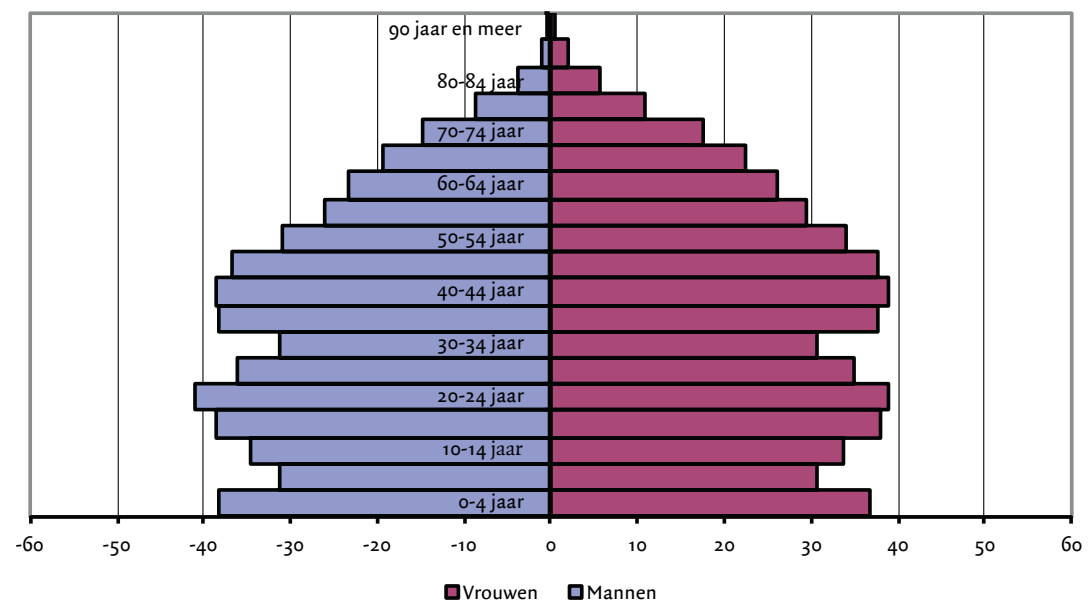

Bron: La Région Liégeoise. Démographie. Logement. Industrie et Commerce, I95I.

Door de dalende tendens in de huwelijksvruchtbaarheid week de leeftijdsopbouw van de bevolking in de Luikse regio na de Tweede Wereldoorlog sterk af van die in België als geheel (zie grafieken 4.5 en 4.6). Vergeleken met België als geheel had de Luikse regio te kampen met een relatief tekort aan jongeren (o-20 jaar), een zogenoemde ontgroening. Dit had gevolgen voor de lokale arbeidsmarkt. Een gering aantal jongeren betekende een gebrek aan potentiële arbeidskrachten. Op de lange termijn hield de groei van de beroepsbevolking 
geen gelijke tred met de vraag naar arbeiders. Vraag en aanbod op de arbeidsmarkt moesten op een andere manier in evenwicht worden gebracht.

\section{DE TWEEDE WERELDOORLOG ALS KATALYSATOR VAN HET ARBEIDSTEKORT}

Een daling van de arbeidsproductiviteit en de vlucht uit de mijnen waren reeds ingezet, maar door het uitbreken van de Tweede Wereldoorlog kon de Belgische steenkoolindustrie geen structureel beleid ontwikkelen om dit te verhelpen. Meer nog, door de oorlog werd de situatie acuut. ${ }^{3 \mathrm{I}}$ De Belgische economie met veel basisgrondstoffen, in het bijzonder steenkool, en een grote nijverheidscapaciteit, vooral in de staalindustrie, kon direct gekoppeld worden aan de Duitse oorlogseconomie. ${ }^{32}$ Het vernietigen van de economische infrastructuur werd vermeden en de Duitse bezetter stond de Belgen toe om hun eigen steenkoolmijnen uit te baten, met alleen een nominale Duitse supervisie. Na het vertrek van de regering naar Frankrijk, zette de gouverneur van de Société Générale met de steun van industriële en financiële leiders het Galopin-comité op. Het beleid van dit comité richtte zich op het voortzetten of hervatten van het werk om tegemoet te komen aan de economische behoeften van België. De bezettingsmacht zou niet voorzien worden van oorlogsmateriaal. FEDECHAR, de patroonsorganisatie van de steenkolenmijnen, vaardigde tevens een richtlijn uit om de productie van steenkool te beperken tot de behoefte van de burgerbevolking. ${ }^{33} \mathrm{Al}$ snel bleek de Galopin-doctrine echter moeilijk toe te passen. Het Duitse militair bestuur eiste brandstoffen en inspanningen om tot een maximale productie te komen. België moest in staat zijn zowel in de eigen noden te voorzien als aan Duitsland te leveren. Later werd België ook nog verplicht te exporteren naar Luxemburg en bezet Frankrijk. ${ }^{34}$

De bezetter richtte in I94I de Reichsvereinigung Kohle op om de voor de oorlogsindustrie belangrijke steenkoolproductie in het Derde Rijk te organiseren. De Belgisch- en Nederlands-Limburgse steenkoolmijnen werden samengevoegd tot de regionale afdeling Kempen Bergbau. Tot een gecentraliseerd beleid op nationaal vlak kwam het niet. De Waalse mijnen stonden rechtstreeks onder toezicht van Heller, hoofd van het Referat I - Bergbau. Er ontstonden snel problemen met de bevoorrading van onder andere mijnhout en rubber en met de beschikbaarheid van arbeidskrachten. ${ }^{35}$ De Belgische steenkolenmijnen moesten hun kolen leveren aan de 'prijs Oberhausen', een kunstmatig laag gehouden verkoopprijs. Dit drukte het rendement van de mijnen. Om deze verliezen te dekken werd op i6 november I94I de Compensatiekas van de Kolennijverheid opgericht. Deze instelling had tot doel de grote verschillen tussen de mijnen in exploitatieresultaat te neutraliseren. Van de winstgevende mijnen zou een deel van de winst herverdeeld worden naar de verlieslatende mijnen. Het

3I De bezetting van België begon met de inval op ro mei I940 en duurde tot de uiteindelijke bevrijding van het laatste deel op I oktober 1944. Later werd nog een deel opnieuw bezet tijdens het Ardennenoffensief. België bleef een militaire zone tot augustus 1945. Zie: Kurgan-Van Hentenryk en Puissant, 'Industrial relations in the Belgian Coal Industry', 257.

32 Milward, War, Economy and Society, 23I; Robinson, 'Report on Belgian coal industry', 455.

33 Vanaf I2 juni 1940, de dag waarop FEDECHAR voor het eerst sinds het begin van de Tweede Wereldoorlog samenkwam en de directieve in lijn met de Galopin-doctrine uitvaardigde, werd FEDECHAR de bemiddelaar met de Duitse autoriteiten over alles wat te maken had met de Belgische steenkolensector (Kurgan-Van Hentenryk en Puissant, 'Industrial relations in the Belgian Coal Industry', 255).

34 Nefors, Industriële 'collaboratie' in België, I7, I57.

35 Minten et al., Een eeuw steenkool in Limburg, 94. 
stelsel raakte echter al snel uit balans en de Belgische overheid moest bijkomende steun verstrekken in de vorm van een subsidie van ca. dertig miljoen BEF per maand.

TABEL 4.3 HeT AANTAL EN AAN DEEL BUITEN LAN DERS ON DER DE LUIKSE MiJNWERKERS, I938-I947 (PER 3I DECEMBER)

\begin{tabular}{|l|r|r|r|r|r|}
\hline & Aantal & Aandeel & & Aantal & Aandeel \\
\hline $\mathrm{I} 938$ & 7.152 & $22 \%$ & $\mathrm{I} 943$ & 4.520 & $\mathrm{I} 6 \%$ \\
\hline $\mathrm{I} 939$ & 7.032 & $22 \%$ & $\mathrm{I} 944$ & $2.92 \mathrm{I}$ & $\mathrm{I} 4 \%$ \\
\hline $\mathrm{I} 940$ & 4.850 & $\mathrm{I} 6 \%$ & $\mathrm{I} 945$ & 3.753 & $\mathrm{I} \%$ \\
\hline $\mathrm{I} 94 \mathrm{I}$ & 3.824 & $\mathrm{I} \%$ & $\mathrm{I} 946$ & 8.950 & $35 \%$ \\
\hline $\mathrm{I} 942$ & $3.62 \mathrm{I}$ & $\mathrm{I} \%$ & $\mathrm{I} \% 47$ & $\mathrm{I} 4.843$ & $47 \%$ \\
\hline
\end{tabular}

Bron: RAH, archief FEDECHAR, inv.nr. 6I2: 'Statistieken'; inv.nrs. I579-1580: 'Personeelsstatistieken'.

N.B.: Zonder dwangarbeiders (onder wie Russische krijgsgevangenen).

Omdat Belgische mijnwerkers die onder de wapens waren geroepen krijgsgevangen werden gehouden, was het aanvankelijk niet mogelijk de bestaande arbeidskrachten te behouden. ${ }^{36}$ Door tijdgenoten wordt bovendien vermeld dat een deel van de mijnwerkers naar niet-bezette gebieden vluchtte. Eind juni I940 was echter reeds 90 procent van die uitgeweken Belgen teruggekeerd. ${ }^{37}$ Het vertrek van de buitenlandse mijnwerkers net voor en tijdens de oorlog zorgde voor een groter verlies aan arbeidskrachten. Hun aandeel daalde in 1940 van 22 naar I6 procent (zie tabel 4.3). Aanvankelijk werd een deel van hen opgeëist om in de Duitse mijnen te gaan werken, ${ }^{38}$ of opgeroepen door het eigen land. $3^{39}$

De uittocht van buitenlandse mijnwerkers werd ook gestimuleerd door voedselschaarste. Door de rantsoenering waren er tekorten aan granen en aardappelen, en het vleesrantsoen van 35 gram per dag per persoon bedroeg nog slechts een derde van de hoeveelheid van voor de oorlog. Voor de mijnwerkers die zware lichamelijke arbeid moesten verrichten, was een degelijke en vooral voldoende voeding noodzakelijk. De weerslag op de algemene gezondheidstoestand van de mijnwerkers was dramatisch. Zij kregen wel aanvullende rantsoenen brood, vlees en margarine, maar deze bleven ontoereikend. Algemeen gewichtsverlies en verminderde weerstand tegen allerlei infecties zorgden voor een toenemende absentie. ${ }^{40}$ Toen tijdens de strenge winter van I94I hongersnood dreigde, legden de Waalse mijnwerkers het werk neer..$^{4}$ De Duitse overheid kwam aan de eisen van de stakers tegemoet door de inrichting van Hilfszug Bayern, een keten van r6o vrachtwagens die instond voor de distributie van soep aan de mijnwerkers. ${ }^{42}$ Ook FEDECHAR vroeg onophoudelijk naar voedselrantsoenen voor de mijnwerkers. Op I mei 1942 kreeg ze eindelijk subsidies om de rantsoenen van de mijnwerkers op hetzelfde niveau van de Duitse arbeiders te bren-

36 Ibidem, 97; Nefors, Industriële 'collaboratie' in België, 72.

37 Ibidem, 71; Piquet, “"Privilegierte” Zwangsarbeiter', 473.

38 Tegen september 1940 waren 7.496 ervaren mijnwerkers, waaronder voornamelijk houwers van Poolse, Italiaanse of Tsjechische afkomst verplicht uit de Belgische en Franse mijnen vertrokken om in het Ruhrgebied of het Akense bekken te werken. Zie: Ibidem. Het Kempische bekken werd hiervan vrijgesteld, het begin van een systematische bevoordeling van het noordelijke bekken. Zie: Nefors, Industriële 'collaboratie' in België, 72.

39 Brial, L'angoissant problème du charbon, 5 ; Logelain, 'Note', 365.

40 Jacquemyns, La société belge, 39-149; Alimentation et état de santé, 129-138.

4I Luyten, 'Stakingen in België en Nederland'.

42 Brial, L'angoissant problème du charbon, 6; Jacquemyns, La société belge; Alimentation et état de santé, 88-95. 
gen, maar toen waren al veel mijnwerkers vertrokken. In de Belgische kranten werden bovendien de arbeidsvoorwaarden in Duitsland aangeprezen. Ongeveer II.0oo mijnwerkers uit de Belgische mijnindustrie lieten zich ertoe verleiden om in Duitsland te gaan werken, overwegend ondergrondse arbeiders. ${ }^{43}$

Voor de arbeidskracht van de Waalse mijnen was het bovendien nadelig dat de Duitsers specifieke maatregelen troffen om de productie van het Kempisch bekken te handhaven vanwege de vetkool die er ontgonnen werd en de hogere productiviteit door de modernere infrastructuur en rijkere lagen. In dit kader schaften de Duitsers het transport af dat de Limburgse mijnwerkers naar de Luikse mijnen bracht. ${ }^{44}$

Het arbeidstekort had grote gevolgen voor de productie van de Luikse mijnen. In grafiek 4.3 is te zien hoe de productie gedurende de oorlogsjaren steeds verder daalde om in 1944 een dieptepunt te bereiken. Er werd toen minder dan 40 procent van de normale vooroorlogse productie gehaald. In alle Belgische bekkens nam het rendement af, het minst echter in de Kempen, waar de productie relatief hoog bleef. Volgens contemporaine bronnen deed bovendien een deel van het Belgische mijnmanagement er tijdens de Duitse bezetting alles aan om de productie te doen dalen en zodoende niet mee te werken aan de Duitse oorlogsmachine. Zo werden eerst de armste steenkolenlagen aangeboord. ${ }^{45}$ Een andere belangrijke reden voor het lage rendement tijdens de Tweede Wereldoorlog was het hoge absenteïsme (niet op het werk verschijnen zonder geldige reden). Tijdens de oorlog waren er veel stakingen, veroorzaakt door de slechte werkomstandigheden en de karige rantsoenen. ${ }^{46}$ Bovendien daalde de productiviteit door de inzet van onervaren 'gelegenheidsarbeiders', die om deportatie te vermijden in de Belgische steenkolenmijnen gingen werken. De kolenindustrie was door de Duitsers bestempeld als kriegswichtig en de mijnwerkers werden in principe niet verplicht om in Duitsland te gaan werken, zeker als men ondergronds werkte. Ook de inzet van Russische krijgsgevangenen had een negatieve invloed op de productiviteit. ${ }^{47}$

\section{DWANGARBEID}

Om het tekort aan arbeidskrachten en de dalende productiecijfers tegen te gaan besloten de Duitse autoriteiten op I juni I94I de lonen met 8 procent te verhogen, gezinsuitkeringen toe te kennen en aanwezigheidsbonussen in te stellen. Op die manier wilde de Duitse bezetter meer arbeiders aantrekken, eventuele werknemersacties voorkomen, en de mijnwerkers aanzetten zich aan te sluiten bij de UTMI (Union des Travailleurs Manuels et Intellectuels), een Belgische vereniging van vakbonden opgezet door de Duitsers. Via het verlengen van de arbeidsduur probeerde de bezetter de productie te verhogen. Zo werden de mijnwerkers verplicht één zondag per maand te werken. Deze maatregelen van de Duitse bezetter hadden slechts een beperkt succes, maar resulteerden wel in een zware financiële last voor de Belgische steenkolenmijnen..$^{8} \mathrm{Om}$ de gestegen lonen en uitkeringen het hoofd te bieden

\footnotetext{
43 Minten et al., Een eeuw steenkool in Limburg, II6.

44 Ibidem, 95.

45 Brial, L'angoissant problème du charbon, I7-I9; Robinson, 'Report on Belgian coal industry', 455.

46 Luyten, 'Stakingen in België en Nederland'.

47 Minten et al., Een eeuw steenkool in Limburg, 95.

48 Ibidem, 97.
} 
trachtten de mijneigenaren de autoriteiten er tevergeefs toe over te halen de verkoopprijzen te doen stijgen. Ze konden echter alleen van het compensatiestelsel en overheidssubsidies gebruikmaken, die maar een deel van het geleden verlies goedmaakten. ${ }^{49}$

TABEL 4.4 Het AANTAL TEWERKGESTELDE RUSSisCHE KRIJGSGEVANGENEN IN DE LUIKSE MIJNEN PER MAAND IN I943 EN I944 (TOT EN MET JULI)

\begin{tabular}{|c|c|c|c|c|c|c|c|c|c|c|c|c|}
\hline 1943 & jan & feb & mrt & apr & mei & juni & juli & aug & sep & okt & nov & dec \\
\hline Batterie & $\mathrm{I} 28$ & $\mathrm{I} 28$ & $\mathrm{I} 28$ & 228 & 225 & 225 & 225 & 222 & 222 & $22 \mathrm{I}$ & $22 \mathrm{I}$ & 227 \\
\hline Espér. Bonne-Fort & I04 & 104 & 103 & 103 & IOI & IOI & IOI & IOO & 97 & 97 & 98 & I42 \\
\hline Grande Bacnure & II2 & III & III & III & Io6 & Io6 & Io6 & Io6 & 103 & I03 & 103 & $\mathrm{II}_{3}$ \\
\hline Hasard & 105 & 105 & 105 & 255 & $35 \mathrm{I}$ & $35 \mathrm{I}$ & $35 \mathrm{I}$ & 350 & 349 & 348 & 348 & 353 \\
\hline Gosson & - & - & - & • & 89 & 89 & • & 88 & 88 & 88 & 88 & 107 \\
\hline Patience & • & • & • & 44 & 70 & 70 & 69 & 67 & 67 & 67 & 67 & 108 \\
\hline Totaal & 449 & 448 & 447 & 74I & 942 & 942 & 852 & 93I & 926 & 924 & 925 & 1.050 \\
\hline
\end{tabular}

\begin{tabular}{|l|r|r|r|r|r|r|r|}
\hline \multicolumn{1}{|c|}{ I944 } & jan & feb & mrt & apr & mei & juni & juli \\
\hline Batterie & 229 & 229 & 230 & 230 & 229 & 225 & 217 \\
\hline Espér. Bonne-Fort & I37 & I37 & I35 & I35 & I34 & I3I & I3I \\
\hline Grande Bacnure & II5 & II3 & II3 & II3 & II3 & II2 & II2 \\
\hline Hasard & 354 & 354 & 354 & 353 & 347 & 347 & 347 \\
\hline Gosson & I06 & I06 & I06 & I06 & I04 & I02 & I02 \\
\hline Patience & 98 & 98 & 99 & I00 & 88 & 88 & 88 \\
\hline Totaal & 1039 & 1037 & 1037 & 1037 & 1015 & 1005 & 997 \\
\hline
\end{tabular}

Bron: RAH, archief FEDECHAR, inv.nr. I579: 'Personeelsstatistieken'.

N.B.: Luikse mijnen die niet opgenomen werden, stelden geen Russische krijgsgevangenen tewerk.

Een andere oplossing om het arbeidstekort (tijdelijk) te lenigen was de tewerkstelling van Ostarbeiter ${ }^{50}$ en Russische krijgsgevangenen. Ostarbeiter werkten alleen in de Kempische mijnen. In juni 1942 werden daar de eerste Russische arbeiders geïntroduceerd. Eind 1942 werkten er reeds meer dan 5.500 Russische en Poolse krijgsgevangenen. De Russen werden daarna nog in andere bekkens ingezet, maar nooit in dezelfde mate als in de Kempen: in maart 1943 maakten ze I4,3 procent van het totale arbeidersbestand in de Kempische mijnen uit, tegenover 2,5 procent in Centre, 3 procent in Charleroi, 2 procent in Luik en I procent in de Borinage. ${ }^{\mathrm{I}}$ Deze buitenproportionele toewijzing aan de Kempen kan worden verklaard door de eerder genoemde vraag naar vetkolen en de hogere productiviteitscijfers. Piquet spreekt over 335 Russische krijgsgevangenen in het Luikse bekken in het begin van I943..$^{2}$ Dat aantal nam daarna snel toe. Per mijn varieerde hun aantal van enkele tientallen tot een paar honderd (tabel 4.4). Deze Russische krijgsgevangenen waren over het alge-

49 Kurgan-Van Hentenryk en Puissant, 'Industrial relations in the Belgian Coal Industry', 255-257.

50 Gedeporteerden uit de door Duitsland veroverde gebieden zoals Oekraïne en Wit-Rusland, zie: Minten et al., Een eeuw steenkool in Limburg, Ir6.

5I Nefors, Industriële 'collaboratie' in België, I7I.

52 Piquet, “'Privilegierte” Zwangsarbeiter', 477 en 492. 
meen onervaren met het mijnwerk, wat een verdere daling van de arbeidsproductiviteit in de hand werkte. ${ }^{53}$ Ze werden door de Duitsers voor het einde van de oorlog, begin september I944, geëvacueerd. 54

Door de inzet van krijgsgevangenen verhinderden de bezetters dat er een structurele oplossing voor het personeelsprobleem kwam. Integendeel, het probleem zou alleen maar verergeren. Na het vertrek van de Russische krijgsgevangenen in 1944 bereikte het aantal arbeidskrachten het laagste niveau sinds het begin van de twintigste eeuw. Het probleem van het arbeidstekort werd opeens erg acuut en groot. Er ontstond een crisissituatie.

\section{DE KOLENSLAG EN DE 'DESERTIE VAN DE ZONEN'}

$\mathrm{Na}$ haar terugkomst in september 1944 zag de Belgische regering zich geconfronteerd met een massaal vertrek van arbeidskrachten uit de mijnen en de daaropvolgende scherpe daling in de productie. Veel mijnwerkers waren tijdens de bezetting in de steenkolenmijnen gaan werken om deportatie naar Duitsland te voorkomen. Na de bevrijding namen zij hun oude beroepen weer op of bleven werkloos. ${ }^{55}$ Ook ex-krijgsgevangenen die voor de oorlog in de mijnen hadden gewerkt, oriënteerden zich nu op andere beroepen. Soms waren er ook praktische problemen. Een deel van de mijnwerkers woonde ver van de mijn en kort na de oorlog was het trein- en tramverkeer nog niet hersteld en waren er te weinig nieuwe fietsbanden. Het karige voedselrantsoen tijdens de bezettingsjaren had ook tot gevolg dat sommige mijnwerkers door uitputting vervroegd met pensioen moesten gaan. ${ }^{56} \mathrm{Na}$ de bevrijding in september 1944 kenden de mijnen een ware leegloop. Werden er in het Luikse bekken aan het eind van 1938 nog bijna 30.000 arbeiders in de mijnen tewerkgesteld, eind I944 was dit aantal met een derde gedaald: toen werkten er nog maar 20.65I mijnwerkers. ${ }^{57}$

Een verklaring voor deze evolutie is onder meer te vinden in de zogenaamde 'desertie van de zonen': een beladen omschrijving die werd gebruikt om een aantal factoren van mijnverlating door de autochtone arbeiders samen te vatten. Er was al een kleiner potentieel aan arbeiders door de demografische situatie, een gevolg van strategisch gedrag aan de aanbodzijde, en dit potentieel kromp nog verder ineen door de afkeer voor en de slechte naam van het mijnwerk. Het beschikbare aanbod koos liever voor een ander beroep. Een vakbondsbestuurder stelde in 1946 vast:

Sinds verscheidene tientallen jaren reeds weigert de Belgische arbeider in de mijn te dalen. Deze tegenzin spruit heel eenvoudig voort uit het feit dat het mijnwerkersberoep het lastigste is ... Het beroep is niet enkel lastig, maar het is gevaarlijk. De mijnwerker is gedurende al de tijd van zijn verblijf onder de grond, aan voortdurende gevaren blootgesteld, instortingen, overstromingen, grauwvuur, enz. ... Het beroep is het ongezondste en het spijt mij te moeten vaststellen dat er te weinig mijnen zijn, die een stelselmatige strijd hebben aangebonden tegen het stof, een der grootste vijanden van de mijnwerker, en die een grote zorg hebben besteed om een minimum verluchting te verzekeren. Wanneer in een streek ... de ouders indruk willen maken op hun kinderen, wanneer zij zich afkerig

53 Minten et al., Een eeuw steenkool in Limburg, 95.

54 Piquet, “"Privilegierte” Zwangsarbeiter', 477; Kohlbacher, Het Russisch kamp, 66-68.

55 Ibidem, 6 en $8 \mathrm{I}-82$.

56 Brial, L'angoissant problème du charbon, 5; Logelain, 'Note', 365-366.

57 Annales des Mines de Belgique, I939, 1945-46. 
tonen voor studie en onderricht, dan slingeren zij hun de traditionele bedreiging naar het hoofd: 'Gij zult nog in de mijn terecht komen'..$^{8}$

Vooral jongeren kozen ervoor niet langer in de mijn af te dalen. ${ }^{59}$ De redenen voor de geringe aantrekkingskracht van het mijnwerkersberoep waren talrijk: de zware en ongezonde arbeidsomstandigheden, de hiërarchische arbeidsrelaties, het opvoeren van het werktempo, ${ }^{60}$ het risico op ongevallen, de relatief lage lonen en de stijgende mechanisering in de ondergrond. ${ }^{6}$ Ook mijnwerkers zelf getuigden hiervan:

We hebben conflicten en veel ruzies meegemaakt in de mijn. Ze probeerden de arbeiders ervan te overtuigen dat er een manier was om meer te doen dan ze deden. Gespecialiseerde arbeiders of opzichters kwamen zich een dag afbeulen, expres om te bewijzen dat je meer kon doen.

$\mathrm{Na}$ de Tweede Wereldoorlog zijn de lonen sterk omhoog gegaan; dat was een lokkertje om nieuw personeel aan te trekken. Ze stelden de mijnwerkers aanzienlijke loonsverhogingen voor om ze in de mijn te houden. Maar tegelijkertijd stegen de kosten van het levensonderhoud ook heel sterk.

De lui die redelijk veel geld verdienden in de mijn waren de 'bacneurs'. Dat waren supervaklui, maar bij hen werd de gezondheid het eerst aangetast door het stof van de hamer-perforators en door het stof dat vrijkwam door het schieten in de mijn. Dat was echt het ongezondste beroep. ${ }^{62}$

Door de mechanisering waren de omstandigheden ongezonder geworden en had het mijnwerkersberoep een andere invulling gekregen, waardoor de beroepseer voor sommigen was verdwenen. ${ }^{6} 3$ Wie van de mijnarbeid zijn hoofdberoep maakte, probeerde op de bovengrond tewerkgesteld te worden. Omdat de levensstandaard was gestegen hoefden de mijnwerkers hun kinderen niet meer naar de mijn sturen. Hiervoor bleek al dat men liever een kleiner aantal kinderen grootbracht, die men dan een betere toekomst kon bieden. Er waren veel mijnwerkers die slechts één of twee kinderen hadden en ze liever in andere beroepen terecht zagen komen. De mijnwerker die z'n zoon naar de mijn stuurde was een uitzondering geworden. ${ }^{64}$ Uit de mond van een Luikse arbeider, die zelf het werk in de kristalfabriek Val-St.-Lambert boven mijnwerk verkoos, klonk het als volgt:

De wens om hun kinderen de bijzondere zware arbeid in de mijn te besparen heeft zich onder de arbeiders verspreid. In de mijn werken is niet meer een soort onafwendbaar noodlot. Ze zoeken voor de kinderen werk in betere omstandigheden, hoewel bepaalde omstandigheden als de oorlog naar een situatie van overmacht doen teruguallen. ${ }^{65}$

Deze afwending van de mijnarbeid manifesteerde zich niet overal even sterk. Er was vooral een groot verschil tussen het Kempische bekken en de Waalse bekkens. Dit had te maken met een afwijkend demografisch patroon (het geboortecijfer in de Kempen daalde minder snel) en een verschil in economische ontwikkeling. Anders dan bijvoorbeeld in de Kempen of de Borinage was er in Luik heel wat alternatieve werkgelegenheid te vinden, onder meer in de metaalnijverheid, de grootste industriële sector in Luik. Die trok in I947 bijna 23

58 Uitspraak van de heer Finet, Secretaris Generaal van het Algemeen Belgisch Vakverbond, geciteerd in: Nationaal Instituut voor Woning en Huisvesting, Het probleem van de huisvesting in België, 57-58.

59 Jacquemyns, La vie sociale, 35 en 39-40.

6o Martens, 25 jaar wegwerparbeiders, I47.

6I Minten et al., Een eeuw steenkool in Limburg, 99.

62 Arbeidersgeschiedenisgroep van Seraing, Seraing. Herinneringen van arbeiders, 34-35 en 55 .

63 Caestecker, 'Arbeidsmarktstrategieën in de Belgische mijnindustrie', 43-45; Jacquemyns, La vie sociale, 44-48.

64 Brial, L'angoissant problème du charbon, 5; Logelain, 'Note', 366.

65 Arbeidersgeschiedenisgroep van Seraing, Seraing. Herinneringen van arbeiders, 39. 


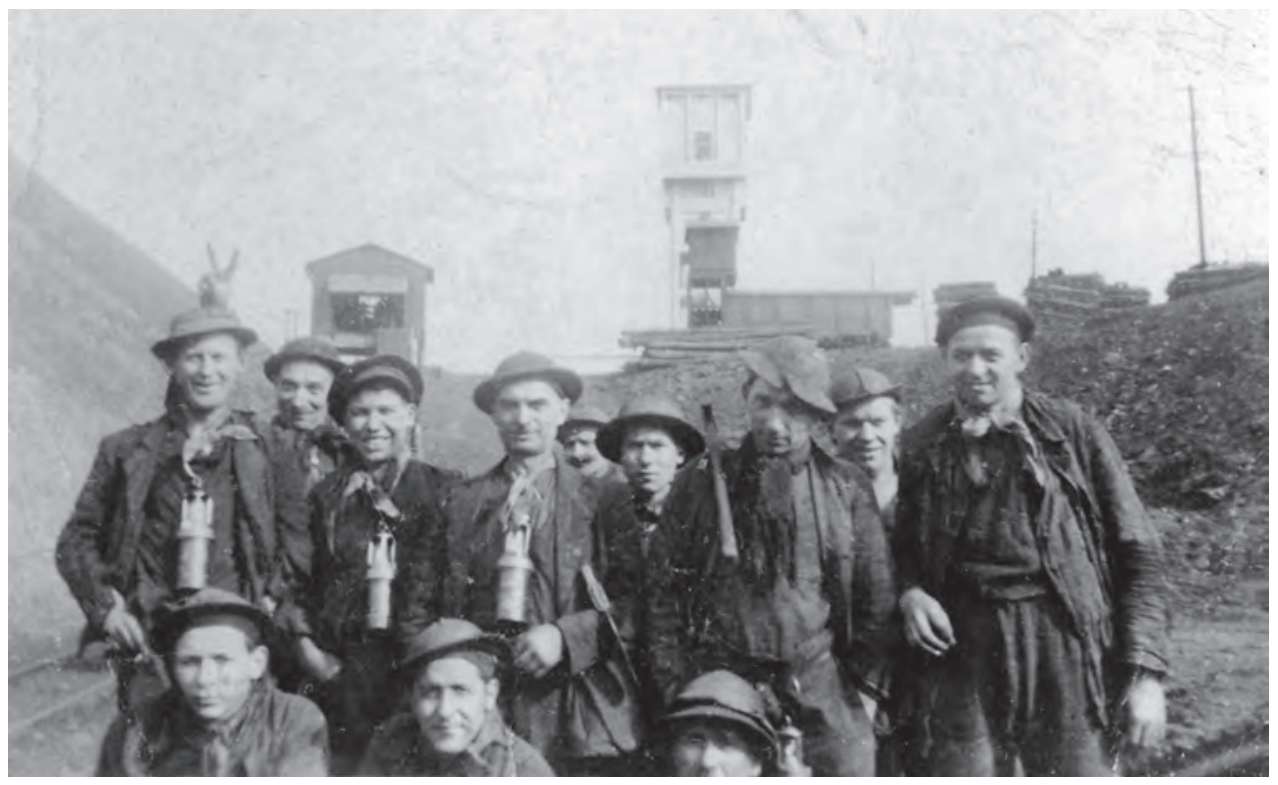

Nachtploeg voor zetel Marie van de NV Argenteau te Trembleur, 1946. (Rechtstaand, van links naar rechts: Pierre Rotheux, Alfred Penay, Joseph Omezzoli, Stephane Gmurowski, ?, Alphonse Demeyer, Stanislas Strusik, Raudne Meme, Stéphane?; Gezeten, van links naar rechts: Franz Vossen, Bruno Moranduzzo, Quinto Omezzoli). Coll. Blegny-Mine.

procent van de Luikse arbeiders, tegenover nog geen I4 procent voor de Luikse steenkoolnijverheid. Ook de textielsector en de bouwsector waren goed vertegenwoordigd in Luik (respectievelijk bijna I2 procent en II procent). ${ }^{66}$ Alhoewel de lonen in de steenkoolsector ondertussen gestegen waren, bleven andere sectoren betere voorwaarden bieden. ${ }^{67}$ Een tijdgenoot merkte hierover op:

Les ouvriers mineurs sont attirés par des professions plus lucratives et plus saines, notamment par les travaux d'entreprises de reconstruction, par la petite industrie et la construction mécanique, où l'on paie des salaires plus élevés qu'à la mine. ${ }^{68}$

Er was in de naoorlogse situatie dus enerzijds sprake van een grotere vraag naar arbeidskrachten in de mijnindustrie om een stijging van de productie te verwezenlijken, maar anderzijds een groter tekort in het aanbod omdat de Belgen weg wilden uit de mijnen. Bovendien had men te maken met een dalende arbeidsproductiviteit. Het was niet alleen de kwantiteit, maar ook de kwaliteit van de arbeiders die te wensen overliet. Om aan de gevraagde productie te voldoen moest men dus niet alleen trachten het vooroorlogse aantal arbeiders te bereiken, maar nog extra arbeiders aantrekken. ${ }^{69}$

66 L'administration communale de Liège, La Région Liégeoise. Démographie. Logement. Industrie et Commerce, 8I.

67 Het voordeel dat mijnwerkers aanvankelijk hadden door hun kortere werkdag verdween door de generalisering van de achturendag. Het uurloon van de arbeiders in andere sectoren onderging daardoor een veel grotere stijging. De mijnwerker was er dus in relatieve zin niet veel op vooruitgegaan. Zie: Fédération des associations charbonnières de Belgique, La Belgique devant le Problème Charbonnier, 40-44.

68 Logelain, 'Note', $365-366$.

69 Jacquemyns, La vie sociale, 36 . 


\section{DE DALENDE ARBEIDSPRODUCTIVITEIT EN DE SLECHTE FINANCIËLE SITUATIE IN DE BELGISCHE MIJNEN}

In juni 1946 bedroeg de gemiddelde dagproductie in de Belgische mijnen niet meer dan 76,3 procent van het vooroorlogse gemiddelde, terwijl het aantal houwers ondertussen al bijna terug was op het niveau van $1938.7^{\circ}$ Rijksmijningenieur Logelain leidde hieruit af dat de goede werkkrachten, in het bijzonder de nationale, meer en meer een afkeer hadden van het mijnwerk. Naast de geologische omstandigheden en het gebrek aan rationalisering en modernisering had ook het hoge absenteïsme een negatief effect op de productie. Er werd wederom veel gestaakt en vooral onder de houwers was er veel sprake van afwezigheid. De afwezige mijnwerkers werden echter geen sancties opgelegd, zoals in de Nederlandse mijnen. Daar werden bij ongeoorloofde afwezigheid boetes uitgedeeld, inhoudingen op het loon doorgevoerd en vakantiedagen geschrapt. Door de ongunstige inkomstenbelasting die een zesde werkdag 40 procent extra belastte,${ }^{71}$ werden de houwers niet gestimuleerd om meer te werken. Door de introductie van de verplichte zorgverzekering nam ook het aantal ziektedagen in de Belgische mijnen toe. ${ }^{72}$

Om de arbeidsproductiviteit te doen stijgen zou verdergaande rationalisatie noodzakelijk zijn geweest. Tijdens de bezetting werd de modernisering op een laag pitje gezet, bij gebrek aan middelen en kapitaal, maar ook om te voorkomen dat de groei van de productie naar de Duitse bezetter zou gaan. Vaak construeerde men snel slechte mijngangen om te kunnen voldoen aan de vraag naar steenkool van de Duitse bezetter. Daardoor verkeerde de ondergrondse infrastructuur na de Tweede Wereldoorlog in slechte staat. Na de oorlog vond er geen inhaalmanoeuvre plaats. Omdat er geen grote vernietigingen hadden plaatsgevonden, zoals in Frankrijk, werden er geen grote vernieuwingen doorgevoerd. ${ }^{73}$ Het was moeilijk voor de Belgische mijnen om voldoende kapitaal en middelen te vinden om de mijnen verder te moderniseren. Reeds voor de oorlog hadden sommige Waalse mijnen te kampen met een slechte financiële situatie, maar de bezetting verergerde de situatie nog. Uit onderzoek naar beheerraden van de mijnen bleek dat er in de na-oorlogse periode steeds minder een beroep werd gedaan op ingenieurs die elders ervaring hadden opgedaan. Bovendien ontstond er een desinteresse bij de investeerders, die hun middelen liever ter beschikking stelden aan andere sectoren..$^{74}$ In die situatie was er noch de nodige expertise, noch voldoende kapitaal om te moderniseren. Bovendien werd de mogelijkheid om moderne afbouwtechnieken te gebruiken sterk bepaald door de geologische omstandigheden. In tegenstelling tot het Kempische bekken, hadden de Waalse bekkens te kampen met steile en dunne lagen en brosse en sterk verontreinigde steenkolen. Waar in de Kempen meer dan de helft van de steenkool in 1956 met behulp van schaaf- en onderzaagmachines werd gewonnen, werd nog 88 procent van de steenkool in het Luikse bekken met de pneumatische afbouwhamer gedolven. ${ }^{75}$

70 Logelain, 'Note', 364.

7I Voor de oorlog was dat slechts 5,7 procent.

72 Brial, L'angoissant problème du charbon, 22-23; Logelain, 'Note', 367; Sunou, Les prisonniers de guerre allemands, 4-5.

73 Frankrijk kon bijvoorbeeld meer profiteren van het Marshallplan. Zie ook: Robinson, 'Report on Belgian coal industry', 455.

74 Caulier-Mathy, 'Les dirigeants de l'industrie houillère belge', 53-54.

75 Helfer, 'Meilensteine technischer Innovationen', 409; Annales des Mines de Belgique, 1956. In de andere Waalse bekkens, Borinage, Centre en Charleroi werd eveneens overwegend gebruikgemaakt van de afbouwhamer. 
Bovendien kondigde de overheid een verplicht lage verkoopprijs van de steenkool aan. De gemiddelde verkoopprijs per ton werd gebracht op $320 \mathrm{BEF}$, een aanzienlijk lager bedrag dan de gemiddelde kostprijs die soms opliep tot $432 \mathrm{BEF} .{ }^{76} \mathrm{Gemiddeld}$ verloor de Belgische steenkoolnijverheid in 1948 zo meer dan 74 BEF per ton geproduceerde steenkool. ${ }^{77}$ De verlieslatende bedrijven werden wel gecompenseerd door subsidies, maar dat was amper voldoende. ${ }^{78}$ Het naoorlogse overheidsbeleid bestond erin de verkoopprijs van de steenkool op een artificiële manier laag te houden. ${ }^{79}$ Hierdoor werd er wel veel omzet gemaakt, maar waren de winstmarges laag. Als gevolg hiervan was het voor een groot deel van de mijnen onmogelijk om de nodige reserves aan te leggen en het benodigde kapitaal te sparen om te moderniseren en rationaliseren.

De lage verkoopprijs van de steenkool werd gecombineerd met verplichte hoge lonen en sociale lasten. ${ }^{80}$ Voor de Tweede Wereldoorlog had de Belgische steenkoolindustrie de laagste loonschaal van alle steenkoolproducerende landen in Europa. Na de oorlog koos de Belgische overheid ervoor in het kader van de steenkolenslag de steenkoolproductie op korte termijn op te voeren door inzet van meer arbeid. Om het werk in de steenkolenmijnen aantrekkelijker te maken werden de loonschalen verhoogd. ${ }^{81}$ De werkgevers verklaarden echter niet in staat in te gaan op de looneisen, indien ze de verkoopprijzen niet voldoende konden laten stijgen. Er ontstond daardoor een permanente confrontatie tussen de opeenvolgende regeringen en de werkgevers over de wens van de regering om te voorzien in voldoende steenkoolvoorraad tegen lage prijzen. Bovendien zorgde het tijdens de oorlog ingestelde compensatiestelsel ervoor dat de winstgevende mijnen een financiële aderlating ondergingen. ${ }^{82}$

The government, in order to hold down inflation, instituted controlled prices and a subsidy plan which was combined with a compulsory industry profit-sharing plan. The latter provided that mines making money had to turn over a substantial portion of their profits to companies losing money..$^{83}$

Ook slaagde de Belgische steenkoolnijverheid er niet in de productie te concentreren. De verspreiding, de geringe kwaliteit en de ingewikkelde geologische gesteldheid van de steenkolenvelden verhinderden dat. In 1958 bedroeg de gemiddelde productie per zetel in België slechts 300.000 ton. De problemen golden met name de Waalse mijnen, want die in de Kempen overschreden met gemak een miljoen ton. ${ }^{8}$ In het Luikse bekken, waar net zoals in Charleroi vooral huisbrandkolen werden geproduceerd, was de sterke opsplitsing in kleine mijnmaatschappijen opvallend. ${ }^{85}$ De Conseil des Charbonnages steunde onvoldoende

76 Sunou, Les prisonniers de guerre allemands, 3 .

77 RAH, archief FEDECHAR, inv.nr. 1869: rapport 'Investigation about the Belgian Coal industry', I949.

78 Kurgan-Van Hentenryk en Puissant, 'Industrial relations in the Belgian Coal Industry', 257-258.

79 Sedert de eerste grote Belgische kolencrisis van 1928 stonden de steenkolenprijzen direct of indirect onder toezicht van de regering. Zie: Federatie der Belgische Kolenverenigingen, 'Opmerkingen gemaakt omtrent het "Verslag Robinson”', 479.

80 RAH, archief FEDECHAR, inv.nr. 1869: rapport 'Investigation about the Belgian Coal industry', I949.

8I Robinson, 'Report on Belgian coal industry', 454-455.

82 Tot september 1947 was deelname aan dit plan nog vrijwillig. Daarna werd het zogenaamde 'Wederuitrustingsplan' door de overheid verplicht gesteld. Zie: Minten et al., Een eeuw steenkool in Limburg, I5I.

83 Robinson, 'Report on Belgian coal industry', 457.

84 Delaet, 'Huit siècles d'exploitation charbonnière en Wallonie'; Federatie der Belgische Kolenverenigingen, 'Opmerkingen gemaakt omtrent het "Verslag Robinson", 482.

85 Minten et al., Een eeuw steenkool in Limburg, 25. In 1946 hadden de Luikse mijnen gemiddeld minder dan $\mathrm{I} .500$ arbeiders in dienst en produceren ze gemiddeld slechts I50.00o ton steenkool per jaar. Zie: Annales des Mines de Belgique, I946-47. 
de concentratie van kleine onrendabele mijnen tot grotere kapitaalkrachtiger eenheden. ${ }^{86}$ Mijnen die na de Tweede Wereldoorlog niet in staat waren een rationalisering door te voeren, konden de concurrentie op de steenkolenmarkt niet volhouden en moesten vroeg of laat om economische redenen sluiten, hoewel die sluiting vaak nog wat werd gerekt door staatsingrijpen. ${ }^{87}$ De financiële situatie en de magere opbrengsten zorgden in het Luikse bekken voor de sluitingen van de mijnen Arbre Saint-Michel (reeds sinds 1934 en liquidatie, stopzetting van de productie in 1949 en formele sluiting in 1952), Gives et Ben (1950) en Six Bonniers (I948)..$^{88}$

\section{DE STEENKOLENSLAG}

In januari 1945 werd door socialistisch premier Achille Van Acker (Achille Charbon) de 'steenkolenslag' uitgeroepen. ${ }^{89}$ Energie was onmisbaar voor de snelle wederopbouw van het land en steenkool was de enige brandstof die onmiddellijk kon worden aangeboord. De steenkolenproductie moest dus zo vlug mogelijk worden opgedreven.${ }^{\circ}$ Het was duidelijk dat een rendementsstijging voor vele Belgische mijnen erg moeilijk te realiseren was. Meer output kon in de meeste steenkolenmijnen alleen verkregen worden door meer input van arbeid. Het beleid richtte zich dus vooral daarop.

In de eerste fase van de kolenslag trachtte de Belgische regering de vlucht uit de mijnen met dwangmaatregelen tegen te gaan. ${ }^{9 \mathrm{I}}$ Op I2 april 1945 kondigde premier Van Acker de burgerlijke mobilisatie af: ieder die na ro september I944 op een gegeven moment als mijnwerker had gewerkt werd op straffe van sancties verplicht zich opnieuw aan te melden voor werk in de mijnen. Werklozen die zonder geldige reden weigerden het werk in de mijnen te hervatten, werden van de werkloosheidsvergoedingen uitgesloten en konden zelfs strafrechtelijk worden vervolgd. Werklozen zonder uitkering kregen een propagandabrief toegestuurd. ${ }^{22}$ Bovendien werden stakingen verboden. Deze burgerlijke mobilisatie werd pas in 1948 afgeschaft. ${ }^{93}$

Door deze dwangmaatregelen werd het arbeidstekort echter niet opgelost. Daarom probeerde men de Belgen opnieuw warm te maken voor het mijnwerkersberoep. Reeds tijdens de oorlog was er nagedacht over maatregelen om het werk in de mijnen voor Belgen aantrekkelijker te maken en zo het arbeidstekort te verhelpen. Deze maatregelen hadden betrekking op de arbeidsomstandigheden en arbeidsvoorwaarden, op het imago van het mijnwerkersberoep, de huisvesting en de opleiding van mijnwerkers.

\footnotetext{
86 Helfer, 'Meilensteine technischer Innovationen', 4I3.

87 Ibidem, 405 .

88 Gegevens ontleend aan Annales des Mines de Belgique, I9or-I953.

89 Kurgan-Van Hentenryk en Puissant, 'Industrial relations in the Belgian Coal Industry', 257.

9o Tot midden 1947 bleef de productie in de meeste industrietakken (staal, metaal, textiel) geremd wegens een gebrek aan brandstoffen. Zie: Martens, 25 jaar wegwerparbeiders, I53-154.

9I Leboutte, 'Coal mining, foreign workers and mine safety', 220.

92 Martens, 25 jaar wegwerparbeiders, I55-I56.

93 Ibidem, 156 en Kurgan-Van Hentenryk en Puissant, 'Industrial relations in the Belgian Coal Industry', 257.
} 


\section{Arbeidsomstandigheden en arbeidsvoorwaarden: het mijnwerkersstatuut}

Om de arbeidsomstandigheden van de mijnwerkers te verbeteren werd in november 1944 op initiatief van de mijnwerkgevers L'Institut d'Hygiène des Mines gecreëerd. Het ministerie van Werkgelegenheid en Sociale Voorzorg volgde op 6 december 1945 met Le conseil supérieur d'hygiène des Mines. Deze instellingen richtten zich vooral op de stofbestrijding, een probleem dat met de mechanisatie erger werd. De strijd tegen de ongevallen werd gestreden door l'Administration des Mines. ${ }^{94}$ De belangrijkste stap bij het herwaarderen van het mijnwerkersberoep was echter het mijnwerkersstatuut:

Al die overwegingen en de onmiddellijke noodzakelijkheid van het opdrijven van de kolenuitdelving om de andere bedrijuen aan den gang te brengen, hebben de Regeering ertoe aangezet den mijnwerker te begiftigen met een 'statuut' dat stoffelijke en zedelijke voordeelen bevat die tot doel hebben hem er van te overtuigen dat zijn arbeid naar zijn wezenlijke waarde wordt geschat en hem te beloonen voor een verdienstelijke buitengewone inspanning. ${ }^{95}$

Het doel van het mijnwerkersstatuut was de levensstandaard van de mijnwerkers te verbeteren en zodoende hun aanwerving te vergemakkelijken. ${ }^{6}{ }^{6}$ Geheime besprekingen gedurende de oorlog tussen de werkgevers en de vakbonden leidden tot een nieuwe wetgeving onmiddellijk na de bevrijding. De wet van Io januari 1945 bepaalde de beginselen van de maatschappelijke zekerheid der mijnwerkers en gelijkgestelden. De doeleinden waren: de ouderdomspensioenen op een behoorlijk bedrag te handhaven of te brengen; het stelsel van de verplichte verzekering tegen ziekte of invaliditeit te verbeteren; te voorzien in de steun aan werklozen, in afwachting van het tot stand brengen van een stelsel van verplichte verzekering; de kinderbijslag voor de mijnwerkers te verhogen; de betaling van de lonen, met een jaarlijkse vakantie, te verzekeren. Een wet van 8 mei 1945 bracht de in de wet van Io januari aangekondigde verbeteringen in het ouderdoms-, overlevings- en invaliditeitsverzekeringsstelsel. ${ }^{7}$ De voordelen van het statuut hadden betrekking op: recht op ouderdomspensioen na dertig jaar ondergrondse arbeid ongeacht de leeftijd; ${ }^{98}$ verhoging van de ouderdomspensioenen; bijkomend jaarlijks verlof; gratis spoorkaarten; een premie bij tewerkstelling (I.000 BEF meteen en nog eens I.000 BEF na zes maanden dienst); vrijstelling van de militaire dienst (voor ondergronders, indien ze in de mijnen bleven werken tot ze 28 jaar oud waren); ${ }^{99}$ gratis huishoudkolen en steenkool tegen gunstige prijzen; extra levensmiddelenrantsoenen; voordelen bij het kopen of bouwen van een huis en goedkope leningen, gratis melkbedeling. ${ }^{100}$

Daarnaast verhoogde de Belgische regering de loonschalen in de Belgische mijnen in die mate dat België na de Tweede Wereldoorlog de hoogste lonen in de Europese steenkoolin-

94 Logelain, 'Note', $369-37$ I.

95 Arbeidsblad, nr. 4-5, april-mei 1945, II6-II7.

96 Logelain, 'Note', 369.

97 De Groote, De pensioenregeling voor mijnwerkers in België, I4-I5.

98 Dit was een grote verandering t.o.v. de vorige pensioenregeling waarbij een minimumleeftijd ( 55 jaar) gold. Indien het aantal ondergrondse dienstjaren de dertig overschreed, werden er nog extra supplementen toegekend. RAH, archief FEDECHAR, inv.nr. I868: 'Evolutie van de arbeidsvoorwaarden, I949-I954' en I870: 'Rapport sur le problème charbonnier en Belgique, I939'.

99 RAH, archief FEDECHAR, inv.nr. 1869: rapport 'Investigation about the Belgian Coal industry', I949.

Iоo Arbeidsblad, nr. 4-5, april-mei 1945, II6-II7; RAH, archief FEDECHAR, inv.nr. I868: 'Evolutie van de arbeidsvoorwaarden, 1949-1954' en 1869: rapport 'Investigation about the Belgian Coal industry', I949. 
dustrie had. ${ }^{\text {Ior }}$ De overheid, de werkgeversorganisaties en de vakbonden hoopten dat met het verbeteren van de materiële voorwaarden Belgische arbeiders weer bereid zouden zijn in de steenkolenmijnen te werken. De nieuwe sociale wetten zorgden er echter paradoxaal genoeg voor dat de steenkoolindustrie nog meer arbeiders verloor. Het recht op pensioen na dertig jaar ondergrondse dienst had tot gevolg dat een groot deel van de ervaren mijnwerkers vertrok. ${ }^{102}$ Op een Nationale Arbeidsconferentie op 5 juli I 946 werd een Commission Nationale Mixte des Mines ingesteld om verder te onderzoeken hoe de condities en materiële toestand van de mijnwerker nog meer konden worden verbeterd, teneinde meer mijnwerkers te kunnen rekruteren. ${ }^{103}$

\section{Propaganda voor mijnarbeid}

Naast het toekennen van een eigen statuut en een verbetering van de arbeidsomstandigheden werd er ook getracht potentiële mijnwerkers aan te trekken door grootscheepse campagnes. Het doel van die campagnes was vooroordelen over de steenkoolnijverheid als een slechte werkgever te bestrijden en het beroep van mijnwerker in ere herstellen. Men wilde als het ware een climat de la mine creëren. ${ }^{\text {I04 }}$ Dit gebeurde via de kranten en de radio, maar men richtte zich ook rechtstreeks tot de jongeren door campagne te voeren op de scholen waar men de I4-jarige jongens informeerde 'hoe mooi het beroep van mijnwerker wel was'. De socialistische minister van onderwijs Herman Vos riep de onderwijzers in juli 1946 op om ruime aandacht te schenken aan het belang van de mijnindustrie. ${ }^{\text {105 }}$

\section{Huisvesting}

Ook door het mijnpatronaat zelf werd er aandacht besteed aan maatregelen om meer Belgen warm te maken voor het mijnberoep. Een probleem dat nauw met dat van de rekrutering van geschikt personeel samenhing was de huisvesting van de mijnwerkers. Indien men voldoende arbeiders wilde aantrekken, moest men ook voldoende woningen voorzien. De Luikse mijnen hadden echter weinig financiële speelruimte. De leningen uit het Fonds du Logement de la Ligue des Familles nombreuses waren in vergelijking met de rest van het land klein. De reden hiervoor was simpel: deze golden alleen voor grote families, waarvan er verhoudingsgewijs maar weinig waren in het Luikse arrondissement. Het probleem van de huisvesting was niet zozeer kwantitatief, maar eerder kwalitatief. Er bestond veel voorlopige huisvesting: barakken van het Fonds du Roi Albert; barakken toehorend aan de industriële ondernemingen; de huisjes opgetrokken in I945-46 om slachtoffers onder te brengen; voorlopige huisvesting afkomstig uit privé initiatief. In het Luikse arrondissement was in 1947 een groter deel van het onroerend goed van tijdelijke aard dan in de andere arrondissementen, en tot het einde van 1953 nam het aantal voorlopige woningen alleen maar toe. Bovendien waren er in 1947 ongeveer II.267 krotwoningen. Uit contemporaine studies blijkt dat

I0I Robinson, 'Report on Belgian coal industry', 455.

102 Logelain, 'Note', 366; Federatie der Belgische Kolenverenigingen, De koolindustrie, I5.

103 Martens, 25 jaar wegwerparbeiders, I57-I58; Logelain, 'Note', 369.

I04 Logelain, 'Note', 372-373.

I05 Kohlbacher, 'Onderwijs en vakopleiding', 265. 


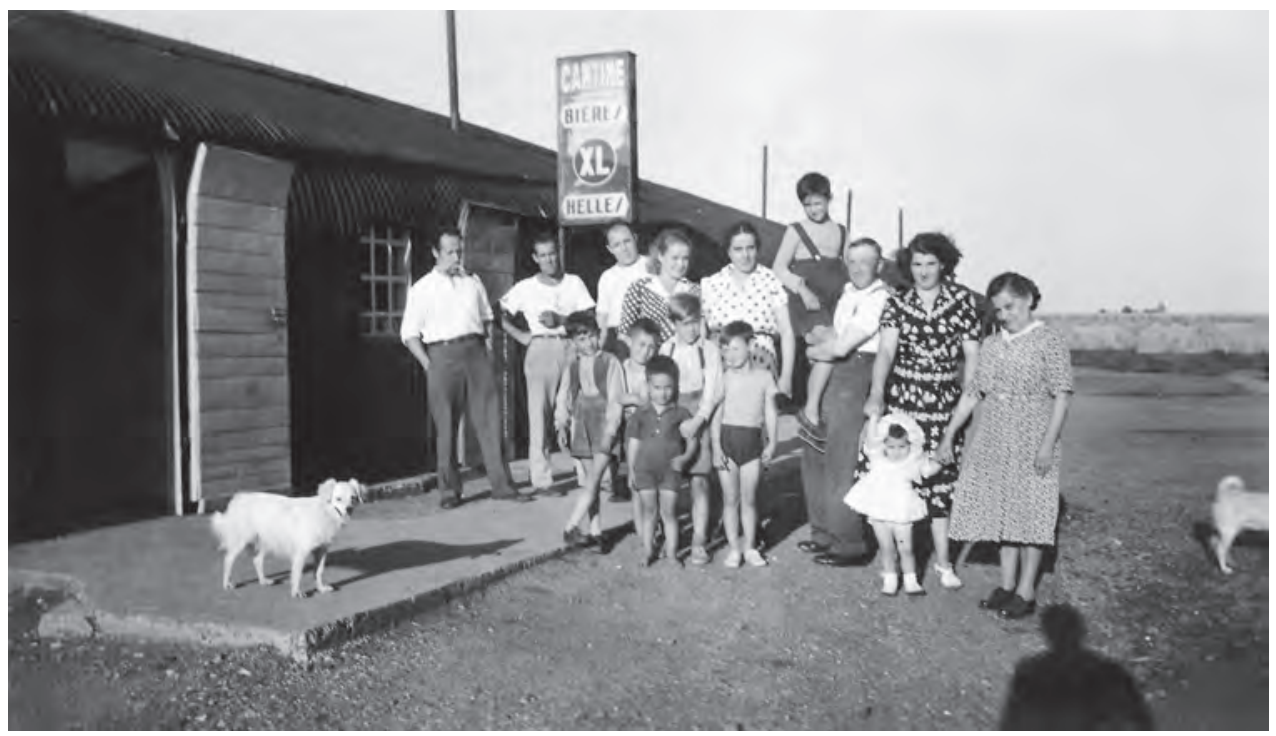

Barakkenkamp bij de NV Argenteau te Trembleur, 1950. Foto Abel Desmit. Coll. Blegny-Mine.

er in het Luikse behoefte was aan bijna $\mathbf{3 2 . 0 0 0}$ nieuwe woningen, zonder daarbij rekening te houden met de komst van de vele buitenlandse arbeiders. Om het probleem van de huisvesting aan te pakken werd door de overheid de Conseil central de la Construction d'habitation pour mineur opgericht om op 5 jaar tijd met 5 miljard BEF ruim 25.000 nieuwe woningen voor mijnwerkers op te richten. Ook werd het regime van leningen aan de mijnarbeiders ingericht. ${ }^{106}$ Hierdoor konden mijnwerkers goedkopere leningen aangaan, waarbij de overheid de kosten van het verschil in rente droeg. ${ }^{107}$ De steenkolenmijnen werd ook toegestaan 40 procent van het 'wederuitrustingsfonds' te gebruiken voor het construeren van mijnwerkerswoningen en logement voor de vreemde arbeidskrachten. ${ }^{108}$ Eind I948 woonden 23.703 mijnwerkers in woningen van de Belgische steenkolenmijnen. ${ }^{\text {109 }}$

\section{Opleiding}

$\mathrm{Na}$ de Tweede Wereldoorlog werden maatregelen genomen om meer uniformiteit aan te brengen in het versnipperde onderwijsaanbod en via een betere opleiding en scholing het mijnwerkersberoep aantrekkelijker te maken. Vanaf 1870 bestonden er aan de Waalse nijverheidsscholen een twintigtal mijnafdelingen, maar in de meeste mijnen werd een traditionele arbeidspolitiek gevoerd zonder veel aandacht voor een hogere arbeidskwalificatie. Kennis en vaardigheden werden over het algemeen van vader op zoon en van ervaren op beginnend mijnwerker overgebracht. Doordat vaders hun zonen liever in een ander be-

Io6 Eind januari 1948 waren er reeds 5.000 woningen in aanbouw. Zie: RAH, archief FEDECHAR, inv.nr. I868: 'Evolutie van de arbeidsvoorwaarden, I949-1954'.

I07 Nationaal Instituut voor Woning en Huisvesting, Het probleem van de huisvesting in België, 173-174 en 236.

Io8 RAH, archief FEDECHAR, inv.nr. I868: 'Evolutie van de arbeidsvoorwaarden, I949-1954'.

Iog Federatie der Belgische Kolenverenigingen, De koolindustrie, 15. 


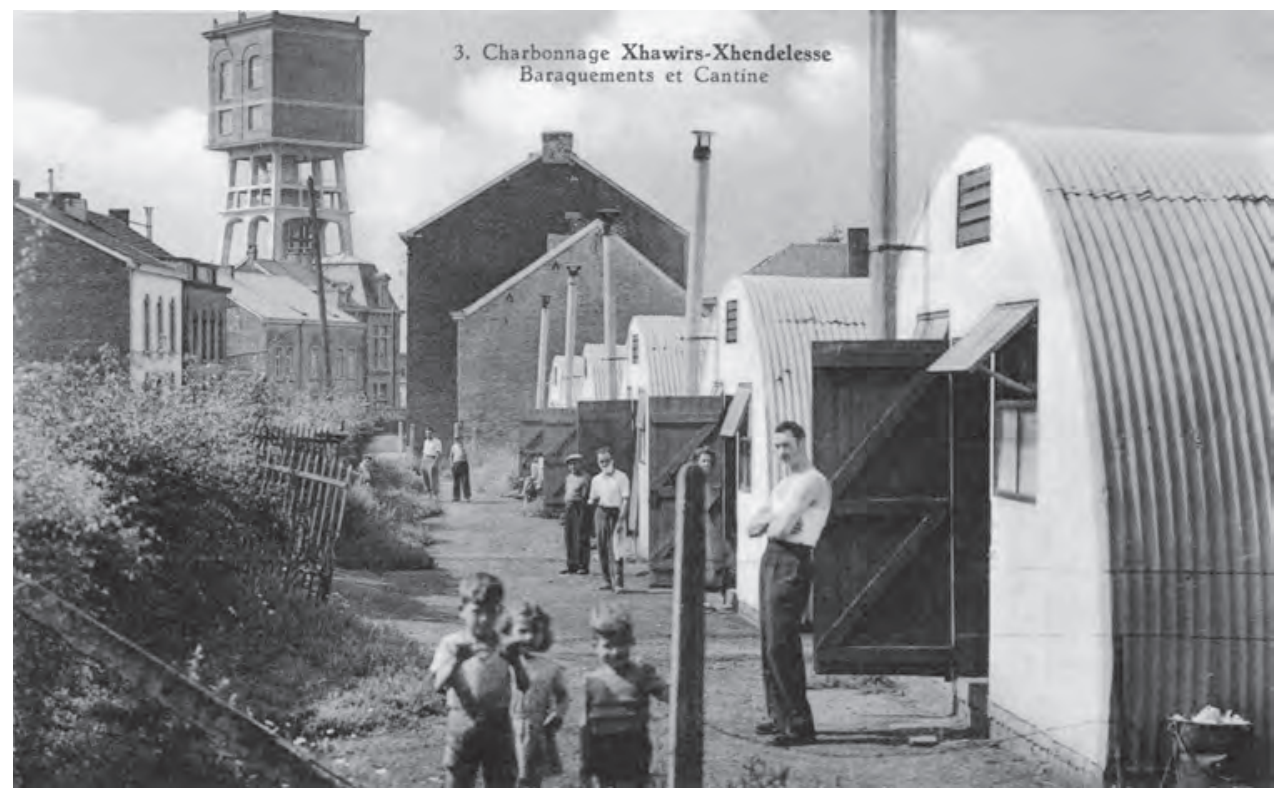

Barakkenkamp bij zetel Xhawirs te Xhendelesse van de NV Wérister, ca. 1960. Coll. Blegny-Mine.

roep zagen, verdween dit systeem geleidelijk. ${ }^{\text {IIo }}$ Mijnafdelingen kenden aanvankelijk een behoorlijk succes, maar na de Eerste Wereldoorlog nam hun populariteit al snel af. Ook de mijnopleidingen kregen dus te kampen met een 'vlucht'. Deze had als gevolg dat die richtingen doorgaans weinig leerlingen telden die daarenboven een laag niveau bereikten en het weinig ernstig opnamen. Deze restcategorie was ondanks de grote investering en de aanpassing van de cursussen eerder een ondankbaar publiek. ${ }^{\mathrm{III}}$ In opdracht van de patroonsorganisatie FEDECHAR onderzocht een in 1947 ingestelde commissie van experts het probleem van de technische en beroepsopleiding in de mijnen. ${ }^{\mathrm{II} 2}$ Mijnbouwonderwijs vormde immers één van de mogelijke remedies om de vlucht uit de mijnen tegen te gaan: opleiding kon het mijnwerkersberoep revaloriseren, veiligheid bevorderen, het personeelsbestand stabiliseren en nieuwe productietechnieken introduceren. In 1954 uniformiseerde de overheid de door het mijnpatronaat ingerichte opleidingen en kwamen de 18 bestaande instellingen onder toezicht van het Mijnwezen. Daar konden jongens vanaf I4 jaar een beroepsopleiding tot mijnwerker volgen. In vergelijking met bijvoorbeeld de Nederlandse Ondergrondse Vakscholen (Ovs) was het aantal leerlingen echter zeer laag: in I95I telden de I8 instellingen tezamen I.299 leerlingen. Afgezet op het totaal aantal arbeiders (132.I34) is dat nog geen I procent. In dat jaar waren er in Nederland 3.007 Ovs-leerlingen, een percentage van bijna $6 .{ }^{\mathrm{II} 3} \mathrm{Dit}$ is een duidelijke indicatie voor de geringe belangstelling van jongeren om de mijn in te gaan. Later, vooral na de ramp van Marcinelle in I956, werd er opnieuw

Iro Jacquemyns, La vie sociale, 38-39.

III Boucneau, Hier porions vormen?, 32-33.

112 Kohlbacher, 'Onderwijs en vakopleiding', 266-267.

II3 Europäische Gemeinschaft für Kohle und Stahl, Die Berufsausbildung im Steinkohlenbergbau, I98; SHCL, archief GSL, Statistiek VIII-I7 (Ovs). 


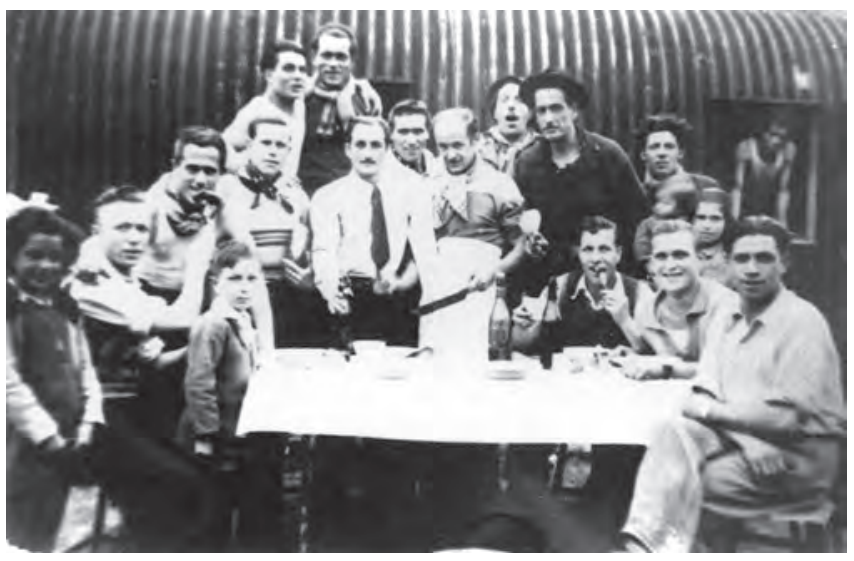

Barakkenkamp bij de NV Argenteau te Trembleur, ca. 1960? Coll. Blegny-Mine.

ingezet op onderwijs om voldoende gekwalificeerde arbeidskrachten te vinden. Ditmaal waren echter niet 'onwillige' jongeren de doelgroep, maar de vele, over het algemeen ongeschoolde en onervaren arbeidsmigranten. Een versnelde beroepsopleiding, training within industry-methode (TWI), moest de volwassen arbeiders op een snelle manier vertrouwd maken met de meest voorkomende ondergrondse taken. Een belangrijk deel van de opleiding was gericht op veiligheid en de methode was onder meer gebaseerd op het feit dat ervaren arbeiders, zogenaamde monitors, bepaalde handelingen in een oefen- of leerpijler voordeden, die door de nieuwkomers, de mijnwerkers in opleiding, werden herhaald. ${ }^{\mathrm{I} 4} \mathrm{De}$ opleiding vond dus voor een groot deel alvast op de eigenlijke werkplek plaats. In het Luikse bekken werd zo in 1964, op initiatief van de Luikse patroonsorganisatie en drie grote mijnbedrijven, S.A. Grande Bacnure, Hasard en Wérister, het Centre de formation professionelle accélérée pour les travailleurs des mines de la Province de Liège opgericht. Deze mijnen zonden regelmatig hun vers aangeworven arbeiders naar dit centrum dat opleidingen verschafte die gebruikmaakten van de TWI-methode. Met de opeenvolgende sluitingen van Wérister (I969), Grande Bacnure (I97I) en de voorlaatste mijnzetel van Hasard in I974, verloor het centrum haar functie en zou het uiteindelijk slechts Io jaar bestaan. ${ }^{\text {II5 }}$

\section{DUITSE KRIJGSGEVANGENEN}

Al deze maatregelen ten spijt werd het arbeidstekort niet opgelost. De Belgen bleven de steenkolenmijnen mijden en men moest een beroep doen op acute oplossingen om de hoogste nood te lenigen. Een (tijdelijke) oplossing werd gevonden in de inschakeling van Duitse krijgsgevangenen. De Belgische regering sloot overeenkomsten met het Britse en Amerikaanse leger voor de overdracht van meer dan 50.000 Duitse krijgsgevangenen. ${ }^{\mathrm{II} 6}$ In

114 Delbroek, 'In de put', 389-391.

II5 Vanvelthem, 'La formation professionnelle de courte durée', 4-5.

II6 Sunou, Les prisonniers de guerre allemands, II-I4. Verschillende bronnen spreken elkaar tegen: 64.00o (Minten et al.) bijna 50.000 (Kohlbacher, Goddeeris), 45.000 (Kurgan-Van Hentenryck en Puissant) 40.000 (Martens). Het verschil schuilt hem in het aantal toegekende Duitse krijgsgevangenen door de Amerikaanse en Britse autoriteiten (64.00o) en het daadwerkelijk aantal tewerkgestelde Duitse krijgsgevangenen. 
GRAFiEK 4.7 Het AANTAl DUITSE KRIJGSGEVANGENEN TEWERKGESTELD IN DE LUIKSE MIJNEN, I945-I947

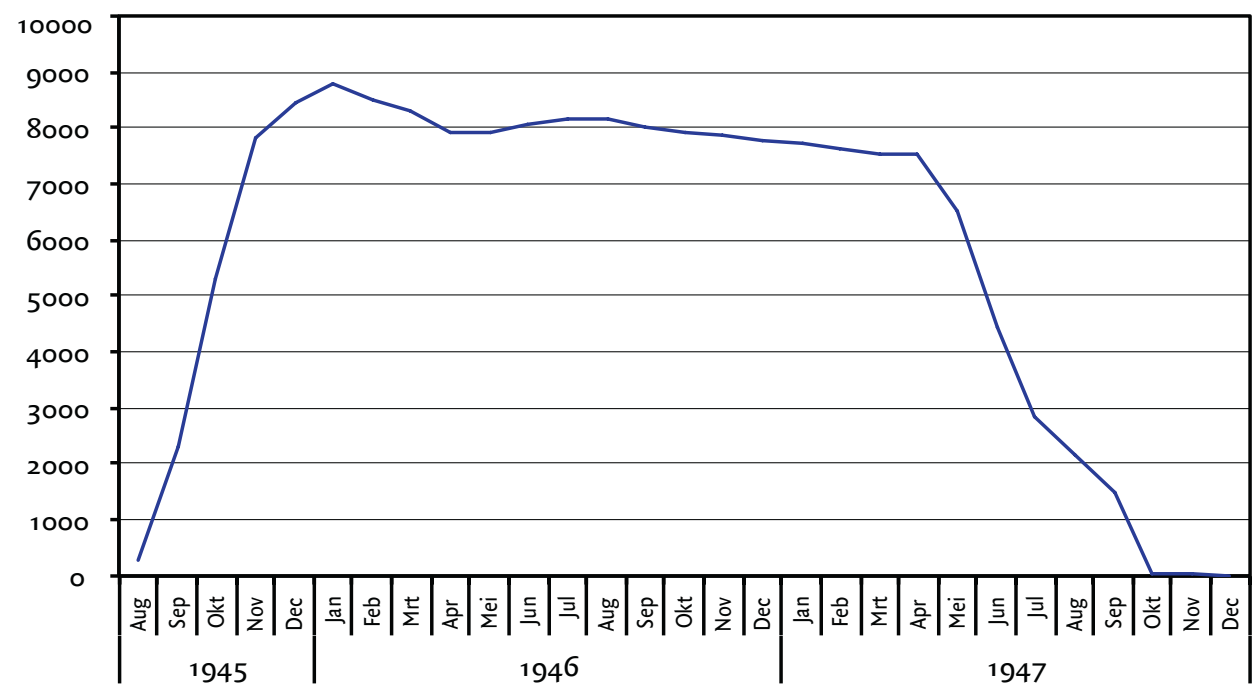

Bron: RAH, archief FEDECHAR, inv.nr. I579: 'Personeelsstatistieken' (eigen berekeningen).

mei 1945 kwamen de eerste groepen aan. ${ }^{117}$ Volgens FEDECHAR werden er op het hoogtepunt in januari 1946 45.927 krijgsgevangenen in de Belgische mijnen tewerkgesteld. Deze waren als volgt verdeeld over de Belgische bekkens: I4.I4I in de Kempen, I0.223 in het bekken van Charleroi, 8.644 in de Luikse mijnen, 6.844 in de Borinage en tot slot 5.874 in Centre. Uit de personeelsstatistieken van FEDECHAR blijkt dat bijna alle Luikse mijnen, behalve Gives en Argenteau-Trembleur, gebruik maakten van deze arbeidskrachten. ${ }^{\text {I18 }}$

Voor de huisvesting van de krijgsgevangenen werden kampen ingericht in Ans, Vottem, Jemeppe, Tilleur, Cheratte, Wandre, Fléron, Micheroux, Seraing en Bois d'Avroy. ${ }^{\text {II } 9}$ Uit gegevens over de productiviteit van de meestal ongeschoolde en onervaren Duitse krijgsgevangenen blijkt dat die naar verhouding sterk achterbleef, met name bij de houwers (grafiek 4.8). Het gebrek aan kwaliteit moest worden goedgemaakt door de ruime kwantiteit.

Tussen mei en november 1947 werden de Duitsers gerepatrieerd, nadat hen in april nog de kans was geboden zich als vrije arbeider bij de Belgische steenkolenmijnen aan te bieden. Slechts 3.865 onder hen maakten gebruik van deze mogelijkheid. ${ }^{120}$ Een andere groep die de arbeidsnood (tijdelijk) kwam lenigen waren de 'onvaderlandse Belgen'. Incivieken werden vanaf 1946 gedwongen tewerkgesteld, maar alleen in de Kempische mijnen. Op het hoogtepunt (tweede helft i946-eerste helft 1947) waren ze met ca. 3.000. Daarna daalde hun aantal tot omstreeks I.500. Eind I948 verdwenen deze incivieken uit de Limburgse mijnen. ${ }^{\mathrm{I} 2 \mathrm{I}}$

II7 Kohlbacher, Het Russisch kamp, 83.

II8 RAH, archief FEDECHAR, inv.nr. I579: 'Personeelsstatistieken'. Dat deze aantallen enigszins afwijken van de aantallen opgegeven in tabel 3.I uit hoofdstuk 3 heeft te maken met een ander telmoment.

II Sunou, Les prisonniers de guerre allemands, I39, annexe I.

I20 Ibidem, 70-7I.

I2I RAH, archief FEDECHAR, inv.nr. I579: 'Personeelsstatistieken'. 
GRAFIEK 4.8 HET VERSCHIL IN RENDEMENT TUSSEN DE VRIJE ARBEIDERS EN DE Duitse KRIJGSGEVANGENEN IN HET LUIKSE BEKKEN, I946 (NETTORENDEMENT IN KG., DIENST VAN $8 \mathrm{U}$ )

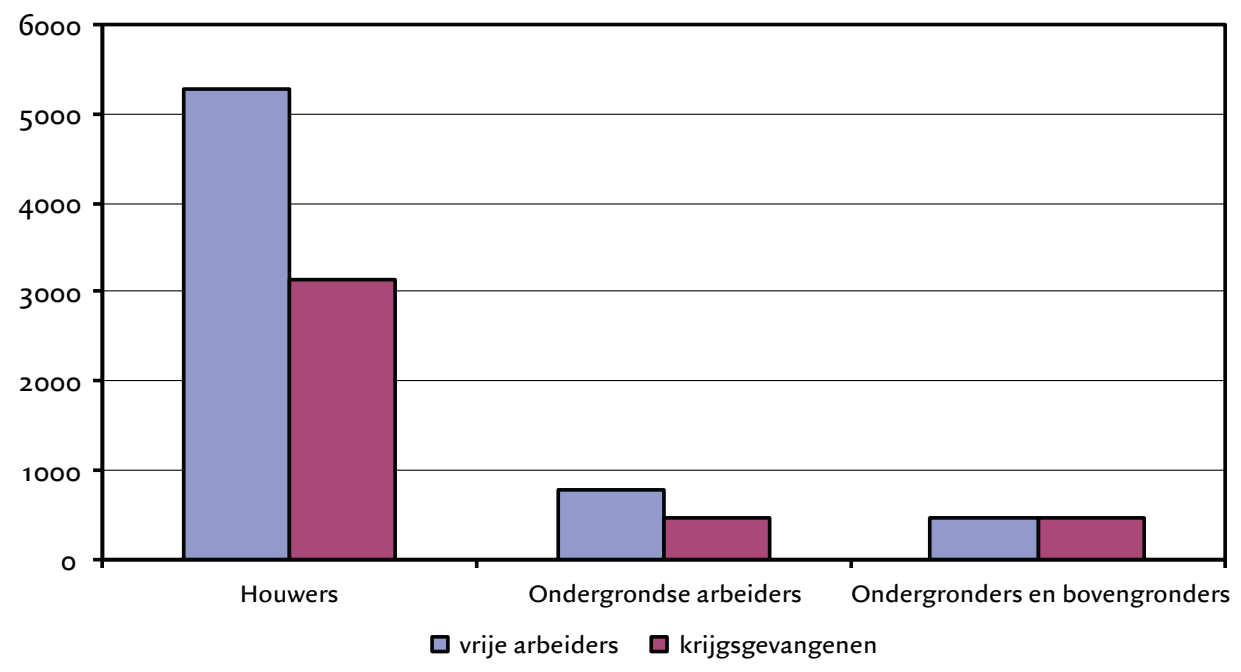

Bron: Annales des Mines de Belgique, I946-1947.

\section{DE KOMST VAN DE VREEMDELINGEN: ONGEWENST MAAR ONVERMIJDELIJK}

Het tekort aan arbeidskrachten werd dus slechts tijdelijk opgelost. Men moest op zoek gaan naar andere arbeiders om een vervanging te vinden voor de Belgen die de mijnen steeds meer de rug toekeerden. Het aantrekken van arbeidskrachten uit het buitenland werd echter net na de oorlog nog niet als een bevredigende oplossing gezien:

Pour remédier à cette crise d'effectifs, on dut faire appel à la main d'oeuvre étrangère: c'était une solution insuffisante. Il faut d'autres remèdes. Il faut rendre au métier de mineur toute l'attraction ancienne qu'il exerçait principalement sur les jeunes couches ouvrières. ${ }^{122}$

Vreemde werkkrachten werden gezien als onervaren en minder betrouwbaar. De rijksmijningenieur stelde: 'Het beroep op uitheemse werkkrachten is een hulpmiddel waarvan echter niet te veel moet verwacht worden.' ${ }^{123}$ De meeste vakbonden (zoals de Centrale des Mineurs) zagen de vreemde arbeidskrachten aanvankelijk ook niet graag komen. ${ }^{124}$ Bepaalde vakbondsleiders bleven ertegen gekant vanwege de mogelijke concurrentie voor de Belgische arbeiders en de vrees dat de vreemdelingen zich voor lagere lonen zouden laten aanwerven. Ze zagen hierin een bedreiging van de arbeiderssolidariteit. ${ }^{125}$

Na verloop van tijd werd het echter steeds meer de vraag of de Belgische steenkoolindus-

I22 Brial, L'angoissant problème du charbon, 20.

123 Logelain, 'Note', 380.

124 Delaet, 'La centrale syndicale', I52-153.

I25 O.m. H. Dethier, één van de leiders van de Nationale mijnwerkerscentrale en H. Van Buggenhout, leider van de Centrale van de Vrije Mijnwerkers, geciteerd in: Martens, 25 jaar wegwerparbeiders, I48. 
trie wel zonder deze extra arbeidskrachten kon. Men ging ervan uit dat het aanwerven van vreemdelingen steeds van tijdelijke, conjuncturele aard was. Volgens Martens werd het Belgische immigratiebeleid tussen 1945 en 1970 steeds herleid tot een conjunctureel tewerkstellingsbeleid. Al naargelang de af- of aanwezigheid van werkloosheid werden buitenlanders aangetrokken of afgewezen. ${ }^{126}$ Zelfs bij een hoge werkloosheid bleef er echter een arbeidstekort voor de steenkolenmijnen. Wanneer we terugkijken naar grafiek 4.I in het begin van dit hoofdstuk is het beeld duidelijk: hoewel niet gezien als de ideale oplossing, gingen de vreemdelingen in de Luikse mijnen vanaf de jaren 1950 meer dan de helft van het arbeidsbestand uitmaken. Op 20 juni 1946 werd een bilateraal akkoord met Italië gesloten worden voor het zenden van Italiaanse arbeidsmigranten in ruil voor steenkool. ${ }^{127}$ In totaal werden er door FEDECHAR tussen I946 en I949 meer dan 77.000 Italianen aangeworven. ${ }^{\text {I28 }}$ Samen met ongeveer 23.000 displaced persons (op grond van een overeenkomst met de geallieerden in januari 1947) ${ }^{129}$ moesten die de Duitse krijgsgevangenen vervangen. In het Luikse bekken kwamen respectievelijk I6.290 Italianen en 5.138 displaced persons aan. ${ }^{13^{\circ}}$ Aanvankelijk gezien als een noodoplossing, werden de voordelen van de rekrutering in het buitenland steeds duidelijker. Het bleek de enige manier om het structurele arbeidstekort in de steenkoolnijverheid op te lossen. De steenkolenslag werd uiteindelijk gewonnen, dankzij de rekrutering in het buitenland, maar men had het over een Pyrrusoverwinning. Alhoewel de productie in de Belgische steenkoolnijverheid in 1948 weer op haar vooroorlogse niveau kwam, bleken de productiekosten per ton erg hoog in vergelijking met de omringende steenkoolproducerende landen. ${ }^{\mathrm{I}}{ }^{\mathrm{I}}$

\section{BEsLuit}

Het mijnwerkersstatuut zorgde er niet voor dat er meer Belgen naar de mijnen trokken, integendeel, veel mijnwerkers maakten gebruik van de nieuwe sociale wetgeving om de mijn vroegtijdig vaarwel te zeggen. Uit de bronnen blijkt dat net na de Tweede Wereldoorlog de Belgische overheid en het mijnpatronaat nog de hoop hadden vooral nationale arbeiders aan te trekken, maar dit bleek een verloren zaak. Door de demografische situatie was er in Luik een algemeen tekort aan jonge mannen en voor hen bestonden er ook nog eens aantrekkelijke andere beroepsperspectieven. De lonen in de steenkoolnijverheid lagen hoger dan het gemiddelde loon van de industriële bedrijven. Toch bleef het aanbod van Belgische arbeiders te klein, waaruit blijkt dat het aangeboden loon steeds onvoldoende was om arbeiders naar die bedrijfstak te halen.

Ook de hoop op een opdrijving van de arbeidsproductiviteit door een voortgezette rationalisering bleek door de financiële situatie en de geologische omstandigheden tevergeefs.

126 Ibidem, 68 en I23-I24.

127 Morelli, 'De immigratie van Italianen', 202.

128 Martens, 25 jaar wegwerparbeiders, I60-163.

I29 Er werden reeds in 1945 Poolse kandidaat-mijnwerkers geworven in Duitse kampen als displaced persons. Vanaf mei 1945 kwamen er 2.369 aan in België, waar ze uitsluitend in de Waalse mijnen tewerkgesteld werden, waarvan 688 in het Luikse bekken. Zie: Goddeeris, De Poolse migratie in België, 54-55 en I5I.

I30 Martens, 25 jaar wegwerparbeiders, I62-I64.

I3I Balace, 'Du coup de semonce au coup de colère', 304-305. 
De gelden ter beschikking gesteld door subsidies en het compensatieplan zorgden niet voor modernisering en concentratie, en de daarbij horende daling van de productiekosten, maar werden ingezet om onrendabele mijnen in leven te houden. Die vormden een blok aan het been voor de mijnen die wel rendeerden. Ondanks alle maatregelen en positieve voorwaarden, en uiteindelijk zelfs gedwongen tewerkstelling via de burgerlijke mobilisatie, slaagden de Belgische overheid en het mijnpatronaat er niet in de gewilde Belgische arbeiders over te halen opnieuw in de steenkolenmijnen aan de slag te gaan. De factoren die de aanleiding vormden tot de enorme vraag naar arbeid: geologische factoren met als gevolg lage arbeidsproductiviteit en weinig mogelijkheden tot mechanisering; arbeidsmarktfactoren als de aard van het mijnwerk en aantrekkelijke alternatieven; demografische factoren en de mentale factor, de onaantrekkelijkheid van het mijnwerk, werden niet opgelost. Om het acute tekort op te lossen stelden de Luikse mijnen vlak na de oorlog Duitse krijgsgevangenen aan, maar deze oplossing kon slechts van tijdelijke aard zijn. Rekrutering in het buitenland werd onvermijdelijk om het structurele probleem van het arbeidstekort het hoofd te bieden. 


\section{Hoofdstuk 5 \\ 'Pour garder un mineur, il faut en recruter plusieurs ${ }^{\star}$ \\ Arbeidsdynamiek en arbeidsverloop}

Voor de arbeidsintensieve steenkoolsector was beschikbaarheid van voldoende arbeid onontbeerlijk. Elk verlies aan ondergrondse mijnwerkers door pensionering, invaliditeit, ziekte, overlijden of vrijwillig ontslag moest worden gecompenseerd. Vooral vertrek van jonge, gekwalificeerde mijnwerkers, die elders ander en beter werk konden vinden, vormde voor de mijnwerkgevers een groot probleem. Het aanwerven van nieuwe arbeiders was voor de mijnen een noodzaak, zelfs in periodes van lage conjunctuur. Geen enkel bassin kon daarom zonder arbeid van migranten, ook niet in gebieden met een grote natuurlijke bevolkingsgroei, zoals Belgisch- en Nederlands-Limburg.

De mijnen moesten niet alleen voldoende arbeiders aantrekken, ze moesten de vers geworven arbeiders ook vasthouden en aan de mijn binden. ${ }^{\mathrm{I}}$ Een zekere mate van stabiliteit was nodig om een constante productie te garanderen. Hoe minder arbeidsverloop de mijnen ondervonden, hoe stabieler de arbeidsmarkt. In dit hoofdstuk wordt onderzocht hoe het arbeidsverloop in de Luikse mijnen zich gedurende de twintigste eeuw ontwikkelde. In hoeverre en hoe slaagden zij erin de mijnwerkers aan zich te binden en hoe sterk verbonden de mijnwerkers zich aan de Luikse mijnen? Zowel de vragers als aanbieders van arbeid, mijnwerkgevers en mijnwerkers, hielden er bepaalde strategieën op na. In welke mate wilden mijnwerkers hun arbeid te koop aanbieden en hoe reageerden de werkgevers op hun arbeidsmarktgedrag? Het is interessant om uit te zoeken of we verschillen in gedrag kunnen ontdekken bij diverse groepen mijnwerkers. Was er verschil in arbeidsverloop bij mijnwerkers van verschillende herkomst? Volgens sommige auteurs werden de buitenlandse migranten behandeld als 'wegwerparbeiders', die werden aangeworven en afgedankt naar gelang de conjuncturele situatie. ${ }^{2}$ Is dit ook in het arbeidsverloop te zien? Was er verschil met de autochtone mijnwerkers?

Onder arbeidsverloop wordt in dit stuk 'de wisseling in de personeelsbezetting', 'het verloop onder de arbeidskrachten' verstaan. Verloop wordt door Van Dale gedefinieerd als 'verlies van personeel doordat werknemers hun dienst verlaten, naar een ander bedrijf, een werkkring verlaten'. In het Engels wordt arbeidsverloop vertaald als labour turnover, in het Duits als die Fluktuation der Arbeitskräfte, en in het Frans als rotation, turn-over of instabilité du personnel. In een aantal Franstalige studies wordt ook het concept mobilité gebruikt. Van Dale geeft als vertaling van mobilité de la main d'oeuvre: de bereidheid van arbeiders om te verhuizen. Mobilité wordt vertaald als 'beweeglijkheid'. Er wordt ook gesproken over mobilité géo-

\footnotetext{
* Trempe, 'La politique de la main-d'œuvre', 67.

I Ibidem, 62-65.

2 Martens, 25 jaar wegwerparbeiders.
} 
graphique. ${ }^{3}$ Het concept mobiliteit heeft dus eerder een geografische connotatie. Verwarrend genoeg worden de concepten mobilité en rotation soms als synoniemen gebruikt. ${ }^{4}$ Bovendien komt in sommige Nederlandstalige studies ook het concept (arbeids)mobiliteit voor, waarmee het aantal indiensttredingen plus het aantal ontslagen per jaar wordt bedoeld. ${ }^{5} \mathrm{Om}$ verwarring te voorkomen wordt in dit onderzoek het begrip arbeidsverloop gebruikt. Niettemin komen enkele aspecten van geografische mobiliteit, zoals de herkomst van de mijnwerkers en het verschil tussen woon- en werkplaats, ook aan bod.

Onder arbeidsverloop verstaan we dus het in en uit dienst treden van werknemers, de in- en uitstroom met andere woorden. Hiermee meten we de voortdurende beweging en herallocatie op de arbeidsmarkt, het in en uit dienst treden van mijnwerkers. Het verloop van arbeiders is een complex fenomeen, waarin onder meer marktverhoudingen, kwaliteit van het aanbod, loonverschillen, arbeidsomstandigheden en bedrijfsculturen een rol spelen. Veranderingen in het arbeidsverloop wijzen op ontwikkelingen in vraag en aanbod op de arbeidsmarkt. Indien er sprake is van een groot arbeidsverloop hebben we te maken met een dynamische arbeidsmarkt. ${ }^{6}$ Het arbeidsverloop wordt continu gemeten. Alle transities binnen het jaar worden meegerekend.

Dit alles vertelt ons enerzijds iets over de arbeidsmarktstrategieën van de aanbodkant, de preferenties van de aanbieders van arbeidskracht en de arbeidsmentaliteit die zij erop nahouden. Arbeidsmarktstrategie wordt hier gezien als de manier waarop individuen gebruikmaken van de arbeidsmarkt om hun doelstellingen te verwezenlijken. ${ }^{7}$ Anderzijds kan dit ons ook iets vertellen over de strategieën van de vragers van arbeid, de mijnwerkgevers. Volgens Serge Langeweg bestond er in de Nederlandse mijnen een dubbele arbeidsmarkt: er was enerzijds een 'vaste stam' van ervaren mijnwerkers, anderzijds een groep mijnwerkers, vaak buitenlanders, die de conjuncturele tekorten opvingen. Wanneer het slechter ging kon deze 'mobiele' groep weer makkelijk worden afgestoten, onder meer door strengere eisen, een migratiestop, of het niet verlengen van arbeidscontracten. ${ }^{8}$ Een zeker arbeidsverloop was dus wenselijk.

In het hoofdstuk over de buitenlandse mijnwerkers in de Luikse mijnen zagen we echter dat het arbeidstekort op de Luikse mijnarbeidsmarkt niet zozeer van conjuncturele aard was, maar structureel. Zo werd de afnemende werkgelegenheid ten tijde van de economische crisis (1930-1934) niet afgewenteld op de buitenlandse arbeidskrachten. Het aandeel Belgen daalde sterker. Indien de buitenlandse mijnwerkers werden gezien als een soort van reserveleger, zoals in de Kempen ${ }^{9}$ en in Nederlands-Limburg, dan zou hun aandeel tijdens economisch slechtere periodes sterker moeten dalen. We betwijfelen dus of de Luikse mijndirecties eenzelfde politiek nastreefden. Het lijkt erop dat het de Luikse mijnwerkgevers vooral ging om zoveel mogelijk arbeidskrachten aan te trekken, ongeacht of het buitenlanders of autochtonen waren. Kwam dit ook in het verloop tot uiting?

\footnotetext{
3 Zie bijvoorbeeld: Nols, 'Zone de recrutement', 323.

4 Zie bijvoorbeeld: Chapelle-Duliere, 'La mobilité des mineurs du charbonnage du Bois-du-Cazier' en Gillet, 'Problèmes de méthode', $5 \mathrm{I}$.

5 Gales et al., Bedrijfsvoering, arbeidsverhoudingen; Van Haegendoren en Pluymers, 'Belgisch-Limburgse mijnwerkers'; Segers omschrijft mobiliteit als 'het vermijdbare, niet natuurlijke verloop', Segers, Het personeelsverloop, 4.

6 Kee, 'Dynamiek in de statistiek: arbeidsmarktdynamiek', 35.

7 Van Haegendoren en Pluymers, 'Belgisch-Limburgse mijnwerkers', 32.

8 Langeweg, 'Bekende buren en verre vreemden', 78-79.

9 Delbroek, 'Op zoek naar koolputters', I02-103.
} 


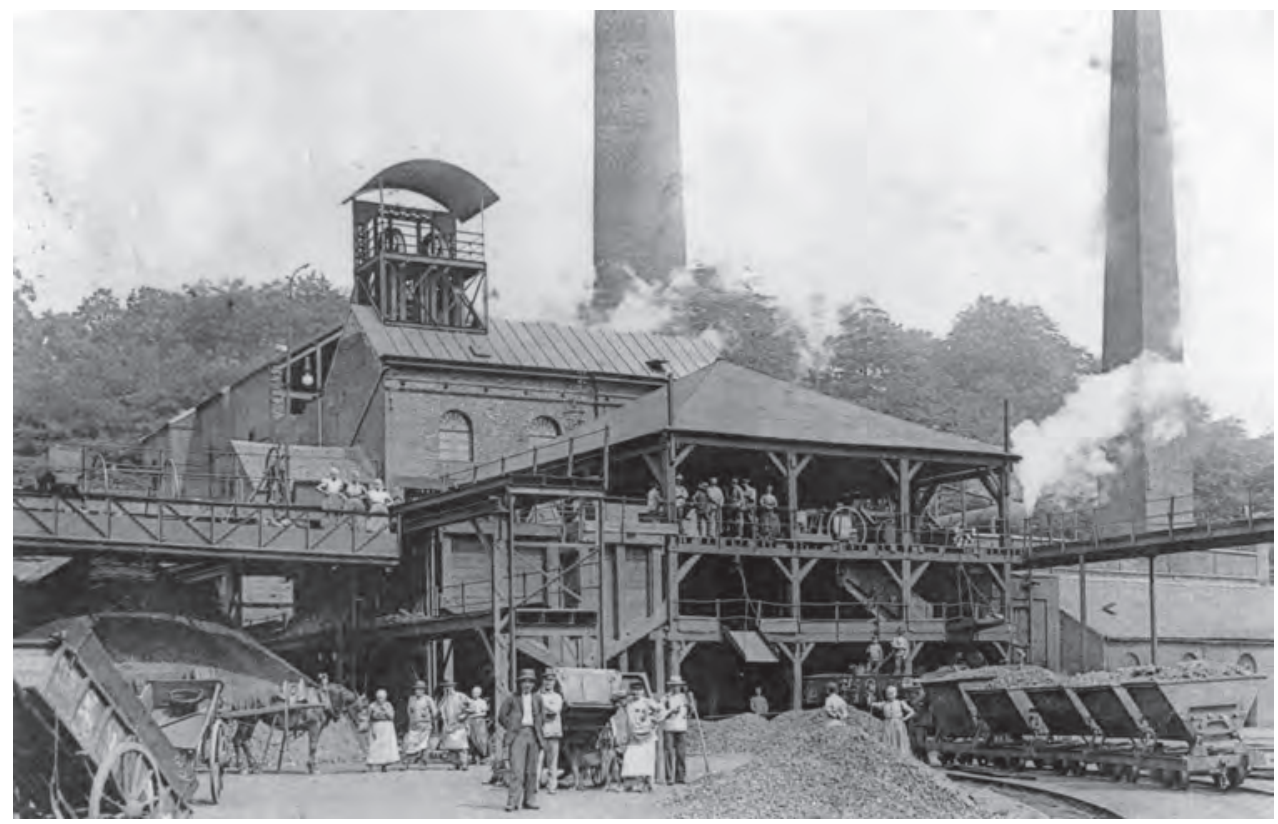

Zetel Val Benoît van de NV Bois d'Auroy, ca. 1920. Coll. Blegny-Mine.

Een belangrijke onderzoeksvraag in dit hoofdstuk is daarom: in hoeverre verschilde het arbeidsmarktgedrag tussen verschillende groepen: Luikenaren, andere Belgen (waaronder pendelaars) en buitenlanders? Hoe veranderde dit in de loop van de tijd? Het antwoord op deze vraag zal ons verder leiden naar mogelijke verklaringen voor het arbeidsmarktgedrag van zowel de aanbieders van arbeidskracht, de mijnwerkers, als de vragers van arbeidskracht, de mijnwerkgevers. Deze verklaringen over het arbeidsmarktgedrag kunnen ons vervolgens wijzen op bepaalde strategieën van de mijnwerkers en mijndirecties.

\section{LITERATUUR OVER HET ARBEIDSVERLOOP}

Over het arbeidsverloop in het Luikse bekken en de Luikse mijnen gedurende de twintigste eeuw is weinig geschreven. Drie belangrijke studies uit de jaren 1950 behandelden de geografische mobiliteit van de arbeidskracht in de Luikse regio, waarbij er vooral werd gekeken naar verschillen tussen woon- en werkplaats en de evolutie door de tijd heen. Zo ging Sporck (1957) na welke de centra van werk waren in de Luikse regio en waar de daar werkzame arbeidskracht vandaan kwam. ${ }^{\mathrm{IO}} \mathrm{Hij}$ deed vooral onderzoek naar de geografische mobiliteit, les mouvements de la main d'oeuvre, niet zozeer naar het arbeidsverloop. Sporck concludeerde dat de Luikse mijnen weinig aantrekkingskracht uitoefenden op de rest van de Luikse regio en dat de leemtes in het arbeidsbestand vooral werden opgevuld door buitenlanders. Ook constateerde hij een algemene daling van het aantal arbeidskrachten dat in de- 
zelfde plaats woonde en werkte. De stijging van de arbeidsmobiliteit in de Luikse regio in de periode I9I0-I930 wees volgens hem op een toenemend tekort aan arbeid en moeilijkheden bij de rekrutering van arbeidskracht. Dit weet hij onder meer aan een gebrek aan huisvesting en de lage nataliteit in de regio.

In de periode 1930-1947 werd de situatie nijpender en moest men buitenlandse arbeiders aantrekken en meer pendelaars van buiten de regio zoeken. Door ontgroening en aantrekkelijke alternatieve werkgelegenheid in andere sectoren was er een tekort aan mijnwerkers uit de regio zelf ontstaan en moest het rekruteringsgebied van de Luikse mijnen fors worden uitgebreid. Sporck beschouwde het vertrek van jongeren uit de mijnbouwgemeenten en de enorme achteruitgang van het aanbod van ter plaatse wonende arbeidskracht als een bewijs voor la désertion de la population de la région vis-à-vis des charbonnages. Sporck besteedde veel aandacht aan het probleem van het arbeidstekort in de Luikse mijnen, maar gaf geen informatie over het arbeidsverloop en noemde het terugdringen ervan niet als mogelijke oplossing voor het arbeidstekort.

In een studie over de mobiliteit op de Luikse arbeidsmarkt besprak Emile Nols enkele jaren later (I960) dezelfde problematiek. ${ }^{\text {II }} \mathrm{Hij}$ stelde dat de geografische mobiliteit in de Luikse mijnen zich op dezelfde wijze ontwikkelde als die in de andere Belgische steenkoolbekkens: Belgische mijnwerkers woonden steeds verder verspreid en gingen vanuit steeds meer perifere regio's deelnemen aan de pendelbeweging naar de steenkolenmijnen. In de Luikse regio moesten de mijnen steeds verder zoeken om een aanvulling op hun arbeidsbestand aan te werven, dit in tegenstelling tot de Luikse staalnijverheid die haar arbeidskracht vooral binnen de eigen regio vond. Volgens Nols ontwikkelde de Belgische bevolking een steeds grotere afkeer van het mijnwerk. Deze afkeer zorgde niet alleen voor een gebrek aan arbeidskracht, maar verhoogde volgens hem ook het arbeidsverloop. Hij berekende dat er in 1955 voor elke I.000 aangenomen Belgen 433 vervangen moesten worden, dit in tegenstelling tot Duitsland en Frankrijk, waar dat slechts voor respectievelijk 275 en 175 mijnwerkers het geval was. Jaarlijks zou men zo 24.000 Belgen moeten aannemen om het ondergrondse personeelsbestand stabiel te houden. Deze kon men alleen aantrekken dankzij de hoge lonen en de bijkomende sociale voordelen in de mijnbouwsector. Het is opvallend dat Nols het probleem van het grote arbeidsverloop niet verder bespreekt en alleen uitspraken doet over de Belgische mijnwerkers, terwijl de buitenlandse arbeiders, zeker in Luik, in de jaren 1950 een belangrijk aandeel in het personeelsbestand hadden.

Aan het verloop onder de arbeidsmigranten werd in 1956 wel meer aandacht besteed door auteur Paul Minon. Hij had het over immigration provoquée: pogingen van zowel de mijnwerkgevers als de overheid om het arbeidstekort op te vangen met georganiseerde rekruteringen in het buitenland. Hij besprak de opeenvolgende migratiegolven na de Tweede Wereldoorlog en het tijdelijk karakter van de migratie, vastgelegd door de duur van het contract. Deze contracten van bepaalde duur hadden tot doel een zekere stabiliteit te verzekeren, maar hadden ook als gevolg dat het in tijden van crisis onvoordelig was deze arbeidsmigranten te ontslaan, waardoor ze zich in een betere positie dan de Belgische arbeiders bevonden: 
Non pas en vertu de la loi, ni de conventions collectives, mais en vertu d'une disposition insérée dans l'ensemble des contrats offerts aux émigrants italiens engagés dans le travail de la mine en Belgique, la durée du contrat de travail ne reste pas indéterminée mais est fixée à un terme limité. Cette disposition avait pour but d'assurer une certaine stabilité à la main d'œuvre engagée. Elle a cependant eu pour conséquence qu'à un moment de crise les employeurs de l'industrie charbonnière ont pu hésiter à mettre des travailleurs étrangers en chômage et ceux-ci ont paru bénéficier pendant un certain temps d'une situation privilégiée par rapport aux Belges. ${ }^{12}$

Bovendien wees Minon op het grote verloop van arbeidsmigranten tussen de verschillende bekkens. Hij verbaasde zich erover dat de Kempische mijnen in de periode I950-I955 ondanks hun betere arbeids- en woonomstandigheden veel buitenlandse arbeiders zagen vertrekken naar het Luikse bekken. Minon duidde de verschillende oorzaken voor het arbeidsverloop van deze arbeiders aan met instabilité professionelle. Arbeidsmigranten ondervonden veel aanpassingsmoeilijkheden door onwetendheid en een gebrek aan ervaring en deze veroorzaakten op hun beurt meer ongevallen en absenteïsme. Dit laatste kwam echter evengoed voor bij de Belgische arbeiders en was vooral te wijten aan de hoge lonen en het systeem van akkoordlonen. Mijnwerkers konden zo in een vier- tot vijfdaagse werkweek over het algemeen voldoende inkomen opbouwen. ${ }^{\text {13 }}$

Ook uit Nederlandse studies blijkt dat er wat het verloop betreft onderscheid moet worden gemaakt tussen verschillende groepen mijnwerkers. Over het arbeidsverloop in het Nederlandse mijnbekken verschenen in 1958 twee gedetailleerde studies. In een studie van Reumkens over de Oranje-Nassau Mijnen werd geconcludeerd dat bij het verloop niet zozeer de nationaliteit van belang was, maar veeleer de wijze waarop de arbeiders bij het mijnbedrijf terecht waren gekomen (spontaan of geworven), en de gebieden van herkomst. ${ }^{\mathrm{I}}$ In een studie van Bardoul over de mijn Julia werd er juist gewezen op het grote verloop onder de buitenlandse arbeiders. ${ }^{15}$ Het feit dat er in de Nederlandse mijnen onderzoek naar dit thema werd gedaan wijst op de behoefte aan kennis over het arbeidsverloop, met het doel om het te beperken. Dit kaderde in het personeelsbeleid van de Nederlandse mijnen, dat er op gericht was een 'vaste stam' van Limburgse mijnwerkers uit te bouwen. Het gebrek aan aandacht voor het arbeidsverloop in de Luikse mijnen geeft de indruk dat het niet als problematisch werd ervaren.

In het onderzoek dat Bart Pluymers (samen met Mieke Van Haegendoren) in het kader van het project Mines et Mineurs deed naar de arbeidsmarkt in de Kempische mijnen vinden we ook informatie over het arbeidsverloop, maar beperkt tot de periode voor de Tweede Wereldoorlog. ${ }^{16}$ Hun aanpak is hier deels nagevolgd. Voor het schrijven van dit stuk werd verder een beroep gedaan op economische, sociologische en contemporaine studies voor inspiratie wat betreft het analyseren van de bronnen. ${ }^{17}$ Meer algemene historische werken werden vervolgens benut om de resultaten in te kaderen.

In dit hoofdstuk zal het arbeidsverloop van de mijnwerkers in het Luikse bekken gedurende de twintigste eeuw worden geschetst. Anders dan in de bestaande studies wordt hierbij een longitudinaal perspectief nagestreefd. Enerzijds zal er in de analyse aandacht

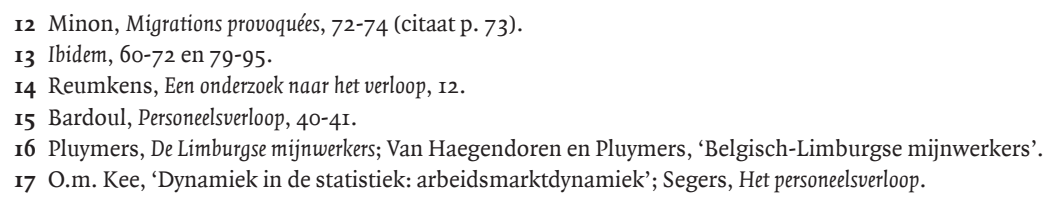




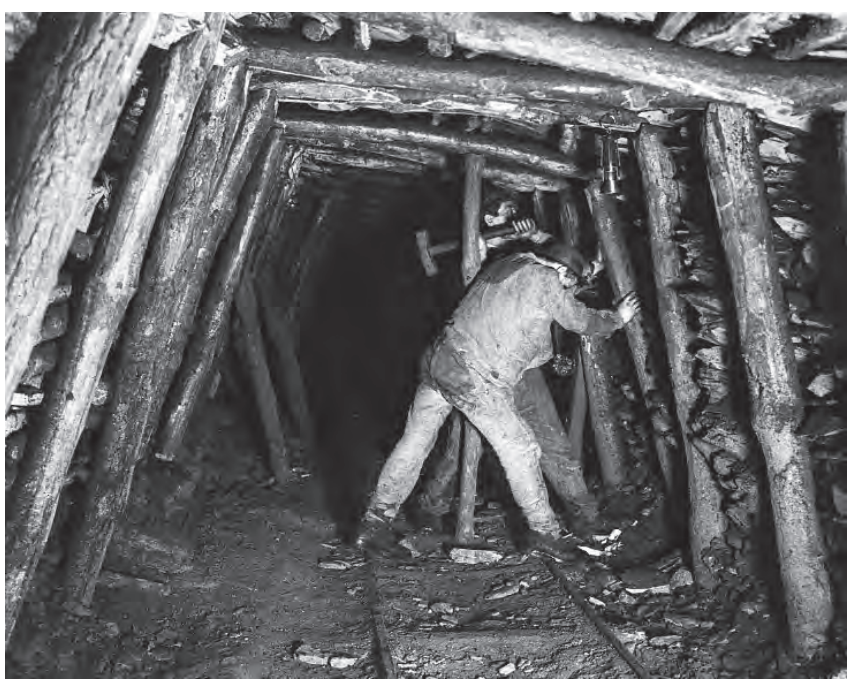

'Boiseurs' (mijnwerkers die de ondersteuning verzorgden), begin twintigste eeuw. Foto Gustave Marissiaux. Copyright Province de Liège-Musée de la Vie wallonne.

zijn voor de verschillen door de tijd heen, anderzijds wordt er rekening gehouden met de verschillen tussen mijnwerkers naar herkomst en woonplaats. Er wordt gekeken naar het verloop tussen de Luikse mijnen, maar ook in en uit het Luikse bekken in zijn geheel (zonder daarmee per se rekening te houden met het interne verloop). Zowel de loyaliteit aan de Luikse steenkoolsector als aan de afzonderlijke mijnbedrijven komen dus aan bod. Zo kon het zijn dat een mijnwerker enorm 'trouw' was aan het Luikse bekken, met bijvoorbeeld een carrière van meer dan 30 jaar, maar daarbij veel wisselde tussen verschillende mijnen.

In de geraadpleegde historische en contemporaine studies over het arbeidsmarktprobleem en het arbeidstekort op de Luikse mijnarbeidsmarkt worden arbeidsverloop en absenteïsme meestal in één adem genoemd. Vooral onder de ondergrondse arbeiders was er veel absenteïsme, wat de diensten ontregelde en een regelmatige productie belemmerde. Het was niet alleen moeilijk om voldoende arbeiders aan te trekken en ze te binden aan de mijn, maar ook om de mijnwerkers constant aan het werk te houden. Een onstandvastige bezetting in de mijnen had een nadelige invloed op de uitbating. Om een hoog rendement te verkrijgen was het belangrijk dat de productie constant verliep. Daarom wordt in dit hoofdstuk ook een analyse gemaakt van het gemiddeld aantal gewerkte dagen per maand en per jaar en het probleem van het absenteïsme.

\section{BRONNEN EN METHODEN}

Het onderzoek voor dit hoofdstuk is grotendeels gebaseerd op een analyse van twee typen bronnen: enerzijds geaggregeerde statistische gegevens die vanaf 1947 werden bijgehouden door de werkgeversorganisatie FEDECHAR, anderzijds gegevens over individuele mijnwerkers die op basis van een eigen steekproef uit de pensioenregistratie zijn verzameld (voor een verantwoording zie bijlage 8). In bedrijfsarchieven, aanwezig in het Rijksarchief in Luik en het Centre Liégeois d'Archives et de Documentation de l'Industrie Charbonnière (CLADIC) te Blegny, werd tevergeefs gezocht naar studies en informatie omtrent het arbeidsverloop van 
Vakbondsafgevaardigden, NV Wérister. Copyright Province de Liège - Musée de la Vie wallonne.

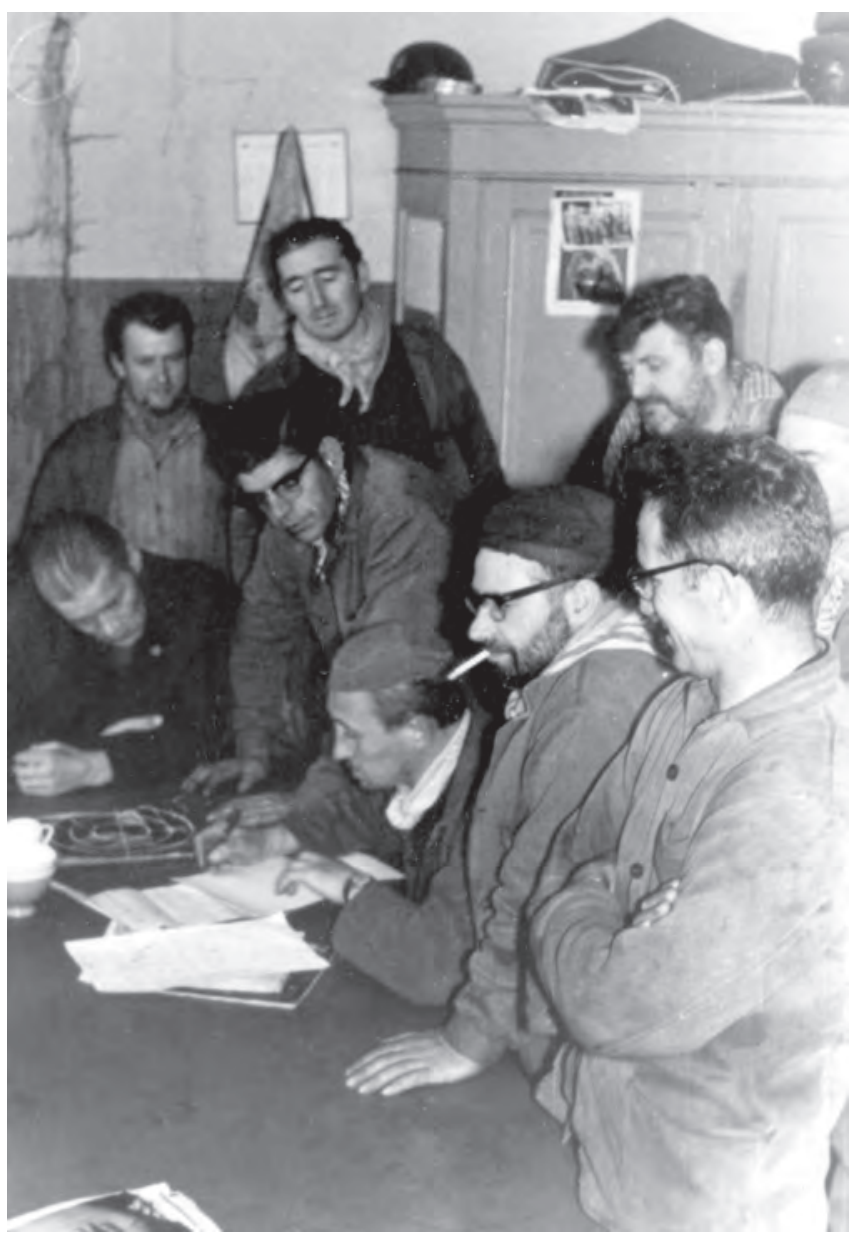

de mijnbedrijven zelf (zoals die in Nederland wel beschikbaar zijn). Willy Geebelen geeft in zijn uit I944 daterende verhandeling aan dat hij geen enkele mijn is tegengekomen die nota hield van de eigen arbeidswisseling. ${ }^{18}$ Pas nadat FEDECHAR aan de (Luikse) mijnen om bepaalde informatie ging vragen, kwamen er gegevens omtrent arbeidsverloop beschikbaar. Niet gepubliceerde geaggregeerde statistieken in het FEDECHAR-archief (Rijksarchief Hasselt) gaven ons meer duidelijkheid over het arbeidsverloop tussen de Luikse mijnen en de arbeidsmarktdynamiek van de Luikse steenkoolnijverheid als geheel in de periode van I947 tot $1977 .{ }^{19}$ Jammer genoeg konden we geen statistieken over in- en uittreders vinden van voor $1947 .{ }^{20}$ In deze stukken werd onderscheid gemaakt naar de verschillende bek-

18 Geebelen, De personeelsorganisatie, 44-48.

I9 RAH, archief FEDECHAR, inv.nrs. 567-597: Statistieken over de Belgische kolennijverheid, 1954-1976; inv.nr. 6r3: Statistieken over tewerkgesteld personeel, toegekende werkvergunningen en buitenlandse arbeidskrachten, I965-1983; inv.nr. 614: Statistieken over tewerkgesteld personeel, binnenkomend en vertrekkend personeel, opsplitsing per nationaliteit, I950-I973; inv. nrs. I579-I582: Briefwisseling en statistieken betreffende Belgische en vreemde arbeidskrachten, I930-1949, I950, Bescheiden met maandelijkse statistieken over het tewerkgesteld personeel, I95I-I953, Bescheiden betreffende het tewerkgesteld personeel, I952 [omvat meerdere jaren].

20 Voor het jaar 1949 vonden we enkel gegevens voor de maand december. 
kens, ondergrondse en bovengrondse arbeiders, en de nationaliteit van de mijnwerkers. Op grond van deze statistieken was het mogelijk systematisch onderscheid te maken tussen mijnwerkers afkomstig uit België en uit het buitenland (zie bijlage 7).

De geaggregeerde gegevens in het FEDECHAR-archief konden worden gebruikt voor berekening van het relatieve arbeidsverloop, dat wil zeggen de som van de in- en uitstroom per jaar gedeeld door twee maal het gemiddeld aantal arbeidsplaatsen in dat jaar. ${ }^{21}$ Bij gebrek aan informatie over de duur van de dienstverbanden en het gemiddeld aantal arbeidsplaatsen werd gekozen voor het aantal arbeidsplaatsen op 3I december van het betreffende jaar. ${ }^{22}$ Het relatieve arbeidsverloop vertelt ons iets over de mate waarin werknemers van baan wisselden en hoe snel er een nieuw dienstverband werd aangegaan. Indien het resultaat van de berekening o procent is, spreken we van een volkomen ondynamisch jaar; indien het resultaat roo procent bedraagt, hebben we te maken met een volkomen dynamisch jaar. In dat laatste geval worden alle arbeidsplaatsen in dat jaar 'ververst'. De omvang van de dynamiek is een belangrijke indicator van de mate van flexibiliteit op de arbeidsmarkt..23

De gegevens uit het FEDECHAR-archief werden ook gebruikt voor een analyse van de ontwikkeling van in- en uitstroom afzonderlijk, en van het saldo daarvan. Het aantal uitgetredenen als percentage van de totale personeelsbezetting wordt het vertrek- of het ontslagpercentage genoemd. ${ }^{24}$ Dit geeft aan hoeveel mijnwerkers de mijnen per jaar moesten vervangen. Deze cijfers kunnen ons iets vertellen over de 'trouw' aan de Luikse mijnen.

Om verder terug te kunnen gaan in de tijd en meer groepen mijnwerkers te kunnen onderscheiden (naast nationaliteit ook bijvoorbeeld de Belgische pendelaars) werd een selecte steekproef genomen uit de registratie van individuele mijnwerkers op zogenaamde rekenkaarten uit het Pensioenfonds (zie bijlage 8). Alle mijnwerkers geboren in januari ıوı en januari 1920 werden geselecteerd. Deze selecte steekproef omvat de periode I924, het jaar waarin de eerste mijnwerker uit de steekproef intrad, tot 1976 , toen de laatste mijnwerker uittrad. In sociologische studies werkt men met zogenaamde overlevingscijfers of overlevingspercentages als indicator van het arbeidsverloop. Hoeveel van de in dienst genomen mijnwerkers was er na een bepaalde periode nog aan het werk?25 Hiervoor werd de selecte steekproef gebruikt. We berekenden hoe lang mijnwerkers in de Luikse mijnbouwnijverheid aanwezig bleven (ongeacht wisselingen tussen de mijnen). Dit vertelt ons iets over de loyaliteit aan de Luikse steenkoolnijverheid van de individuele Luikse mijnwerker. Met behulp van de selecte steekproef was het ook mogelijk de evolutie van de lengte van de dienstverbanden te onderzoeken. Die geeft een indicatie van de trouw aan de afzonderlijke mijnen in het bekken en het verloop tussen de mijnen onderling.

2I Dit gemiddelde kan worden berekend door vermenigvuldiging van het aantal banen met de gemiddelde baanduur. Kee, 'Dynamiek in de statistiek: arbeidsmarktdynamiek', 38.

22 Het gemiddeld aantal arbeidsplaatsen per jaar is vanaf 1954 gepubliceerd in de rubriek: 'Technische kenmerken van de Belgische Steenkolenontginning', Annales des Mines de Belgique, I956 e.v. Daarin werd echter geen onderscheid gemaakt naar Belgen en buitenlanders.

23 Kee, 'Dynamiek in de statistiek: arbeidsmarktdynamiek', 35-38.

24 Bardoul, Personeelsuerloop, i6; Segers, Het personeelsuerloop, 62-63.

25 Segers, Het personeelsuerloop, 8r. 


\section{DE ONTWIKKELING VAN HET RELATIEVE ARBEIDSVERLOOP NA DE TWEEDE WERELDOORLOG}

Aan de ontwikkeling van het relatieve arbeidsverloop na de oorlog (grafiek 5.I) kunnen we de conjuncturele gebeurtenissen aflezen: in de periode van de kolenslag tot en met 1956 was er een hoog arbeidsverloop. Daarna was er een daling tijdens de kolencrisis (I957/58). In het begin van de jaren I960 ging het herstel van de arbeidsmarkt gepaard met een stijging van het arbeidsverloop. In de tweede helft van de jaren ig6o daalde het verloop weer door de vele mijnsluitingen in het Luikse bekken. Er waren dus twee periodes met een hoog relatief arbeidsverloop, onderbroken door de kolencrisis. De algemene ontwikkeling door de tijd heen valt te omschrijven als een neergaande tendens.

Grafiek 5.I Het relatieve arbeidsverloop in De Luikse mijnen, i947I972

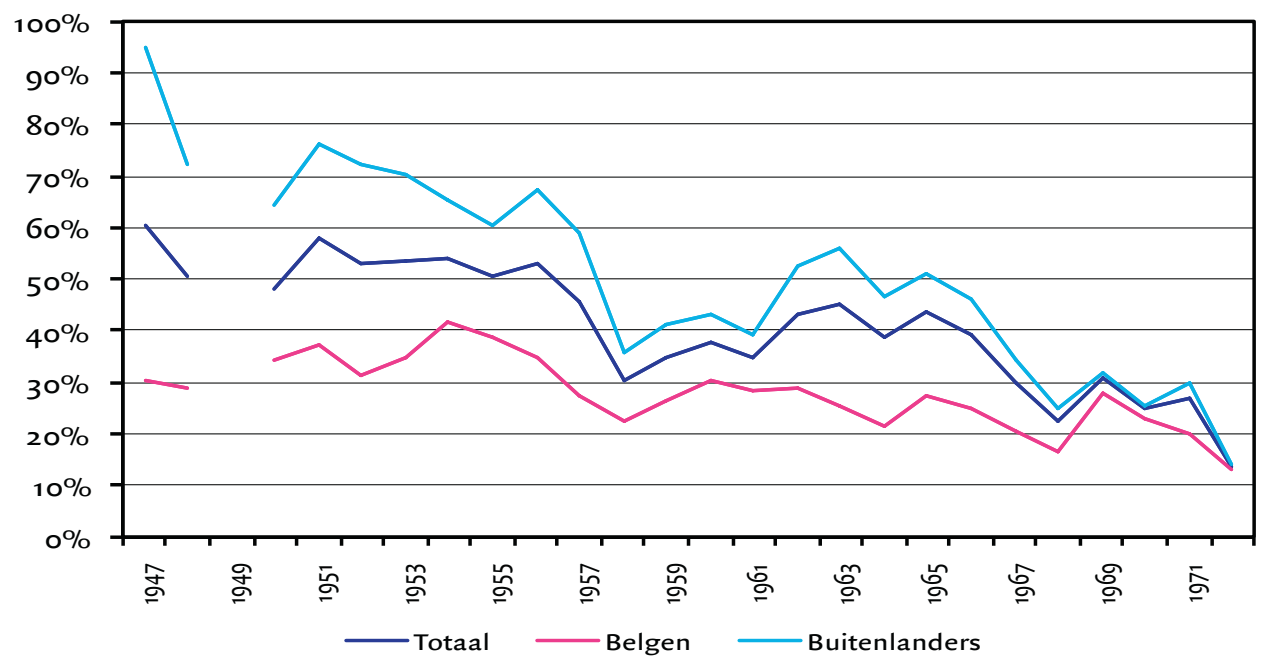

Bron: berekend naar RAH, archief FEDECHAR, inv.nrs. 6I4 en I579-I58I; Annales des Mines, I948-1974.

In de periode tussen 1947 en de kolencrisis was er, zowel tussen als van en naar alle Luikse mijnen, een arbeidsverloop van meer dan 50 procent van alle arbeiders. Dat percentage is vergelijkbaar met het hedendaagse verloop in zeer dynamische sectoren met veel seizoensarbeid, zoals de landbouw en de horeca. ${ }^{26}$ Heden ten dage wordt de industrie met een relatief arbeidsverloop van ca. I5 procent niet als een erg dynamische sector gezien. Mijnen waren volcontinue bedrijven, maar het lijkt wel alsof de arbeidsmarkt voor mijnwerkers in Luik functioneerde alsof mijnwerk seizoenswerk was.

Het grote verloop in 1947 werd veroorzaakt door de in- en uitstroom van buitenlandse arbeiders. Voor hen zien we een vrijwel volledig dynamisch jaar, dat wil zeggen dat in dat jaar bijna alle nieuw geworven migranten werden vervangen. Dit had te maken met de massale aankomst van Italianen. Omdat ze niet geschikt werden bevonden voor het zware mijn- 

LOOP IN DE LUIKSE MIJNEN, I947-I972

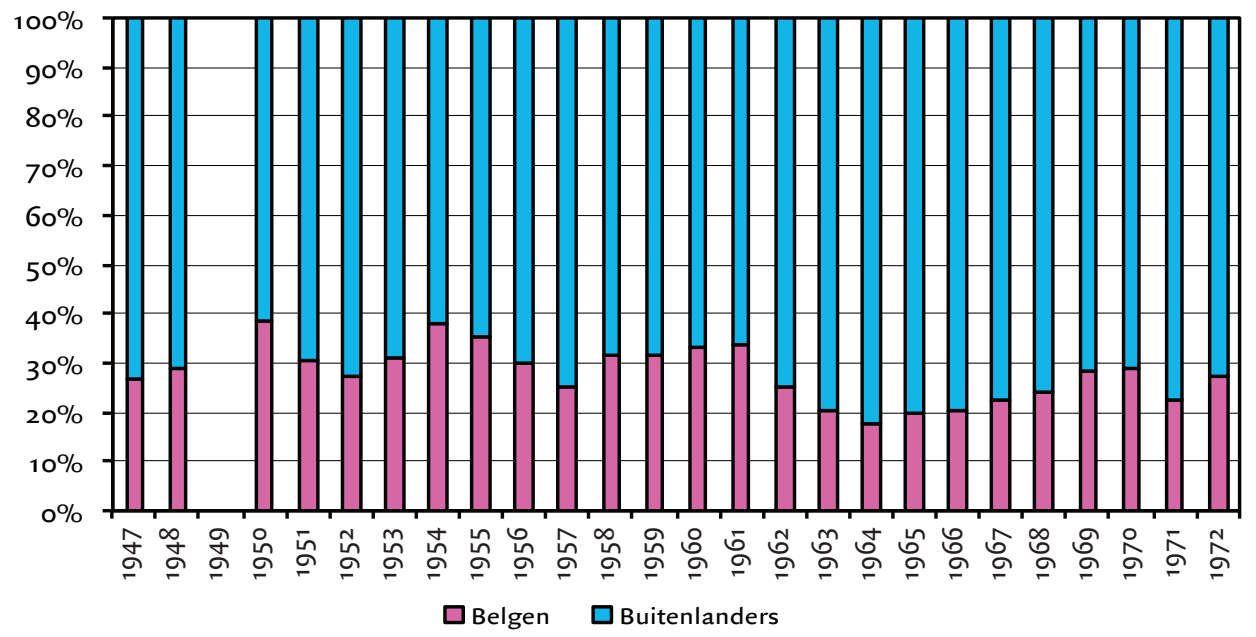

Bron: berekend naar RAH, archief FEDECHAR, inv.nrs. 6I4 en I579-I58I.

werk, of omdat ze zelf het mijnwerk niet zagen zitten, vertrok een groot aantal al snel terug naar het thuisland. Ook de abominabele huisvesting speelde daarbij een rol. Er was hen een gepaste en nette woning beloofd, maar bij gebrek aan huisvesting verbleef een groot deel van de arbeidsmigranten noodgedwongen in 'tijdelijke' barakken. Zonder behoorlijke huisvesting was het voor de mijnen moeilijk de nieuwe arbeiders aan de mijn te binden.

In 1956 werd de piek in het arbeidsverloop veroorzaakt door een grote uitstroom van buitenlanders. Tegelijk was de instroom van Italianen sinds het midden van de jaren 1950 afgenomen door de wervingsstop die de Italiaanse regering had afgekondigd. Ten tijde van de internationale kolencrisis in 1958 en in de jaren daarna werd de arbeidsmarkt stabieler. De door de EGKS opgelegde productiebeperkingen veroorzaakten een daling in de vraag naar arbeidskracht en deden het arbeidsverloop dalen. In deze jaren varieerde het tussen de 20 en 40 procent. Na deze relatief rustige periode kreeg de Belgische steenkoolsector in het begin van de jaren ig6o opnieuw te maken met een behoorlijk tekort aan arbeidskrachten. Een nieuwe golf aanwervingen van ditmaal Spaanse en Griekse gastarbeiders volgde. In I962 was er weer een stijging in het arbeidsverloop (tussen 45 en 55 procent), die duurde tot I966. Het grote verloop in de eerste maanden na de aanwervingen wijst op een onvoldoende selectie van de nieuwe kandidaten. Voor de mijnen was dit problematisch: zij hadden geïnvesteerd in aanwerving en opleiding van de nieuwe mijnwerkers en konden daarvan pas na enkele maanden de (productieve) vruchten plukken. Vertrokken deze nieuwelingen al vlug, dan was de investering verloren.

De ontwikkeling van het arbeidsverloop werd vooral bepaald door de in- en uitstroom van buitenlandse arbeidskrachten. Die is bij de buitenlanders in de meeste jaren twee tot vier keer zo groot als bij de Belgen (grafiek 5.2; zie ook bijlage 7). Het aandeel van de buitenlanders in het totale arbeidsverloop bedraagt 60 tot zelfs meer dan 80 procent (in I964).

We kunnen het relatieve arbeidsverloop ook alleen voor de ondergrondse arbeiders be- 


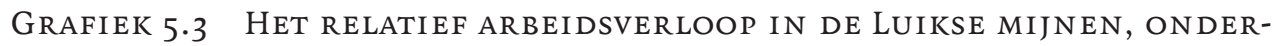
GRONDERS, I95I-I968

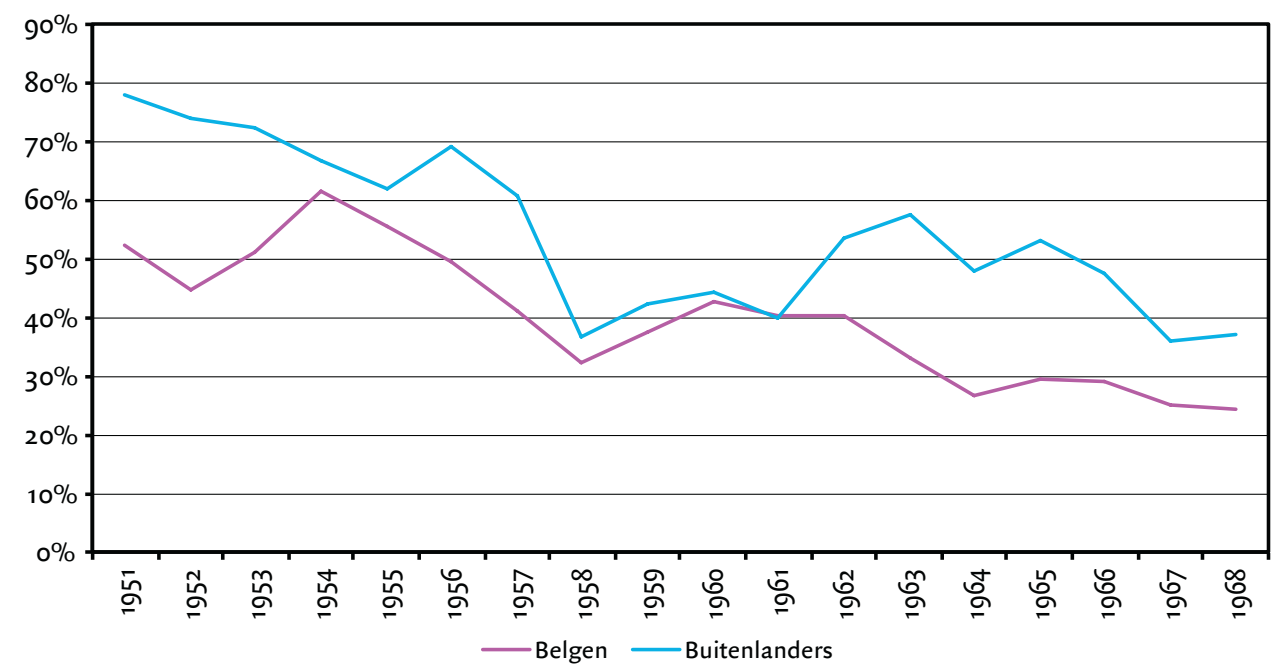

Bron: berekend naar RAH, archief fEDECHAR, inv.nrs. 6r4 en I579-I58I; Annales des Mines, I948-r974.

kijken (grafiek 5·3). Meteen valt op dat hierbij het verloop van de buitenlandse arbeidskrachten minder verschilde met dat van de ondergronds werkende Belgen dan met dat van het hele Belgische personeelsbestand. Bovengrondse dienstverbanden waren minder onderhevig aan een groot arbeidsverloop. ${ }^{27}$ Dit had te maken met de betere werkomstandigheden, maar ook met het feit dat er naar verhouding meer geschoolde arbeiders bovengronds werkten. ${ }^{28}$ Bovendien was de verhouding tussen Belgen en buitenlanders anders. Terwijl er ondergronds ongeveer 65 tot 75 procent buitenlandse arbeidskrachten waren, bedroeg dit aandeel voor de bovengrond ongeveer I5 $_{5}$ procent. ${ }^{29}$ Nieuw aangeworven buitenlandse arbeiders werden in principe steeds ondergronds tewerkgesteld. Men ging ervan uit dat men voor het lichtere en beter gewaardeerde bovengrondse werk nog voldoende lokale arbeidskrachten kon vinden. ${ }^{30}$ Het verschil in arbeidsverloop tussen alle Belgen en buitenlanders (grafiek 5.I) was dus ook gerelateerd aan hun verschillende aandeel onder- of bovengronds. De piek in het arbeidsverloop van de Belgische ondergronders in 1954 wordt veroorzaakt door een combinatie van grote in- en uitstroom in dat jaar. Er begonnen 5.096 Belgen in de ondergrond te werken, terwijl er in datzelfde jaar 4.886 Belgische ondergronders vertrokken.

27 Dat de bovengrondse mijnwerkers honkvaster waren, en langer bij dezelfde mijn bleven blijkt uit de selecte steekproef. Na de Tweede Wereldoorlog had ongeveer 35 procent van de bovengrondse dienstverbanden een duur langer dan 5 jaar (in tegenstelling tot slechts I5 procent van de ondergrondse dienstverbanden).

28 Geebelen, De personeelsorganisatie, 48.

29 In de jaren r 960 stegen de aandelen naar respectievelijk ongeveer 80 en 20-35 procent. Berekend naar RAH, archief FEDECHAR, inv.nrs. I579-158I.

30 In de selecte steekproef konden we toch 6 buitenlandse arbeiders terugvinden die enkel bovengronds werkten. Ook kwam het voor dat een buitenlandse arbeider één of enkele dagen ondergronds werd ingeschreven en daarna bovengronds aan de slag ging. Dit wijst er op dat, althans in de Luikse mijnen, ook bovengronds een beroep gedaan werd op buitenlandse arbeiders. We veronderstellen dat dit eventueel te maken had met gezondheidsproblemen. Na een ongeval of langdurige ziekte kon het zijn dat een mijnwerker eerst een tijdje bovengronds werd tewerkgesteld totdat hij het ondergrondse werk weer aankon. 


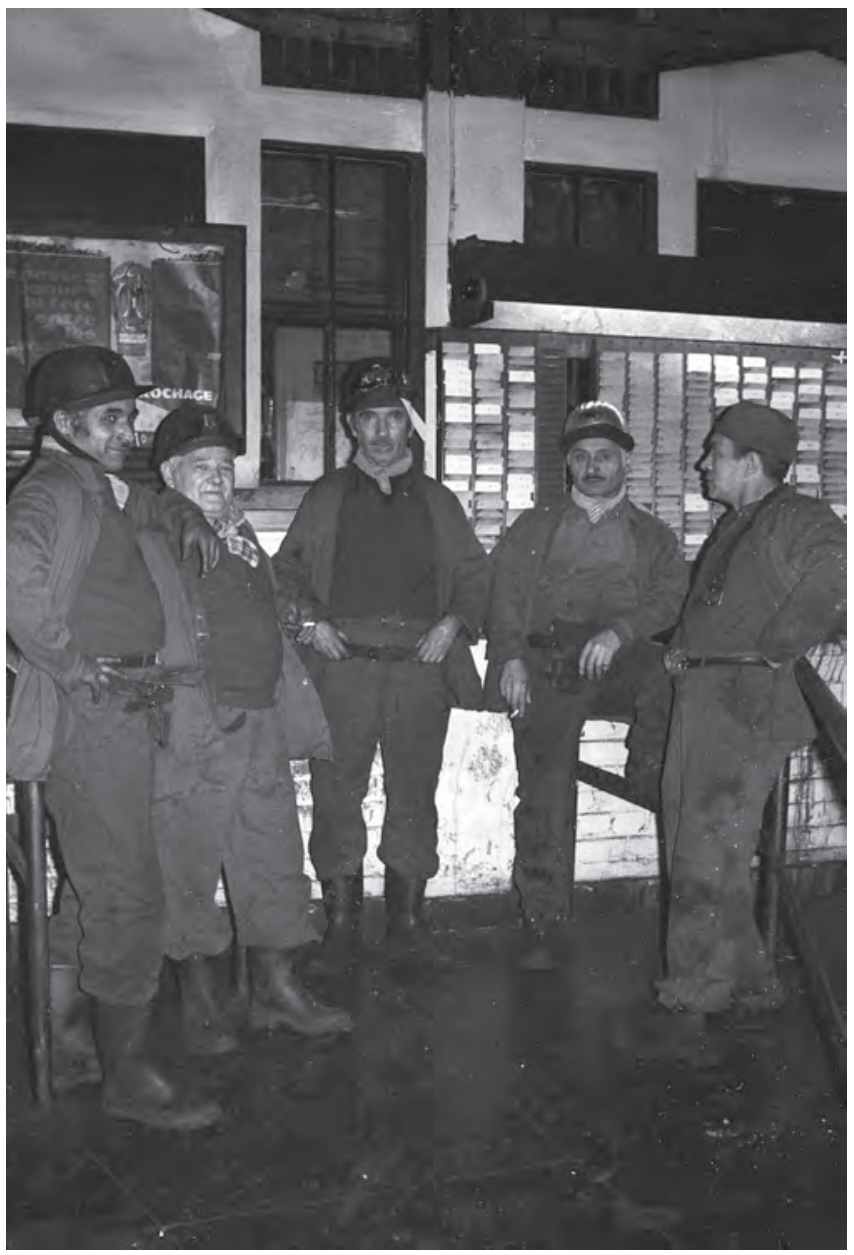

Bij aanvang van de shift, zetel te Cheratte van de NV Hasard, 1977. Foto Théodore Bellefroid. Coll. Blegny-Mine.

Het arbeidsverloop van zowel Belgische als buitenlandse mijnwerkers werd mede beïnvloed door de concurrentie tussen Luikse mijnen onderling en die met de mijnen in de Kempen. Ook na de Tweede Wereldoorlog bestonden er nog verschillen tussen de Luikse mijnen wat betreft de hoogte van de lonen en loonsystemen. ${ }^{3 \mathrm{I}}$ Een mijn met een zekere differentiatie in de lonen was aantrekkelijker voor jonge en krachtige mijnwerkers, omdat het daar mogelijk was door grotere prestaties hogere lonen te krijgen. ${ }^{32}$ Hoewel het wettelijk gezien voor arbeidsmigranten in het eerste jaar niet mogelijk was om van mijn te wisselen, zetten sommige concurrerende mijnen hen er toch toe aan hun arbeidscontract bij de hen toegewezen mijn te verbreken door repatriëring aan te vragen, maar dat vervolgens niet te melden bij gemeente of politie. Op die manier behielden deze migranten hun verblijfsvergunning en konden ze opnieuw worden aangenomen bij een andere mijn. ${ }^{33}$ Dit werd als

31 Zie hiervoor bijlage r.

32 Bardoul, Personeelsuerloop, 24-25.

33 De mijnadministratie was verplicht een formulier tot repatriëring in te dienen wanneer een arbeidsmigrant terug wilde vertrekken en dit te melden aan de lokale politie. Deze moest op haar beurt een rapport opstellen en doorsturen naar de 
De werkverdeling, zetel te Cheratte van de NV Hasard, 1977. Foto Théodore Bellefroid. Coll. BlegnyMine.

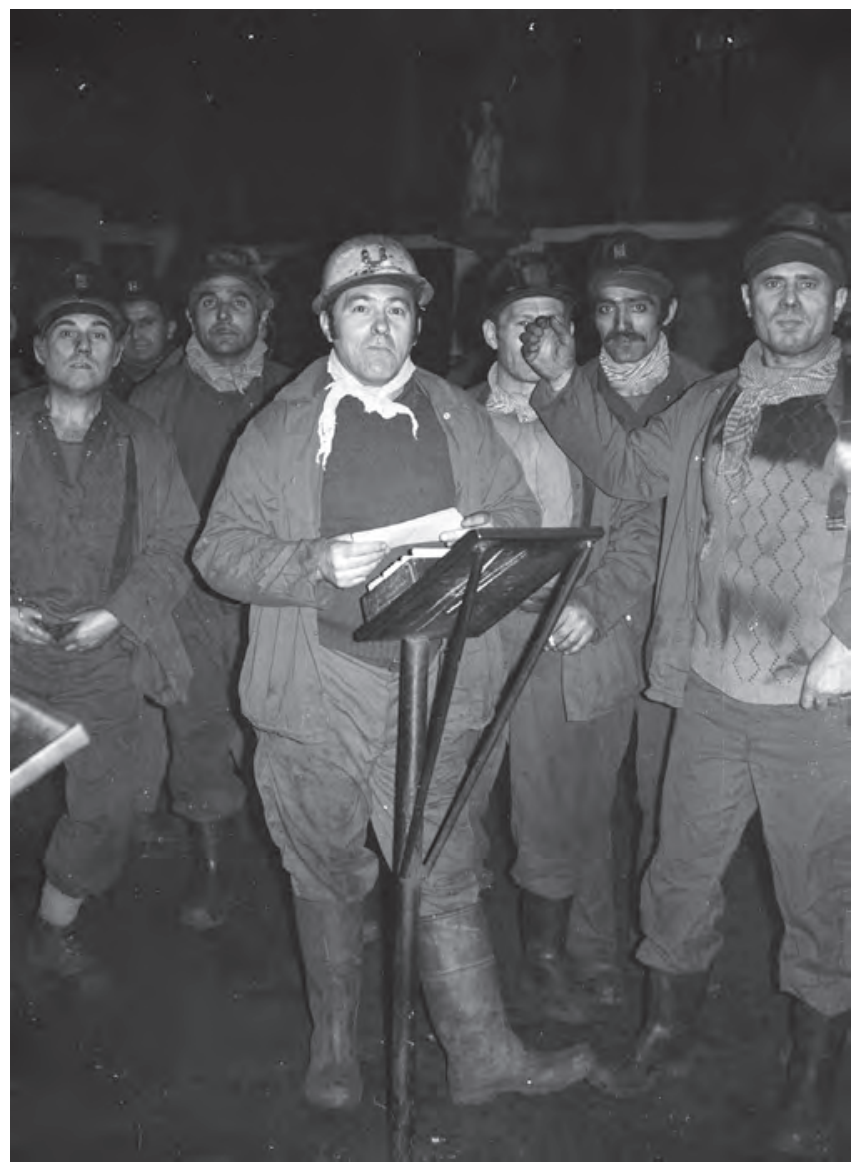

een oneerlijke praktijk beschouwd, maar uit de uitgebreide briefwisseling van Luikse mijnen met FEDECHAR met klachten omtrent het arbeidsverloop van de buitenlandse arbeidskrachten kunnen we opmaken dat het behoorlijk vaak voorkwam. Dat deze praktijk geen uitzondering was mag ook blijken uit discussies omtrent de verdeling van ontvangst-, introductie- en aanpassingskosten (frais d'accueil, d'initiation et d'adaptation). Indien een mijn had geïnvesteerd in een nieuwe arbeidskracht en deze vervolgens zag vertrekken naar een andere mijn, wilde men de gemaakte kosten op die mijn verhalen. Het bedrag voor deze gemaakte kosten werd vastgesteld op I0.000 BEF. Indien bewezen kon worden dat een mijnwerker deze introductieperiode bij de ene mijn had doorlopen en dat daar vervolgens een andere mijn de vruchten van plukte, kon er een aanvraag ingediend worden ter terugvordering van de kosten. ${ }^{34}$

Vreemdelingenpolitie. Ook moest de lokale politie melden wanneer de migrant zich niet presenteerde om de verblijfsvergunning/ identiteitskaart terug in te dienen. In de praktijk ging het vaak mis met deze dubbele administratie. Bovendien was het voor een mijn ook moeilijk te controleren of een migrant daadwerkelijk gerepatrieerd was omdat er werd gewerkt met coupons die werden ingeruild voor treintickets. Eén van de voorstellen om een beter zicht te krijgen op de arbeidsmigranten was dan ook de controle van de coupons. Indien deze niet werden ingeruild voor treintickets moest de mijn die de coupons had verstrekt hiervan op de hoogte worden gesteld. In: RAH, archief FEDECHAR, inv.nr. II2I: Briefwisseling met Waalse mijnen, I955-I975.

34 Ibidem. 
Een goede selectie van de nieuwe mijnwerkers en een gedegen introductie tot het mijnwerk waren van belang om het arbeidsverloop tegen te gaan. ${ }^{35}$ In België werd er na de mijnramp te Marcinelle (1956) werk gemaakt van een opleidingssysteem in de bedrijven met speciaal daarvoor opgeleide instructeurs. Mijnen die een goed opleidingsprogramma opzetten voor de volwassen nieuwkomers verwachtten een stabilisering van de arbeidskracht en een daling van het aantal vertrekkende mijnwerkers. Sommige mijnen constateerden ook een daling van het absenteïsme en het aantal ongevallen, en een stijging van de rendementen in de ploegen met een bedrijfsinstructeur. ${ }^{36}$ Het is mogelijk dat de Luikse mijnen door hun kleinere omvang in vergelijking met de Limburgse mijnen in zowel België als Nederland hiervoor minder goede voorzieningen hadden en dat deze maatregel daardoor minder succesvol was. Door de afkeer voor het mijnwerk van de plaatselijke bevolking was een goed opleidingssysteem voor jongeren, zoals de Ondergrondse Vakschool bij de Nederlandse mijnen, een verloren zaak. In hoofdstuk 4 werd reeds aangehaald dat het aantal I4-jarigen dat koos voor een beroepsopleiding tot mijnwerker bijzonder laag was. Liever zetten de Luikse mijndirecties in op de rekrutering van buitenlanders.

\section{De in- en uitstroom nader bekeken: het saldo}

Keken wij tot nu toe alleen naar het totaal van in- en uitstroom als maatstaf voor het verloop, in grafiek 5.4 is het resultaat van beide bewegingen weergegeven: het jaarlijkse saldo van inen uittreders. Een positief saldo betekent dat de personeelsomvang in dat jaar aangroeide, een negatief dat die afnam. Opnieuw blijkt dat de buitenlandse mijnwerkers een doorslaggevende rol speelden in de hoogte en omvang van het arbeidsverloop. De uitkomst van het verloop was gedurende de gehele periode grotendeels van hen afhankelijk. Duidelijk is te zien dat het verloop van de Belgen vooral door een grote uitstroom werd bepaald: het saldo van in- en uitgetreden Belgen is gedurende de besproken periode negatief. In elk jaar gingen er meer Belgen weg dan er in dienst traden.

Positieve saldi zien wij in I947-48, I95I, I955, I957 en I963-64 (met pieken in I947, I95I, I955, I957 en I964). In die jaren namen de Luikse mijnen dus meer arbeiders in dienst dan er vertrokken. Aangezien men er nooit in slaagde extra Belgische krachten aan te trekken, zijn deze positieve saldi volledig op het conto te schrijven van de buitenlandse arbeiders. De jaren met positieve saldi komen overeen met jaren waarin massaal buitenlanders werden geworven. In I95I vooral Italianen en Oost-Europeanen; in I955 nog vooral Italianen. De piek in I957 kan worden toegeschreven aan de massale aanwerving van Spaanse en Griekse arbeiders; in 1963 werd de groei ook veroorzaakt door de komst van diverse andere nationaliteiten. ${ }^{37}$ Vrijwel elke piek werd echter gevolgd door een sterke daling: dat is het geval in I952-54, I956, I958-6o en I965. Dit wijst erop dat er een jaar na de massale rekrutering van buitenlanders in de meeste gevallen meteen weer een groot verlies aan arbeidskrachten plaatsvond.

35 Bardoul, Personeelsverloop, 23-24; Reumkens, Een onderzoek naar het verloop, 68.

36 RAH, archief FEDECHAR, inv.nr. II2I: Briefwisseling met Waalse mijnen, I955-1975.

37 'Technische kenmerken van de Belgische Steenkolenontginning', Annales des Mines, I952-1964. Met andere nationaliteiten worden die buitenlandse arbeiders bedoeld die niet tot de Italiaanse, Nederlandse, West-Duitse, Algerijnse, Spaanse, Griekse, Hongaarse, Baltische, Poolse, Russische of Joegoslavische nationaliteit behoren. 
GRAFIEK 5.4 HET SALDO VAN IN- EN UITSTROOM VAN DE LUIKSE MIJNEN, I9471972

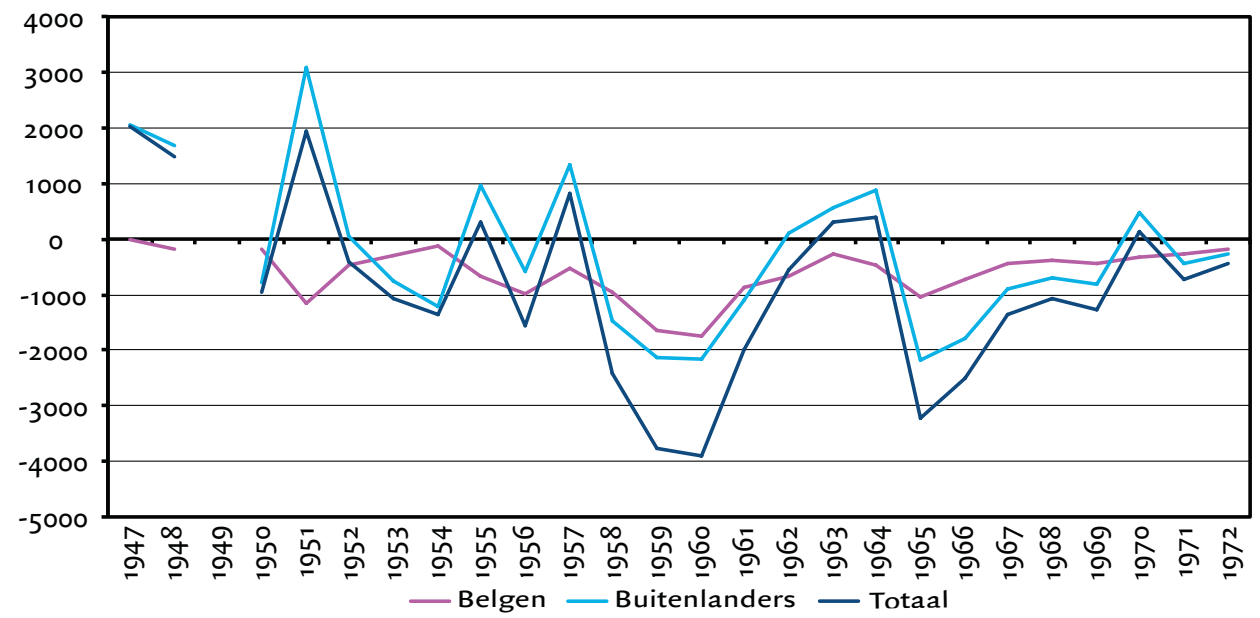

Bron: berekend naar RAH, archief FEDECHAR, inv.nr. 6I4 en inv.nrs. I579-I58I.

GRAFIEK 5.5 HET SALDO VAN IN-EN UITSTROOM NAAR NATIONALITEIT IN DE LUIKSE MIJNEN (ONDERGRONDERS), I95I-I972

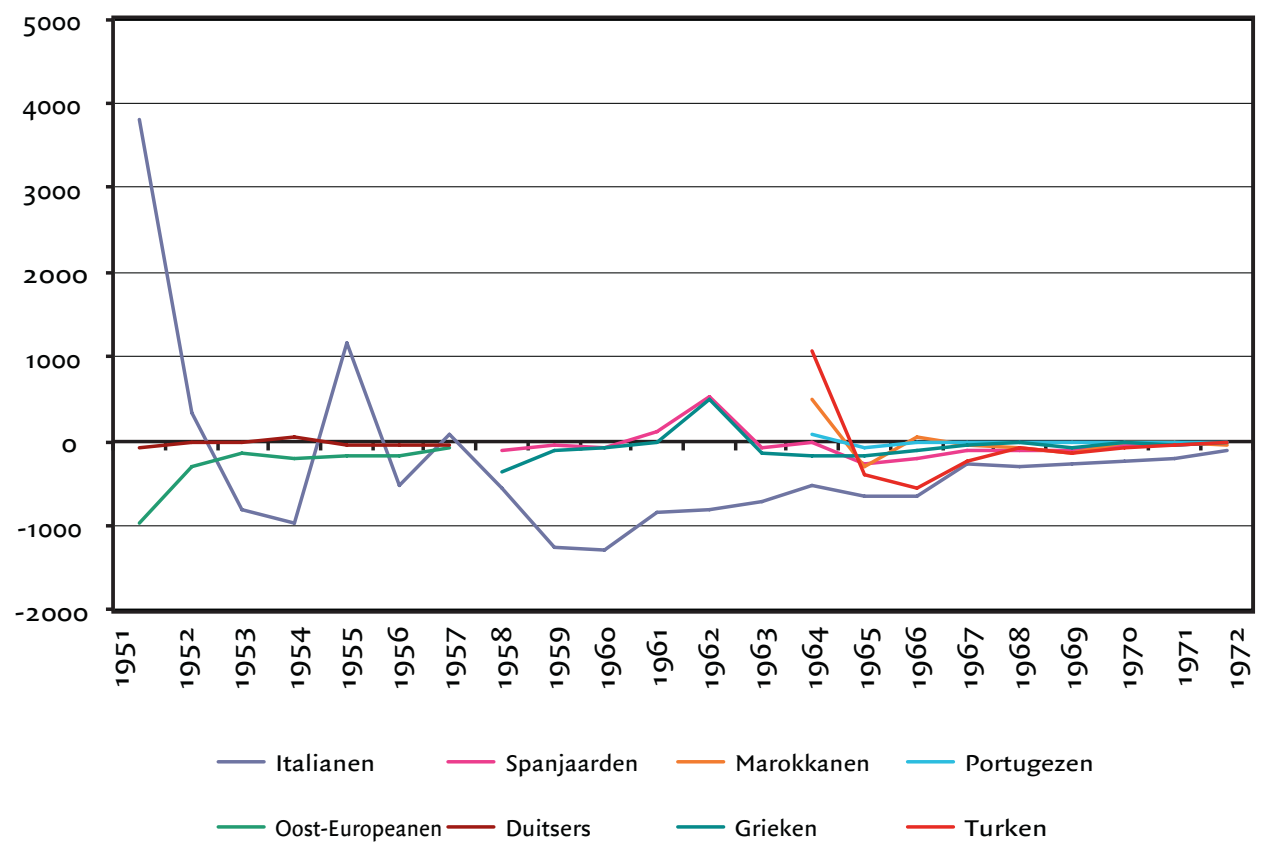

Bron: berekend naar RAH, archief FEDECHAR, inv.nr. 6I4 en inv.nrs. I579-I58I. 
GRAFIEK 5.6 HET AANDEEL VAN I4-30-JARIGEN IN DE TOTALE ONDERGRONDSE BEZETTING, I956-I976

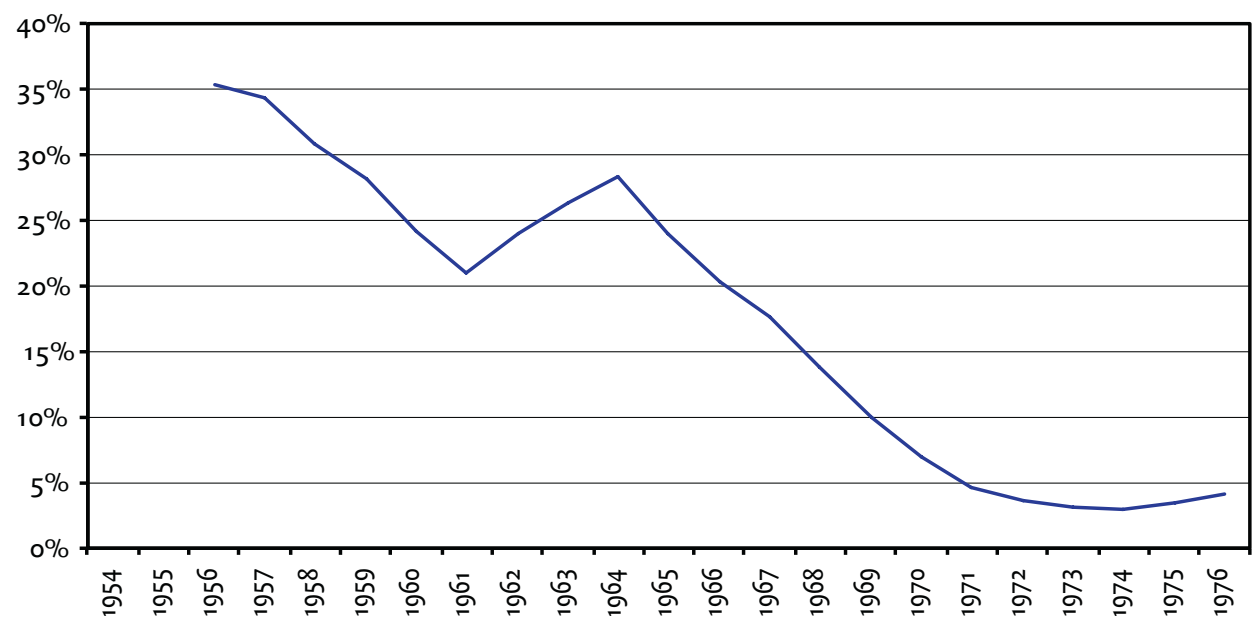

Bron: berekend naar RAH, archief FEDECHAR, inv.nr. 568 e.v.

GRAFIEK 5.7 DE GEMIDDELDE LEEFTIJD VAN DE ONDERGRONDERS IN HET LUIKSE BEKKEN, I956-I976

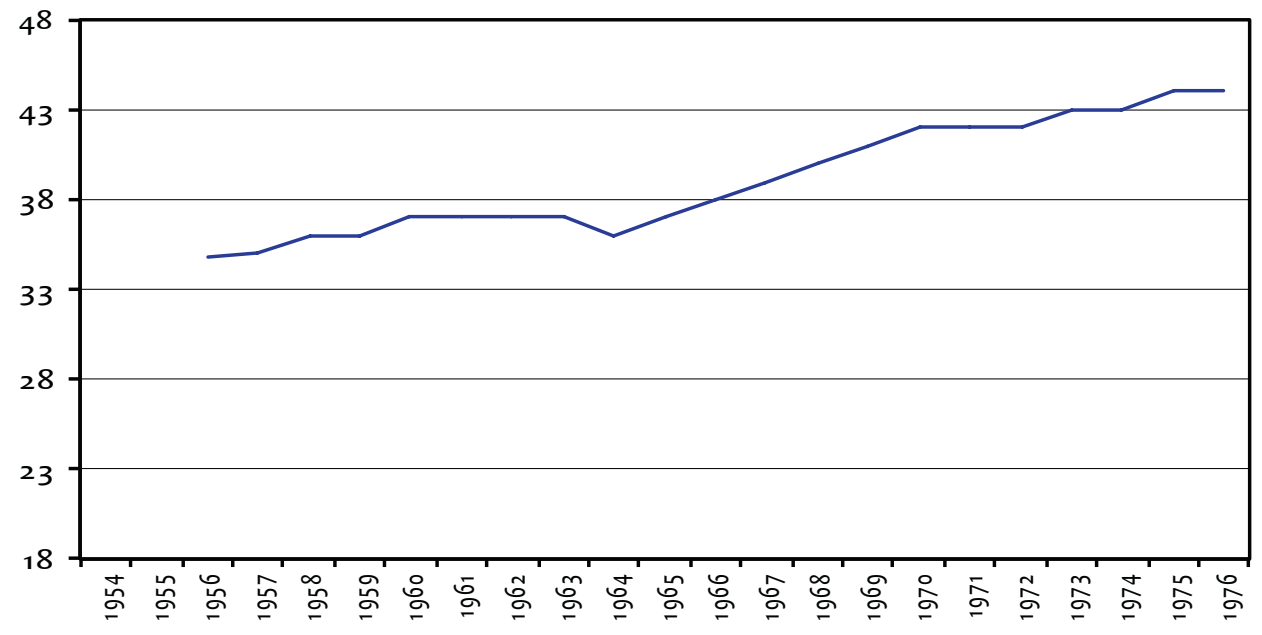

Bron: RAH, archief FEDECHAR, inv.nr. 568 e.v.

In grafiek 5.5 is het saldo van de buitenlandse mijnwerkers uitgesplitst naar nationaliteit. Daaruit blijkt dat de in de jaren I940 en I950 geworven Italianen in I953 en I954, en definitief na 1956 in groten getale uitstroomden. Aangezien de cijfers voor Spanjaarden en Grieken pas in 1958 beginnen, zien we in de grafiek niet de massale instroom in 1956 en 1957 volgend op de respectievelijke bilaterale verdragen. Wel zien we een piek in ${ }_{9} 62$ (gevolgd 
door een daling in 1963): een nieuwe golf van rekruteringen in Spanje en Griekenland. De wervingspiek van I964 van diverse groepen buitenlanders (waaronder Turken en Marokkanen) sloeg in het jaar daarna eveneens om.

De steenkolenmijnen wilden het liefst een evenwicht tussen oudere, ervaren en jonge, productieve mijnwerkers, die de vervanging van de eerste groep konden verzekeren. In grafiek 5.6 is echter te zien dat vooral jonge arbeiders het mijnwerk vaarwel zeiden of moeilijk te rekruteren waren: in de tweede helft van de jaren I 950 en opnieuw na I964 verouderde het arbeidsbestand snel. In het begin van de jaren ig6o werd de afname van het aandeel I4-30-jarigen onderbroken. Dit had te maken met een nieuwe golf van (jonge) migranten. In die jaren kwamen veel Grieken en Spanjaarden en daarna ook Marokkanen en Turken, hun geluk beproeven in de Luikse mijnen. Na 1964 zette de daling onverminderd voort, zodat er in de jaren 1970 ondergronds nog geen 5 procent jonge mijnwerkers te vinden was. Een verklaring voor deze 'ontgroening' van het Luikse mijnwerkersbestand kan zijn dat de mijnen door het tekort op de arbeidsmarkt genoodzaakt waren oudere arbeiders aan te werven. $\mathrm{Zij}$ konden zich niet permitteren veel eisen omtrent leeftijd te stellen. De sluiting van de mijnbedrijven was toen al ingezet. Mogelijk waren de mijnbedrijven toen ook niet langer meer op zoek naar jonge mijnwerkers omdat ze geen vervanging meer nodig hadden. Voor jongeren was het ook niet aantrekkelijk zich te engageren in een wegkwijnende industrie.

Het gevolg van dit alles was dat de gemiddelde leeftijd van de mijnwerkers in het Luikse steeg van 35 jaar omstreeks het midden van de jaren I950 tot bijna 45 in 1975-76 (grafiek 5.7). Deze toename wijst erop dat het personeel niet vernieuwd werd. ${ }^{8}$ Het aannemen van contingenten jonge buitenlanders bracht slechts tijdelijk soelaas. In de praktijk slaagden de Luikse mijnen er evenmin in jonge migranten aan zich te binden. In vergelijking met de Kempen hadden de Luikse mijnen een aanmerkelijk ouder personeelsbestand. ${ }^{39}$

\section{De in- en uitstroom nader bekeken: de instroom}

De veroudering van het personeel was mede een gevolg van het feit dat er op den duur in verhouding tot het aanwezige bestand steeds minder nieuwe arbeidskrachten instroomden. Dat is te zien in grafiek 5.8, waarin het aantal jaarlijks nieuw geworven mijnwerkers wordt uitgedrukt in percentages van de aanwezige bezetting per 3I december. Het percentage buitenlanders was steeds hoger dan dat van de Belgen, maar de fluctuaties zijn sterker. De instroom van Belgen daalde geleidelijk vanaf I954. In dat jaar werd het naoorlogse maximum aan nieuwe dienstverbanden voor Belgische arbeiders bereikt: meer dan 5.000. Het aantal nieuw geworven Belgen kende een eerste dieptepunt tijdens de kolencrisis in 1958, toen er slechts I.575 Belgen intraden. Na I963 daalde het aantal Belgen snel, om in I 970 een aantal van minder dan roo te bereiken.

De instroom van buitenlandse arbeiders was in I958 ook erg laag: 4.44I, terwijl het aantal nieuwe dienstverbanden van buitenlanders in 1957 nog meer dan I0.00o bedroeg. In de jaren I962 en I963 zien we opnieuw een stijging van de instroom met de komst van nieuwe contingenten migranten.

38 'Technische kenmerken van de Belgische Steenkolenontginning in 1970'; Annales des Mines de Belgique (1972) 465.

39 Ibidem (1974) 599. 


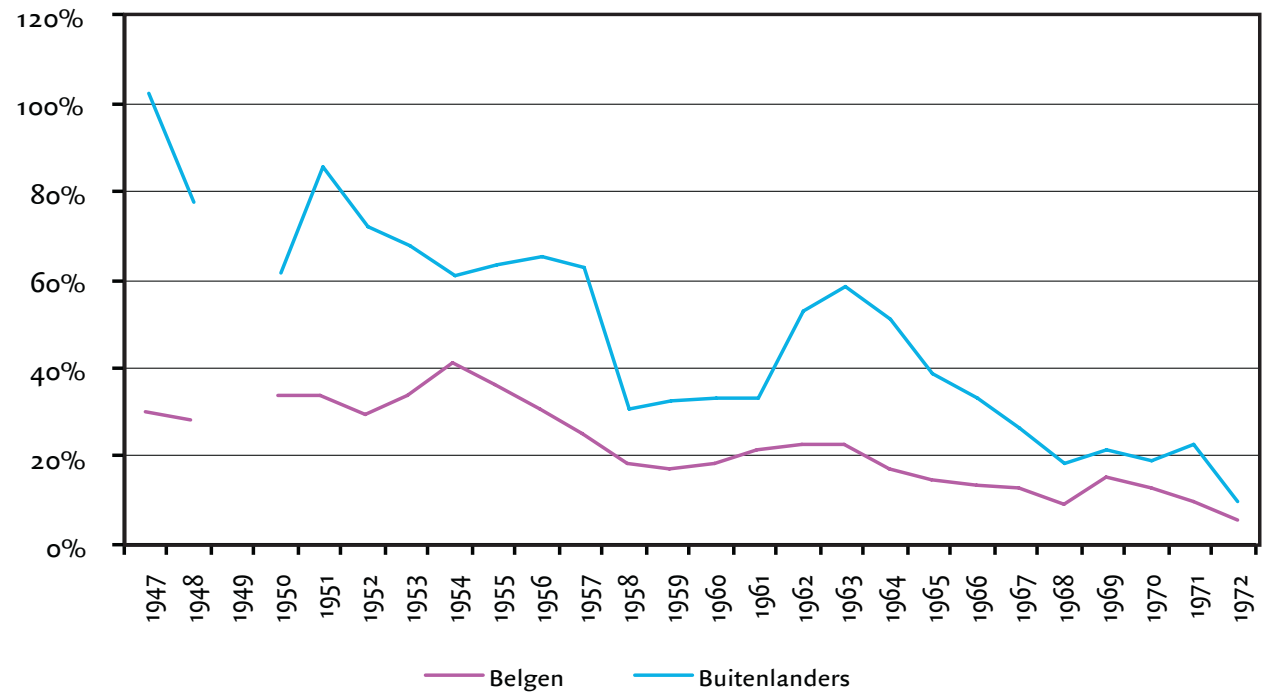

Bron: berekend naar RAH, archief FEDECHAR, inv.nr. 6I4 en inv.nrs. 1579-I58I; Annales des Mines de Belgique, 1948-1974.

De effecten van de kolencrisis en de nieuwe golven buitenlanders zijn ook zichtbaar wanneer we bekijken waar de inkomende mijnwerkers vandaan kwamen. In grafiek 5.9 wordt onderscheid gemaakt tussen intreders afkomstig van andere zetels van eenzelfde NV, uit het Luikse bekken zelf, uit andere mijnbekkens, en nieuwkomers zonder ervaring in het mijnwerk ('andere'). De laatste groep bestond vooral uit onervaren buitenlanders. Tot aan de kolencrisis vormde deze groep onervaren nieuwkomers steeds de helft of meer van de nieuwe intreders.

In 1958 en volgende jaren sloeg dit om en werden minder arbeiders zonder mijnervaring aangetrokken. In 1959 en I960 had minder dan 30 procent van de inkomende mijnwerkers geen ervaring; meer dan 70 procent van de nieuwkomers had toen in andere mijnen gewerkt. Dit kan worden verklaard door de terugval in de rekrutering van buitenlandse arbeiders gedurende de kolencrisis. De mijnen kwamen toen grotendeels toe met het reeds beschikbare mijnwerkersbestand. Dit veranderde in 1962 , toen wederom de meerderheid van de 'nieuwe' mijnwerkers elke ervaring miste. Het betrof nieuwe groepen migranten: nieuwe contingenten uit Griekenland en Spanje in I962 en twee jaar later, vanaf I964, ook Marokkanen en Turken..$^{\circ}$ Door voortschrijdende sanering van de mijnzetels - sinds I964 baatten de meeste mijnbedrijven nog slechts één zetel uit ${ }^{-{ }^{4}}$ nam het verloop tussen zetels van eenzelfde NV ook drastisch af.

In de FEDECHAR-statistieken werd voor de mijnwerkers afkomstig van andere bekkens

40 Zie hoofdstuk 3 .

4I Volgens Annales des Mines de Belgique waren er in I964 I4 mijnbedrijven en I6 mijnzetels in het Luikse bekken. De zetels van de ondernemingen Hasard en Wérister werden als aparte mijnbedrijven genoteerd. Zie: 'Tableau des mines de houille', Annales des Mines de Belgique (1965) 775-776. 


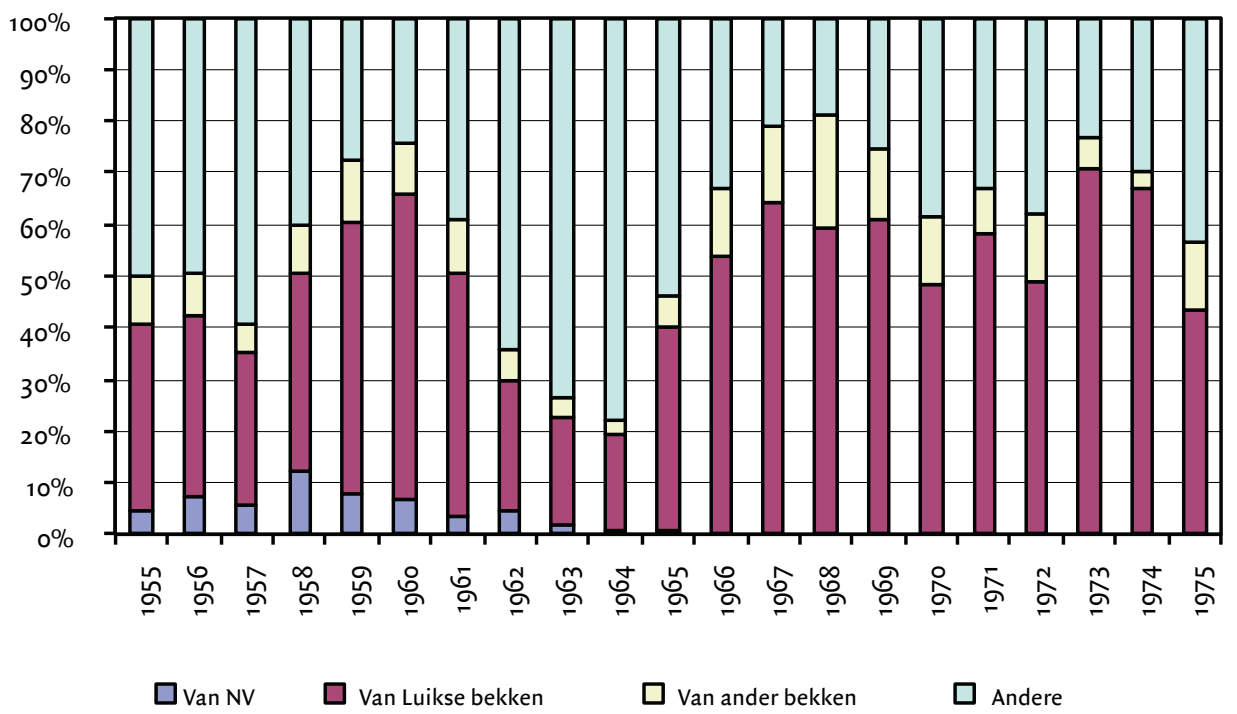

Bron: RAH, archief FEDECHAR, inv.nr. 568 e.v.

ook opgegeven waar ze vandaan kwamen (grafiek 5.Io). Daaruit blijkt dat er in het begin van de jaren 1950 een groot verloop was tussen het Luikse en Kempische bekken. Op het hoogtepunt, in 1952, werden er I.800 mijnwerkers gewisseld tussen deze aangrenzende mijnbouwregio's. Uit grafiek 5.II blijkt dat dit verloop overduidelijk in het voordeel van de Luikse mijnen was. Tot 1956 slaagde zij erin meer mijnwerkers van de Kempische mijnen af te snoepen, zij het sinds 1952 in afnemende mate. Daarna stabiliseerde de situatie zich.

Een belangrijke verklaring voor deze populariteit van het Luikse bekken ten opzichte van het Kempische bekken zijn de loonverschillen. In het begin van de jaren I950 lagen de nettolonen voor de houwers in Luik gemiddeld zo'n ro procent hoger dan in de Kempen. ${ }^{42}$ Mogelijk speelden ook culturele factoren mee. Paul Minon geeft aan dat veel buitenlandse arbeiders de Zuiderbekkens verkozen, hoewel de omstandigheden in de Kempen als beter werden gezien. Vooral de Italiaanse mijnwerkers zouden zich beter thuis hebben gevoeld in het Franstalige en meer verstedelijkte Wallonië. 43

Na 1952 zien we het arbeidsverloop van en naar de Belgisch-Limburgse mijnen dalen (grafiek 5.Io); ook het verlies aan Luik neemt af (grafiek 5.II). In de jaren I96o, I965 en I970 vertrokken er zelfs meer mijnwerkers uit de Luikse mijnen naar Belgisch-Limburg dan dat ze er voor terugkregen. Deze stabilisering van het verloop van Kempische mijnwerkers naar de Luikse mijnen kan niet worden verklaard door een vermindering van het loonverschil. Dat daalde in 1957 even tot iets meer dan 5 procent, maar over het algemeen bleven er

42 'Economische statistiek van de extractieve nijverheid en van de metaalnijverheid', Annales des Mines de Belgique, I95I-1967. Zie ook bijlage $\mathrm{I}$.

43 Minon, Migrations provoquées, 8I. 
GRAFIEK 5.IO HET ARBEIDSVERLOOP VAN EN NAAR HET LUIKSE BEKKEN, I950I969

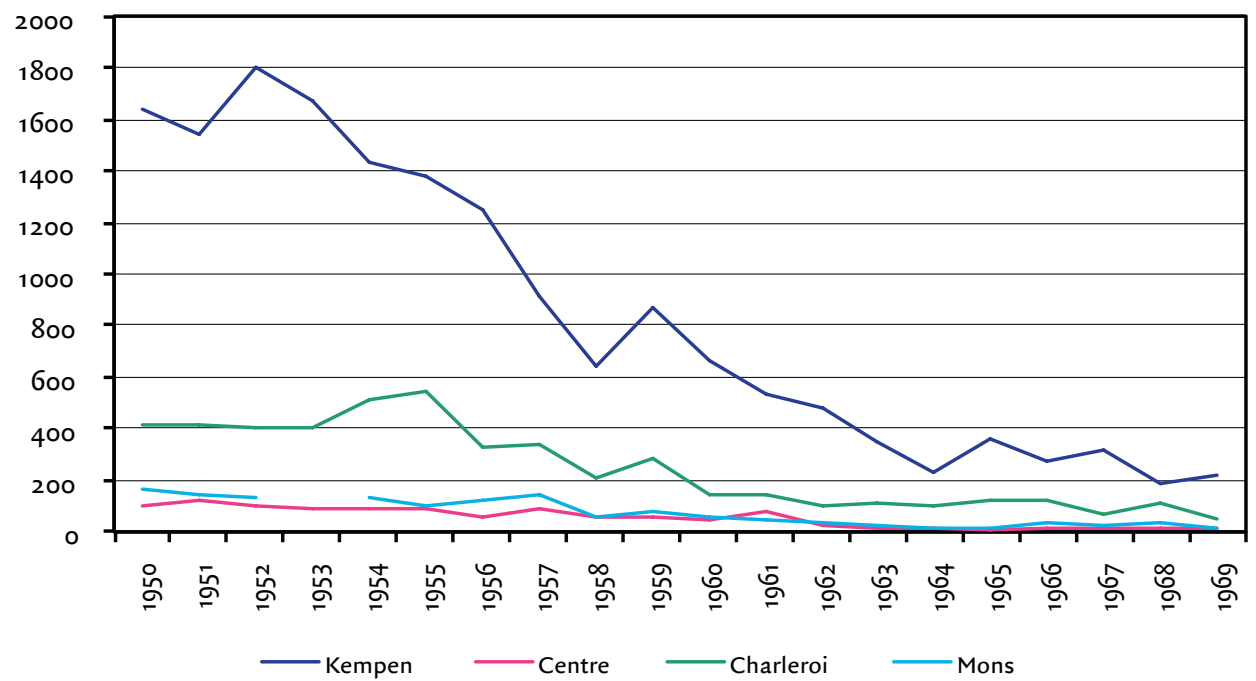

Bron: berekend naar RAH, archief FEDECHAR, inv.nr. 6I4 (arbeidsverloop = som van in- en uitstroom).

GRAFIEK 5.II DE WINST VAN OF VERLIES AAN MIJNWERKERS UIT ANDERE BELGISCHE BEKKENS, I950-I969

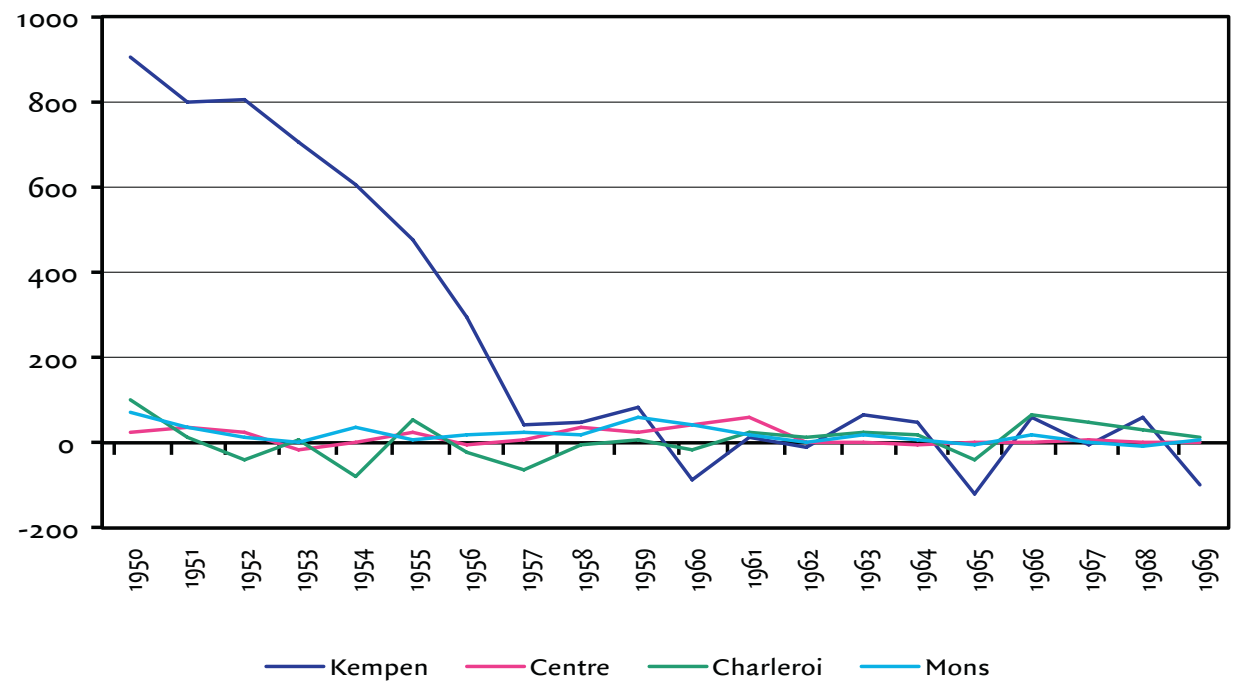

Bron: RAH, archief FEDECHAR, inv.nr. 6I4 (winst of verlies = saldo van in- en uitstroom).

loonverschillen tussen de Luikse en Kempische mijnen bestaan. Het heeft wellicht eerder te maken met het aantal beschikbare arbeidsplaatsen. In de jaren 1950 stelden de Kempische mijnen 10.000 meer arbeiders te werk dan de Luikse; in 1958 was dat meer dan 15.000 om I64 
daarna steeds verder te stijgen. In $1_{96} 6$ bedroeg het verschil in tewerkgestelde mijnwerkers al bijna $20.000 .{ }^{44}$

De uitwisseling van arbeid met de andere Zuiderbekkens was van minder belang. Alleen met het bekken van Charleroi, dat net zoals het Luikse voornamelijk huisbrandkolen produceerde, was er een bescheiden verloop, maar het uiteindelijke saldo toont geen uitschieters.

\section{De in- en uitstroom nader bekeken: de uitstroom}

Volgens FEDECHAR vertrok in het begin van de jaren 1950 elk jaar minstens één ondergrondse mijnwerker op vier (of 25 procent) om zijn geluk elders te beproeven. ${ }^{45}$ Analoog aan het relatieve arbeidsverloop en de relatieve instroom kunnen we het jaarlijks aantal vertrokken arbeiders uitdrukken als percentage van de gemiddelde personeelsbezetting: het vertrek- of ontslagpercentage (grafiek 5.I2). In de onderzochte periode beëindigden jaarlijks tussen de 30 en 40 procent van de in België geboren mijnwerkers hun dienstverband. Deze uitstroom kan verklaard worden door de aanwezigheid van aantrekkelijke alternatieve werkgelegenheid. Op de arbeidsmarkt in het sterk geïndustrialiseerde Luikse bekken bestond veel concurrentie van nijverheden als de staal-, glas- en wolindustrie, en het was voor de steenkoolsector moeilijk de arbeidsomstandigheden veel te verbeteren. Het was nu eenmaal een zwaar, vuil en lastig beroep. De afkeer van Belgen voor het mijnwerk was al langer een probleem.

GRAFIEK 5.I2 DE JAARLIJKS VERTROKKEN BELGEN EN BUITENLANDERS ALS PERCENTAGE VAN HUN TOTALE BEZETTING, LUIKSE MIJNEN, I947-I972

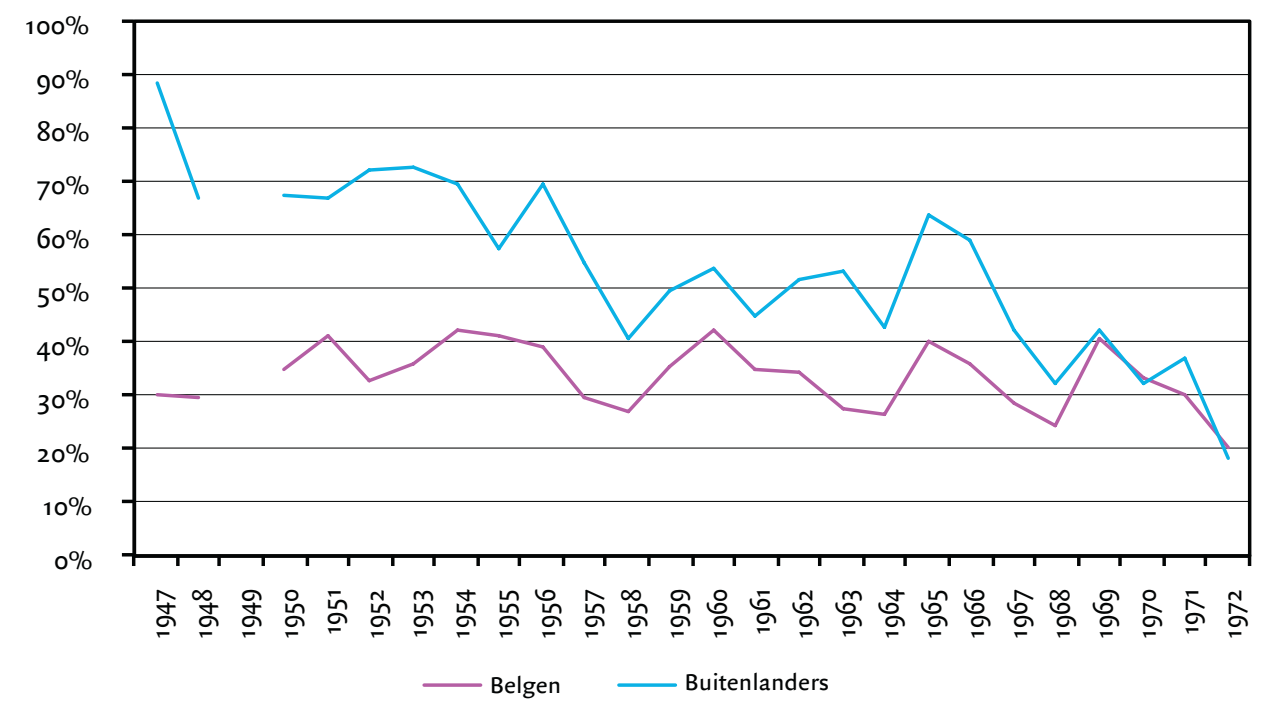

Bron: berekend naar RAH, archief FEDECHAR, inv.nr. 6I4 en inv.nrs. I579-I58I.

44 'Technische kenmerken van de Belgische Steenkolenontginning', Annales des Mines, I959-rg66.

45 Minon, Migrations provoquées, 79-80. 


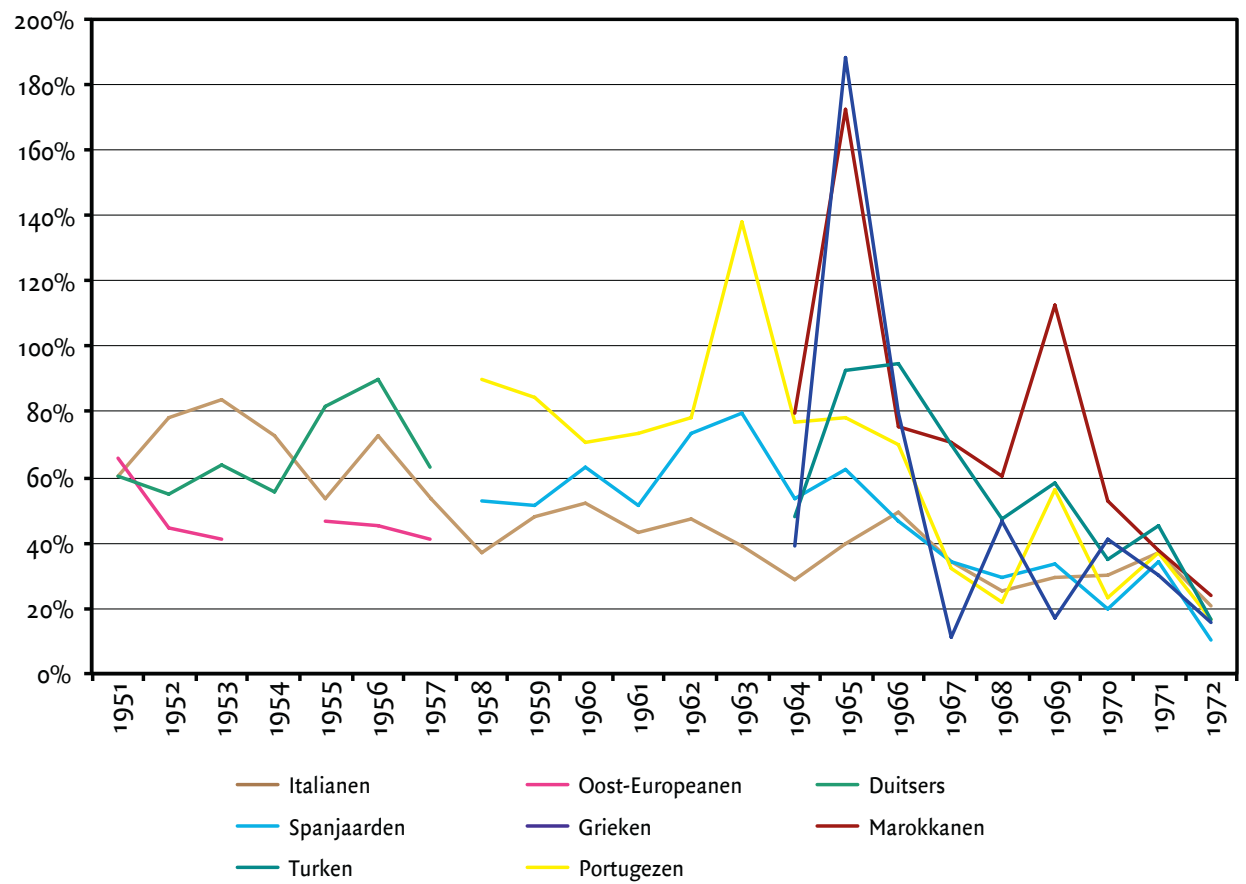

Bron: berekend naar RAH, archief FEDECHAR, inv.nr. 6I4 en 'Technische Kenmerken van de Belgische Steenkolenontginning', Annales des Mines de Belgique, I952-I972. In de statistieken van FEDECHAR werd pas vanaf I95I onderscheid gemaakt naar nationaliteit.

Deze concurrentie van andere sectoren speelde in het geval van de buitenlandse arbeiders een minder grote rol, want zij waren voor minstens vijf jaar aan de steenkoolsector gebonden. Toch lag het vertrekpercentage van de buitenlandse arbeidskrachten over het algemeen nog hoger dan dat van de Belgen. Het jaar 1947, waarin bijna 9o procent van de buitenlandse mijnwerkers z'n werk bij een Luikse mijn stopzette, was wel heel uitzonderlijk, maar in andere jaren schommelde het aandeel vertrokken buitenlandse mijnwerkers nog altijd tussen 40 en 70 procent. Zoals eerder opgemerkt had dit deels te maken met het feit dat ze over het algemeen ondergronds werkten, waar het arbeidsverloop groter was dan bovengronds. Pas aan het einde van de jaren I96o stabiliseerde dit percentage zich op het niveau van de Belgische mijnwerkers (30-40 procent). Dit was nog altijd een heel stuk hoger dan in de Nederlandse mijnen. Voor het jaar 1957 werden ontslagpercentages opgetekend van II en 24 procent in respectievelijk de Domaniale mijn en de mijn Julia, een aandeel waar de Luikse mijnen alleen maar van konden dromen! $4^{6}$

De oorzaak van het grote arbeidsverloop van de arbeidsmigranten werd door de mijndirecties, werkgeversorganisaties en FEDECHAR gezocht in de afkomst van de nieuwe mijn- 


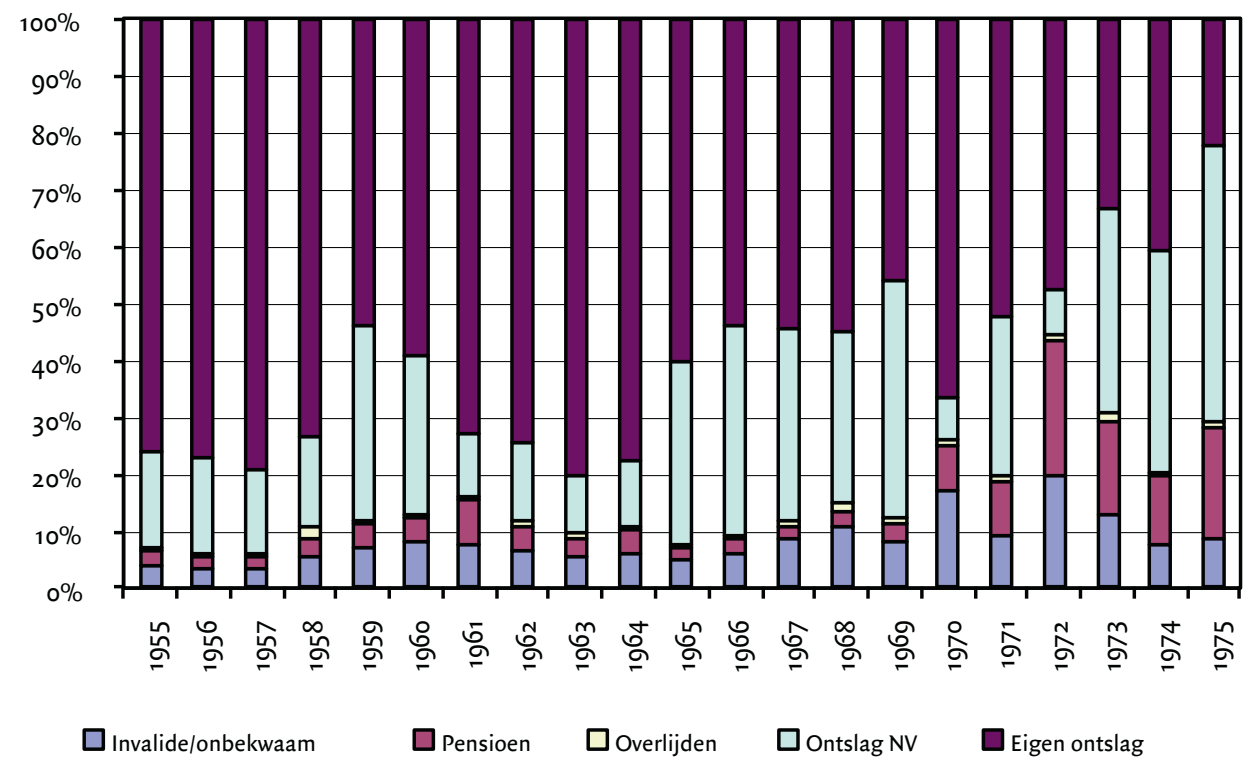

Bron: RAH, archief FEDECHAR, inv.nr. 568 e.v.

werkers en de kwaliteit van de rekrutering. ${ }^{47}$ Het grootste deel van de nieuwkomers was afkomstig uit streken gelegen buiten industriële bekkens en had zodoende geen ervaring met het mijnwerk. Op de rekruteringsaffiches en door de wervingsbureaus werd het mijnwerk en het leven in België rooskleurig voorgesteld. Bij aankomst bleek het werk in de mijnen soms te zwaar en de heimwee naar het thuisland te groot. De opleiding voor de nieuwkomers liet bovendien te wensen over, waardoor het moeilijker was van deze onervaren werkkrachten succesvolle mijnwerkers te maken.

Uitsplitsing van het vertrekpercentage naar nationaliteit (grafiek 5.I3) laat zien dat jaren van massale aanwerving over het algemeen werden gevolgd door een piek in de uitstroom. Vele nieuwelingen beëindigden hun dienstverband voortijdig, zoals bij de Grieken in I963 en de Marokkanen en Portugezen in 1965. De jaarlijkse vertrekpercentages van de Italiaanse arbeiders blijken zich in deze periode te stabiliseren. Dit kan wijzen op een slechte selectie van de nieuwste groepen gastarbeiders. De Spanjaarden vertoonden in $1_{9} 63$ een lager ontslagpercentage. De Luikse mijnen hadden dan wel geen andere keuze dan buitenlandse arbeidskrachten aantrekken om het arbeidstekort op te lossen, ze hadden wel hun preferenties wat betreft afkomst. Zo werden de Grieken als onbetrouwbaar en moeilijk te rekruteren gezien en de Spanjaarden als een betere keuze. ${ }^{48}$ De vertrekpercentages lijken dit te bevestigen. 


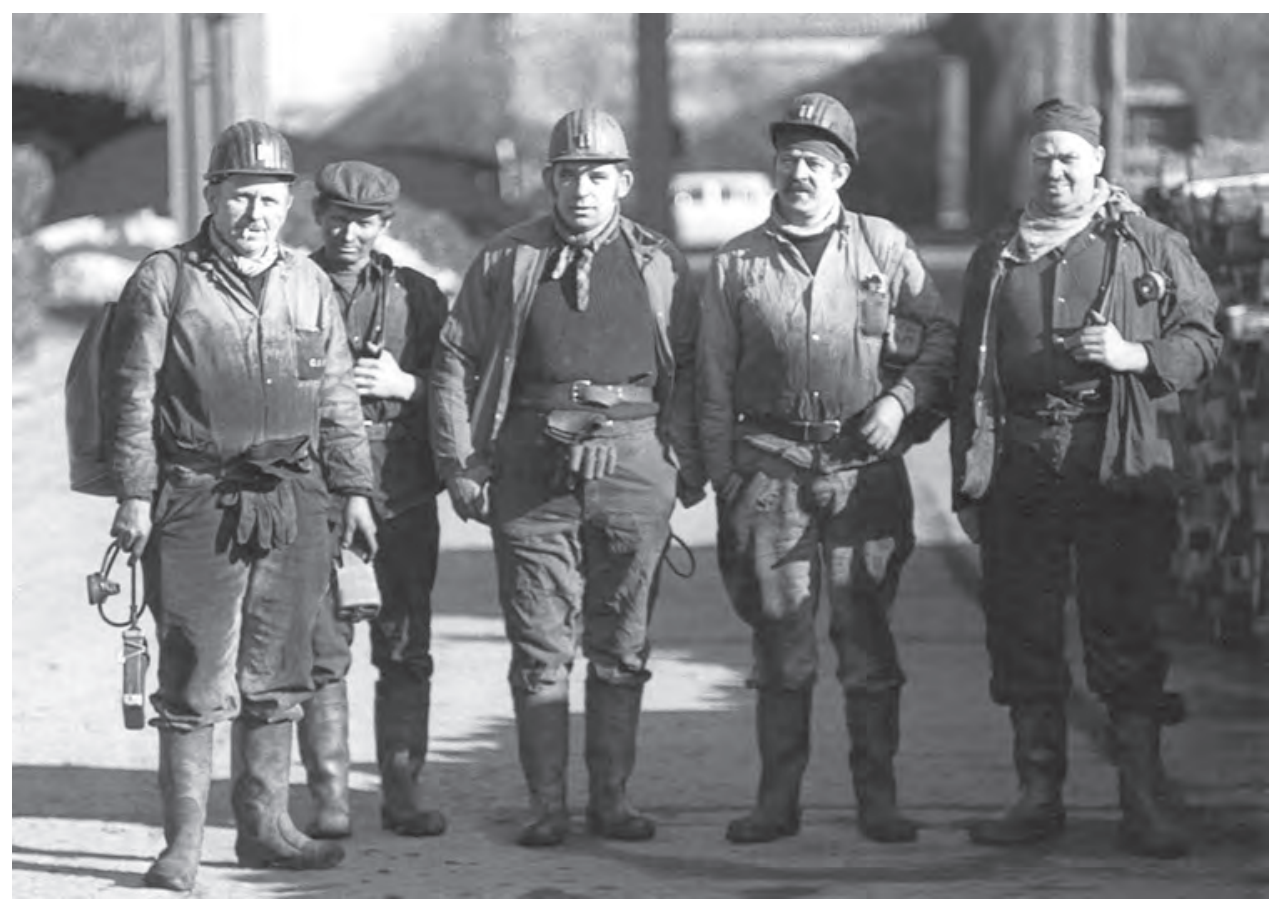

Groep mijnwerkers van de NV Argenteau te Trembleur, ca. 1980. Foto Alfred Janssen-Reul. Coll. Blegny-Mine.

Het vrijwillige vertrek onder mijnwerkers was zeker tot de kolencrisis erg groot. Verreweg het grootste deel van de vertrekkers na 1955 had zelf ontslag genomen (grafiek 5.I4). In I959 en I960 was het aandeel van onvrijwillig ontslagen mijnwerkers groter. Door de daling van de vraag naar mijnarbeid tijdens de kolencrisis konden de mijnbedrijven kieskeuriger zijn en arbeiders die niet aan hun eisen voldeden ontslaan. Zodra het arbeidstekort in het begin van de jaren 1960 groter werd, daalde het onvrijwillig ontslag weer en werd het aandeel mijnwerkers dat zelf vertrok groter, met name na de komst van de nieuwe contingenten

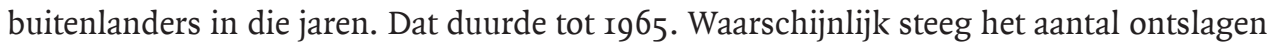
door de mijnbedrijven door het grote aantal mijnsluitingen na dat jaar. Voordien kon dat worden voorkomen door mijnwerkers bij de sluiting van een mijnzetel naar een andere zetel van een mijnbedrijf over te plaatsen. In de tweede helft van de jaren I96o sloten volledige mijnbedrijven hun deuren. ${ }^{49}$ De stijging van het aandeel mijnwerkers dat vertrok vanwege invaliditeit of onbekwaamheid en pensioen in de jaren 1970 kan ook in dit licht worden bezien en had wellicht ook te maken van een versoepeling van de criteria: vanaf I970 was een diensttijd van ro jaar voldoende om recht te hebben op een invaliditeitspensioen, ongeacht de leeftijd van de mijnwerker..$^{\circ}$

49 Zo stopten zowel zetel Bonne-Fin als Batterie met produceren, wat het einde van de S.A. des Charbonnages de Bonne Espérance, Batterie, Bonne-Fin et Violette betekende in 1965. Op twee jaar tijd, tussen 1967 en 1969 , stopten eveneens de twee overgebleven zetels van de S.A. des Charbonnages de Wérister, Romsée en José, met produceren. 'Tableau des mines de houille', Annales des Mines de Belgique, I966I970.

50 Cf. Telefonisch onderhoud op 7 oktober 2013 met Eric Verbraeken, attaché Dienst uitkeringen Mijnwerkers bij het RIZIV. 


\section{HET 'OVERLEVINGSPERCENTAGE' ALS MAATSTAF VOOR HET VERLOOP, I924-I976}

Aan de hand van de in het FEDECHAR-archief overgeleverde statistieken konden wij het relatieve arbeidsverloop slechts reconstrueren voor de periode na de Tweede Wereldoorlog. Bovendien kon hiermee alleen een onderscheid worden gemaakt naar nationaliteit. Met behulp van de selecte steekproef uit de pensioenregistratie kunnen ook over vroegere periodes uitspraken worden gedaan en is het mogelijk het Belgische mijnpersoneel verder uit te splitsen naar woonplaats. Met name de belangrijke groep pendelaars komt zo in beeld. De selecte steekproef bevat gegevens van de geboortecohortes van januari I9Io en januari I920, met dienstverbanden van 1924 tot 1976 (zie bijlage 8). Zoals in de inleiding van dit hoofdstuk al werd aangekondigd, worden de gegevens van de steekproef gebruikt voor het meten van het zogenaamde overlevingspercentage of de overlevingskromme: een lijn die aangeeft hoeveel werknemers na een bepaalde tijd nog in dienst is, uitgedrukt als percentage van de totale groep in dienst getreden werknemers. ${ }^{51} \mathrm{Er}$ is voor gekozen na te gaan hoe lang mijnwerkers aanwezig bleven in de Luikse mijnen, ongeacht eventuele wisselingen tussen Luikse mijnen onderling.

Om de analyse door de tijd heen te vereenvoudigen werden de geboortecohortes in de selecte steekproef van Igro en 1920 onderverdeeld in intredecohortes. Een mijnwerker geboren in januari Igro kon immers reeds intreden in I924, op I4-jarige leeftijd, maar ook pas veel later, bijvoorbeeld na de Tweede Wereldoorlog in 1949. We onderscheidden de volgende intredecohortes, waarbij het criterium het specifieke karakter van de periode was en niet de lengte daarvan:

I 1924-1930 Het beginjaar van deze periode werd gekozen om praktische redenen; in dat jaar ging een mijnwerker uit de steekproef voor het eerst een dienstverband aan (I75 mijnwerkers);

2 I93I-I944 Crisistijd, stakingen en oorlogsjaren (I96 mijnwerkers);

3 1945-I955 Wederopbouw van de arbeidsmarkt (4II mijnwerkers);

4 I956-1967 Kolencrisis (4I mijnwerkers). Deze laatste cohort omvat betrekkelijk weinig mijnwerkers en bovendien is het mogelijk dat leeftijdseffect (de ingetreden mijnwerkers zijn respectievelijk 36 tot 47 jaar oud) hier een rol begint te spelen, daarom zal deze cohort verder buiten beschouwing worden gelaten.

Grafiek 5.15 toont de overlevingspercentages van de totale steekproefpopulatie (intredecohort 1924-I930, I93I-I944 en I945-I967). Daaruit blijkt dat minder dan 30 procent van de ooit ingetreden mijnwerkers langer dan tien jaar in de Luikse steenkoolindustrie aanwezig bleven. In de pensioenregistratie werd de reden voor het beëindigen van het dienstverband niet opgegeven. Dat de overlevingskromme een nogal sterk verval kent heeft wellicht opnieuw te maken met het geforceerde karakter van de werving. Door het vrijwel permanente tekort werden ook minder geschikte of weinig gemotiveerde arbeiders aangetrokken, die geen lange carrière in het mijnbedrijf nastreefden en al snel hun ontslag indienden. De mobiliteit in het eerste jaar na de indiensttreding had te maken met het feit dat de mijnwerker nog niet veel had geïnvesteerd in zijn nieuwe situatie: er waren nog geen belangrijke pensioenaanspraken en ook de emotionele binding met het werk en de collega-mijnwerkers 
GRAFIEK 5.I5 HET OVERLEVINGSPERCENTAGE IN DE STEEKPROEF FNROM ALS GEHEEL (NAAR UITTREDEJAAR)

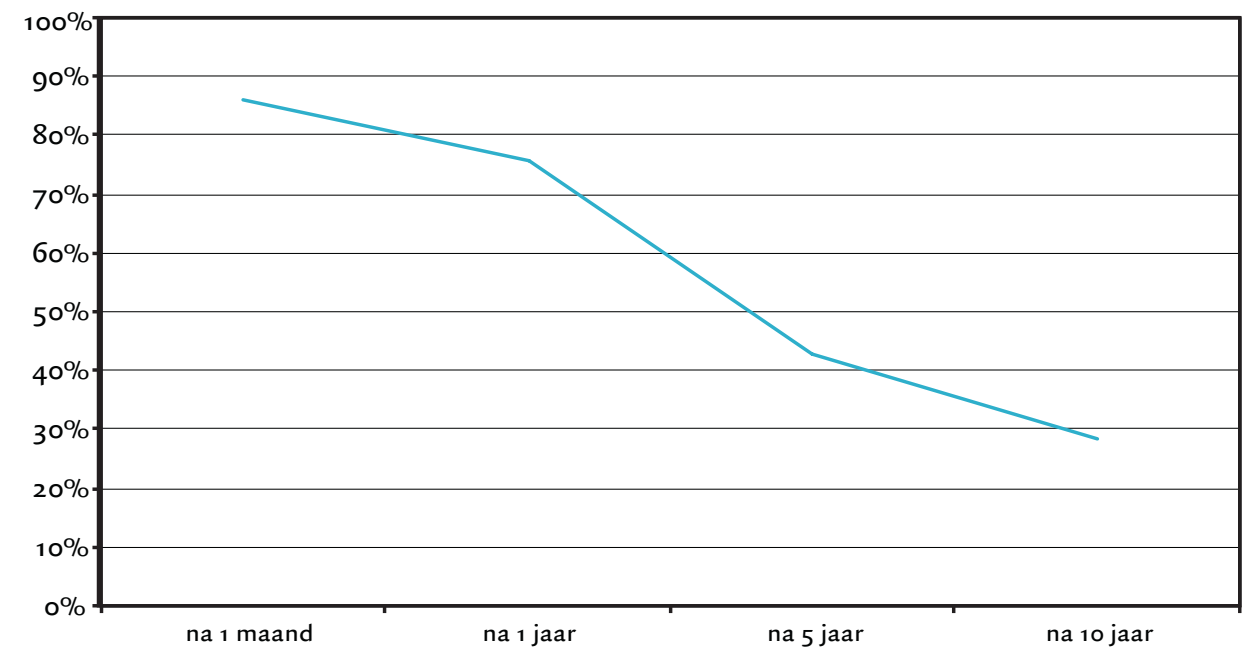

Bron: Steekproef FNROM (zie bijlage 8).

GRAFIEK 5.I6 HET OVERLEVINGSPERCENTAGE NAAR INTREDECOHORTES (STEEKPROEF FNROM NAAR UITTREDEJAAR)

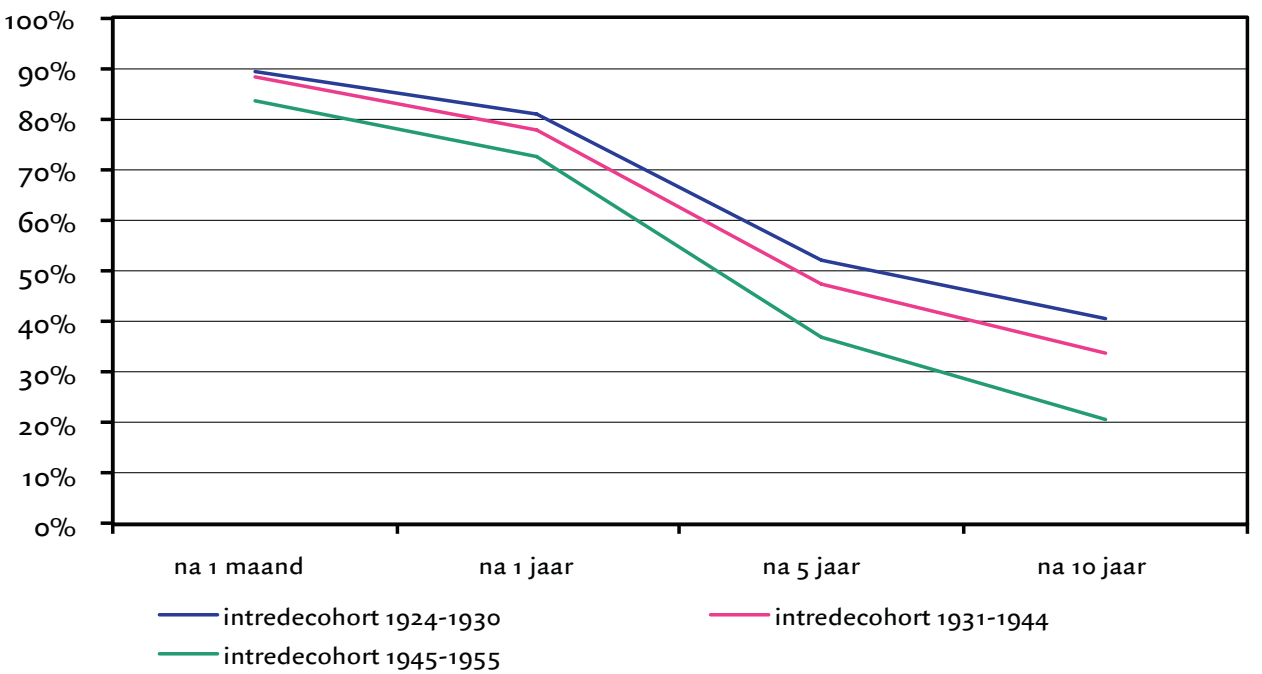

Bron: Steekproef FNROM (zie bijlage 8).

was nog niet sterk..$^{2}$ Dat er ook tussen het eerste en het vijfde jaar nog vrij veel mijnwerkers afvielen kan te maken hebben met aantrekkelijker alternatieven. 
In de loop van de onderzochte periode namen de overlevingspercentages per intredecohort af (grafiek 5.I6). Mijnwerkers bleven dus steeds minder lang aanwezig in de Luikse steenkoolnijverheid. ${ }^{53}$ Men zou kunnen verwachten dat de 'trouw' aan de Luikse steenkoolnijverheid tijdens de crisis- en oorlogsjaren (intredecohort I93I-I944) zou zijn toegenomen, enerzijds omdat alternatieve werkgelegenheid toen schaarser werd, anderzijds omdat het mijnwerk in oorlogstijd allerlei voordelen opleverde, maar dit was niet het geval.54

TABel 5.I Het vertrek uit de Luikse mijnen. Cumulatieve percentages VAN HET TOTAAL AANTAL MIJNWERKERS IN DE INTREDECOHORT

\begin{tabular}{|l|c|c|}
\hline Intredecohort & Vertrokken na 5 jaar & Vertrokken na Io jaar \\
\hline I924-I930 & $48,0 \%$ & $59,4 \%$ \\
\hline I93I-I944 & $52,5 \%$ & $66,3 \%$ \\
\hline I945-I955 & $63,0 \%$ & $79,3 \%$ \\
\hline
\end{tabular}

Bron: Steekproef FN ROM (zie bijlage 8).

De standvastigste groep mijnwerkers waren die van intredecohort I924-I930. Van hen was gemiddeld 8I procent na een jaar nog in de Luikse steenkoolsector werkzaam. Na vijf jaar was dat nog 52 procent en na tien jaar nog iets meer dan 40 procent. Het intredecohort I93I-I944 vertoont ongeveer dezelfde evolutie, al lagen daar de overlevingspercentages iets lager. Intredecohort I945-I955 kende de laagste overlevingspercentages: na een jaar werkte nog iets meer dan 72 procent in de Luikse mijnen, na vijf jaar nog bijna 37 procent en na tien jaar net geen 2I procent. We hielden bij deze berekeningen geen rekening met eventuele wissels tussen de Luikse mijnen onderling; het gaat hier dus om loyaliteit aan de Luikse steenkoolnijverheid als geheel.

We kunnen concluderen dat gemiddeld ongeveer drie kwart van de mijnwerkers langer dan een jaar bleef, maar dat het erg moeilijk was om ze langer dan vijf jaar vast te houden. Van de intredecohortes I924-I930 en I93I-I944 gaf ongeveer de helft er binnen vijf jaar de brui aan; in de naoorlogse periode was dit opgelopen tot 63 procent (tabel 5.I). Dit wijst erop dat het mijnwerk steeds meer als een tijdelijke loopbaankeuze werd gezien en steeds minder als een carrière. Lange carrières kwamen steeds minder voor. Bij intredecohort I924 tot 1930 had nog iets meer dan 40 procent van de mijnwerkers een carrière van meer dan tien jaar. Bij de intreders in de periode I93I-I944 was dat nog 33 procent, maar na de Tweede Wereldoorlog was nog maar ca. 20 procent van de ingetreden mijnwerkers bereid langer dan tien jaar in de Luikse mijnen te werken. Men zou kunnen stellen dat hier ook een leeftijdseffect een rol speelt. Immers, alle mijnwerkers uit de onderzoekspopulatie werden geboren in I9Io en I920. Aangezien we als criterium voor een lange carrière een diensttijd van meer dan ro jaar nemen, hoeft dit geen vertekening op te leveren. Alle mijnwerkers, zowel diegenen geboren in I9ro als I920 kunnen in principe in intredecohort I945-I955 een

53 Aangezien gebruik werd gemaakt van geboortecohortes voor de analyse dient er ook rekening gehouden te worden met eventuele leeftijdseffecten. Een vergelijking van de overlevingspercentages van geboortecohort I9Io met geboortecohort 1920 voor de intredecohort I945-1955 toonde echter geen significante verschillen aan. De invloed van leeftijdseffecten op het dalende overlevingspercentage voor intredecohort I945-I955 is dus minimaal.

54 Onder meer bescherming tegen deportatie, hogere lonen en rantsoenen; zie hoofdstuk 4. 
diensttijd van Io jaar volbrengen. Eerder bleek trouwens dat een hogere intredeleeftijd voor de Luikse mijnbazen geen probleem was. ${ }^{55}$

\section{Overlevingspercentages naar afkomst}

Op basis van de selecte steekproef is het mogelijk onderscheid te maken tussen Luikenaren (afkomstig uit de provincie Luik), andere Belgen (afkomstig uit en eventueel woonachtig in andere Belgische provincies), en buitenlanders (afkomstig uit het buitenland). In tabel 5.3 worden de mijnwerkers uit de selecte steekproef naar hun geboorteplaats geordend, dus niet naar woonplaats. Omdat een aantal van de mijnwerkers uit een andere provincie zich in de Luikse regio had gevestigd gaat het bij de niet-Luikse Belgen in deze tabel niet alleen om pendelaars. In de pensioenregistratie werd niet steeds een woonplaats genoteerd en veranderingen daarin werden in de meeste gevallen niet aangegeven. Daarom kunnen wij alleen iets over het belang van de pendel zeggen op basis van de woonplaatsen bij het eerste dienstverband. Van de I49 Belgen in de geboortecohort I9Io waarvan de woonplaats werd genoteerd waren er 50 als pendelaars afkomstig uit een andere provincie. Daarnaast kunnen ook de 23 mijnwerkers uit de provincie Luik, maar van buiten de Luikse regio als pendelaars worden beschouwd. In de geboortecohort 1920 waren 43 van de I 48 Belgen met een woonplaats afkomstig uit een andere provincie; 2I pendelaars zijn wel afkomstig uit de provincie Luik, maar wonen buiten de Luikse regio.

TABEL 5.2 HeT PERCENTAGE BELGISCHE MIJNWERKERS WOONACHTIG BUITEN DE Luikse REgio EN BUITEN DE PROVINCIE LUIK BIJ HET EERSTE DiENSTVERBAN D

\begin{tabular}{|l|c|c|}
\hline Intredecohort & Buiten Luikse regio & Buiten provincie Luik \\
\hline I924-I930 & $4 \mathrm{I}, 9 \%$ & $32,4 \%$ \\
\hline I93I-I944 & $36,8 \%$ & $20,8 \%$ \\
\hline I945-I955 & $63,4 \%$ & $47,9 \%$ \\
\hline
\end{tabular}

Bron: Steekproef FNROM. Het aantal pendelaars in intredecohort 1956-1966 was te klein om te verwerken.

Uit tabel 5.2, waarin deze pendelaars naar jaar van intrede zijn geordend, blijkt dat het aandeel van de pendelaars, na een daling tijdens de crisis en de oorlogsjaren, na de Tweede Wereldoorlog sterk was toegenomen. Bijna de helft van de Belgische arbeidskrachten in de Luikse mijnen pendelde toen vanuit een andere provincie. Dat definitieve migratie steeds minder voorkwam blijkt ook uit het afnemend aandeel van Vlamingen dat in het Luikse arrondissement woonachtig was. In I9Io sprak nog meer dan 2,5 procent van de inwoners bijna uitsluitend Nederlands, in I 947 was dit gedaald naar I,63 procent. Naast de vooruitgang in de transportsector worden ook problemen met de huisvesting genoemd als oorzaak voor het grote aantal pendelaars. ${ }^{56}$

Uit tabel 5.3 kunnen we afleiden welke groepen arbeiders tijdens de verschillende periodes belangrijk waren. In de eerste intredeperiode was de groep mijnwerkers afkomstig uit

55 Dumoulin, 'Pour une histoire de l'immigration italienne en Belgique', 37. 56 Nols, 'Zone de recrutement', 357. 
Luik het belangrijkst, op de tweede plaats stonden de buitenlandse mijnwerkers, en dan de arbeiders afkomstig uit Belgisch-Limburg en Brabant.

TABEL 5.3 DE GEOGRAFISCHE HERKOMST VAN DE ARBEIDERS IN DE LUIKSE MIJNEN NAAR GEBOORTEPLAATS, I924-I966

\begin{tabular}{|c|c|c|c|c|c|c|c|c|c|}
\hline \multirow{2}{*}{\multicolumn{2}{|c|}{\begin{tabular}{|l} 
Geboorteplaats \\
\end{tabular}}} & \multicolumn{8}{|c|}{ Intredecohort } \\
\hline & & 1924-1930 & $\%$ & I93I-I944 & $\%$ & I945-1955 & $\%$ & 1956-1966 & $\%$ \\
\hline \multicolumn{2}{|c|}{ Antwerpen } & 0 & & 2 & $\mathrm{I}, \mathrm{I} \%$ & 9 & $2,2 \%$ & $\mathrm{I}$ & $2,6 \%$ \\
\hline \multicolumn{2}{|c|}{ Brabant } & Io & $6,9 \%$ & 9 & $4,9 \%$ & 9 & $2,2 \%$ & - & \\
\hline \multicolumn{2}{|c|}{ Oost-Vlaanderen } & $\mathrm{I}$ & $0,7 \%$ & 2 & $\mathrm{I}, \mathrm{I} \%$ & 4 & $\mathrm{I}, \mathrm{O} \%$ & - & \\
\hline \multicolumn{2}{|c|}{ West-Vlaanderen } & 3 & $2, \mathrm{I} \%$ & 2 & $\mathrm{I}, \mathrm{I} \%$ & 2 & $0,5 \%$ & - & \\
\hline \multicolumn{2}{|c|}{ Belgisch-Limburg } & 24 & $\mathrm{I} 6,7 \%$ & 23 & $\mathrm{I} 2,5 \%$ & I6 & $4,0 \%$ & $\mathrm{I}$ & $2,6 \%$ \\
\hline \multicolumn{2}{|c|}{ Namen } & 2 & $\mathrm{I}, 4 \%$ & 3 & $\mathrm{I}, 6 \%$ & I & $0,2 \%$ & - & \\
\hline \multicolumn{2}{|c|}{ Henegouwen } & - & & 3 & $\mathrm{I}, 6 \%$ & 2 & $0,5 \%$ & - & \\
\hline \multicolumn{2}{|c|}{ Luxemburg } & - & & 2 & $\mathrm{I}, \mathrm{I} \%$ & I & $0,2 \%$ & - & \\
\hline \multirow[t]{4}{*}{ Luik } & Huy & 4 & $2,8 \%$ & 7 & $3,8 \%$ & 2 & $0,5 \%$ & $\mathrm{I}$ & $2,6 \%$ \\
\hline & Luik & 53 & $36,8 \%$ & 88 & $47,8 \%$ & 20 & $5,0 \%$ & 2 & $5, \mathrm{r} \%$ \\
\hline & Verviers & 4 & $2,8 \%$ & 8 & $4,3 \%$ & 2 & $0,5 \%$ & 2 & $5, \mathrm{I} \%$ \\
\hline & Waremme & I & $0,7 \%$ & 2 & $\mathrm{I}, \mathrm{I} \%$ & $\mathrm{I}$ & $0,2 \%$ & - & \\
\hline \multicolumn{2}{|c|}{ Buitenland } & 42 & $29,2 \%$ & 33 & $17,9 \%$ & 332 & $82,8 \%$ & 32 & $82, \mathrm{I} \%$ \\
\hline \multicolumn{2}{|c|}{ Totaal } & I44 & & 184 & & 401 & & 39 & \\
\hline
\end{tabular}

Bron: Steekproef FNROM (zie bijlage 8).

Het valt op dat er naar verhouding weinig arbeiders afkomstig waren uit de aan de Luikse regio grenzende arrondissementen in de provincie (Huy, Verviers, Waremme). In intredecohort I93I-I944 nam het aandeel van buitenlanders af, dat van mijnwerkers uit het arrondissement Luik toe. In de crisisjaren werd werk buiten de mijnen schaarser en gingen er meer lokale arbeidskrachten de mijn in. In de oorlogsperiode keerden veel buitenlanders terug naar hun thuisland. In de periode I945-I955 was dan weer meer dan 80 procent van de nieuwe intreders van buitenlandse afkomst.

We bekijken de overlevingspercentages van de Luikenaren, de andere Belgen en de buitenlanders nu achtereenvolgens voor de drie intredecohortes (grafiek 5.17-5.I9). Voor alle cohortes geldt dat mijnwerkers afkomstig uit Luik het trouwst waren. Tijdens de crisis- en de oorlogsjaren daalden hun overlevingspercentages wel; die periode hadden de mijnen dus steeds meer moeite de autochtone mijnwerkers vast te houden.

Mijnwerkers uit andere Belgische provincies werden in de loop van de tijd minder honkvast. In het intredecohort I924-I930 behoorden ze tot de groep met de snelste afvallers binnen het jaar, maar als ze eenmaal langer dan een jaar in de Luikse mijnen waren gebleven, was dat voor die intredecohort al snel voor een langere periode. In de intredecohort I93II944 verminderden ook die 'blijvers' en in de periode na de Tweede Wereldoorlog blijken de niet uit Luik afkomstige Belgen de laagste overlevingspercentages te hebben. Het ligt voor de hand dit in verband te brengen met het sterk gegroeide aandeel van de pendelaars (zie hierboven). Zij waren minder standvastig dan de buitenlandse mijnwerkers, waarvan we 
Grafiek 5.I7 De OVERLEVINGSPERCENTAges NAAR AFKOMST, INTREDECOHORT I924-I930

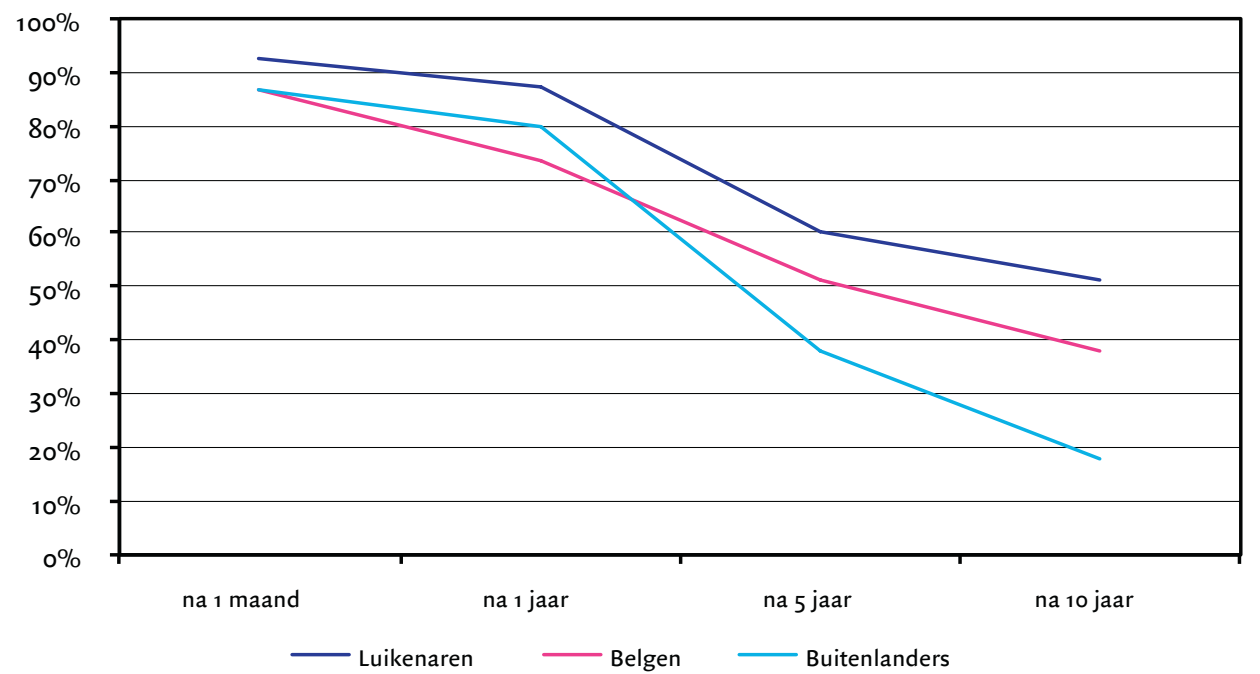

Bron: Steekproef FNROM (zie bijlage 8).

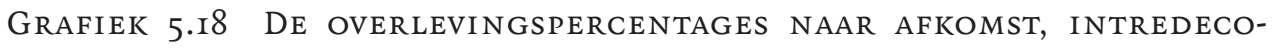
HORT I93I-I944

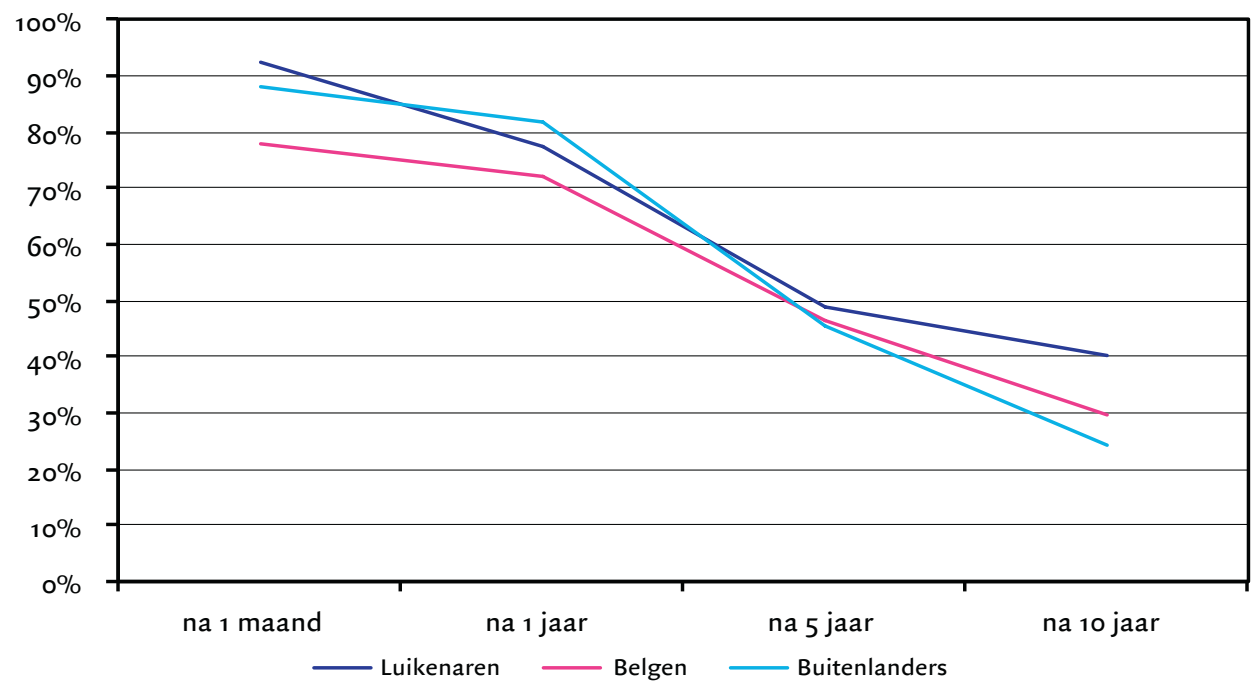

Bron: Steekproef FNROM (zie bijlage 8).

dachten dat ze tot de minst loyale groep zouden behoren. De meeste buitenlandse mijnwerkers hadden arbeidscontracten moeten ondertekenen voor minstens één jaar. Belgen hoefden zo'n contract niet te ondertekenen. 
Grafiek 5.I9 De OVERleVingspercentages NAAR AFKomst, intredecoHORT I945-I955

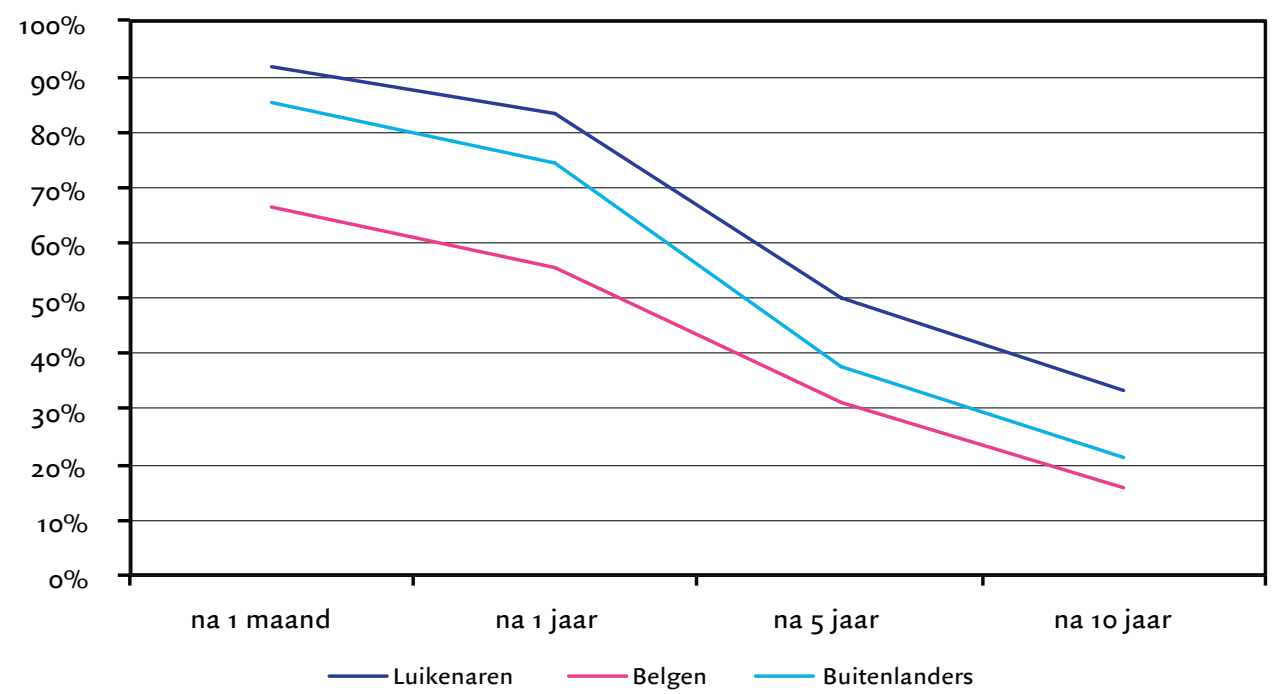

Bron: Steekproef FNROM (zie bijlage 8).

TABEl 5.4 Het VertreK Uit de Luikse mijnen nAAR AFKomst. Cumulatieve PERCENTAGES VAN HET TOTAAL AANTAL MIJNWERKERS NAAR AFKOMST IN DE INTREDECOHORT

\begin{tabular}{|c|c|c|c|c|}
\hline Intredecohort & Vertrek in eerste jaar & Vertrek $\mathrm{t} / \mathrm{m}_{5}$ jaar & Vertrek $\mathrm{t} / \mathrm{m}$ Io jaar & Vertrek na io jaar \\
\hline \multicolumn{5}{|l|}{ Luikenaren } \\
\hline I924-I930 & $\mathrm{I} 2,5 \%$ & $40,0 \%$ & $48,8 \%$ & $51,2 \%$ \\
\hline I93I-I944 & $22,4 \%$ & $5 \mathrm{I}, 3 \%$ & $59,7 \%$ & $40,3 \%$ \\
\hline I945-I955 & $\mathrm{I} 6,6 \%$ & $49,9 \%$ & $66,5 \%$ & $33,5 \%$ \\
\hline \multicolumn{5}{|l|}{ Andere Belgen } \\
\hline I924-I930 & $26,7 \%$ & $48,9 \%$ & $62,2 \%$ & $37,8 \%$ \\
\hline I93I-I944 & $27,8 \%$ & $53,7 \%$ & $70,4 \%$ & $29,6 \%$ \\
\hline I945-I955 & $44,4 \%$ & $68,8 \%$ & $84,3 \%$ & $15,7 \%$ \\
\hline \multicolumn{5}{|l|}{ Buitenlanders } \\
\hline I924-I930 & $20,0 \%$ & $62,2 \%$ & $82,2 \%$ & $\mathrm{I} 7,8 \%$ \\
\hline I93I-I944 & I8,8\% & $55,2 \%$ & $76,4 \%$ & $24,6 \%$ \\
\hline I945-I955 & $25,5 \%$ & $62,2 \%$ & $78,8 \%$ & $21,2 \%$ \\
\hline
\end{tabular}

Bron: Steekproef FN ROM (zie bijlage 8).

Wanneer we de verschillende groepen door de tijd heen bekijken valt op dat de Luikenaren de laagste overlevingspercentages kenden tijdens de crisis- en oorlogsjaren. In die periode vertrok 22,4 procent binnen het eerste jaar (tabel 5.4). Hierboven zagen wij dat er in deze periode wel meer Luikenaren instroomden, maar blijkbaar waren die snel weer verdwenen. 
Voor alle periodes geldt dat de meerderheid tussen de één en vijf jaar in de Luikse mijnen bleef. Ook langere carrières kwamen veelvuldig voor. Na tien jaar was er van het eerste intredecohort nog meer dan 50 procent, in het tweede nog ruim 40 procent, en in de naoorlogse periode nog één derde van de mijnwerkers afkomstig uit Luik aan de slag als mijnwerker. Het afnemende aandeel wijst wel op een achteruitgang van de 'vaste stam'. Steeds minder mijnwerkers uit Luik sloten hun carrière in de mijnen af. De mijnwerkers afkomstig uit provincies buiten Luik - steeds meer pendelaars - kenden na de Tweede Wereldoorlog een enorme daling van de overlevingspercentages. In deze groep vertrok een meerderheid reeds in het eerste jaar. De Luikse mijnen slaagden er dus niet in de pendelarbeiders voor langere tijd aan zich te binden.

De buitenlandse mijnwerkers vertonen gedurende de drie periodes min of meer gelijke overlevingspercentages. De meerderheid onder hen bleef tussen één en vijf jaar in de Luikse mijnen werken. Lange carrières kwamen ook in deze groep weinig voor: tussen de ca. I7 en 25 procent bleef langer dan tien jaar in de Luikse mijnen. De concurrentie met de andere nijverheden in het Luikse speelde ook in het geval van deze arbeiders een rol. Het was niet uitzonderlijk dat zij na het beëindigen van hun contract in de steenkoolindustrie (over het algemeen na vijf jaar) arbeidsmogelijkheden zochten in bijvoorbeeld de staalindustrie. ${ }^{57}$

\section{DE GEPRESTEERDE DIENSTTIJD}

Met behulp van het overlevingspercentage kon alleen de trouw aan de gehele Luikse steenkoolnijverheid worden geanalyseerd, niet die aan elke mijn afzonderlijk. Het arbeidsverloop tussen de mijnzetels werd niet gemeten. Om daarover uitspraken te kunnen doen kijken we naar de gemiddelde duur van de dienstverbanden, maar alleen van de met behulp van de steekproef geselecteerde ondergrondse mijnwerkers. Omdat de ondergrondse omstandigheden en ook de arbeidsvoorwaarden van mijn tot mijn konden verschillen, was er ook veel verloop tussen de mijnen onderling.

Uit een vergelijking van de diensttijden per intredecohort (tabel 5.5) blijkt dat het arbeidsverloop tussen de Luikse mijnen in de loop van de tijd afnam. In de eerste intredecohort was meer dan 65 procent van de dienstverbanden binnen het jaar beëindigd, tijdens de crisis- en oorlogsjaren daalde dit aandeel tot 6r procent, en in de naoorlogse periode bedroeg dit iets meer dan 57 procent. Dit wil zeggen dat iets meer dan 40 procent van de mijnwerkers die tussen 1945 en 1955 in de Luikse mijnen begonnen te werken na een jaar nog bij dezelfde mijn werkzaam was. In de eerste intredecohort was dit slechts een derde van de mijnwerkers.

Deze stijging van de gemiddelde gepresteerde diensttijd wijst op een toenemende trouw aan één werkgever. Hiervoor zagen we echter een daling van de overlevingspercentages, wat dan weer wijst op een afname in de trouw aan de Luikse steenkoolnijverheid als geheel. Het

57 Nols, 'Zone de recrutement', 334; 'Technische kenmerken van de Belgische Steenkolenontginning in I968', Annales des Mines de Belgique (1970) 1244. Voor de arbeidsmigranten die in het kader van een bilateraal verdrag werden gerekruteerd gold over het algemeen een periode van 5 jaar waarin ze enkel aan de slag konden in de steenkoolindustrie. Voor arbeidsmigranten die via een toeristenvisum het land waren ingekomen, werd een strengere eis gehanteerd: zij moesten in de regel minimum io jaar in de mijnindustrie aan de slag blijven. 
arbeidsverloop van en naar de Luikse steenkoolindustrie nam dus toe bij gelijktijdige afname van het verloop tussen de mijnen onderling. De carrière van een mijnwerker was na de Tweede Wereldoorlog gemiddeld korter, maar bestond ook uit minder verschillende dienstverbanden dan daarvoor.

We veronderstellen dat dit onder meer te maken had met het grote aantal Italiaanse arbeiders dat vanaf 1946 massaal tewerkgesteld werd in de Luikse mijnen. Deze arbeidsmigranten waren in theorie voor minstens één jaar gebonden aan dezelfde mijn en hadden dus niet dezelfde mogelijkheden als de autochtone arbeiders om op zoek te gaan naar betere arbeidsvoorwaarden en werkomstandigheden. Bovendien stopten in tien jaar tijd (I946-I955) negen Luikse mijnen met produceren, waardoor er praktisch gezien ook minder andere mijnen waren waar de mijnwerkers naar toe konden.

TABEL 5.5 DE GEPRESTEERDE DIENSTTIJD PER INTREDECOHORT, ALLE DIENSTVERBANDEN ONDERGRON DSE MIJNWERKERS

\begin{tabular}{|c|c|c|c|c|}
\hline Intredecohort I924-I930 & & frequentie & $\%$ & Cumulatief \\
\hline$<30$ dagen & $<$ maand & 75 & $22,6 \%$ & $22,6 \%$ \\
\hline 3I-92 dagen & $<$ half jaar & 83 & $25,0 \%$ & $47,6 \%$ \\
\hline 93-I85 dagen & $<$ jaar & 58 & $17,5 \%$ & $65, \mathrm{I} \%$ \\
\hline I86-370 dagen & $<2$ jaar & 49 & $\mathrm{I} 4,8 \%$ & $79,8 \%$ \\
\hline 37I-555 dagen & $<3$ jaar & 23 & $6,9 \%$ & $86,7 \%$ \\
\hline $55^{6-740}$ dagen & $<4$ jaar & 5 & $\mathrm{I}, 5 \%$ & $88,3 \%$ \\
\hline 74I-925 dagen & $<5$ jaar & 8 & $2,4 \%$ & $90,7 \%$ \\
\hline \multirow[t]{2}{*}{$>925$ dagen } & $>5$ jaar & $3 \mathrm{I}$ & $9,3 \%$ & I00,०\% \\
\hline & Totaal & 332 & & \\
\hline Intredecohort I93I-I944 & & frequentie & $\%$ & Cumulatief \\
\hline$<30$ dagen & $<$ maand & II3 & $23,6 \%$ & $23,6 \%$ \\
\hline 3I-92 dagen & $<$ half jaar & I02 & $2 \mathrm{I}, 3 \%$ & $44,9 \%$ \\
\hline $93-185$ dagen & $<$ jaar & 77 & $\mathrm{I} 6, \mathrm{I} \%$ & $61,0 \%$ \\
\hline I86-370 dagen & $<2$ jaar & 6I & $\mathrm{I} 2,7 \%$ & $73,7 \%$ \\
\hline 37I-555 dagen & $<3$ jaar & 34 & $7, \mathrm{I} \%$ & $80,8 \%$ \\
\hline $55^{6-740}$ dagen & $<4$ jaar & I9 & $4,0 \%$ & $84,8 \%$ \\
\hline 74I-925 dagen & $<5$ jaar & I6 & $3,3 \%$ & $88, \mathrm{I} \%$ \\
\hline \multirow[t]{2}{*}{$>925$ dagen } & $>5$ jaar & 57 & II, $9 \%$ & $100,0 \%$ \\
\hline & Totaal & 479 & & \\
\hline Intredecohort I945-I955 & & frequentie & $\%$ & Cumulatief \\
\hline$<30$ dagen & $<$ maand & I68 & $19,4 \%$ & $19,4 \%$ \\
\hline $3 \mathrm{I}-92$ dagen & $<$ half jaar & 172 & $19,8 \%$ & $39,2 \%$ \\
\hline $93-185$ dagen & $<$ jaar & 159 & $18,3 \%$ & $57,6 \%$ \\
\hline I86-370 dagen & $<2$ jaar & II2 & $\mathrm{I} 2,9 \%$ & $70,5 \%$ \\
\hline 37I-555 dagen & $<3$ jaar & 65 & $7,5 \%$ & $78,0 \%$ \\
\hline 556-740 dagen & $<4$ jaar & 30 & $3,5 \%$ & $8 \mathrm{I}, 4 \%$ \\
\hline
\end{tabular}




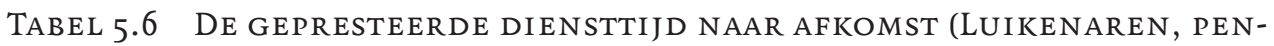
DELAARS EN BUITENLANDERS), ALLE DIENSTVERBANDEN

\begin{tabular}{|c|c|c|c|c|}
\hline Luikenaren & & frequentie & $\%$ & Cumulatief \\
\hline$<30$ dagen & $<$ maand & 39 & $16,4 \%$ & $\mathrm{I} 6,4 \%$ \\
\hline 3I-92 dagen & $<$ half jaar & 33 & $13,9 \%$ & $30,3 \%$ \\
\hline $93-185$ dagen & $<$ jaar & $3 \mathrm{I}$ & $13,0 \%$ & $43,3 \%$ \\
\hline I86-370 dagen & $<2$ jaar & 36 & $\mathrm{I} 5, \mathrm{I} \%$ & $58,4 \%$ \\
\hline $37 \mathrm{I}-555$ dagen & $<3$ jaar & 33 & $13,9 \%$ & $72,3 \%$ \\
\hline $55^{6-740}$ dagen & $<4$ jaar & I6 & $6,7 \%$ & $79,0 \%$ \\
\hline 74I-925 dagen & $<5$ jaar & I3 & $5,5 \%$ & $84,5 \%$ \\
\hline \multirow[t]{2}{*}{$>925$ dagen } & $>5$ jaar & 37 & $15,5 \%$ & I00,0\% \\
\hline & Totaal & 238 & & \\
\hline Pendelaars & & frequentie & $\%$ & Cumulatief \\
\hline$<30$ dagen & $<$ maand & 4I & $34,7 \%$ & $34,7 \%$ \\
\hline 3I-92 dagen & $<$ half jaar & 25 & $21,2 \%$ & $55,9 \%$ \\
\hline $93-185$ dagen & $<$ jaar & I6 & $13,6 \%$ & $69,5 \%$ \\
\hline I86-370 dagen & $<2$ jaar & 6 & $5, \mathrm{I} \%$ & $74,6 \%$ \\
\hline $37 \mathrm{I}-555$ dagen & $<3$ jaar & 8 & $6,8 \%$ & $8 \mathrm{I}, 4 \%$ \\
\hline 556-740 dagen & $<4$ jaar & 6 & $5,1 \%$ & $86,4 \%$ \\
\hline 74I-925 dagen & $<5$ jaar & 2 & $\mathrm{I}, 7 \%$ & $88, \mathrm{I} \%$ \\
\hline \multirow[t]{2}{*}{$>925$ dagen } & $>5$ jaar & $\mathrm{I} 4$ & II, $9 \%$ & $100,0 \%$ \\
\hline & Totaal & II8 & & \\
\hline Buitenlanders & & frequentie & $\%$ & Cumulatief \\
\hline$<30$ dagen & $<$ maand & 83 & $19,5 \%$ & $19,5 \%$ \\
\hline $3 \mathrm{I}-92$ dagen & $<$ half jaar & 77 & $\mathrm{I} 8, \mathrm{I} \%$ & $37,6 \%$ \\
\hline 93-I85 dagen & $<$ jaar & 69 & I6,2\% & $53,8 \%$ \\
\hline 186-370 dagen & $<2$ jaar & $5 \mathrm{I}$ & $\mathrm{I} 2,0 \%$ & $65,7 \%$ \\
\hline $37 \mathrm{I}-555$ dagen & $<3$ jaar & $4 \mathrm{I}$ & $9,6 \%$ & $75,4 \%$ \\
\hline $55^{6-740}$ dagen & $<4$ jaar & 13 & $3, \mathrm{I} \%$ & $78,4 \%$ \\
\hline 74I-925 dagen & $<5$ jaar & 20 & $4,7 \%$ & $83,1 \%$ \\
\hline \multirow[t]{2}{*}{$>925$ dagen } & $>5$ jaar & 72 & $16,9 \%$ & I00,0\% \\
\hline & Totaal & 426 & & \\
\hline
\end{tabular}

Bron: Steekproef FNROM (zie bijlage 8).

\begin{tabular}{|l|l|r|r|r|}
\hline $74 \mathrm{I}-925$ dagen & $<5$ jaar & 29 & $3,3 \%$ & $84,8 \%$ \\
\hline$>925$ dagen & $>5$ jaar & $\mathrm{I} 32$ & $\mathrm{I} 5,2 \%$ & $100,0 \%$ \\
\hline & Totaal & 867 & & \\
\hline
\end{tabular}

Bron: Steekproef FNROM (zie bijlage 8).

De gegevens over gepresteerde diensttijd konden ook worden ingedeeld naar de categorieën Luikenaren, buitenlanders en pendelaars (tabel 5.6). Ditmaal werden pendelaars ge- 
definieerd als woonachtig in een andere provincie..$^{8}$ De verschillen in gemiddelde diensttijd geven hetzelfde beeld als de overlevingspercentages. De Luikenaren, afkomstig en/of woonachtig in de provincie, waaronder ook diegenen afkomstig uit een andere provincie maar met een domicilie in de provincie Luik, waren niet alleen het trouwst aan de Luikse steenkoolnijverheid, zoals bleek uit de overlevingspercentages, maar ook aan een bepaalde mijn. De buitenlanders komen op een tweede plaats: bijna de helft hield het meer dan een jaar vol bij dezelfde mijn. De pendelaars (voor zover woonachtig in een andere Belgische provincie) waren het minst trouw: minder dan een derde bleef langer dan een jaar in dienst. Mogelijk speelde de reisafstand een rol bij de lagere overlevingspercentages en kortere diensttijden van de pendelaars. Blijkbaar zagen veel pendelaars het mijnwerk als een tijdelijke bezigheid, of als een manier om snel geld te verdienen.

\section{HET ABSENTEÏSME}

Behalve met een groot arbeidsverloop kampten de mijnwerkgevers met nog een ander probleem: het was maar de vraag of de mijnwerkers wel consequent kwamen opdagen. Veel mijndirecties hadden moeite om alle mijnwerkers regelmatig aan het werk te krijgen of te houden en door de vele afwezigen was het werk moeilijk te organiseren. ${ }^{59}$ Uit verscheidene contemporaine bronnen blijkt dat de Luikse houwers, zoals in andere mijnbekkens, vaak afwezig waren op maandag, de zogenaamde lundi perdu of Saint Lundi. ${ }^{60}$ In het begin van de twintigste eeuw bedroeg het percentage afwezigen op maandag ongeveer 7,5-10 per dag. Op basis van een enquête onder de leden berekende de Luikse patroonsorganisatie in 1907 dat dagelijks ongeveer $3.07 \mathrm{I}$ van de in totaal 21.582 bij de aangesloten leden ingeschreven arbeiders afwezig waren, dus 14,2 procent. ${ }^{6 r}$ Op maandag en daags na feestdagen kon dit aandeel sterk oplopen: in de periode 1905 -I907 tot tussen de 15 en 50 procent. Een verhoogde (onaangekondigde) afwezigheid werd ook geconstateerd op de zaterdagse nachtposten na uitbetaling van de quinzaine. Dat vooral de jonge, sterke en productieve mijnwerkers op die dagen thuis bleven, was de werkgevers natuurlijk een doorn in het oog.

In het enquêteverslag werden de hoge lonen als de belangrijkste reden voor dit absenteisme genoemd. De directie van Grande Bacnure stelde dat de afwezigheid op maandag in periodes met hogere lonen verdubbelde ten opzichte van periodes met lage lonen. De meeste mijnwerkers waren tevreden met een inkomen van een vier- tot vijfdaagse werkweek, dus waarom zouden ze dan zes dagen werken? Ook werkten ze liever een aantal dagen over, met bijhorende hogere inkomsten, om dan op zondag en maandag van wat vrije tijd te kunnen

\footnotetext{
58 Aangezien niet alle Luikse mijnen zich in de Luikse regio bevonden (als belangrijkste: Zetel José van de S.A. des Charbonnages de Wérister en La Minerie te Battice en Argenteau te Trembleur) werd er voor gekozen de mijnwerkers die van buiten de provincie Luik moesten komen, te onderscheiden als pendelaars. Hiertoe behoren ook een aantal grensarbeiders ( 9 uit Nederland en I uit Duitsland, geboortecohort I920) en een aantal buitenlandse pendelaars ( 9 Italianen, I Hongaar, I Joegoslaaf en I Tsjechoslovaak, geboortecohort 1920), allen woonachtig in de provincie Limburg. Deze buitenlandse pendelaars werden niet meegeteld bij de buitenlanders. Onder de Luikenaren verstaan we de Belgen afkomstig en/of woonachtig in de provincie Luik.

59 Luyten, 'Stakingen in België en Nederland', 156.

6o Puissant, 'Les congés taxés', 2I. Puissant wijst er wel op dat deze Saint Lundi nooit systematisch is bestudeerd, ook in onze bronnen vonden we vooral kwalitatieve aanwijzingen terug.

6r Commission d'enquête, Enquête orale. Ook in de Annales des Mines zijn er gegevens terug te vinden over afwezigheid, er wordt echter niet uitgesplitst naar dag van de week. Bovendien werden afwezigheden pas sinds het begin van de Tweede Wereldoorlog in alle mijnen systematisch bijgehouden. In: Geebelen, De personeelsorganisatie, 8o.
} 
genieten. De mogelijkheid tot overwerk wordt zelfs door verschillende mijnen vermeld als reden voor het arbeidsverloop. Als het mogelijk was in een mijn vaak en veel over te werken, was dat een belangrijke aantrekkingsfactor. Van de kant van de vakbonden en sommige werknemers werd een andere reden aangehaald waarom de mijnwerkers op maandagen thuisbleven: oververmoeidheid. Dit valt echter moeilijk te rijmen met het feit dat de meeste mijnwerkers vrijwillig overuren maakten. ${ }^{62}$ Joassart Constant, directeur van de mijn Maireux et Bas-Bois dacht dat het absenteïsme op maandag moeilijk te bestrijden viel: 'Mais je ne crois pas à une diminution des chômages: il y a trop de fêtes, trop de courses de bicyclettes et trop de pigeons dans notre pays'. ${ }^{63}$

Desondanks werden er allerlei maatregelen genomen om het absenteïsme op maandag terug te dringen. Het onderhoud in de mijnen werd verwaarloosd door opeenvolgende lage bezetting tijdens de nachtposten, de wel aanwezige arbeiders werden ontevreden omdat ze andere functies moesten uitoefenen, en de productie op maandag ging er sterk op achteruit. ${ }^{64} \mathrm{Om}$ de mijnwerkers aan te zetten toch op maandagen en daags na feestdagen te komen werken kregen ze een premie als ze een volledige quinzaine (I2 dagen op I4) aanwezig waren. De mijn Grande Bacnure voerde een andere diensttijd in: mijnwerkers daalden op maandag pas af om half zeven in plaats van om half zes. Veel mijnen signaleerden ook een grotere afwezigheid tijdens de maandagse nachtpost, terwijl deze mijnwerkers toch al een dag hadden kunnen uitrusten van hun zondagse activiteiten. De mijn Bois d'Auroy kende zelfs (even) gratis woonruimte toe aan mijnwerkers die er een regelmatig werkritme op nahielden. ${ }^{6}$ Ook verloren mijnwerkers die te vaak afwezig waren het recht op een deel van de gratis steenkool. In 1945 werd er bepaald dat een mijnwerker per dag vrijwillige afwezigheid Io kg steenkolen minder kreeg. ${ }^{66}$

De meeste maatregelen haalden echter weinig uit en Saint Lundi bleef een probleem. De boete voor onwettige afwezigheid mocht maximaal een vijfde van het (dag)loon beslaan, een te klein bedrag om de mijnwerkers te overreden. ${ }^{67} \mathrm{Nog}$ in de jaren 1960 gaven bepaalde mijnen kortingen op het transport van en naar de mijn indien er geen onwettige afwezigheid was. ${ }^{68}$ Dit soort steeds terugkerend, wekelijks absenteïsme wees erop dat het arbeidsaanbod niet toenam als de beloning omhoog ging. Het aanbod nam juist af omdat de arbeiders ervoor konden kiezen thuis te blijven door hun hoge lonen. Dit fenomeen staat bekend als een back bending supply curve of labour. ${ }^{69}$

In de negentiende eeuw was het niet ongebruikelijk geweest dat mijnen in agrarische

62 In de meeste mijnen was er een systeem van overwerk waarbij het mogelijk was een deel van een dienst, een halve dienst of zelfs een volledige dienst extra te werken. In mijnwerkersjargon heette het dan: faire le quart, la demi, of la double journée. Commission d'enquête, Enquête orale, I47, I59.

63 Ibidem, 306. In deze context moet chômage worden vertaald met 'niet-werken' in plaats van werkloosheid.

64 De directeur van de mijn Patience schatte dat er op maandag en daags na feestdagen slechts 57 procent van de normale productie kon bereikt worden. Commission d'enquête, Enquête orale, 29.

65 Ibidem, 13-313.

66 L'Association Charbonnière de la Province de Liège: Dossiers 'Charbon Gratuit', Carton I, Circulaire du 9 Juin 1945.

67 Puissant, 'Les congés taxés', 22; Commission d'enquête, Enquête orale, II7-I18, I73.

68 Zo gaf Espérance et Bonne-Fortune een korting van 50 procent aan arbeiders zonder onwettige afwezigheden en de mijn Bonnier liet mijnwerkers die een volledige week kwamen werken maar $20 \mathrm{BEF}$ in plaats van $50 \mathrm{BEF}$ bijdragen in het transport per autobus. In: L'Association Charbonnière de la Province de Liège: Dossiers Divers, Carton II, Directoire de l'Industrie Charbonnière. Direction 'Problèmes du Travail' - Avantages extra-légaux et extra-conventionnels aux ouvriers mineurs.

69 Van Haegendoren en Pluymers, 'Belgisch-Limburgse mijnwerkers', 44-45; Gales et al., Bedrijfsvoering, arbeidsverhoudingen, 73. 


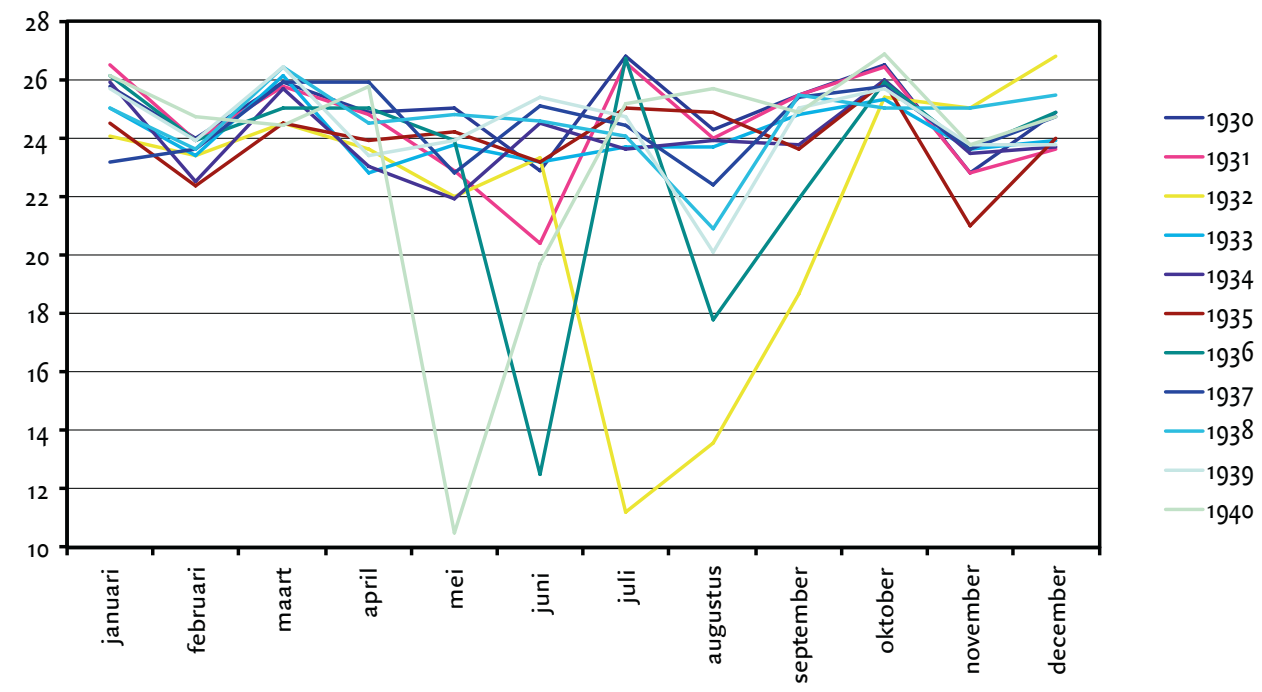

Bron: 'De Belgische steenkolennijverheid tijdens het jaar ...', Annales des Mines de Belgique, I93I-I945.

streken alleen in de winter actief waren..$^{70}$ In de zomer werd er op het land gewerkt en in de winter ging men de ondergrond in. In de maand augustus was het ook vaak te warm om in de mijnen te werken. ${ }^{71}$ In de tweede helft van de twintigste eeuw deden zich opnieuw algemene zomersluitingen voor, nu vanwege de jaarlijkse vakantie van de vele buitenlandse arbeiders. Voor hen bestond de mogelijkheid een maand extra (onbetaalde) vakantie aan te vragen, die ze dan konden doorbrengen in het land van herkomst. ${ }^{72}$ Wanneer een mijn een groot deel van haar productieve arbeiders, de houwers, moest missen, was het simpelweg niet meer mogelijk efficiënt te produceren. Het was dan logischer de mijn enkele weken te sluiten. ${ }^{73}$

Tijdelijke sluitingen kwamen ook voor wanneer een mijn te kampen had met ontginningsmoeilijkheden of wanneer de vraag naar steenkool laag was. In Luik, waar vooral huisbrandkolen werden geproduceerd, was er een duidelijke seizoensinvloed merkbaar in de vraag. Een verkooppiek in huisbrandkolen vond plaats in de nazomer en herfst (van september tot december); tegen de lente daalde de vraag naar antraciet. Om niet al te veel voorraden te vormen, werden er tijdens de 'moeilijke' maanden bepaalde kortingen op de verkoopprijs toegekend en trachtte men de productie in te perken door stillegging wegens gebrek aan afzet. Tijdens deze periodes van lage vraag, crisis en/of ontginningsmoeilijkheden werd er door de mijndirecties soms ook overgegaan tot werktijdverkorting.

Ook stakingen konden de productiviteit van een mijn sterk reduceren. In grafiek 5.20 is

70 Ibidem, 74 .

7I Gaier, Huit siècles de houillerie liégeoise, I7I.

72 L'Association Charbonnière de la Province de Liège: Dossiers Divers, Carton II, Directoire de l'Industrie Charbonnière. Direction 'Problèmes du Travail' - Avantages extra-légaux et extra-conventionnels aux ouvriers mineurs.

73 'Beknopte Statistiek', Annales des Mines de Belgique (1974) 53 I. 


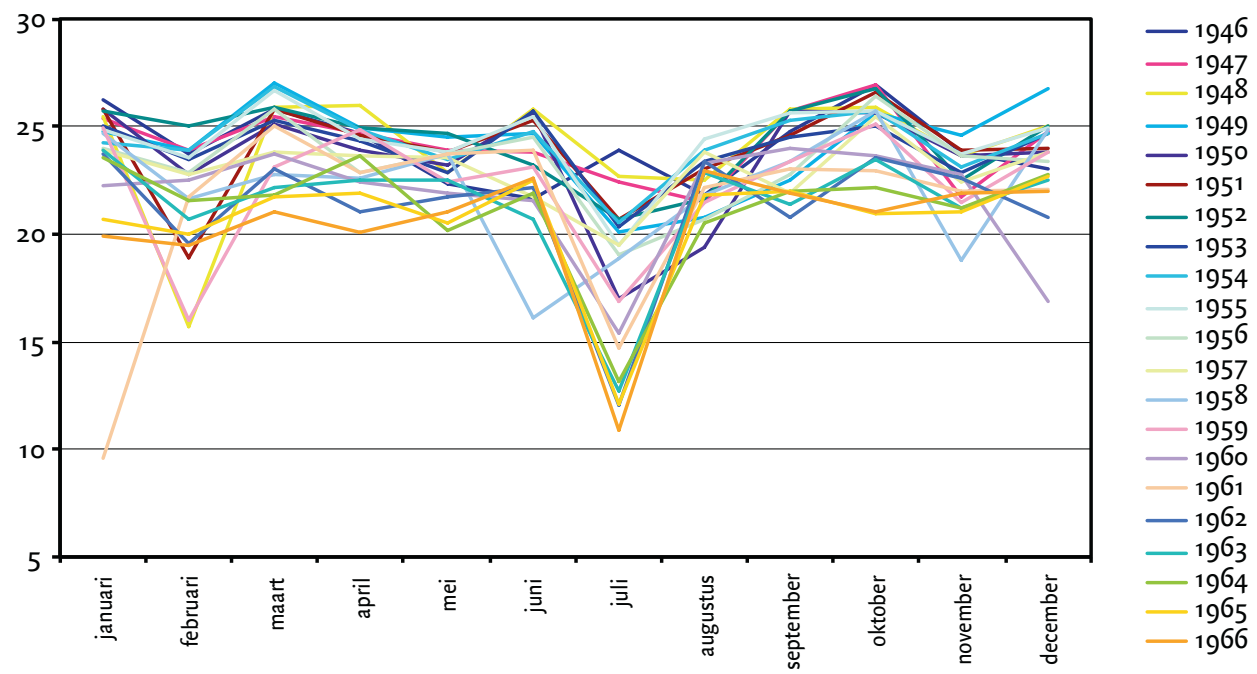

Bron: 'De Belgische steenkolennijverheid tijdens het jaar ...', Annales des Mines de Belgique, 1947-1967.

de invloed van de grote stakingen van 1932 en 1936 op het gemiddeld aantal gewerkte dagen per maand duidelijk te zien, net als die van de bezetting van België in mei i940. In de periode I930-I940 varieerde het aantal gewerkte dagen per maand tussen 22 en $26 .{ }^{74} \mathrm{Na}$ de Tweede Wereldoorlog vallen de jaarlijkse vakanties in juli dan weer erg op (grafiek 5.2I). Ook de algemene staking als reactie op de Eenheidswet tijdens de winter van i960 en I96I is in grafiek 5.2I zichtbaar. ${ }^{75}$ De ondergrens van het gemiddeld aantal gewerkte dagen per maand daalde naar 20 .

In vergelijking met de mijnen in de Kempen kenden de Luikse mijnen over het algemeen een lager gemiddeld aantal gewerkte dagen per jaar (grafiek 5.22). In de Kempen werd het werk in de vakantie niet stilgelegd. De verlofdagen per arbeider werden over een langere periode gespreid, zonder dat de kolenwinning werd onderbroken. Na het midden van de jaren I950 daalde het gemiddeld aantal gewerkte dagen sterk. Dit was een gevolg van werkloosheid wegens gebrek aan afzet. Tussen 1950 en I970 stopten er 35 Luikse mijnzetels met produceren. In de Kempen werd een eerste dieptepunt bereikt in 1959, net na de kolencrisis. Het gemiddeld aantal werkdagen in de Luikse mijnen daalde geleidelijker omdat de daar voornamelijk gedolven huisbrandkolen een stabielere afzetmarkt hadden. ${ }^{76}$

Voor de geboortecohortes werd er ook een gemiddeld aantal gewerkte dagen per jaar berekend (grafiek 5.23). Uiteraard ligt dat gemiddelde lager dan het algemene gemiddelde,

74 Een dag werd een gewerkte dag genoemd indien het normaal aantal ondergrondse arbeiders die dag verzocht was te werken en daadwerkelijk gewerkt heeft, ongeacht hoeveel kolen er opgehaald werden. Dagen waarop niet gewerkt werd waren de rustdagen, vakantiedagen, dagen waarop het werk werd stilgelegd omwille van technische moeilijkheden en/of wegens gebrek aan afzet, verkorting van de werktijd en dagen waarop het werk door de arbeiders werd neergelegd: werkstakingen. 'Technische kenmerken van de Belgische Steenkolenontginning in 1967', Annales des Mines de Belgique (1969) 1064, 1069.

75 Meynen, 'De grote werkstaking ig6o-196I', 504.

76 'Technische kenmerken van de Belgische Steenkolenontginning in Ig68', Annales des Mines de Belgique (I970) 502. 
GRAFIEK 5.22 Het GEMIDDELD AANTAL GEWERKTE DAGEN IN DE LUIKSE EN KEMPISCHE MIJNEN, PER JAAR (I930-I966)

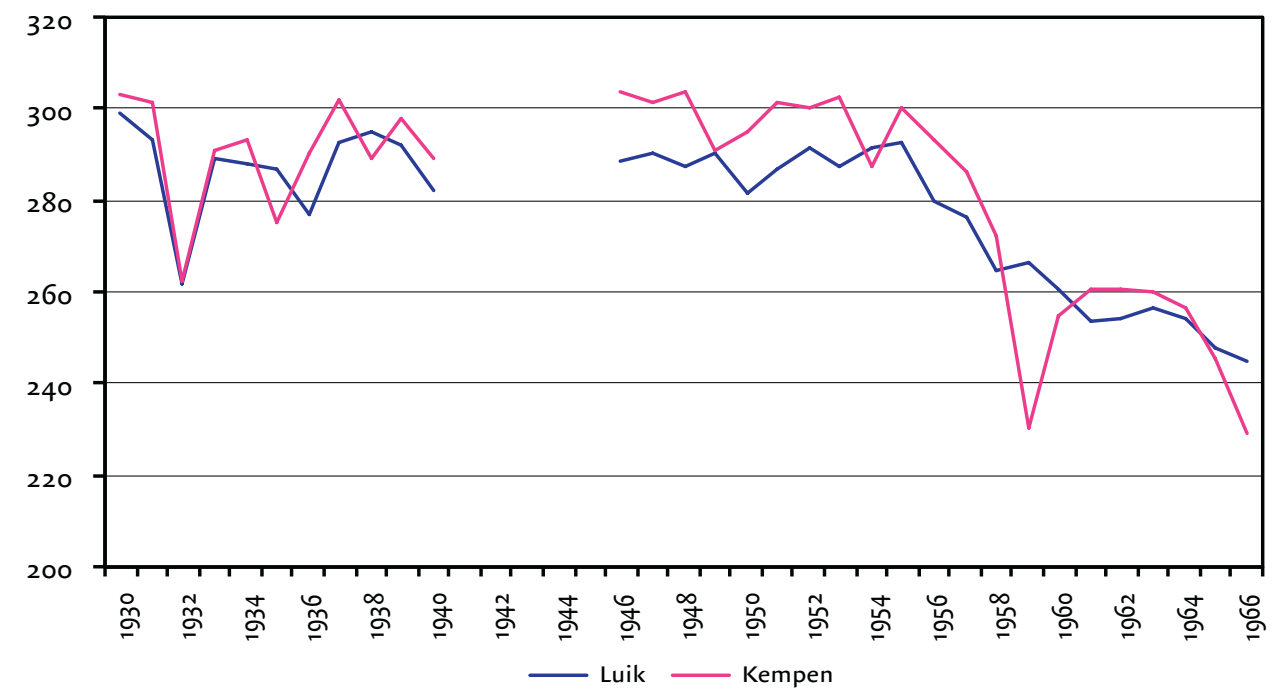

Bron: 'De Belgische steenkolennijverheid tijdens het jaar ...', Annales des Mines de Belgique, I93I-1967; 'Technische kenmerken van de Belgische Steenkolenontginning', Annales des Mines de Belgique, I968-197I.

GRAFIEK 5.23 Het GEMIDDELD AANTAL GEWERKTE DAGEN PER JAAR (GEBOORTECOHORT I9IO EN I920)

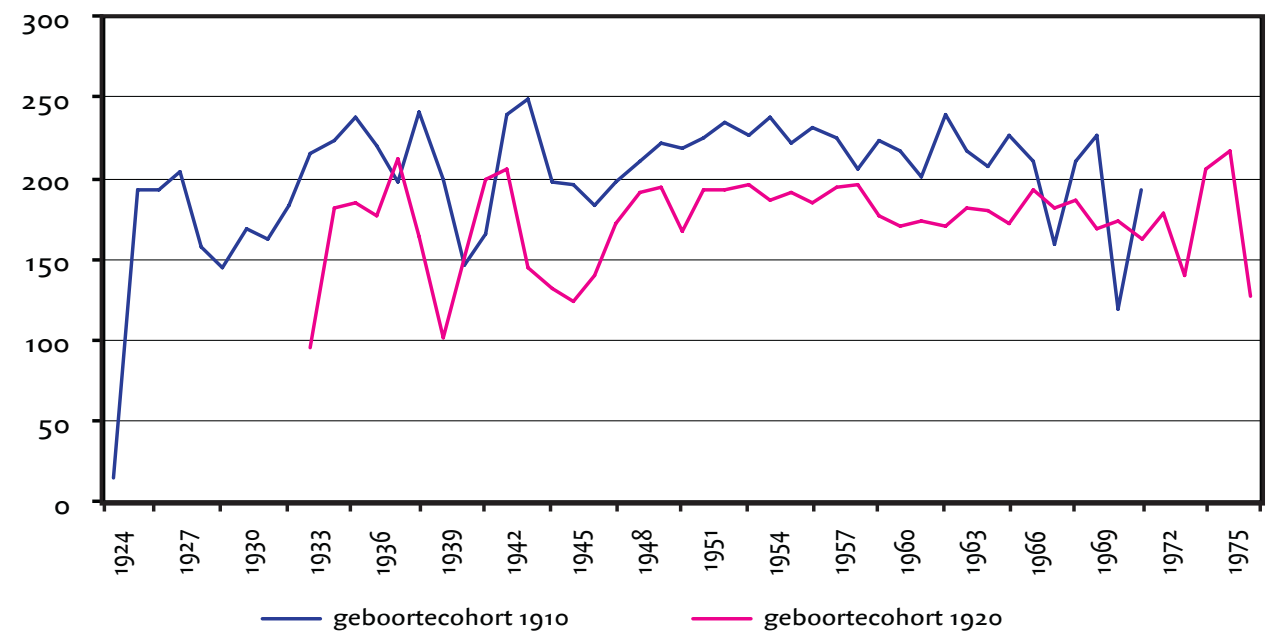

Bron: Steekproef FN ROM (zie bijlage 8). 
want als basis gold het aantal gewerkte dagen van de mijnwerkers en niet het aantal gewerkte dagen in de mijnen. Wat vooral opvalt is het verschil tussen de cohortes. De mijnwerkers geboren in januari 1920 werkten over het algemeen gemiddeld minder dagen per jaar dan de mijnwerkers geboren in januari I9I0. Dat heeft wellicht te maken met het grotere aandeel buitenlanders en pendelaars in geboortecohort I920, die zoals we eerder zagen, ook al werden gekenmerkt door kortere dienstverbanden.

\section{BESLUIT}

In hoeverre slaagden de Luikse mijnen erin de mijnwerkers aan zich te binden en in hoeverre verbonden de mijnwerkers zich aan de Luikse mijnen? Uit de hiervoor gepresenteerde cijfers komt een ogenschijnlijk tegenstrijdige ontwikkeling naar voren: uit de op basis van de selecte steekproef berekende overlevingspercentages blijkt dat de sector als geheel steeds meer een duiventil werd, vooral na de Tweede Wereldoorlog. De trouw aan de mijnindustrie, gemeten aan de duur van het dienstverband in de sector als geheel, was afgenomen. Tegelijk verminderde het relatieve arbeidsverloop, gemeten aan de jaarlijkse in- en uitstroom. De verklaring is dat de mijnwerkers wel korter als mijnwerker werkten, maar dat in toenemende mate bij één en dezelfde mijn deden. Het dienstverband per mijn werd langer en het verloop tussen de Luikse mijnen onderling daalde. Een van de oorzaken was het groeiend aandeel van buitenlanders. Zij waren op z'n minst één jaar gebonden aan dezelfde mijn en vijf jaar aan de steenkoolnijverheid. Bovendien beschikten ze over minder kennis om zich vrij te bewegen op de arbeidsmarkt. Een tweede oorzaak is de veranderde structuur van de mijnindustrie in het Luikse bekken. Na de Tweede Wereldoorlog verminderde het particularisme en de rivaliteit van de vele afzonderlijke bedrijven. ${ }^{77}$ Ook de onderlinge concurrentie op de arbeidsmarkt, die voor de oorlog onder meer tot uiting kwam in grote verschillen wat betreft lonen en loonsystemen, ${ }^{78}$ werd daardoor minder. Door de concurrentie op de arbeidsmarkt hadden de mijnen het hoge arbeidsverloop zelf in de hand gewerkt. In het Interbellum vond er echter een aantal fusies plaats, waardoor grotere ondernemingen ontstonden, zoals Hasard en Wérister, en de onderlinge concurrentie op de arbeidsmarkt werd beperkt. Na de Tweede Wereldoorlog werd deze concentratiebeweging voortgezet. ${ }^{79}$ De verschillen tussen bedrijven werden kleiner en daarmee werd een belangrijke reden voor het arbeidsverloop weggenomen. ${ }^{80}$ Het was niet langer altijd de moeite om van werkgever te wisselen om een hoger salaris te verwerven.

De gelijktijdige afname van de binding aan de sector als geheel is onder meer zichtbaar in het negatieve saldo van de in- en uitstroom van de Belgen in de naoorlogse periode. Volgens tijdgenoten hadden de autochtone Luikse mijnwerkers een afkeer van het mijnwerk gekregen, die tot 'desertie' had geleid. Het verloop van de Belgen werd vooral door een grote uit-

77 Gaier, Huit siècles de houillerie liégeoise, I26, I31.

78 Ibidem, 167.

79 In 1950 ontstond de S.A. des Charbonnages de Bonne Espérance, Batterie, Bonne-Fin et Violette uit de fusie van de S.A. des Charbonnages de Bonne Espérance, Batterie et Violette met de S.A. des Charbonnages de Bonne-Fin en in 1955 ontstond de S.A. des Charbonnages de Gosson-Kessales uit de S.A. des Charbonnages de Gosson-La Haye et Horloz réunis en de S.A. des Charbonnages de Kessales et de la Concorde réunis. Zie: Annales des Mines de Belgique; rapport Bruno Guidolin (CLADIC); Geerkens, 'La rationalisation dans les charbonnages'.

80 Ibidem. 
stroom bepaald. Er gingen meer Belgen weg dan er in dienst traden. Jaarlijks beëindigden tussen de 30 en 40 procent van de in België geboren mijnwerkers hun dienstverband. Dit had te maken met het grote aantal aantrekkelijke alternatieven in de regio, onder meer in de bloeiende staalnijverheid. Het gevolg was dat er steeds minder personeel overbleef dat het mijnwerk als een beroep voor het hele werkzame leven beschouwde. Mijnwerker worden was geen traditie meer in het Luikse bekken; de 'mijnwerkersklasse' begon uit te sterven. In plaats van een levenslange carrière werd het werken in de mijn eerder als een tijdelijke loopbaankeuze gezien, een noodzakelijk kwaad in economisch minder goede tijden, een optie bij gebrek aan beter. Pogingen van de mijnwerkgevers om via opleidingen een reservoir aan nieuwe mijnwerkers te vormen, waren tevergeefs. Het aantal leerlingen bleef beperkt en er was veel verzuim. Het bleef een uitzondering dat mijnwerkers van zo'n instelling afkomstig waren. $^{81}$

Op de lange termijn nam de gemiddelde lengte van het verblijf in de mijnindustrie van de Luikenaren af: terwijl ruim de helft van de mijnwerkers in de selecte steekproef die tussen I924 en 1930 waren ingetreden gedurende meer dan tien jaar in de mijnindustrie werkzaam bleef, was dit bij de naoorlogse intreders gedaald tot slechts een derde. Dit wijst op een achteruitgang van de 'vaste stam', de ervaren kern van het arbeidsbestand. Niettemin bleven de uit Luik zelf afkomstige mijnwerkers, ondanks een slinkend aandeel en een krimpende verblijfsduur, trouwer aan de mijnsector dan de andere onderscheiden groepen: buitenlandse arbeidsmigranten en Belgische pendelaars. Luikenaren hadden gemiddeld langere carrières, maar bleven ook het langst trouw aan dezelfde mijn. Er bleef een aanzienlijk verschil in arbeidsverloop tussen de (Luikse) Belgen en de buitenlanders. Dit hing deels samen met een groter aandeel van Belgen bovengronds, waar het arbeidsverloop geringer was dan ondergronds.

Mijnwerkers afkomstig uit andere Belgische provincies dan Luik, van wie een groot deel pendelde uit Belgisch-Limburg en Brabant, werden in de loop van de tijd eveneens minder honkvast. In het intredecohort I924-I930 was er nog een groep pendelaars geweest die zich voor een langere periode aan de mijnen had gebonden, maar in de periode na de Tweede Wereldoorlog kenden de niet uit Luik afkomstige Belgen de laagste overlevingspercentages, het grootste verloop en de kortste dienstverbanden. Men kan de pendelaars als 'gelegenheidsarbeiders' beschouwen: voor hen was het mijnwerk een tijdelijke bezigheid, een manier om snel geld te verdienen.

De slinkende groep trouwe en ervaren Luikse mijnwerkers werd na de oorlog geconfronteerd met steeds weer nieuwe golven onervaren buitenlanders, die veelal snel na het aflopen van hun contract, of zelfs eerder, weer even zo hard vertrokken. De meerderheid van de buitenlandse migranten bleef één tot vijf jaar in de Luikse mijnen werken. Lange carrières kwamen zelden voor, maar waren niet geheel afwezig: tussen de ca. I7 en 25 procent van de buitenlanders bleef langer dan tien jaar in de Luikse mijnen werkzaam. Het gaat vooral om een kern van Italiaanse migranten. ${ }^{82}$ De jaarlijkse vertrekpercentages van de Italiaanse ar-

8I Gaier, Huit siècles de houillerie liégeoise, 172.

82 Een hypothese is dat deze mijnwerkers zo lang in de mijn bleven om recht te kunnen hebben op een invaliditeitspensioen. Aan een combinatie van ro jaar dienst en een leeftijdscriterium moest worden voldaan. De meerderheid van de Italianen uit de onderzoeksgroep bleef echter na die ro jaar gewoon doorwerken in de mijn, wat erop wijst dat dit, althans voor de onderzochte mijnwerkers, geen strategie was. 
beiders werden in de jaren I96o lager, wat er op wijst dat de overblijvers een stabielere factor vormden. Anders dan de grote massa van hun landgenoten in de jaren I940 en I950, wist deze groep zich in deze tijd een vaste plaats te verwerven.

Het enorme arbeidsverloop moet de mijnbedrijven, en ook de kern van 'blijvers' die steeds weer nieuwe krachten moesten inwerken en begeleiden, voor grote problemen hebben gesteld. Het arbeidsverloop van de buitenlanders was in de meeste jaren twee tot vier keer zo groot als bij de Belgen; in sommige jaren liep het aandeel van de buitenlanders in het totale arbeidsverloop op tot 60 en zelfs 80 procent. Jaren van massale aanwerving van nieuwe migrantengroepen werden over het algemeen gevolgd door een piek in de uitstroom. Van de in 1947 en volgende jaren aangekomen Italianen keerde een groot aantal al snel terug naar hun vaderland. In het eerste jaar (1947) was dat zelfs voor bijna alle nieuw geworven gastarbeiders het geval. Na een onderbreking van de werving tijdens de kolencrisis werden in de jaren 1960 nieuwe groepen migranten aangetrokken (Grieken, Spanjaarden, Marokkanen en Turken), van wie een aanzienlijk deel, net als de Italianen in een eerdere fase, weer snel vertrok.

Wanneer we bovenstaande conclusies plaatsen binnen het breder kader van de arbeidsmarkt als arena kunnen we vaststellen dat de onderscheiden groepen mijnwerkers een verschillend strategisch gedrag vertoonden. Het gedrag van de Luikse mijnwerkers werd in hoofdzaak gekenmerkt door mijnverlating; de uit andere provincies afkomstige pendelaars manifesteerden zich meer en meer als gelegenheidsarbeiders. Uit de buitenlandse migranten, die steeds opnieuw moesten worden aangeworven, kon evenmin een stabiel personeelsbestand worden opgebouwd. Langs de vraagkant werd er vooral een korte termijnvisie op nagehouden: het lukte de mijnbedrijven niet te investeren in opleidingen zodat er een vaste groep aan mijnwerkers kon ontstaan.

Deze gang van zaken kan niet worden losgezien van de neergaande fase waarin de Luikse mijnindustrie zich bevond. Dat blijkt onder meer door de ontwikkeling in Luik te vergelijken met die in de Kempen. In de Kempische mijnen was het midden van de jaren 1930 een breekpunt in de arbeidsmarktstrategieën van het mijnpatronaat en de mijnwerkers. ${ }^{8_{3}}$ De arbeidsmarkt werd meer en meer geïnstitutionaliseerd en gestructureerd en er ontstonden stabielere arbeidsmarktverhoudingen. In Luik vormt het midden van de jaren I930 eveneens een breekpunt, maar hier luidde die periode het einde van de stabiele verhoudingen in. In Luik werd in de jaren I930 reeds de afbouw van de lokale mijnarbeidsmarkt ingezet. Men moest steeds meer buitenlanders aantrekken om het stijgende tekort aan Belgische arbeiders op te vangen. Het stabiliseren van de Belgische mijnwerkers was een gepasseerd station. Omdat de migranten in het algemeen niet bereid waren zich aan het mijnbedrijf te binden, kwamen de Luikse mijnen wat betreft de arbeidsvoorziening in een vicieuze cirkel terecht. Zij moesten steeds nieuwe groepen onervaren buitenlanders aanwerven en inwerken, die de mijnindustrie in meerderheid zo snel mogelijk weer verlieten. Het grote verloop en het lage overlevingspercentage, zoals die in dit hoofdstuk konden worden berekend, zijn daar de uitdrukking van. 


\section{Samenvatting en conclusie}

Het Luikse steenkolenbekken behoorde tot de oudste mijnbouwregio's in Europa en die lange voorgeschiedenis was bepalend voor de structuur en de omvang van de mijnbedrijven, voor de inrichting en de organisatie van het werk ondergronds, voor de productiviteit, en ook voor de ontwikkeling van de arbeidsmarkt. In de loop van de twintigste eeuw ondervonden de Luikse mijnen steeds grotere problemen bij hun arbeidsvoorziening. Dit toenemende tekort is het centrale thema van dit boek. Hoe groot was dit arbeidstekort en hoe evolueerde het? Wat waren de oorzaken en hoe werd het opgelost?

Er is inzicht verkregen in de strategieën en het gedrag van de actoren op de arbeidsmarkt door op individueel niveau verzamelde microgegevens over de mijnwerkers en hun carrières te combineren met macrogegevens over de ontwikkeling van de werkgelegenheid in de steenkoolnijverheid en in de Luikse regio in het algemeen.

Het vraagstuk van het arbeidstekort is benaderd vanuit zowel de vraag- als de aanbodzijde. Wat betreft de vraagzijde zijn volgende vragen gesteld: Hoe trachtten de mijnwerkgevers het arbeidstekort op te lossen? Met welke problemen en uitdagingen werden zij daarbij geconfronteerd? Wat was de rol van de overheid? Was er sprake van deelmarkten voor bijzondere groepen mijnwerkers? In hoeverre slaagden werkgevers erin voldoende mijnwerkers aan zich te binden?

Aan de aanbodzijde stelden we deze vragen: Welke groepen arbeiders kozen voor een beroep als mijnwerker? Wat was hun geografische en sociale afkomst en hoe verliepen hun carrières? Welke rol speelde hun demografische gedrag voor het aanbod op de arbeidsmarkt? Hoe was het arbeidsverloop en in hoeverre verschilden groepen mijnwerkers in hun arbeidsmarktgedrag?

Het beginpunt van het onderzoek situeert zich aan het einde van de negentiende eeuw. De steenkolenwinning in Luik was op dat moment al lang een gevestigde industrie. Vanaf omstreeks I8go leidden ontwikkelingen aan zowel de vraag- als aanbodzijde van de arbeidsmarkt tot structurele wijzigingen in de personeelssamenstelling. In die evolutie weerspiegelde zich een toenemend tekort aan lokale en regionale arbeidskrachten voor de Luikse mijnen.

In vijf deelstudies werd telkens een ander aspect van het tekort aan arbeidskrachten belicht. In de eerste deelstudie, die in hoofdstuk I werd gepresenteerd, stonden structurele ontwikkelingen op de arbeidsmarkt centraal. Door het in kaart brengen van de evolutie in het Luikse mijnbouwlandschap werd inzichtelijk gemaakt dat de vraagzijde voortdurend in beweging was. Vanaf het begin van de twintigste eeuw stopte een aantal Luikse mijnen met produceren en gingen kleine zetels op in grotere eenheden, die op hun beurt in een latere fase de productie beëindigden. Van de bijna 80 mijnzetels omstreeks I9oo waren er in 1958 
nog 22 over. In I980 sloot de mijn Argenteau-Trembleur (Blegny) als laatste.

Ook aan de aanbodzijde deden zich ontwikkelingen voor die van grote invloed waren op de arbeidsmarkt. Het tweede deel van dit eerste hoofdstuk had demografie als onderwerp. Door structurele veranderingen in demografisch gedrag nam het beschikbare aanbod aan arbeidskracht in de loop van de twintigste eeuw drastisch af.

Het thema van de deelstudie in hoofdstuk 2 was de vrouwenarbeid. Nog in Igoo maakten vrouwen een aanzienlijk deel uit van de arbeidskracht in de Luikse mijnen. In I892 was er in België, als één van de laatste West-Europese landen, echter een wet in werking getreden die de arbeid van vrouwen in de mijnen (op termijn) verbood. Voor de personeelsvoorziening van de Luikse mijnen betekende het verbod een forse aderlating.

Doordat de steenkolenmijnbouw in het Luikse bekken omstreeks Igoo reeds een gevestigde industrie was, konden de mijnen putten uit een vast aanbod van regionale arbeidskrachten. De Luikse mijnen konden erop rekenen dat mijnwerkers elkaar van generatie op generatie opvolgden. Arbeidsmigranten uit den vreemde waren in die situatie niet in groten getale nodig. Dat veranderde in de loop van de twintigste eeuw. In hoofdstuk 3 werd de ontwikkeling geschetst van een arbeidsmarkt die in toenemende mate een beroep moest doen op buitenlandse arbeidskrachten. Vooral na de Tweede Wereldoorlog nam de inzet van arbeidsmigranten uit het buitenland een grote omvang aan. In de jaren I970 waren er zelfs Luikse mijnen waar ondergronds geen Belg meer te vinden was.

De specifieke oorzaken van het grote tekort aan Belgische arbeidskrachten onmiddellijk na de Tweede Wereldoorlog kwamen uitgebreid aan bod in hoofdstuk 4. Betoogd werd dat de zogenaamde kolenslag die premier Achille Van Acker uitriep, moest worden gestreden met een vreemdelingenlegioen, omdat de eigen troepen 'deserteerden'. Dat vertrek van regionale arbeidskrachten uit de Luikse mijnen, dat in hoofdstuk 5 in detail werd geanalyseerd, was vooral het gevolg van de slechte reputatie die de verouderde Luikse mijnen inmiddels hadden, in combinatie met de alternatieve werkgelegenheid die er in die jaren van economische opgang elders in de Luikse industrie te vinden was. Een positief effect van het eerder geconstateerde proces van bedrijfsconcentratie in de mijnbouwsector was dat het verloop van arbeidskrachten tussen de mijnzetels afnam.

\section{STRUCTUURELEMENTEN}

Uit de deelonderzoeken zoals hierboven kort geschetst kwam duidelijk naar voren dat de problemen met de arbeidsvoorziening bij de Luikse mijnen in de loop van de twintigste eeuw steeds groter werden. De zorgen daarover vonden we terug in allerlei contemporaine rapporten en konden we afleiden uit het steeds belangrijker aandeel arbeidsmigranten in de Luikse mijnen. Terwijl in I923 nog slechts 5,7 procent van de arbeidskrachten in de Luikse mijnen een niet-Belgische nationaliteit had, was dat aan de vooravond van de Tweede Wereldoorlog toegenomen tot bijna een kwart. Na de oorlog steeg dat percentage aanzienlijk van 50 procent in 1947 tot meer dan 70 procent in het begin van de jaren I970. De in de deelonderzoeken gepresenteerde analyses geven inzicht in de oorzaken van het tekort. Die werden gevonden in een combinatie van factoren aan de vraag- en aanbodzijde en gaan terug tot de tijd rond $\mathrm{I} 900$. 
In de sociologische benadering van de arbeidsmarkt die in dit boek werd gevolgd, wordt gezocht naar de voorwaarden en vormen van arbeidsmarktgedrag. Het begrip 'strategie' vormt in deze benadering een belangrijk concept. De mogelijkheden van strategisch gedrag zijn echter niet onbegrensd. Economische, maatschappelijke en ideologische grenzen beperken de handelingsvrijheid van de actoren, zowel aan de vraag- als aan de aanbodzijde. De mijnwerkgevers en de mijnwerkers opereerden in een omgeving die ze niet (volledig) naar hun hand konden zetten. Een aantal structurele elementen vormde de context, de speelruimte waarin de mijnwerkgevers en mijnwerkers zich op de arbeidsmarkt bewogen.

De vraag naar steenkool steeg bij aanvang van de onderzoeksperiode een eerste maal toen in het laatste kwart van de negentiende eeuw de markt voor huisbrandkolen door veranderende stookgewoonten veel groter werd. In Luik, waar veel steenkool voor huishoudelijk gebruik werd gewonnen, nam de werkgelegenheid voor mijnwerkers in het laatste decennium van de negentiende eeuw snel toe om in de eerste decennia van de twintigste eeuw een hoogtepunt te bereiken. De markt voor huisbrandkolen was een stuk stabieler dan die voor vetkolen. In het interbellum liep de vraag naar steenkool weer terug door de concurrentie van petroleum, hydraulische energie en elektriciteit, en de crisis van de jaren 1930.

Net na de Tweede Wereldoorlog steeg de vraag naar steenkool opnieuw bijzonder sterk in het kader van de kolenslag. In tegenstelling tot de Franse en Duitse mijnen waren de Belgische mijnen vrijwel onbeschadigd uit de oorlog gekomen. Voor de aanvoer van steenkool, broodnodige brandstof voor de wederopbouw, werd naar het kleine België gekeken. Al snel, tegen I948, daalde de vraag naar steenkool echter weer tot het normale niveau. Omringende landen startten hun steenkoolproductie weer op.

Mijnarbeid stond in het algemeen bekend als zwaar, onveilig, ongezond en vuil. Dat gold vooral voor het ondergrondse werk, waarvoor de vraag naar arbeidskrachten steeds het grootst was. Bovendien had het Luikse bekken te kampen met specifieke en moeilijke geologische omstandigheden: dunne en verkreukelde steenkolenlagen met veel wateroverlast. Doordat de Luikse mijnen reeds vroeg waren begonnen, werd de ontginning moeilijker en arbeidsintensiever. Men moest steeds dieper graven aangezien de makkelijk toegankelijke steenkolenlagen uitgeput raakten. Hierdoor was de arbeidsproductiviteit vrij laag. Het Luikse bekken was aanvankelijk verdeeld in vele kleine concessies. De manier waarop de meeste mijnen in de negentiende eeuw waren ingericht zorgde voor een zekere 'padafhankelijkheid': het viel niet mee de vaak artisanaal ingerichte familiebedrijfjes om te bouwen tot moderne twintigste-eeuwse ondernemingen. De Luikse steenkoolindustrie, die zich in de tweede helft van de negentiende eeuw zo sterk en snel had ontwikkeld, kwam na de Eerste Wereldoorlog in een trager tempo terecht. ${ }^{\mathrm{I}}$ De wet van de remmende voorsprong is hier van toepassing.

Rationalisering en mechanisering lukten maar ten dele door genoemde geologische omstandigheden en de negentiende-eeuwse erfenis, maar ook door een gebrek aan investeringen. De Luikse steenkoolindustrie werd gekenmerkt door een kleinschalige opzet, zeker in vergelijking met de Limburgse bekkens. Er waren enkele grote mijnbedrijven met duizenden mijnwerkers, maar aan de vooravond van de Tweede Wereldoorlog stelde een groot deel van de Luikse mijnen slechts enkele honderden arbeiders te werk. Vaak was de productie 
van een onderneming verdeeld over verschillende mijnzetels, althans tot aan de kolencrisis in 1958. Bijna twee derde van de ondernemingen was in die periode nog steeds volledig financieel onafhankelijk. De invloed, en daardoor ook de investeringen, van grote holdings en banken bleef beperkt in het Luikse bekken en de versnipperde eigendomsstructuren bemoeilijkten zware investeringen. De kunstmatig laag gehouden steenkoolprijs die de overheid na de Tweede Wereldoorlog invoerde in combinatie met de hoge lonen en sociale lasten, zorgde er bovendien voor dat er wel veel omzet werd gedraaid, maar weinig winst werd gemaakt. Reserves om te kunnen rationaliseren en moderniseren werden zo niet opgebouwd. Het ondernemersklimaat in de Luikse mijnindustrie werd gekenmerkt door concurrentie, rivaliteit en isolement, ook ten opzichte van andere bekkens. Een verdere concentratie van de productie door fusies en overnames kwam niet of pas laat op gang.

Zolang het arbeidsaanbod voldoende was, hoefde dit voor de vragers van arbeid, de werkgevers, geen probleem te vormen. In het sterk geïndustrialiseerde Luikse bekken waren echter veel andere sectoren evengoed op zoek naar voldoende arbeidskrachten. Verschillende industrieën, zoals de metaalnijverheid en de bijhorende cokes- en hoogovens, de machinebouw, de wapennijverheid, de glasnijverheid en de wolnijverheid (te Verviers) boden al in de negentiende eeuw veel mogelijkheden voor mensen op zoek naar werk. In de twintigste eeuw kwam daar nog de diensten- en handelssector bij.

Het aanbod voor de Luikse mijnen nam niet alleen door deze concurrentie met andere bedrijfstakken en sectoren af. Vanaf de tweede helft van de negentiende eeuw zorgden secularisering, verstedelijking en beter onderwijs ervoor dat arbeiders, met als pioniers de metaalbewerkers en mijnwerkers, geboortebeperking gingen toepassen. Het demografisch gedrag veranderde en werd gekenmerkt door een lage huwelijksvruchtbaarheid. Dit zorgde vanaf het begin van de twintigste eeuw voor een dalend geboorteoverschot, om na de Eerste Wereldoorlog zelfs te veranderen in een sterfteoverschot.

\section{DE VRAAGZIJDE: DE ZOEKTOCHT NAAR MIJNWERKERS}

De vraag naar mijnwerkers nam toe toen de vraag naar huisbrandkolen aan het eind van de negentiende eeuw sterk steeg. Net in die periode konden mijnwerkgevers niet langer een beroep doen op vrouwen om het ondergronds personeelsbestand te versterken. Tot die tijd hadden zij een belangrijk aandeel in de Luikse arbeidsmarkt voor mijnwerkers. De voordelen voor de mijnwerkgevers waren divers: de aanzienlijk lagere lonen voor vrouwen in een nijverheid waar de productiekosten in belangrijke mate uit loonkosten bestonden, en de onmogelijkheid om bepaalde 'vrouwelijke' taken te mechaniseren vanwege de kosten of de moeilijke geologische omstandigheden. Vóór het in werking treden van het verbod op ondergrondse vrouwenarbeid was er sprake van verticale segregatie: vrouwen oefenden bepaalde functies in het mijnbedrijf uit. Door het in werking treden van het verbod in 1892 verdwenen vrouwen geleidelijk aan uit het ondergronds mijnbedrijf, zodat er ook sprake was van een horizontale arbeidsmarktsegregatie: vrouwen bevonden zich niet langer op de deelmarkt van ondergrondse arbeid.

De Luikse mijnen spanden zich in die periode en in de eerste decennia van de twintigste eeuw in om op de lokale, maar ook regionale en nationale arbeidsmarkt voldoende arbeids- 
krachten te rekruteren. Luikse mijnwerkers konden over het algemeen worden aangevuld met arbeidskrachten uit andere delen van België: vooral de rurale arrondissementen van de Luikse provincie en het Zuid-Limburgse Haspengouw vormden interessante rekruteringsgebieden. De werkgevers lokten deze arbeiders door hoge lonen te bieden, vooral in vergelijking met de lonen in de agrarische sector, en door het transport van en naar de mijnen te vergemakkelijken. De overheid droeg zijn steentje bij door geschikte treinabonnementen te ontwikkelen en te subsidiëren.

De komst van de Vlaamse arbeidskrachten was echter niet voldoende om het tekort aan lokale mijnwerkers te dekken. Na het chaotische intermezzo van de Eerste Wereldoorlog kon er weliswaar snel weer normaal geproduceerd worden, maar de benodigde mijnwerkers bleken moeilijk te vinden. De Luikse mijnen kregen te maken met concurrentie van de modernere Limburgse mijnen, die soms betere arbeidsvoorwaarden aanboden en vaak beter bereikbaar waren. Zij trokken veel Vlamingen aan die voordien naar het Luikse bekken hadden gependeld. De pendel naar het Luikse bekken verdween daardoor niet, maar het rekruteringsgebied breidde zich in de loop van de twintigste eeuw nog verder uit. Uit het feit dat de pendelaars van steeds verder weg moesten komen blijkt dat het moeilijker werd om lokaal en regionaal voldoende mijnwerkers te vinden. Het lukte de werkgevers niet het vertrek van de traditionele autochtone mijnwerkers tegen te houden.

Zoals in de meeste andere mijnbekkens moesten de directies van de Luikse mijnen ook een beroep doen op mijnwerkers van buiten de landsgrenzen. In de jaren tussen de Eerste en Tweede Wereldoorlog zorgden gerichte wervingsacties door patroonsorganisatie FEDECHAR ervoor dat er ook in de Luikse mijnen Italiaanse en Poolse arbeiders werden tewerkgesteld. De Italianen waren doorgaans onervaren. De Polen waren afkomstig uit de mijnbouwregio's in Silezië of het Ruhrgebied en hadden over het algemeen wel ervaring in het mijnwerk. Een andere grotendeels ervaren groep arbeidsmigranten waren de Maghrebijnen die werden aangetrokken vanuit de Franse kolenbekkens. Het aandeel van buitenlandse werkkrachten op de Luikse markt voor mijnwerkers groeide geleidelijk van minder dan 6 procent in 1923 tot meer dan 22 procent aan de vooravond van de Tweede Wereldoorlog.

In het interbellum trachtten de Luikse mijnwerkgevers te rationaliseren om de productiviteit op te drijven. Er vonden fusies plaats tussen ondernemingen waardoor de financiële middelen werden geconcentreerd om te mechaniseren. Wegens de geologische omstandigheden was een volledige mechanisatie niet mogelijk, maar de rationalisatie resulteerde wel in een stijging van de arbeidsproductiviteit in de eerste helft van de jaren I930. Hierdoor ging de daling van het aantal arbeiders tijdens de economische crisis vooralsnog niet gepaard met een productiedaling.

Opvallend is dat de afnemende werkgelegenheid niet op de buitenlanders werd afgewenteld, zoals in naburige mijnstreken gebeurde. Tussen 1930 en 1934 vertrokken er naar verhouding meer Belgen dan buitenlanders uit de Luikse mijnen. In de beide Limburgen was die verhouding andersom. Daaruit blijkt dat het mogelijk was een voorkeursbeleid te voeren voor lokale Limburgse arbeiders.

In de Luikse mijnen nam de afhankelijkheid van buitenlandse werkkrachten daarentegen vanaf de economische heropleving in 1936 verder toe. Ook grensarbeiders speelden hierbij een belangrijke rol. De Luikse mijnen boden over het algemeen goede arbeidsvoorwaarden en hoge lonen en hadden minder strenge selectiecriteria dan bijvoorbeeld de Ne- 
derlandse mijnen. De Tweede Wereldoorlog werkte als katalysator voor het arbeidstekort: tijdens en na de oorlog zagen de mijnwerkgevers en de Belgische regering zich geconfronteerd met een massaal vertrek van arbeidskrachten uit de mijnen en de daaropvolgende scherpe daling in de productie. Er moesten snel nieuwe mijnwerkers worden gezocht.

Net na de Tweede Wereldoorlog hoopte men nog arbeiders uit België zelf aan te kunnen trekken om de kolenproductie te vergroten en daarmee de wederopbouw mogelijk te maken, maar het mijnwerkersstatuut en bijbehorende voordelen zorgden er niet voor dat er meer Belgen naar de mijnen trokken. Integendeel, veel mijnwerkers maakten gebruik van de nieuwe sociale wetgeving om de mijn vroegtijdig vaarwel te zeggen. Deze maatregelen pakten dus averechts uit.

Mijnbouwonderwijs vormde ook één van de mogelijke remedies om de vlucht uit de mijnen tegen te gaan: opleiding kon de prestige van het mijnwerkersberoep vergroten en het personeelsbestand stabiliseren. De bestaande opleidingen hadden echter weinig succes, omdat aanvankelijk in de meeste Luikse mijnen op een traditionele manier de kennis en vaardigheden werden doorgegeven: van vader op zoon en van een ervaren op een beginnend mijnwerker. Na de oorlog werd een poging ondernomen om, onder toezicht van het Mijnwezen, de beroepsopleiding nieuw elan te geven. Het aantal leerlingen dat de opleiding begin jaren 1950 ging volgen was echter verwaarloosbaar. Uiteindelijk slaagden de Belgische overheid en het mijnpatronaat er niet in de gewilde Belgische arbeiders over te halen om opnieuw in de steenkolenmijnen aan de slag te gaan, ondanks de aantrekkelijke arbeidsvoorwaarden en de hoge lonen.

Tijdelijke tewerkstelling van Duitse krijgsgevangenen kon de nood gedurende korte tijd lenigen, maar rekrutering in het buitenland werd onvermijdelijk om het structurele probleem van het arbeidstekort het hoofd te bieden. Omdat de Belgen massaal 'deserteerden', werd de 'kolenslag', die premier Achille Van Acker in 1945 had uitgeroepen, in de Luikse mijnen daarom gestreden door een vreemdelingenlegioen.

De aanwezigheid van een steeds groter aandeel buitenlanders op de arbeidsmarkt voor de Luikse steenkoolnijverheid wijst er duidelijk op dat het aanbod op de lokale arbeidsmarkt ontoereikend was. Om buitenlandse werkkrachten aan te trekken gingen de mijndirecties eerst zelf op zoek. Later werd dit meer geregeld door de overheid die verdragen afsloot met de betreffende emigratielanden. Om het mijnwerk aantrekkelijk te maken werden er beloftes gedaan qua huisvesting en salaris. Het bilateraal verdrag tussen Italië en België zorgde ervoor dat vanaf 1946 grote contingenten Italianen de weg naar de Luikse mijnen vonden. Via een overeenkomst met de geallieerden slaagde de Belgische overheid er ook in om duizenden zogenaamde Displaced Persons voor de mijnen te werven. Na de mijnramp te Marcinelle in 1956 werd de officiële migratie door de Italiaanse regering stopgezet. Nieuwe wervingsakkoorden werden afgesloten met Spanje (I956) en Griekenland (I957).

Uit de buitenlandse migranten kon echter geen stabiel personeelsbestand worden opgebouwd. Omdat het verloop onder migranten over het algemeen groot was, kwamen de Luikse mijnen wat betreft de arbeidsvoorziening in een vicieuze cirkel terecht. Zij moesten steeds nieuwe groepen onervaren gastarbeiders aanwerven en inwerken, die de mijnindustrie in meerderheid zo snel mogelijk weer verlieten. Jaren van massale aanwerving van nieuwe migrantengroepen werden over het algemeen gevolgd door een piek in de uitstroom. Na het Italiaanse verdrag, het Spaanse en het Griekse, volgden nog tewerkstel- 
lingsverdragen met Marokko en Turkije (I964), Tunesië (I969) en Algerije (I970). Het vinden van voldoende arbeidsmigranten was een constante zorg en hun aanwezigheid op de arbeidsmarkt werd een structureel verschijnsel.

\section{DE AANBODZIJDE: DE VLUCHT UIT DE MIJNEN}

De toename van de vraag naar mijnwerkers aan het einde van de negentiende eeuw kwam net op een moment dat zich aan de aanbodzijde ontwikkelingen aftekenden die van groot belang zouden worden voor de evolutie van het arbeidsaanbod voor de mijnen in de twintigste eeuw. Het eerder genoemde verbod op ondergrondse arbeid voor vrouwen en kinderen speelde hierbij een rol, maar op langere termijn bleken andere ontwikkelingen belangrijker.

In het oude Luikse mijnbouwbekken bestond aan het eind van de negentiende eeuw een vaste kern van lokale en regionale families, waarin het beroep van mijnwerker werd overgedragen van generatie op generatie. De traditie om van vader op zoon in de put af te dalen begon echter te verdwijnen. Daarbij speelde de vermindering van de huwelijksvruchtbaarheid een rol. Aanvankelijk lag de huwelijksvruchtbaarheid bij de mijnwerkersfamilies bijzonder hoog. Kinderen gingen al op jonge leeftijd werken in de mijn en droegen zo bij aan het gezinsinkomen. De levensstandaard onder mijnwerkersgezinnen was hoog, maar door de economische neergang in het laatste kwart van de negentiende eeuw kwam deze in het gedrang. Vooral ongeschoolden, vrouwen en kinderen, werden getroffen door werkloosheid. Onder de traditionele mijnwerkersbevolking werd een mentaliteitswijziging zichtbaar die zich uitte in een veranderd demografisch gedrag. Mijnwerkers verkozen een ander beroep voor hun kinderen, minder zwaar en met meer sociaal prestige. Om dat mogelijk te maken beperkten zij het aantal nakomelingen, zodat er meer financiële ruimte kwam om de kinderen meer en langer onderwijs te laten volgen met het oog op betere kansen op de arbeidsmarkt. Deze strategie van arbeidersgezinnen resulteerde in een afnemend aanbod op de arbeidsmarkt. Het dalende geboortecijfer zorgde op termijn voor een afwijkende leeftijdsopbouw. Vergeleken met België als geheel had de Luikse regio te kampen met een tekort aan jongeren, een zogenaamde ontgroening.

Tijdens de crisis van de jaren I930 ging de uittocht van lokale arbeiders gewoon door. Hun afkeer voor het beroep van mijnwerker bleef sterk, zeker voor het ondergrondse werk dat veel minder aantrekkelijk was dan de vele alternatieven in bijvoorbeeld de staal- en bouwnijverheid. Door het verdwijnen van de beroepseer als gevolg van technologische ontwikkelingen en rationalisatie veranderde het mijnwerkersberoep in die mate dat bovendien nog meer traditionele mijnwerkers afhaakten. Bovendien was er vanaf die jaren sprake van een sterfteoverschot. Er werden in de Luikse regio minder kinderen geboren dan er mensen stierven, zodat het aanbod aan potentiële arbeidskrachten verder afnam.

Het uitbreken van de Tweede Wereldoorlog zorgde ervoor dat nog meer arbeiders de Luikse mijnen verlieten. Net voor en tijdens de oorlog vertrokken veel buitenlanders, opgeroepen door het eigen land, of opgeëist om in de Duitse mijnen te werken. Ook ervaren Belgische mijnwerkers verlieten de Luikse mijnen, aanvankelijk om het land te dienen, later ook om in de Duitse mijnen te gaan werken die betere arbeidsvoorwaarden boden. Dat het 
aandeel Belgische mijnwerkers in de Luikse mijnen niet al te drastisch daalde had te maken met het aanbod van 'gelegenheidsarbeiders'. Deze, over het algemeen onervaren arbeiders, boden zich aan als mijnwerker om aan verplichte tewerkstelling in Duitsland te ontkomen. Toen de oorlog voorbij was vertrokken deze 'gelegenheidsarbeiders' even snel als ze gekomen waren. De zogenaamde 'vlucht uit de mijnen' die zich voor de oorlog had aangekondigd, zette zich na de bevrijding in alle hevigheid door. Op het moment dat de Belgische steenkoolnijverheid vele mijnwerkers nodig had om de steenkolenslag te winnen, verlieten de Belgen massaal de mijnen. Iets wat naar analogie met de heersende oorlogsterminologie werd omschreven als de 'desertie van de zonen'.

Uit de analyse van de steekproef uit het pensioenfonds bleek dat jaarlijks tussen de 30 en 40 procent van de in België geboren mijnwerkers hun dienstverband beëindigden. Er gingen veel meer Belgen weg dan er in dienst traden en er bleef steeds minder personeel over dat het mijnwerk als een beroep voor het hele werkzame leven beschouwde. In plaats van een levenslange carrière werd het werken in de mijn eerder als een tijdelijke loopbaankeuze gezien, een noodzakelijk kwaad in economisch minder goede tijden, een optie bij gebrek aan beter.

Mijnwerkers afkomstig uit andere Belgische provincies dan Luik, vooral pendelaars uit Belgisch-Limburg en Brabant, werden in de loop van de tijd eveneens minder honkvast. In de periode na de Tweede Wereldoorlog kenden zij het grootste verloop en de kortste dienstverbanden. Men kan de pendelaars ook als 'gelegenheidsarbeiders' beschouwen: voor hen was het mijnwerk een tijdelijke bezigheid, een manier om snel geld te verdienen.

Nederlandse grensarbeiders werden eind jaren 1940 aangetrokken door de gunstige primaire en secundaire arbeidsvoorwaarden en de voordelige koers van de Belgische frank. Bovendien waren de selectiecriteria van de Luikse mijnen minder streng. Heel wat Nederlanders die niet in de Nederlandse mijnen aan de slag konden omdat zij te oud waren, weinig of geen ervaring hadden, te vaak verzuimden of te strijdbaar waren, werden wel aanvaard in het Luikse bekken.

Terwijl het totaal aantal tewerkgestelden in de Luikse mijnen vanaf het eind van de jaren I920 gedurig afnam, groeide het aantal buitenlandse werkkrachten vanaf I947 vrijwel constant. De noodzakelijke verbreding van het rekruteringsveld bracht diverse nationaliteiten naar het Luikse bekken. De Italianen hadden hierin het grootste aandeel: in de jaren 1950 vormden ze bijna twee derde van de geïmmigreerde arbeidskrachten. Na een onderbreking van de werving tijdens de kolencrisis werden in de jaren ig6o nieuwe groepen migranten aangetrokken (Grieken, Spanjaarden, Marokkanen en Turken).

De beloftes die mijnwerkgevers deden aan arbeidsmigranten in verband met huisvesting en salaris werden niet steeds waargemaakt, waardoor een aanzienlijk deel al snel weer op zoek ging naar betere arbeidsvoorwaarden. Bovendien kon een deel van de naoorlogse migranten niet wennen aan het ondergrondse werk en vertrok snel uit de kolenmijnen; een ander deel bleek ongeschikt voor het vak, ondanks de gehanteerde selectiecriteria. Er arriveerden steeds weer nieuwe groepen onervaren buitenlanders. De meerderheid van de buitenlandse migranten bleef één tot vijf jaar in de Luikse mijnen werken. Ze waren door hun arbeidscontract maar voor een jaar gebonden aan één mijn; na vijf jaar mochten ze ook buiten de steenkoolnijverheid aan de slag. Een levenslange carrière in de Luikse mijnen werd door de meeste arbeidsmigranten niet nagestreefd. 


\section{ARBEIDSMARKTGEDRAG EN DE WET VAN DE REMMENDE VOORSPRONG}

De Luikse arbeidsmarkt voor mijnwerkers illustreert de stelling van Van Hoof dat er deelmarkten kunnen zijn waarop bepaalde categorieën arbeiders een relatief sterke arbeidsmarktpositie verwerven. Het tekort aan mijnwerkers in de Luikse regio zorgde ervoor dat het voordeel op de arbeidsmarkt bij de autochtone arbeiders lag. Voor de werkgevers was er sprake van een krappe arbeidsmarkt: de vraag naar arbeid was groter dan het lokale aanbod. In die situatie was een loonstijging onvermijdelijk en hadden de aanbieders van arbeid de banen voor het uitzoeken hadden. De krapte op de arbeidsmarkt werd aanvankelijk 'opgelost' door de werving van pendelaars, grensarbeiders en arbeidsmigranten, waardoor de Luikse werkgevers de nadelen van de ongelijke machtspositie tot op zekere hoogte ongedaan wisten te maken. Het probleem van het arbeidstekort escaleerde echter na de Tweede Wereldoorlog en de Luikse mijnwerkgevers waren genoodzaakt hun mijnwerkers steeds verder weg te zoeken en steeds massaler aan te trekken. Het aandeel buitenlandse mijnwerkers op de totale arbeidskracht in de Luikse mijnen won steeds meer aan belang.

Een traditionele verklaring voor de aanwezigheid van buitenlanders op de arbeidsmarkt is de theorie van de dubbele arbeidsmarkt. Arbeidsmigranten bevinden zich dan in het onderste segment waarin de arbeidsplaatsen met lagere lonen, weinig of geen werkzekerheid en promotiekansen zich bevinden. Ze vervullen een bufferfunctie en de migratiepolitiek is erop gericht tijdelijke arbeidscontracten aan te bieden waarmee periodes van arbeidstekorten kunnen worden opgevangen. Kortom, het aantrekken van arbeidskracht uit het buitenland wordt conjunctureel gestuurd. Deze theorie over een tweedeling op de arbeidsmarkt stelt de situatie van de Luikse mijnwerkers te simpel voor. Op de Luikse mijnarbeidsmarkt werd de rekrutering van arbeidsmigranten na de Tweede Wereldoorlog namelijk een structureel verschijnsel. Bovendien konden we meerdere groepen onderscheiden met elk een eigen arbeidsmarktgedrag.

Het gedrag van de Luikse mijnwerkers werd in hoofdzaak gekenmerkt door mijnverlating; de uit andere provincies afkomstige pendelaars manifesteerden zich meer en meer als gelegenheidsarbeiders. Uit de buitenlandse migranten, die steeds opnieuw moesten worden aangeworven, kon evenmin een stabiel personeelsbestand worden opgebouwd.

De Luikse mijnwerkgevers hielden er vooral een korte termijnvisie op na. Er werd na de Tweede Wereldoorlog hoofdzakelijk ingezet op het aantrekken van steeds nieuwe contingenten arbeidsmigranten die na een verkorte beroepsopleiding snel aan de slag konden. Deze acties haalden weliswaar steeds nieuwe mijnwerkers naar het Luikse bekken, maar de werkgevers wisten ze niet voor langere termijn aan de Luikse mijnen te binden.

Het is opvallend dat de Luikse mijnen met hun tegen het einde van de negentiende eeuw opgebouwde gekwalificeerde bestand van mijnwerkers er niet in slaagden in de twintigste eeuw een duurzaam personeelsbestand in stand te houden. De wet van de remmende voorsprong die van toepassing was op de structuur en de productiemogelijkheden van het Luikse bekken, manifesteerde zich ook in het Luikse personeelsbeleid. De traditionele mijnwerkerscultuur speelde een afremmende rol bij het innoveren van het personeelsbeleid. Het binden van arbeiders door middel van een beroepsopleiding voor jongens was niet succesvol. Bovendien kon die gevestigde mijnwerkersklasse zich steeds minder vinden in de meer gerationaliseerde en gemoderniseerde mijnen. 
Of de mijnwerkgevers andere of meer maatregelen hadden kunnen of moeten nemen is achteraf moeilijk te zeggen. Het mijnwerk bleef, ondanks modernisering en mechanisering, een zwaar, vuil en ongezond beroep. In alle mijnbekkens was het een uitdaging voldoende en ervaren arbeiders te vinden. Dat de beide Limburgse bekkens er in de twintigste eeuw desondanks in slaagden om een min of meer stabiel personeelsbestand op te bouwen wijst er wel op dat het mogelijk was een succesvol personeelsbeleid in de mijnindustrie te voeren. Het midden van de jaren 1930 vormde daar een breekpunt in de arbeidsmarktstrategieën van het mijnpatronaat en de mijnwerkers. De arbeidsmarkt werd meer en meer geïnstitutionaliseerd en gestructureerd en er ontstonden stabielere arbeidsmarktverhoudingen. In Luik vormde het midden van de jaren 1930 eveneens een breekpunt, maar daar luidde die periode juist het einde van de stabiele verhoudingen in.

Bij een vergelijking tussen de Euregionale mijnbekkens is een aantal verschillen aan te duiden: de Luikse werkgevers hadden in tegenstelling tot de Limburgse veel concurrentie van andere sectoren die aantrekkelijker alternatieven aanboden; de Luikse regio had te kampen met een negatieve demografische ontwikkeling, in tegenstelling tot de Limburgse bekkens waar voldoende jongeren op de arbeidsmarkt kwamen, en het lukte de Luikse mijnbedrijven niet voldoende te investeren in beroepsopleidingen zodat er geen vaste groep aan mijnwerkers kon ontstaan, zoals in de Limburgse mijnen. Het is echter de vraag of andere strategieën met de gegeven structuurelementen mogelijk zouden zijn geweest. 


\section{Bijlagen}

I Lonen en arbeidsduur

2 Overzicht van de mijnsluitingen in het Luikse bekken, I903-I980

3 Overzicht van de soorten ontgonnen steenkool in het Luikse bekken in I93I

4 De Luikse regio in 1947

5 De belangrijkste mijnwerkersgemeenten in de provincie Luik (naar het aantal inwonende mijnwerkers op totale bevolking), I9Io

6 De werkboekjes als bron voor vrouwenarbeid in de Luikse mijnen

7 Gegevens over de in- en uitstroom van Belgische en buitenlandse mijnwerkers per jaar, 19471972

8 De administratie van het Fonds National de Retraite des Ouvriers Mineurs (FNROM) / Nationaal Pensioenfonds voor Mijnwerkers (N PM) als bron

9 Verantwoording van het kaartmateriaal

Io De nettoproductie van steenkolen bij de Luikse mijnen, I900-I979

II De personeelsbezetting bij de Luikse mijnen, I900-I979

I2 Het aantal buitenlandse arbeiders in het ondergrondse personeelsbestand van de Luikse mijnen naar nationaliteit, I95I-I976

I3 Het aantal Belgen en buitenlanders in het bovengrondse personeelsbestand van de Luikse mijnen, I95I-1976 


\section{BIJLAGE I Lonen en arbeidsduur}

\section{De arbeidsduur}

In I889 duurde een houwersdienst in het Luikse bekken gemiddeld 8 uur en 48 minuten, andere ondergronders brachten gemiddeld to uur en 17 minuten in de ondergrond door. Diensten van II tot I2 uur kwamen ook voor. Uit de industrietelling van I 896 kunnen we afleiden dat een houwersdienst toen gemiddeld ongeveer 9 uren bedroeg (zie tabel 2 in deze bijlage). In het begin van de twintigste eeuw was er nog sprake van een tweepostensysteem (dag- en nachtpost), maar later werd er overgegaan naar een driepostensysteem met een ochtend-, middag en nachtpost (van telkens acht uren). De dagpost daalde normaal gezien rond zes uur af en hield zich overwegend bezig met de productieve taken. De nachtpost daalde tegen zeven uur's avonds af en had vooral voorbereidende en onderhoudstaken. De middagpost vervulde een gemengd takenpakket. ${ }^{\mathrm{I}}$

Eén van de belangrijkste eisen van de Belgische Werkliedenpartij (BWP) en de vakbonden tegen het einde van de negentiende eeuw was het terugdringen van de arbeidsduur. In I895 dienden zowel Bertrand van de BWP en Joris Helleputte, een katholiek, een voorstel in bij de Kamer van Volksvertegenwoordigers om onder meer de zondagsrust en de arbeidsduurbeperking in te voeren voor bepaalde sectoren. Deze voorstellen bleven lange tijd zonder gevolg, maar tien jaar later werd de zondagsrust voorgeschreven. Voor de mijnwerkers was dit eigenlijk alleen de officiële bevestiging van een vrije zondag die in praktijk al lang bestond. ${ }^{2}$ Als een mijnwerker bij uitzondering op zondag moest werken was het voor herstelwerkzaamheden. In de productieve functies, zoals die van houwer, was de zondag traditioneel een rustdag. ${ }^{3}$ In 1906 diende Helleputte een amendement in waarin hij de toekenning van concessies wilde koppelen aan een beperking van de ondergrondse arbeidsduur tot acht uur, aan een verbod op ondergrondse arbeid voor vrouwen en jongens jonger dan $\mathrm{I} 4$ jaar en aan een pensioenregeling. Op I2 april 1907 werd het amendement-Helleputte op de maximum arbeidsduur van acht uur voor houwers en op tien uur voor de andere mijnwerkers aanvaard. De regering nam echter ontslag en de al gestemde wet werd nog ingetrokken.

Ondertussen was er een commissie opgericht die de arbeidsduurbeperking verder moest onderzoeken. Een groot punt van discussie was de basis waarop het aantal werkuren werd berekend. De patroons verkozen de durée du travail effectif, het effectieve aantal gewerkte uren zonder pauzes, tijd voor afdaling en het transport van en naar het kolenfront. Deze effectieve arbeidstijd overschreed bij de meeste functies de acht uren niet. De arbeidsduurverkorting die door de BWP en de vakbonden werd nagestreefd had betrekking op de hele arbeidsdag, van het afdalen tot het terug naar de bovengrond komen, het zogenaamde de jour à jour. In deze periode bedroeg een dergelijke werkdag in de mijnen van Cockerill tussen de 9,5 en I0,5 uur, naargelang de functie. Sommige zwaardere functies zoals de stutters en diegenen verantwoordelijk voor boorwerkzaamheden kenden een kortere werkdag van 8 uren. ${ }^{4}$ Eind Igog werd er dan eindelijk een verplichte beperking van de arbeidsdag in de mijnsector ingesteld: alle ondergronders kregen een negenurendag. Deze beperking werd uiteindelijk pas in I9I2 ingevoerd. Een jaar voordien, in I9II, werd de algemene mijnwet van kracht. Het verbod op ondergrondse arbeid voor vrouwen en jongens onder 14 jaar en een pensioenregeling werden nu ook van kracht. ${ }^{5}$

Na de Eerste Wereldoorlog klonk de eis voor de achturendag steeds luider. Op I8 januari I9I9 werd de Commission Mixte pour l'Etude de la Réduction du Travail dans les mines opgericht. Zij bracht de werkdag van alle ondergronders vanaf $\mathrm{I}$ juni eerst naar 8,5 uur en vervolgens vanaf I december igIg naar 8 uur.

\footnotetext{
I Gaier, Huit siècles de houillerie liégeoise, I70.

2 Willems, 'De lijdensweg van een rustdag', 73, 87-88.

3 Puissant, 'Les congés taxés', 18, 22.

4 Commission d'enquête, Enquête orale.

5 De Maeyer en Van Molle (red.), Joris Helleputte, I43.
} 
Ook de werkdag van de bovengronders werd ingekort: vanaf I april I920 kregen zij ook de achturendag. In juni I92I volgde dan de algemene invoering van de achturendag en 48-uren week. Het was een bevestiging van de al bestaande situatie voor mijnwerkers en een teken dat de steenkoolsector voorliep op de andere sectoren. ${ }^{6}$

Onder druk van de staking van 1936 werd in 1937 de 45 -uren week (met diensten van 7,5 uren) voor de steenkoolsector ingevoerd, maar in verband met de oorlogsdreiging werd die begin I 940 weer afgeschaft. Omdat mobilisatie en oorlogsdreiging tot een vermindering van de steenkoolproductie en een verhoging van de kostprijs hadden geleid, werd de 45-urenweek door de overheid vervangen door een 48-uren week (en achturendag). Niet alle mijnen voerden deze maatregel in; ze vonden de loonstijging die gepaard ging met de langere arbeidsduur niet opwegen tegen de kleine stijging in de productie. In Luik bleven de mijnen Abhooz, Arbre Saint-Michel, Six Bonniers, Kessales et Concorde, La Minerie en Ougrée voorlopig bij het oude systeem. Sommige andere mijnen die de 48-uren week wel invoerden kregen te maken met stakingen. ${ }^{7}$

Op 25 oktober 1963 werd door La Commission Nationale Mixte des Mines opnieuw de officiële arbeidsuren voor de mijnsector vastgelegd. Zaterdag werd een niet gewerkte dag (als er in die week geen feestdag voorkwam) en een arbeidsdienst voor de ondergrond werd op 8 uren gebracht, de dienst voor de bovengrond op 8 uur en 15 minuten. ${ }^{8}$

\section{De lonen}

Traditioneel werd het salaris van de mijnwerkers steeds de laatste dag, een zaterdag, van elke quinzaine (periode van twee weken) uitbetaald. Aanvankelijk waren uur- of daglonen het meest gangbaar. In de negentiende eeuw werd met het oog op een hoger rendement le travail à marché of akkoordloon het populairst. Het akkoordloon wordt betaald naar de verrichte arbeid en is dus gebaseerd op het voltooien van bepaalde taken, ongeacht de aan de taak besteedde tijd. In het algemeen was het wel zo dat de mijnwerkers gebonden waren aan de diensttijden in de mijn. ${ }^{9}$ Dit systeem bevoordeelde de jonge en sterke arbeiders ten nadele van de oudere, minder geschikte en risicomijdende arbeiders. Het maakte het mogelijk in korte tijd veel geld te verdienen, soms ten koste van de veiligheid. Het akkoordloon werd over het algemeen berekend op basis van 'ontkoolde' oppervlakte of lengte, maar soms ook naar aantal gevulde mijnwagens. ${ }^{10}$

Het niveau van de lonen varieerde niet alleen naar prestatie, maar ook naargelang de uitgeoefende functie, ervaring, economische conjunctuur, en, zolang er vrouwen in de Luikse mijnen werkten, naar

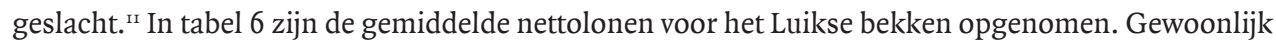
verdienden de houwers het meest en bereikte een mijnwerker zijn hoogste inkomen omstreeks de leeftijd van 30 jaar. ${ }^{12}$ Veelal werd er in een groep aan het kolenfront gewerkt en werd het loon collectief, per team, berekend. ${ }^{13}$ Uit de Industrietellingen van 1896 blijkt dat een houwer in die tijd gemiddeld tussen de 4 à 5 BEF per dag kon verdienen, maar een inkomen van 8 BEF kon ook worden bereikt (zie tabel I en 2). Het grootste deel van de houwerslonen werd naar collectief akkoordloon berekend (voor 3.844 personen), akkoordloon per individu kwam ook voor, maar beperkt (voor 706 personen). Slechts ca. Io procent van de houwers werd uitbetaald in dagloon (402 personen).

6 Gaier, Huit siècles de houillerie liégeoise, 172.

7 L'Association Charbonnière de la Province de Liège, Dossiers 'Durée du Travail', Carton IX, Durée du Travail souterrain dans les mines de Houille - A.R. du I5-I2-I939.

8 In de Kempen telden beide diensten I5 minuten meer. In: 'Beknopte statistiek', Annales des Mines de Belgique, maart Ig69, 282.

9 Gaier, Huit siècles de houillerie liégeoise, I70.

Io Geerkens, La rationalisation dans l'industrie belge, 630.

II Zie hoofdstuk 2.

12 Leboutte, Reconversions de la main-d'œuvre et transition démographique, III.

I3 Geerkens, La rationalisation dans l'industrie belge, 630 . 
TABEL B.I DE AARD VAN DE BELONING EN DE ARBEIDSDUUR VAN HOUWERS IN HET LUIKSE BEKKEN IN I896

\begin{tabular}{|c|c|c|c|c|}
\hline \multirow[b]{2}{*}{ mijn } & \multicolumn{3}{|c|}{ aantal houwers en aard van de beloning } & \multirow[b]{2}{*}{ arbeidsduur } \\
\hline & dagloon & akkoordloon coll. & akkoordloon ind. & \\
\hline I & - & 313 & - & 8.30 \\
\hline 2 & - & 290 & - & 10.30 \\
\hline 3 & 7 & II2 & 207 & 8.00 \\
\hline 4 & I59 & I59 & - & 8.00 \\
\hline 5 & - & 344 & - & 8.00 \\
\hline 6 & - & - & 240 & 7.45 \\
\hline 7 & - & $4 \mathrm{I} 7$ & - & 8.30 \\
\hline 8 & - & I5I & - & IO.I5 \\
\hline 9 & 74 & 209 & - & $9 \cdot 30$ \\
\hline IO & - & 92 & I49 & 9.00 \\
\hline II & - & 304 & - & 9.00 \\
\hline $\mathrm{I} 2$ & - & I66 & - & 8.30 \\
\hline I3 & 37 & I76 & - & 8.00 \\
\hline $\mathrm{I} 4$ & - & 88 & - & 8.00 \\
\hline I5 & - & I29 & - & 8.30 \\
\hline I6 & - & 32 & 27 & 9.00 \\
\hline I7 & - & 62 & - & IO.00 \\
\hline I8 & - & 69 & - & 9.00 \\
\hline I9 & - & - & 83 & I0.30 \\
\hline 20 & - & 48 & - & 9.00 \\
\hline $2 \mathrm{I}$ & $5^{6}$ & 8 & - & 8.30 \\
\hline 22 & I9 & 46 & - & 9.00 \\
\hline 23 & - & 49 & - & $9 \cdot 30$ \\
\hline 24 & - & 53 & - & 9.00 \\
\hline 25 & I8 & 87 & - & 9.00 \\
\hline 26 & - & 69 & - & 8.30 \\
\hline 27 & - & 96 & - & 9.00 \\
\hline 28 & - & - & - & \\
\hline 29 & 28 & 3 & - & $7 \cdot 30$ \\
\hline 30 & - & 67 & - & 8.45 \\
\hline $3 \mathrm{I}$ & - & 47 & - & 9.00 \\
\hline 32 & - & $4 \mathrm{I}$ & - & I0.00 \\
\hline 33 & - & 53 & - & 8.30 \\
\hline 34 & - & 44 & - & 8.30 \\
\hline 35 & - & 20 & - & 8.30 \\
\hline 36 & 4 & - & - & 6.30 \\
\hline 37 & - & 40 & - & 9.00 \\
\hline Totaal & 402 & 3.844 & 706 & \\
\hline
\end{tabular}

Bron: Recensement général des industries et des métiers (31 octobre 1896). (coll.=collectief; ind.=individueel) N.B.: De mijnen werden niet bij naam genoemd, alleen genummerd. Mijn 28 gaf geen gedetailleerde informatie over de houwers op. De arbeidsduur werd berekend vanaf het moment van afdaling tot de terugkeer naar de oppervlakte. In sommige mijnen was de dienst pas afgelopen wanneer alle afgehouwen steenkool weggehaald was (mijnen II en I6). 
TABEL B.2 De houWERSLONEN IN Het LUiKSE BEKKEN IN I896

\begin{tabular}{|c|c|c|c|c|c|c|c|c|c|c|c|c|}
\hline \multirow[b]{2}{*}{ mijn } & \multicolumn{12}{|c|}{ Aantal houwers met salaris in BEF } \\
\hline & $\begin{array}{l}\mathbf{I}, 5^{-} \\
\mathbf{I}, 99\end{array}$ & $\begin{array}{c}2- \\
2,49\end{array}$ & $\begin{array}{l}2,5- \\
2,99\end{array}$ & $\begin{array}{c}3^{-} \\
3,49\end{array}$ & $\begin{array}{l}3,5- \\
3,99\end{array}$ & $\begin{array}{c}4^{-} \\
4,49\end{array}$ & $\begin{array}{l}4,5^{-} \\
4,99\end{array}$ & $\begin{array}{c}5- \\
5,49\end{array}$ & $\begin{array}{c}5,49- \\
5,99\end{array}$ & $\begin{array}{c}6- \\
6,49 \\
\end{array}$ & $\begin{array}{l}6,5- \\
6,99\end{array}$ & $>7$ \\
\hline I & - & - & - & - & 9 & I87 & I07 & 8 & 2 & - & - & - \\
\hline 2 & - & - & 3 & 6 & II & 227 & 38 & 2 & 3 & - & - & - \\
\hline 3 & - & - & 4 & $\mathrm{I} 2$ & 70 & I64 & 67 & 7 & I & I & - & - \\
\hline 4 & - & - & - & 5 & 139 & 170 & 2 & 2 & - & - & - & - \\
\hline 5 & - & - & - & 2 & 15 & 312 & $\mathrm{I} 4$ & I & - & - & - & - \\
\hline 6 & - & I & - & I & 2 & 6 & $\mathrm{I} 43$ & 26 & 25 & I3 & I8 & 5 \\
\hline 7 & I & - & 2 & 26 & 56 & I99 & $\mathrm{I} 2 \mathrm{I}$ & IO & 2 & - & - & - \\
\hline 8 & - & - & - & I & 27 & 53 & 37 & I9 & $\mathrm{I} 2$ & 2 & - & - \\
\hline 9 & - & - & - & I & 3 & 255 & 24 & & - & - & - & - \\
\hline IO & - & I & - & 2 & 23 & 54 & 84 & 48 & 23 & 5 & - & I \\
\hline II & - & - & 5 & IO & 55 & 45 & 27 & I59 & - & - & 3 & - \\
\hline $\mathrm{I} 2$ & - & - & - & I9 & 85 & 23 & $2 \mathrm{I}$ & I8 & - & - & - & - \\
\hline I3 & - & - & - & $\mathrm{I} 4$ & 70 & 9I & $3^{8}$ & - & - & - & - & - \\
\hline $\mathrm{I} 4$ & - & - & - & - & - & 26 & 27 & $2 \mathrm{I}$ & 2 & 8 & I & 3 \\
\hline I5 & - & - & - & - & - & 30 & 44 & 36 & 9 & IO & - & - \\
\hline I6 & - & - & - & - & I & 36 & IO & 5 & 7 & - & - & - \\
\hline I7 & - & - & - & - & - & $2 \mathrm{I}$ & 37 & 4 & - & - & - & - \\
\hline I8 & - & - & - & 30 & 35 & 3 & I & - & - & - & - & - \\
\hline I9 & - & - & I & 2 & 23 & 34 & 20 & 2 & I & - & - & - \\
\hline 20 & - & - & - & 5 & 27 & 6 & 5 & 3 & - & - & - & - \\
\hline $2 \mathrm{I}$ & - & - & - & - & - & 56 & - & - & 4 & 4 & - & - \\
\hline 22 & - & - & - & 9 & I8 & 23 & - & - & I5 & - & - & - \\
\hline 23 & - & - & - & - & - & 49 & - & - & - & - & - & - \\
\hline 24 & - & - & I & I5 & $\mathrm{I} 3$ & I6 & 3 & 2 & 3 & - & - & - \\
\hline 25 & - & - & - & - & - & $5^{6}$ & $3 \mathrm{I}$ & I8 & - & - & - & - \\
\hline 26 & - & - & - & - & 42 & 27 & - & - & - & - & - & - \\
\hline 27 & - & - & - & - & - & - & 72 & 24 & - & - & - & - \\
\hline 28 & • & • & • & • & • & • & • & • & • & • & • & • \\
\hline 29 & - & - & - & - & 29 & 2 & - & - & - & - & - & - \\
\hline 30 & - & - & - & 6 & - & $\mathrm{I} 2$ & 25 & 24 & - & - & - & - \\
\hline $3 \mathrm{I}$ & - & - & - & - & - & 6 & I6 & 25 & - & - & - & - \\
\hline 32 & - & - & - & - & - & I9 & 7 & 7 & - & 4 & - & 4 \\
\hline 33 & - & - & - & - & 25 & - & IO & I8 & - & - & - & - \\
\hline 34 & - & - & - & 8 & $\mathrm{I} 4$ & $2 \mathrm{I}$ & I & - & - & - & - & - \\
\hline 35 & - & - & - & - & 20 & - & - & - & - & - & - & - \\
\hline 36 & - & 4 & - & - & - & - & - & - & - & - & - & - \\
\hline 37 & - & - & - & I5 & 7 & I8 & - & - & - & - & - & - \\
\hline Totaal & I & 6 & I6 & I89 & 819 & 2247 & 1.032 & 489 & 109 & 47 & 22 & 13 \\
\hline
\end{tabular}

Bron: Recensement général des industries et des métiers (31 octobre 18g6).

N.B.: De mijnen werden niet bij naam genoemd, alleen genummerd. Mijn 28 gaf geen gedetailleerde informatie over de houwerslonen op. 
Tegen het einde van de negentiende eeuw was een van de belangrijkste eisen van de Belgische Werkliedenpartij (BWP) en de vakbonden het instellen van minimumlonen en loonschalen voor de steenkoolnijverheid. Onder druk van vakbonden en de BwP stegen de lonen bij een aantrekkende economie tot het uitbreken van de Eerste Wereldoorlog, een periode van onzekerheid en hoge voedselprijzen. $\mathrm{Na}$ de oorlog werd de stijgende tendens van de lonen voortgezet tot aan de crisisjaren. ${ }^{\mathrm{I}}$ In 1920 werd de toekenning van gratis steenkool aan de mijnwerkers officieel gemaakt. In datzelfde jaar werden de mijnwerkerslonen ook gekoppeld aan de prijsindex. De mijnwerkers waren de eersten die van deze maatregel konden profiteren. De mijnwerkerslonen werden vanaf 1926 ook afhankelijk van de verkoopprijs van steenkool. ${ }^{15}$ In goede tijden was dit een voordelig systeem voor de mijnwerkers, maar in tijden van een lage conjunctuur zorgde dit samen met de indexdaling ervoor dat de nominale lonen in de steenkoolsector sterk daalden.

De crisis in het begin van de jaren I930 was een dergelijke slechte periode. Vanaf juli I 930 tot juni I932 vonden er zeven officiële loondalingen plaats, waardoor de lonen daalden met 30 tot 35 procent. Bovendien maakten verscheidene Luikse mijnwerkgevers aan de officieuze loonsverhogingen (glissements extra conventionnels) ongedaan, die waren toegekend in tijden van groei om extra arbeidskrachten aan te kunnen trekken. Ook daalden de reële lonen omdat er een systeem van werktijdverkorting (chômage partiel) werd ingesteld. Hierbij verplichtten de mijndirecties de mijnwerkers slechts een beperkt aantal diensten per week te werken om de loonkosten en de productie te doen dalen. Hierdoor werd het aantal ontginningsdagen beperkt, kon er voldaan worden aan de productiequota en kon vermeden worden dat er te grote voorraden ontstonden.

Ondertussen werd in een aantal mijnen het akkoordloon niet langer per team, maar individueel berekend, wat nadelig was voor sommige mijnwerkers en voor de ondergrondse samenwerking. De mijnen hoopten door deze individualisering van het loon door een minieme loonstijging een grote rendementsstijging te bewerkstelligen. Door de vakbonden werd het als volgt uitgedrukt: Les patrons veulent diviser pour régner. ${ }^{16}$ Over het algemeen was het patronaat erg gekant tegen welke loonsstijging dan ook, omdat deze in hun ogen feitelijk een rendementsdaling en een stijging van het absenteïsme zou veroorzaken. ${ }^{17}$

In juli 1932 werd er in alle Belgische bekkens gestaakt tegen een nieuwe poging van de werkgevers om de lonen te verlagen. ${ }^{18}$ In Luik staakten alle bijna 32.000 mijnwerkers van 9 tot I 8 juli. Daarna volgden nog gedeeltelijke stakingsacties in de maand augustus. Tegen ro september konden de mijnwerkers een magere loonsverhoging van een procent afdwingen en de situatie stabiliseerde zich tot begin I935. De algemene staking van juni 1936, waarbij de Luikse mijnwerkers samen met de Antwerpse dokwerkers het voortouw namen, kende een groter succes wat betreft verworven arbeidsvoorwaarden. Tegen die tijd was de economie weer wat aangetrokken en kregen de stakingsbewegingen eerder een offensief karakter, in tegenstelling tot de meer defensieve mijnstaking van $1932 .{ }^{19}$ Er werd een algemene loonsverhoging, invoering van het minimumloon, vakbondsvrijheid en betaald verlof (6 vakantiedagen per jaar) bereikt. Ook eisten de mijnwerkers een volledige terugkeer naar het collectief akkoordloon, maar dit werd door de mijndirecties niet als een optie gezien. In l'Association Charbonnière de la Province de Liège werd de kwestie besproken en werd onder meer als argument gebruikt dat de mijnwerkers zelf dit systeem verkozen.

Sinds 1920 was er in het systeem van akkoordlonen sprake van minimumlonen indien mijnwerkers een ontoereikende productie hadden bereikt. Dit minimumloon werd echter niet door alle mijn-

14 Gaier, Huit siècles de houillerie liégeoise, I65-169.

I5 Geerkens, La rationalisation dans l'industrie belge, 617.

I6 Ibidem, 616-617, 619, 628-631, 631, noot 75 .

17 Puissant, 'Les congés taxés', 23.

I8 Deruette, 'La grève de l'été I932', 45-46, 55.

I9 Hanotte, 'Mineurs en lutte!', 78-89, 94. 
directies gerespecteerd of toegepast. Bovendien werd in deze moeilijke tijden strenger toegezien op de criteria voor het ontvangen van een volledig salaris. ${ }^{20}$ Nog tot in het interbellum bestonden er wat loonshoogte en loonsystemen betreft grote verschillen tussen de mijnen in het Luikse bekken. Voor dezelfde functie of dezelfde taken kon een mijnwerker bij een andere mijn soms meer verdienen en dat zorgde uiteraard voor verloop tussen de mijnen. Door het onzekere karakter van het mijnwerk, ontginningsmoeilijkheden, verschillende soorten kolenlagen en ongevallen beïnvloedden de rentabiliteit en het rendement behoorlijk, konden zowel de mijndirecties als de mijnwerkers niet rekenen op vaste inkomsten. ${ }^{2 \mathrm{I}}$

Bij het begin van de Tweede Wereldoorlog voerde de bezetter een loonstop in. Ook nu werd door de patroons de strategie van werktijdverkorting benut om de productiemoeilijkheden ten gevolge van de bezetting op te vangen. De bepalingen over het te presteren werk om het minimumloon uitbetaald te krijgen werden restrictiever geïnterpreteerd en de patroons eisten twintig dagen aanwezigheid per maand om aanspraak te kunnen maken op gratis steenkool. De ravitaillering van de mijnwerkers liet al te wensen over, maar in combinatie met deze lagere inkomsten, waardoor het ook moeilijk werd om op de zwarte markt de nodige voedselaanvullingen aan te schaffen, werd de situatie echt acuut. Al vlug volgden er stakingen met als voornaamste eis een betere voedselvoorziening. Op ro mei I94I, precies een jaar na de inval, vond een grote algemene staking plaats met wederom een betere ravitaillering als onderwerp, maar nu aangevuld met een eis van 25 procent loonsverhoging. De Duitse overheid had er alle belang bij dat de steenkolenproductie van het bezette België op peil bleef en beantwoordde de eisen van de stakers positief. De lonen werden met 8 procent verhoogd, er werden voorschotten op het vakantiegeld gegeven en ondergrondse arbeiders kregen een stiptheidspremie. ${ }^{22}$ Op die manier traden de mijnwerkers tijdens de oorlog toe tot de groep van best betaalde arbeiders in België.

Deze tendens werd na de bevrijding voortgezet. Ditmaal was het de Belgische overheid die maatregelen nam om het mijnwerkersberoep aantrekkelijk te maken. In het kader van de steenkolenslag werd er aan de mijnwerkers een speciaal statuut toegekend met allerlei voordelen en werden de lonen verhoogd. Terwijl de Belgische mijnwerkers in het interbellum nog tot de slechts betaalde arbeiders behoorden, waren ze in de jaren 1950 de best betaalde arbeiders in de Europese Economische Gemeenschap geworden. ${ }^{23}$ Uit een studie van de Hoge Autoriteit van de EGKs blijkt echter dat in 1953 de gemiddelde loonkosten per uur (en sociale lasten) in Frankrijk ondertussen die van België overschreden hadden (tabel 3). Tegen r96r lagen de loonkosten ook in Duitsland en Nederland hoger en was België haar koppositie kwijt. Alleen Italië kende lagere loonkosten per uur. Wanneer we alleen naar de directe loonkosten kijken, blijken de Belgische mijnen toch nog bij de best betalende van de EGKS te horen. Slechts de Nederlandse mijnen moesten ze voor laten gaan.

TABEL B.3 DE LOONKOSTEN IN DE STEEN KOOLNIJVERHEID IN DE LANDEN VAN DE EGKS, IN BEF

\begin{tabular}{|c|c|c|c|c|c|c|c|c|c|c|c|}
\hline & \multicolumn{4}{|c|}{ Loonkosten per uur + sociale lasten (in BEF) } & \multicolumn{4}{c|}{ Loonkosten per uur (in BEF) } \\
\hline & België & $\begin{array}{c}\text { Frank- } \\
\text { rijk }\end{array}$ & $\begin{array}{c}\text { Duits- } \\
\text { land }\end{array}$ & $\begin{array}{c}\text { Neder- } \\
\text { land }\end{array}$ & Italië & & België & $\begin{array}{c}\text { Frank- } \\
\text { rijk }\end{array}$ & $\begin{array}{c}\text { Duits- } \\
\text { land }\end{array}$ & $\begin{array}{c}\text { Neder- } \\
\text { land }\end{array}$ & Italië \\
\hline I953 & 42,54 & 49,60 & 40,97 & 36,27 & 27,07 & I953 & $29,7 \mathrm{I}$ & 25,73 & 24,23 & 22,03 & I3,65 \\
\hline I96I & $6 \mathrm{I}, 95$ & 74,73 & 74,36 & $7 \mathrm{I}, 25$ & 48,79 & I96I & $4 \mathrm{I}, \mathrm{II}$ & 32,37 & 40,30 & 42,36 & 20,62 \\
\hline
\end{tabular}

Bron: C.E.C.A. $1952-1962,245$.

20 Geerkens, La rationalisation dans l'industrie belge, 630-633.

2I Gaier, Huit siècles de houillerie liégeoise, I67.

22 Luyten, 'Stakingen in België en Nederland', I56-I68. Zie ook hoofdstuk 4.

23 Gaier, Huit siècles de houillerie liégeoise, I65-169. 
FEDECHAR deed in november 1956 een onderzoek naar de akkoordlonen in de Luikse mijnen (zie tabellen 4 en 5). Aan de hand van een enquête werd de mijnen gevraagd naar het aantal mijnwerkers onder akkoordloon, of dat collectief of individueel werd berekend, en of de ondersteuning (boisage) al dan niet werd verrekend in het salaris. Ook werd ze gevraagd naar de samenstelling van de brutosalarissen. ${ }^{24}$ Hieruit blijkt dat in 1956 bijna 95 procent van de Luikse houwers onder akkoordloon werkte; van de andere ondergronders was dat bij bijna 20 procent het geval. Bij meer dan 77 procent van de houwers onder akkoordloon werd het salaris individueel berekend, bij de andere ondergronders was de situatie omgekeerd: bij meer dan 7I procent werd het salaris collectief, per ploeg berekend. Deze voorkeur voor het individueel berekende akkoordloon werd door de directie van Grande Bacnure als volgt beargumenteerd: 'nous avons préféré le marché individuel avec prix au m2 abattu.... parce que, avec partie fixe, certains ouvriers peu qualifiés se contentaient de la partie fixe; parce que les bons ouvriers préféraient avoir le marché total, de manière à accentuer leur gain'. Andere mijndirecties voerden gelijksoortige argumenten aan, zoals die van Argenteau-Trembleur, Gosson-Kessales en Patience et Beaujonc.

TABEl B.4 HeT AANTAL PERSONEELSLEDEN ONDER AKKOORDLONEN PER MIJN IN I956

\begin{tabular}{|c|c|c|c|c|c|c|}
\hline & \multicolumn{2}{|c|}{$\begin{array}{c}\text { houwers onder } \\
\text { akkoordloon }\end{array}$} & \multicolumn{2}{|c|}{$\begin{array}{c}\text { anderen onder } \\
\text { akkoordloon }\end{array}$} & \multicolumn{2}{|c|}{ totaal akkoordloon } \\
\hline & Individueel & ploeg & Individueel & ploeg & Individueel & ploeg \\
\hline Ans et Rocourt & - & 86 & - & $6 \mathrm{I}$ & - & $\mathrm{I} 47$ \\
\hline Argenteau-Trembleur & 90 & - & - & - & 90 & - \\
\hline Bois d'Avroy & 33 & I8 & - & 42 & 33 & 60 \\
\hline Micheroux & - & 7 & - & 4 & - & II \\
\hline Bonne Espérance & $55^{\circ}$ & - & - & $27 \mathrm{I}$ & 550 & $27 \mathrm{I}$ \\
\hline Bonnier & IOO & - & - & I02 & IOO & I02 \\
\hline Cockerill-Ougrée & 95 & - & 39 & $5 \mathrm{I}$ & $\mathrm{I} 34$ & $5 \mathrm{I}$ \\
\hline Espérance & II5 & 82 & 243 & 30 & $35^{8}$ & II 2 \\
\hline Gosson-Kessales & 685 & - & 336 & I.0I5 & $\mathrm{I} .02 \mathrm{I}$ & I.OI5 \\
\hline Grande Bacnure & $\mathrm{I} 78$ & - & - & $28 \mathrm{I}$ & $\mathrm{I} 78$ & $28 \mathrm{I}$ \\
\hline \multirow[t]{3}{*}{ Hasard } & - & 84 & - & IIO & - & I94 \\
\hline & - & 243 & 87 & 172 & 87 & $4 \mathrm{I} 5$ \\
\hline & II6 & - & - & 95 & II6 & 95 \\
\hline Patience et Beaujonc & 160 & - & 93 & 324 & 253 & 324 \\
\hline Quatre Jean & 73 & - & 32 & 37 & 105 & 37 \\
\hline La Minerie & - & 89 & 40 & 77 & 40 & I66 \\
\hline Wérister & I55 & 75 & 231 & 65 & 386 & $\mathrm{I} 40$ \\
\hline Totaal & 2.350 & 684 & I.IOI & 2.737 & $3 \cdot 45^{I}$ & $3 \cdot 42 \mathrm{I}$ \\
\hline
\end{tabular}

Bron: RAH, archief FEDECHAR, inv.nr. I679.

De directies moesten ook opgeven welk systeem van akkoordloon ze hanteerden (tabel 5). Een deel van de beloning kon al dan niet vast zijn, en de ondersteuning kon ook meegenomen worden in de berekening van het loon. Het loon van de meeste Luikse houwers (57 procent) werd samengesteld uit een deel vast loon en een deel naar geproduceerde hoeveelheid. De houwers die alleen betaald werden naar geproduceerde hoeveelheid vormden de tweede grootste groep ( 28 procent). Bij de andere on-

24 RAH, archief FEDECHAR, inv.nr. I679: Bescheiden betreffende een onderzoek in de mijnen over de lonen op basis van de vooruitgang in de productie, 1956 . 
dergronders was de groep die betaald werd naar geproduceerde hoeveelheid het grootst (bijna 8o procent). De redenen voor een vast loondeel waren: onvoorziene omstandigheden (onder meer Espérance et Bonne Fortune) en het feit dat minder geschikte arbeiders zo toch het minimumloon konden verdienen (onder meer Wérister). Over het algemeen werd er in overeenstemming met de arbeiders door de directie besloten wat de minimum geproduceerde hoeveelheid was onder normale omstandigheden wat betreft werk en veiligheid. Indien er sprake was van onenigheid werd er ook wel gekeken naar de productie van een moniteur (instructeur), onder meer in de mijn van Micheroux.

Een ander punt van discussie was het stutwerk. Slechts in vier mijnen werd hiermee rekening gehouden bij de bepaling van de lonen: Bois d'Avroy, Bonnier, Ougrée en Espérance et Bonne Fortune. Alle mijnen namen echter maatregelen om te zorgen dat dit goed gebeurde. Zo werd het loon pas volledig uitbetaald indien de boisage voltooid was (Bonne Espérance), kreeg de houwer die nog extra ondersteuning moest uitvoeren die zijn voorganger had verzuimd, extra betaald (Bonnier), werd er loon ingehouden indien het werk niet of onvoldoende was uitgevoerd (Wérister) en/of volgden er boetes of zelfs declassering naar een lagere functie (Quatre Jean). De controlerende rol van de surveillants of porions en het bureau de marquage werden hierbij benadrukt. De porions moesten aan het bureau de marquage de dagelijks geproduceerde hoeveelheden doorgeven; op basis van deze gegevens berekende het bureau het loon.

TABEL B.5 DE BEREKENINGSWIJZE VAN DE AKKOORDLONEN VAN ONDERGRONDERS IN I956

\begin{tabular}{|l|c|}
\hline & Aantal \\
\hline Houwers & 86 I \\
\hline Verloning naar geproduceerde hoeveelheid & 343 \\
\hline Verloning naar geproduceerde hoeveelheid en het stutten & I.730 \\
\hline Een deel vaste verloning en een deel verloning naar geproduceerde hoeveelheid & I00 \\
\hline Een deel vaste verloning, een deel naar geproduceerde hoeveelheid en het stutten & 3.127 \\
\hline Andere ondergronders & 242 \\
\hline Verloning naar geproduceerde hoeveelheid & 260 \\
\hline Verloning naar geproduceerde hoeveelheid en het stutten & 285 \\
\hline Een deel vaste verloning en een deel verloning naar geproduceerde hoeveelheid & \\
\hline Een deel vaste verloning, een deel naar geproduceerde hoeveelheid en het stutten & \\
\hline
\end{tabular}

Bron: RAH, archief FEDECHAR, inv.nr. I679.

De basis waarop dit akkoordloon werd berekend verschilde per mijn. Zo kon er gekeken worden naar het aantal afgehouwen vierkante meters steenkool, naar het aantal gevulde berlaines (mijnwagens), of naar het aantal bèle boisée, de afstand tussen twee ondersteunende dwarsbalken. Er bestonden dus verschillen tussen de mijnen wat betreft de grondslag van de berekening, een deel vast of niet, en of het akkoordloon collectief of individueel werd berekend. Hier geven we een voorbeeld van hoe het uiteindelijke loon werd berekend, rekening houdende met al deze parameters. In de mijn La Minerie werkten in een pijler zes houwers. Het vaste loondeel bedroeg 173 BEF en per mijnwagen kregen ze 30 BEF akkoordloon. De wekelijkse productie in die pijler bedroeg 360 mijnwagens. Gemiddeld werden er dus dagelijks ro mijnwagens per houwer geproduceerd (360: 6 gewerkte dagen x 6 houwers $=36$ ). Een houwer verdiende in dat geval dus 473 BEF per dag: (IOX3OBEF) + I73 BEF.

Uit het bovenstaande blijkt dat er ook na de Tweede Wereldoorlog nog behoorlijk wat verschillen tussen de Luikse mijnen bestonden wat de hoogte van de beloning en de beloningssystemen betreft. 
TABel B.6 DE GEMidDELdE NETTOLONEN PER DAG OF PER DiENST IN HET LUIKSE BEKKEN IN BEF, I904-I966

\begin{tabular}{|c|c|c|c|c|}
\hline jaar & houwers & ondergrondse arbeiders & bovengrondse arbeiders & samen \\
\hline 1904 & 5,00 & 4,33 & 2,93 & 3,97 \\
\hline 1905 & $5, \mathrm{I} 3$ & 4,49 & 2,96 & 4,09 \\
\hline 1906 & 5,86 & 5,04 & 3, OI & 4,51 \\
\hline 1907 & 6,35 & $5,5 \mathrm{I}$ & 3,30 & 4,95 \\
\hline 1908 & 6,03 & 5,26 & 3,29 & 4,75 \\
\hline I909 & 5,36 & 4,76 & 3,19 & 4,34 \\
\hline I9Io & 5,53 & 4,90 & 3,20 & 4,44 \\
\hline IgII & 5,50 & 4,85 & 3,24 & $4,4 \mathrm{I}$ \\
\hline 1912 & 6,02 & 5,25 & 3,33 & 4,74 \\
\hline 1913 & 6,68 & 5,79 & 3,62 & 5,22 \\
\hline I919 & $\mathrm{I} 6,26$ & 13,23 & 8,46 & $\mathrm{II}, 82$ \\
\hline 1920 & 29,20 & $24, \mathrm{I} 8$ & $\mathrm{I} 6,25$ & 21,90 \\
\hline I92I & 30,03 & 24,82 & 16,55 & 22,44 \\
\hline 1922 & 26,10 & 22,23 & $\mathrm{I} 4,69$ & I9,99 \\
\hline 1923 & 30,90 & 27,13 & 18,08 & 24,45 \\
\hline 1924 & 36,06 & $3 \mathrm{I}, 8 \mathrm{o}$ & 21,27 & 28,77 \\
\hline 1925 & $3 \mathrm{I}, 90$ & 28,32 & 19,68 & 25,74 \\
\hline 1926 & 37,75 & $33,5 \mathrm{I}$ & 22,88 & 30,35 \\
\hline 1927 & 50,49 & 44,13 & 30,21 & 40,15 \\
\hline 1928 & 50,36 & 44,58 & 30,83 & 40,63 \\
\hline 1929 & 57,55 & $52, \mathrm{I} 4$ & 36,65 & 47,58 \\
\hline 1930 & 6I,6I & $54,9 \mathrm{I}$ & 39,38 & 50,43 \\
\hline I93I & 52,47 & 46,45 & 33,49 & 42,75 \\
\hline 1932 & 44,99 & $39,7 \mathrm{I}$ & 28,88 & 36,56 \\
\hline 1933 & $43,6 \mathrm{I}$ & 38,36 & 28,15 & 35,44 \\
\hline 1934 & $42,8 \mathrm{I}$ & 38,94 & $28,2 \mathrm{I}$ & 35,13 \\
\hline 1935 & $4 \mathrm{I}, 95$ & 36,94 & 27,37 & $34, \mathrm{I} 4$ \\
\hline 1936 & 45,19 & 39,76 & $29,8 \mathrm{I}$ & 36,86 \\
\hline 1937 & 55,55 & 48,22 & 35,92 & 44,66 \\
\hline 1938 & 60,01 & $5 \mathrm{I}, 59$ & 37,90 & 47,72 \\
\hline 1939 & 59,85 & $5 \mathrm{I}, 50$ & 37,83 & 47,65 \\
\hline I945 & I 47,87 & $\mathrm{I} 25,79$ & $8 \mathrm{I}, 62$ & 107,75 \\
\hline 1946 & 195,99 & I62,25 & $107,4 \mathrm{I}$ & 140,76 \\
\hline I947 & $233, \mathrm{II}$ & 190,03 & 126,05 & I 68,56 \\
\hline 1949 & 267,88 & $22 \mathrm{I}, 62$ & $\mathrm{I} 50, \mathrm{I} 5$ & 200,40 \\
\hline 1950 & 275,80 & 228,20 & I 49,47 & 204,32 \\
\hline I95I & 295,62 & 242,07 & I59,I2 & 218,58 \\
\hline
\end{tabular}




\begin{tabular}{|c|c|c|c|c|}
\hline jaar & houwers & ondergrondse arbeiders & bovengrondse arbeiders & samen \\
\hline 1952 & 302,97 & 247,79 & 163,09 & 224,77 \\
\hline 1953 & 303,00 & 250,14 & $\mathrm{I} 64,85$ & 227,17 \\
\hline I954 & 308,40 & 252,09 & I6I,72 & 228,69 \\
\hline 1955 & 320,71 & $26 \mathrm{I}, 27$ & I66,97 & 237,35 \\
\hline 1956 & 369,96 & $301,5 \mathrm{I}$ & 193,58 & 274,07 \\
\hline I957 & $42 \mathrm{I}, 50$ & 338,54 & 217,30 & 308,66 \\
\hline 1958 & $4 \mathrm{I} 9, \mathrm{I} 2$ & 335,74 & 2I $8,0 \mathrm{I}$ & 307,92 \\
\hline 1959 & $4 \mathrm{I} 2,49$ & 332,51 & 215,49 & 302,46 \\
\hline I96o & $4 \mathrm{I} 3,9 \mathrm{I}$ & 334,29 & 219,08 & 302,92 \\
\hline I96I & 424,09 & 348,57 & 223,35 & $3 \mathrm{I} 2,4 \mathrm{O}$ \\
\hline 1962 & 476,69 & 386,25 & 252,87 & 347,97 \\
\hline 1963 & $5^{16,94}$ & $4 \mathrm{I} 2,9 \mathrm{I}$ & 274,34 & 374,03 \\
\hline 1964 & 546,07 & $43^{6}, 3^{2}$ & 301,87 & $400,9 \mathrm{I}$ \\
\hline 1965 & 597,53 & $48 \mathrm{I}, 5 \mathrm{I}$ & 317,58 & 437,77 \\
\hline I966 & 668,03 & 514,96 & 352,92 & $47 \mathrm{I}, 28$ \\
\hline
\end{tabular}

Bron: 'Economische Statistiek van de extractieve nijverheden en van de metaalnijverheid', Annales des Mines de Belgique, I903-1967. N.B.: Vóór de oorlogsjaren waren er geen cijfers beschikbaar, de periode 1945-1947 heeft alleen betrekking op de vrije arbeiders en niet de Duitse dwangarbeiders en vanaf 1967 worden er alleen nog brutolonen opgegeven. Het gaat hier om nominale lonen, er werd geen rekening gehouden met inflatie. 


\section{BIJLAGE 2}

\section{Overzicht van de mijnsluitingen in het Luikse bekken, 1903-1980}

\begin{tabular}{|c|c|c|}
\hline NV & Zetel & Einde productie \\
\hline Argenteau-Trembleur & Marie & I980 \\
\hline Hasard-Cheratte & Cheratte & I977 \\
\hline Cockerill & Colard & 1976 \\
\hline Espérance et Bonne Fortune & Saint-Nicolas & I974 \\
\hline Hasard & Micheroux $^{1}$ & 1974 \\
\hline Espérance et Bonne Fortune & Nouvelle Espérance & 1973 \\
\hline Grande Bacnure & Petite Bacnure & I97I \\
\hline Patience et Beaujonc & Bure aux femmes & I969 \\
\hline Wérister & José ${ }^{2}$ & I969 \\
\hline Hasard & Belle-Vue & I968 \\
\hline Wérister & Romsée & 1967 \\
\hline Bonnier & Péry & I967 \\
\hline Ans et Rocourt & Levant $^{3}$ & I966 \\
\hline Gosson-Kessales & Gosson I & I966 \\
\hline Bonne Espérance, Batterie, Bonne Fin et Violette & Batterie & 1965 \\
\hline Bonne Espérance, Batterie, Bonne Fin et Violette & Bonne-Fin ${ }^{4}$ & 1965 \\
\hline Moha & Moha & I964 \\
\hline Abhooz et Bonne-Foi-Hareng & Milmort & 1962 \\
\hline Espérance et Bonne Fortune & Bonne-Fortune & 1962 \\
\hline Bonne Espérance, Batterie, Bonne Fin et Violette & Nord5 & 1960 \\
\hline La Minerie & Battice & I96o \\
\hline Quatre-Jean de Retinne et Queue du Bois & Mairie & 1959 \\
\hline Bois d'Avroy & Val Benoît & 1959 \\
\hline Gosson-Kessales & Gosson $2^{6}$ & 1959 \\
\hline Bois de Micheroux & Théodore & 1958 \\
\hline Gosson-Kessales & Kessales & 1958 \\
\hline Gosson-Kessales & Grand Makets & 1958 \\
\hline Bonne Espérance, Batterie, Bonne Fin et Violette & Sainte Marguerite & 1958 \\
\hline Gosson-Kessales & Bon Buveur & 1956 \\
\hline Bonne Espérance, Batterie, Bonne Fin et Violette & Aumônier ${ }^{7}$ & 1956 \\
\hline Hasard & Fléron & 1955 \\
\hline Bonne Espérance, Batterie, Bonne Fin et Violette & Bonne Espérance & 1955 \\
\hline Ougrée-Marihaye & Nr. I (Ougrée) & 1955 \\
\hline Ougrée-Marihaye & Vieille Marihaye & 1954 \\
\hline Ougrée-Marihaye & Boverie & 1954 \\
\hline Grande Bacnure & Gérard Cloes & 1954 \\
\hline Ougrée-Marihaye & Many(-Flémalle) & 1953 \\
\hline La Meuse & Saint Honoré & 1952 \\
\hline Wérister & Xhawirs & 1952 \\
\hline Wérister & Vaux $^{8}$ & I95I \\
\hline
\end{tabular}




\begin{tabular}{|c|c|c|}
\hline NV & Zetel & Einde productie \\
\hline Wérister & Beyne-Homvent & I95I \\
\hline Abhooz et Bonne-Foi-Hareng & Abhooz & I95I \\
\hline Kessales et Concorde & Xhorré & I950 \\
\hline Gives et Ben & Saint Paul & I950 \\
\hline Espérance et Envoz & Lamalle & I950 \\
\hline Bois d'Avroy & Grand Bac & I949 \\
\hline Bois d'Avroy & Perron(-Bois d'Avroy) & I949 \\
\hline Arbre Saint-Michel & Halette & I949 \\
\hline Six Bonniers & Nouveau Siège & I948 \\
\hline Arbre Saint-Michel & Galerie de la Bougerie & 1948 \\
\hline Arbre Saint-Michel & Cowa & I948 \\
\hline La Meuse & Saint Lambert & I948 \\
\hline Gives et Ben & Galerie de Ben & I944 \\
\hline Arbre Saint Michel & Galerie des Awirs ${ }^{9}$ & I944 \\
\hline La Meuse & Paix Dieu & I943 \\
\hline Patience et Beaujonc & Fanny & 1940 \\
\hline Bois d'Avroy & Bois d'Avroy ${ }^{\mathrm{Io}}$ & 1938 \\
\hline Gives & Saint Paul ${ }^{\mathrm{II}}$ & 1937 \\
\hline Kessales et Concorde & Champs d'Oiseaux & 1935 \\
\hline Ougrée-Marihaye & Flémalle & I935 \\
\hline Bonne-Fin & Bâneux & I935 \\
\hline La Haye & Laveu & I934 \\
\hline Bonne-Fin, Baneux et Batterie & Sainte Barbe & I934 \\
\hline Bonne Espérance, Batterie et Violette & Violette & I934 \\
\hline Horloz & Horloz $^{12}$ & I933 \\
\hline Gosson-La Haye et Horloz & Saint Gilles & I933 \\
\hline Ougrée-Marihaye & Fanny & I933 \\
\hline Gives & Galerie du Fond Gorgin & 1932 \\
\hline Gives & Sainte Barbe & 1932 \\
\hline Gives & Henri & I932 \\
\hline Wérister & Rancy $^{13}$ & 1932 \\
\hline Kessales et Concorde & Corbeau & I93I \\
\hline Hasard & Maireux & I93I \\
\hline Hasard & Bas-Boix & I93I \\
\hline La Meuse & Bellevue & I93I \\
\hline La Haye & Piron & 1930 \\
\hline Horloz & Braconier & 1930 \\
\hline Pays de Liège & Horion & 1929 \\
\hline Kessales & Artistes & 1928 \\
\hline Lonette & Retinne & 1928 \\
\hline Nouvelle Montagne & Héna & I924 \\
\hline Nouvelle Montagne & Tincelle & I924 \\
\hline
\end{tabular}




\begin{tabular}{|c|c|c|}
\hline NV & Zetel & Einde productie \\
\hline Espérance et Envoz & Galerie du Bois de Champia & I922 \\
\hline Andenne & Galerie de Java ${ }^{14}$ & I922 \\
\hline Patience et Beaujonc & Beaujonc & I92I \\
\hline Wérister & François & I920 \\
\hline Oupeye & Pieter & I9I4 \\
\hline Wérister & Onhons Saint Léonard & I9I3 \\
\hline Maireux et Bas-Bois & Guillaume & 1913 \\
\hline Ans et Rocourt & (Puits de) Rocourt & 1912 \\
\hline Nouvelle Montagne & Galerie de la Mallieue & I9I2 \\
\hline Est d'Andenne & Galerie de Ben & I9II \\
\hline Angleur & Aguesses & IgII \\
\hline Cowette-Rufin, Grand-Henri & Gueldre & I9Io \\
\hline Cockerill & Marie & I9Io \\
\hline Est de Liège & Bois de Breux & 1908 \\
\hline Joli-Fonds & Malsemaine & I907 \\
\hline Ougrée-Marihaye & Nr. I & 1903 \\
\hline Maireux et Bas-Bois & Avalaresse à la gare & 1903 \\
\hline
\end{tabular}

Bron: Annales des Mines de Belgique, I900-I979.

N.B.: Dit zijn de sluitingen zoals ze werden opgenomen in de Annalen. Sommige zetels gaan na een onderbreking toch terug in productie, al dan niet onder een andere naam.

\section{Noten bij tabel bijlage 2}

I Eerder bekend als Grand bure.

2 Eerder bekend als Halles.

3 Eerder bekend als Bure du Levant.

4 Eerder bekend als Aumônier.

5 Ook bekend als Wandre.

6 Ten gevolge van een fusie tussen zetel Gosson 1 en Gosson 2.

7 Ging later opnieuw in productie onder de naam Bonne-Fin.

8 Eerder bekend als Soxhluse.

9 Ook bekend als Galerie Paire centrale.

ro Fusie met zetel Perron in 1938.

II Gaat in I944 opnieuw kortstondig in productie (tot I950).

12 Ook bekend als Tilleur, gaat weer in productie van I935-I952.

I3 Voorheen bekend als Basse Rancy.

I4 Nadien nog even kortstondig in productie van I946-I947. 
BIJLAGE 3

Overzicht van de soorten ontgonnen steenkool in het Luikse bekken in I93I

\begin{tabular}{|c|c|}
\hline Anthracite (4-8\% Matières Volatiles) & Demi-gras (13-18\% M.V.) \\
\hline Abhooz et Bonne-Foi Hareng & Grande Bacnure \\
\hline Argenteau-Trembleur & Basse Ransy \\
\hline Bonne-Espérance, Batterie et Violette & Bois d'Avroy \\
\hline Espérance et Bonne Fortune & Bois de Micheroux \\
\hline Réunis de la Minerie & Bonne Fin \\
\hline Anthraciteux et maigres (8-II\% M.V.) & Cockerill \\
\hline Ans et Rocourt & Espérance et Bonne Fortune \\
\hline Grande Bacnure & Canal de Fond-Piquette \\
\hline Belle Vue et Bien Venue & Gosson Lagasse \\
\hline Bonne-Espérance, Batterie et Violette & Hasard \\
\hline Bonne Fin & Horloz \\
\hline Bonnier & Kessales et Concorde réunis \\
\hline Espérance et Bonne Fortune & La Haye \\
\hline Gosson Lagasse & Ougrée-Marihaye \\
\hline Hasard & Patience et Beaujonc \\
\hline Herve-Wergifosse & Quatre-Jean \\
\hline Meuse & Six-Bonniers \\
\hline Patience et Beaujonc & Wérister \\
\hline Pays de Liège & Charbons gras à vapeur (18-26\% M.V.) \\
\hline Quart-gras (II-I3\% M.V.) & Horloz \\
\hline Arbre Saint-Michel & Ougrée-Marihaye \\
\hline Basse Ransy & Pays de Liège \\
\hline Bonne-Espérance, Batterie et Violette & Charbons à coke \\
\hline Bonnier & Horloz \\
\hline Espérance et Bonne Fortune & Ougrée-Marihaye \\
\hline Gosson Lagasse & Pays de Liège \\
\hline \multicolumn{2}{|l|}{ Herve-Wergifosse } \\
\hline \multicolumn{2}{|l|}{ Maireux et Bas-Bois } \\
\hline Patience et Beaujonc & \\
\hline
\end{tabular}

Bron: Atlas Châtel et Dollfus. 


\section{BIJLAGE 4}

\section{De Luikse regio in 1947}

In een aantal studies op basis van de volkstelling van 1947 en I96r werden de resultaten geanalyseerd voor de gemeenten behorend tot de 'Luikse regio' ${ }^{25}$ Deze regio omvat 65 gemeenten en vormde het industriële zwaartepunt van de provincie Luik (zie het overzicht hieronder). Deze gemeenten vormden in 1947 ca. 53 procent van de totale bevolking in de Luikse provincie om tegen I 96 I ca. 55 procent van de provinciale bevolking uit te maken. Dit onderscheid tussen regio en provincie werd gemaakt omdat de provincie Luik ook een aantal meer rurale en bosgebieden omvat, zoals het arrondissement Waremme/Borgworm en het oostelijk deel van het arrondissement Verviers (Hoge Venen). De Luikse industriële regio werd gedefinieerd als alle $6_{5}$ gemeenten waarin het aandeel van de actieve bevolking in de landbouw minder dan ro procent bedraagt, maar waarbij de dichtheid van de actieve bevolking meer dan Ioo per vierkante kilometer bedraagt. Bovendien moeten in deze gemeenten, de typische industriële activiteiten in de Luikse regio: mijnbouw, metallurgie, chemische industrie, glasnijverheid en klein metaal, minstens 50 procent van de totale industriële arbeidskracht tewerkstellen.

\section{Gemeenten behorende tot de Luikse regio}

\begin{tabular}{|l|l|l|}
\hline Alleur & Gleixhe & Ougrée \\
\hline Angleur & Grâce-Berleur & Oupeye \\
\hline Ans & Grivegnée & Queue-du-Bois \\
\hline Argenteau-Trembleur & Haccourt & Ramet-Ivoz \\
\hline Awans & Hermalle & Retinne \\
\hline Ayeneux & Hermée & Richelle \\
\hline Bellaire & Herstal & Rocourt \\
\hline Beyne-Heusay & Heure-le-Romain & Romsée \\
\hline Bierset & Hollogne-aux-Pierres & Saint Georges \\
\hline Boncelles & Horion-Hozémont & Saint-Nicolas \\
\hline Bressoux & Jemeppe & Seraing \\
\hline Chaudfontaine & Jupille & Soumagne \\
\hline Chênée & Les Awirs & Tilff \\
\hline Cheratte & Liège & Tilleur \\
\hline chokier & Lixhe & Vaux-sous-Chèvremont \\
\hline Embourg & Loncin & Velroux \\
\hline Engis & Magnée & Visé \\
\hline Flémalle-Grande & Micheroux & Vivegnis \\
\hline Flémalle-Haute & Milmort & Voroux-Goreux \\
\hline Fléron & Mons-lez-Liège & Vottem \\
\hline Forêt & Montegnée & Wandre \\
\hline Glain & Mouland & \\
\hline & & \\
\hline
\end{tabular}




\section{BIJLAGE 5}

De belangrijkste mijnwerkersgemeenten in de provincie Luik (naar het aantal inwonende mijnwerkers op totale bevolking), rgı

\begin{tabular}{|c|c|c|c|}
\hline gemeente & mijnwerkers & totale bevolking & $\%$ \\
\hline Alleur & I96 & I.934 & IO,I $3 \%$ \\
\hline Ans & $\mathrm{I} .258$ & 10.482 & $\mathrm{I} 2,00 \%$ \\
\hline Awirs & $27 \mathrm{I}$ & 2.223 & $\mathrm{I} 2, \mathrm{I} 9 \%$ \\
\hline Ayeneux & 243 & $\mathrm{I} .402$ & $17,33 \%$ \\
\hline Beyne-Heusay & 920 & $4.70 I$ & $\mathrm{I} 9,57 \%$ \\
\hline Flémalle-Grande & $\mathrm{I} .035$ & 5.123 & $20,20 \%$ \\
\hline Flémalle-Haute & 629 & 4.831 & $\mathrm{I} 3,02 \%$ \\
\hline Fléron & $44^{2}$ & 2.909 & $15,19 \%$ \\
\hline Glain & 554 & 2.900 & $19,10 \%$ \\
\hline Grâce-Berleur & $\mathrm{I} .269$ & $5 \cdot 720$ & $22,19 \%$ \\
\hline Hollogne-aux-Pierres & $55^{6}$ & $5 \cdot 4 \mathrm{I} 2$ & I0, $27 \%$ \\
\hline Horion-Hozémont & 430 & 4.004 & IO, $74 \%$ \\
\hline Jemeppe & I.699 & II. $85 \mathrm{I}$ & $\mathrm{I} 4,34 \%$ \\
\hline Melen & 226 & $\mathrm{I} .474$ & $15,33 \%$ \\
\hline Micheroux & 165 & 670 & $24,63 \%$ \\
\hline Milmort & $2 \mathrm{I} 4$ & I. 658 & $\mathrm{I} 2,9 \mathrm{I} \%$ \\
\hline Mons & 574 & 4.298 & $13,36 \%$ \\
\hline Montegnée & I.935 & $9 \cdot 492$ & $20,39 \%$ \\
\hline Oupeye & 209 & I. 575 & $\mathrm{I} 3,27 \%$ \\
\hline Queue-du-Bois & 480 & I.904 & $25,2 \mathrm{I} \%$ \\
\hline Retinne & 344 & $\mathrm{I} .775$ & $19,38 \%$ \\
\hline Romsée & 462 & $2.59 \mathrm{I}$ & $17,83 \%$ \\
\hline Saint-Nicolas & $2.2 \mathrm{II}$ & 8.935 & $24,75 \%$ \\
\hline Seraing & 4.130 & 41.015 & I0,07\% \\
\hline Soumagne & 995 & 4.669 & $21,31 \%$ \\
\hline Tilleur & I.I 58 & $6.75^{\circ}$ & $\mathrm{I} 7, \mathrm{I} 6 \%$ \\
\hline Vivegnis & 290 & 2.300 & $\mathrm{I} 2,6 \mathrm{I} \%$ \\
\hline Vottem & 575 & 4.248 & I $3,54 \%$ \\
\hline Xhendelesse & Io6 & 978 & Iо, $84 \%$ \\
\hline
\end{tabular}

Bron: Recensement de l'industrie et du Commerce (31 décembre 1910). 


\section{BIJLAGE 6}

\section{De werkboekjes als bron voor vrouwenarbeid in de Luikse mijnen}

In hoofdstuk 2 werden de werkboekjes gebruikt als bron om licht te werpen op het weinig bekend fenomeen van 'mijnwerksters'. In de regel werden de boekjes bewaard door de laatste werkgever, die ze dan op zijn beurt doorspeelde aan de Pensioenkas. ${ }^{26}$ Het Centre Liégeois d'Archives et de Documentation de l'Industrie Charbonnière (CLADIC) beschikt over een grote verzameling van deze werkboekjes. Zij zijn daar alfabetisch geordend en worden momenteel ingevoerd in een database. ${ }^{27}$ Ten tijde van dit onderzoek was het mogelijk alle werkboekjes van personen waarvan de achternaam begint met een a, b of c (circa 9.000 boekjes) op te zoeken in de database. In de database wordt geen onderscheid gemaakt naar geslacht. Wel worden vermeld: naam, voornaam, geboorteplaats en -datum en datum van uitgave (redactiedatum) van het werkboekje. Voor de steekproef werd eerst in de database een selectie gemaakt naar redactiedatum. Aangezien de wet van het verbod op de ondergrondse arbeid voor vrouwen (en kinderen) onder de $2 \mathrm{I}$ jaar in de loop van I892 inging, werden alle werkboekjes met een redactiedatum vóór of gedurende het jaar 1892 geselecteerd. Dit leverde circa I.500 livrets op. In decennium I88I-I89o werkten er gemiddeld 25.000 mijnwerkers in het Luikse bekken. ${ }^{28}$ Dat is ruim I5 keer zo veel. Alhoewel het in deze selecte steekproef slechts om de drie beginletters gaat, lijkt het alsof er wel erg veel werkboekjes in de loop van de tijd verloren zijn gegaan. Dit doet enigszins twijfelen aan de representativiteit van deze bron.

Uit deze I.50o werkboekjes werden vervolgens alle vrouwen(namen) geselecteerd. Op die manier bleven er I2I werkboekjes over. Deze werden stuk voor stuk nagekeken op hun bruikbaarheid voor het onderzoek (sommige boekjes bleken toch te behoren bij mannen en één boekje had een redactiedatum na I892). Uiteindelijk werden de gegevens van ro7 boekjes integraal ingevoerd in een database. Dit komt neer op circa 7,2 procent vrouwelijke mijnarbeiders. Het aandeel van vrouwen in de Luikse mijnarbeid gedurende de negentiende eeuw varieerde van iets meer dan I 3 procent in I 846 naar minder dan 8 procent in 188 o tot 6, I procent in 1896 , toen het verbod op ondergrondse mijnarbeid voor vrouwen onder de 2I jaar reeds een aantal jaren van kracht was. Het percentage vrouwen in de selecte steekproef is hiermee vergelijkbaar. René Leboutte vond in zijn steekproef van I.I7o werkboekjes slechts 2 vrouwen terug en wijt dit aan het verbod op ondergrondse vrouwenarbeid vanaf I889 (sic). Waar de oorzaak van dit verschil zit, is moeilijk te achterhalen, aangezien niet nader te bepalen viel uit welke collectie werkboekjes René Leboutte zijn steekproef haalde. ${ }^{29}$

Het oudste werkboekje uit de selecte steekproef werd aangemaakt in I 828 en het jongste heeft als redactiedatum 4 augustus I892. De meeste werkboekjes dateren uit de periode I880-I892, namelijk 73. Opvallend is dat het merendeel van de werkboekjes (69) uit de selecte steekproef werden aangemaakt onder de wet van 1883 , toen de werkboekjes facultatief werden. In de steenkoolnijverheid had dit facultatieve karakter echter weinig te betekenen en bleven de werkgevers een werkboekje eisen. Zijn oudere boekjes meer verloren gegaan of heeft dit te maken met een stijging van de vrouwelijke arbeidskrachten? Na I883 werd de informatie in de werkboekjes ook uniformer, wat de verwerking in een database eenvoudiger maakt. ${ }^{\circ}$

Volgens Bart Delbroek kan door het facultatieve karakter van de werkboekjes sinds 1883 nooit de

26 Delbroek, 'Werkboekjes in de $20^{\mathrm{e}}$ eeuw', 7-27.

27 http://www.blegnymine.be/Cladic/CLADIC.htm

28 Leboutte en Delrée, 'L'archéologie industrielle', 36-67.

29 Leboutte, Le livret d'ouvrier dans la province de Liège, 4I-42. De steekproef waarvan hier sprake is, werd genomen op basis van een collectie werkboekjes uit de Pensioenkas (Iо.0oo). Het is mogelijk dat er later nog andere werkboekjes bij deze collectie werden gevoegd, al dan niet voordat ze werden gedoneerd aan het CLADIC.

30 Leboutte, Le livret d'ouvrier dans la province de Liège, 35 . 
Voorbeeld van een Livret d'ouvrier (werkboekje) met persoonsinformatie. Bron: Livret de travail van Joséphine Drapier, 1880. Fonds Institut liégeois d'histoire sociale. Coll. Blegny-Mine.
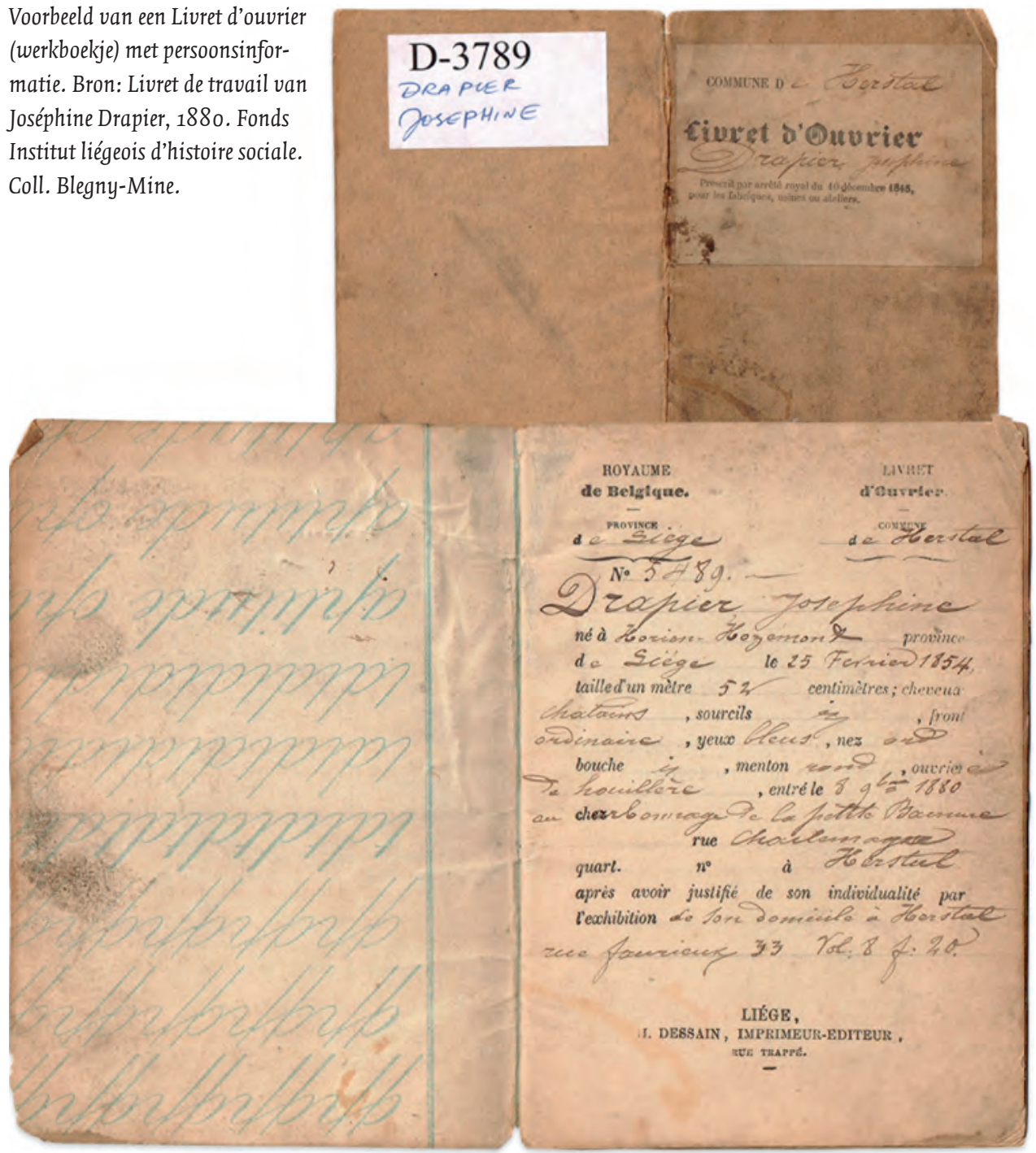

volledige loopbaan van arbeiders/sters worden onderzocht. ${ }^{31}$ Uit zijn onderzoek bleek dat er vaak grote lacunes waren tussen twee inschrijvingen en dat niet zomaar kan worden aangenomen dat dit om langdurige werkloosheid gaat. Kleinere bedrijven, individuele werkgevers of andere economische sectoren hanteerden het werkboekje misschien niet langer. Dit probleem stelt zich eveneens in onze selecte steekproef. Bovendien wijst Delbroek erop dat het beroep slechts eenmalig, bij de aanvraag van het werkboekje, wordt vermeld. Dat is in de meeste gevallen ook het geval bij 'onze' werkboekjes.

Een andere belangrijke tekortkoming van de werkboekjes is dat er weinig of nooit werd aangeduid of een vrouw ondergronds of bovengronds werkte. Tegen het einde van de negentiende eeuw vinden we wel enkele stempels terug met de naam van de NV, de betreffende zetel en een aanduiding fond of surface, maar zeker niet alle werkgevers deden dit consequent. Misschien werkten alleen de grotere be- 


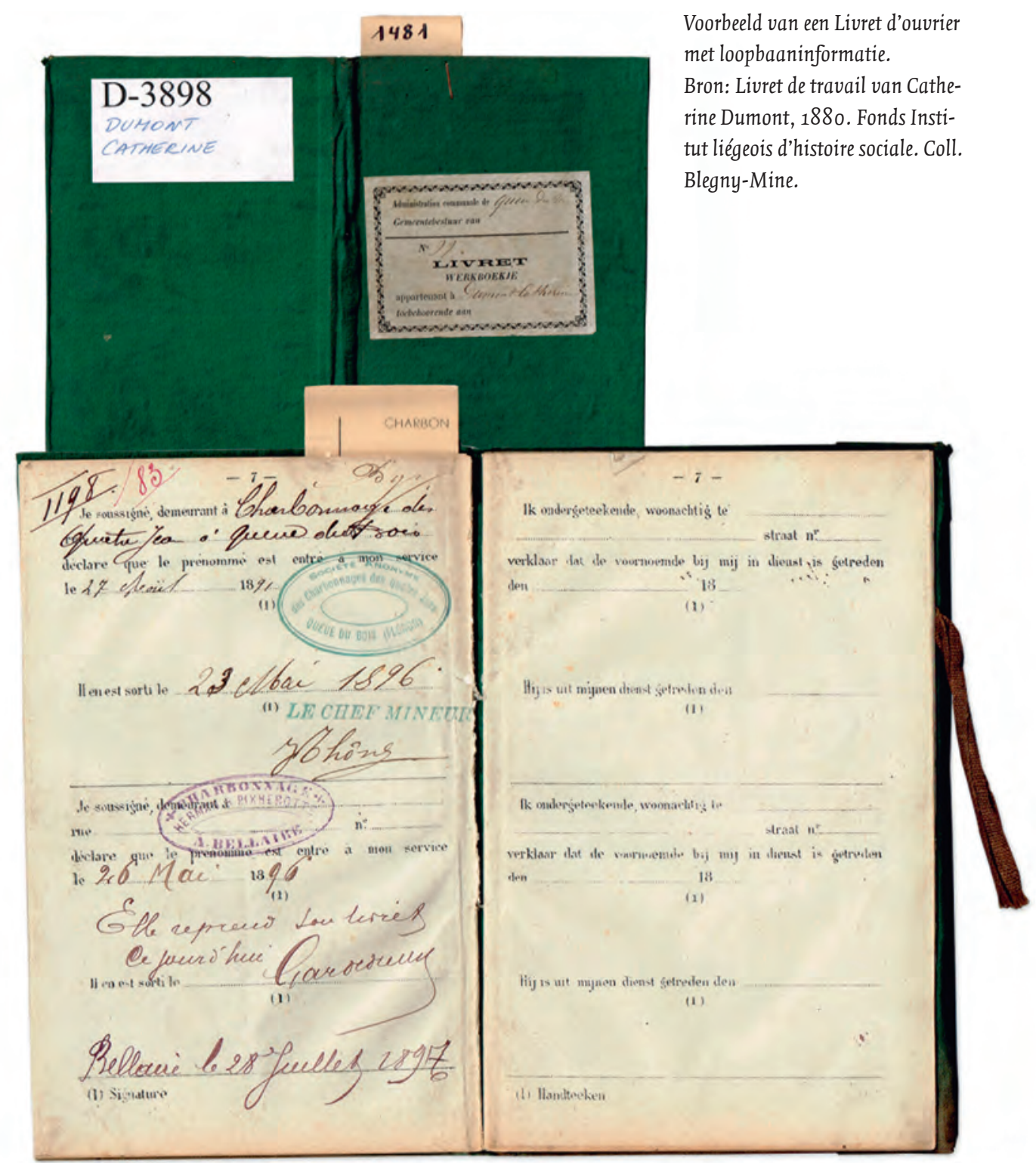

drijven met stempels. De vraag is of het vooral de grote of juist de kleine bedrijven waren die vrouwen aanwierven. Indien een aanwijzing werd teruggevonden, werd dit uiteraard in de database verwerkt, maar de groep vrouwen waarbij niets werd aangeduid is erg groot. De beroepsaanduiding kan hierover misschien iets meer duidelijkheid geven. Sommige vrouwen werden aangeduid met journalière terwijl anderen expliciet de functieomschrijving ouvrière (de) houillère meekregen. Of dit iets zegt over ondergronds of bovengronds werk is niet duidelijk. Mogelijk zouden andere bronnen zoals personeelsregisters uit bedrijfsarchieven aanvullende informatie kunnen geven, maar in het kader van dit onderzoek was het niet mogelijk deze te raadplegen. Opvallend is wel dat in geen enkel werkboekje de term hiercheuse terug te vinden is, nochtans de eigentijdse benaming voor mijnwerkster. In de industrietellingen van 1896 vinden we deze aanduiding wel terug. 


\section{BIJLAGE 7}

Gegevens over de in- en uitstroom van Belgische en buitenlandse mijnwerkers per jaar, 1947-1972

TABEL B.7 DE IN KOMEN DE EN UITGAAN DE BELGEN PER JAAR, I947-I972

\begin{tabular}{|c|c|c|c|c|c|}
\hline jaar & instroom & uitstroom & arbeidsverloop & $\begin{array}{r}\text { totaal aantal } \\
\text { einde van het jaar }\end{array}$ & relatief arbeidsverloop \\
\hline I947 & $5 \cdot 140$ & 5.158 & I0.298 & 17.067 & $30,17 \%$ \\
\hline I948 & 4.785 & 4.974 & 9.759 & I6.806 & $29,03 \%$ \\
\hline I949 & $\bullet$ & $\cdot$ & $\cdot$ & I6.636 & \\
\hline 1950 & 5.406 & $5 \cdot 579$ & 10.985 & I6.057 & $34,21 \%$ \\
\hline I95I & 5.026 & 6.189 & II.2I5 & I4.990 & $37,41 \%$ \\
\hline 1952 & $4 \cdot 340$ & 4.798 & 9.138 & I4.564 & $31,37 \%$ \\
\hline I953 & 4.837 & 5.126 & 9.963 & I4.293 & $34,85 \%$ \\
\hline I954 & 5.866 & 5.998 & II. 864 & $\mathrm{I} 4 . \mathrm{I} 4 \mathrm{O}$ & $4 \mathrm{I}, 95 \%$ \\
\hline 1955 & 4.757 & $5 \cdot 42 \mathrm{I}$ & I0.178 & 13.185 & $38,60 \%$ \\
\hline 1956 & 3.787 & 4.762 & 8.549 & I2.22I & $34,98 \%$ \\
\hline 1957 & 2.942 & 3.463 & 6.405 & II. 684 & $27,4 \mathrm{I} \%$ \\
\hline 1958 & I. 976 & 2.928 & 4.904 & 10.8I2 & $22,68 \%$ \\
\hline 1959 & I. 592 & 3.238 & 4.830 & 9.175 & $26,32 \%$ \\
\hline 1960 & I. 378 & 3.125 & 4.503 & $7 \cdot 423$ & $30,33 \%$ \\
\hline I96I & I. 447 & 2.318 & 3.765 & 6.675 & $28,20 \%$ \\
\hline 1962 & I. 354 & 2.030 & $3 \cdot 384$ & 5.901 & $28,67 \%$ \\
\hline 1963 & I. 298 & I. 572 & 2.870 & 5.657 & $25,37 \%$ \\
\hline I964 & 870 & I. 350 & 2.220 & $5 \cdot 137$ & $2 \mathrm{I}, 6 \mathrm{I} \%$ \\
\hline 1965 & 595 & I. 625 & 2.220 & 4.026 & $27,57 \%$ \\
\hline I966 & 448 & I.I82 & I.630 & 3.282 & $24,83 \%$ \\
\hline I967 & 354 & 788 & I.I42 & 2.776 & $20,57 \%$ \\
\hline I968 & 223 & 593 & $8 \mathrm{I} 6$ & 2.436 & I6,75\% \\
\hline I969 & 276 & 726 & 1.002 & I. 788 & $28,02 \%$ \\
\hline I970 & 212 & $55^{\circ}$ & 762 & I. 657 & $22,99 \%$ \\
\hline I97I & I35 & $4 \mathrm{I} 2$ & 547 & I. 367 & $20,01 \%$ \\
\hline 1972 & 68 & 247 & 315 & I. 217 & $\mathrm{I} 2,94 \%$ \\
\hline
\end{tabular}

Bron: RAH, archief FEDECHAR, inv.nr. 6I4 en inv.nrs. 1579-158I: 'Personeelsstatistieken', Annales des Mines de Belgique, I948-I974. 
TABEl B.8 De IN KOMEN DE EN UITGAAN DE BUITEN LAN DERS PER JAAR, I947-I972

\begin{tabular}{|c|c|c|c|c|c|}
\hline jaar & instroom & uitstroom & arbeidsverloop & $\begin{array}{r}\text { totaal aantal } \\
\text { einde van het jaar }\end{array}$ & relatief arbeidsverloop \\
\hline 1947 & 15.152 & 13.105 & 28.257 & $\mathrm{I} 4.843$ & $95, \mathrm{I} 9 \%$ \\
\hline 1948 & $\mathrm{I} 2.758$ & II.08I & 23.839 & 16.509 & $72,20 \%$ \\
\hline I949 & • & • & $\cdot$ & $\mathrm{I} 4.520$ & \\
\hline 1950 & 8.406 & 9.200 & 17.606 & I3.667 & $64,41 \%$ \\
\hline I95I & I4.294 & II.Ig6 & 25.490 & I6.74I & $76,13 \%$ \\
\hline 1952 & I2.IOI & $\mathrm{I} 2.058$ & 24.159 & I6.747 & $72,13 \%$ \\
\hline 1953 & 10.823 & II.59I & 22.414 & I5.975 & $70,15 \%$ \\
\hline 1954 & 8.996 & I0.22I & 19.217 & $\mathrm{I} 4.746$ & $65,16 \%$ \\
\hline 1955 & 9.855 & 8.894 & I8.749 & 15.537 & $60,34 \%$ \\
\hline 1956 & 9.797 & I0.37I & 20.168 & I4.964 & $67,39 \%$ \\
\hline 1957 & I0.243 & $8.9 I I$ & I9.154 & I6.297 & $58,77 \%$ \\
\hline 1958 & 4.565 & 6.024 & 10.589 & I4.853 & $35,65 \%$ \\
\hline 1959 & 4.175 & 6.295 & 10.470 & $\mathrm{I} 2.722$ & $4 \mathrm{I}, \mathrm{I} 5 \%$ \\
\hline 1960 & 3.497 & 5.652 & 9.149 & 10.539 & $43,41 \%$ \\
\hline I96I & 3.140 & 4.252 & 7.392 & $9 \cdot 442$ & $39,14 \%$ \\
\hline 1962 & 5.058 & 4.943 & I0.00I & 9.534 & $52,45 \%$ \\
\hline 1963 & 5.947 & $5 \cdot 375$ & II.322 & I0.126 & $55,91 \%$ \\
\hline 1964 & 5.569 & 4.686 & I0.255 & 10.939 & $46,87 \%$ \\
\hline 1965 & 3.358 & 5.537 & 8.895 & 8.685 & $5 \mathrm{I}, 2 \mathrm{I} \%$ \\
\hline I966 & 2.256 & 4.036 & 6.292 & $6.84 \mathrm{I}$ & $45,99 \%$ \\
\hline 1967 & $\mathrm{I} .520$ & $2.43 \mathrm{I}$ & $3.95 \mathrm{I}$ & 5.757 & $34,31 \%$ \\
\hline I968 & 922 & I. 623 & 2.545 & 5.049 & $25,20 \%$ \\
\hline I969 & 856 & I.666 & 2.522 & 3.929 & $32,09 \%$ \\
\hline 1970 & 713 & I.I85 & г.898 & 3.699 & $25,66 \%$ \\
\hline I97I & 726 & I.I80 & I.906 & 3.182 & $29,95 \%$ \\
\hline 1972 & 289 & 547 & 836 & 2.993 & $13,97 \%$ \\
\hline
\end{tabular}

Bron: RAH, archief FEDECHAR, inv.nr. 6r4 en inv.nrs. I579-I58I: 'Personeelsstatistieken', Annales des Mines de Belgique, I948-1974. 


\section{BIJLAGE 8}

\section{De administratie van het Fonds National de Retraite des Ouvriers Mineurs (FNROM) I Nationaal Pensioenfonds voor Mijnwerkers (NPM) als bron}

\section{Historisch overzicht van de sociale verzekering voor mijnwerkers}

Het Fonds National de Retraite des Ouvriers Mineurs (FNrOM) of het Nationaal Pensioenfonds voor Mijnwerkers (NPM) werd gecreëerd door de wet van 20 augustus $1920 .{ }^{32}$ Het was een publieke instelling, afhankelijk van het Ministerie van Arbeid en Sociale Voorzorg, en had als functie het overschot aan inkomsten uit sommige Regionale Voorzorgskassen te gebruiken om de tekorten bij andere Regionale Voorzorgskassen aan te vullen en om verder de voorziene voordelen uit te keren aan de mijnwerkers.

Deze voorzorgskassen bestonden reeds sinds 1839, ten gevolge van de grote mijnramp te Seraing in de mijn Espérance in 1838 . De Belgische overheid installeerde toen, op aandringen van de directeur van l'Administration des Mines, regionale voorzorgskassen. Tussen I839 en I844 werden ze overal in België ingericht en ze zorgden ervoor dat geblesseerde of gewonde mijnwerkers hulp kregen en dat de invaliden een pensioen ontvingen. Ook kregen de nabestaanden van omgekomen mijnwerkers een vergoeding. Sinds I8o7 bestonden er wel enkele hulpkassen, opgericht door de mijnondernemingen, maar hun steun bleef miniem en sporadisch. Vaker was het geval dat er na een mijnramp geld ingezameld werd om een (tijdelijk) hulpfonds in te richten. Ook ten tijde van de Voorzorgskassen was dit het geval. Aangezien zij geen rechtspersoonlijkheid bezaten konden ze niet optreden om onwillige mijnuitbaters te verplichten hun verbintenissen na te komen. Dit veranderde met de wet van 28 maart I 868 die de Voorzorgskassen als instellingen van Openbaar Nut erkende, zodat ze dus rechtspersoonlijkheid verwierven. Ook voorzag de regering erin dat de mijnuitbaters verplicht werd hun exploitatie bij een Voorzorgfonds aan te sluiten. Deze hervorming elimineerde echter niet alle nadelen: het regionalisme bleef in de organisatie van de Voorzorgskassen en de ongelijkheid in behandeling van de verzekerden bleef. Een Koninklijk Besluit van I7 augustus I874 regelde deze kwestie door de Voorzorgskassen onder de voogdij van de Staat te plaatsen: de Bestendige commissie der Voorzorgskassen. De Voorzorgskassen werden gefinancierd door bijdragen van de arbeiders, de werkgevers, de overheid en liefdadigheid. Door de wetten van ro mei rgoo op de ouderdomspensioenen en van 24 december I903 op de arbeidsongevallen werden de Voorzorgskassen alleen bevoegd op het gebied van ouderdomspensioenen. Dit systeem van Voorzorg bleef vrijwillig tot de wet van 5 juni IgII, die de verzekering verplicht stelde en aan de Voorzorgskassen eenzelfde bevoegdheid toekende als aan de erkende mutualiteiten. Oorspronkelijk waren er vijf Voorzorgskassen: Mons, Centre, Charleroi, Namur en Liège. Later kwam daar de Kempen bij; die Voorzorgskas werd goedgekeurd bij Koninklijk Besluit van 2I december I9I2.

Er was een fundamentele ongelijkheid tussen de oude mijnbekkens en de pas opgerichte Voorzorgskas van de Kempen. Daar waar de eersten veel gepensioneerde mijnwerkers ten laste hadden, genoot de Voorzorgskas van de Kempen het voordeel van de jonge bijdragebetalers zonder pensioengerechtigden. Om die reden werd een gemeenschappelijk reservefonds opgericht: het FNROM of NPM. De wet van 9 april 1922 zorgde ervoor dat het FNROM rechtspersoonlijkheid kreeg en voegde aan het bijzonder stelsel der mijnwerkers een nieuw verzekeringsdomein toe: de ziekte-invaliditeit. Een invaliditeitstoelage werd toegekend aan arbeiders die ten minste 20 jaar dienst hadden, die volledig werkonbekwaam en in nood waren. Ook het principe van de overlevingsverzekering werd ingevoerd: een overlevingspensioen werd toegekend aan de weduwen die op het moment van het overlijden van de man de pensioengerechtigde ouderdom nog niet hadden bereikt. De grote hervorming van een regionale naar een unitaire organisatie kwam er met de wet van 30 december I924. Het FNROM 
absorbeerde toen alle bestaande instellingen en de grondslagen van de ouderdoms-, invaliditeits- en overlevingsverzekering werden vastgelegd. Grotere voordelen werden toegekend aan de ondergrondse mijnwerkers en een wezentoelage werd ingevoerd. De tussenkomst van de staat in de samenstelling van de pensioenen werd belangrijker. Dit manifesteerde zich door de toekenning van toeslagen en verhogingen aan de gepensioneerden zelf en door de toekenning van subsidies aan de verzekeringsinstellingen. ${ }^{33}$

Na de Tweede Wereldoorlog volgde dan de besluitwet van ro januari 1945, die de beginselen van de maatschappelijke zekerheid der mijnwerkers en daaraan gelijkgestelden bepaalde. Hierdoor werden de ouderdomspensioenen op een behoorlijk bedrag gehandhaafd of daartoe gebracht, het stelsel van verplichte verzekering tegen ziekte of invaliditeit werd verbeterd, er werd voorzien in steun aan werklozen, kinderbijslagen werden verhoogd en de betaling van de lonen, met de daarbij horende jaarlijkse vakantietoeslagen werd verzekerd. Om dit doel te bereiken werden de aan het FNROM te storten bijdragen, die II procent van de lonen bedroegen en alleen de invaliditeits-, ouderdoms- en overlijdensrisico's dekten, op 25,5 procent van de lonen gebracht; 17,5 procent kwam ten laste van de werkgever en 8 procent ten laste van de arbeider. In een besluitwet van 2I september 1945 werden dan nog dezelfde voordelen gewaarborgd aan arbeiders van vreemde nationaliteiten als aan de Belgische mijnwerkers. ${ }^{34}$

De wet van 28 april 1958 legde min of meer de definitieve vorm van het FNROM/NPM vast. Ook legde zij de financiering van het nieuwe rust- en overlevingsstelsel vast. Deze gebeurde enerzijds door de verhoging van I, 5 procent (evenredig verdeeld over mijnwerker en werkgever) van de sociale bijdragen betreffende de ouderdomsverzekering en anderzijds door een vaste Rijkstoelage die jaarlijks aan het FNROM gestort werd. 35

Het FNROM/NPM bestond uit een beheerscomité en vier verschillende bestuurscommissies, overeenkomstig de Voorzorgskassen van Bergen/Mons, Charleroi, Luik en de Kempen. Eveneens was er een directie met daarin het Algemeen Bestuur, het Hoofdbestuur en de Buitendiensten (per bekken). ${ }^{36}$ Het NPM deed om de 3 maanden een overdracht van een deel van haar inkomsten naar respectievelijk:

- RWP: de Rijksdienst voor Werknemerspensioenen ten behoeve van de Rust- en overlevingspensioenen;

- RIZIV: het Rijksinstituut voor Ziekte- en Invaliditeitsverzekering ten behoeve van Ziekte en Invaliditeitsverzekering;

- $\quad$ RKW: de Rijksdienst voor Kinderbijslagen voor Werknemers ten behoeve van de Kinderbijslagen en het Gezinsvakantiegeld;

- RVA: de Rijksdienst voor Arbeidsvoorziening ten behoeve van werkloosheidsuitkeringen

- FBZ: het Fonds voor Beroepsziekten ten behoeve van beroepsziekten;

- FAO: het Fonds voor Arbeidsongevallen ten behoeve van arbeidsongevallen;

- Het Ministerie van Tewerkstelling en Arbeid ten behoeve van Sociale Promotie en het Fonds tot vergoeding van de ontslagen arbeiders.

Een ander deel van de inkomsten van het N PM werd benut voor de Invaliditeitspensioenen en de jaarlijkse vakantie der mijnwerkers. ${ }^{37}$

33 De Groote, De pensioenregeling, 5-I2.

34 Ibidem, I4-I5.

35 Ibidem, I7.

36 Jaarverslag 1980, 9-I2.

37 Ibidem, 25. 


\section{De archieven van het FNROM/NPM}

Het Institut d'Histoire Ouvrière Economique et Sociale (IHOES) te Seraing is in bezit van een deel van het archief van het voormalig FNROM te Luik. In feite was het de bedoeling dit archief te vernietigen, aangezien alle benodigde documenten/bronnen op microfiche waren gezet en uiteindelijk overgeheveld werden naar het Rijksinstituut voor Ziekte- en Invaliditeitsverzekering (RIZIV) te Hasselt. Voormalig directeur van het IHOEs, Michel Hannotte, slaagde er echter in een overeenkomst te sluiten met het FNROM in 1996 om een deel van het archief van het FNROM-Luik over te brengen naar de depots van het IHOES, waar het sindsdien wordt bewaard. $3^{8}$ Voorlopig is er nog geen inventaris beschikbaar, maar een enkele auteur wees reeds op de inhoud, waarde en de mogelijkheden van het FNROM-archief. ${ }^{39}$ Deze bronnen bevinden zich In het IHOEs-depot aan de Rue Wiertz te Luik, waar ik met hulp van de huidige IHOEs-directeur Ludo Bettens toegang toe kreeg.

De RIzIV/INAMI Hasselt: Dienst voor uitkeringen Cel Mijnwerkers is het centrale bewaarpunt voor de pensioendossiers en men kan daar terecht voor het samenstellen van zo'n dossier op basis van de daar bewaarde bronnen: rekenkaarten (vanaf geboortejaar I913, vanwege de praktische reden dat mijnwerkers geboren vóór die tijd (meestal) niet meer in leven zijn); aansluitingskaarten bij het Nationaal Pensioenfonds voor Mijnwerkers; verlofkaarten.

De administratie van het FNROM bevat de volgende onderdelen:

- Rekenkaarten: vanafgeboortejaar I880 tot geboortejaar I9I4 (de periode van I9I4 tot aan de mijnsluitingen is nog nietontsloten). Er is sprakevan dat deze rekenkaarten sinds geboortejaar 1850 bestaan hebben, maar deze geboortejaren werden (vooralsnog) nog nietteruggevonden in het I HOEs. Derekenkaarten bevatten devolgende gegevens: naam, voornaam, geboorteplaats en -datum, burgerlijkestand, eventuele huwelijksdatum, naam, geboorteplaats en -datum van de partner, aantal gewerkte dagen, plaats en type (ondergronds-bovengronds) van het werk, uitgekeerde lonen, en de later bijgevoegde opgespaarde pensioenrente.

- Biografische fiches: vanaf geboortejaar I850 (?) tot aan de mijnsluiting (recentelijk alfabetisch geordend). Bevatten: (voor)naam, adres, nationaliteit, geboorteplaats en -datum, naam echtgenote, geboorteplaats en -datum, huwelijksdatum, pensioenleeftijd, aantal werkjaren, oorzaak eventuele invaliditeit, salaris, pensioen en bijkomende voordelen

- Model 34-35-L: vanaf I925 werkgeversinformatie, (jaarlijks) register per mijn, chronologisch op geboortejaar, salaris per trimester, geen nationaliteit opgegeven, maar wel de herkomst van de mijnwerker. ${ }^{\circ}$

De Cartons Comptes of rekenkaarten bevatten per mijnwerker ruim de meeste informatie.

\section{De selecte steekproef}

Er is een selecte steekproef genomen uit de rekenkaarten aanwezig op het IHOEs, die in archiefkasten op geboortedatum geordend werden. De rekenkaarten hebben verschillende kleuren, enerzijds naargelang trimester (van het geboortejaar), anderzijds naargelang gewerkte periode. (Van I925 tot I934 zijn er roze fiches, van I920 tot 1933 oranje fiches, ...). Vanaf 1958 verandert ook het type rekenkaart: de dienstverbanden worden niet langer horizontaal, maar verticaal ingeschreven, en er zijn afzonderlijke kolommen voor ziektedagen, naam van het ziekenfonds, feestdagen, toegekende dagen ten gevolge van een ongeval, technische werkloosheid, ... Vanaf geboortejaar I880 tot ca. I9I4 zijn deze te raadplegen.

40 De mogelijkheden van deze bron worden geïllustreerd door o.m. het onderzoek van Paola Manno naar Italiaanse mijnwerkers in het Luikse bekken: Manno, 'La communauté des ouvriers mineurs', 445-467. 


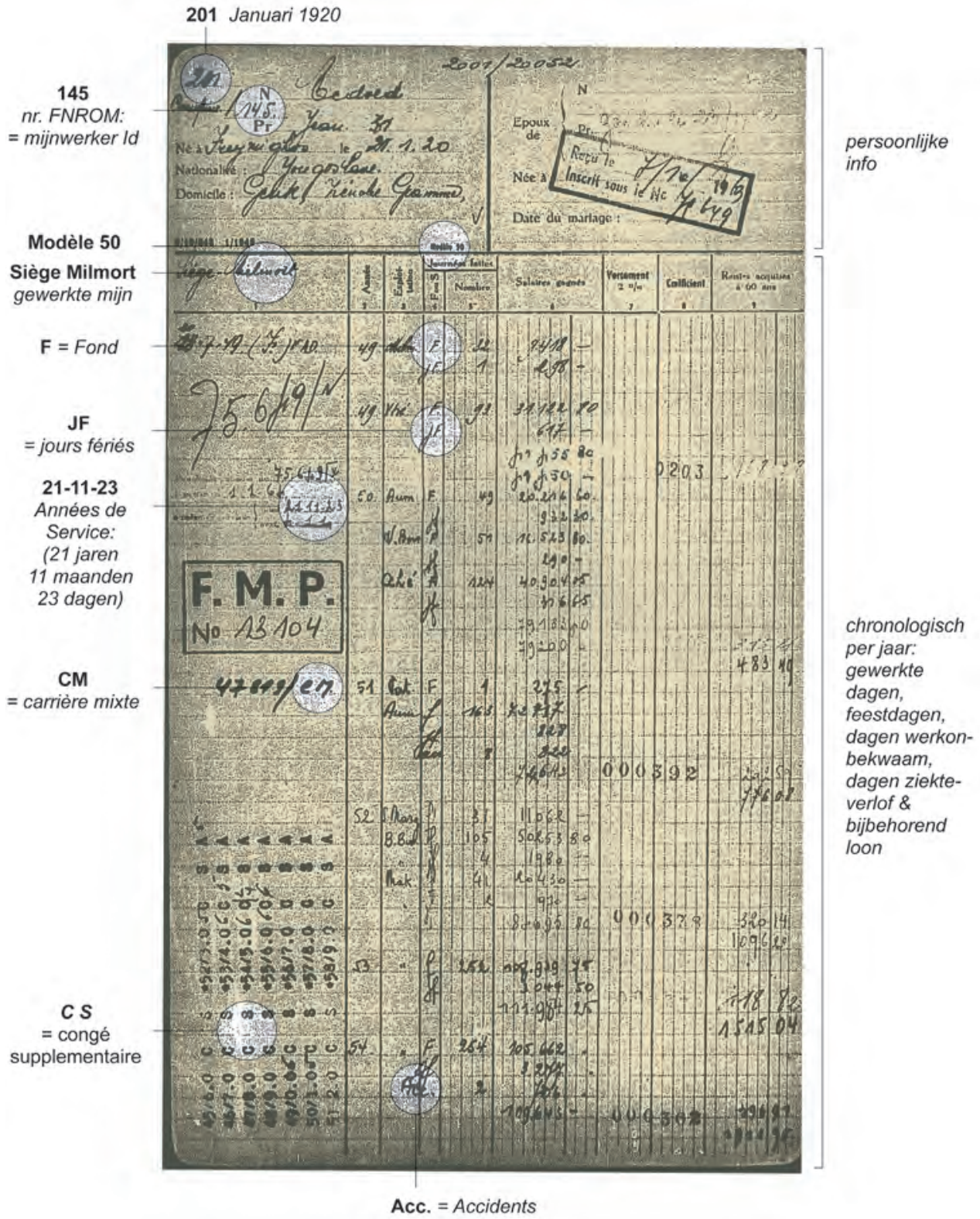

Voorbeeld van een carton comptes (rekenkaart), met daarop aanwijzingen over gebruikte afkortingen, codes, stempels, enz. (1e fiche voorzijde). Carton comptes, 201/145. FNROM. Coll. RIZIV. 


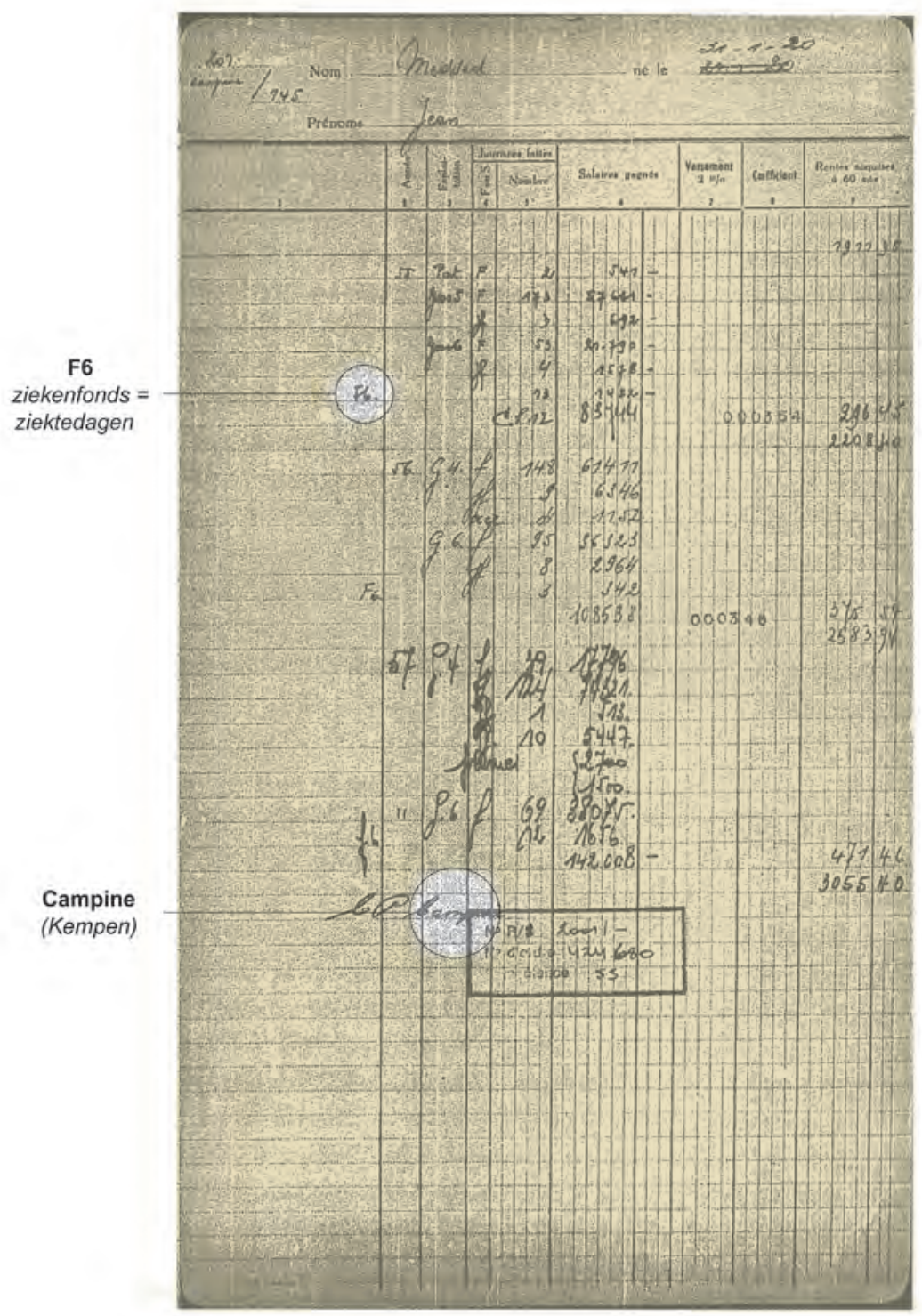

Voorbeeld van een carton comptes (rekenkaart), met daarop aanwijzingen over gebruikte afkortingen, codes, stempels, enz. (1e fiche achterzijde). Carton comptes, 201/145. FNROM. Coll. RIZIV. 


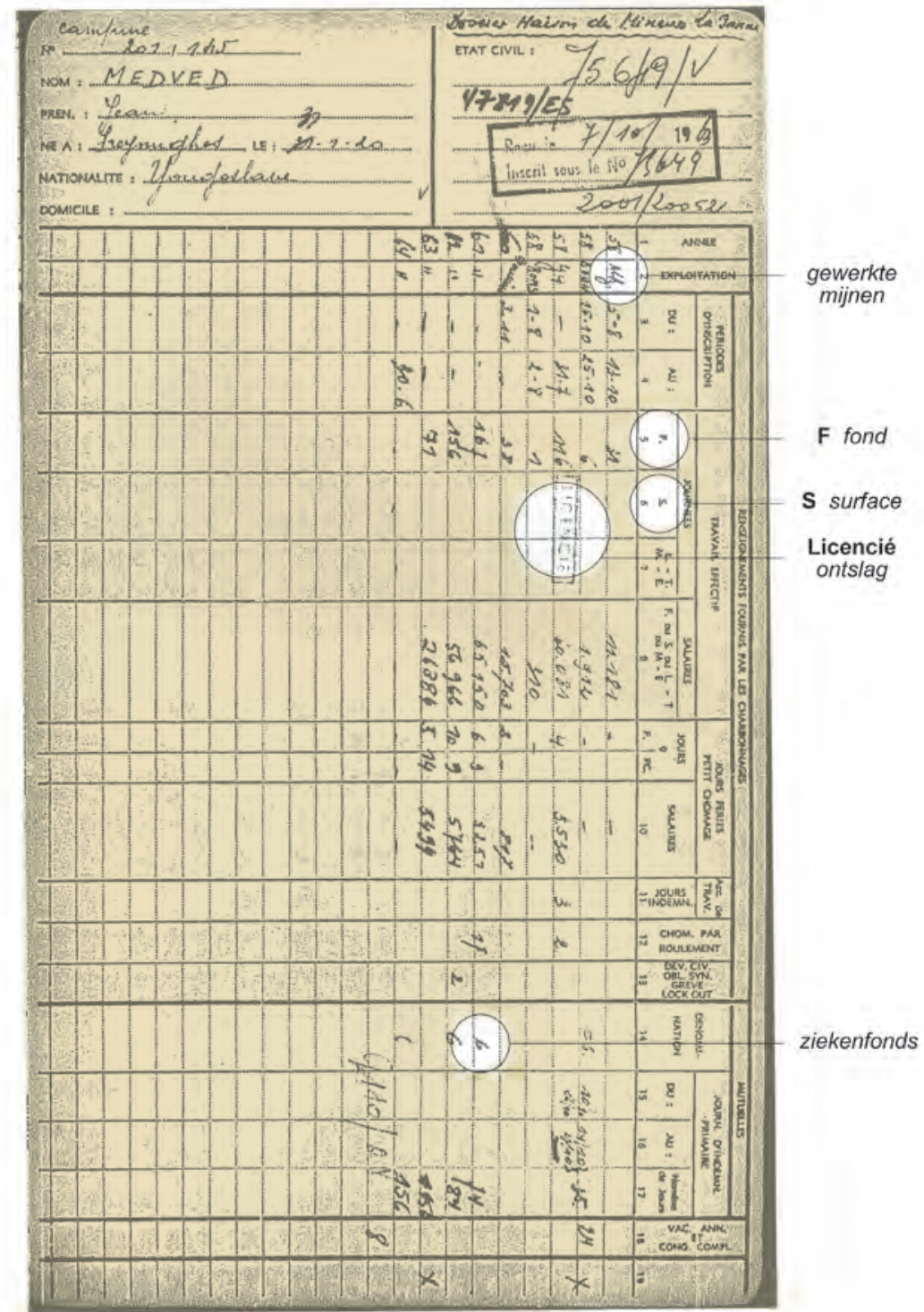

Voorbeeld van een carton comptes (rekenkaart), met daarop aanwijzingen over gebruikte afkortingen, codes, stempels, enz. (2e fiche). Carton comptes, 201/145. FNROM. Coll. RIZIV. 
Latere geboortedata waren ten tijde van het onderzoek nog niet raadpleegbaar, want opgeslagen in dozen. De manier waarop deze bron wordt bewaard liet geen zuivere, a-selecte steekproef toe en er werd besloten op basis van het enigszins objectief criterium van geboortedatum een selecte steekproef te nemen. ${ }^{4 \mathrm{I}}$ Alle mijnwerkers geboren in januari rgIo werden geselecteerd.

André Jansen, voormalig medewerker van het FNROM Luik en huidig attaché van het INAMI te Luik, verschafte de nodige informatie over de op de rekenkaarten gebruikte afkortingen, codes voor de mijnbekkens en de afzonderlijke mijnzetels (zie de tabellen 9 en ro in deze bijlage). Samen met Eric Geerkens van de Universiteit Luik en Ludo Bettens gaf hij de nodige handvaten om de rekenkaarten te kunnen analyseren.

Uit de microfiches bij het RIZIV te Hasselt werd eveneens een selecte steekproef genomen uit de rekenkaarten aan de hand van geboortedatum (geboortecohort). Alle mijnwerkers geboren in januari I920 werden voor de steekproef geselecteerd en ingevoerd in de database. Hiervoor kregen we ondersteuning en toestemming van Eric Verbraeken (Attaché Dienst Uitkeringen Mijnwerkers). ${ }^{42}$

\section{TABEL B.9 DE GEBRUIKTE CODES VOOR DE BEKKENS EN NV'S}

\begin{tabular}{|l|c|c|c|c|}
\hline Bergen/Mons & $\mathrm{A}$ & $\mathrm{MO}$ & $\mathrm{M}$ & $\mathrm{I}$ \\
\hline Centrum/Centre & $\mathrm{B}$ & $\mathrm{CE}$ & $\mathrm{C}$ & 2 \\
\hline Charleroi & $\mathrm{C}$ & $\mathrm{CH}$ & $\mathrm{CH}$ & 3 \\
\hline Namen/Namur & $\mathrm{D}$ & $\mathrm{LN}$ & $\mathrm{N}$ & 4 \\
\hline Luik/Liège & $\mathrm{E}$ & $\mathrm{LU}$ & $\mathrm{L}$ & 5 \\
\hline
\end{tabular}

TABel B.io De GebruikTE Codes Voor de MiJNZETELS

\begin{tabular}{|l|l|l|l|}
\hline Code & Charbonnage & Code & Charbonnage \\
\hline 501 & Abhooz et Bonne Foi Hareng & 524 & Lonette \\
\hline 502 & Angleur & 525 & Minerie \\
\hline 503 & Ans et Rocourt & 526 & Cockerill \\
\hline 504 & Arbre Saint-Michel & 527 & Marihaye \\
\hline 505 & Argenteau-Trembleur & 528 & Ougrée \\
\hline 506 & Bois d'Avroy & 529 & Oupeye \\
\hline 507 & Bois de Micheroux & 530 & Patience et Beaujonc \\
\hline 508 & Bonne Espérance, Batterie, Violette & 531 & Pays de Liège \\
\hline 509 & Bonne Fin & 532 & Quatre Jean \\
\hline 510 & Wandre & 533 & Six Bonniers \\
\hline 511 & Bonnier & 534 & Wérister \\
\hline 5 I2 & Espérance et Bonne Fortune & 535 & Est de Liège \\
\hline 513 & Espérance et d'Envoz & 536 & Basse Rancy \\
\hline 514 & Gives & 537 & Fond Piquette \\
\hline 515 & La Haye & 538 & Herve Wergifosse \\
\hline 516 & Gosson & 540 & Mines de Couthuin (Mine Metallique) \\
\hline & & & \\
\hline 5
\end{tabular}

4I Kleine kanttekening: in het geval van Turkse en Marokkaanse arbeidsmigranten kan geboortedatum wel een vertekening opleveren. Bij gebrek aan precieze geboortedatum werden veel arbeiders afkomstig uit die landen ingeschreven als geboren op I/I/IgXX of I/7/IgXX. In die geboortemaanden zal er dus proportioneel een te grote groep Turken en Marokkanen terug te vinden zijn. Deze groepen komen echter pas in grote getale vanaf begin jaren ig6o de Belgische arbeidsmarkt op: een periode die in het onderzoek naar arbeidsverloop buiten beschouwing wordt gelaten.

42 Ook Brigitte Baetens en An Frederix van het RIZIV ondersteunden bij het raadplegen van de rekenkaarten. 


\begin{tabular}{|l|l|l|l|}
\hline Code & Charbonnage & Code & Charbonnage \\
\hline 517 & Horloz & $54 \mathrm{I}$ & Vieille Montagne (Mine Metallique) \\
\hline 518 & Kessales & 543 & Carrières Blondet (Exploitation assimilée) \\
\hline 519 & Grande Bacnure & 553 & Moha \\
\hline 520 & Hasard & 555 & Socochar (Exploitation assimilée) \\
\hline 521 & Maireux & 560 & Carrières Ourthe et Meuse \\
\hline 522 & Belle Vue & 567 & Nossin et Papelier \\
\hline 523 & La Meuse & & \\
\hline
\end{tabular}

\section{De database}

Een database werd ontworpen en met de hulp van Theo Dibbets (vrijwillig medewerker van het SHCL) werd de informatie van de rekenkaarten ingevoerd. Het inschrijvingsnummer van het FNROM (bv. 20I/I45 wat zoveel wil zeggen als: uit het geboortejaar 1920, maand I, januari, mijnwerker 145) werd opgenomen als uniek Mijnwerker ID. Via dit nummer kunnen relaties worden gelegd tussen de persoonlijke informatie en de informatie over de dienstverbanden op twee subformulieren:

I. Het subformulier 'persoonlijke informatie': naam; geboortedatum; geboorteplaats; geboorteland; nationaliteit; domicilie; burgerlijke stand; huwelijksdatum; pensioendatum.

2. Het subformulier 'carrièreverloop', met informatie over de verschillende dienstverbanden: ingangsdatum van het eerste dienstverband (indien die werd ingevuld, in de meeste gevallen bleek dit niet het geval); de dienstjaren; het aantal gewerkte dagen; de plaats in het bedrijf (ondergronds/bovengronds); de betreffende mijnzetel.

Op basis van de rekenkaarten werd de persoonlijke informatie verder aangevuld met:

- het aantal dienstjaren (het aantal jaren waarin effectief gewerkt werd, ongeacht het aantal gewerkte dagen);

- het totaal aantal gewerkte dagen (de som van het aantal gewerkte dagen uit het subformulier carrièreverloop);

- of het al dan niet om een kort dienstverband ging (minder dan of gelijk aan 30 gewerkte dagen). In dat geval werd het aantal dienstjaren niet genoteerd $(=0)$;

- in welk jaar de mijnwerker intrad in het mijnbedrijf;

- wat zijn of haar laatste gewerkte jaar was;

- of zich onderbrekingen in de mijnwerkerscarrière hadden voorgedaan (met aanduiding van welke jaren), waaronder ook jaren van invaliditeit en/of ziekte (art. 29 \& 30).

Aangezien het FNROM ook arbeiders uit aanverwante bedrijven (zoals cokesfabrieken, steenkoolverwerkende fabrieken, enz.) en uit andere extractieve nijverheden (zoals steengroeven en metaalmijnen) in het fonds opnam, zijn ook deze dienstverbanden in de database opgenomen.

Indien mogelijk werd de bedrijfsinformatie aangevuld met de betreffende NV en plaats. Daarbij werd aangeduid of het ging om een nieuw dienstverband. Telkens wanneer een mijnwerker dagen werkte bij een andere zetel (ook indien de zetels behoorden tot éénzelfde NV) of er meer dan een jaar niet gewerkt werd in de Luikse mijnen (onderbreking), werd een nieuw dienstverband aangevinkt.

Ook werd aangeduid welke periode van het jaar (per trimester) of hoeveel dagen er gewerkt was. Als een mijnwerker 270 dagen of meer had gewerkt, werd dat aangeduid als 'hele jaar', indien hij of zij minder had gewerkt werd het: 'gedeelte van het jaar'. Door het RIZIV werd een gemiddelde van I 85 
dagen gebruikt voor een volledig gewerkt jaar, waarbij 30 keer 185 gewerkte dagen telt als een volledige mijnwerkerscarrière. ${ }^{43}$ In onze analyse naar gepresteerde diensttijd werd deze hoeveelheid aangehouden. Informatie op de rekenkaarten omtrent aantal ziektedagen, feestdagen, vrije dagen ten gevolge van een ongeval, en dergelijke werd niet opgenomen in het subformulier carrièreverloop (wel bij opmerkingen).

Hoewel het uitgangspunt was dat er alleen dienstverbanden in het Luikse bekken werden genoteerd, bleken er op de kaarten vaak aanwijzingen voor te komen over eventuele andere dienstverbanden in andere bekkens (vers Campine, vers Charleroi, ...) - deze werden dan vermeld bij de opmerkingen in het databaseformulier. Indien er sprake was van dienstverbanden in verschillende bekkens (waaronder minstens één in een Luikse mijn), werden alle dienstverbanden opgenomen in het subformulier carrièreverloop.

Tijdens het invoeren van de rekenkaarten in de database, kwamen we tot de ontdekking dat heel wat rekenkaarten afkomstig waren uit kas 4 van het FNROM, namelijk Namur/Namen (dit werd aangeduid met een gestempelde 4). Uit nader onderzoek bleek dat deze mijnwerkers allen, op een enkele uitzondering na, niet in de Luikse mijnen hebben gewerkt, maar in de andere Waalse bekkens. Deze mijnwerkers werden uitgesloten van verdere analyse. Bij geboortecohort januari rgro werden zo 47 mijnwerkers uitgesloten, waardoor er nog 4I8 overbleven. De uiteindelijke groep mijnwerkers uit deze cohort bestaat uit 33 vrouwen en 338 mannen. Bij geboortecohort januari r 920 werden 52 mijnwerkers uitgesloten, wat resulteerde in een totaal van 5 Io mijnwerkers, waaronder 15 vrouwen en 443 mannen.

In de selecte steekproef komen ook vrouwen voor, maar aangezien zij al eerder onderwerp van onderzoek vormden (zie hoofdstuk 2), zijn ze bij deze analyse verder weggelaten.

43 I8 5 dagen lijkt weinig voor een gewerkt jaar. Door de beslissing op 25 oktober 1963 werd het aantal gewerkte dagen voor een mijnwerker die slechts voor zijn wettelijk verlof afwezig was, gebracht op 232 ('Technische kenmerken van de Belgische Steenkolenontginning in I967', Annales des Mines de Belgique, oktober 1969, I06I). We kozen er echter voor het criterium van het RIZIV aan te houden: een tewerkstelling van één dienstjaar wordt voldaan wanneer er tussen r januari en 3I december minstens I 85 werkdagen of gelijkgestelde dagen (ziekte, verlof, staking) vallen. Met die gelijkgestelde dagen werd in onze berekeningen geen rekening gehouden, we hanteerden dus iets strengere criteria. (www.riziv.fgov.be/citizen/nl/miners/miners32.htm) 


\section{BIJLAGE 9}

\section{Verantwoording van het kaartmateriaal}

De reeks kaarten werden vervaardigd door dr. Erwin Steegen van het Regionaal Historisch Centrum Limburg te Maastricht met behulp van GIS-software (Geografisch Informatiesysteem). Hierbij worden geografische gegevens (in digitale vorm) in relatie gebracht met zogenoemde attribuutgegevens. Dit zijn hoofdzakelijk kwantitatieve data die in deze studie inzicht verschaffen in de historische ontwikkeling van de arbeidsmarkt van mijnwerkers in de provincie Luik. Hiernaast zijn ook kwalitatieve (attribuut)gegevens verwerkt, met name om de spreiding en evolutie van de mijnzetels in de provincie Luik in kaart te brengen. Het basismateriaal - shapefiles met lambertcoördinaten - voor de kaarten betreft de grenzen van gemeenten uit de Belgische provincies Limburg en Luik, jaren I840, 1930, 1963. Voor een aantal kaarten werden grenscorrecties ten behoeve van de toenmalige gemeentelijke indelingen doorgevoerd. De gehanteerde GIS-sets voor het basismateriaal (shapefiles) zijn afkomstig van de HISSTAT databank van de Universiteit Gent, Vakgroep Nieuwste Geschiedenis. Dit is een centrale gegevensbank gekoppeld aan een informatieinfrastuctuur voor het maken van historisch kaartmateriaal (http://www.hisstat.be). De locatie van de mijnzetels werd bepaald door gebruik te maken van de Carte génerale des concessions houillères de Belgique uit 1946.44

De statische data (attribuutgegevens) die worden weergegeven op de kaarten zijn het resultaat van eigen onderzoek in de volks- en industrietellingen (I910, I930, I947 en I961), twee afzonderlijke studies over de Luikse regio in 1947 en $196 \mathrm{I}^{45}$ en een studie van het Office National du Placement et du Chômage..$^{6}$

\footnotetext{
44 Direction Générale des Mines à Bruxelles. Carte génerale des concessions houillères de Belgique Édition I946. Échelle I:40.000e (5042 Institut Géographique Militaire 1947 (La Cambre-Bruxelles), Bassin du Sud (Feuille 6 - Liège; Feuille 5 - Waremme).

45 L'administration communale de Liège, La Région Liégeoise (I95I en I96I).

46 Main-d'œuvre et production dans les mines.
} 


\section{BiJLAgE IO}

De nettoproductie van steenkolen bij de Luikse mijnen, I900-I979

\begin{tabular}{|c|c|c|c|}
\hline Jaar & Productie (x r.ooo ton) & Jaar & Productie (x I.000 ton) \\
\hline 1900 & 6.I9I & 1940 & $4 \cdot 542$ \\
\hline I9OI & $5 \cdot 784$ & I94I & $4 \cdot 4 \mathrm{I} 4$ \\
\hline 1902 & 6.236 & I942 & 4.029 \\
\hline 1903 & 6.444 & I943 & 3.679 \\
\hline I904 & 5.887 & I944 & 2.244 \\
\hline 1905 & 5.874 & I945 & 2.313 \\
\hline I906 & 6.014 & I946 & 3.610 \\
\hline I907 & $5 \cdot 779$ & I947 & 3.912 \\
\hline 1908 & 5.918 & 1948 & 4.063 \\
\hline I909 & 5.987 & I949 & $4 \cdot 495$ \\
\hline I9IO & 6.I4I & 1950 & 4.465 \\
\hline IgII & 5.763 & I95I & 4.785 \\
\hline I9I2 & 6.184 & I952 & 4.957 \\
\hline I9I3 & 5.998 & 1953 & 5.003 \\
\hline I9I4 & 4.135 & I954 & 4.963 \\
\hline I9I5 & 4.008 & I955 & $4.8 \mathrm{I} 8$ \\
\hline I9I6 & 4.223 & I956 & $4.53 \mathrm{I}$ \\
\hline I9I7 & 3.156 & I957 & $4 \cdot 323$ \\
\hline I9I8 & 3.113 & 1958 & 4.069 \\
\hline I9I9 & 4.406 & I959 & 3.823 \\
\hline 1920 & 5.439 & I96o & 3.538 \\
\hline I92I & 5.016 & I96I & 3.069 \\
\hline I922 & 5.165 & I962 & 3.080 \\
\hline I923 & 5.413 & I963 & 3.082 \\
\hline I924 & $5 \cdot 5^{16}$ & I964 & 3.076 \\
\hline I925 & 5.199 & I965 & 2.693 \\
\hline 1926 & 5.538 & I966 & 2.262 \\
\hline I927 & 5.835 & I967 & I. 880 \\
\hline I928 & 5.799 & I968 & I. 504 \\
\hline I929 & 5.477 & I969 & $3.53^{8}$ \\
\hline I930 & 5.487 & I970 & I. 300 \\
\hline I93I & 5.495 & I97I & I.058 \\
\hline I932 & $4.44^{2}$ & I972 & 956 \\
\hline I933 & 5.IOI & I973 & 834 \\
\hline I934 & 5.238 & I974 & 602 \\
\hline I935 & 5.188 & I975 & 403 \\
\hline 1936 & 5.225 & I976 & 286 \\
\hline I937 & 5.400 & I977 & I68 \\
\hline 1938 & $5 \cdot 5 \mathrm{I} 4$ & I978 & 93 \\
\hline I939 & $5 \cdot 5^{16}$ & I979 & 66 \\
\hline
\end{tabular}

Bron: I900-I979: Annales des Mines de Belgique, I90I-I980; I9I9-I922: Geerkens, La rationalisation dans l'industrie belge, I24I (Tableau 2); RAH, archief FEDECHAR, inv.nrs. 606-609: 'Jaarlijkse statistische overzichten' (I940-I945).

N.B.: De productiecijfers voor de jaren 1975-1979 werden berekend op basis van de afzonderlijke opgaven per mijn ('Tableau des mines de houille', Annales des Mines de Belgique, 1976-1980). 


\section{BIJLAGE II}

De personeelsbezetting bij de Luikse mijnen, I900-I979

\begin{tabular}{|c|c|c|c|c|c|}
\hline Jaar & Arbeidskracht & Ondergronds & Bovengronds & Belgen & Buitenlanders \\
\hline I900 & 32.992 & $\bullet$ & $\bullet$ & $\bullet$ & $\bullet$ \\
\hline I9OI & 34.204 & - & - & - & - \\
\hline 1902 & 34.446 & $\cdot$ & • & - & $\cdot$ \\
\hline 1903 & $35 \cdot 322$ & $\bullet$ & • & • & • \\
\hline I904 & $34.8 \mathrm{I} 5$ & 25.903 & 8.912 & $\cdot$ & $\cdot$ \\
\hline 1905 & 33.719 & 25.078 & $8.64 \mathrm{I}$ & - & • \\
\hline I906 & 34.553 & 25.768 & 8.785 & • & $\cdot$ \\
\hline 1907 & 34.505 & $25.83 \mathrm{I}$ & 8.674 & - & - \\
\hline 1908 & 36.505 & 27.157 & 9.348 & • & • \\
\hline I909 & 36.792 & $27.18 I$ & $9.6 \mathrm{II}$ & $\cdot$ & • \\
\hline I9IO & 37.210 & 27.363 & 9.847 & • & $\bullet$ \\
\hline IgII & 36.718 & 26.940 & 9.778 & $\cdot$ & $\cdot$ \\
\hline I9I2 & 37.878 & 28.052 & 9.826 & - & - \\
\hline I9I3 & $3^{8.432}$ & $28.5 \mathrm{I} 6$ & 9.916 & - & - \\
\hline I9I4 & $\bullet$ & • & $\bullet$ & - & • \\
\hline I9I5 & $\cdot$ & $\cdot$ & $\cdot$ & $\cdot$ & $\cdot$ \\
\hline I9I6 & - & • & - & - & - \\
\hline I9I7 & - & . & . & . & - \\
\hline I9I8 & • & $\bullet$ & • & - & • \\
\hline I9I9 & 34.006 & 24.293 & 9.713 & - & • \\
\hline 1920 & 39.216 & 28.208 & II.008 & - & - \\
\hline I92I & 4I.I66 & $29 \cdot 722$ & II.444 & - & - \\
\hline I922 & 38.888 & 27.632 & II. 256 & $\cdot$ & $\cdot$ \\
\hline 1923 & $39 \cdot 320$ & 27.957 & II. 363 & - & - \\
\hline I924 & 4I.0I9 & $29 \cdot 513$ & II. 506 & $\cdot$ & $\cdot$ \\
\hline 1925 & 38.192 & $27.08 \mathrm{I}$ & II.III & • & • \\
\hline 1926 & $38 . \mathrm{II} 2$ & $27.07 \mathrm{I}$ & II.04I & - & - \\
\hline I927 & 40.675 & 29.285 & II.390 & - & - \\
\hline I928 & 36.845 & 26.422 & I0.423 & - & - \\
\hline I929 & 32.857 & 23.418 & 9.439 & $\bullet$ & $\bullet$ \\
\hline 1930 & 33.560 & 24.128 & 9.432 & 32.802 & 6.232 \\
\hline I93I & 33.507 & 24.200 & $9 \cdot 307$ & 31.866 & 6.424 \\
\hline 1932 & $3 \mathrm{I} .957$ & 23.088 & 8.869 & 30.139 & $5.8 \mathrm{I} 4$ \\
\hline I933 & 30.693 & 22.137 & $8.55^{6}$ & 28.450 & $5.60 \mathrm{I}$ \\
\hline I934 & 28.024 & 20.126 & 7.898 & 25.682 & 4.997 \\
\hline I935 & 26.366 & I8.854 & $7 \cdot 512$ & $25 \cdot 359$ & 5.220 \\
\hline 1936 & 27.124 & 19.389 & 7.735 & $25 \cdot 4 \mathrm{I} 5$ & 5.457 \\
\hline I937 & $27 \cdot 72 \mathrm{I}$ & I9.894 & 7.827 & $25 \cdot 364$ & $7 \cdot 507$ \\
\hline 1938 & 28.710 & 20.784 & 7.926 & 26.078 & 7.152 \\
\hline 1939 & 28.120 & 20.383 & 7.737 & 24.245 & 7.032 \\
\hline I940 & 29.939 & $\bullet$ & • & 25.089 & 4.850 \\
\hline I94I & 28.886 & $\cdot$ & $\cdot$ & 25.062 & 3.824 \\
\hline I942 & 26.898 & $\cdot$ & $\cdot$ & 23.277 & 3.621 \\
\hline
\end{tabular}




\begin{tabular}{|c|c|c|c|c|c|}
\hline Jaar & Arbeidskracht & Ondergronds & Bovengronds & Belgen & Buitenlanders \\
\hline I943 & 27.824 & $\bullet$ & $\bullet$ & 23.304 & $4.520^{I}$ \\
\hline I944 & $20.65 \mathrm{I}$ & I2.956 & 7.695 & 17.730 & $292 \mathrm{I}$ \\
\hline I945 & 21.529 & $\bullet$ & • & I7.776 & $3.753^{2}$ \\
\hline I946 & $25 \cdot 580$ & - & - & I6.630 & $8.950^{3}$ \\
\hline I947 & 31.910 & 22.570 & $9 \cdot 340$ & 17.067 & I4.843 \\
\hline 1948 & $33 \cdot 315$ & 24.134 & $9.18 \mathrm{I}$ & I6.806 & I6.509 \\
\hline 1949 & 31.156 & 22.436 & 8.720 & I6.636 & $\mathrm{I} 4.520$ \\
\hline 1950 & 29.724 & 21.629 & 8.095 & I6.057 & 13.667 \\
\hline I95I & $3 \mathrm{I} .73 \mathrm{I}$ & 24.002 & 7.729 & I4.990 & I6.74I \\
\hline 1952 & $3 \mathrm{I} .3 \mathrm{II}$ & $23.8 \mathrm{I} 7$ & 7.494 & $\mathrm{I} 4.564$ & I6.747 \\
\hline I953 & 30.268 & 22.960 & $7 \cdot 308$ & I4.293 & I5.975 \\
\hline I954 & 28.886 & 21.992 & 6.894 & $\mathrm{I} 4 . \mathrm{I} 4 \mathrm{O}$ & I 4.746 \\
\hline I955 & 28.722 & 22.238 & 6.484 & 13.185 & I5.537 \\
\hline 1956 & 27.185 & 20.798 & 6.387 & $\mathrm{I} 2.22 \mathrm{I}$ & I4.964 \\
\hline I957 & $28.07 \mathrm{I}$ & 21.764 & 6.307 & II. 700 & I6.37I \\
\hline 1958 & $25.79 \mathrm{I}$ & 19.782 & 6.009 & I0.846 & I4.945 \\
\hline I959 & 21.897 & I6.75I & 5.146 & 9.I75 & $\mathrm{I} 2.722$ \\
\hline I96o & 17.962 & I3.592 & 4.370 & 7.423 & I0.539 \\
\hline I96I & I6.II7 & I2.045 & 4.072 & 6.675 & 9.442 \\
\hline 1962 & I5.435 & II.599 & 3.836 & 5.901 & $9 \cdot 534$ \\
\hline 1963 & I5. 783 & II. 852 & 3.931 & 5.657 & IO.I26 \\
\hline 1964 & I6.076 & $\mathrm{I} 2.350$ & 3.726 & 5.137 & I0.939 \\
\hline 1965 & I2.7II & 9.684 & 3.027 & 4.026 & 8.685 \\
\hline I966 & IO.I23 & 7.562 & $2.56 \mathrm{I}$ & 3.282 & $6.84 \mathrm{I}$ \\
\hline 1967 & 8.533 & 6.338 & 2.195 & 2.776 & 5.757 \\
\hline I968 & 7.485 & 5.518 & I.967 & 2.436 & 5.049 \\
\hline I969 & 5.717 & 4.218 & I.499 & I. 788 & 3.929 \\
\hline I970 & 5.356 & 3.900 & I. 456 & I. 657 & 3.699 \\
\hline I97I & 4.549 & $3 \cdot 346$ & I. 203 & I. 367 & 3.182 \\
\hline 1972 & 4.210 & 3.102 & I.IO8 & $\mathrm{I} .217$ & 2.993 \\
\hline I973 & 3.588 & 2.635 & 953 & I.047 & $2.54 \mathrm{I}$ \\
\hline I974 & 2.746 & $2.01 I$ & 735 & $79 \mathrm{I}$ & I.955 \\
\hline I975 & 2.064 & 1.603 & $46 \mathrm{I}$ & 533 & I.53I \\
\hline 1976 & I. 488 & I.I67 & $32 \mathrm{I}$ & 369 & I.II9 \\
\hline I977 & 927 & $\bullet$ & • & • & $\bullet$ \\
\hline 1978 & 478 & - & • & • & • \\
\hline I979 & 375 & • & • & • & • \\
\hline
\end{tabular}

Bron: Ig0o-Ig03: Pasleau, Industries et populations, 594-595; I904-I974: Annales des Mines de Belgique, I905-I980; RAH, archief FEDECHAR, inv.nr. 612: 'Statistieken'.

N.B.: De aantallen Belgen en buitenlanders in de periode I930-I939 zijn afkomstig uit RAH, archief FEDECHAR, inv.nr. 6I2: 'Statistieken', en geven opgeteld een hoger totaal aan arbeidskrachten. Dit kan te maken hebben met een ander telmoment: Les Annales geven het aantal ingeschreven arbeiders op 3I december, de betreffende statistiek uit het FEDECHAR archief het aantal op 30 september.

Het aantal arbeiders voor de jaren 1975-1979 werd berekend op basis van de afzonderlijke opgaven per mijn ('Tableau des mines de houille', Annales des Mines de Belgique, 1976-1980).

\section{Noten bij tabel bijlage II}

I Zonder Russische krijgsgevangenen.

2 Zonder Duitse krijgsgevangenen.

3 Ibidem. 


\section{BIJLAGE I2}

Het aantal buitenlandse arbeiders in het ondergrondse personeelsbestand van de Luikse mijnen naar nationaliteit, 195I-1976

\begin{tabular}{|c|c|c|c|c|c|c|c|c|c|c|c|c|}
\hline & $\begin{array}{r}\text { (West)- } \\
\text { Duitsers }\end{array}$ & $\begin{array}{r}\text { Fran- } \\
\text { sen } \\
\end{array}$ & $\begin{array}{r}\text { Italia- } \\
\text { nen }\end{array}$ & $\begin{array}{l}\text { Neder- } \\
\text { landers }\end{array}$ & $\begin{array}{l}\text { Luxem- } \\
\text { burgers }\end{array}$ & $\begin{array}{c}\text { Alge- } \\
\text { rijnen }\end{array}$ & $\begin{array}{r}\text { Span- } \\
\text { jaarden }\end{array}$ & $\begin{array}{r}\text { Grie- } \\
\text { ken }\end{array}$ & $\begin{array}{r}\text { Honga- } \\
\text { ren } \\
\end{array}$ & $\begin{array}{r}\text { Marok- } \\
\text { kanen }\end{array}$ & $\begin{array}{l}\text { Bal- } \\
\text { ten }^{1}\end{array}$ & $\begin{array}{l}\text { Po- } \\
\text { len }\end{array}$ \\
\hline I95I & 573 & I65 & 10.363 & I.I62 & I8 & • & I9 & • & I49 & • & II9 & 2.207 \\
\hline 1952 & 542 & $\mathrm{I} 4 \mathrm{O}$ & I0.635 & I. 287 & I8 & • & I9 & • & I33 & • & II 2 & 2.056 \\
\hline I953 & 533 & I52 & 9.856 & I. 443 & I9 & • & 28 & • & $\mathrm{I} 26$ & • & 107 & I.9I6 \\
\hline I954 & 603 & 83 & 8.880 & I. 468 & 13 & 68 & 36 & • & $\mathrm{I} 22$ & 29 & 94 & I. 786 \\
\hline I955 & 559 & 90 & 9.975 & I. 329 & II & 58 & 52 & 130 & II7 & $\mathrm{I} 4$ & 80 & I. 620 \\
\hline 1956 & 395 & 243 & 9.443 & I.IO4 & $\mathrm{I} 2$ & 64 & 224 & 337 & 246 & $\mathrm{I} 4$ & 80 & $\mathrm{I} .4 \mathrm{I} 8$ \\
\hline 1957 & $5^{18}$ & 88 & $9 \cdot 518$ & I.I99 & IO & I06 & 869 & 928 & 266 & IO & 63 & I.335 \\
\hline 1958 & 447 & $7 \mathrm{I}$ & 8.958 & I.097 & 8 & 76 & 753 & 583 & 2I9 & 6 & $6 \mathrm{I}$ & I. 264 \\
\hline 1959 & 369 & 62 & 7.730 & 858 & 7 & 6I & 717 & 472 & 185 & 4 & 50 & I.084 \\
\hline I96o & 289 & 52 & 6.462 & 557 & 7 & 44 & 656 & 396 & 136 & 5 & 44 & $93 \mathrm{I}$ \\
\hline I96I & $24 \mathrm{I}$ & 55 & 5.629 & 362 & 5 & $4 \mathrm{I}$ & 828 & 324 & 105 & 6 & $5 \mathrm{I}$ & 762 \\
\hline 1962 & $22 \mathrm{I}$ & 43 & 4.824 & 325 & 3 & 35 & I. 323 & 922 & $9 \mathrm{I}$ & 22 & 49 & 725 \\
\hline 1963 & 208 & 39 & 4.139 & 293 & 4 & 75 & $\mathrm{I} .24 \mathrm{I}$ & 769 & 78 & 296 & 43 & 680 \\
\hline 1964 & I89 & 42 & 3.574 & 226 & - & 96 & I. 245 & 625 & 79 & 797 & $4 \mathrm{I}$ & 603 \\
\hline I965 & I55 & 37 & 2.907 & 185 & - & 66 & 968 & 444 & 56 & 490 & 24 & 490 \\
\hline I966 & $\mathrm{II}_{3}$ & 38 & 2.210 & I43 & - & 62 & 745 & 329 & $4 \mathrm{I}$ & 540 & I5 & 394 \\
\hline 1967 & 78 & 37 & I.9I4 & II 2 & - & 58 & $62 \mathrm{I}$ & 274 & 36 & 495 & $\mathrm{I} 4$ & 330 \\
\hline I968 & 73 & 30 & I. 623 & 96 & - & 56 & 528 & 246 & 37 & 429 & $\mathrm{I} 2$ & 285 \\
\hline I969 & 49 & 24 & I. 255 & 88 & - & $4 \mathrm{I}$ & $4 \mathrm{I} 4$ & 170 & 29 & 258 & 7 & 229 \\
\hline I970 & • & • & I.I42 & • & • & 40 & 382 & 173 & • & 282 & $\bullet$ & I97 \\
\hline I97I & - & $\bullet$ & 923 & • & • & 37 & $33 \mathrm{I}$ & I33 & • & 274 & • & I75 \\
\hline I972 & • & • & 836 & - & • & 36 & 312 & I33 & - & 246 & • & I59 \\
\hline I973 & • & • & 699 & • & - & 27 & 283 & II9 & - & $2 \mathrm{I} 3$ & • & II 6 \\
\hline I974 & • & • & 519 & • & - & 20 & 225 & 92 & • & $\mathrm{I} 74$ & • & 68 \\
\hline I975 & • & • & $33^{8}$ & • & • & I9 & I97 & 90 & • & I83 & - & 23 \\
\hline 1976 & $\cdot$ & $\cdot$ & I95 & • & $\cdot$ & $\mathrm{I} 2$ & I64 & 73 & $\cdot$ & I 45 & $\cdot$ & I7 \\
\hline
\end{tabular}

\begin{tabular}{|c|c|c|c|c|c|c|c|c|c|c|}
\hline & $\begin{array}{l}\text { Portu- } \\
\text { gezen }\end{array}$ & $\begin{array}{l}\text { Tsjechen/ } \\
\text { Tsjecho- } \\
\text { slowaken }\end{array}$ & Turken & Russen & \begin{tabular}{|l|}
$\begin{array}{l}\text { Joego- } \\
\text { slaviërs }\end{array}$ \\
\end{tabular} & \begin{tabular}{|l|} 
Oekraï- \\
ners
\end{tabular} & $\begin{array}{l}\text { Overige + } \\
\text { Vaderlands } \\
\text { lozen } \\
\end{array}$ & $\begin{array}{l}\text { Totaal } \\
\text { Buiten- } \\
\text { landers } \\
\end{array}$ & Belgen & $\begin{array}{l}\text { Totaal } \\
\text { Ondergrond }\end{array}$ \\
\hline I95I & $\cdot$ & $\mathrm{I} 23$ & $\cdot$ & 72 & 227 & 304 & 295 & I5.796 & 8.206 & 24.002 \\
\hline 1952 & - & II3 & $\bullet$ & 74 & 210 & 248 & 238 & 15.825 & 7.992 & $23.8 \mathrm{I} 7$ \\
\hline 1953 & $\bullet$ & IIO & $\bullet$ & 74 & $22 \mathrm{I}$ & 202 & 250 & I5.037 & 7.925 & 22.960 \\
\hline I954 & $\cdot$ & I04 & • & 73 & I93 & 176 & I75 & 13.903 & 8.089 & 21.992 \\
\hline I955 & 4 & 87 & • & I34 & I99 & • & 235 & I4.694 & $7 \cdot 544$ & 22.238 \\
\hline 1956 & 5 & 80 & • & 99 & I59 & • & 201 & I4.I24 & 6.674 & 20.798 \\
\hline I957 & 6 & 70 & $\bullet$ & II6 & 176 & $\bullet$ & I77 & I5.455 & 6.309 & 21.764 \\
\hline 1958 & 5 & 63 & $\cdot$ & 89 & 158 & $\cdot$ & I77 & I4.035 & 5.747 & I9. 782 \\
\hline I959 & 4 & $5 \mathrm{I}$ & - & 75 & I3I & - & 153 & $\mathrm{I} 2.0 \mathrm{I} 3$ & 4.738 & I6.75I \\
\hline I96o & 5 & 45 & $\cdot$ & 55 & 107 & $\cdot$ & $\mathrm{I} 20$ & 9.9II & $3.68 \mathrm{I}$ & $\mathrm{I} 3.592$ \\
\hline I96I & $\mathrm{I} 2$ & 36 & $\cdot$ & $4 \mathrm{I}$ & 176 & $\cdot$ & I33 & 8.807 & 3.238 & I2.045 \\
\hline
\end{tabular}




\begin{tabular}{|c|c|c|c|c|c|c|c|c|c|c|}
\hline & $\begin{array}{l}\text { Portu- } \\
\text { gezen }\end{array}$ & \begin{tabular}{|l|} 
Tsjechen/ \\
Tsjecho- \\
slowaken
\end{tabular} & Turken & Russen & $\begin{array}{l}\text { Joego- } \\
\text { slaviërs }\end{array}$ & $\begin{array}{l}\text { Oekraï- } \\
\text { ners }\end{array}$ & $\begin{array}{l}\text { Overige + } \\
\text { Vaderlands } \\
\text { lozen }\end{array}$ & $\begin{array}{l}\text { Totaal } \\
\text { Buiten- } \\
\text { landers } \\
\end{array}$ & Belgen & $\begin{array}{l}\text { Totaal } \\
\text { Ondergrond }\end{array}$ \\
\hline 1962 & I7 & 37 & • & $3 \mathrm{I}$ & 92 & • & 77 & 8.837 & 2.762 & II.599 \\
\hline 1963 & 29 & 34 & I.I7I & 28 & 83 & $\cdot$ & 78 & 9.288 & 2.564 & II. 852 \\
\hline 1964 & $\mathrm{I} 26$ & 28 & 2.203 & $2 \mathrm{I}$ & 82 & - & 87 & 10.064 & 2.286 & $\mathrm{I} 2.350$ \\
\hline 1965 & 52 & 23 & I.807 & I9 & 60 & $\cdot$ & 83 & 7.866 & $\mathrm{I} .8 \mathrm{I} 8$ & 9.684 \\
\hline I966 & 39 & I8 & $\mathrm{I} .267$ & $\mathrm{I} 4$ & 43 & - & 78 & 6.089 & I. 473 & $7 \cdot 5^{62}$ \\
\hline I967 & 36 & 17 & 986 & 8 & 35 & - & 59 & 5.IIO & $\mathrm{I} .228$ & $6.33^{8}$ \\
\hline I968 & 32 & I5 & 898 & IO & 33 & - & 46 & 4.449 & I.069 & $5 \cdot 518$ \\
\hline r969 & 29 & II & 770 & 5 & 23 & $\bullet$ & 39 & $3 \cdot 44 \mathrm{I}$ & 777 & 4.218 \\
\hline I970 & 22 & $\cdot$ & 709 & - & $\bullet$ & - & 247 & 3.194 & 706 & 3.900 \\
\hline I97I & 20 & • & $67 \mathrm{I}$ & • & • & • & $20 I$ & 2.765 & $58 \mathrm{I}$ & $3 \cdot 346$ \\
\hline I972 & I9 & • & 672 & • & • & • & 185 & 2.598 & 504 & 3.102 \\
\hline I973 & I7 & • & 594 & • & • & • & $\mathrm{I} 4 \mathrm{I}$ & 2.209 & 426 & 2.635 \\
\hline I974 & $\mathrm{I} 2$ & - & 480 & - & • & - & 95 & I.985 & 326 & $2.0 I I$ \\
\hline I975 & IO & • & 432 & • & • & • & 64 & I. $35^{6}$ & 247 & I. 603 \\
\hline I976 & IO & • & 336 & • & • & $\cdot$ & 46 & 998 & I69 & I.I67 \\
\hline
\end{tabular}

Bron: 'Technische Kenmerken van de Belgische Steenkolenontginning', Annales des Mines de Belgique, I954-I970; RAH, archief FEDECHAR, inv.nr. 6I2: 'Statistieken'; inv.nr. 6I4: 'Statistieken over tewerkgesteld personeel'.

N.B.: Vanaf 1970 worden (West)Duitsers, Fransen, Nederlanders, Luxemburgers, Hongaren, Balten, Tsjechen-Tsjechoslowaken, Russen en Joegoslaviërs niet meer apart geteld. Zij vallen vanaf dan onder de categorie 'Overige en Vaderlandslozen'.

Noot bij tabel bijlage 12

I Esten, Letten en Litouwers. 


\section{BIJLAGE 13}

Het aantal Belgen en buitenlanders in het bovengrondse personeelsbestand van de Luikse mijnen, I95I-I976

\begin{tabular}{|c|c|c|c|}
\hline & Belgen & Buitenlanders & Totaal Bovengrond \\
\hline I95I & 6.784 & 945 & 7.729 \\
\hline 1952 & 6.572 & 922 & 7.494 \\
\hline 1953 & 6.570 & 938 & 7.506 \\
\hline 1954 & $6.05 \mathrm{I}$ & 843 & 6.894 \\
\hline 1955 & $5.65 \mathrm{I}$ & 900 & $6.55 \mathrm{I}$ \\
\hline 1956 & 5.555 & 892 & 6.447 \\
\hline 1957 & 5.391 & 916 & 6.307 \\
\hline 1958 & 5.099 & 910 & 6.009 \\
\hline 1959 & 4.437 & 709 & 5.146 \\
\hline 1960 & $3 \cdot 742$ & 628 & 4.370 \\
\hline I96I & 3.437 & 635 & 4.072 \\
\hline 1962 & 3.139 & 697 & 3.836 \\
\hline 1963 & 3.093 & 838 & $3.93 \mathrm{I}$ \\
\hline 1964 & $2.85 \mathrm{I}$ & 875 & 3.726 \\
\hline 1965 & 2.208 & 8I9 & 3.027 \\
\hline 1966 & I.809 & 752 & $2.56 \mathrm{I}$ \\
\hline 1967 & I. 548 & 647 & 2.195 \\
\hline 1968 & I. 367 & 600 & I.967 \\
\hline 1969 & I.OII & 488 & I.499 \\
\hline 1970 & $95 \mathrm{I}$ & 505 & I. 456 \\
\hline I97I & 786 & $4 \mathrm{I} 7$ & $\mathrm{I} .203$ \\
\hline 1972 & 713 & 395 & I.IO8 \\
\hline 1973 & $62 \mathrm{I}$ & 332 & 953 \\
\hline 1974 & 465 & 270 & 735 \\
\hline 1975 & 286 & 175 & 46I \\
\hline 1976 & 200 & I2I & 321 \\
\hline
\end{tabular}

Bron: 'Technische Kenmerken van de Belgische Steenkolenontginning', Annales des Mines de Belgique, I954-I970; RAH, archief FEDECHAR, inv.nr. 6I2: 'Statistieken'; inv.nr. 6I4: 'Statistieken over tewerkgesteld personeel'. 


\title{
Gebruikte afkortingen
}

\author{
AEL Archives de l'Etat à Liège \\ Amsab Instituut voor Sociale Geschiedenis \\ CLADIC Centre liégeois d'archives et de documentation de l'industrie charbonnière \\ FNROM Fonds National de Retraite des Ouviers Mineurs \\ GIS Geographic Information System \\ IHOES Institut d'Histoire Ouvrière Economique et Sociale \\ INAMI Institut National d'Assurance Maladie-Invalidité \\ NIS/INS Nationaal Instituut voor de Statistiek/Institut National de Statistique \\ RAH Rijksarchief Hasselt \\ RAL Rijksarchief Luik \\ RIZIV Rijksinstituut voor Ziekte- en Invaliditeitsverzekering
}




\section{Geraadpleegde bronnen}

\section{ARCHIEVEN}

CLADIC - Centre liégeois d'archives et de documentation de l'industrie charbonnière

- Caisse de Prévoyance - Livrets d'ouvriers

- Commission d'enquête sur la Durée du travail dans les mines de houille, Enquête orale. Dépositions des témoins. Section de Liège (Bruxelles ig07)

- Direction Générale des Mines à Bruxelles. Carte génerale des concessions houillères de Belgique Édition I946. Échelle I:40.000 (5042 - Institut Géographique Militaire 1947 (La Cambre-Bruxelles), Bassin du Sud (Feuille 6 - Liège; Feuille 5 - Waremme)

- Office National du Placement et du Chômage (Ministère du Travail et de la Prévoyance Sociale) Main-d'œuvre et production dans les mines (Bruxelles I954) s.p. (Collection 'Notes documentaires').

- Rapport mijnzetels van Bruno Guidolin

\section{IHOES - Institut d'Histoire Ouvrière Economique et Sociale}

- FNROM - Cartons Comptes/Rekenkaarten met geboortedatum in januari Igio

- L'Association Charbonnière de la Province de Liège: Dossiers 'Charbon Gratuit', Carton I, Circulaire du 9 Juin 1945

- L'Association Charbonnière de la Province de Liège: Dossiers Divers, Carton II, Directoire de l'Industrie Charbonnière. Direction 'Problèmes du Travail' - Avantages extra-légaux et extra-conventionnels aux ouvriers mineurs

- L'Association Charbonnière de la Province de Liège: Dossiers 'Durée du Travail', Carton IX, l'Industrie Charbonnière Belge devant le Problème de la Réduction de la durée du Travail, I9361937

- L'Association Charbonnière de la Province de Liège: Dossiers 'Durée du Travail', Carton IX, Durée du Travail souterrain dans les mines de Houille-A.R. du 15-I2-I939

\section{Rijksarchief Hasselt}

- Fédération des Charbonnages de Belgique (FEDECHAR, I909-I993)

Inventarisnummers:

567-597: Statistieken van FEDECHAR over de Belgische kolennijverheid, 1954-1976

606-609: Jaarlijkse statistische overzichten, I930-197I

6I0-6II: Statistieken van tewerkgesteld personeel, I943-1949

6I2: Statistieken van allerlei aard betreffende het tewerkgesteld personeel, I970-1976

613: Statistieken over tewerkgesteld personeel, toegekende werkvergunningen en buitenlandse arbeidskrachten, 1965-1983

6I4: Statistieken over tewerkgesteld personeel, binnenkomend en vertrekkend personeel, opsplitsing per nationaliteit, I950-I973

II2I: Briefwisseling met Waalse mijnen, I955-1975

I579-I580: Personeelsstatistieken; Briefwisseling en statistieken betreffende Belgische en vreemde arbeidskrachten, I930-I950 
I58I: Bescheiden met maandelijkse statistieken over het tewerkgesteld personeel, I95I-I953 (sic. omvat meerdere jaren)

1582: Bescheiden betreffende het tewerkgesteld personeel, 1952 (sic. omvat meerdere jaren)

I679: Bescheiden betreffende een onderzoek in de mijnen over de lonen op basis van de vooruitgang

in de productie, 1956

I868: Evolutie van de arbeidsvoorwaarden, I949-I954

I869: Kim \& Kimler rapport "Investigation about the Belgian Coal industry", I949

I870: Rapport sur le problème charbonnier en Belgique, I939

RIZIV/INAMI Hasselt: Dienst voor uitkeringen Cel Mijnwerkers

- FNROM-Rekenkaarten met geboortedatum in januari 1920

Regionaal Historisch Centrum Limburg, Maastricht

- Centraal Archief DSM, Personeel, nr. I79 (Rapport Staatsmijnen)

Sociaal Historisch Centrum voor Limburg, Maastricht

- Archief Gezamenlijke Steenkolenmijnen in Limburg (GSL), Statistiek VIII-I7 (Ovs)

\section{UITGEGEVEN BRONNEN}

L'administration communale de Liège, La Région Liégeoise. Démographie. Logement. Industrie et Commerce. L'Évolution depuis 1846 et les données du recensement général de 1947 (Liège 195I).

L'administration communale de Liège, La Région Liégeoise. Démographie. Logement. Industrie-Commerce-Services. L'Évolution depuis 1947 et les données du recensement général de 1961 (Liège ig66).

Ministère de l'Industrie et du Travail - Administration des Mines, Annales des Mines de Belgique - années 18g6-1934 (Bruxelles).

Ministère des affaires économiques / Ministerie van economische zaken - Administration des Mines/ Administratie van het mijnwezen, Annales des Mines de Belgiquel Annalen der Mijnen van België - années 1934-1983 (Bruxelles).

'Tableau des mines de houille en activité dans le royaume de Belgique', Annales des Mines de Belgique, I900-I920, I924-I94I.

'Statistique des mines, minières, carrières, usines métallurgiques et appareils à vapeur du Royaume de Belgique', Annales des Mines de Belgique, I920-1967.

'Statistiques. L'Industrie charbonnière belge pendant l'année-en/De Belgische steenkolennijverheid tijdens het jaar-in, I90I-I9I9, I923-I940, I946-I966', Annales des Mines de Belgique/Annalen der Mijnen van België I900-I920, I924-I94I, I944-I969.

'Statistique économique/Economische statistiek van de extractieve nijverheden en van de metaalnijverheid, I904-1973', Annales des Mines de Belgiquel Annalen der Mijnen van België, I905-1975.

'Statistique des industries extractives et métallurgiques et des appareils à vapeur, année I940', Annales des Mines de Belgique, 1947-48.

'Statistique des industries extractives et des appareils à vapeur, année 1953', Annales des Mines de Belgique, 1954 .

'L'exploitation charbonnière belge en I955', Annales des Mines de Belgique, Juillet 1956.

'Divers', Annales des Mines de Belgique, I92I-I923.

'Mines de houille', Annales des Mines de Belgique, I94I-I948.

'Mines de houille en activité', Annales des Mines de Belgique, Mai 1949, Mai 1950.

'Tableau des mines de houille en activité en I95I-I954, I955', Annales des Mines de Belgique, Mai I95I, 
Mai 1952, Mai 1953, Mai 1955 .

'Tableau des mines de houille/Steenkolenmijnen/Lijst der/van de Steenkolenmijnen', Annales des Mines de Belgiquel Annalen der Mijnen van België, Mai 1956, Mai 1957, Mai 1958, Mai 1959, Mai I96o, Mai/Mei ı96ı, Mai/Mei 1962, Mai/Mei ı663, Mai/Mei 1964, Mai/Mei 1965, Avril/April ı666, Avril/April I967, Avril/April ı968, Avril/April ı969, Avril/April 1970, Mai/Mei 1971, Février/Februari 1972, Avril/April 1973, Avril/April 1974, Avril/April 1975, Janvier/Januari 1976, Avril/April 1977, Avril/April 1978, Avril/April 1979, 4/1980.

'Mines de Houille au I/I/1978-r979', Annales des Mines de Belgique, Avril I978, Avril 1979.

'Aspects techniques de l'exploitation charbonnière belge en /Technische kenmerken van de Belgische Steenkolenontginning in 1954, I955, I956, I957, 1958, 1959, I960, I961, 1962, 1963, 1964, 1965, I966, I967, I968, 1969, 1970, 1971, 1972, 1973, 1974, 1975, 1976, I977’, (Extrait des) Annales des Mines de Belgique/Annalen der Mijnen van België, Janvier/Januari 1956, Août/Augustus 1957, Septembre/September 1958, Septembre/September 1959, Novembre/November 1960, Septembre/September I961, Septembre/September 1962, Novembre/November 1963, Janvier/Januari 1965, Decembre/ December 1965, Octobre/Oktober 1966, Janvier/Januari 1968, Octobre/Oktober 1969, Avril/April I970, Novembre/November 197I, Mai/Mei 1972, Juillet-Août/Juli-Augustus 1973, Juin/Juni I974, Juillet-Août/Juli-Augustus I975, Octobre/Oktober 1976, Juillet-Août/Juli-Augustus 1977, Septembre/September 1978, Juillet-Août/Juli-Augustus 1979.

'Ontwikkeling van het personeelsbestand. Indeling van de arbeiders naar nationaliteit', in: Extrait des Annales des Mines de Belgique/Annalen der Mijnen van België, I958, I970, I972.

'Statistique sommaire (de l'exploitation charbonnière, des cokeries, des fabriques d'agglomérés et aperçu du marché des combustibles solides)/Beknopte statistiek (van de kolenwinning, de cokesen de agglomeratenfabrieken en overzicht van de markt van de vaste brandstoffen)', Annales des Mines de Belgique/Annalen der Mijnen van België, Mars/Maart 1969, Septembre/September 1969, Juin/ Juni 1970, Juin/Juni 1971, Novembre /November 1972, Mai /Mei 1974, Mai/Mei 1975, Novembre/ November 1972, Juin/Juni 1973, Mai/Mei 1975, Mei/Mai 1976, Mei/Mai 1977.

Comptoir belge des Charbons/Belgisch Kolenbureau, Statistiques de base de l'industrie charbonnière/Basisstatistieken over de kolenindustrie (Brussel I964-1973, I978, I980).

Direction Générale des Mines à Bruxelles, Carte Générale des concessions houillères de Belgique-Bassin du Sud - Liège-feuille 6, édition 1946.

Pasinomie: collection complète des lois, décrets, arrêtés et règlements généraux qui peuvent être invoqués en Belgique (Bruxelles I889, igri en I9I4).

'Arrêté Royal de 8 août 1958 interdisant certains travaux souterrains aux travailleurs âgés de moins de 2I ans dans les mines, minières et carrières', Moniteur Belge, 2I Août I958.

'Arrêté Royal de 4 Avril 1972 interdisant aux jeunes travailleurs de moins de I6 ans l'exécution de travaux souterrains', Moniteur Belge, 2I Avril 1972.

'Loi de I5 Juillet 1957 modifiant la loi sur le travail des femmes et des enfants', Moniteur Belge, 26 Juillet 1957 .

\section{Statistique de la Belgique}

Ministère de l'Intérieur, Population. Recensement général (15 octobre 1846) (Bruxelles I849).

Ministère de l'Intérieur, Industrie. Recensement général (15 octobre 1846) (Bruxelles I85I).

L'Industrie en Belgique. Exposé d'après le recensement de 188 o de l'état des principales industries (Bruxelles I887).

Ministère de l'Industrie et du Travail - Office du Travail, 'Volume IX, Dénombrement A: Répartition du personnel ouvrier après le taux des salaires dans les industries des mines, des carrières et des métaux', Recensement Général des industries et des métiers, 31 octobre 1896 (Bruxelles I9or).

Office du Travail. Section de la Statistique, Recensement de l'Industrie et du Commerce (31 décembre 1910) (8 
delen; Bruxelles I9I3-I92I).

Ministère de l'Intérieur et de l'Hygiène, Population - Recensement Général du 31 décembre 1910 (5 delen; Bruxelles I9I2-I6).

Ministère de l'Intérieur et de l'Hygiène, Population - Recensement Général du 31 décembre 1920 (3 delen; Bruxelles ig26).

Office central de statistique/Centrale dienst voor de statistiek, Population - Recensement Général au 31 décembre 1930/ Bevolking - Algemeene telling op 31 december 1930 (8 delen; Bruxelles/Brussel 1934-I938).

Ministerie van economische zaken. Centrale dienst voor de statistiek, Economische en sociale telling van 27 februari 1937 (5 delen; Brussel 1937).

Institut National de Statistique, Recensement général de la population, de l'industrie et du commerce au 31 décembre 1947 (I4 delen; Bruxelles I949-I953).

Ministère des affaires économiques et de l'énergie. Institut National de Statistique. Recensement général de la population, de l'industrie et du commerce au 31 décembre 1961 (Io delen; Bruxelles I963).

Nationaal Instituut voor de Statistiek, Algemene volkstelling op 31 december 1970 (I3 delen; Brussel 1972).

\section{GEBRUIKTE LITERATUUR}

'Chronologisch overzicht van de Europese Gemeenschap voor Kolen en Staal', in: Kolen, Charbon, Kohle, Coal, 225-229.

'Een schone strijd bekroond met een prachtige overwinning', De Belgische Vakbeweging (Officieel orgaan der Syndikale Kommissie) (29 juni 1936) nr. 6, Io9-II8 (AMSAB).

'L'immigration comme régulateur de main-d'œuvre', in: http://www.wallonie-en-ligne.net/1996_Societe-wallonne-depuis-Liberation/dossier/BI.HTM

'Le main-d'œuvre étrangère dans les charbonnages belges', Revue du Travail/Office du Travail de Belgique (Juin I930) 934-943.

'Le Mouvement Syndical. II. Réunions et Congres', Revue du Travail/Office du Travail de Belgique (Décembre 1927) I675-I683.

'Opmerkingen gemaakt omtrent het "Verslag Robinson” door de Belgische kolennijverheid', Annalen der Mijnen van België (195I) 479-487.

40 jaren spoor en mijnen in Zuid-Limburg, 1896-1936 (Heerlen 1936 ).

Alexandre, S. en J., 'Les migrations définitives et alternantes dans les régions voisines de la Région Industrielle Liégeoise', in: Fourmarier et al., Congrès de l'Association Française pour l'Avancement des Sciences, 3II-3I7.

Anciaux, H., 'L'industrie charbonnière pendant l'année i940. Statistique sommaire et vue d'ensemble sur l'exploitation', Annales des Mines de Belgique (1944) 769-794.

Annales des Mines de Belgique (Bruxelles I9II).

Arbeidsblad / Arbeidsambt van België, nr. 4-5, april-mei 1945 .

Arbeitsdokument für die Informationstagung, Berufsausbildung und Mechanisierung im Kohlenbergbau der Länder der Gemeinschaft' (Luxemburg 1956).

Art, J. (ed.), Hoe schrijf ik de geschiedenis van mijn gemeente? Deel I: 19de en 2oste eeuw (Centrum voor Geschiedenis Universiteit Gent) (Gent 1993).

Atlas Châtel et Dollfus. Les houillères européenes (Paris I93I).

Atlas van België / Atlas de Belgique. Nationaal Comité voor Geografie (Brussel I950-I972).

Attar, R., 'De geschiedenis van de Maghrebijnse immigratie naar België', in: Morelli (ed.), Geschiedenis van het eigen volk, 297-316.

Aubert, Roger, Felice Dassetto en Michel Dumoulin, Limmigration italienne en Belgique. Histoire, Langues, Identité. Bibliographie 1945-1985. Collana di cultura e umanità, 3 (Bruxelles/Louvain-la-Neuve I985). 
Bade, Klaus J., Europa in Bewegung. Migration vom späten 18. Jahrhundert bis zur Gegenwart (München 2000). Baeyens, André, 'Délimitation de la région', in: Lambert en Mineur, Léconomie de la région liégeoise, I5-2I. Bairin, P., Le travail des femmes dans mines de la province de Liège (1849-1859) (Liège 1976).

Balace, Francis, 'Du coup de semonce au coup de colère (I945-I950)', in: Dumoulin en Kupper (eds.), Histoire de la Wallonie, 302-310.

Bardoul, H.J., Personeelsverloop in het ondergrondse bedrijf der mijn Julia in een tijd van hoogconjunctuur. Scriptie (z.p. mei 1958).

Barlet, Jacques et al., Le patrimoine industriel et sa reconversion. Wallonie-Bruxelles (Liège 1987).

Baud, Michiel en Theo Engelen, 'Nawoord: arbeid, inkomen en gezinsstrategie', in: Baud en Engelen, Samen wonen, samen werken?, I49-158.

Baud, Michiel en Theo Engelen, Samen wonen, samen werken? Vijfessays over de geschiedenis van arbeid en gezin (Hilversum 1994).

Baudhuin, Fernand, Histoire économique de la Belgique, 1914-1939. Tôme premier: Grandeurs et misères d'un quart de siècle (Bruxelles I944).

Bayar, A. (m.m.v. L. Ertorun), 'Een economisch overzicht van de Turkse inwijking', in: Morelli (ed.), Geschiedenis van het eigen volk, 317-333.

Belchem, John en Klaus Tenfelde (eds.), Polish and Irish Migration in Comparative Perspective (Essen 2003).

Belder, Jos De en Eric Vanhaute, 'Sociale en economische geschiedenis', in: Art (ed.), Hoe schrijf ik de geschiedenis van mijn gemeente?, 79-158.

Berger, Stefan, 'Introduction', in: Berger et al., Towards a comparative history, I-II.

Berger, Stefan, Andy Croll en Norman LaPorte (eds.), Towards a comparative history of coalfield societies (Aldershot 2005).

Berwart, Roger et al., L'héritage des gueules noires de l'histoire au patrimoine industriel (Charleroi 1994).

Bless, M.J.M., J. Bouckaert, J.A.M. Finger en E. Paproth, Oorsprong en winning van steenkool langs Henne, Samber, Maas en Worm (Valkenburg a/d Geul/Tervuren I984).

Blomme, Jan en Peter Scholliers, 'De economische geschiedenis van België tijdens de nieuwste tijd. Onderzoekstrends in de jaren tachtig', NEHA Bulletin. Tijdschrift voor de economische geschiedenis in Nederland 7 (I993) nr. I, 5-38.

Boucneau, Johan, Hier Porions vormen? Een historisch-pedagogisch onderzoek naar de behoefte aan en het ontstaan van mijnbouwonderwijs in het Kempisch bekken - 1901-1954. Onuitgegeven licentiaatsverhandeling in de Pedagogische wetenschappen (Leuven I987).

Boulger, D.C., Belgian Life in Town and Country (New York 1904).

Bourgeois, Walter, 'Projet de normalisation des sections de mineurs des Ecoles Industrielles moyenne', Annales des Mines de Belgique (1943) I53-167.

Brabander, G.L. De, J. Gadisseur, R. Gobyn en J. Liébin (ed.), De industrie in België. Twee eeuwen ontwikkeling 1780-1980. Gemeentekrediet van België en Nationale Maatschappij voor Krediet aan de Nijverheid (Brussel I98I).

Brabander, Guido L. De, De regionaal-sectoriële verdeling van de economische activiteit in België (1846-1979): een kritische studie van het bronnenmateriaal. Interuniversitair centrum voor hedendaagse geschiedenis, Bijdragen 97 (Leuven/Brussel I984).

Bracke, Nele, 'De vrouwenarbeid in de industrie in België omstreeks I9oo. Een 'vrouwelijke' analyse van de industrietelling van 1896 en de industrie- en handelstelling van I9Io', Belgisch Tijdschrift voor Nieuwste Geschiedenis/Revue Belge d'Histoire Contemporaine XXVI (I996) nrs. I-2, I65-207.

Brassé, Paul en Willem van Schelven, Assimilatie van vooroorlogse immigranten. Drie generaties Polen, Slovenen en Italianen in Heerlen ('s-Gravenhage I980).

Brial, Jean-Paul, L'angoissant problème du charbon. L'avenir de la Belgique dépend de sa solution (Charleroi I945). 
Brood en Rozen, Tijdschrift voor de Geschiedenis van Sociale Bewegingen themanummer 3: Arbeid en arbeidsverhoudingen in de Limburgse mijnen (1999).

Brood en Rozen, Tijdschrift voor de Geschiedenis van Sociale Bewegingen themanummer 3: Tutti Cadaveri! (2006).

Bruwier, Marinette, 'La prépondérance de la grande industrie', in: Hasquin (ed.), La Wallonie, 93-II5.

Bruwier, Marinette, 'Que sont devenus les mineurs des charbonnages belges? Une première approche: problématique et méthodologie’, Belgisch Tijdschrift voor Nieuwste Geschiedenis/Revue Belge d'Histoire Contemporaine XIX (I988) nrs. I-2, 173-203.

Bruyn, André De, Anciennes Houillères de la Région liégeoise (Liège I988).

Bunge, E.M., In het schijnsel van de mijnlamp (Amsterdam z.j.).

C.E.C.A. 1952-1962. Résultats. Limites. Perspectives. Communauté Européenne du Charbon et de l' AcierHaute Autorité (Luxembourg 1963).

Caestecker, Frank, Alien Policy in Belgium, 1840-1940. The Creation of Guest Workers, Refugees and Illegal Aliens (New York 2000).

Caestecker, Frank, 'Arbeidsmarktstrategieën in de Belgische mijnindustrie tot 1940', Tijdschrift voor Sociale en Economische Geschiedenis 5 (2008) nr. 3, 30-52.

Caestecker, Frank, 'Centraaleuropese mijnwerkers in België', in: Morelli (ed.), Geschiedenis van het eigen volk, $165-174$.

Caestecker, Frank, 'Polish Migrants' Children in Interwar Belgium: the Choice for Ethnic Education', in: Belchem en Tenfelde (eds.), Polish and Irish Migration, I69-182.

Caestecker, Frank, 'Vakbonden en etnische minderheid, een ambigue verhouding. Immigratie in de Belgische mijnbekkens, I900-I940', Brood en Rozen I (I997) 5I-63.

Caestecker, Frank, 'Vervanging of verdringing van de buitenlandse mijnwerkers in Limburg. De emancipatie van de Limburgse mijnwerkers. Migratie naar het Limburgse mijnbekken. Een vergelijking met de migratie naar de Waalse mijnen (I920-I940)', Limburg-Het Oude Land van Loon 77 (1998) 309-326.

Caestecker, Frank, 'Vlaamse arbeidsmigranten in Wallonië', in: Goddeeris en Hermans (red.), Vlaamse migranten in Wallonie, 42-67.

Campbell, A., N. Fishman en D. Howell, Miners, unions and politics, 1910-1947 (Aldershot 1996).

Caulier-Mathy Nicole, 'De wording van de steenkoolindustrie', in: Van der Herten et al. (red.), Nijver België, $177-223$.

Caulier-Mathy, Nicole, 'Industrie et politique au Pays de Liège. Frédéric Braconier (I826-I9I2)', Belgisch Tijdschrift voor Nieuwste Geschiedenis/Revue Belge d'Histoire Contemporaine (I980) nrs. I-2, 3-83.

Caulier-Mathy, Nicole, 'L'industrie houillère du bassin liégeois au XIXe siècle', in: Herrmann en Wynants (eds.), Acht Jahrhunderte Steinkohlenbergbau, I5 I-I74.

Caulier-Mathy, Nicole, 'La persistance de l'Ancien Regime: le droit liégeois et la loi imperiale de I8Io sur les mines', Belgisch Tijdschrift voor Nieuwste Geschiedenis/Revue Belge d'Histoire Contemporaine (I983) nrs. I-2, 53-89.

Caulier-Mathy, Nicole, 'Le patronat et le progres technique dans les charbonnages liégeois I80oI9I4', in: Kurgan-van Hentenryk en Stengers, L'innovation technologique, 4I-6I.

Caulier-Mathy, Nicole, 'Les dirigeants de l'industrie houillère belge de 1935-1955', Belgisch Tijdschrift voor Nieuwste Geschiedenis/Revue Belge d'Histoire Contemporaine XIX (I988) nrs. I-2, 35-54.

Caulier-Mathy, Nicole, Statistiques de la province de Liège sous le Régime hollandais. Centre interuniversitaire d'histoire contemporaine, Cahiers 25 (Louvain I962).

Centenaire de l' Association des Ingénieurs sortis de l'École de Liège (A.I.Lg) Congres 1947. Section mines (Liège 1949).

Chapelle-Duliere, Jacqueline, 'La mobilité des mineurs du charbonnage du Bois-du-Cazier (Igoo- 
1945)', Revue du Nord LXXII (Janvier-Mars I990) nr. 284, II3-I33.

Chapelle-Duliere, Jacqueline, 'Septembre I893 au charbonnage de Bois-du-Luc: une grève au féminin?', Belgisch Tijdschrift voor Nieuwste Geschiedenis/Revue Belge d'Histoire Contemporaine XIX (Ig88) nrs. $3-4,247-267$.

Collinson, D., Managing the shopfloor. Subjectivity, masculinity, and workplace culture (New York 1992).

Conseil Économique Wallon, Economie wallonne. Rapport présenté au gouvernement belge par le conseil économique wallon le 20 mai 1947 (z.p. z.j.).

Coppé, Albert, Problème d'économie charbonnière. Essai d'orientation économique (Bruges I940).

Courtois, L., J. Pirotte en F. Rosart (eds.), Femmes des années '80: un siècle de condition féminine (1889-1989) (Louvain-la-Neuve r989).

Custers, Raf, 'Spaanse mijnwerkers voor en na Marcinelle', Brood en Rozen 3 (2006) 30-45.

Davin, Louis E. en $\mathrm{H}$. Priebe, Économie régionale sans frontière: actes du Colloque scientifique belgo-allemand d'économie régionale, Liège, octobre 1965 (Liège 1968) (Travaux du Séminaire interdisciplinaire des professeurs Harsin et Davin; no 3).

Davin, Louis E. en Jean Le Pas, Industries d'avenir: MarchéCommun et province de Liège (Liège I962) (Bibliothèque de l'Institut de Science Économique, Université de Liège; no. 2).

Davin, Louis E., Léon Degeer en Jean Paelinck, Problèmes de croissance: dynamique économique de la région liégeoise (Liège 1959).

De Belder, Jos, zie: Belder, Jos De

De Brabander, G.L., zie: Brabander, G.L. De

De Bruyn, André, zie: Bruyn, André De

De Groeve, A., zie: Groeve, A. de

De Groot, Gertjan, zie: Groot, Gertjan de

De Groote, V., zie: Groote, V. De

De Leener, Georges, zie: Leener, Georges De

De Maeyer, Jan, zie: Maeyer, Jan De

De Rijck, Tine, zie: Rijck, Tine De

De Roeck, Marie-Louise, zie: Roeck, Marie-Louise De

De Vos, Patrick, zie: Vos, Patrick De

De koolindustrie in dienst van het land. Federatie der Belgische Kolenverenigingen (Brussel I95I).

Delaet, Jean-Louis, 'Huit siècles d'exploitation charbonnière en Wallonie', Brood en Rozen 3 (I999) 9I99.

Delaet, Jean-Louis, 'La centrale syndicale des travailleurs des mines de Belgique et la fermeture des charbonnages wallons (I947-I960)', Belgisch Tijdschrift voor Nieuwste Geschiedenis/Revue Belge d'Histoire Contemporaine XIX (I988) nrs. I-2, I47-I7I.

Delbroek, Bart et al. (red.), De koolputters. Geschiedenis van de Limburgse mijnwerkers, I8 dln. (Zwolle 20052007).

Delbroek, Bart, 'In de put'. De dagelijkse werking van de arbeidsmarkt voor mijnwerkers in Belgisch-Limburg (1900-1966). Onuitgegeven manuscript Vrije Universiteit Brussel (Brussel 20II).

Delbroek, Bart, 'Op zoek naar koolputters. Buitenlandse mijnwerkers in Belgisch-Limburg in de twintigste eeuw', Tijdschrift voor Sociale en Economische Geschiedenis 5 (2008) nr. 3, 80-103.

Delbroek, Bart, 'Werkboekjes in de 200 eeuw: de charmes van een vergeten bron', Brood en Rozen 2 (2006) 7-27.

Delforge, Paul (ed.), Wallons d'ici et d'ailleurs. La société wallonne depuis la Libération (Charleroi 1996)

Demeure de Lespaul, Adolphe, Crise. Étude d'une Concentration de l'Exploitation des Mines de Houille des Bassins du Sud de la Belgique (Bruxelles r93r).

Demeure de Lespaul, Charles, L'Avenir de notre production de houille. Extrait de Bulletin de l'Institut de 
Recherches Economiques et Sociales de l'Université de Louvain, XIIIe année, n. 3, I947 (Louvain 1947).

Demeure, Charles, 'L'Industrie Charbonnière Belge et la Crise', in: Bulletin de l'Institut de Recherches Économiques, IIIe année, nr. 2 (Louvain I932) I65-I88.

Demeure de Lespaul, Charles, L'industrie charbonnière belge devant la menace des importations. Extrait de Bulletin de l'Institut de Recherches Economiques et Sociales de l'Université de Louvain, XVe année, n. I, I949 (Louvain 1949).

Demeure de Lespaul Charles, L'industrie charbonnière belge et le plan Schuman, Extrait du Bulletin de I'Institut de Recherches Économiques et Sociales de l'Université de Louvain, XVIIe année, nr. 3, mai I95I (Louvain I95I).

Demeure de Lespaul, Charles, La situation inquiétante de l'industrie houillère belge, Extrait du Bulletin de l'Institut de Recherches Économiques et Sociales de l'Université de Louvain, XIVe année, nr. 4, août I948 (Louvain I948).

Demeure de Lespaul, Charles, 'La solution du problème charbonnier belge', in: Bulletin de l'Institut de Recherches Économiques, IXe année, nr. 4 (Louvain 1938) 303-320.

Demoulin, Bruno en Jean-Louis Kupper, Histoire de la Wallonie: de la préhistoire au XXIe siecle (Toulouse 2004).

Deneubourg, P. en Ch. Wouters, Réflexions sur le travail des femmes dans les mines (Mons I870).

Deprez, Marcel, 'Siamo tutti neri!' Etudes et témoignages sur l'immigration italienne en Wallonie. IHOES (Seraing I998).

Derks, Wim, 'De arbeidsmarkt in Limburg I960-2005: is de sluiting van de mijnen verwerkt?', Studies over de sociaal-economische geschiedenis van Limburg/Jaarboek van het Sociaal Historisch Centrum voor Limburg L (2005) I73-196.

Deruette, Serge, 'La grève de l'été 1932 dans l'histoire ouvrière belge', in: Deruette et al., Mineurs en lutte!, I3-6r.

Deruette, Serge, Michel Hanotte, Jacques Lemaître en Robert Devleeshouwer, Mineurs en lutte! La grève générale de l'été '32. Fondation Joseph Jacquemotte et Institut d'Histoire Ouvrière, Economique et Sociale (Bruxelles/Seraing I994).

Dethier, N., Centrale Syndicale des Travailleurs des Mines de Belgique. 60 années d'action 1890-1950 (La Louviere I950).

Devos, Greta, 'Belgische initiatieven in de erts- en steenkoolmijnen en in de metaalindustrie in grensgebieden, $\mathbf{I}^{\mathrm{e}}$-begin $20 \mathrm{e}$ eeuw', in: J.C.G.M. Jansen (red.), Economische betrekkingen in grensregio's, 173-193.

Die Berufsausbildung im Steinkohlenbergbau. Länder der Gemeinschaft. Europäische Gemeinschaft für Kohle und Stahl. Hohe Behörde (Luxemburg 1956).

Donnay, P. en L. Loneux, De Luikse steenkolenmijnen (Luik 1980).

Doorslaer, Bert Van, 'Inleiding', in: Minten et al., Een eeuw steenkool in Limburg, 22.

Doorslaer, Bert Van, Koolputterserfgoed. Een bovengrondse toekomst voor een ondergronds verleden. Provinciaal Centrum voor Cultureel Erfgoed Provincie Limburg (z.p. 2002).

Doorslaer, B. Van en P. Viaene, L'Héritage des gueules noirs, de l'histoire au patrimoine industriel. Wallonie, Limbourg, Nord-Pas-de-Calais, Aix-la-Chapelle - Koolputterserfgoed in Noord-Frankrijk, Wallonië, beide Limburgen en het Akense mijnbekken. Provinciaal Centrum voor Cultureel Erfgoed, officieuze gelegenheidsvertaling t.g.v. opstelling van de tentoonstelling in de voormalige persluchthal van de mijnzetel Winterslag, 2I september tot en met 27 oktober 1996 (Borgloon/Rijkel).

Dumoulin, Bruno en Jean-Louis Kupper (eds.), Histoire de la Wallonie. De la préhistoire au XXIe siècle (Toulouse 2004).

Dumoulin, Michel (ed.), La question charbonniere et l'immigration en Belgique. Bibliographie rétrospective 
1945-1970 (SYBIDi Document IV, r988).

Dumoulin, Michel, 'Pour une histoire de l'immigration italienne en Belgique: 1945-1956', in: Aubert et al., Limmigration italienne en Belgique, 27-52.

Edwards, C. en M. Bird, Management control and union power: a study of labour relations in coal-mining (Oxford I989).

Eeckhout, Patricia Van den, 'Van werkboekje tot arbeidscontract. De negentiende-eeuwse arbeidsrelaties revisited', Belgisch Tijdschrift voor Nieuwste Geschiedenis/Revue Belge d'Histoire Contemporaine XXXV (2005) 2-3, 153-200.

Eeckhout, Patricia Van den en Guy Vanthemsche, Bronnen voor de studie van het hedendaagse België, $19^{\text {de- }}$ $20^{\text {ste }}$ eeuw (Brussel 1999).

Eeckhout, Patricia Van den en Peter Scholliers, 'Social history in Belgium: old habits and new perspectives', Tijdschrift voor Sociale Geschiedenis 23 (I997) nr. 2, I47-I8I.

Eenheid en scheiding van de beide Limburgen. Verslagbundel van het op 26 mei 1989 te Alden Biesen gehouden congres bij gelegenheid van de herdenking 150 jaar beide Limburgen. Maaslandse Monografieën, 47 (Leeuwarden I989).

EGKS, Europese Gemeenschap voor Kolen en Staal (Amsterdam 1959).

Eisenstein, Z.R. (ed.), Capitalist Patriarchy and the Case for Socialist Feminism (New York 1979).

Eycken, M. Van der, 'Verkeerswegen als bindteken? Een overzicht van 150 jaar relaties tussen beide Limburgen op het vlak van de verkeersinfrastructuur', in: Eenheid en scheiding, 69-94.

Eycken, Michel Van der (m.m.v. Chantal Vancoppenolle), Inventaris van het archief van de Fédération des charbonnages de Belgique (FEDECHAR) 1909-1993 (Brussel 2007).

Feldman, Gerald D. en Klaus Tenfelde (ed.), Workers, owners and politics in coal mining. An international comparison of industrial relations (New York/Oxford/Munich 1990).

Foulon-Busine, Françoise, Autour des fosses. Labeur et vie quotidienne dans le borinage minier (Boussu 2002).

Fourmarier, P., O. Tulippe, F. Dussart, S. en J. Alexandre, J. Sporck en Ch. Christians, Congrès de l'Association Française pour l'Avancement des Sciences. Luxembourg 1953 (Liège I955).

Fraikin, J., 'Het Waalse ijzer in het vuur. De Luikse ijzerindustrie tussen de $\mathrm{I} 6^{\text {de }}$ en $18^{\text {de }}$ eeuw', in: Manning en De Vroede (red.), Spectrum atlas van historische plaatsen, I60-I63.

Gaier, Claude, 'Het Luikse mijnbekken', in: Van Doorslaer en Viaene, L'Héritage des gueules noirs, 37-38.

Gaier, Claude, 'Le bassin minier de Liège', in: Berwert et al., L'héritage des gueules noires, I57-Igo.

Gaier, Claude, Huit siècles de houillerie liégeoise. Histoire des hommes et du charbon à Liège (Liège I988).

Gales, Ben, Delven en slepen. Steenkolenmijnbouw in Limburg: techniek, winning en markt gedurende de achttiende en negentiende eeuw. Maaslandse Monografieën, 67 (Hilversum 2004).

Gales, Ben, 'Goed betaald? Mijnwerkerslonen en arbeidsmarkt in het Nederlands-Duits-Belgische grensgebied in de achttiende en negentiende eeuw', Studies over de sociaal-economische geschiedenis van Limburg/Jaarboek van het Sociaal Historisch Centrum voor Limburg LIII (2008) 57-87.

Gales, B.P.A., H. van der Hoogen, G. Legebeke en J. de Roos, Bedrijfsvoering, arbeidsverhoudingen in de Limburgse mijnen 1920-1940. Doctoraalscriptie Katholieke Universiteit Nijmegen (Nijmegen z.j.).

Gasson, P.M., Histoire des sciences et des techniques: John Cockerill et le nouveau monde industriel: ses précurseurs, ses contemporains, ses successeurs: la découverte de la terre et l'exploitation de ses ressources des origines à nos jours (Seraing 1980).

Geebelen, Willy, De personeelsorganisatie in de Belgische steenkolenmijnen. Licentiaatsverhandeling Handels- en Financiële Wetenschappen (Leuven 1944).

Geerkens, Eric, 'La rationalisation dans les charbonnages belges pendant l'entre-deux-guerres', in: Herrmann en Wynants (eds.), Acht Jahrhunderte Steinkohlenbergbau, 339-365.

Geerkens, Eric, La rationalisation dans l'industrie belge de l'Entre-deux-guerres. Histoire quantitative et développement de la Belgique aux XIXe et XXe siècles, 2e série (XXe siècle) t. III, vol. rb (Bruxelles 2004). 
Genderwetswijzer Arbeid, Nederlandstalige Vrouwenraad (2004).

Georges, Edmond et al. (ed.), Seraing. Herinneringen van arbeiders 1886-1986. Vert. uit het Frans (Nijmegen 1987$)$.

Gillen, Jacques, 'L'histoire de l'immigration vue à travers les archives du Fonds national de retraite des ouvriers mineurs', Brood en Rozen I (I998) 37-45.

Gillet, Marcel, Histoire sociale du Nord et de l'Europe du nord-ouest. Recherches sur les XIXe et XXe siècles (Lille I984).

Gillet, Marcel, 'Problèmes de méthode: L'utilisation par sondage des dossiers de la Caisse Autonome Nationale de Sécurité Sociale dans les Mines', in: Gillet, Histoire sociale, 51-54.

Gillingham, J., Geld maken in oorlogstijd. Economische collaboratie 1940-1945 (Leuven 1979).

Goddeeris, Idesbald, De Poolse migratie in België 1945-1950. Politieke mobilisatie en sociale differentiatie (Amsterdam 2005).

Goddeeris, Idesbald en Roeland Hermans (red.), Vlaamse migranten in Wallonië, 1850-2000 (Leuven 20II).

Grimmeau, Pierre, 'De immigratiegolven en de spreiding van de vreemdelingen in België', in: Morelli (ed.), Geschiedenis van het eigen volk, II5-I25.

Groeve, A. de, 'De Belgische Steenkoolindustrie', in: Kolen. Charbon. Kohle. Coal, 63-77.

Grond, A., 'Onze kolen, waar ze liggen en hoe ze ontstonden', Steenkool (I947) 7-9.

Groot, Gertjan de, Fabricage van verschillen. Mannenwerk, vrouwenwerk in de Nederlandse industrie (18501940) (Amsterdam 200I).

Groote, V. De, De pensioenregeling voor mijnwerkers in België. Licentiaatsverhandeling Bestuurswetenschappen (Brussel z.j.).

Haegendoren, Mieke Van en Bart Pluymers, 'Belgisch-Limburgse mijnwerkers in de jaren twintig. Willige slachtoffers van het kapitaal of een 'blauwe-maandag compagnie?', Tijdschrift voor Sociale Geschiedenis 24 (I998) nr. I, 3I-55.

Halleux, Robert en Alain Bouchard, Cockerill: deux siecles de technologie (Alleur 2002).

Hannecart, Roch, Le dernier carré. Les charbonniers belges, libres entrepreneurs face à la CEGA (1950-1959) (Bruxelles 2010).

Hanotte, Michel, 'Mineurs en lutte! La grève générale de l'été I932', in: Deruette et al., Mineurs en lutte!, 63-103.

Hansotte, Georges, Inventaire des archives du charbonnage des Six-Bonniers à Seraing (Bruxelles I959).

Hartmann, Heidi, 'Capitalism, patriarchy and job segregation by sex', in: Eisenstein (ed.), Capitalist Patriarchy, 206-247.

Hartog, F., Het Belgische wonder (Den Haag 1950).

Hasquin, Hervé (ed.), La Wallonie. Le pays et les hommes. Histoire - économies - sociétés. Tome II: de 1830 à nos jours (Bruxelles I976).

Haust, Jean, La houillerie liégeoise. I. Vocabulaire philologique et technologique de l'usage moderne dans le bassin de Seraing-Jemeppe-Flémalle (Liège 1925).

Havelange, Carl, Helin Etienne en Leboutte René, Vivre et survivre. Témoignages sur la condition populaire au pays de Liège XII-XXe siecles (Liège 1994) (Collection d'études publiée par le Musée de la Vie wallonne, 7).

Helfer, Malte, 'Meilensteine technischer Innovationen und ihre räumlichen auswirkungen im Steinkohlenbergbau der Nachkriegszeit. Eine vergleichende Betrachtung der Reviere Saar, Lothringen, Aachen, Wallonien und Campine', in: Herrmann en Wynants (eds.), Acht Jahrhunderte Steinkohlenbergbau, 403-425.

Herrmann, Hans-Walter en Paul Wynants (eds.), Acht Jahrhunderte Steinkohlenbergbaul Huit siècles de charbonnage (Namur 2002). 
Herten, Bart Van der, Michel Oris en Jan Roegiers (red.), Nijuer België. Het industriële landschap omstreeks 1850 ( Antwerpen-Brussel 1995).

Het probleem van de huisvesting in België, Nationaal Instituut voor Woning en Huisvesting (Brussel 1946). Hilden, Patricia J., 'The rhetoric and iconography of reform: women coal miners in Belgium, I840I9I4', The Historical Journal XXXIV (I99I) nr. 2, 4II-436.

Hilden, Patricia J., Women, work, and politics: Belgium 1830-1914 (Oxford I993).

Historiens et populations: Liber amicorum Etienne Hélin (Louvain-la-Neuve I99I).

Hoof, J. van, De arbeidsmarkt als arena. Arbeidsmarktproblemen in sociologisch perspectief (Amsterdam I987).

Hullebroeck, Patrick, 'Het algemene migrantenbeleid en de wetgeving over de vreemdelingen', in:

Morelli (ed.), Geschiedenis van het eigen volk, I33-I37.

Humphries, Jane, ““... the Most Free From Objection ...”. The Sexual Division of Labor and Women's

Work in Nineteenth-Century England', The Journal of Economic History XLVII (I987) nr. 4, 929-949.

Jaarverslag 1980, Nationaal Pensioenfonds voor Mijnwerkers (Brussel z.j.).

Jaarverslagen van den Ingenieur / Hoofd-Ingenieur / Inspecteur-Generaal der Mijnen (1898-1974).

Jacquemyns, Guillaume, La société belge sous l'occupation allemande 1940-1944 (Bruxelles 1950).

Jacquemyns, Guillaume, La vie sociale dans le borinage houiller. Notes, Statistiques, Monographies (Bruxelles 1939).

Jaffe, J., The struggle for market power: industrial relations in the British coal industry, 1800-1840 (Cambridge I99I).

Jansen, J.C.G.M. (red.), Economische betrekkingen in grensregio's in een industrieel tijdperk 1750-1965 - Wirtschaftliche Verflechtungen in Grensraümen in industriellen Zeitalter, 1750-1965 - Relations économiques dans les regions frontalières à l'ère industrielle, 1750-1965. Verslagbundel van het op I4 en I5 september 1995 te Maastricht gehouden congres van de Verenigingen voor economische geschiedenis in België, Duitsland en Nederland. Maaslandse monografieën, 58 (Leeuwarden 1996).

John, Angela, By the sweat of their brow: women workers at Victorian coal mines (London I984).

Joris, Freddy en Natalie Archambeaue, Wallonie. Atouts et références d'une Région. Gouvernement Wallon (z.p. 1995).

Kee, Peter, 'Dynamiek in de statistiek: arbeidsmarktdynamiek', in: Mol et al., Dynamiek in de sociale statistiek, 35-46.

Keymolen, Denise, 'Vrouwenarbeid in België omstreeks I860. Vigerende en alternatieve opvattingen m.b.t. vrouwelijke huis- en fabrieksarbeid', Tijdschrift voor Sociale Geschiedenis XXV (I982) nr. 8, I-29. Khoojinian, Mazyar, 'L'accueil et la stabilisation des travailleurs immigrés turcs en Belgique, 1963I980', Cahiers d'Histoire du Temps Présent/Bijdragen tot de Eigentijdse Geschiedenis I7 (2006) 73-Ir6.

Kisacik, Fendiye, Itinéraire Turc ou l'immigration turque dans l'industrie charbonnière belge. Centre liégeois d'archives et de documentation de l'industrie charbonnière (z.p. z.j.)

Kisacik, Fendiye, L'immigration turque dans l'industrie charbonnière belge. Eléments pour la comprehension de la politique de recrutement et de gestion de la main d'œuvre. Onuitgegeven licentiaatsverhandeling Université Libre (Bruxelles 2002).

Klank, Kristin, 'Secondary labour force or permanent staff? Foreign workers in the Aachen coal mines', Tijdschrift voor Sociale en Economische Geschiedenis 5 (2008) nr. 3, I26-I54.

Knotter, Ad, 'Inleiding', in: Kok et al., Levensloop en levenslot, I-I5.

Knotter, Ad, 'National states and transnational labour markets in the twentieth century. A comment', in: Walter (Hg.), Geschichte der Arbeitsmärkte, 313-317.

Kohlbacher, Jan, Het Russisch kamp. De kampen bij de Limburgse mijnen 1942-1965 (z.p. 1998).

Kohlbacher, Jan, 'Onderwijs en vakopleiding', in: De koolputters, deel II, 25I-270.

Kok, Jan, 'Collectieve strategie en individuele levensloop', in: Baud en Engelen, Samen wonen, samen werken?, 97-I2I. 
Kok, Jan et al., Levensloop en levenslot: arbeidersstrategieën van gezinnen in de negentiende en twintigste eeuw. Historia agriculturae, 29 (Groningen 1999).

Kolen, Charbon, Kohle, Coal. De mijnindustrie in de kolenproducerende landen der wereld (Amsterdam 1962).

Kreukels, L.H.M., Mijnarbeid: volgzaamheid en strijdbaarheid: geschiedenis van de arbeidsverhoudingen in de Nederlandse steenkolenmijnen, 1900-1940. Maaslandse Monografieën, 42 (Assen/Maastricht I986).

Kroker, Werner (ed.), Frauen und Bergbau. Zeugnisse aus fünf Jahrhunderten. Ausstellung des Deutschen Bergbau-Museums Bochum vom 29. August bis 10. Dezember 1989 (Bochum I989).

Kuborn, Hyacinthe, Rapport sur l'enquête faite au nom de l'Académie royale de médicine de Belgique par la Commission chargée d'étudier la question de l'emploi des femmes dans les travaux souterrains des mines (Bruxelles I868).

Kuborn, Hyacinthe, Topographie médicale du Royaume de Belgique. Zone VII. Bassins houillers. Sections 10 et 11 (Liège 1908).

Kumps, Anne-Maris en Robert Witterwulghe, 'Industrie: l'effondrement de la preponderance wallone', in: Hasquin (ed.), La Wallonie, 213-229.

Kurgan-Van Hentenryk, Ginette en Jean Puissant, 'Industrial relations in the Belgian Coal Industry since the End of the Nineteenth Century', in: Feldman en Tenfelde (ed.), Workers, Owners and Politics in Coal Mining, 203-270.

Kurgan-Van Hentenryk, G. en J. Stengers, L'innovation technologique. Facteur de changement (XIXe-XXe siecles) (Bruxelles I986).

Kurgan-Van Hentenryk, Ginette, Serge Jaumain en Valérie Montens, Dictionnaire des patrons en Belgique. Les hommes, les entreprises, les reseaux (Bruxelles 1996).

Kusters, Johan, De tocht der duizenden: Maaslandse brikkenbakkers naar Duitsland, 1840-1914 (Eisden I998).

La Belgique devant le Problème Charbonnier. Fédération des associations charbonnières de Belgique (Bruxelles i945).

Lambert, Paul en Joseph Mineur, L'économie de la région liégeoise. Analyse et perspectives. Éléments d'une politique (Paris ig6o).

Landry, Yves, John A. Dickinson, Suzy Pasleau en Claude Desama (eds.), Les chemins de la migration en Belgique et au Québec (Louvain-la-Neuve 1995).

Langeweg, Serge, 'Bekende buren en verre vreemden. Buitenlandse arbeiders in de Nederlandse steenkolenmijnen, I900-I974', Tijdschrift voor Sociale en Economische Geschiedenis 5 (2008) nr. 3, 53-79.

Langeweg, Serge, Mijnbouw en arbeidsmarkt in Nederlands-Limburg. Herkomst, werving, mobiliteit en binding van mijnwerkers tussen 1900 en 1965 . Maaslandse Monografieën, 75 (Hilversum 20II).

Langeweg, Serge, 'Trekarbeiders en pendelaars; grensarbeid in oostelijk Zuid-Limburg, I875-1914', in: Zestig jaar vorsen in de geschiedenis: Jubileumboek Het Land van Herle 1945-2005 (Heerlen 2006) 295308.

Langeweg, Serge, Van adreskantoor tot arbeidsvoorziening: arbeidsbemiddeling en arbeidsmarkt in Zuid-Limburg, 1904-1994 (Leeuwarden 1994).

Langeweg, Serge en Leen Roels, 'Buitenlandse arbeiders in de steenkolenmijnen van Luik en Nederlands-Limburg in de twintigste eeuw: een vergelijking', Studies over de sociaal-economische geschiedenis van Limburg/Jaarboek van het Sociaal Historisch Centrum voor Limburg LIII (2008) 88-II5.

Langeweg, Serge, Leen Roels en Ad Knotter, 'Regional labour markets and international migration in twentieth-century Europe: the cases of coal mining in Liège (B) and Limburg (NL) compared', Mitteilungsblatt des Instituts für soziale Bewegungen. Forschungen und Forschungsberichte 40 (2008) IOI-I2O.

Le Tirant, Dominique, zie: Tirant, Dominique le

Leboutte, René, 'Coal mining, foreign workers and mine safety: steps towards European integration, 1946-85', in: Berger et al. (eds.), Towards a comparative history, 219-237.

Leboutte, René, Le livret d'ouvrier dans la province de Liège. Une source méconnue en histoire sociale. Présentation 
et premiers résultats d'exploitation. Collections d'Etudes publiées par le Musée de la Vie Wallonne, 5 (Liège I988).

Leboutte, René, 'Mobilité spatiale de la main-d'œuvre dans les bassins industriels au XIXe siècle L'apport des livrets d'ouvrier', in: Landry et al. (eds.), Les chemins de la migration, 219-237.

Leboutte, René, 'Motivations des acteurs de la transition démographique. De l'analyse quantitative à l'enquête orale dans la région liégeoise (fin XIXe-XXe siècle)', in: Historiens et populations, 28I-300.

Leboutte, René, Reconversions de la main-d'œuvre et transition démographique. Les bassins industriels en aval de Liège XVIIe-XXe siècles. Bibliothèque de la Faculté de philosophie et lettres de l'Université de Liège, fasc. 25I (Paris I988).

Leboutte, René en Henri Delree, 'L'archéologie industrielle et l'assainissement des sites charbonniers', in: Barlet et al., Le patrimoine industriel et sa reconversion, 35-67.

Lecocq, Freddy, 'L'emploi dans la région liégeoise', in: Lambert en Mineur, L'économie de la région liégeoise, 376-4I6.

Leener, Georges De, 'Les abonnements ouvriers aux chemins de fer belges et leurs résultats économiques et sociaux', Revue du Travail/Officie du Travail de Belgique 4I (Mai I940) nr. 5, 585-595.

Leerstof voor de Houwersopleiding, Deel I. Gezamenlijke Steenkolenmijnen in Limburg (Heerlen 1965).

Lefevre, P., 'La situation présente et passée de l'industrie charbonnière en Belgique', in: Centenaire de l' Association des Ingénieurs sortis de l'École de Liège, 345-354.

Lemaire, A., La Wallonie qui meurt. Etude sur la natalité en Wallonie (Bruxelles I920).

Les carrières en Wallonie. Un monde à (re)découvrir. Service public de Wallonie. Direction générale opérationnelle de l'agriculture, des ressources naturelles et de l'environnement (2010).

Lesthaeghe, Ron J., The Decline of Belgian Fertility, 1800-1970 (Princeton 1977).

Lister, Louis, Europe's Coal and Steel Community: an experiment in economic union (New York 1960).

Logelain, Georges (Ingénieur Principal des Mines), 'Note. La problème de la main d'œuvre dans les mines belges', Annales des Mines de Belgique (1947-1948) 363-38r.

Loriaux, Florence, L'immigration marocaine en Belgique (1964-2004), Centre d'Animation et de Recherche en Histoire Ouvrière et Populaire (http://www.carhop.be/arto4.pdf)

Loriaux, Florence, Les travailleurs immigrés en Belgique durant l'entre-deux-guerres: la présence marocaine, Centre d'Animation et de Recherche en Histoire Ouvrière et Populaire (http://www.carhop.be/ arto3.pdf)

Lourens, P. en J. Lucassen, Arbeitswanderung und berufliche Spezialisierung. Die lippische Ziegler im 18. und 19. Jahrhundert (Osnabrück 1999).

Lucassen, Jan (ed.), Global Labour History. A State of the Art (Bern 2008).

Luyten, Dirk, 'Stakingen in België en Nederland, I940-I94I', Bijdragen tot de Eigentijdse Geschiedenis/Cahiers d'Histoire du Temps Présent I5 (2005) I49-I75.

Maes, Jef en Kristien Van Rie, 'Internationale en Belgische politieke besluitvorming inzake arbeidsduurvermindering (I9I8-I964)', in: Scholliers en Scholliers, Werktijd en werktijdverkorting, 60-70.

Maeyer, Jan De en Leen Van Molle (red.), Joris Helleputte. Architect en politicus. 1852/1925 (Deel I: biografie) KADOC Artes I (Leuven 1998).

Mahaim, Ernest, 'Les ouvriers mineurs abonnés aux chemins de fer en Belgique', Annales des Mines de Belgique (Bruxelles I9II) 67-II5.

Main-d'œuvre et production dans les mines s.p. (Collection 'Notes documentaires'). Office National du Placement et du Chômage (Ministère du Travail et de la Prévoyance Sociale) (Bruxelles I954).

Manning, A.F. en M. De Vroede (red.), Spectrum atlas van historische plaatsen in de lage landen (Utrecht/ Antwerpen 198I).

Manno, Paola, 'La communauté des ouvriers mineurs de la région de Lecce (Pouilles) dans le bassin de Liège (1946-I956)', Belgisch Tijdschrift voor Nieuwste Geschiedenis/Revue Belge d'Histoire Contemporaine 
XXXVII (2007) nrs. 3-4, 445-467.

Mark-Lawson, Jane en Anne Witz, 'From "family labour" to "family wage"? The case of women's labour in nineteenth-century coalmining', Social History XIII (I988) I5I-I74.

Maron, C., Le travail des femmes et des enfants dans les mines du Hainaut 1830-1914. Verhandeling Université Libre (Brussel 1975).

Martens, Albert, 25 jaar wegwerparbeiders. Het Belgisch Immigratiebeleid na 1945 (Leuven 1973).

Masset, Henri, 'Les migrations', in: Lambert en Mineur, L'économie de la région liégeoise, I36-I49.

Matthijs, K., De mateloze negentiende eeuw. Bevolking, huwelijk, gezin en sociale verandering (Leuven 200I).

Meynen, Alain, 'De grote werkstaking I960-I96r. Een inleidend overzicht van de ekonomische en socio-politieke achtergronden van de grote werkstaking I960-196I', Belgisch Tijdschrift voor de Nieuwste Geschiedenis/Revue Belge d'Histoire Contemporaine IX (I978) 3-4, 48I-5I5.

Michaux, Joseph, 'Organisation der Berufsausbildung des Personals zur Bedienung und Instandhaltung der elektrischen und maschinellen Anlagen im Untertagebetrieb des belgischen Kohlenbergbaus', in: Arbeitsdokument für die Informationstagung,

Milward, A.S., The reconstruction of Western Europe. 1945-51 (London 1984).

Milward, A.S., War, Economy and Society. 1939-1945 (London 1977).

Minon, Paul, Migrations provoquées et problèmes sociaux de mobilité ouvrière. Travaux de l'Institut de Sociologie de la Faculté de Droit de Liège, V (Liège 1956).

Minten, Luc, Ludo Raskin, Antoon Soete, Bert Van Doorslaer en Theo Coun, Een eeuw steenkool in Limburg (Tielt 1992).

Mitchell, B.R., International historical statistics. Europe 1750-1993 (fourth edition; London 1998).

Mol, M., H.J. Dirven en R. van den Bie (red.), Dynamiek in de sociale statistiek (Voorburg/Heerlen 2008).

Morelli, Anne, 'Ambiguités et contradictions des rapports entre syndicats et étrangers: le cas des Italiens', Brood en Rozen 2 (I997) nr. I, 65-7I.

Morelli, Anne, 'De immigratie van Italianen in België in de $19^{\text {de }}$ en de $20^{\text {ste }}$ eeuw', in: Morelli (ed.), Geschiedenis van het eigen volk, 197-209.

Morelli, Anne (ed.), Geschiedenis van het eigen volk: de vreemdeling in België van de prehistorie tot nu (Leuven 1993).

Morelli, Anne, 'Histoire de l'immigration et histoire ouvrière. Pour un inventaire des sources sur l'histoire de l'immigration en Belgique', Brood en Rozen I (1998) 37-45.

Morelli, Anne, 'L'appel à la main d'œuvre italienne pour les charbonnages et sa prise en charge à son arrivée en Belgique dans l'immédiat après-guerre', Belgisch Tijdschrift voor Nieuwste Geschiedenis/Revue Belge d'Histoire Contemporaine I9 (I988) 83-Izo.

Nandrin, Jean-Pierre, 'À la recherché d'un acte fondateur mythique: la loi du I3 décembre 1889 sur le travail des femmes et des enfants', in: Courtois et al. (eds.), Femmes des années '80, II-I6.

Nefors, Patrick, Industriële 'collaboratie' in België. De Galopindoctrine, de emissiebank en de Belgische industrie in de Tweede Wereldoorlog (Leuven 2000).

Neuville, Jean, Naissance et croissance du syndicalisme. L'Origine des premiers syndicats (Bruxelles 1979).

Nols, Emile, 'L'enseignement', in: Lambert en Mineur, L'économie de la région liégeoise, 192-320.

Nols, Emile, 'Zone de recrutement et mobilité interrégionale de la main-d'œuvre', in: Lambert en Mineur, L'économie de la région liégeoise, 322-369.

Noordegraaf, L., 'Arbeid en arbeidsmarkt. Recent onderzoek in historiografisch perspectief', Tijdschrift voor Sociale Geschiedenis I3 (november 1987) nr. 4, 257-372.

Pasleau, Suzy, Industries et populations: l'enchaînement des deux croissances au Seraing à XIXe siècle. Bibliothèque de la Faculté de Philosophie et Lettres de l'Université de Liège - fasc. 275 (Liège I998).

Pasleau, Suzy, 'La femme, un acteur à part entière de l'industrialisation. Seraing, I846-I880', Revue du Nord LXXXI (2002) nr. 347, 615-632. 
Pasleau, Suzy, 'Les innovations techniques dans les mines de charbon (fin XVIIIe-milieu XXe siècles). Les échanges entre les bassins de Liège, d'Aix-la-Chapelle et de la Ruhr: facteurs d'expansion', in: Jansen (red.), Economische betrekkingen in grensregio's, II3-I52.

Pasleau, Suzy, 'Les migrations de main-d'œuvre en Belgique', in: Landry et al. (eds.), Les chemins de la migration en Belgique et au Québec, I72-194.

Phimister, Ian, 'Global Labour History in the Twenty-First Century: Coal Mining and Its Recent Pasts', in: Lucassen (ed.), Global Labour History, 573-589.

Piquet, Nathalie, “Privilegierte” Zwangsarbeiter. Sowjetische und Serbische Arbeitskräfte im nordfranzösischen und belgische Steinkohlenbergbau während der deutschen Besatzung', in: Tenfelde en Seidel (ed.), Zwangsarbeit im Bergwerk, 467-493.

Pluymers, Bart, De Limburgse mijnwerkers (1917-1939). Ontstaan en consolidatie van de arbeidsmarkt voor mijnarbeid, Osw nr. I996/o2 (Onderzoek uitgevoerd i.o.v.: Euregio Maas-Rijn: Interreg, Provincie Limburg, Sociale Investeringsmaatschappij, Limburgs Universitair Centrum) (z.p. 1996).

Pluymers, Bart, Personeelsbeleid in de Belgisch-Limburgse steenkoolmijnen (1917-1939). Onuitgegeven paper K.U. Leuven, Centrum voor Economische Studies (I5 september 1997).

Poelmans, Eline, 'Concentration of Ecsc Coal Companies, I952-I967', Business and Economic History On-Line 7 (2009) (http://www.thebhc.org/publications/BEHonline/2009/poelmans.pdf)

Pott-Buter, H.A., Facts and Fairy Tales about Female Labor, Family and Fertility. A seven-country comparison, 1850-1990 (Amsterdam I993).

Poulain, M. en M. Foulon, 'L'immigration flamande en Wallonie: évaluation à l'aide d'un indicateur anthroponimique', Belgisch Tijdschrift voor Nieuwste Geschiedenis/Revue Belge d'Histoire Contemporaine I2 (I98I) 204-244.

Pressat, Roland en Alfred Sauvy, Le rapport Sauvy sur le problème de l'économie et de la population en Wallonie. Éditions du Conseil Économique Wallon (Liège 1962).

Puissant, Jean, 'Les congés taxés avant les congés payés: réflexions à propos du temps de travail en Belgique au XIXe siècle', in: Scholliers en Scholliers, Werktijd en werktijdverkorting, I8-24.

Puissant, Jean, L'évolution du mouvement ouvrier socialiste dans le Borinage. Mémoires de la Classe des Lettres/Académie Royale de Belgique, $2^{\mathrm{e}}$ série, t. 65 , fasc. 5 (Bruxelles I982).

Quairiaux, Yves, 'Migrants flamands en Wallonie avant I9I4', Histoire de la population de la Belgique et de ses territoires. Chaire Quetelet 2005. Centre de Recherche en Démographie et Sociétés, Université catholique de Louvain (Louvain-La-Neuve 2010) 337-364.

Raedts, C.E.P.M., De opkomst, de ontwikkeling en de neergang van de steenkolenmijnbouw in Limburg. Maaslandse Monografieën, I8 (Assen 1974).

Raedts, C.E.P.M., 'Het mijnbekken van Luik (8): Kolenmijnbouw als fundament van een moderne metaalindustrie', Steenkool (I950) 39-4I.

Remits, Jacqueline, Des mines et des hommes au Pays de Liège (Liège 200I) (Collection Reliance dirigée par Lily Portugaels, 3).

Renckens, R., 'Energie in Europa', in: Kolen, Charbon, Kohle, Coal, 9-I9.

Renckens, R., Kompels in Engeland, Frankrijk, Duitsland en België (Nederlandse Katholieke Mijnwerkersbond, Reportages uit 'De Volkskrant' (1947).

Reumkens, P.J.M., Een onderzoek naar het verloop van mijnwerkers werkzaam bij de Oranje-Nassau mijnen (z.p. I958).

Rice, A. K., J.M.M. Hill en E.L. Trist, 'Representation of labour turnover as a social process', Human Relations. Studies towards the integration of the social sciences 4 (1950) 349-372.

Rijck, Tine De en Griet Van Meulder, De ereburgers. Een sociale geschiedenis van de Limburgse mijnwerkers (Berchem 2000).

Robert, André, ‘Wallonie I93I-I996. D’une forte croissance à une régression potentielle. Deux révo- 
lutions démographiques dans un contexte d'immigration de conjoncture', in: Delforge (ed.), Wallons d'ici et d'ailleurs, $17-28$.

Robinson, Neil, 'Report on Belgian coal industry', Annales des Mines de Belgique (I95I) 452-470.

Roeck, Marie-Louise De, Paul Lootens en Julie Urbain, Tutti Cadaveri: Le Proces De La Catastrophe Du Bois Du Cazier à Marcinelle (Bruxelles 2006).

Roels, Leen, 'Buitenlandse arbeiders in de Luikse steenkolenmijnen, I900-I974', Tijdschrift voor Sociale en Economische Geschiedenis 5 (2008), nr. 3, I04-I25.

Roels, Leen, “'In Belgium women do all the work". De arbeid van vrouwen in de Luikse mijnen, negentiende- begin twintigste eeuw', Belgisch Tijdschrift voor Nieuwste Geschiedenis XXXVIII (2008) 45-86.

Rolans, Carl, 'Le logement', in: Lambert en Mineur, L'économie de la région liégeoise, I63-IgI.

Rouge Métal: 100 ans d'histoire des métallos liégeois de la FGTB. IHOES - FGTB Métal Liège-Luxembourg (Bruxelles 2006).

Ruelle, Pierre, Le vocabulaire professionnel du houilleur borain. Étude dialectologique (Bruxelles I98I).

Rummelen, F.H. van, 'Carbonische steenkolen in beeld', Steenkool (I95I) 546-547.

Rutten, Willibrord, 'Alsof de taalgrens niet bestond. Limburgse kompels in de Luikse kolenmijnen na de Tweede Wereldoorlog', Het Land van Herle, Historisch tijdschrift voor oostelijk Zuid-Limburg, De Geschiedenis van de Limburgse mijnwerkers (2009) 3-4, II4-I24.

Rutten, Willibrord, 'Buitenbeentjes. Nederlandse kompels in de Luikse kolenmijnen na de Tweede Wereldoorlog', Studies over de sociaal-economische geschiedenis van Limburg/Jaarboek van het Sociaal Historisch Centrum voor Limburg LVI (201I) 3-53.

Rutten, Willibrord, 'Russen niet gewenst: de mislukte inzet van Russische dwangarbeiders in de Nederlandse steenkoolmijnen in de Tweede Wereldoorlog', Studies over de sociaal-economische geschiedenis van Limburg/Jaarboek van het Sociaal Historisch Centrum voor Limburg XLIX (2004) I65-Igo.

Rutten, Willibrord, 'Werken over de grens', Weet je nog koempel? De mijnen in Limburg deel I9 (Zwolle 2005) $44 \mathrm{I}-464$.

Salée, Dominique, Le travail des femmes et des enfants dans les charbonnages au regard de la législation. Un cas typique: l'application dans les bassin de Seraing (1889-1914). Mémoire présenté en vue de l'obtention du grade de licencié en Histoire - Université de Liège (Liège 1996).

Sas, N.C.F. Van en E. Witte (eds.), Historical Research in the Low Countries. Bibliografische reeks van het Nederlands Historisch Genootschap, 8 (Den Haag 1992).

Scholliers, Peter, 'Het project arbeid en arbeidsverhoudingen in de Limburgse mijnen: een korte historiografische noot', Brood en Rozen (I999) nr. 3, 7-9.

Scholliers, E. en P. Scholliers (eds.), Werktijd en werktijdverkorting/ Durée du travail et diminution du temps du travail (Brussel I983).

Segers, J.H.G., Het personeelsverloop in het ondergronds mijnbedrijf. Methoden en Resultaten. Proefschrift Sociale Wetenschappen (Tilburg i968).

Sillekens, J.Th., De Limburgse arbeidsmarkt na de Tweede Wereldoorlog. Doctoraalscriptie sociaal-economische geschiedenis Katholieke Universiteit (Nijmegen 1974).

Spierenburg, Dirk en Raymond Poidevin, The history of the High Authority of the European Coal and Steel Community: supranationality in operation (London I994).

Sporck, J.A., 'Les mouvements de la main-d'oeuvre industrielle' in: Sporck, L'activité industrielle, 73-86. Sporck, J.A., L'activité industrielle dans la région liégeoise. Etude de géographie économique (Liège i957).

Stassart, Joseph, 'La structure démographique', in: Lambert en Mineur, L'économie de la région liégeoise, 99-I35.

Sunou, Philippe, Les prisonniers de guerre allemands en Belgique et la bataille du charbon, 1945-1947. Centrum voor Militaire Geschiedenis - Bijdragen, I5 (Brussel I980).

Tenfelde, Klaus (ed.), Sozialgeschichte des Bergbaus im 19. und 20. Jahrhundert: Beiträge des Internationalen 
Kongresses zur Bergbaugeschichte, Bochum, Bundesrepublik Deutschland, 3.-7. September 1989: Towards a social history of mining in the 19th and 20th centuries (München I992).

Tenfelde, Klaus, 'The Miners' Community and the Community of Mining Historians', in: Tenfelde (ed.), Sozialgeschichte des Bergbaus, I2OI-I2I5.

Tenfelde, Klaus, 'On the History of Industrial Relations in Mining', in: Feldman en Tenfelde (ed.), Workers, owners and politics in coal mining, I-II.

Tenfelde, Klaus, Towards a social history of mining in the $19^{\text {th }}$ and $20^{\text {th }}$ centuries / Sozialgeschichte des Bergbaus im 19. und 20 Jahrhundert. Papers presented to the International History Congress Bochum, Federal Republic of Germany September $3^{\text {rd }}-7^{\text {th }}, 1989$ / Beiträge des Internationalen Kongresses zur Bergbaugeschichte Bochum, Bundesrepublik Deutschland, 3.-7. September 1989 (München 1992).

Tenfelde, Klaus en Hans-Christoph Seidel (ed.), Zwangsarbeit im Bergwerk. Der Arbeitseinsatz im Kohlenbergbau des Deutschen Reiches und der besetzten Gebiete im Ersten und Zweiten Weltkrieg. Band I: Forschungen (Essen 2005).

Thijs, A.K.L., 'Bedrijfsgeschiedenis in België: peiling naar de ontwikkeling van mentale achtergronden', NEHA-Jaarboek voor economische, bedrijfs- en techniekgeschiedenis LII (I989) 3I-4I.

Tirant, Dominique le, Femmes à la mine, femmes de mineurs. Enquête sur les femmes dans la société minière du Nord de la France. Centre Historique Minier de Lewarde, Collection 'Mémoires de Gaillette', 7 (Lewarde 2002).

Touwen, Jeroen, 'Voortbouwen op Braudel of Fogel? Een pleidooi voor interdisciplinaire economische geschiedenis in Nederland en Vlaanderen', Tijdschrift voor Sociale en Economische Geschiedenis 5 (2008) nr. 2, II7-I37.

Trempe, Rolande, 'La politique de la main d'œuvre de la libération à nos jours en France', Belgisch Tijdschrift voor Nieuwste Geschiedenis/Revue Belge d'Histoire Contemporaine XIX (I988) I-2, 55-82.

Tulippe, Omer, Atlas de Belgique: natalité, mortalité, étrangers (planches 25 et 26) (Bruxelles 1960) (Académie Royale de Belgique - Comité National de Géographie - Commission de l'Atlas national).

Urbain, Julie, 'Le procès de la catastrophe du Bois du Cazier (I959-I962)', Brood en Rozen 3 (2006) 7-30.

Van den Eeckhout, Patricia, zie: Eeckhout, Patricia Van den

Van der Eycken, M., zie: Eycken, M. Van der

Van der Herten, Bart, zie: Herten, Bart Van der

Van Doorslaer, Bert, zie: Doorslaer, Bert Van

Van Haegendoren, Mieke, zie: Haegendoren, Mieke Van

Van Hoof, J., zie: Hoof, J. van

Van Rummelen, F.H., zie: Rummelen, F.H. van

Van Sas, N.C.F., zie: Sas, N.C.F. Van

Van Waterschoot van der Gracht, W.A.J.M., zie: Waterschoot van der Gracht, W.A.J.M. van

Vandenbroeke, Chris, Sociale geschiedenis van het Vlaamse volk (Beveren/Nijmegen I98I).

Vandendriessche, E., La centrale des Francs-Mineurs. Son histoire, sa vie, Centrale des Francs Mineurs (Bruxelles ig86).

Vandeputte, Robert, Economische geschiedenis van België: 1944-1984 (Tielt/Weesp I985).

Vandersmissen, Georges, 'Tentatives et échecs de la reconversion industrielle', in: Hasquin (ed.), La Wallonie, 44I-456.

Vanja, Christina, 'Bergarbeiterinnen. Zur Geschichte der Frauenarbeit im Bergbau, Hütten- und Salinenwesen seit dem späten Mittelalter. Teil I: Spätes Mittelalter und frühe Neuzeit', Der Anschnitt. Zeitschrift für Kunst und Kultur im Bergbau XXXIX (I987) nr. I, 2-I5.

Vanja Christina, 'Bergarbeiterinnen. Zur Geschichte der Frauenarbeit im Bergbau, Hütten- und Salinenwesen. Teil II: Die Entwicklung im I9. und 20. Jahrhundert', Der Anschnitt. Zeitschrift für Kunst und Kultur im Bergbau XL (I988) nr. 4, I28-I43. 
Vanja, Christina, 'Frauenarbeit im Bergbau - ein Überblick', in: Kroker (ed.), Frauen und Bergbau, II-29. Vanthemsche, Guy, 'Recent trend in the social and economic historiography of contemporary Belgium (nineteenth century to 1940)', in: Van Sas en Witte (eds.), Historical Research in the Low Countries, 47-57.

Vanvelthem, Lionel, 'La formation professionnelle de courte durée: un instrument au profit des travailleurs ou des industriels? L'exemple du Centre de formation professionnelle accélérée pour les travailleurs des mines de la Province de Liège (I964-I974)', Analyse de l'ıhoes, nr. 79 (22 mars 20II).

Verbeken, Pascal, Arm Wallonië. Een reis door het beloofde land (Antwerpen/Amsterdam 2007).

Versteegh, A.P., De onvermijdelijke afkomst? De opname van Polen in het Duits, Belgisch en Nederlands mijnbedriff in de periode 1920-1930. N.W. Posthumus Reeks, 3 (Hilversum 1994).

Vinck, François, 'De toekomst van de steenkool en de concurrentie op het gebied van de energie in de gemeenschap', in: EGKS, 6I-69.

Vos, Patrick De, 'De historische evolutie van de arbeidsduur in België', Brood en Rozen 3 (1997) 7-37.

Walter, Rolf (Hg.), Geschichte der Arbeitsmärkte. Erträge der 22. Arbeitstagung der Gesellschaft für Sozial- und Wirtschaftsgeschichte. 11. bis 14. April 2007 in Wien. vsWG-Beiheft, 199 (Stuttgart 2009).

Waterschoot van der Gracht, W.A.J.M. van, 'De Limburgsche steenkoolmijnindustrie gedurende de laatste 40 jaar', in: 40 jaren spoor en mijnen, 60-77.

Westen, J.M.J., 'Statistisch overzicht van productie, bezetting en prestaties van de Limburgse steenkolenmijnen', Geologie en Mijnbouw 50 (maart-april I97I) 312-319.

Wet van 13 december 1976 houdende goedkeuring van de bilaterale akkoorden betreffende de tewerkstelling in België van buitenlandse werknemers, Belgisch Staatsblad 17/06/1977.

Willems, Hans, 'De lijdensweg van een rustdag: de wet op de zondagsrust (I905)', Belgisch Tijdschrift voor Nieuwste Geschiedenis/Revue Belge d'Histoire Contemporaine 32 (2002) I-2, 73-II8.

Wolters, J.B., Mijnbouwkundige nomenclator. Nederlands-Engels-Frans-Duits-Spaans (Groningen 1949).

Zanden, Jan Luiten van, 'Economische en sociale geschiedenis voor de eenentwintigste eeuw', Tijdschrift voor Sociale en Economische Geschiedenis 5 (2008) nr. 2, 87-92.

Zola, Emile, De Mijn (Amsterdam I993).

\section{GERAADPLEEGDE WEBSITES}

http://europa.eu.int/ecsc/index_nl.htm

http://eur-lex.europa.eu/nl/treaties/dat/II95IK/tif/TRAITES_I95I_CECA_I_EN_oooI.tif

www.riziv.fgov.be/citizen/nl/miners/miners32.htm 


\section{Résumé et conclusion}

Le bassin houiller de Liège faisait partie des régions minières les plus anciennes de l'Europe occidentale et cette longue histoire fut décisive dans la structuration et la taille des houillères, pour l'établissement et l'organisation des travaux souterrains, pour la productivité et pour l'évolution du marché du travail. Au cours du XXe siècle, les charbonnages liégeois éprouvaient de plus en plus de difficultés en matière de recrutement de main-d'œuvre. Cette pénurie croissante est le thème central de cet ouvrage. Quelle était l'ampleur de cette pénurie de main-d'œuvre et comment évoluait-elle? Quelles en étaient les causes et comment auront-elles été résolues?

La combinaison des micro-données recueillies au niveau individuel sur les mineurs et leurs carrières avec les macro-données relatives à l'évolution de l'emploi dans l'industrie houillère, et dans la région liégeoise en particulier, a permis de mieux comprendre les stratégies et le comportement des acteurs du marché du travail.

La question de la pénurie de main-d'œuvre a été abordée tant du point de vue de la demande que de celui de l'offre. En ce qui concerne la demande, les questions suivantes ont été posées: Comment les employeurs des mines essayaient-ils de résoudre la pénurie de main-d'œuvre? Devant quels problèmes et défis se retrouvaient-ils? Quel était le rôle du gouvernement? Etait-il question d'une segmentation du marché pour des groupes particuliers de mineurs? Dans quelle mesure les employeurs arrivaient-ils à attirer suffisamment de mineurs?

Du côté de l'offre, nous nous sommes posés les questions suivantes: Quels groupes de travailleurs choisissaient un emploi en tant que mineur? Quelles étaient leurs origines géographiques et sociales et comment leurs carrières se déroulaient-elles? Quel était l'impact de leur comportement démographique sur l'offre de travail? Comment évoluait la rotation du personnel et dans quelle mesure le comportement du marché du travail au sein de différents groupes de mineurs se distinguait-il?

L'étude débute à la fin du dix-neuvième siècle. A ce moment-là, les charbonnages de la région liégeoise étaient déjà une industrie établie de longue date. Vers I89o, des évolutions au sein du marché du travail, tant du côté de la demande que du côté de l'offre, avaient structurellement changé la composition du personnel. La pénurie croissante de main-d'œuvre locale et régionale dans les charbonnages de Liège en fut le reflet.

Chacune des cinq études partielles de cet ouvrage a mis en évidence un aspect différent lié à la pénurie de main-d'œuvre. La première étude partielle, qui est abordée dans le chapitre I, est consacrée aux éléments structurels présents sur le marché du travail. En réalisant l'inventaire de l'évolution du paysage minier de la région liégeoise, il y est démontré que les facteurs propres à la demande étaient constamment en mouvement. Dès le début 
du vingtième siècle, un certain nombre de charbonnages liégeois avaient cessé leurs activités tandis que des sièges d'extraction de taille plus modestes avaient fusionné pour former des entités plus grandes avant, elles aussi, de mettre un terme à leur exploitation dans une phase ultérieure. Ainsi, des 80 sièges d'extraction qui existaient vers I9oo, seuls 22 subsistaient toujours en 1958 et la dernière houillère liégeoise, celle d'Argenteau-Trembleur (Blegny), fermait ses portes en I980.

L'offre avait également une grande influence sur le marché du travail. La démographie est d'ailleurs le sujet de la deuxième partie du premier chapitre. Suite à des changements structurels dans le comportement démographique, l'offre de main-d'œuvre disponible s'était considérablement réduite au cours du vingtième siècle.

L'étude partielle du chapitre 2 est consacrée au travail des femmes. En I9oo, une large part de la main-d'œuvre des charbonnages de la région liégeoise était encore composée de femmes. En I892, une loi interdisant le travail des femmes dans les charbonnages était cependant entrée en vigueur en Belgique, qui fut l'un des derniers pays d'Europe occidentale à adopter une telle législation. Cette interdiction représentait une perte substantielle pour l'effectif des charbonnages liégeois.

A l'époque, les mines de charbon du bassin houiller de Liège étaient une industrie bien établie. Les houillères pouvaient faire appel à une réserve fixe de travailleurs régionaux et les charbonnages de la région liégeoise pouvaient compter sur des mineurs qui se succédaient de génération en génération. De ce fait, il n'était pas indispensable de faire appel à des travailleurs migrants. Cette situation changera au cours du vingtième siècle. Le chapitre 3 décrit l'évolution d'un marché du travail nécessitant de plus en plus de travailleurs étrangers, surtout après la Seconde Guerre mondiale. Dans les années I970, il existait même des charbonnages liégeois où plus aucun Belge n'était employé dans les travaux souterrains.

Les causes spécifiques de la grande pénurie de main-d'œuvre belge juste après la Seconde Guerre mondiale sont largement discutées dans le chapitre 4. Il y est détaillé que la dite Bataille du charbon, lancée par le Premier Ministre Achille Van Acker, devait être menée par une 'légion étrangère', assimilant par cette assertion les troupes ouvrières belges à des 'déserteurs'. Le départ de la main-d'œuvre régionale des charbonnages liégeois, analysé en détails dans le chapitre 5 , était surtout dû à la mauvaise réputation des houillères liégeoises vieillissantes ainsi qu'aux possibilités d'emplois qu'offraient d'autres industries liégeoises dans ces années de croissance économique. Un effet positif du processus de concentration industrielle constaté antérieurement dans le secteur minier était que l'on remarquait moins de rotation de main-d'œuvre entre les sièges d'extraction.

\section{ELÉMENTS STRUCTURELS}

Les études partielles, telles que brièvement décrites ci-dessus, démontrent bien qu'au cours du vingtième siècle les problèmes de recrutement dans les charbonnages liégeois n'avaient fait que s'accroître. Les préoccupations qui en résultaient étaient décrites dans toutes sortes de rapports contemporains et pouvaient être déduites de l'augmentation du nombre de travailleurs migrants dans les charbonnages liégeois. Tandis qu'en I923 seuls 5,7 pour cent de la main-d'œuvre des charbonnages principautaires étaient des 'non-Belges', cette propor- 
tion s'était portée à près de vingt-cinq pour cent avant la Seconde Guerre mondiale. Après ce conflit, le pourcentage s'accroîtra considérablement, de 50 pour cent en 1947 à plus de 70 pour cent au début des années I970! Les analyses présentées dans les études partielles expliquent les causes de cette pénurie. Celles-ci étaient à trouver dans une combinaison de facteurs présents tant du côté de la demande et que du côté de l'offre et remontaient à l'aube du XXe siècle.

L'approche sociologique du marché du travail, décrite dans ce livre, recherche les conditions et les formes du comportement du marché du travail. Dans cette approche, le mot 'stratégie' est une notion importante. Les alternatives d'un comportement stratégique n'étaient cependant pas illimitées. Des frontières économiques, sociales et idéologiques restreignaient la liberté d'action des acteurs, aussi bien du côté de la demande que du côté de l'offre. Le patronat des mines et les mineurs opéraient dans un environnement qu'ils ne dominaient pas (complètement). Un certain nombre d'éléments structurels constituait le contexte, la marge dans laquelle le patronat et les mineurs évoluaient sur le marché du travail.

Au début de la période d'étude, la demande de charbon avait augmenté une première fois lorsqu'à partir du dernier quart du dix-neuvième siècle, le marché du charbon à usage domestique s'élargissait considérablement en raison de l'évolution des habitudes de chauffage. A Liège, où l'on produisait beaucoup de charbon de ce type, les possibilités d'emplois pour les mineurs augmentaient à un rythme rapide dans la dernière décennie du dix-neuvième siècle pour atteindre un pic dans les premières décennies du vingtième siècle. Le marché du charbon à usage domestique était beaucoup plus stable que celui du charbon gras mais, durant l'entre-deux-guerres, la demande s'effondrait face à la concurrence du pétrole, de l'énergie hydraulique et de l'électricité et, surtout, en raison de la crise des années I930.

A l'issue de la Seconde Guerre mondiale, dans le contexte de la Bataille du charbon, la demande de charbon gonflait de nouveau fortement. Contrairement aux houillères françaises et allemandes, les houillères belges étaient sorties presque indemnes de la guerre. Pour le ravitaillement en charbon, un combustible plus que nécessaire pour la reconstruction, les yeux se tournaient vers la petite Belgique. Peu de temps après, vers I948, la demande de ce combustible chutait une nouvelle fois pour atteindre son niveau normal tandis que les pays voisins redémarraient leur production de charbon.

Il avait toujours été reconnu que travailler dans une exploitation minière était dur, dangereux, mauvais pour la santé et sale. Cela s'appliquait surtout au travail souterrain, pour lequel la demande de main-d'œuvre était toujours la plus forte. Le bassin de Liège était en outre affecté par des circonstances géologiques spécifiques et difficiles: des veines de charbon minces et accidentées avec d'importants problèmes d'eau. Les charbonnages liégeois étaient en activité depuis longtemps déjà et l'extraction y devenait plus difficile. Les veines de charbon facilement accessibles s'épuisaient et il était alors nécessaire de creuser plus profondément, ce qui réduisait considérablement la productivité du travail. Le bassin de Liège était initialement divisé en plusieurs petites concessions. L'agencement de la plupart des charbonnages au dix-neuvième siècle créait une certaine 'dépendance au sentier' (path dependence): il n'était pas facile de transformer de petites entreprises familiales, souvent agencées de façon artisanale et imbriquées les unes dans les autres, en entreprises modernes du vingtième siècle. L'industrie houillère liégeoise, qui dans la seconde moitié 
du dix-neuvième siècle avait connu un développement rapide et important, entrait dans un rythme plus lent après la Première Guerre mondiale. ' 'La loi sur l'avance freinante' (Wet van de remmende voorsprong) y est d'application.

En raison des circonstances géologiques précitées et de l'héritage du dix-neuvième siècle, conjugué au manque d'investissements, la rationalisation et la mécanisation ne s'était imposée que partiellement. L'industrie houillère liégeoise se caractérisait par une structure modeste, surtout lorsqu'on la comparait avec les bassins charbonniers limbourgeois. Il y avait bien quelques grandes compagnies qui employaient des milliers de mineurs mais, au seuil de la Seconde Guerre mondiale, la majeure partie des charbonnages liégeois n'occupait que quelques centaines de mineurs chacune. Souvent, la production d'une entreprise était répartie sur plusieurs sièges d'extraction, du moins jusqu'à la crise du charbon en 1958. Durant cette période, près de deux tiers des entreprises étaient encore complètement indépendantes financièrement parlant. Dans le bassin liégeois, l'influence, et de ce fait aussi les investissements, des grands holdings et des banques étaient limités et les structures de propriétés fragmentées compliquaient des investissements plus conséquents. Le prix du charbon maintenu artificiellement bas, mesure que le gouvernement avait introduite après la Seconde Guerre mondiale, couplé aux salaires et charges sociales élevés, faisait augmenter le chiffre d'affaires mais les bénéfices restaient limités. Il était donc difficile voire impossible de constituer des réserves en vue de rationaliser et de moderniser. La concurrence, la rivalité et l'isolement étaient également des caractéristiques typiques du climat des affaires dans l'industrie houillère liégeoise, caractéristiques que l'on retrouvait aussi vis-à-vis des autres bassins charbonniers. Ceci explique qu'aucune concentration de la production ne fut poussée plus loin, sinon tardivement, au travers de fusions ou de reprises.

Tant que l'offre d'emplois était suffisante, cela ne posait pas de problèmes aux demandeurs de main-d'œuvre. Cependant, dans un bassin hautement industrialisé comme celui de Liège, beaucoup d'autres secteurs étaient aussi à la recherche de main-d'œuvre en suffisance. Au dix-neuvième siècle déjà, plusieurs industries, dont la métallurgie avec les fours à coke et les hauts fourneaux y associés, l'ingénierie, l'industrie de l'armement, l'industrie du verre et l'industrie lainière (à Verviers) offraient bon nombre de possibilités aux personnes à la recherche d'un emploi. Au vingtième siècle, les secteurs des services et du commerce s'y étaient ajoutés.

Mais, pour les charbonnages liégeois, l'offre ne diminuait pas uniquement à cause de cette concurrence avec les autres industries et secteurs. A partir de la seconde moitié du dixneuvième siècle, la sécularisation, l'urbanisation et une meilleure éducation avaient eu pour conséquence une baisse de la natalité parmi la main-d'œuvre, avec à la tête de ce «mouvement» les métallurgistes et les mineurs. Le comportement démographique changeait et se caractérisait par une fertilité conjugale plus faible. Dès le début du vingtième siècle, le taux de natalité plongeait, ce qui se traduira même, après la Première Guerre mondiale, par un excédent de décès.

I Sporck, L'activité industrielle, I02; Conseil Économique Wallon, Economie wallonne, 156-157. 
Quand, à la fin du dix-neuvième siècle, la demande de charbon à usage domestique avait fortement augmenté, la demande de mineurs s'était, elle aussi, accrue. Cependant, à cette période, les employeurs des mines ne pouvaient plus compter sur les femmes pour renforcer l'effectif souterrain. Jusque-là, elles avaient joué un rôle important sur le marché du travail des mineurs. Les employeurs en avaient tiré plusieurs avantages: des paiements de salaires nettement inférieurs pour les femmes dans une industrie où le coût de la maind'œuvre représentait une grande partie des frais de production et l'impossibilité de mécaniser certaines tâches 'féminines' en raison du coût ou des circonstances géologiques difficiles. Avant l'entrée en vigueur de l'interdiction du travail souterrain des femmes, il était question de ségrégation verticale: les femmes exerçaient certaines fonctions dans les charbonnages. L'entrée en vigueur de leur interdiction au fond en I892 entraînait leur disparition progressive du monde souterrain des charbonnages. On parle alors d'une ségrégation horizontale du marché du travail: les femmes ne se trouvaient plus sur le marché segmenté du travail souterrain.

A cette période et durant les premières décennies du vingtième siècle, les charbonnages liégeois s'étaient efforcés de s'approvisionner en personnel sur le marché local, régional et national. En général, les effectifs liégeois pouvaient être complétés par des travailleurs issus d'autres régions belges: étaient surtout concernés les districts ruraux de la province de Liège et de la Hesbaye sud-limbourgeoise que l'on considérait alors comme des zones de recrutement intéressantes. Les employeurs attiraient ces travailleurs en leur offrant des salaires plus élevés, surtout en comparaison des salaires appliqués dans le secteur agricole, et en facilitant leur mobilité entre leurs domiciles et leurs lieux de travail. Le gouvernement y contribuera par la suite en créant et en subventionnant des abonnements de train adaptés.

L'arrivée de la main-d'œuvre flamande ne suffisait cependant pas à résorber la pénurie de mineurs locaux. Certes, après l'intermède chaotique de la Première Guerre mondiale, la production s'était rapidement rétablie pour atteindre un niveau normal, mais il semblait difficile de trouver les mineurs nécessaires. Les charbonnages de Liège étaient confrontés à la concurrence des charbonnages modernes du Limbourg, qui offraient souvent de meilleures conditions de travail et étaient plus aisément accessibles. Ces mines attiraient beaucoup de Flamands qui effectuaient auparavant la navette vers le bassin liégeois. La navette n'avait pas disparu pour autant car, au cours du vingtième siècle, les zones de recrutement s'étendaient toujours plus. Le fait que les navetteurs provenaient toujours de régions de plus en plus éloignées démontrait qu'il devenait plus difficile de s'approvisionner en mineurs locaux et régionaux. Les employeurs ne parvenaient pas à juguler le départ des mineurs autochtones traditionnels.

Tout comme dans la plupart des autres bassins, les directions des charbonnages de Liège allaient devoir faire appel à des mineurs étrangers. Durant l'entre-deux-guerres, des campagnes de recrutement menées par l'association patronale FEDECHAR avaient entraîné l'embauche de mineurs italiens et polonais dans les charbonnages liégeois. Les Italiens n'avaient généralement pas d'expérience mais les Polonais venaient des régions minières de la Silésie ou du bassin de la Ruhr et bénéficiaient d'un certain savoir-faire. Les Maghrébins recrutés dans les bassins houillers français formaient un autre groupe de migrants gé- 
néralement bien qualifiés. Le nombre de mineurs étrangers présents sur le marché liégeois qui représentait 6 pour cent de la main-d'œuvre en 1923 avait progressivement atteint puis dépassé la cote des 22 pour cent juste avant la Seconde Guerre mondiale.

Dans l'entre-deux-guerres toujours, les employeurs des mines liégeoises avaient tenté de rationaliser cette industrie afin d'en augmenter la productivité. Des entreprises avaient fusionné, concentrant les moyens financiers en vue de procéder à la mécanisation des installations. En raison des circonstances géologiques citées précédemment, une mécanisation complète s'avérait impossible mais la première moitié des années 1930 voyait les efforts de rationalisation porter leurs fruits et contribuer à une hausse de la productivité du travail. De ce fait, la diminution du nombre d'ouvriers pendant la crise économique n'entraîna pas directement une réduction de la production.

Il est frappant de constater que la baisse de l'emploi ne s'était pas projetée sur les migrants, comme cela s'était pourtant produit dans les zones minières voisines. Entre 1930 et 1934, on remarque que proportionnellement plus de Belges quittaient les charbonnages liégeois par rapport aux migrants. Cette proportion était complètement inversée dans les deux Limbourg.

Dans les charbonnages de Liège par contre, la dépendance aux travailleurs étrangers avait été ressentie plus durement dès la relance économique de 1936 . C'est ici que les travailleurs frontaliers entrèrent en scène. Les charbonnages de Liège leur offraient en général de meilleures conditions de travail et des salaires plus élevés que dans leur pays d'origine. De plus, les critères de sélection y étaient moins sévères que, par exemple, dans les charbonnages néerlandais. La Seconde Guerre mondiale a joué un rôle de catalyseur dans la pénurie de main-d'œuvre: pendant et après la guerre, les employeurs des mines et le gouvernement belge étaient confrontés à un grand exode de la main-d'œuvre de charbonnages ainsi qu'à une forte baisse de la production qui l'avait accompagné. Il était nécessaire de trouver rapidement de nouveaux mineurs.

A l'issue du deuxième conflit mondial, l'espoir existait toujours de pouvoir attirer des ouvriers belges afin d'augmenter la production de charbon et relancer ainsi la reconstruction du pays mais le statut du mineur et les avantages y associés n'auront pas l'effet escompté. Au contraire, beaucoup de mineurs se servaient de la législation sociale pour quitter le charbonnage précocement.

La formation professionnelle des mineurs fut un autre moyen étudié pour éviter la désertion des mines: cet enseignement aurait pu rendre le métier de mineur plus prestigieux et stabiliser ainsi l'effectif du personnel. Les formations existantes ne rencontraient cependant qu'un succès négligeable notamment parce que, dans la plupart des charbonnages de Liège, les connaissances et les compétences se transmettaient de père en fils et d'un mineur expérimenté à un novice. Après la guerre, une tentative de relance de la formation professionnelle voyait le jour, sous l'égide de l'Administration des Mines. Le nombre d'élèves suivant cette formation au début des années 1950 était cependant très modeste. Au bout du compte, le gouvernement belge et le patronat minier, malgré des conditions de travail attirantes et des salaires élevés, ne parvenaient toujours pas à convaincre les ouvriers belges de reprendre le travail dans les charbonnages.

Pendant une courte période, le travail temporaire de prisonniers de guerre allemands avait pu soulager la détresse, mais le recrutement à l'étranger s'avérait inévitable pour faire 
face au problème structurel de la pénurie de main-d'œuvre. En raison de la 'désertion' massive des Belges, 'la Bataille du charbon', que le Premier Ministre Achille Van Acker avait lancée en I945, était, de ce fait, menée, dans les charbonnages liégeois, par une 'légion étrangère'.

La présence d'un nombre croissant d'étrangers sur le marché du travail de l'industrie du charbon liégeoise indique clairement que l'offre sur le marché du travail local n'était pas suffisante. Pour attirer des travailleurs étrangers, les directions minières lançaient des actions de recrutement à leur propre initiative et avec leurs propres moyens. Elles seront relayées par la suite par le gouvernement belge qui prendra le problème à bras-le-corps en signant des accords avec les pays d'émigration en question. Pour que le travail dans les charbonnages fût plus attrayant, on promettait des logements et des salaires intéressants. A partir de I946, grâce à une convention bilatérale signée entre l'Italie et la Belgique, un grand nombre d'Italiens se retrouvaient intégrés dans des charbonnages liégeois. Grâce à un accord avec les Alliés, le gouvernement belge avait également réussi à embaucher des milliers de 'personnes déplacées' pour les charbonnages. Mais après la catastrophe minière de Marcinelle en 1956, le gouvernement italien mit un terme à la migration officielle de ses ressortissants. De nouvelles conventions de recrutement furent alors conclues avec l'Espagne (I956) et la Grèce (I957).

Les migrants étrangers ne permettaient cependant pas de constituer un effectif stable. Face à une rotation du personnel migrant très importante, les charbonnages de Liège se retrouvaient dans un cercle vicieux. Ils étaient contraints d'embaucher et d'initier continuellement de nouveaux groupes d'immigrés sans expérience, qui quittaient l'industrie du charbon aussitôt que possible. Le recrutement massif de nouveaux migrants était généralement suivi d'un pic de sortie. Les conventions italiennes, espagnoles et grecques seront encore suivies de conventions bilatérales avec le Maroc et la Turquie (I964), la Tunisie (I969) et l'Algérie (I970). La recherche de travailleurs migrants en nombre suffisant était une préoccupation constante et leur présence sur le marché du travail deviendra un phénomène structurel.

\section{LE CÔTÉ DE L'OFFRE: L'ABANDON DE LA MINE}

L'augmentation de la demande de mineurs à la fin du dix-neuvième siècle s'était manifestée au moment où l'offre connaissait des mutations d'une grande importance dans l'évolution de l'offre d'emplois pour les charbonnages du vingtième siècle. L'interdiction susmentionnée du travail souterrain des femmes et des enfants y avait contribué mais, à long terme, d'autres causes prendront plus d'effet.

A la fin du dix-neuvième siècle, il existait un noyau solide de familles locales et régionales dans l'ancien bassin houiller de Liège, dans lesquelles le métier de mineur se transmettait de génération en génération. La tradition de descendre dans la fosse de père en fils tendait néanmoins à disparaître. La réduction de la fertilité conjugale n'y était pas étrangère. Dans les familles de mineurs, la fertilité conjugale était auparavant particulièrement élevée. Dès leur plus jeune âge, les enfants travaillaient dans les mines et contribuaient ainsi aux revenus du ménage. Des familles de mineurs avaient un niveau de vie plus élevé mais le ralen- 
tissement économique du dernier quart du dix-neuvième siècle risquait d'y mettre fin. Le chômage touchait surtout les non-qualifiés, les femmes et les enfants. Un changement de mentalité qui se traduisait dans le comportement démographique de la classe ouvrière minière. Les mineurs envisageaient pour leurs enfants un autre métier, moins lourd et avec plus de prestige social. Pour y parvenir, ils limitaient le nombre de descendants, pour qu'il y ait plus d'espace financier permettant à leurs enfants de suivre un enseignement et ainsi bénéficier d'opportunités plus nombreuses sur le marché du travail. Cette stratégie des familles ouvrières avait engendré une réduction de l'offre sur le marché du travail. Quant à la baisse du taux de natalité, elle mènera à la longue à une répartition par âge différente de la main-d'œuvre. Par rapport à l'ensemble de la Belgique, la région liégeoise comptait trop peu de jeunes et se trouvait donc confrontée à un vieillissement de ses effectifs.

Pendant la crise des années I930, la renonciation au travail de la mine par les travailleurs locaux s'était poursuivie. Les ouvriers continuaient à ressentir une forte aversion pour le métier de mineur, d'autant plus pour le travail souterrain, beaucoup moins attractif que les nombreuses alternatives proposées par exemple dans la sidérurgie ou la construction. Avec la disparition de la probité professionnelle suite aux progrès technologiques et à la rationalisation, le métier de mineur se métamorphosait de telle sorte que des mineurs de longue date délaissaient eux aussi les chantiers. Ces années étaient en outre caractérisées par une surmortalité. Dans la région de Liège, il y avait moins de naissances que de décès, ce qui concourrait, là aussi, à réduire l'offre de main-d'œuvre potentielle.

Le déclenchement de la Seconde Guerre mondiale n'aura fait qu'accentuer plus encore l'abandon des charbonnages par les ouvriers. Beaucoup d'étrangers s'en allaient parce qu'ils étaient rappelés dans leur pays d'origine ou parce qu'ils étaient réquisitionnés pour aller travailler dans les charbonnages allemands. Des mineurs belges expérimentés quittaient également les charbonnages de Liège, initialement pour se mettre en service du pays, et par la suite pour aller aussi travailler dans les charbonnages allemands qui offraient de meilleures conditions de travail. Que la chute du nombre de mineurs belges dans les charbonnages de Liège ne fût pas si spectaculaire s'expliquait par le nombre d'ouvriers dits 'temporaires'. Ces ouvriers, généralement inexpérimentés, se présentaient comme mineurs pour échapper au travail forcé en Allemagne. Après la guerre, ces 'temporaires' partaient aussi vite qu'ils étaient venus. Cet 'abandon de la mine', amorcé dès avant la guerre, se poursuivra avec une ampleur considérable après la libération. Au moment où l'industrie houillère belge réclamait beaucoup de mineurs pour gagner la Bataille du charbon, les Belges lâchaient en grand nombre les charbonnages. Par analogie avec la terminologie de guerre en vogue, on appelait ce phénomène 'la désertion des fils'.

Une analyse du sondage effectué au fonds de pension a démontré que, chaque année, 30 à 40 pour cent des mineurs nés en Belgique mettaient fin à leur contrat de travail. La balance des mineurs d'origine belge montre un excédent de départs par rapport aux arrivées. De moins en moins de personnes considéraient le travail à la mine comme un métier à vie mais plutôt comme un choix de carrière temporaire, un mal nécessaire en période de ralentissement économique, une option par défaut.

Avec le temps, les mineurs des provinces belges autres que Liège délaissèrent progressivement la région liégeoise, surtout des navetteurs provenant du Limbourg belge et du Brabant. Pour ces derniers, leur rotation était la plus élevée et la durée de leur carrière la plus 
courte dans l'immédiat après-guerre. Les navetteurs pouvaient également être considérés comme des 'ouvriers temporaires': le travail à la mine n'était pour eux qu'une occupation temporaire, un moyen rapide de gagner de l'argent.

A la fin des années I940, les conditions de travail primaires et secondaires favorables et le taux avantageux du franc belge attiraient des ouvriers frontaliers néerlandais. De plus, les critères de sélection en vigueur dans les charbonnages de Liège étaient moins sévères. Beaucoup de Néerlandais qui ne trouvaient pas de travail dans leurs charbonnages parce qu'ils étaient soit trop vieux, soit trop peu expérimentés, soit trop souvent absents, soit trop revendicatifs, pouvaient espérer être engagés dans le bassin de Liège.

Tandis qu'à partir de la fin des années I920 le nombre total d'ouvriers dans les charbonnages liégeois diminuait sans cesse, le nombre de travailleurs étrangers augmentait de façon presque constante à partir de i947. L'expansion nécessaire de la zone de recrutement rassemblait un large panel de nationalités au cœur du bassin liégeois. Les Italiens étaient les plus nombreux: dans les années I950, ils représentaient presque deux tiers des ouvriers immigrés. Après une interruption du recrutement pendant la crise du charbon, de nouvelles vagues de migrants seront attirées dans les années i960 (des Grecs, des Espagnols, des Marocains et des Turcs).

Les promesses que les employeurs des mines avaient faites aux migrants quant au logement et au salaire n'étaient pas toujours tenues et un grand nombre de nouveaux venus s'était déjà mis en quête de meilleures conditions de travail peu de temps après leur arrivée. Une partie des migrants de l'après-guerre ne parvenait pas à s'adapter au travail souterrain et abandonnait vite les charbonnages; une autre partie, malgré les critères de sélection, se révélait physiquement inapte au métier. Il y avait constamment de nouveaux groupes d'étrangers inexpérimentés qui arrivaient. La plupart des migrants étrangers travaillait entre un et cinq ans dans les charbonnages (leur contrat de travail ne les liait pas plus d'un an à un charbonnage spécifique); après ces cinq années, ils pouvaient choisir de quitter les mines et se diriger vers d'autres industries. L'essentiel des migrants ne visaient pas, eux non plus, une carrière à vie dans les charbonnages de Liège.

\section{LE COMPORTEMENT SUR LE MARCHÉ DU TRAVAIL ET 'LA LOI SUR L'AVANCE FREINANTE'}

Le marché liégeois du travail des mineurs illustre la thèse de Van Hoof selon laquelle il peut y avoir des segmentations du marché où certaines catégories d'ouvriers obtiennent une position relativement forte. En conséquence de la pénurie de mineurs dans la région liégeoise, les ouvriers autochtones se trouvaient plus avantagés sur le marché du travail. Les employeurs avaient dû faire face à une insuffisance de l'offre de main-d'œuvre, la demande de travail étant plus grande que l'offre locale. Dans ce contexte, une hausse des salaires paraissait inévitable tandis que, pour les prestataires de travail, les occasions d'emploi étaient légion. La question de la pénurie de main-d'œuvre sur le marché du travail fut, dans un premier temps, 'résolue' par le recrutement de navetteurs, d'ouvriers frontaliers et de travailleurs migrants, ce qui aidait les employeurs liégeois à atténuer dans une certaine mesure les inconvénients de leur position de force inégale. Après la Seconde Guerre mondiale, le problème de la pénurie de main-d'œuvre était cependant plus criant que jamais et les employ- 
eurs liégeois s'étaient trouvés forcés de chercher leurs mineurs de plus en plus loin et de les attirer en masse. Le pourcentage de mineurs étrangers sur la main-d'œuvre totale dans les charbonnages de Liège allait devenir de plus en plus important.

Une explication commune à la présence d'étrangers sur le marché du travail est la théorie d'un marché de travail dual. Les travailleurs migrants se trouvent dans le segment inférieur, où se situent les emplois à bas salaires, avec peu ou pas de sécurité de maintien ou de possibilités de promotion. Ils remplissent une fonction de réserve et la politique de migration vise uniquement à offrir des contrats de travail temporaires permettant de sortir d'une période de pénurie de main-d'œuvre. Bref, l'attraction de main-d'œuvre étrangère est cycliquement réglée. Mais cette théorie de la dichotomie du marché du travail est une représentation trop simpliste de la situation des mineurs liégeois. Après la Seconde Guerre mondiale, le recrutement de travailleurs migrants allait constituer un phénomène structurel sur le marché du travail liégeois. De plus, plusieurs groupes pouvaient être distingués, chacun avec son comportement propre sur le marché du travail.

Le comportement des mineurs liégeois était substantiellement caractérisé par l'abandon de la mine; les navetteurs provenant d'autres provinces se manifestaient de plus en plus comme des travailleurs temporaires. Les migrants étrangers, devant être renouvelés régulièrement, ne permettaient pas de constituer un effectif de personnel stable.

Les employeurs des mines liégeoises faisaient preuve d'une vision à court terme. Après la Seconde Guerre mondiale, ils visaient surtout à renouveler systématiquement les contingents de travailleurs migrants, qui, après une formation professionnelle de courte durée, pouvaient se rendre au travail. Il est évident que ces actions amenaient toujours de nouveaux mineurs dans le bassin de Liège, mais les employeurs n'arrivaient pas à les y maintenir à long terme.

Il est surprenant qu'avec le nombre de mineurs qualifiés qu'ils avaient rassemblés au crépuscule du XIXe siècle, les charbonnages liégeois avaient été incapables de conserver un effectif durable au vingtième siècle. 'La loi sur l'avance freinante' qui s'appliquait à la structure et aux méthodes de production du bassin liégeois, se manifestait aussi dans la gestion liégeoise du personnel. La culture traditionnelle des mineurs avait un rôle inhibiteur face à l'innovation dans la gestion du personnel. Maintenir des ouvriers en place grâce à la formation professionnelle des hommes ne rencontrait pas de succès. En plus, cette classe établie de mineurs soutenait de moins en moins les charbonnages plus rationalisés et modernisés.

A posteriori, il est difficile de dire si les employeurs des mines auraient dû prendre d'autres mesures ou en adopter plus. Malgré la modernisation et la mécanisation, travailler dans les mines restait un métier lourd, sale et mauvais pour la santé. Trouver suffisamment d'ouvriers expérimentés constituait un défi dans tous les bassins houillers. Au vingtième siècle, les deux bassins limbourgeois étaient tout de même parvenus à constituer un effectif relativement stable, ce qui prouve que, dans l'industrie houillère, mettre en place et réussir une politique de gestion des ressources humaines réussie était possible. Le milieu des années I930 marque une transition dans les stratégies d'emploi du patronat des mines et des mineurs. Le marché du travail allait être de plus en plus institutionnalisé, structuré, et les relations collectives allaient gagner en stabilité. Cette période est aussi un tournant pour Liège mais dans le sens contraire car elle s'y inscrit la fin des relations stables. Lorsqu'on compare les bassins houillers eurégionaux, on peut mettre en exergue un grand nombre de 
différences: contrairement aux employeurs limbourgeois, les employeurs liégeois devaient faire face à une rude concurrence d'autres secteurs offrant des alternatives plus attrayantes; contrairement aux bassins charbonniers limbourgeois où des jeunes entraient sur le marché du travail, la région de Liège se trouvait confrontée à une évolution démographique négative et les houillères liégeoises n'arrivaient pas à investir suffisamment dans la formation professionnelle, de telle sorte qu'il était impossible de créer un ensemble de mineurs fixes, comme c'était le cas dans les houillères du Limbourg. Toutefois, en considération des éléments structurels, il est douteux que d'autres stratégies aient été possibles. 


\section{Summary and conclusion}

The Liege coal basin was one of the oldest mining regions in Europe, and that long prehistory determined the structure and scale of the mining companies, the layout and organisation of the work underground, the productivity, and the development of the labour market. During the course of the twentieth century, the Liege mines encountered increasingly greater challenges in the size of their labour force. This increasing shortage is the central theme of this book. How large was the labour shortage, and how did it evolve? What were the causes and how was it resolved?

We have gained insight into the strategies and behaviour of the actors on the labour market by combining micro data about the miners and their careers at the individual level with the development of employment in the coal industry and in the Liege region.

We approached the labour shortage issue from both the supply and demand sides. Concerning the demand side, we posed the following questions: How did the mining companies attempt to resolve the labour shortage? What challenges and problems did they face therein? What was the role of the government? Were there separate market segments for particular groups of miners? Did the employers manage to retain sufficient miners once they were hired?

We posed the following questions concerning the supply side: Which groups of labourers chose to become miners? What was their geographic and social background, and how did their careers develop? How did their demographic behaviour affect the supply on the labour market? How was the labour turnover and what were the differences in labour market behaviour between groups of miners?

The starting point of this research is situated at the end of the nineteenth century. The Liege coal industry had already been well established at that time. From around I89o, developments on the demand side as well as the supply side of the labour market led to structural changes in the composition of the labour force. Reflected in that evolution was an increasing shortage of local and regional labour for the Liege mines.

Five separate studies each highlight a different aspect of the labour shortage. The first study, presented in Chapter I, focused on structural developments on the labour market. By identifying the evolution in the Liege mining industry, it became apparent that the demand side was continuously evolving. From the start of the twentieth century on, a number of Liege mines ceased production and a number of small extraction sites merged into larger coalmines, which in turn ceased production in a later phase. Of the nearly 80 coalmines in production around I9oo, there were only 22 left in 1958 . The last mine to close was the Argenteau-Trembleur (Blegny) mine, in 1980.

Developments on the supply side were also of great influence on the labour market. The 
subject of the second part of this first chapter was demography. Due to structural changes in demographic behaviour, the available labour supply decreased drastically during the course of the twentieth century.

The theme of the study in Chapter 2 was female labour. In I9oo, women formed a substantial part of the labour force in the Liege mines. In I892, Belgium was one of the last Western European countries that introduced a law to forbid female labour in the mines. The prohibition meant a substantial loss for the labour provision in the Liege mines.

Since the coal mining industry was an established industry in the Liege region around I90o, the mining companies were able to draw from a steady regional labour force. The Liege mines were able to count on the fact that miners would succeed one another from generation to generation. In that situation, not many foreign workers were needed. That changed during the course of the twentieth century. Chapter 3 presents the development of a labour market, which increasingly had to attract foreign labourers. Especially after World War II, the employ of migrant workers from abroad took up large proportions. In the I970s, there were even Liege mines where there were no longer Belgians doing the underground work.

The specific causes of this large shortage of Belgian labourers immediately after World War II is detailed in Chapter 4. It is argued that the so-called 'battle for coal', declared by Prime Minister Achille Van Acker, had to be fought with a legion of foreigners, because their own troops had 'deserted'. The disappearance of regional labourers from the Liege mines analysed in detail in Chapter 5 , was mostly because of the bad reputation of the out-of-date Liege mines, in combination with alternative forms of employment in the Liege industry, well available in those years of economic prosperity. A positive effect of the previously noted process of industrial concentration in the mining sector was a decline in labour turnover.

\section{STRUCTURAL ELEMENTS}

As described above in short, it became apparent that problems with the labour supply in the Liege mines increased during the course of the twentieth century. We found concerns about this in all kinds of contemporary reports and this could be deduced from the increasingly larger share of migrant labour in the Liege mines. While only 5,7 percent of the labour force in the Liege mines in I923 had non-Belgian nationality, it increased to almost 25 percent leading up to World War II. After the war, that percentage increased considerably from 50 percent in 1947 to more than 70 percent at the start of the I970s. The analyses presented in the different studies give us insight into the causes of the shortage, which were found in a combination of factors on the supply and demand sides, and date back to the rgoos.

The sociological approach to the labour market that was applied in this book searches for the conditions and forms of labour market behaviour. The concept of 'strategy' is important in this approach. However, opportunities for strategic behaviour are not unlimited. Economic, social, and ideological boundaries limit the freedom of action of the actors, on both the supply and demand sides. The miners and mining companies operated in an environment that they could not (completely) control. A number of structural elements formed the context, the space where the miners and employers manoeuvred on the labour market. 
The demand for coal increased for the first time at the start of the research period, in the last quarter of the nineteenth century, when the market for domestic coal became much greater due to changing heating practices. In Liege, where a lot of coal for domestic use was extracted, the employment for miners quickly expanded during the last decade of the nineteenth century, and reached a climax in the first decades of the twentieth century. The market for domestic coal was much more stable than the market for bituminous coal. In the interwar period, the demand for coal decreased due to the competition of petroleum, hydraulic energy and electricity, and the crisis of the I93os.

Just after World War II, there was once again a strong increase in the demand for coal, as part of the 'battle for coal'. In contrast to the French and Dutch mines, the Belgian mines were largely undamaged by the war. Belgium provided the supply of coal, which was an essential fuel for post-war European reconstruction. However, towards 1948 , the demand for coal quickly, returned to normal levels. Surrounding countries started their coal production again.

Mining labour was generally known as heavy, unsafe, unhealthy, and dirty. That was especially true for the work underground, for which the labour demand was always the greatest. Moreover, the Liege basin had specific and difficult geological circumstances: thin and rumpled coal layers with a lot of flooding. Due to the Liege mines starting early, exploitation became increasingly difficult and more labour-intensive. Mining companies had to dig ever deeper since the accessible layers were exhausted. This made productivity fairly low. The Liege basin was initially divided into many small concessions. The way in which most mines were organised in the nineteenth century created a certain 'path dependency': it was difficult to transform the often traditional family companies into modern, twentieth century enterprises. The development of the Liege coal industry, while strong and fast during the second half of the nineteenth century, slowed down after World War I. ${ }^{2}$ The law of the handicap of $a$ head start applies here.

Rationalisation and mechanisation was only partially successful due to the aforementioned geological circumstances and the nineteenth century legacy, but also due to a lack of investments. The Liege coal industry was characterised by small-scale operations, especially in comparison with the coal basins in Belgian and Dutch Limburg. There were a few large mining companies with thousands of miners, but on the eve of World War II, a large part of the Liege mines only employed a few hundred labourers. An enterprise's production was often spread out over several extraction sites, at least until the coal crisis in 1958. Nearly two-thirds of the mining companies were still completely financially independent in that period. The influence, and therefore also the investments, of large holdings and banks was limited in the Liege basin, and the fragmented ownership structures hampered heavy investments. Furthermore, the coal prices that were kept artificially low by the government after World War II, in combination with high wages and expensive social security, generated a lot of revenue but there was little profit. Hence, there was no accumulation of reserves for rationalisation and modernisation. The entrepreneurial climate in the Liege mining industry was characterised by competition, rivalry, and isolation, also towards other coal basins. A further concentration of the production by mergers and take-overs did not occur or

2 Sporck, L'activité industrielle, I02; Conseil Économique Wallon, Economie wallonne, 156-157. 
did not happen in time.

As long as the labour supply was sufficient, these circumstances did not cause too many problems for the mining companies. In the heavily industrialised Liege basin however, there were many other sectors also looking for sufficient labour forces. Already in the nineteenth century different industries, such as the metallurgical industry and the corresponding coke and blast furnaces, the machine industry, the arms industry, the glass industry, and the wool industry (in Verviers) offered many possibilities for people seeking employment. In the twentieth century the services and trade sectors grew and they too looked for and attracted workers.

The supply for the Liege mines not only declined due to this competition with other branches and sectors. From the second half of the nineteenth century secularisation, urbanisation, and improved education influenced labourers to use birth control. Metalworkers and miners were pioneers in family planning. Demographic behaviour changed and was characterized by a low fertility rate. This instigated a decline in births from the beginning of the twentieth century on, which even turned into an excess of deaths after World War I.

\section{THE DEMAND SIDE: THE SEARCH FOR MINERS}

The demand for miners increased when the demand for domestic coal increased sharply at the end of the nineteenth century. It was during that time that mining companies could no longer employ female labour to strengthen the underground labour force. Until then, women had filled an important portion of the Liege labour market for miners. The advantages for the mining companies to use women's labour were diverse: the considerably lower wages for women in a trade where the cost of production was largely made up of the cost of wages, and the impossibility of mechanising certain 'women's' tasks due to the costs or the difficult geological circumstances. Before the implementation of the ban on underground female labour, there was a vertical segregation: women had specific roles within the mining company. Due to the implementation of the ban in 1892 , women gradually disappeared from underground mining, thereby causing a horizontal segregation: women were no longer found in the underground labour market segment.

In that period and in the first decades of the twentieth century, the Liege mines made a great effort to recruit sufficient labourers on the local, regional, and national labour market. Liege miners were generally supplemented by labourers from other parts of Belgium: especially the rural districts of the Liege province and the Southern Limburg Haspengouw region were interesting recruitment areas. Mining companies attracted these workers by offering high wages, especially in comparison with the wages in the agrarian sector, and by facilitating the transport to and from the mines. The government contributed by developing and subsidising suitable rail passes and commutation tickets.

The arrival of the Flemish labourers was, however, insufficient to cover the shortage of local miners. After the chaotic intermezzo of World War I, the mining companies could quickly produce normally again, but the necessary miners were difficult to find. The Liege mines had competition from the more modern coalmines in Belgian and Dutch Limburg that sometimes offered more favourable conditions of employment and were often more 
accessible. They attracted many Flemings that used to commute to the Liege basin. The commuting to the Liege basin did not disappear, but the recruitment area expanded even more during the course of the twentieth century. The fact that commuters had to come from further away reveals that it was becoming more and more difficult to find local and regional miners. The employers were not successful in preventing traditional, local miners from leaving the mines.

Just as in most other mining basins, management of the Liege mines had to appeal to miners from outside the national borders. In the years between the first and second world wars, targeted recruitment campaigns were organised by the employers' organisation FEDECHAR to provide the Liege mines with Italian and Polish labourers. The Italian workers were usually inexperienced. The Poles came from the mining region of Silesia or the Ruhr region, and generally had mining experience. Another mostly experienced group of migrant labourers were the Maghrebs coming from the French coal basins. The portion of foreign labourers on the Liege market gradually grew from less than 6 percent in 1923 to more than 22 percent on the eve of World War II.

In the interwar period, the Liege mining companies tried to rationalise in order to increase productivity. There were mergers between enterprises, which allowed for the concentration of financial means in order to modernise. Due to geological circumstances, complete mechanisation was not possible, but rationalisation resulted in a rise in productivity in the first half of the I93os. This is why, for the time being, the decline in labourers during the economic crisis did not result in a decreased production.

It is remarkable that the decreasing employment opportunities were not passed on to foreigners, as was the case in neighbouring mining regions. Between I930 and I934, more Belgians than foreigners left the Liege mines. In both Dutch and Belgian Limburg, that ratio was the other way around. This makes clear that a policy to attract local labour could be successful in Limburg.

In contrast, in the Liege mines the dependency on foreign labourers increased from the economic revival in 1936 on. Cross-border labourers also played an important role. The Liege mines generally offered good employment conditions and high wages and had less strict selection criteria than for example the Dutch mines. World War II worked as a catalyst for the labour shortage: during and after the war, mining companies and the Belgian government were confronted with a mass exodus of labour forces from the mines, and the ensuing sharp drop in production. They had to find new miners quickly.

Directly after World War II, there was still hope to attract labourers from Belgium to expand coal production for the post-war reconstruction, but the special regulations for miners and the accompanying advantages did not ensure that more Belgians went to the mines. On the contrary, many miners used the new social legislation to bid the mine farewell prematurely. Therefore, these measures had an adverse effect.

Professional training for miners was also one of the possible remedies to counteract the 'flight from the mines': training could increase the prestige of the mining profession and stabilise the labour force. The existing training programs however had little success, because initially in most Liege mines, knowledge and skills were acquired and passed on traditionally: from father to son and from an experienced to a novice miner. After the war, an attempt was made to give the professional training new impetus, under the State Super- 
vision of Mines. The number of students that followed the training program in the early I950s, however, was negligible. Eventually, the Belgian government and the mining companies did not succeed in convincing the favoured Belgian labourers to resume their work in the coalmines, despite the attractive employment conditions and high wages.

Temporary employment of German prisoners of war could alleviate the need during a short period, but recruitment across the borders was inevitable to resolve the structural problem of labour shortage. Because of the Belgians' mass 'desertion', the 'battle for coal' declared by Prime Minister Achille Van Acker in I945, was fought largely by a foreign legion in the Liege mines.

The presence of an increasingly large percentage of foreigners on the labour market of the Liege coal industry clearly indicates that the supply on the local labour market was insufficient. In order to attract foreign labourers, mining companies went looking abroad. Later, the government stepped in to conclude treaties with the emigration countries concerned. To make the mining work attractive, promises were made in terms of housing and wages. A bilateral treaty between Italy and Belgium ensured that from 1946 onwards, large contingents of Italians made their way to the Liege mines. Via an agreement with the allies, the Belgian government also succeeded in recruiting thousands of so-called Displaced Persons for the mines. After the mining disaster in Marcinelle in 1956, official migration was halted by the Italian government. New recruiting agreements were concluded with Spain (I956) and Greece (I957).

However, it was not possible to establish a stable labour force from the foreign migrants. Due to the fact that there was a large labour turnover among migrants, the Liege mines came into a vicious cycle in terms of labour supply. They continually had to recruit and train new groups of inexperienced migrant labourers, which left the mining industry again as quickly as possible. Years of mass recruitment of new migrant groups were generally followed by a peak in the outflow. After Italian, Spanish, and Greek treaties, bilateral treaties with Morocco, Turkey (I964), Tunisia (I969), and Algeria (I970) followed. Finding sufficient migrant labourers was a constant concern, and their presence on the labour market became a structural phenomenon.

\section{THE SUPPLY SIDE: THE 'FLIGHT' FROM THE MINES}

The increase in demand for miners at the end of the nineteenth century occurred at the same time as certain developments on the supply side with great influence on the evolution of labour supply for the mines. The ban on underground labour for women and children mentioned previously played a part, but in the long term, other developments turned out to be more important.

In the old Liege mining basin at the end of the nineteenth century, there was a steady core of local and regional families, in which the mining trade was passed on from generation to generation. The tradition of descending into the pit, passed on from father to son, began to disappear however. The decline in fertility proved to be significant. Initially, the fertility rate of mining families had been remarkably high. Children went to work in the mines at a young age in order to contribute to the household income. Living standards of mining 
families were high, but they were affected due to the economic downfall in the last quarter of the nineteenth century. Especially the uneducated, women, and children were afflicted by unemployment. There occurred a distinct change of mentality in the traditional mining population, which was expressed in an altered demographic behaviour. Miners chose a different career for their children, less heavy, and with more social prestige. To achieve that, they limited the number of children, as a result of which there was more financial room to provide their children with more and long-term education, in order to have better chances on the labour market. These strategies of working class families resulted in a decrease in supply on the labour market. The decline in birth rate provoked a deviant age distribution in the long run. Compared with Belgium as a whole, the Liege region had a shortage of youth, a so-called 'dejuvenation'.

During the crisis of the I930s, the exodus of local labourers continued. Their aversion to the mining trade remained strong, especially for the underground work that was much less attractive than the many alternatives, for example in steel or construction trades. Due to the disappearance of the professional pride as a result of technological developments and rationalisation, the mining trade changed to such an extent that even more traditional miners resigned. Moreover, from that period onwards, there was actually excess mortality, in the Liege region: fewer children were born than people died, which resulted in an even greater decrease in potential labour force.

At the outbreak of World War II, even more labourers left the Liege mines. Just before and during the war, many foreigners were called upon by their own countries, or demanded to work in the German mines. Experienced Belgian miners also deserted the Liege mines, initially to serve their country, but later also to work in the German mines, which offered better employment conditions. The fact that the number of Belgian miners in the Liege mines did not decline drastically had to do with the supply of 'temporary labourers'. They were generally inexperienced labourers, who volunteered as miners in order to escape forced labour in Germany. When the war ended, these 'temporary labourers' left just as quickly as they had arrived. The so-called 'flight from the mines' that had presented itself already before the war, continued in force after liberation. At a time when the Belgian coal industry needed a great number of miners to win the 'battle for coal', the Belgians left the mines en masse. This was referred to as the 'desertion of the sons' by analogy with dominant war terminology.

The analysis of the sample from the pension fund shows that between 30 and 40 percent of the Belgium-born miners ended their employment contracts each year. More Belgians resigned than there were Belgians recruited, and less and less workers considered mining a lifelong career. Instead, working in the mine was rather seen as a temporary career choice, a necessary evil in times that were not as economically prosperous; an option when there was nothing else available.

Miners from other Belgian provinces than Liege, especially commuters from Belgian Limburg and Brabant, in due course also became less dedicated to the miners' trade. In the period after World War II, they show the highest labour turnover and the shortest employment contracts. One could consider the commuters to be 'temporary labourers': for them, mining was a temporary occupation, a way of earning money quickly.

Dutch cross-border labourers were attracted at the end of the I940s by the favourable 
primary and secondary employment conditions and the favourable exchange rate of the Belgian Franc. Moreover, the selection criteria of the Liege mines were less strict. Many Dutchmen who were rejected in the Dutch mines because they were too old, had little or no experience, were absent too often or too militant, were engaged in the Liege basin.

While the total number of employees in the Liege mines continually declined from the end of the I920s onwards, after 1947 the number of foreign labourers grew steadily. The necessary expansion of the recruitment area brought diverse nationalities to the Liege ba$\sin$. The Italians had the largest share: in the I950s, they formed nearly one-third of the immigrated labour force. After a pause in recruitment during the coal crisis, new groups of migrants were recruited in the ig6os (Greeks, Spaniards, Moroccans, and Turks).

The promises made by the employers concerning housing and wages for migrant workers were not always fulfilled, as a result of which a large proportion quickly went looking for better employment conditions. Moreover, a part of the post-war migrants could not get accustomed to the work underground and quickly left the coalmines; another part turned out to be unsuitable for the trade, despite the selection criteria. New groups of inexperienced foreigners arrived continuously. The majority of the foreign migrants worked in the Liege mines one to five years. They were bound to work at least one year for a specific mining company by their employment contract; after five years, they were allowed to look for work outside of the coal industry. A lifelong career in the Liege mines was not the aim for most migrant labourers.

\section{LABOUR MARKET BEHAVIOUR AND THE LAW OF THE HANDICAP OF A HEAD START}

The Liege labour market for miners illustrates Van Hoof's position that there can be market segments in which certain categories of labourers acquire a relatively strong position on the labour market. The shortage of miners in the Liege region ensured that the native labourers had an advantage on the labour market. For the employers, it was a tight labour market: the demand for labour was larger than the local supply. In that situation, a wage increase was inevitable and those offering their labour were in the position to be selective. The shortage on the labour market was initially 'resolved' by recruiting commuters, cross-border labourers, and migrant labourers, whereby the Liege employers to some extent managed to reverse the uneven power relations. The problem of the labour shortage escalated after World War II, and the Liege mining companies were forced to look for their miners further away, and in greater numbers. The portion of foreign miners on the total labour force in the Liege mines became increasingly important.

A traditional explanation for the presence of foreigners on the labour market is the dual labour market theory. Migrant labourers are found in the lowest market segment, with low wages, and with little or no job security or mobility. They fulfil a buffer function, and the migration politics are aimed at offering temporary employment contracts in order to absorb periods of labour shortage. In short, attracting foreign labourers is cyclically directed. This theory of a divide on the labour market presents the situation of the Liege miners too straightforward. After World War II, the recruitment of migrant labourers on the Liege labour market for miners became a structural phenomenon. Moreover, we could distinguish 
several groups, each with their own labour market behaviour.

The behaviour of the Liege miners was primarily characterised by a desertion of the mines; commuters from other provinces manifested themselves increasingly as temporary labourers. It was also not possible to establish a stable labour force among the foreign migrants who continually had to be recruited.

The Liege mine employers held on to a rather short-term vision. After World War II, mining companies were mainly focusing on attracting new contingents of migrant labourers that quickly started working after a short professional training course. These actions continually attracted new miners to the Liege basin, but the employers were not able to get them to commit to the Liege mines for the long term.

It is remarkable that the Liege mines with their stable labour force at the end of the nineteenth century could not manage to consolidate a work force in the twentieth century. The law of the handicap of a head start that applied to the structure and production possibilities in the Liege basin was also manifested in the Liege employment policies. The traditional miner culture played an inhibiting part in the innovation of personnel policy. Gaining labourers' loyalty by means of professional training for boys was not successful. In addition, the established miners' class could identify less and less with the rationalised and modernised mines.

Whether the mining companies could have or should have taken different or more measures is difficult to say after the fact. Mining remained, despite modernisation and mechanisation, a heavy, dirty, and unhealthy profession. In all mining basins, it was a challenge to find sufficient and experienced labourers. The fact that coal basins in both Belgian and Dutch Limburg succeeded in developing a more or less stable labour force nevertheless indicates that it was possible to implement a successful personnel policy in the mining industry. In the mid-I930s, there was a breaking point in the labour market strategies of these mining companies and miners. Their labour market became more and more institutionalized and structured, and more stable labour relations developed. In Liege there was also a breaking point in the mid-I93os, however this marked the end of stable relationships.

In a comparison of the Euregional mining basins, there are a number of differences to point out: the Liege mining companies, in contrast with the Limburg companies, experienced a lot of competition from other sectors that offered more attractive alternatives; the Liege region also had a negative demographic development, in contrast with the coal basins in Belgian and Dutch Limburg, where the labour market attracted sufficient young people, and the Liege mining companies didn't manage to invest sufficiently in professional training in a way that a stable group of miners could emerge, as in the Limburg mines. However, it is a question of whether other strategies would have been possible with the given structural elements. 


\section{Register}

Aarschot 5I

Abhooz (et Bonne-Foi-Hareng), mijn $\quad 42$, I99, 208209, 2II, 225

Abruzzen 63

Achille Charbon (bijnaam) zie Acker, Achille Van Acker, Achille Van $\quad$ 40, 70, I07, I35, I88, I92

Administration des Mines, zie ook: Mijnwezen 24, 77,79

Aken 26, 65, 103

Algemeen Rijksarchief Brussel 24

Algerije II3, I93

Andenne 5I

Andenne (Est d'), mijn 210

Angleur, mijn 2IO, 212, 225

Ans $30,35,50, \mathrm{I} 4 \mathrm{I}$

Ans et Rocourt, mijn 37, 107, 204, 208, 210-2II, 225

Antwerpen 5I, 90

Apulië 63

Arbeidsbeurs van Sittard 60

Arbre Saint-Michel, mijn 36, I35, I99, 209, 2II, 225

Archives de l'Etat à Liège (AEL), zie ook: RAL 25

Argenteau 42

Argenteau-Trembleur, mijn $\quad 27,48$, I32, I38, I40-

I4I, I68, I88, 204, 208, 2II-2I2, 225

Association Charbonnière de la Province de Liège 25

Associations Charbonnières 25

Australië 4I

Ayeneux 49

Bairin, Paule 9I

Banque de Belgique 36

Bardoul, H.J. $\quad$ I49

Batterie, mijn 107

Battice 208

België (Belgen) I5, 2I-22, 26, 29, 32, 34, 38, 4I, $43-44,48,5160-61,64,66,68,70-71,7375,78-$

79, 83, 93-94, 96, IOO-IOI, I05, IO7-IO9, III-II5,

II7-II9, I2I, I23, I25-I27, I32, I34-I37, I40-

I43, I46-I48, I52, I54-I55, I58, I6I, I65, I72-

I73, I8I, I84-I85, I88-I89, I9I-I94, 203, 2I9

Belgisch-Limburg, zie: Limburg, Belgisch-
Belgische Werkliedenpartij (BWP) 7I, I98, 202

Benedenmaas 30

Beringen 50

Bettens, Ludo 22I, 225

Beyne 29

Beyne-Heusay 49, 212-213

Beyne-Homvent 209

Blegny 23, 27, I50, I88

Bonne-Fin, (Baneux et Batterie), mijn 209

Bois d'Avroy I4I

Bois d'Avroy, mijn $\quad 3 \mathrm{I}, 34,36, \mathrm{I47}, \mathrm{I} 80,204-205$, 208-209, 2II, 225

Bois-du-Cazier, mijn III

Bollenge 90

Bonne-Espérance, mijn 42

Bonne-Espérance, Batterie, Bonne Fin et Violette, mijn 208-209, 2II, 225

Bonnier, mijn 42, I07, 204-205, 208, 2II, 225

Borgworm 44, $2 \mathrm{I} 2$

Borinage 22, 29-30, 43, 79, 82, 99, I29, I3I, I4I

Bovenmaas 30

Bracke, Nele 75-76

Brussel 24, 26, 109

Bruyn, André De 22

Caestecker, Frank 22, 100

Caulier-Mathy, Nicole 22

Centrale des Mineurs $\quad 142$

Centre I29, I4I, 219

Centre de formation professionelle accélérée pour les travailleurs des mines de la Province de Liège $\quad$ I4O

Centre Liégeois d'Archives et de Documentation de l'Industrie Charbonnière (CLADIC) 23-25, I50, $2 \mathrm{I} 4$

Centre-Midi 65

Charleroi 22, 30, 84, 90, 99, I29, I34, I4I, I65, 219-220, 227

Chaudfontaine 99

Cheratte 35,49 , I08, I4I, I56-I57

Children's Employment Commission 72

Cockerill, mijn $\quad 34,36,74,91$, IIO, I98, 204, 208, 2IO-2II, 225 
Cockerill, John $\quad$ 2I, 32

Collinet, Marie 88

Commission Mixte pour l'Etude de la Réduction du Travail dans les mines 198

Commission Nationale Mixte des Mines I37, 199

Compensatiekas van de Kolennijverheid I26

Conseil central de la Construction d'habitation pour mineur ${ }_{13} 8$

Conseil des Charbonnages 134

Conseil supérieur d'hygiène des Mines I36

Constant, Joassart I80

Corps des Mines 32

Couillet 90

Cowette-Rufin, mijn 2IO

Davin, Louis 26

Delbroek, Bart 2I, 77, 214-215

Demeure de Lespaul, Charles 26

Dibbets, Theo 226

Diest 5I

Direction générale Statistique et Information économique 24

Directoire de l'Industrie Charbonnière $4 \mathrm{I}$

Domaniale mijn $\mathrm{I} 66$

Duitsland (Duitsers) 29, 38-39, 42, 44, 61, 88, 96, I03, I07, I09, I15, I26, I28, I30, I4I, I48, I94, 203

Düsseldorf 73

East-Scotland 72

Engeland $\quad$ 15, 34, 38-39, 72, 75, 96-98

Espérance (et Bonne Fortune), mijn 36, 42, 50-5I, I07, II9, 205, 208, 2 II

Espérance et Envoz, mijn 209-2IO, 225

Est de Liège, mijn 210, 225

Euregio Maas-Rijn 26, II5

Europa $\quad 65,83,107,134,187$

Europese Gemeenschap voor Kolen en Staal (EGKS) I5, 32, 4I, 65, II7, I20, I54, 203

Fédération des Associations Charbonnieres de Belgique (FEDECHAR) 24-25, I05, I08, I20, I26-I27, I39, I4I, I43, I50-I52, I57, I62, I65-I66, I69, I9I, 204

Flémalle 32, 99

Flémalle-Grande 49-50

Fléron I4I

Fonds du Logement de la Ligue des Familles nombreuses $\quad 137$

Fonds du Roi Albert 137

Fonds National de Retraite des Ouvriers Mineurs

(FNROM), zie ook: NPM 23-24, 219-22I, 225-227
Fonds voor Arbeidsongevallen (FAO) 220

Fonds voor Beroepsziekten (FBZ) 220

Frankrijk 34, 40, 42, 65, 72-73, 84, 96-97, 105, I26, I33, I48, 203

Gaier, Claude 22-23, 64, I20

Galopin-comité I26

Geebelen, Willy I5I

Geerkens, Eric I2I, 225

Geetbets 90

Gelinden 50

Genk 50

Gérard Cloes, mijn 90, 208

Gillingham, J. II9

Gingelom 50

Gives (et Ben), mijn I35, I4I, 209, 225

Glain 49, II5

Goddeeris, Idesbald 22

Gosson, mijn 6I, 74, 208, 225

Gosson-Kessales, mijn 42, 61, 204, 208

Gosson-Lagasse, mijn $\quad 85$, 90, 2 II

Gosson-La Haye et Horloz, mijn 209

Grâce-Berleur 49

Grand Makets, mijn 27, 208

Grande Bacnure, mijn 3I, 90, 129, I40, 179-I80, 204, 208, 2II, 226

Griekenland (Grieken) III, I60-I62, I67, I86, I92, 194

Groot, Gertjan de 76, 86, 97

Groot-Brittannië 4I, 7I-73, 96

Haegendoren, Mieke Van 2I, I49

Hageland 69, ro6

Hannotte, Michel 22I

Hartmann, Heidi 98

Hasard(-Cheratte), mijn 33, 36, 49, I07, I29, I40, I56-I57, I84, 204, 208-209, 2II, 226

Haspengouw 30,50 , 191

Hasselt 25, 50-5I, 90, 104, I5I, 22I, 225

Haye, La, mijn 9o, 209, 2II, 225

Heerlen 66

Heller, hoofd Referat I - Bergbau I26

Henegouwen 30, 34, 44, 78, 82, 90-91, 97, 99

Hermicheux 90

Herstal 29, 35

Herten 50

Herve 30, 32-34, 48-49, 5 I

Herzogenrath 6I

Hilden, Patricia $\quad 73-75,78,82-83,87-88$, 9I, 98

Hoepertingen 50

Hoge Venen 2 I2

Hoof, J. van I8, I95 
Horloz, mijn 34, 90, 209, 2II, 226

Humain 90

Huy 30, 173

Institut d'histoire ouvrière, économique et sociale

(IHOES) 24-25, 22 I

Institut d'Hygiène des Mines I36

Institut National de Statistique 24

Italië (Italianen) I7, 22, 29, 43, 62-64, 70, IO2, I04-I06, I08-IO9, III-II3, I43, I49, I53-I54, I58, I6o, I63, I67, I77, I85-I86, I9I-I92, I94, 203

Jacquemyns, Guillaume 2I

Jansen, André 225

Jemeppe I24, I4I

John, Angela 73, 78, 82

Joli-Fonds, mijn 2 Io

Julia, mijn I49, I66

Kempen 2I, 30, 36, 5I, 60, 65, I06, II2, I22, I28-I29, I3I, I33-I34, I4I, I56, I6I, I63, I82, I86, 219, 220

Kempen Bergbau I 26

Kempische bekken I07, I20, I3I, I33, I63

Kerkrade 36, 60, I03

Kessales (et Concorde), mijn 33, 90, 199, 208-209, 2II, 226

Kohlbacher, Jan II9

Koninksem 50

Kuborn, Hyacinthe $8_{3}$, $9 \mathrm{I}$

Kurgan-Van Hentenryck, Ginette 2I

Langeweg, Serge 2I, I46

Leboutte, René 40, 44, 77, 87, 92, I02, 2 I4

Leuven 5I, I04

Limburg, Belgisch- I9, 2I, 50-5I, I63, I73, I85, I94

Limburg, Nederlands- 20-2I, 26, 29, 46, 65, 99, Io6, II6, I45-I46

Logelain, Georges $\quad$ I33

Lotharingen 65

Lonette, mijn 209, 225

Luik I5, I7, I9, 2I, 24, 26, 28-30, 35, 4I, 50-5I, 6I, 66, 68-69, 78-79, 8I-84, 86, 92-94, 96-97, 99, I02, I04, I06-I07, IO9, III-II3, II5, II7, I20-I2I, I29, I3I-I32, I43, I48, I50, I53, I63, I73, I75, I8I, I85-I87, I89, I96, I99, 202, 22022I, 225

Luik, prinsbisdom 30

Luik, provincie $22,44-45,49,5 \mathrm{I}, 65,82, \mathrm{I} 23$, I72, I79, I85, I94, 2I2, 228

Luikse bekken I5-I7, 2I, 23, 26-27, 29-30, 32-38, 40, 44, 48, 6o, 63, 78-79, 82, 85, 90, 94, 99-100,
II5, I2I, I29-I30, I33-I35, I40, I43, I47, I49I50, I53, I62-I63, I65, I84, I88-I9I, I94-I95, I98-I99, 203, 2I4, 227

Luikse Mijnschool 38

Luxemburg 44, 90, 126

Maasvallei 30

Mahaim, Ernest $\quad 48,50-5 \mathrm{I}$

Maheu, Cathérine 72

Maireux et Bas Bois, mijn I8o, 209-2II, 226

Many, mijn 64, 208

Marche-en Famenne 90

Marcinelle 22, 64, III, I39, I58, I92

Marihaye, mijn 34, 9I

Marokko (Marokkanen) 46, II3, I6I-I62, I67, I86, I93-I94

Martens, Albert IOI, I20, I43

Medische Commissie van Henegouwen 78

Melen 49

Meuse, La, mijn 208-209, 226

Micheroux 49, I4I

Micheroux (Bois de), mijn 204-205, 208, 2I2

Midden-Limburg 50

Mijnwezen, Het, zie ook: Administration des Mines 24, I20, I39, I92

Millen 50

Milward, A.S. II9

Minerie, La, mijn $\quad 34$, I99, 204-205, 208, 225

Ministère de l'Industrie et du Travail 24, 77, 79

Ministerie van Economische Zaken 24

Ministerie van Werkgelegenheid en Sociale Voorzorg 136

Minon, Paul I48-I49, I63

Minten, Luc I20

Moha, mijn 208, 226

Montegnée 30, 49-50

Morelli, Anne 22

Munby, Arthur 73,84

Musée de la Vie wallonne 22

Namen 82

Nationaal Instituut voor de Steenkolennijverheid $\mathrm{I} 20$

Nationaal Pensioenfonds voor Mijnwerkers (NPM), zie ook: FNFROM 23-24, I52, I94, 2I9-22I

Nederland (Nederlanders) I5, I7, 2I, 26, 35-36, 4I-42, 44, 60-6I, 66, 68-70, I03, II5, II7, I33, I39, I46, I49, I5I, I58, I65, I72, I94, 203

Nederlands-Limburg, zie: Limburg, NederlandsNefors, Patrick II9

Nols, Emile $\quad$ I48 
Noord-Afrika (Noord-Afrikanen) I05, II3, II5

Noordegraaf, Leo I9

Noordelijke Kempen $5 \mathrm{I}$

Noord-Frankrijk 29, 7I-73, 75

Nord-Pas-de-Calais 34,65

Nouvelle Montagne, mijn $\quad 34,209-210$

Olmen 90

Ondergrondse Vakscholen (Ovs) I39, I58

Oost-Europa $\quad$ II5, 158

Oost-Limburg 5I

Oranje-Nassau Mijn(en) 66, 149

Ordingen 50

Ougrée(-Marihaye), mijn $\quad 32,50-51$, 9I-92, I07, I99, 204-205, 208-2II, 225

Oupeye 99

Oupeye, mijn 210, 212-213, 225

Paal 50

Parti Ouvrier Belge $7 \mathrm{I}$

Pasleau, Suzy 22, 92

Pays de Liège, mijn 209, 2II, 225

Patience (et Beaujonc), mijn 6o, I29, 204, 208-21I, 225

Piquet, Nathalie I29

Pluymers, Bart 2I, I49

Polen (Polen) 29, 4I, 62, I04-I05, I09, I9I

Pruisen 34, 73, 103

Prusse 88, 90, I03

Puissant, Jean 2I

Quaregnon, mijn 64

Quatre-Jean (et Minerie), mijn 34,2 II

Quatre-Jean de Retinne et Queue du Bois, mijn 208

Queue-du-Bois 49

Regionaal Historisch Centrum Limburg

(RHCL) 25, 228

Reichsvereinigung Kohle I26

Renard, kunstenaar 84

Renckens, René I5, I7

Retinne 49

Reumkens, P.J.M. I49

Rijksarchief Hasselt (RAH) I3, 25, I5I

Rijksarchief Luik (RAL), zie ook: AEL I3, I50

Rijksdienst voor Arbeidsvoorziening (RVA) 220

Rijksdienst voor Kinderbijslagen voor Werknemers (RKW) 220

Rijksdienst voor Werknemerspensioenen (RWP) 220

Rijksinstituut voor Ziekte- en Invaliditeitsverzekering (RIZIV) 220

Rijnland 34

Romsée 49
Ruhrgebied 29, 38, 62, 65, I05, II5, I9I

RWTH Aachen 26

Saarland 65

Saint-Lambert, kathedraal 30

Saint-Nicolas 49

Salée, Dominique 78, 8I, 86, 94

Sauvy, demograaf $26, \mathrm{II} 3$

Sclessin 3I, 9I

Sclessin, mijn I03

Seraing 30, 32, 50, 78, 83, 92-93, I03, IIO, I4I, 2I 19,221

Sicilië 63

Silezië 29, I05, I9I

Sint-Truiden 50-5I

Six-Bonniers, mijn I07, I35, 199, 209, 211, 225

Sociaal Historisch Centrum voor Limburg

(SHCL) 26, 226

Société Générale 36,126

Soumagne 49

South-Wales 72

Spanje (Spanjaarden) 22, III, I53, I58, I60-I62, I67, I86, I92, I94

Sporck, José A. 26, 49, I47-I48

St. Léonard, spinnerij $9 \mathrm{I}$

Staatsmijnen 15,36

Steegen, Erwin 25, 228

Sunou, Philippe II9

Tenfelde, Klaus 20

Tessenderlo 50

Thimister-Clermont 99

Tilleur 42, 49, 6I, I03, I4I

Tongeren 44, 50-5I, I04

Trembleur $\quad 42, \mathrm{I} 32, \mathrm{I} 38, \mathrm{I} 4 \mathrm{O}, \mathrm{I} 68$

Tulippe, Omer 26

Tunesië II3, I93

Turkije (Turken) 22, 46, II3, I6I-I62, I86, I93-

194

Turnhout 5I

Union des Travailleurs Manuels et Intellectuels

$$
\text { (UTMI) } \quad \text { I } 28
$$

Universiteit Maastricht (UM) 26

USSR 4I

Val Benoît, mijn 27, I47, 208

Val-St.-Lambert, kristal- en glasfabriek 82 , I3I

Vanja, Christina 84

Veneto 63

Verbraeken, Eric 225

Verenigde Staten $38,4 \mathrm{I}$

Verviers 82, I73, I90, 212, 257, 267

Vinck, François II7 
Vlaams-Brabant 28, 50-5I, 90, I72, I85, 194

Vlaanderen 44, II5

Vottem I4I

Vrije Universiteit Brussel (VUB) 26

Wallonië 22, 28, 6o, 68, I04, I06, II3, II6, I23, I63

Wandre I4I

Wandre, mijn 225

Waremme I73, 212

Wérister, mijn 33-34, 42, 90, I39-I40, I5I, I84, 204-205, 208-2II, 225

West-Europa $\quad 39,4 \mathrm{I}, 75$
West-Lancashire 72

Wezeren 90

Willem-Sophia, mijn 36

Winterslag, mijn 50

Yorkshire 72

Zola, Emile $7 \mathrm{I}-73$

Zonhoven 50, 90

Zuid-Afrika 4I

Zuid-België 29

Zuid-Europa II5

Zuid-Limburg 50, 123, I9I

Zuiderbekkens $2 \mathrm{I}, 27, \mathrm{I} 6_{3}, \mathrm{I} 6_{5}$ 


\section{Curriculum Vitae}

Leen Roels (I98I) studeerde Geschiedenis aan de Universiteit Gent en Vrouwenstudies aan de Universiteit Antwerpen. Van 2005 tot 201 I werkte zij als promovenda bij de Universiteit Maastricht aan het onderzoek naar de arbeidsmarkt voor mijnwerkers in het Luikse bekken. Na een aanstelling bij het E, til (Economisch Technologisch Instituut Limburg) waar ze onderzoek deed naar de sociale en economische effecten van de mijnsluitingen in internationaal perspectief en een periode als medewerker bij het Discovery Center Continium voor het project 'Mijnverleden, Mijn Toekomst', werkt zij sinds 2012 als inhoudelijk coördinator voor Erfgoedcel Mijn-Erfgoed in Belgisch-Limburg. 


\section{Maaslandse Monografieën}

50 Dr. Hans van Dijk, Panorama van drie eeuwen muziek in Limburg

5 I Dr. P.J.M. Teeuwen, Uit aarde geschapen*

52 Prof. Dr. J.C.G.M. Jansen en Drs. W.J.M.J. Rutten, Geschiedenis van de landbouw in Limburg in de twintigste eeuw

53 Dr. E. Lavigne, Kroniek van de abdij van Sint-Truiden, deel 3:1558-1679

54 Drs. J.M.B. Tagage, De Ordinarius Chori van de collegiale Sint-Servaaskerk te Maastricht

55 Dr. A.P.M. Cammaert, Het verborgen front, deel $I^{\star}$

56 Dr. A.P.M. Cammaert, Het verborgen front, deel II*

57 Dr. E.M.F. Koch, De kloosterpoort als sluitpost? Adellijke vrouwen langs Maas en Rijn tussen huwelijk en convent, 1200$1600 *$

58 Economische betrekkingen in grensregio's in een industrieel tijdperk, 1750-1965. Verslagbundel van het op I4 en I5 september 1995 te Maastricht gehouden congres van de Verenigingen voor economische geschiedenis in België, Duitsland en Nederland

59 Robert Nouwen, Tongeren en het Land van de Tungri (31 v.Chr.-284 n.Chr.)*

60 Dr. P.Th.R. Mestrom, Uurwerken en uurwerkmakers in Limburg, $1367-1850^{\star}$

6I W.A.J. Munier, Het simultaneum in de landen van Overmaas. Een uniek instituut in de Nederlandse kerkgeschiedenis (1632$1878)^{\star}$

62 Arnout Mertens, Loons, Diets en Luiks. Hasselt en de volksvertegenwoordiging in het land van Loon en het prinsbisdom Luik $(1477-1538)^{\star}$

63 Dr. P.J.H. Ubachs, Handboek voor de geschiedenis van Limburg ${ }^{\star}$

64 Dr. Hans van Dijk, Henri Hermans (I883-I947). De grondlegger van het Limburgs muziekleven

65 Dr. M.C.A. Kessels-van der Heijde, Maastricht, Maestricht, Mestreech. De taalverhoudingen tussen Nederlands, Frans en Maastrichts in de negentiende eeuw ${ }^{\star}$

66 Dr. J.H. Verhage, Katholieken, Kerk en Wereld. Roermond en Helmond in de lange negentiende eeuw

67 Dr. B.P.A. Gales, Delven en slepen. Steenkolenmijnbouw in Limburg: techniek, winning en markt gedurende de achttiende en negentiende eeuw

68 Jos Wassink, Van stad en buitenie. Een institutionele studie van rechtspraak en bestuur in Weert 1568-1795

69 Erwin Steegen, Kleinhandel en stedelijke ontwikkeling. Het kramersambacht te Maastricht in de vroegmoderne tijd

70 Thunnis van Oort, Film en het moderne leven in Limburg. Het bioscoopwezen tussen commercie en katholieke cultuur politiek (1909-1929)

7I Sophie Bouwens, Over de streep. Grensarbeid vanuit Zuid-Limburg naar Duitsland, 1958-2001

72 Lou Spronck, Theodoor Weustenraad (1805-1849) en de 'Percessie van Scherpenheuvel'

73 Paul Bronzwaer, Maastricht en Luik bezet. Een comparatief onderzoek naar vijf aspecten van de Duitse bezetting van Maastricht en Luik tijdens de Tweede Wereldoorlog

74 Hans van Hall, Eijsden, een vrijheid met Luikse stadsrechten. Een rechtshistorische schets van de ontwikkeling van een Minderstadt tussen Maas en Rijn (ca. 1300-ca. 1550)

75 Serge Langeweg, Mijnbouw en arbeidsmarkt in Nederlands-Limburg. Herkomst, werving, mobiliteit en binding van mijnwerkers tussen 1900 en 1965

76 Herman van Rens, Vervolgd in Limburg. Joden en Sinti in Nederlands-Limburg tijdens de Tweede Wereldoorlog

77 Leen Roels, Het tekort. Studies over de arbeidsmarkt voor mijnwerkers in het Luikse kolenbekken vanaf het einde van de negentiende eeuw tot 1974

* Deze titels zijn uitverkocht 